edited by Mohamed Hashes, Jan Jaap de Ruiter, and Riels Valdemar Winding

Imams in Western Europe

Developments, Transformations, and Institutional Challenges 
Imams in Western Europe 



\title{
Imams in Western Europe
}

\author{
Developments, Transformations, \\ and Institutional Challenges
}

Edited by Mohammed Hashas, Jan Jaap de Ruiter, and Niels Valdemar Vinding

With the collaboration of Khalid Hajji 
Cover illustration: Rome, Grand Mosque

Photo: Eckhard Ahmed Krausen

Cover design: Coördesign, Leiden

Lay-out: Crius Group, Hulshout

ISBN $\quad 9789462983830$

e-ISBN $\quad 9789048540006$ (pdf)

DOI $\quad 10.5117 / 9789462983830$

NUR $\quad 717 / 740$

(C) Mohammed Hashas, Jan Jaap de Ruiter \& Niels Valdemar Vinding / Amsterdam University Press B.V., Amsterdam 2018

All rights reserved. Without limiting the rights under copyright reserved above, no part of this book may be reproduced, stored in or introduced into a retrieval system, or transmitted, in any form or by any means (electronic, mechanical, photocopying, recording or otherwise) without the written permission of both the copyright owner and the author of the book.

Every effort has been made to obtain permission to use all copyrighted illustrations reproduced in this book. Nonetheless, whosoever believes to have rights to this material is advised to contact the publisher. 


\section{Table of contents}

Acknowledgements

Preface

Jørgen S. Nielsen

\section{Part I}

1 Imams in Western Europe

Developments, transformations, and institutional challenges

Mohammed Hashas, Jan Jaap de Ruiter, Niels Valdemar Vinding, and Khalid Hajji

2 Rethinking Islamic law for Europe

The concept of the Land of Islam

Jasser Auda

3 The making of Islamic authority in Europe

Thijl Sunier

4 Islams in Europe

Satellites or a Different Universe?

Jonathan Laurence

5 The European imam

A nationalized religious authority

Mohammed Hashas

6 Imam training in Europe

Changes and challenges

Farid el Asri

7 Studying Islamic theology at European universities

Göran Larsson

8 The reinvented role of imams in French society 
9 The imam as an organic public intellectual The case of Yassin Elforkani in the Netherlands

Welmoet Boender and Jan Jaap de Ruiter

10 i-Imams studying female Islamic authority online Claudia Carvalho

11 Islamic female religious authority between agency and governmentality

From the Moroccan model to 'multicultural' Europe Sara Borrillo

\section{Part II}

12 Towards a typology of imams of the West

Niels Valdemar Vinding

13 For a 'visible' Islam

The emergence of protest speech in French mosques

Romain Sèze

14 From conservative Islam to the 'Theology of acculturation'

The social and religious trajectory of a French imam

Cédric Baylocq

15 Muslim chaplaincy as a model for imamship

From liminality to immanent spirituality

Mansur Ali

16 Re-examining the decline narrative

Cambridge Muslim College and the changing face of imam training in Britain

Alyaa Ebbiary

17 Imam training in the legal context of Islam in Spain Juan Ferreiro Galguera 
18 The Italian legal system and imams

A difficult relationship

Francesco Alicino

19 In and around the mosque

381

Profile and territory of the Italian imam

Mohammed Khalid Rhazzali

20 The training of imams in Italy

The case of CO.RE.IS

Yahya Pallavicini

21 Efforts to establish an imam-training programme in Finland

Tuomas Martikainen and Riitta Latvio

Index

\section{List of figures and tables}

Figure 1 Attitudes towards the proposal to start an educational programme for imams in Sweden

Figure 2 What kind of educational needs are imams asking for in Sweden?

Table 1 Heuristic four-level scheme for researching public intellectuals

Table $1 \quad$ Jihadist linguistic terminology

198

Table 1 List of in-depth interview participants 211

Table 1 Typology of 'Imams of the West' 



\section{Acknowledgements}

This book would not have been realized without the generous support of a number of institutions and individuals. The book is the offspring of an international conference entitled 'Imams in Western Europe: Authority, Training, and Institutional Challenges', held on 5-7 November 2014 at the LUISS Guido Carli University and John Cabot University in Rome. The conference benefitted from substantial grants from the Norms and Narratives in the Nordic Nations (NoNa) programme of NordForsk, the Nordic Research Network for Sound Studies, and the European Council of Moroccan Ulema in Brussels (CEOM), as well as endorsements from the Department of Political Science and the MISLAM Programme of the School of Government at LUISS Guido Carli University, the Netherlands Interuniversity School for Islamic Studies (NISIS), the Department of Cross-Cultural Studies at the University of Copenhagen, and the Department of Political Science and International Affairs at John Cabot University. The editors are grateful to these institutions, and to the following people for their help in co-organizing and hosting the conference proceedings: Professor Francesca M. Corrao, Professor Sebastiano Maffettone, and Professor Carmela Decaro from LUISS Guido Carli University, as well as various colleagues and students who were helpful in taking good care of the conference proceedings; Dr. Tom Bailey and Dr. Michael Driessen at John Cabot University were also very kind in commenting on the project and hosting parts of its proceedings. Finally, we are grateful to Leonie van Esch and Renate Krabbendam for their editorial support for the book.

January 2018

Mohammed Hashas, Rome

Jan Jaap de Ruiter, Tilburg

Niels Valdemar Vinding, Copenhagen 



\title{
Preface
}

\author{
Jørgen S. Nielsen
}

This fascinating book on imams in Western Europe is well timed to respond to the European discourse on Islam and Muslims, coming at a time of remarkable developments in the imam as a concept, as a religious institution, and as an authority for the Muslims of Western Europe.

What are the origins of the concept of the 'imam', what lies behind it, and what are the historical antecedents that provide context for its current use? The present book provides pertinent answers to such questions; my short remarks here shall serve only to suggest the broadest possible framing of the many important themes, perspectives, and research on imams in Western Europe to be found within the following pages. By way of introduction to the multifaceted understandings and multiple usages of the concept of the imam, I trace three increasingly common and popular perspectives on the position of the imam. These are: first, the imam as the prayer leader; second, the imam as a religious authority; and, third, the imam - still almost exclusively a male role - as a kind of priest; the three perspectives lead to some of the complications and confusions that we are dealing with in the Western European context.

\section{The imam as prayer leader}

While the word 'imam' has its origins in the Quran - like many of the Islamic terms that have a social life and context in Western Europe - it did not originally have the technical sense that was later built into it. In the Quran, 'imam' means someone or something that is the moral model or guide for a community, which is held together by the shared ideal morality demonstrated by the imam. When leading his people into hellfire, for example, the Pharaoh is described as an 'imam' (Quran 28:41). The book of Moses and the record of each person's deeds are also described as 'imams', in that they are models, examples, or prescriptions of proper behaviour (Quran 46:12 and 36:12, respectively). Equally, Abraham (Quran 2:124) is described as an example for all people, and therefore an 'imam'. It is only later that the word 'imam' began to take on a variety of more specific meanings. 
Most commonly, 'imam' now refers to someone who leads the prayer. Strictly speaking, that person is only the imam while the prayer is being led; anyone who has the competence to lead the prayer and knows enough Quranic passages to do so is an imam. The idea that one has to be highly qualified to be an imam does not necessarily follow.

The concept began to be applied as an honorific title to someone who regularly leads the prayer in a community. More formally - and this came with the passage of time and growing institutionalization in the early centuries of the Islamic world - individuals were officially appointed to the post of imam in larger mosques and provided with an income. In the biggest mosques in populous cities, the imam would be only one of several official posts attached to the mosque.

Then the term 'imam' began to be applied to the leader of the community. Initially, this was most common amongst the Shia current of Islam, and was applied to Ali and his descendants. This was true for both the Ismailis and the Twelvers, for whom a religious authority is appointed in the absence of a political authority - although in the Fatimid dynasty, the two aspects became united into the imam-caliph. In the modern period, Ayatollah Khomeini in Iran was often called 'imam' by some Shia factions, although he himself refused to claim that he was the returning twelfth imam.

Among the majority Sunnis, the term was applied to the khalifa/amir al-mu'minin ('commander of believers') from very early on, and especially in medieval political theory. In the work of al-Mawardi the word used is 'imam' rather than khaliffa ('caliph'). It is also applied to the great religious scholars of the formative period, so there are imams of different madhähib ('schools of law and theology'), both Sunni and Shia.

With the passage of time, the role of the imam as a prayer leader was impacted by their official appointments, which linked imams to the political authority. Historically, an early sign of dissent against a political authority has been the refusal of the community to pray behind the officially appointed imam. This often applies even today.

In the Western European context, local Islamic communities with or without a fixed mosque or prayer room have often made informal arrangements for someone to lead the prayer. It may be the same person on subsequent Fridays, but it may also be different ones. From the 196os to the 1980 , it was left to the community itself to define what it meant by 'religious leader'; immigration authorities would usually accept the community's definition. The tightening of immigration rules in the 1980s and 1990s impacted the criteria of what constituted a religious leader. 


\section{The imam as religious authority}

The organized networks within the Islamic world and increasingly in Europe have tended to see the office of imam as the most effective access point to influence and organize European Muslim communities. The networks of the Turkish Diyanet especially, but also the Pakistani Jamaat-i-Islami and others, have organized their activities around trying to place members of their networks as imams in European communities. The local mosque communities often welcomed this, mostly because in the first generation they did not have the resources to give their imam an income or a place to live. There were instances in Britain, for example, where a small local community from a village in Kashmir would rent or purchase a property, set up a mosque, and bring in someone from their village who traditionally would have functioned as an imam. This person would be given a room in the same dwelling as the mosque. Because the imam would often speak little, if any, English, he would not be able to play a role in the leadership of the community other than leading the prayer and teaching basic prayer rituals and some Quranic texts to the children in the mosque's school. Representing the mosque community to the wider society, media, or local government, would be taken care of by a community member, often a businessman, occasionally an academic or a professionally trained lawyer or doctor. The exception, of course, is the Diyanet with its often treaty-based dispatch of community-leader imams to Turkish immigrant communities in the Scandinavian countries, Germany, Belgium, the Netherlands, and the United Kingdom.

It is worth noting that in the European and more generally Western environment a whole new institution with no precedent in the historical Muslim world appeared, namely the generic Islamic Cultural Centre. This organization usually has at least a director and often has more than one full-time person. The director of the Cultural Centre also becomes known as an imam, and the centres enjoy significant financial and political sponsorship, sometimes from the countries of origin, but just as often from other affluent Muslim countries.

\section{The imam as priest}

The concept of the imam as a kind of priest comes from the confluence of the imam's role of representing a tradition of religious authority and the European concept of priesthood - whether Catholic or Protestant. In 
the early phases of the establishment of Muslim communities in Western Europe, local Muslim communities were often placed in a difficult situation when local governments or churches wanted to enter into some form of dialogue with them. Through its priest, the local church would contact the equivalent peer in the Muslim community - most often a poorly trained, uneducated imam who could not speak the local language, and who was therefore unable to meet the church's expectations of interreligious dialogue. More precarious was when the local government wanted to engage with the Muslim community for reasons of social welfare, education, or integration policy, and found that the person they thought they were going to be talking to was - to put it frankly - absolutely useless. These imams were uneducated and unprepared for this new role. It was not a role that they had expected; in fact, nobody had expected it. Even if an imam had some learning, language problems remained. For instance, in Germany in the 1980s one of the big problems was that, although the imams the Diyanet were sending had theology degrees, they did not speak German. This produced an extended period of German converts to Islam playing a key role in communication with the authorities and other communities. In Britain, imams never played this role because they always stayed among the South Asian immigrants, while there was always someone else who could speak English and act on behalf of the community. This is why converts in Britain were seriously marginalized for a very long time.

In fact, there is a precedent for this role - a precedent that many Muslims for political reasons do not particularly like to face, even when they know about it: namely, the rabbi. In Judaism, the rabbi is traditionally a learned individual. He is a scholar, much more akin to a mufti, certainly, than to a prayer leader. But the rabbi has come to be treated as analogous to the Catholic priest or Protestant minister.

With the passage of time, the growth of Muslim communities, and the increased importance of integration, there is a growing need for communication with the administrative and social environment. This in turn has fostered a process of 'ecclesiastification:' professionalization modelled on Christian theological leadership. Such a process requires competent personnel, not only in terms of Islamic theology and law, but also with extensive skills in and knowledge of European law, politics, education, and communication - competencies that are commonly shared by priests and pastors. Hypothetically, to train new imams, then, one might as well send trainees to a Protestant or Catholic faculty, and focus on all that the religions share - law, pastoral theology, and so on - while replacing the Catholic or the Protestant theology with Islamic theology and religious 
teachings. These shared skills include the ability to deal with all the new expectations of the community, the Muslim intellectuals both at home and abroad, and state institutions at the local and national level, not to mention the media and politicians - including populists, with their often vocal attitudes towards imams and Muslim leadership. This competence also extends to all of the new skills, tools, and modes of communication that the twenty-first century demands of imams.

This book rises to the occasion to dig beneath the simplistic surface and identifies the variety of imams' roles in Western Europe and their implications for authority, training, and - possibly - developmental priorities.

Jørgen S. Nielsen, Birmingham

January 2018 

Part I 



\section{Imams in Western Europe}

Developments, transformations, and institutional challenges

Mohammed Hashas, Jan Jaap de Ruiter, Niels Valdemar
Vinding, and Khalid Hajji

Hashas, Mohammed, Jan Jaap de Ruiter, and Niels Valdemar Vinding (eds), Imams in Western Europe: Developments, Transformations, and Institutional Challenges. Amsterdam: Amsterdam University Press, 2018 DOI: 10.5117/9789462983830/CHO1

The study of imams, the office of the imamate, and Islamic religious authority is not new, but has an intricate history within the disciplinary confines of Islamic studies. With the advent of what may be called 'European Islamic thought' and 'European Islamic studies,' the role of imams as agents of religious authority and leadership raises new questions in theology, sociology, anthropology, political science, law, migration studies, and religious and interreligious studies.

This book presents an omnibus academic inquiry into contemporary Islamic religious authority with a focus on imams and the imamate - on which, until now, not much has been written in English. Our ambition is to contribute deeper and more fruitful analyses of the changes and challenges experienced by this source of religious authority in the context of the secular-liberal societies of Western Europe since the Second World War and the subsequent migration and refugee flows. At the same time, this research also serves to highlight secular-liberal institutions and their adaptation, or lack thereof, to the multiculturalism that characterizes Western European states. The social facts of globalization, transnational migration, and various interpretations of secularism have challenged the visibility of religion in the public sphere in Western societies. This has most importantly and urgently required religious authorities to revisit their organization, governance, and internal hierarchy, and Islamic religious authority is no exception. Throughout the Muslim-majority countries and in Europe, Islamic religious authority is still struggling to negotiate its place among the institutions of 
the modern state in the 'secular age' in the words of Charles Taylor (2007). The imamate is one of the institutions that are currently experiencing a shift of roles and functions in society. Scholars and historians of religion in particular are attentive to this shift.

2

\section{Nomenclature}

In the English edition of Hans Wehr's A Dictionary of Modern Written Arabic (1961), the definition of imam is a prayer leader, leader, or master, with the plural a'imma. In its original meaning, the word implies leadership, control, governance, and authority in different aspects of political, spiritual, and theological affairs. According to Hanna Kassis's A Concordance of the Qur'an (1983), the word imām appears twelve times in the Quran, in singular or plural form, with a number of different meanings such as model, example, leader, and guide. Both Abraham and the Book of Moses are described as 'imam,' meaning examples or models to be followed. Closely associated with 'imam' and drawn from the same root is the word imàma, meaning the function or office of the prayer leader, a position of leadership in a small or big group, a mosque, or a community. This is the collective term that denotes the wider Islamic institution of the imam, independent of individual imams. It is neither meant as an occupation or as a rank; rather, it is an office and a function to fulfil. Other terms that share the same root are umm, which means mother, but also source, origin, and foundation, and umma, which means the nation, people, or community.

With the many specific historical applications of the word 'imam' come a variety of understandings that require unpacking. Most plainly, the imam is the prayer leader in a mosque, or simply the Muslim worshiper who leads the recitation of prayer when two or more worshipers are present. He is the example to follow in the bowing down and prostrations of the prayer. In early Islam, 'imam' was used to denote the highest office of the Muslims, who in legal and political terms was the lawful temporal leader of the community of believers in the times of the Rightly Guided Caliphs. After the death of the prophet Muhammad in 632, the question of imāma, legitimate religious and political leadership and legitimate authority in Islam, became central. According to Sunni sources, Muhammad had not given directions about the appointment of his successor - and paradoxically, for this very first of urgent issues there was little help to find in either the Quran or the sunna, the words and deeds of the prophet. This demonstrates the struggle of the community of believers to deal with the realities of power after the end of 
the direct divine guidance delivered through revelation and in the practice of their prophet.

After the wars of succession and the establishment of the hereditary Umayyad dynasty, the word imam began to acquire a specific meaning for the Shia. For them, an imam is he who is recognized as the legitimate, faithful leader of the Muslim community by claiming direct descent from Muhammad. Amongst the Twelver Shia, such twelve descendants of Muhammad are regarded as divinely appointed spiritual and temporal leaders. In its later, mainly Sunni, application, and in a more abstract sense focusing on leadership through knowledge and merit, the word 'imam' also came to mean an exemplarily authoritative scholar, specifically one of the founders of the four madhhabs ('schools of law and theology').

Very much a developing word and concept, the imams discussed in this book are prayers leaders, community leaders, and religious professionals in the present Western European context. As such, while the authors of this book take great care to be specific in describing their object of study in each chapter, the word 'imam' has taken on a shorthand meaning in contemporary parlance. In much of the current literature, the 'imam' is an Islamic religious professional who holds the responsibility for a variety of religious, social, and communal functions among Muslims. This book is concerned with the figure of the imam - mostly male, but also female, such as murshidas ('female guides') - and the functions that revolve around his or her work: being a preacher, chaplain, teacher, community organizer, mosque spokesman, chairman, director, and organization representative. Imams sometimes perform all of these functions themselves, or they are performed in collaboration with others in the community and society at large.

\section{3 \\ Vested interests in imams in Western Europe: Current status}

Socio-anthropological and security studies of Islam and Muslims in Western Europe after World War II hardly focus on religious authority, let alone imams per se. Political Islam, transnational Islamic movements, and radical Muslims have been central to the study of Islam and Muslims in European scholarship until recently. Studying religious authority, let alone thinking of training programmes for imams and community leaders, has been out of sight for decades. The Grand Mosque of Paris initiative in the mid-199os might be considered the first one aimed at training imams, but it did not win support and attention from state or non-state actors until the mid2000s, after the terrorist events of 11 September 2001 in the United States. 
Western Europe, most of which bound together by the institutions of the European Union, has not, and apparently will not, develop shared policies on religious affairs on Islam in particular, since each member state has its own particular relationship with religion. Strategic reports solicited or prepared by institutions of the European Union on the topic of Islamic religious leadership are scarce, to the extent that the first report on the topic was prepared by a body not of the European Union (King Baudouin Foundation, 2007). One example of a report on this topic that was co-financed by an institution of the European Union is Education and Training of Islamic Faith Leaders in Europe: A Comparative Evaluation of Approaches in France and Germany, prepared by the Institute for Strategic Dialogue and co-financed by the Commission DG Home Affairs of the European Union (Hussain and Tuck, 2010).

Earlier scholarship on Islam and Muslims in Western Europe did not take the authority and roles of imams as a central topic of research, with the exception of the work of Franck Frégosi (1998) on France. Examples include the works of Felice Dassetto (1996), Jytte Klausen (2005), Jørgen Nielsen (1999), Tariq Ramadan (1999), and Wasif Shadid and Pieter Van Koningsveld (2002), to name but a few. Belonging, integration of second-generation immigrants, citizenship, loyalty, secularization, modernity, and representative bodies of Islam were the major topics that mostly consumed scholarly attention until 2001.

As post-World War II immigrants and their descendants are becoming citizens of Europe, and the debate about Islam in Europe is emerging as a debate about European Islam, the question is taking a different turn. It is the localization of the religious leaders of these Muslim citizens and residents that appears to be of paramount importance, and rightly so. Scholarship has turned toward examination of this theme to some extent; three recent works, by Willem B. Drees and Pieter Sjoerd van Koningsveld (2008), Juan Ferreiro Galguera (2011), and Ednan Aslan and Zsofia Windisch (2012), have begun to shed light on the topic. The first (Drees and van Koningsveld) mostly concerns religious freedom, and briefly gives space to the topic of imams in countries like the Netherlands and Italy. The third (Aslan and Windisch) mostly focuses on central Europe and the long experience of the Balkan countries, especially Bosnia-Herzegovina, with forming and training teachers and imams for the European context. It is the second (Galguera) that appears to be the first comprehensive, descriptive text in English that tries to map the major imam-training centres in 27 countries of the European Union. Galguera shows how few of these centres are actually available, how scarce their funds and local 
training faculty are, and how states and stakeholders are working more and more to develop them. Still, the study requires follow up to see how many of the institutes that were in the planning stage during the time of data collection have found their ways to realization, what they are teaching to the new imams of Europe, and what the best practices, their strong points, and their challenges are.

It is important to state the obvious: many have vested interests in the future of Islam in Western Europe, and therefore also in the imams and Islamic leadership that are experiencing change and innovation, as Felice Dassetto, Silvio Ferrari, and Brigitte Maréchal (2007) inform us in their report Islam in the European Union: What's at Stake in the Future. Overall, these interests can be divided into internal and external ones.

On the internal level, it is Muslims and congregations in mosques that are looking to imams for direction and leadership - both literally, during prayer, and in the more comprehensive sense of navigating life and circumstances in Europe. Mosques, their directors and boards, and the networks and organizations working on Muslim issues in Europe, are all concerned with the religious and social maintenance of the community. They employ imams for the primary function of leading the prayer, giving the Friday khutba ('sermon'), and guiding and counselling the community in the event of marriages, divorces, births, funerals, and the like.

Externally, at least three levels of interest or concern can be listed. First, public institutions are trying to accommodate the needs of Muslim citizens, including their spiritual needs. A number of public and private institutions, such as hospitals, prisons, the armed forces, and universities, are employing imams as chaplains to offer a service to Muslims commensurate with what other religious communities receive. With this service comes a long list of demands and requirements in terms of training, security, and professionalization.

Second, at a discursive level, many politicians, opinion-makers, and leading media outlets across Europe are concerned with the public and communal positions of imams and the impact these are assumed to have not only on Muslims but also on a long list of public concerns. This appears to be a shared concern across Europe - Western Europe in particular - and there is a dire need to train home-grown imams or imams that know the European context and its values and needs.

Third, outside Europe, a number of international actors, institutions, movements, governments, and ministries follow the case of imams in Europe and intervene in their affairs. These actors are either invited by the community to contribute to their religious life through education, 
personnel, and funds, or are invited through bilateral agreements between states. Such agreements are few and have often come too late to answer the needs of the community, especially as various Western European Muslim denominations do not receive state funds nor receive recognition for the training offered by their schools and seminaries, which is one of the main reasons why the issue of imam training and recruitment is problematic.

This leads to the next point, which can be described as an intertwining space of concern for both internal and external stakeholders. In many ways, the question of Islam and imams in Europe speaks to the current status of secularism and the relationship between religion and the state. Normative claims have repeatedly been made that modern liberal democracies are characterized by the separation between church and state. Just as often, such claims have been challenged: each Western European state has its own version of secularism, and often has a 'preferred' or 'historical religion' that benefits from state institutions more than others, whether minimally, as in the case of the very laïc ('secular') France, or maximally, as in the cases of Spain and Italy. Borrowing the words of Jocelyne Cesari (2013), there is a clear 'externalization' of Islam from the European context and culture, which impacts its institutional integration.

Focusing on imams sheds light on the state's relationship with national Muslim bodies, its wish to relate to one single Muslim body (and/or the failure of these), its control over the building of mosques and Islamic centres, the security issues related to terrorism that urge the state to interfere in Islamic affairs, and lastly, the overall role of the imam in the European context. The state sees in the imam more than a simple prayer leader; he is perhaps incorrectly seen as a Muslim equivalent of a rabbi or priest. It is assumed that imams are leaders and representatives of their communities, and that states and governments can address them to fix social issues and grievances. Especially since the tragic events of 11 September 2001, the interest in opening training programmes for imams, religious leaders, and activists has grown, though still dominantly from a security approach - which, however, does not always lead to the desired fruits that engaged religious figures will solve issues related to religious discourse in the public sphere, deradicalization of the youth, and Muslims' integration into society. Too much is expected of the imam at a time when the mosques and institutions where he functions lack a faculty of experts that enjoy legitimacy from both Muslim trainees and their community, institutional visibility, and financial support. There is clear institutional ignorance and negligence of the field and its importance for quite a number of believing citizens in society. 
This book seeks to explore the role, function, and position of imams and the implications of the imamate as a religious-institutional authority in Western Europe. The first part intends to be more theoretical, with a focus on themes related to religious authority, theology, and their manifestation in the modern context of Western Europe. The second part mostly consists of country-specific case studies based on fieldwork. The two parts are complementary, though at times they might intertwine.

In the first chapter of the first part, Jasser Auda revisits the concept of the Land of Islam and the criteria that make a land, Europe in this case, open to be interpreted as a Land of Islam. Based on reading the definitions offered by classical and modern Islamic political theology, Auda proposes that security, justice, and the freedom to practice Islamic basic rituals do give an Islamic aspect to lands that are not dominantly Islamic in demography or governance: lands where justice, security, and freedom of worship prevail are Islamic lands, irrespective of the (lack of) religiosity of their lawmakers and governors, which certain interpretations of the Islamic tradition prioritize. Through this reading, Auda proposes that European Muslims, including their imams, should move from an 'integration' to a 'contribution' approach toward Europe.

This contribution of Islam to Europe is further raised by Thijl Sunier, who underlines the crucial but neglected role of ordinary Muslims in the making of religious authority and leadership. Sunier argues that the sources of Islamic religious authority are more diverse and unstable than ever before. The Islamic landscape is complex; multi-socio-political, economic, and media factors play a big role in forming such complexity. The multiplication of religious audiences and their followers has opened a market of competition among both old and new generations of leaders, each trying to use and find a place in the media world that broadcasts their performance and rhetoric widely. The new media has especially become a challenge to traditional religious authority. Modern schools that use up-to-date technology to disseminate a plural and reformulated religious discourse and interpretation of religious norms are challenging the old centres of learning in special Islamic centres. The same norms are being lived and practiced differently by different generations or by the same generation in different locations, be they marginal or central. Ordinary Muslims play a major role in this process, which consequently shifts religious authority from classical leaders to new 
stakeholders, according to Sunier. Such a multiplicity of interpretations of religious norms worries the nation states that are trying to domesticate Islam and Muslims' behaviour in the public sphere - an endeavour that endangers the neutrality that a secular state should uphold.

Away from both the externalization of Muslims and Islam in Europe and the negligence that ordinary Muslims and emerging religious authorities face, Jonathan Laurence brings in the Roman Catholic question in America in the nineteenth century to argue that Muslims in Europe are experiencing a similar historical moment of adjustment to a new context through implantation, institutionalization, and professionalization. American Catholics in the early nineteenth century lacked churches, dioceses, professional priests, and colleges; to meet the needs of the ever growing Catholic communities in the mid-nineteenth century, the Roman Catholic Church had to create an 'American College' in Rome to train proper Catholic priests, and similar colleges were created elsewhere in Europe to cater to the need for professionalization and houses of worship. Laurence provides some comparative statistics to show that Muslims are not lagging when compared with the example of American Catholics. Like them, Muslims in Europe lack professionalism, places of worship, and colleges - but these have been increasing for the last couple of decades. This increase is especially caused by continuing contact with Muslims' countries of origin and influential capitals like Rabat, Algiers, Ankara, and others. Laurence argues that the power of the countries of origin over their diasporas will change with time, and is already changing; what will remain is what he calls 'spiritual fatherhood' or 'spiritual leadership', through which the capitals that train the imams and religious leaders for Europe will maintain a link with their diaspora. Laurence says that this should not be read as a political defeat of the countries of origin, but rather a mere transfer of power to the Muslims who are trying to implant themselves into their new soil, Europe. This leads to the formation of local Islams: French Islam, German Islam, British Islam, and so on.

The localization of religious authority is further probed by Mohammed Hashas, who argues that the imamate, as a new field of study and policy focus for Islamic scholarship and modern nation-state institutions, is becoming a nationalized and dependent religious authority under the surveillance of state institutions, unlike the past independence of local communities in choosing their own imams. Hashas gives the example of the role of the imam as stipulated by the Ministry of Endowments and Islamic Affairs in Morocco: a role that lists duties and obligations that make the imam subject to state institutions and focalizes the discourse of Islamic ethics rather 
than political issues, which imams are not allowed to deal with. Hashas also gives the example of imams in France as another instance in which the nationalization of this religious function is underlined by state surveillance, in which the religious power the imam holds is of an ethical-spiritual dimension. These examples illustrate that this religious function that has gained prominence and attention in recent years has been nationalized, institutionalized, and rendered dependent, with a clearly defined role of ethical (i.e., non-political) teaching.

The chapter by Farid El Asri also deals with the question of religious authority and its multiplication among Muslims in Europe. El Asri emphasizes the dynamics of a once-silenced Muslim presence, and the growth of various bodies that complement and at times strongly compete with each other as representatives of a pluralist community. He focalizes the growth of engaged young generations of Muslims and their attempts to organize their communities through acculturation, integration, and cohabitation through various interpretations of religious norms. El Asri also discusses his view of the development of training programmes for imams and religious leaders, and the challenges facing them.

Still related to the question of imams' training, but from a Swedish perspective, Göran Larsson highlights the complexity and difficulty of teaching Islamic theology in secular Western universities. First, he reviews the differences between religious and theological studies, presenting 'academic theology' as the convenient approach/discipline that studies religion, and theology in particular, critically and not apologetically, irrespective of the differences among religions. Afterwards, he dwells on the initiative of the Swedish Ministry of Education in 2009, which was followed up in 2014, to offer a training programme for imams in state universities. In the questionnaire that circulated widely among Muslim representative councils, associations, and religious leaders, the informants showed interest in a training programme for subjects that deal with language, society, and other topics, but not for pursuing Islamic theology studies in secular universities. Larsson argues that Muslims who are interested in such training leave out theology because they do not consider a secular university (with faculty who are probably not Muslim) to be an able or legitimate source of learning about Islamic theology, particularly subjects concerning the creed. These Muslims often obtain training elsewhere in the Islamic world. Moreover, Larsson also illustrates how difficult it is for the teaching faculty in Western secular societies to provide such training for very diverse Muslims belonging to different madhhabs and different models of imam training in their countries of origin. 
The contribution of Solenne Jouanneau provides a typology of French imams according to their presence in the country since World War I, the various paths of their institutionalization, and the challenges they have faced during this process. Her chapter is a synthesis of six years of fieldwork on imams in France, during which she interviewed about thirty imams and about fifteen senior civil servants from the Ministry of Internal Affairs and the Ministry of Foreign Affairs, as well as accessing state archives. Jouanneau also examines the French Law of 1905 and how state institutions tend to transgress it with regard to Islamic issues, such as imam selection. She outlines different ways the Ministry of Internal Affairs and Ministry of Foreign Affairs have been intervening in the selection of imams since the 1990s: using diplomatic relations and the consular networks of the sending countries to select 'consular imams'; using the residence permit cards that imams apply for in monitoring their good conduct as only 'good imams' can secure residence cards; and monitor the imam-training programmes, their content of good practices, and their 'legitimate beliefs.' Jouanneau critiques this interference and argues that it actually backfires, because imams and programmes that are controlled by the state risk losing legitimacy and authority among Muslims.

In the Netherlands, Welmoet Boender and Jan Jaap de Ruiter propose a different reading of the function of the imam in the public sphere, away from the traditional and limited space of the mosque. They consider the engagement of Yassin Elforkani - the 'imam of the young', as he describes himself - to be that of an organic public intellectual. Integrating religion into the definition of the public intellectual, they show how this imam uses different arguments (theological and non-theological) to challenge both the sceptical part of Dutch society and its religious Salafi counterparts in order to position himself and others that share his ideas in the heart of intense public debates.

Claudia Carvalho takes us into the digital world to examine how religious authority is both practiced and challenged. The Internet has opened a new space for the agency of Muslim women and youths, who have not found themselves or their ideas in traditional spaces of worship (mosques) or represented by traditional forms of religious authority, including imams. The privatization and individualization of religious knowledge is manifest in their online discussions. Based on online fieldwork tracing the discussions of $5^{0}$ Muslim women of Moroccan origin or converts in Catalonia, Spain, in 2013-2014, Carvalho describes these 'potential jihadists' and their praise of the Islamic State, their dreams of joining it, and their use of classical concepts like hijra ('migration') and da'wa ('proselytizing') to recruit jihadists 
online. Carvalho ends her chapter by referring to a female religious scholar's argument that this individualized digital jihadism is not representative of the community or of Islamic scholarship.

Continuing with the study of female religious authority in a country that is present in Europe through both its diaspora and its programmes of training imams, Sara Borrillo presents the gender-based reform of Morocco's Ministry of Endowments and Islamic Affairs in 2004, which institutionalized women's participation in official Islamic bureaucracy and knowledge production. The reform introduced murshidāt ('female religious preachers') and 'álimāt ('female religious scholars') into the Islamic public discourse and authority structure. Borrillo reads this reform as a form of empowerment of women in the public space, but in which they remain under the tutelage of male authority and the state apparatus. She also analyses it from Islamic feminist perspectives as a form of women's agency and subjectivity. Unlike in secular-liberal societies, where gender equality in institutions is the norm, in Morocco female agency is still looked at from 'complementarity' of genders perspective. For this reason, the Moroccan state was able to intervene and provide a space for women in the public sphere and public institutions. In Europe, the empowerment of Muslim women takes a different path because the state cannot intervene in religious affairs to offer Muslim women a special space in their community.

\section{$5 \quad$ The parts and their contributions: Part II}

The second part is concerned with the institutionalization of Islam in Western Europe as seen through the role of imams. These processes are directed both by the Muslims themselves and by the states they settle in. This part contains ten chapters of case studies on imams: their day-to-day life, education, and institutional challenges and aspirations. The cases are located in the following countries: the United Kingdom (Mansur Ali and Alyaa Ebbiary), France (Cédric Baylocq and Romain Sèze), Spain (Juan Ferreiro Galguera), Finland (Tuomas Martikainen and Riitta Latvio), Sweden (Göran Larsson), the Netherlands (Welmoet Boender and Jan Jaap de Ruiter), and Italy (Francesco Alicino, Yahya Pallavicini, and Khalid Rhazzali). Niels Valdemar Vinding opens the second part with a chapter on the typology of imams in Europe, based on his fieldwork.

While there are aspects that all of the examined countries share, it is difficult to propose a scheme that can place all of these case studies into a single clear framework - an idea to which we return in the concluding 
remarks of this introduction. There is the question of the success or failure of national representative Muslim organizations in the concerned countries; the relationship between the government and any national Muslim bodies that was ultimately formed; the state's desire to deal with a single Muslim body (and the failure of these); the control over the building of mosques and Islamic centres; the role of imams, not only as bearers of religious authority but also as intermediates between civil authorities and Muslim communities; security issues related to terrorism that urge the state to interfere in Islamic affairs; the desire of parts of Muslim communities to establish good relationships with the state; the lack of financial support for imams (i.e. salaries) and their education; the competition of various external bodies to import imams; the fear of being accused of dismissive attitudes in society; the desire to establish imam-training programmes and Islamic studies programmes in universities; and other related issues.

The second part opens with an exploratory analysis of the institutional and epistemic authority of imams, which Vinding develops into a typology. He focuses on the two expressions of religious authority in Islam, and argues for their centrality to the legitimacy of imams and their work. His proposed typology can be understood as an expression of the interrelations embodied by imams during their movement within the diverse institutional frameworks of both Western and Islamic knowledge.

The study of the French and Italian contexts takes up a good amount of space in this book, which shows how the imamate can be approached differently in the same geographical-institutional-and-political context. Jouanneau's chapter in the first part focalizes the question of the relationship between churches/mosques and the state, ending with a critique of state intervention in the internal dynamics of the Islamic 'cult', particularly by choosing imams. In this part, Sèze, whose conclusions are based on fieldwork conducted between 2006 and 2012, describes the internal dynamics of the imamate as a function in quite a secular context; he argues that imams tend to take up a leadership role in their communities, as well as acting as markers of Muslim identity. In their public discourse, imams critique both the state laws that limit Muslim religious freedom and visibility and the 'excessive' visibility of some Muslims, in the words of the author. To gain societal recognition, imams exhort their co-religionists to be active and engaged citizens. Baylocq explores more of the details of this French debate by examining the role of the theologian-imam Tareq Oubrou. He presents Oubrou's intellectual trajectory and his key theological concepts, like 'sharia of minority', his overall contribution to the institutionalization of Islam in France, and his founding role in the birth of a French Islam. 
Ali and Ebbiary each consider a specific case of an imam-training programme in the United Kingdom, highlighting the programmes' shortcomings and achievements. Ali starts his chapter by describing the important training most functioning imams in the United Kingdom take from the widespread South Asian schools of Darul Uloom, including their Dars-i Nizami curriculum. Ali focalizes the work of chaplaincy and proposes it as a model for imamship (i.e. the imamate): he sees that imams have to learn a number of professional skills, most importantly how to 'talk with' believers in a tolerant mode, instead of 'talking to' or only preaching to them in the traditional sense. Ali calls 'immanent spirituality' a value, which imams are advised to adopt and make apparent in their work.

Ebbiary deals with the shortcomings of the Darul Uloom seminaries in the United Kingdom and the critiques they receive, and then examines the establishment and vision of the Cambridge Muslim College (CMC), founded in 2011. Cambridge Muslim College is presented as a project to train more advanced, highly educated imams and religious leaders - the hub that gathers and trains the 'best' graduates from the Darul Ulooms. In Ebbiary's words, Cambridge Muslim College was 'established to provide a higher education experience for the graduates of the traditional Indian-style Darul Ulooms in the United Kingdom [...] with a curriculum emphasizing citizenship, political and cultural awareness, interfaith understanding, community building, counseling, and other pastoral skills.'

This part also considers the southern part of Europe, which is especially important due to its large number of Muslims. Until very recently, hardly any Muslims lived in Spain, but due to growing immigration since the 1970 s the kingdom now has a sizable Muslim population. While the country was the cradle of the Moorish presence for eight centuries, during the 'Reconquista' in 1492 most Muslims left or fled the country, or converted (in)voluntarily to Christianity. Ferreiro Galguera considers the presence of Muslims in Spain in the context of Spanish legislation since 1975, especially since the Cooperation Agreement of 1992, which recognizes certificates of theology studies from theology centres at universities. Ferreiro Galguera describes the efforts of Muslim communities to obtain recognition under this law. He recounts that while there used to be Islamic studies courses offered by two universities and two courses organized by two Islamic organizations, now there is only one solid imam-training programme in the country, organized by the Spanish Federation of Islamic Religious Entities (FEERI) in cooperation with the Islamic University of Rotterdam in the Netherlands. Ferreiro Galguera says that Muslim institutionalization in Spain still has a long way to go. He calls for the establishment of a 'European Institute' or 'University of Islamic Studies', 
like Al-Azhar in Cairo, which would work in close collaboration with Islamic authorities in Muslim countries to develop legitimate training for Islamic religious authorities in Europe, as well as for interreligious dialogue.

Italy is well represented in this publication, with chapters from Alicino, Rhazzali, and Pallavicini. Alicino describes the complexity of the institutionalization of Islam in a country that has a special legal relationship with the Catholic Church, whose headquarters are in the Italian capital, Rome. Alicino describes Italy's relationship between church and state as 'limited secularism'. The absence of the recognition of Islam as a religion in Italy leads to the ongoing disorganized structure of its Muslim communities, characterized by growing initiatives for mosque-building and the setting up of imam-training programmes, despite the lack of institutional recognition, training cadres, and financial support.

Rhazzali puts the Italian imams into context. After presenting a map of imam types in Europe, he localizes their situation and types for the Italian context, furthering this typology with a map of the mosques in Italy to illustrate the geographical distribution of Islamic religious authority in the country. For Rhazzali, Muslim communities' search for an identity in Italy consists of claiming 'Italianicity' from an autonomous perspective.

Pallavicini is a practicing imam and the chairman of Comunità Religiosa Islamica Italiana, the Italian Islamic Religious Community (CO.RE.IS); his contribution gives the reader an inside view of the institutionalization of Islam in Italy, which is quite burdensome and slow. Echoing Rhazzali's argument, he states that 'imported imams, or those either appointed by international Islamic organizations from abroad or religious institutions of foreign governments, represent in the eyes of CO.RE.IS an obstacle for the active participation of the faithful and the ministers of the faith in the country's activities'; imported imams 'are [...] conditioned by a vision that is not fully compatible with how Italian Islam should look like'. This is why CO.RE.IS has been involved in training home-grown imams since 1995 .

Finland is another country with a recent history of Muslim migration although it has historically been home to the Islamic Tatars, whose religious affairs were taken care of by earlier legislation. The new migrants posed new questions, including how to set up imam-training programmes. The chapter by Martikainen and Latvio gives lucid insight into the efforts of the Finnish government and the feedback of the Muslim community, particularly its leaders and imams. At the moment, the issue is still undecided; both the government and the Muslim communities are still discussing the possible solutions, and new initiatives have been taken to further the processes of negotiation. 
These two parts aim to contribute to the emerging field of imams as agents of religious authority, who develop new forms of understanding the imamate in relation to national institutions that are either already in place or in development. Taken as a whole, three major points can be retained from these studies. First, there are significant efforts, many led by the Muslim communities themselves, to address the void of representation and leadership within the community. This representation is spiritual, cultural, and institutional. Spiritually, the imam is the nearest person who is given the responsibility of leading rituals with spiritual significance, and therefore becomes the symbol of Islamic presence in the land or country; it is through mosques and the imams that inhabit them that Muslims feel their spirituality is first non-spatial, and then part of Europe. Culturally, the imam is an identity marker; it is through him that Muslims identify with the mosque and their religion (leaving aside the fact that imams are not always welcomed by or considered the best representatives of their communities). The role of the imam in the cultural aspects of marriages, divorces, male circumcision festivities, funerals, and general consultations represents an affiliation with a particular way of life and spiritual-cultural belonging in a multicultural context. Institutionally, the imam is often, but not always, an institutional axis for the community of believers - although in this he is sometimes in direct or indirect competition with other Muslim representative bodies. Whether he is directly the point of focus himself, or it is the community and the mosque where he functions that is at the centre of such institutional care or contact is open to further examination, as this book illustrates in different contexts and countries. These three aspects of the imam's role render the figure of the imam and the imamate worth investigating.

Second, the imamate is winning more and more interest from various stakeholders because of its spiritual, cultural, and institutional roles. After decades of negligence, Western European nation-states have woken up to the fact that Muslim communities lack imams who know the country where they function, its language(s), history, laws, and other related information. They have also come to realize that imams cannot solve integration problems - even if the states want to give them that responsibility in the attempt to prevent the radicalization of youths from Muslim backgrounds. European states have discovered that the imamate has been under the influence and control of various other external actors, including embassies, consulates, and international Islamic movements. This renders the issue extremely delicate, and divisions among Muslim representative bodies about how to deal with 
state institutions are not new. Despite this contestation of the imamate, many Muslim communities and the concerned imams actively seek the recognition that will normalize their presence in Europe, through, among others, institutional representation, funding, and civil society activism.

Third, there is high interest from the Muslim community and its stakeholders, as well as from various state institutions, in developing adequate training programmes for the imams, religious leaders, and teachers of Islamic education in Europe. This interest, nurtured by the various factors tackled in this book, indicates the dire need for a well-educated and well-trained imam corps. While European nation-states expect Muslim communities to care about such an important aspect of their internal affairs, for decades governments have ignored the institutional and financial needs of these communities; it is unfortunate that only terrorist attacks have awakened them to this vital need of a part of their society. After the interest in training programmes has grown, most public state institutions have discovered that they too do not have the means or workforce to contribute to such programmes, and the state-representative Islamic councils that have been formed over the last decade or so often enjoy little recognition from Muslim communities for various reasons, as this book shows. The public universities that might contribute to such training often lack faculty trained in Islamic studies, which consequently affects their legitimacy among the community of believers and their representative bodies. It is for these reasons that working with Muslim bodies and their training programmes, and with 'embassy Islam' for the symbolic legitimacy they have in the field, appears the most reasonable path to follow (as the case studies in this book chart) until full-fledged national programmes that can graduate home-grown imams are developed.

Learning from the experience of Islam in the Balkans and the rest of the world where Muslim minorities have developed interesting imam-training programmes also remains an option and opportunity for the exchange of practical experiences and theoretical considerations in the new field of the study of Islam in Europe, and European Islam. Moreover, the historical experiences of institutionalizing religious authorities (e.g. rabbis and priests) in Europe and the United States might suggest the role of time in the slow absorption of the 'Muslim problem' before they take a natural course in social affairs, without fear and suspicion - as is slowly happening now with Islam and Muslims in Western Europe.

Finally, we wish to remind the reader of the broader context in which the issue of the imamate is and should be discussed: modernity and globalization. First, the issue of imam training cannot be disentangled from thorny 
questions, such as those concerning Islam and modernity or migration in the era of globalization. It is undoubtedly a form of self-deception to focus exclusively on the training of imams as an effective measure to counteract religious extremism. The imam - it should not be forgotten - is one of the most vulnerable links in the chain of religious institutions and discourses. He is not a leader appointed by a divine authority, but an employee at the behest of his employer - the community of believers or the state, or both. This is why the improvement of imams' legal status is no less urgent than their training.

Second, the discord that threatens to undermine the unity of European societies can by no means be ascribed to the imams' omission of duties; rather, it should be attributed to the forms of fragility caused by globalization. The open world in which we live remodels all societies, no matter how rich, poor, developed, or developing they are. This state of fragility renders it expedient for Europe to renegotiate the place of Islam in its space. For many European leaders, multiculturalism is no longer the pledge of a perfect union between the different constituents of European citizens. In this context, the question of imams might seem like the tip of the iceberg, or the tree that hides a forest of other, bigger problems.

To extricate European societies from the consequences of the collapse of multiculturalism - and, unlike some political leaders, we are not saying multiculturalism has collapsed - it is wise to persevere in endeavours to include Islam in the European socio-cultural and institutional ambit. It is necessary to devise ways and means to harmonize the following three exigencies: (1) it is necessary to respect Islamic traditions - Muslim communities in Europe must not relish the feeling of being discriminated against; (2) it is necessary to respect the sovereignty of European countries - heeding the spirit of modern times, Muslims living in Europe must accommodate their cultural heritage to their new surroundings, discerning between the cultural practices of the Arab-Islamic world and the spirit of the religion; and (3) it is necessary that European cultures evolve freely towards a new historic concordance where citizens of different faiths and beliefs can converge into a more harmonious multitude.

The training of imams is but one small measure that should be part of a range of measures prescribed to banish the suspicions between different constituents of European citizenship, to restrain citizens from committing acts of hostility against each other, to restore mutual confidence between communities, to maintain order and justice, and to preserve liberty. The challenge confronting Europe, a continent in gestation in the age of globalization, is not exclusively related to the religion of Islam, but mainly a challenge to 
accommodate the cultures and traditions of immigrants from the Islamic world and post-colonial societies, and in general to adjust to the changing, globalized world. Whether in imams' training or other measures related to migration in general, it is wise to adopt a new approach that would combine respect for Islamic traditions, compliance with the undeniable sovereignty of the host countries, and the responsible use of liberties afforded by the new media of communication. As Ednan Aslan writes, we should not build an image of a 'super-imam' who we expect to be the panacea to all societal ills (Aslan and Windisch, 2012, p. 61). Instead, we have to be realistic and steady in our study of the phenomenon for the betterment of society.

\section{References}

Aslan, Ednan and Zsofia Windisch. eds. 2012. The Training of Imams and Teachers for Islamic Education in Europe. Frankfurt am Main: Peter Lang.

Cesari, Jocelyne. 2013. Why the West Fears Islam: An Exploration of Muslims in Liberal Democracies. New York: Palgrave Macmillan.

Dassetto, Felice. 1996. La construction de l'islam européen: Approche socioanthropologique. Paris: L'Harmattan.

Dassetto, Felice, Silvio Ferrari, and Brigitte Maréchal. 2007. Islam in the European Union: What's at Stake in the Future. Brussels: European Parliament.

Drees, Willem and Pieter Sjoerd van Koningsveld. 2008. The Study of Religion and the Training of Muslim Clergy in Europe:Academic and Religious Freedom in the $27^{\text {st }}$ Century. Leiden: Leiden University Press.

Ferreiro Galguera, Juan. 2011. Islam and State in the EU:Church-State Relationships, Reality of Islam, Imams Training Centres. Frankfurt am Main: Peter Lang Verlag. Frégosi, Franck. 1998. La formation des cadres religieux musulmans en France. Approaches socio-juridiques. Paris: L'Harmattan.

Hussain, Dilwar and Henry Tuck. 2010. Education and Training of Islamic Faith Leaders in Europe: A Comparative Evaluation of Approaches in France and Germany. London: Institute for Strategic Dialogue.

Kassis, Hanna E. 1983. A Concordance of the Qur'an. Oakland: University of California Press.

King Baudouin Foundation. 2007. Training Imams in Europe: The Current Status. Brussels: King Baudouin Foundation.

Klausen, Jytte. 2005. The Islamic Challenge: Politics and Religion in Western Europe. Oxford: Oxford University Press.

Nielsen, Jørgen. 1999 Towards a European Islam. London: Palgrave Macmillan. Ramadan, Tariq. 1999. To Be a European Muslim. Nairobi: The Islamic Foundation. 
Shadid, Wasif and Pieter van Koningsveld, eds. 2002. Religious Freedom and the Neutrality of the State: The Position of Islam in the European Union. Leuven: Peeters.

Taylor, Charles. 2007. A Secular Age. Boston: Belknap Press.

Wehr, Hans. 1961. A Dictionary of Modern Written Arabic. Wiesbaden: Otto Harrassowitz.

\section{About the authors}

Mohammed Hashas is a Postdoctoral Research Fellow at LUISS Guido Carli University of Rome. In 2017 he was a Visiting Research Fellow at the Oxford Center for Islamic Studies and a Guest Scholar at the Leibniz-ZMO Zentrum Moderner Orient in Berlin. Besides the publication of various journal articles, Hashas has co-edited Islam, State and Modernity: Mohamed Abed Al Jabri and the Future of the Arab World (Palgrave, 2018), and is authoring The Idea of European Islam (Routledge, 2018).

Jan Jaap de Ruiter is an Assistant Professor at Tilburg University and trained as an Arabist. He is active in the public debate in the Netherlands on Islam and Muslims, and is the author of numerous opinion articles and columns in all of the major Dutch newspapers. Columns of his appeared on the website of Al Jazeera and the Huffington Post. His The speck in your brother's eye: Islam's perceived war against the West (Amsterdam: Rozenberg Publishers, 2012) analyses the ideology of the Dutch Party for Freedom in relation to Islam.

Niels Valdemar Vinding is an Assistant Professor at the Department of Cross-Cultural and Regional Studies at the University of Copenhagen, with a specific focus on Islam in Europe and European Muslim institutions. His current research, 'Imams of the West', is funded from 2014 to 2017 by the Carlsberg Research Foundation. His Ph.D. (2013) was on Muslim Positions in the Religio-Organisational Fields of Denmark, Germany and England.

Khalid Hajji is Secretary General of the European Council of Moroccan Ulema, and President of Brussels Forum for Wisdom and World Peace, both in Brussels. Hajji is also a professor of English Studies at Mohammed I University in Oujda, Morocco. He previously authored Lawrence d'Arabie ou l'Arabie de Lawrence (in French, 2003), From Modernity to Arab-Islamic Creativity (in Arabic, 2005), and edited Islam and the West: Toward a Better World (in Arabic, 2008). 



\title{
2 Rethinking Islamic law for Europe
}

The concept of the Land of Islam

Jasser Auda

Hashas, Mohammed, Jan Jaap de Ruiter, and Niels Valdemar Vinding (eds), Imams in Western Europe: Developments, Transformations, and Institutional Challenges. Amsterdam: Amsterdam University Press, 2018 DOI: 10.5117/9789462983830/CHO2

\begin{abstract}
The figh al-aqalliyāt ('Islamic law for Muslim minorities') is based on the problematic concept of living outside the 'Land of Islam'. This chapter offers a brief survey of the criteria for a land to be judged a 'Land of Islam'. It is shown that the basic criteria are the freedom and security for Muslims to practice the basic $s h a^{c} \bar{a}$ 'ir al-islām ('Islamic rules') and to serve $a l^{c}{ }^{c} a d l$ ('the cause of justice'). Ironically, a general assessment of many Western and Eastern Muslim-minority countries according to these criteria gives them a relatively high score on the 'Land of Islam' scale.
\end{abstract}

Keywords: fiqh al-aqalliyyāt, Land of Islam, Land of war, Land of Justice, Land of security

1 'Fiqh for minorities': On what basis?

Technically, a 'minority' is a community that counts for less than 50 per cent of a larger community. 'Muslim minorities' are believed to comprise somewhere between 40 and $5^{\circ}$ per cent of Muslims worldwide (Auda, 2005; Khalidi, 1989). However, a quick look at the body of literature developed for the figh al-aqalliyāt ('law for minorities') shows that the basic consideration for Muslims to be considered an aqalliya ('minority') is not population. Instead, it is whether Muslims live in what is called a non-Muslim 'country' (Hoffman, 2002), 'society' (Rath, Penninx, Groenendijk, and Meyer, 2001), 'context' (Murad, 1997), 'polity' (Masud, 1989), or under 'non-Muslim rule' (Waardenburg, 200o). Thus, the 'exceptional circumstance' here is not about the number of Muslims, but rather about how the country runs its 'polity', 'system', or 'rule' - which can be labelled 'non-Muslim', as far as 
the current discourse goes. For this reason, the political view of Muslims necessitated the creation of a special law which is called fiqh al-aqalliyāt ('Islamic law for minorities'), figh al-ghurba ('Islamic law for the homesick'), al-madhhab alūrübbiyy ('European School of Law'), European sharia, or European Islam (e.g. Haddad, 1991; Hofmann, 2002; Ramadan, 2000; Rohe, 2001).

However, the questions that are typically raised under the 'fiqh of minorities' theme do not have a clear relationship with this basic premise. Examples of such questions are whether or not it is lawful to: deal with banks, insurance companies, or mortgage lenders; work in restaurants or supermarkets that sell wine or serve pork; apply for citizenship in the 'non-Muslim' country of residence, especially if the oath of citizenship involves adherence to its monarchy, constitution, or military service; participate in a 'secular political system' by joining a political party, supporting certain (non-Muslim) candidates, or running for elections; greet non-Muslims, congratulate them during their religious festivals, or attend their weddings or funerals; and accept a marriage or divorce ceremony or court ruling from a non-Muslim judge or based on 'nonMuslim law' (Al-Saify, 2004). In all of these queries, there is no clear link between the juridical point of view and the fact that the inquirer does or does not live outside the 'Land of Islam'. In fact, all of these questions are valid everywhere.

The basic premise of a 'Land of Islam' is not about the percentage of Muslims in a country. Re-visiting the wide variety of fiqh literature to find what makes a certain territory or land 'Islamic' to start with, one realizes that:

1 The criteria of a 50 per cent + 1 majority of Muslims in a nation-state regardless of whether the state's constitution declares it to be a 'secular country', as in Turkey, or does not designate any specific religion, as in Nigeria and Indonesia, whether the head of state is non-Muslim, such as Lebanon, or whether Islamic rituals and acts of worship are not generally practiced, as in a number of former Soviet Union States - is not accurate. In fact, classical Islamic sources clearly state that whether Muslims are a majority or minority in a certain country is irrelevant when determining whether a land is a 'Land of Islam', and suggest other criteria instead. ${ }^{1}$

1 For example, Al-Qummi Al-Naisaburi (d. 728 h), 1996, vol. 3, p. 459; and Al-Bayhaqi (d. $45^{8}$ h), 1994, vol. 9, p. 16 
2 There is no mention of the other popularly mentioned criteria (recently applied to some regions of tribal Pakistan and Afghanistan, and of course under the 'Islamic State' (IS), in an attempt to be in a 'Land of Islam'): the application of 'Islamic' criminal law (or huudūd). I found no explicit mention in any school of law that specifically related the 'Islamicity of a state' or the concept of the 'Land of Islam' to the hudūd.

\section{$2 \quad$ What is the 'Land of Islam' or 'Islamic territory'?}

The question, then, is: What are the classic criteria for being inside or outside the 'Land of Islam', or the 'Islamic territory', which figh al-aqalliyāt is supposedly addressing? The results of a survey I carried out on various Sunni, Shia, and Ibadi Schools of Islamic Law, can be summarised in the following five criteria:

1 A land where Islamic rules (ậkām al-islām) apply. ${ }^{2}$

2 A land where a Muslim ruler has control (istīla $\left.\bar{a}^{\prime}\right)$ over its affairs. ${ }^{3}$

3 A 'Land of Security' (al-amn). ${ }^{4}$

4 A land where the practicing of public acts of worship (shac âंir al-islām) is allowed. 5

5 A 'Land of Justice' (dār al- $\left.{ }^{c} a d l\right) .{ }^{6}$

The following is a brief analysis of each of these concepts and their implications.

2 For example, Ibn Al-Qayyim (d. 751 h), 1997, vol. 2, p. 728; Reda, 1971; Al-Qummi Al-Naisaburi, vol. 3, p. 459; Al-Sarakhsi (d. 483 h), n.d., vol. 9, p. 182; and Al-Yunini (d. 726 h), n.d., vol. 2, p. 58. 3 For example, Al-Mawardi (d. 45o h), 1999, vol. 14, p. 267; Reda, 1971; Reda, n.d., p. 50; AlMawardi, 1985, vol. 1, p. 22; Al-Mawsili (d. 683 h), 2005, vol. 4, p. 178; and Al-Qummi Al-Naisaburi, 1996, vol. 3, p. 459 .

4 For example, Al-Bayhaqi, 1994, vol. 9, p. 16; Al-Kasani (d. $5^{8} 7$ h), 1982, vol. 7, p. 131; Al-Sarakhsi, n.d., vol. 9, p. 182.

5 For example. Ibn Taymiyyah (d. 728 h), 1386 h, vol. 1, p. 197; Al-Razi (d. 606 h), 1400 h, vol. 4, p. 43; Al-Mawardi, 1985, vol. 1, p. 275; Al-Nasa'i (d. 303 h), n.d., p. 10; Al-Kalabadhi Al-Bukhari (d. 384 h), 1999, vol. 1, p. 130; Al-Mawardi, 1999, vol. 2, p. 48; Ibn Al-Arabi (d 543 h), n.d., vol. 1, pp. 368 , 530; Al-Kasani, 1982, vol. 7, p. 113; Al-Razi (d. 604 h), n.d., vol. 32, p. 108; Al-Mawsili, 2005, vol. 4, p. 178; Al-Yunini, n.d., vol. 2, p. 58; Ibn Taymiyyah, n.d., vol. 23, p. 146, and vol. 28, p. 408.

6 For example, Ibn Taymiyyah, n.d., vol. 28, p. 146; Reda, n.d., pp. 50, 62; Al-Mawardi, 1985, vol. 1, p. 22; Al-Sarakhsi, n.d., vol. 9, p. 182; Al-Kasani, 1982, vol. 7, p. 80; Ibn Qudamah (d. 620 h), 1405 h, vol. 9, p. 14; Al-Nawawi (d. 676 h), 1405 h, vol. 10, p. 49; Al-Zar'i (d. 751h), 1405 h, vol. 1, p. 101; Ibn Abidin (d. 1252 h), 2000, vol. 4, p. 45; Al-Alusi (d 1270 h), n.d., vol. 18, p. 91; Nizam, 1991, vol. 2, p. 179; Reda, n.d., p. 5 o. 


\subsection{The 'Land of Islamic rulings'}

A popular definition of the 'Land of Islam' in classic sources is 'the land where the Islamic rulings apply'. 'What are these 'Islamic rulings'? Without getting into a technical juridical analysis of analogy by legal 'causes' and 'purposes', a rule can be labelled 'Islamic' if it fulfils the following two conditions:

1 The legal philosophy and purpose is to achieve the purpose and higher objectives of the maqāșid al-sharīca ('Islamic Law'), such as justice, freedom of choice, orderliness, and the preservation of faith/religion, soul/life, lineage/family, mind/intellect, dignity/honour, and wealth/ property (Auda, 2008).

2 It does not go against any fixed fundamental of Islam. Defining what is 'fixed' and what is 'variable' is a complex question, which I have attempted to answer elsewhere (Auda, 2006).

However, one could also say that a law is 'Islamic' if it is not 'non-Islamic'. I had an interesting conversation with a Muslim convert from London who insisted that every law in the United Kingdom is 'non-Islamic'. And when I asked why, he replied: 'Because the United Kingdom is outside the "Land of Islam".' And when I asked him to explain what he meant by that, he stated: 'Because the legislators are not Muslim.' I asked: 'The laws that criminalize theft, killing, monopoly, bribery, abuse, and so on, aren't they “Islamic laws"?' He answered: 'No, because the people who proposed them are not Muslim.' I replied: 'But that is irrelevant, isn't it?' He replied: 'No, because they did not have the right "intention” (niyya) when they proposed them.' I asked: 'What do you think their intention was?' He said: 'The achievement of justice, merely.' I exclaimed: 'Isn't justice an “Islamic” intention?' He replied: 'No, because they applied justice because it served the well-being of the people, not because it is ordained by God!' I said: 'But the well-being of the people is exactly the purpose of God's order to establish justice, isn't it?' We failed to agree on whether the purpose of Islamic law is justice, or if 'we apply the "Islamic law" anyway and justice will then emerge'.

In any case, given that the concept of law in the qānūn ('canon') sense was not known in the Muslim-majority countries until the late nineteenth century (Reda, 1898), it is safe to assume that the 'application of the sharia in the legal system', or 'sharia-compliant laws', were not part of the classic interpretation of the 'Land of Islam'. These concepts have a 'post-colonial'

7 For example, ref. 1, 4, 5, 12, 32. Ibn Al-Qayyim, 1997, vol. 2, p. 728; Reda, 1971; Al-Qummi Al-Naisaburi, 1996, vol. 3, p. 459; Al-Sarakhsi, n.d., vol. 9, p. 182; and Al-Yunini, n.d., vol. 2, p. 58. 
context, the analysis of which is beyond the scope of this chapter. Thus, the ahkām al-islām ('Islamic rulings') were explained in several other senses, which the rest of this chapter will attempt to explain.

\subsection{The 'Land of a Muslim ruler'}

To have a Muslim ruler in istīlä' ('control') over the affairs of a certain land is a criterion that some classic and contemporary scholars used for judging whether it is indeed a 'Land of Islam'. ${ }^{8}$ Al-Mawardi, for example, explicitly mentions that 'when Muslims reside in and control a certain land, it becomes a Land of Islam' (1999, vol. 14, p. 267). However, this criterion is subject to a number of conditions, most importantly the ability of Muslims to practice their religious obligations, a public feeling of security, and the application of justice. A Muslim ruler who fails to observe or work towards these obligations jeopardizes his or her jurisdiction's status as a 'Land of Islam'. Sheikh Rashid Reda (n.d., p. 50) summarized the related opinions as follows:

The Land of Islam is a Land of Justice that has a true Muslim leader. This is contrary to a land that could be called a Land of Injustice, ruled by force dictated by nationalistic Muslims who do not observe the proper conditions of a legitimate Islamic leadership.

Thus, the existence of a level of security and freedom that is adequate for allowing Muslims to practice religion is, juridically, more essential than the religion of the ruler.

\subsection{The 'Land of Security'}

A number of imams - meaning the founders of the main legal theories or madhhabs - state that security is the original maqșüd ('purpose') of the differentiation between 'Land of Islam' and 'Land of War', and not 'Islam' versus 'non-Islam', per se. For example, imam Abu Hanifa states: 'The purpose ( $m a q s \underline{u} d)$ of calling a certain land a "Land of Islam" or a "Land of Disbelief" (kufr) is not Islam versus kufr. It is security versus insecurity' (Al-Kasani, 1982, vol. 7, p. 131).

In July 2008, I witnessed an interesting debate in Deoband, India, where a group of students from Darul Uloom University were asked: 'What do you

8 For example, Al-Mawardi, 1999, vol. 14, p. 267; Reda, 1971; Al-Qummi Al-Naisaburi, 1996, vol. 3, p. 459; and Al-Bayhaqi, 1994, vol. 9, p. 16. 
think India is? Dar al-Harb or Dar al-Islam (Land of War or Land of Islam)?' At first, there was almost a consensus on the fact that India cannot be Dar al-Islam, since 'Islam' has not ruled it since the days of the Mughals. I exclaimed: 'But it cannot be Dar al-Harb either because there is no actual "war" going on in India.' Many students, however, thought that the 'war on terror' in India is actually a war on Islam, and thus it converted India into a Dar al-Harb. Other students referred to the fact that Muslims in India do have the freedom to practice their religion and they are generally 'secure', which makes today's India a 'Land of Security', based on imam Abu Hanifa's statement above. I was delighted when I learned that in April 2009 Darul Uloom scholars had finally issued a fatwa stating that India is not Dar al-Harb but rather Dar al-Amn (Land of Security) - the purpose behind the classification anyway, as Abu Hanifa stated.

Mecca itself - according to imam al-Bayhaqi, for example - became a 'Land of Islam' after its 'conquest' only because of its newfound sense of security. He writes: "Mecca became a "Land of Islam" and "Land of Security" after its conquest because no one there was forced against his/her religion. Any other land is likewise if it acquires the same kind of security' (1994, vol. 9, p. 16).

It is clear from the classic definitions that security itself is a means to obtain the freedom to practice Islamic 'public acts of worship'. Several scholars mentioned that Muslims who enjoy enough security and freedom to practice public acts of worship actually live in a 'Land of Islam', even if they are a minority. Al-Qummi Al-Naisaburi explains: 'Muslims, even a minority, have a higher moral ground than non-Muslims, even if they were a majority, if they are not prevented from practicing the public Islamic acts of worship' (1996, vol. 3, p. 459). The next section elaborates on the Islamic 'public acts of worship', which appear to form a more basic criterion for whether a country can be considered a 'Land of Islam'.

\subsection{The 'Land of Freedom to Practice Islam'}

The majority of scholars and schools of Islamic law find the 'freedom to practise Islam' to be the 'true sign' that a land is a 'Land of Islam'. Many of them refer to prophetic traditions that are interpreted to mean just that, such as prophetic sayings about the importance of certain identifying acts, such as group prayers in the mosque, the call for prayer (adhān), pilgrimage, the celebration of religious feasts, and so on. Al-Mawardi writes: "The public acts of worship (shac $\left.a^{\prime} i r\right)$ of Islam such as group prayers in mosques and [the] call for prayers are the criteria by which the Prophet, peace be upon him, differentiated between the Land of Islam and the Land of Disbelief' 
(1985, vol. 1, p. 275). Al-Razi writes: 'If the Islamic acts of worship are evident in streets and public places, this certainly entails that Islam is dominant' (1400 h, vol. 4, p. 43). And Ibn Taymiyyah writes: 'The public acts of worship $\left(s h a^{c} \bar{a}^{\prime} i r\right)$ of Islam are the true signs that a certain land is a Land of Islam' (1386 h, vol. 1, p. 197).

I found that the 'public acts of worship' include a variety of Islamic rituals from the following list, according to all schools of Islamic law:

1 The five prayers. ${ }^{9}$

2 Calling for the prayers. ${ }^{10}$

3 Friday prayers. ${ }^{11}$

4 Fasting in Ramadan. ${ }^{12}$

5 Giving zakat ('charity'). ${ }^{13}$

6 Pilgrimage. ${ }^{14}$

7 Ablution. ${ }^{15}$

8 Feast prayers. ${ }^{16}$

9 Reading the Qur'an. ${ }^{17}$

10 Circumcision. $^{18}$

11 Sacrificing animals to feed the poor. ${ }^{19}$

12 Building mosques, and especially minarets. ${ }^{20}$

13 Greeting people with 'peace be upon you'. ${ }^{21}$

14 Charitable endowments $(a w q \bar{a} f) .{ }^{22}$

If we - objectively - assess various countries around the world based on Muslims' freedom to practice the above specific Islamic acts of worship, and create some sort of 'index' for them, we will quickly realise that many European countries score much higher than a number of Muslim-majority countries.

9 Al-Mawardi, 1985, vol. 1, p. 275; Ibn Al-Arabi, n.d., vol. 1, pp. 368, 530; Al-Razi, n.d., vol. 32, p. 108; and Ibn Taymiyyah, n.d., vol. 28, p. 408.

10 Ibid.

11 Ibid.

12 Ibn Al-Arabi, n.d., vol. 1, p. 530.

13 Al-Razi, n.d., vol. 32, p. 108.

14 Al-Kalabadhi Al-Bukhari, Bahral-Fawa'id, vol. 1, p. 130.

15 Ibid.

16 Al-Mawardi, 1999, vol. 2, p. 48.

17 Ibn Al-Arabi, n.d., vol. 1, p. 368; and Ibn Taymiyyah, 1386 h, vol. 28, p. 408.

18 Al-Kalabadhi Al-Bukhari, 1999, vol. 1, p. 130.

19 Al-Kalabadhi Al-Bukhari, 1999, vol. 23, p. 146.

20 Al-Kalabadhi Al-Bukhari, 1999, vol. 28, p. 408; Al-Yunini, n.d., vol. 2, p. $5^{8}$.

21 Al-Kasani, 1982, vol. 7, p. 113.

22 Al-Yunini, n.d., vol. 2, p. $5^{8}$. 


\section{Conclusion: The 'Land of Justice'}

This criterion, i.e., the achievement of justice, is so central to the Islamic concept of the 'Land of Islam' to the extent that the term 'Land of Justice' appears to be used interchangeably with 'Land of Islam' in numerous sources. ${ }^{23}$ Justice is the basis of all of the above criteria, according to Islamic jurists, and hence more fundamental to Islamic principles and purposes. Thus, an 'Islamic leadership' that is not based on justice but on 'aşabiyya ('ethnic solidarity') does not constitute a valid condition for a 'Land of Islam'. Rashid Reda (1922), for example, writes:

The land of justice, which is the Land of Islam, is a land that has a true leader who establishes justice. This is contrary to the land of injustice and aggression', in which governorship is based on some Muslims' 'ethnic solidarity' ('așabiyya), regardless of the establishment of the Islamic rulings. ${ }^{24}$

Al-Mawardi also stresses the importance of the 'competence' and 'good character' of the leader of the 'Land of Justice'. He writes: 'People who are qualified to make decisions in the Land of Justice should choose a leader who possesses a good character and [who is] competent' (1985, vol. 1, p. 22). Ibn Taymiyyah holds the 'achievement of justice' in a state as the most fundamental and deserving of God's support, even for a 'nation of disbelievers'. He writes:

In this life, people's situations uphold when justice prevails in their society even if they fall into various kinds of sins. However, people's situations do not uphold when injustice and lack of rights prevail in their society. That is why the saying goes: God upholds a state established on justice, even if it were a nation of disbelievers, and would not uphold a state established on injustice, even if it were a nation of Muslims. The other saying goes: This world lives with justice and disbelief, and does not live with injustice and Islam. The Prophet, peace be upon him, had said: 'No sin has a faster divine punishment than the sin of injustice ...' Thus, people of injustice fail in this life, even if they were to be forgiven in the hereafter. This is because justice is the universal law of things. (n.d., vol. 28, p. 146)

23 For example, Ibn Taymiyyah, n.d., vol. 28, p. 146; Reda, n.d., pp. 5o, 62; Al-Mawardi, 1985, vol. 1, p. 22; Al-Sarakhsi, n.d., vol. 9, p. 182; Al-Kasani, 1982, vol. 7, p. 80; Ibn Qudamah, 1405 h, vol. 9, p. 14; Al-Nawawi, 1405 h, vol. 10, p. 49; Al-Zar i, 1405 h, vol. 1, p. 101; Ibn Abidin, 2000, vol. 4, p. 45; Al-Alusi, n.d., vol. 18, p. 91; Nizam, 1991, vol. 2, p. 179.

24 Reda, n.d., pp. 5o, 62. 
The 'Land of Islam' and 'Land of War' is, then, a false dichotomy; a more realistic and 'logical' classification looks at not only the grey levels between the black and white extremes, but also at the various colours. In other words, the achievement of the above criteria, especially the three that are most fundamental (namely, security, freedom of practicing religion, and justice) is relative, whether in Muslim-majority or Muslim-minority societies.

Therefore, and regardless of popular opinion, a country that is juridically worthy of being a 'Land of Islam', a 'Land of Security', or a 'Land of Justice' will achieve a relatively high score on the criteria detailed above. This judgment obviously requires a comprehensive and realistic survey of various countries to create a 'ranking' of some sort. However, a rough but very reasonable assessment of many Western and Eastern Muslim-minority countries' performance on the above criteria gives them a relatively high score on the 'Land of Islam' scale.

\section{References}

Al-Alusi, Shihabuddin. N.d. Ruh al-Màani fi Tafsir al-Quran al-Adheem, vol. 18. Beirut: Dar Ihyaa al-Turath al-Arabi.

Al-Bayhaqi, Ahmad Ibn Al-Hussein. 1994. Sunan al-Bayhaqial-Kubra, vol. 9. Mecca: Dar al-Bazz.

Al-Kalabadhi Al-Bukhari, Abu-Bakr. 1999. Bahr al-Fawa'id, vol. 1. Beirut: Dar alKutub al-Ilmiyah.

Al-Kasani, Alauddin. 1982. Bada'i al-Sana'i' fi Tartib al-Shara'i', vol. 7. Beirut: Dar al-Kitab al-'Arabi.

Al-Mawardi, Ali Ibn Mohammad. 1985. Al-Ahkam al-Sultaniyah wal-Wilayat alDiniyah, vol. 1. Beirut: Dar al-Kutub al-Ilmiyah.

Al-Mawardi, Ali Ibn Mohammad. 1999. Al-Hawi al-Kabeer fi Figh Madhab al-Imam al-Shafie, vol. 2 \& 14. Beirut: Dar al-Kutub.

Al-Mawsili, Abdullah. 2005. Al-Ikhtiyan, vol. 4. Beirut: Dar al-Kutub al-Ilmiyah.

Al-Nasa'i, Ahmad. N.d. Al-Jum'ah. Amman: Al-Turath.

Al-Nawawi, Muhammad. 1405 h. Rawdat al-Talibin wa 'Umdat al-Muftim, vol. 10. Beirut: Al-Maktab al-Islami.

Al-Qummi Al-Naisaburi, Nizamuddin. 1996. Tafsir Ghara'ib al-Qur'an, vol. 3. Beirut: Dar al-Kutub al-Ilmiyyah.

Al-Razi, Mohammad Ibn Omar. 1400 h. Al-Mahsul, vol. 4. Riyad: Jamiat al-Imam. Al-Razi, Mohammad Ibn Omar. N.d. Al-Tafsir Al-Kabeer, vol. 32. Beirut: Dar al-Kutub al-Ilmiyah. 
Al-Saify, Mahmoud. 2004. 'Fiqh for Muslim Minorities: A New Era for Islamic Jurisprudence'. MA thesis, University of Leiden.

Al-Sarakhsi, Shamsuddin. N.d. Al-Usul, vol. 9. Beirut: Dar al-Marifa.

Al-Yunini, Qutbuddin. N.d. Dhail Mir'at al-Zaman, vol. 2 Amman: Al-Turath.

Al-Zar i, Mohammad Ibn Abu Bakr. 1405 h. Al-Jawab al-Kafi Liman Sa'al 'an al-Dawa' al-Shafi, vol. 1. Beirut: Dar al-Kutub al-Ilmiyah.

Auda, Jasser. 2005. 'Islam'. In Encyclopedia of the Developing World, edited by Thomas M. Leonard. New York: Routledge.

Auda, Jasser. 2006. Figh al-Maqasid. Virginia: International Institute of Islamic Thought (IIIT).

Auda, Jasser. 2008. Maqasid al-Shariah as Philosophy of Islamic Law: A Systems Approach. London: International Institute of Islamic Thought (IIIT).

Haddad, Yvonne Yazbeck. 1991. 'The Challenge of Muslim Minorityness: The American Experience'. In The Integration of Islam and Hinduism in Western Europe, edited by Wasif Shadid and Pieter van Koningsveld, 134-153. Kampen: Kok Pharos.

Hoffman, Abdul Hadi Christian H. 2002. 'Muslim Minorities in Non-Muslim Countries'. Paper presented at 'The Reality of Islam in a Changeable World', the $14^{\text {th }}$ General Conference of the Supreme Council for Islamic Affairs, Cairo, Egypt, May.

Hofmann, Murad Wilfred. 2002. 'Muslims as Co-Citizens of the West: Rights, Duties \& Prospects' [interview], IslamOnline website, 25 May.

Ibn Abidin, Mohammad. 200o. Hashiyat Raddul-Mukhtar, vol. 4. Beirut: Dar al-Fikr. Ibn Al-Arabi, Abu Bakr. N.d. Ahkam al-Quran, vol. 1. Lebanon: Dar al-Fikr.

Ibn Al-Qayyim, Shamsuddin. 1997. Ahkam Ahlal-Dhimmah, vol. 2. Beirut: Ramady/ Ibn Hazm.

Ibn Qudamah, Abdullah Al-Maqdisi. 1405 h. Al-Mughni fi Fiqh al-Imam Ahmad, vol. 9. Beirut: Dar al-Fikr.

Ibn Taymiyyah, Ahmad. 1386 h. Al-Nubuwat, vol. 1. Cairo: Al-Matba`ah al-Salafiyah. Ibn Taymiyyah, Ahmad. N.d. Kutub wa Rasa'il wa Fatawa, vols. 23 \& 28. Cairo: Maktabat Ibn Taymiyyah.

Khalidi, Omar. 1989. 'Muslim Minorities: Theory and Experience of Muslim Interaction in Non-Muslim Societies'. Journal Institute of Muslim Minorities Affairs, 10(2): 425-437.

Masud, Muhammad Khalid. 1989. 'Being Muslim in a Non-Muslim Polity: Three Alternative Models'. Journal Institute of Muslim Minorities Affairs, 10(1): 118-128.

Murad, Abdul Hakim. 1997. 'British and Muslim'. Paper presented at a conference of British converts, September.

Nizam, al-Sheikh. 1991. Al-Fatawa al-Hindiyah, vol. 2. Beirut: Dar al-Fikr.

Ramadan, Tariq. 2000. To be a European Muslim. Leicester: The Islamic Foundation. 
Rath, Jan, Rinus Penninx, Kees Groenendijk, and Astrid Meyer. 2001. Western Europe and its Islam. Leiden: Brill.

Reda, Rashid. 1898. 'Mujmal Al-Ahwal Al-Siyasiyah'. al-Urwah al-Wuthqa, 29 February.

Reda, Rashid. 1971. Fatawa. Compiled by Salahuddin Al-Munajjid and Yusuf Khouri. Beirut: Dar al-Kitab al-Jadeed.

Reda, Rashid. [1922] N.d. Al-Khilafah. Cairo: Al-Zahra.

Rohe, Mathias. 2001. 'The Formation of European Shari'ah'. Paper presented at the 'Muslim Minority Societies in Europe International Workshop' at the University of Erfurt, 2-3 March.

Waardenburg, Jacques. 2000. 'Normative Islam in Europe'. In Paroles d'islam: Individus, sociétés et discours dans l'islam européen contemporain, edited by Felice Dassetto, 49-68. Paris: Maisonneuve \& Larose.

\section{About the author}

Jasser Auda is the Chairman of the Maqasid Institute and a Founding and Board Member of the International Union for Muslim Scholars. He is an international authority on the topic of objectives of the Sharia, and the author of Maqasid Al-Shariah as Philosophy of Islamic Law: A Systems Approach (The International Institute of Islamic Thought, 2008). 



\title{
3 The making of Islamic authority in Europe
}

\author{
Thijl Sunier
}

Hashas, Mohammed, Jan Jaap de Ruiter, and Niels Valdemar Vinding (eds), Imams in Western Europe: Developments, Transformations, and Institutional Challenges. Amsterdam: Amsterdam University Press, 2018 DOI: $10.5117 / 9789462983830 / \mathrm{CHO} 3$

\begin{abstract}
There is a growing body of scholarly work that addresses the transformations taking place in the ways Muslims experience, practice, and live Islam in Europe. One of the issues that have been taken up is the changing relationship between (established) religious authority and ordinary Muslims. ${ }^{1}$ There is a growing consensus that these relations are under pressure. Older, established configurations of authority are destabilized and increasingly challenged by rival voices and practices. However, neither the position that Islamic authority is simply generated from Islamic sources or the depiction of the Islamic landscape in Europe as thoroughly fragmented and individualized properly address the question of how religious authority is produced. How does authority become acknowledged, and how is it incorporated into people's life worlds? In this chapter, I argue that modes of religious knowledge production and conveyance do not just operate cognitively, but also involve a whole range of sensorial experiences that shape the relationship between religious practitioners and leaders.
\end{abstract}

Keywords: Islam in Europe, Islamic authority, globalization, knowledge production, lived Islam

1 I prefer the term 'ordinary Muslim' over the more commonly used 'lay Muslims' for want of a better way to denote on the one hand those Muslims who are not religious experts or necessarily knowledgeable in matters of Islamic theology, and on the other ordinary ways of acting, acting in everyday situations. I critically engage with the dominant assumption that theological reflection is first and foremost a matter of theologians. 
In the fall of 1977, an ideological conflict emerged between two groups of Turkish Muslims in the Netherlands. The conflict reached an apogee when a church located in a Rotterdam neighbourhood with a relatively large proportion of Turkish immigrants put its building at the disposal of Turkish Muslims during Ramadan. Two imams were invited from Turkey to lead the ceremonies. One belonged to the Süleymanli Movement, which had already been active among Turkish Muslims in Europe for years. The other was sent by the Turkish Directorate of Religious Affairs (Diyanet), the government department that regulates religious life in Turkey. The Diyanet feared that the Süleymanli Movement would gain more influence among Turkish Muslims at the time when the development of religious infrastructure in the Netherlands was gaining momentum. Both organizations claimed to speak on behalf of the majority of Turkish Muslims, so it was decided to let the attendees decide which of the two imams should lead the rest of the celebrations. The majority chose the Diyanet imam. Afterwards a debate broke out about how to interpret this choice. For Diyanet, it was a clear sign that the majority of Turkish Muslims opted for the official version of Islam promoted by the Turkish state - or at least a sign that there would be no major objection against the further involvement of Diyanet in religious affairs in Europe (Sunier, 1996). Similar conflicts also emerged in other European countries about the representation and guidance of Turkish Muslims. Soon after this event, the Diyanet's supporters founded the Islamic Association for Cultural and Social Guidance of Turks. One of the objectives was to maintain contact with the Diyanet in Turkey, which would not only provide imams for Turkish mosques in Europe, but also issue religious material, organize the pilgrimage to Mecca, and provide a whole range of other services for Muslims in the diaspora. ${ }^{2}$

Around 1983, Diyanet signed agreements with a number of European governments to send imams for a designated period, whose salaries the Turkish government would pay. The need for trained religious personnel among the quickly growing Turkish migrant community was one of the most pressing issues at that time. Although regular labour immigration had already been stopped for a number of years, these 'Diyanet imams' were exempt from the general immigration restrictions because of their special capacities. After serving a certain number of years, they would be replaced by new ones. 
By investing in the institutionalization of Islam in Europe and supporting the local initiatives of the mosque communities, Diyanet and the Turkish government made a very clever strategic move. The majority of Muslims in Europe still maintained strong ties with their country of origin and were relatively poor. The decision to financially support the building of the Islamic religious infrastructure in Europe gave Diyanet a very strong bargaining position in relation to rival movements, which had to organize their own religious services.

The reasons for Turkish organizations to extend or to transfer activities to Europe were manifold and differed from organization to organization. In Turkey, the state control of religious affairs was very strict, and the constitutional prohibition on using religion as a political tool left little room for religious organizations. In Europe, the constitutional freedom of religion provided much better opportunities (Sunier and Landman, 2015, p. 14). Opposition groups tried to escape state repression and the ever-stricter measures to control dissident religious activity by fleeing to Europe. The state-controlled Islam responded by investing in European activities.

Others considered the growing number of Turkish migrants in Europe an appropriate field to increase their influence. The largest actors were the Süleymanlis, the Milli Görüş, and the Diyanet, but Turkish nationalist parties also became active in the European scene. These actors struggled for control over the existing mosque associations, inviting them to join the umbrella organizations they had established. This often led to the fusion and fission of various groups, adding to the dynamics of organizational developments (Akgönül, 2005; Canatan, 2001; Kühle, 2012; Landman, 1992; Maréchal and El Asri, 2012; Sunier and Landman, 2015; Yükleyen, 2012). The Nurcu Movement and its offshoot Gülen Movement also extended their network to Europe, but chose to focus on knowledge acquisition and study rather than competing for the control of mosques. As a result of this competition, the institutionalization of Turkish Islam in Europe evolved relatively quickly. In the course of the 1980 s the Turkish landscape was more or less accomplished.

The case of the Rotterdam community described at the beginning of this chapter can be simply explained as an example of a fierce ideological struggle for influence over the rank-and-file between rival Islamic movements not particularly unique among Turkish Muslims, with only very limited relevance for how ordinary Muslims practice their religion. In this particular case, the common argument was that the majority of Muslims in the 1970s and 1980s had a rural background and were therefore not familiar with the ideological struggles taking place in Turkish cities. They simply wanted good and cheap accommodation. 
Such an explanation assumes that the Islamic (Turkish in this case) landscape in Europe was simply a copy of the situation in the countries of origin. I question that perspective. Patterns of settlement and institutionalization and negotiations with local authorities about religious accommodation are of course important factors that contributed to the shaping of Islam under migrant conditions. However, this case was first and foremost a struggle about religious authority and legitimacy in new circumstances. In many studies that address the processes of institutionalization, religious authority seems to be taken as self-evident or is not even mentioned at all (e.g., Laurence, 2012; Maussen, 2006; Mügge, 2010; Rath, Penninx, Groenendijk, and Meyer, 2001; Shadid and Van Koningsveld, 2008). I argue that, first, the making of religious authority is a decisive factor in the way Islam takes shape - especially under new and changing circumstances and in times of rapid societal change. Second, I argue that ordinary Muslims play a crucial role in the making and un-making of religious authority.

2

\section{Authenticating religious authority}

Let me first ponder the two concepts that I have introduced here: 'religious authority' and 'ordinary Muslims'. 'Religious authority' refers to theological legitimacy and persuasive powers (Chaves, 2003), and is much broader than leadership. It is a domain where negotiation and power are central constituting processes and where tensions - but also innovations - in Muslim communities become manifest (Volpi and Turner, 2007). It is commonly accepted that modernization, globalization, and the emergence of the modern mass media have unsettled traditional religious authority (Caeiro, 2010; Mandaville, 2007; Masud, Salvatore, and Van Bruinessen, 2009; Salvatore, 2006, 2007; Van Bruinessen, 2003). The modern mass media has allowed a tremendous increase in the number of voices in the public sphere (De Koning, 2008; Eickelman and Anderson, 2003). This shift has been referred to as the fragmentation and pluralization of religious authority and knowledge production; it has also affected Islamic authority. It can be observed throughout the Muslim world, but probably most explicitly in Europe. However, to refer to these developments in terms of the fragmentation of authority is only partly true. As Peter Mandaville rightly argues:

The tacit normative undercurrent within this line of analysis has often been the idea that such changes represent a positive and progressive 'democratization' of knowledge production and reception in Islam, with 
Muslims increasingly reshaping religion with their own hands (rather than relying on 'crusty' clerics) and willing to offer these new formulations to critical consumers within the market of the public sphere. Yet it should be obvious that the mere fact alone of more people being able to serve up a wider range of ideas about religion - that is, a widening of the public sphere - does not in itself produce more pluralistic (in the sense of being more tolerant or open-ended) knowledge. (2007, p. 102)

In many studies of contemporary religious change and renewal there is a tendency to consider religious authority as an external normative force located in the domain of conformity, power, and obligation, which is set against the domain of spirituality, authenticity, individualization, and personal subjectivity - a distinction much in line with Charles Taylor's 'subjective turn' (Taylor, 2002).

But although the individual search for knowledge may certainly have contributed to the fragmentation of authority, this does not necessarily mean that authority has faded or become irrelevant. New forms of acquiring knowledge and new (lay) preachers may contribute to fragmentation, but they do not replace existing religious authorities altogether; rather, they are new players on the religious market alongside other religious specialists. As Daan Beekers shows, religious subjectivation is not just an individual process of self-fulfilment, the victory of individual religious agency over submission to an external religious authority. Subjectivation also entails a process of subjection to religious authority, a quest for truth. This is what he calls a 'Foucauldian understanding of subjectivation' (Beekers, 2015, p. 139). It should be emphasized that subjection to religious authority (human or otherwise) does not mean unconditional and unquestioning submission to a certain regime of truth.

Religious authority is not just a normative external force vested in established institutions, religious scholarship, or religious sources that ordinary believers either submit to or reject. Rather, as George Husinger (1961) has reminded us, a theological utterance and its application are inextricably linked to each other and cannot be separated. Religious texts are mute, unless they have an audience and are applied and interpreted. Talal Asad has argued:

That enquiry, broadly speaking, has to do with the theme of power and religion, not merely in the sense in which political interests have used religion to justify a given social order or to challenge and change it (an important question in itself) but in the sense in which power constructs 
religious ideology, establishes the preconditions for distinctive kinds of religious personality, authorises specifiable religious practices and utterances, produces religiously defined knowledge. (Asad, 1983, p. 237)

What is at stake here is the contextuality of authority and knowledge production in what Michael Lambek calls a 'political economy of knowledge': 'How are we to characterize the order to which people submit? Where is the locus of power?' (Lambek, 1990, p. 28). I define (the making of) religious authority as an ongoing process of the authentication and production of religious knowledge. This authentication process is inextricably linked with legitimacy and persuasion.

Making religious authority is a constant dynamic; it is not just the imposition of normative frames onto ordinary believers, but also bottom-up critical reflection on authoritative frames. These reflections are related to the everyday lives and experiences of 'ordinary Muslims'. 'Everyday Islam', 'lived Islam', and 'ordinary Muslims' all refer to an emerging scholarly field in the study of religion and an epistemological and methodological shift from institution to practice. 'Ordinary' denotes two things: Muslims who are not religious experts; and quotidian activities, practices, and experiences. 'Everyday religion' addresses the bottom-up experiences and religious practices of people of faith. The focus on everyday experiences, ordinary ethics, and everyday religion postulates that theologies are not made exclusively in official venues by religious experts, but at a multiplicity of places and occasions and not only by experts. 'Expert religion' is, then, a specific domain of activity and reasoning, to be distinguished from the no less important religious activities of non-experts (Davie, 2006, p. 274). Samuli Schielke and Liza Debevec (2012) draw on Michel De Certeau's (1984) notion of the everyday as the domain where ordinary Muslims confront the order and discipline of powerful institutions. 'Everyday Islam' brings back the agency of ordinary Muslims (Bracke, 2008; Mahmood, 2005), who practice 'tactical religion' as a domain of creativity and innovation that is in constant interaction with the dominant 'strategic religion', which is 'constantly engaged in operations to delimit and guard its sacred spaces' (Woodhead, 2013, p. 16). In short, 'ordinary Muslims' and 'everyday Islam' refer to a perspective and category of practices that is less visible, but can be innovative and even transformative.

Skimming the recent literature that operates the concept of 'everyday Islam' or 'lived Islam', however, it seems too often be too broad and hardly focused on the ethical and normative dimensions of how Islam is lived and experienced in daily situations. 'Lived Islam' tends to become shorthand for the things done by people whom we generically call Muslims. According to this definition, an individual performing his or her religious duties is as much 
'lived Islam' as the practice of a football team made up of people with an Islamic background. In other words, there is a tendency to categorize the activities and views of people with Islamic backgrounds as Islamic without any thorough conceptual underpinning. I would, in certain circumstances, qualify both activities as Islamic - but not because they are performed by 'Muslims'. Do we use the term 'Muslim' generically, or does it have specific (religious or cultural) connotations? Are Muslims' practices different from those of non-Muslims? Is it a cultural category? Or are Muslims the people who practice a religion? The way we categorize people has crucial methodological implications because it determines where and how we observe, what we include, and what we leave out in our observations. We also need to not distinguish the acts, practices, and convictions of Muslims on the basis of a priori ethical criteria. We need to not distinguish between the practices of people with faith and those of people with only Islamic backgrounds; rather, we have to critically and rigorously address the ethical issues that are at stake and how people reflect on them.

Different experiences lead to different interpretations of the same normative frames. When people find themselves in situations in which authoritative scripts are no longer self-evident or when a moral breakdown occurs, transformation is likely to follow. As Jarrett Zigon argues, ethics is always about stepping into an uncanny situation and back again into the unreflective comfort of the familiar. 'But this return from the ethical moment is never a return to the same unreflective moral dispositions. [...] It is in the moment of breakdown, then, that it can be said that people work on themselves, and in so doing, alter their very way of being-in-the-world' (Zigon, 2007, p. 138, my emphasis). Two Muslims, one living all of his or her life in a tiny, remote village, the other in a big city in Europe, may refer to the same normative principles, but they have built up completely different ethical reference schemes. If one shares their experiences with others - a process that has been altered tremendously due to the use of modern media - we come closer to a reflection on the very authoritative status quo. Critical reflection may generate inventiveness and renewal, and will impact religious authentication, the social process that confers normative authority on persons, rules, or institutions.

\section{$3 \quad$ A political economy of religious knowledge}

The Islamic landscape in Europe towards the end of the 1980s was formed by the configuration of power amongst Muslims, host countries' policies on migration and integration, and the relationship between the states and 
religion (see Laurence, Part I). The general observer of the organizational landscape of Muslims in Europe about three decades ago would probably conclude that the picture was clear and simple: there were Muslims with strong familial ties back home; religious practices were rooted firmly in their countries of origin; and mosques were run by Muslim organizations that had origins in the home countries, and were often controlled from a headquarters there as well. Political and doctrinal dividing lines followed a similar pattern, and religious authority was firmly in the hands of the traditional ulama, who were often sent from the home countries. Islamic observances and religious life revolved around the mosque and were practiced in familial and communal networks based on a common origin. Leadership and sources of religious authority were believed to self-evidently emanate from religious doctrine.

Since the vast majority of Muslims in European countries have a migrant background, issues of integration, minoritization, and not least political and cultural controversies largely determine how political decision-making evolves and how religious freedom and religious equality take shape. Until the end of the 1970s, the cultural and religious background of migrants did not play a significant role in debates about their position in society. Migrants were defined in terms of their ethnic origin, but this had no political consequences. Migrants were primarily seen as members of a temporary labour force who would return to their countries of origin. Policies across Europe were based on this idea of temporariness. The creation of religious facilities was therefore seen as something that should be left solely to private initiatives. No special policies were needed, as it was believed to be a self-regulating process (Nielsen, 1992; Rath, Penninx, Groenendijk, and Meyer, 2001; Sunier, 1996).

Towards the end of the 1970s, some important developments took place. The number of immigrants increased considerably, mainly through family reunions. These families settled in the old quarters of the main town centres and altered the urban landscape considerably. Although returning to their country of origin was still the intention of the vast majority of Muslims, their actual return was postponed. Many migrants could not afford to return home. As a consequence, the need for religious facilities increased, especially the need for qualified religious personnel (Abadan-Unat, 2011; Landman, 1992). Towards the beginning of the 1980s, governments acknowledged that the majority of the migrants were planning to stay permanently. In some countries this resulted in elaborate programmes to integrate migrants into the host countries; in other countries, it was basically through general legislation that integration would take place. The gradual transformation from migrants to 
settlers also resulted in a stronger emphasis on their cultural backgrounds. Governments realized that migrants brought their cultural and religious backgrounds with them. This 'culturalization' process would intensify in the 1990s and 2000s (Duyvendak, Tonkens, and Hurenkamp, 2010).

Across Europe, the emerging Islamic organizations were increasingly perceived as organizations for migrants. This was certainly not unfavourable for Islamic organizations, as it provided the political legitimization to set up an Islamic infrastructure. But a seemingly opposite effect took place at the same time. Developments in the Islamic world such as the revolution in Iran (1979) and the assassination of the Egyptian president Sadat (1981) resulted in the 'Islamization' of migrants: the over-emphasis on the religious background of migrants as an explanation for their moods and motivations. Migrants with completely different backgrounds were lumped together under the heading of 'Muslim culture'. Although the position of migrants was the result of a complex interplay of economic, social, political, and ideological factors, assumptions about the nature of Islam became a dominant explanatory factor. Towards the end of the 1980s, this discursive transformation was almost fully accomplished and would further develop in the 1990s and 2000 s.

One of the consequences of the 'Islamization' of policy discourses was the emergence of a specific type of leadership among Muslims. These leaders had lived in Europe for quite some time, knew the language and society of residence quite well, and acted as intermediaries between Muslim migrants and the host society. They were entrepreneurs rather than 'ideologists', and were oriented towards mobilizing as many resources as possible. They emphasized that Islamic organizations should be considered the main forms of 'self-organization' among migrants. These leaders increasingly took part in societal discussions about the position of migrants, thereby influencing the ways the situation was understood and assessed. They represented the Muslim populations in the countries of residence and articulated Muslim needs and what it meant to be Muslim in a non-Islamic society. By stressing the 'foreign' aspect of Islam as part of the cultural heritage of a specific group of migrants, they were able to convince policymakers that certain facilities were necessary. What these leaders were in fact emphasizing was the unique character of this cultural and religious heritage, and the fact that they were the only ones who had access to these communities. This 'enclavization' of culture and religion impacted how religious authority was produced and reconfirmed. The almost complete conflation of religion and migrant culture made Islam into a 'foreign' element, and reinforced the idea of the exceptional position of Islam and that religious authority was predominantly a matter of the countries of origin. 
In the course of the 1990s, many Muslim organizations had made a fundamental shift in their political agendas. This was mainly the result of the increasing influence of a younger generation and the 'cognitive shift' from an orientation towards the countries of origin into a focus on the host country (Sunier, 1996). There were two main reasons for this shift: the increasing upward mobility of Muslims, and the fundamental transformation of Muslims from migrants to permanent residents in European societies. From organizations of 'foreigners', they developed into organizations that asked for a place in society as Muslim citizens. Whereas in the 1980 os the 'migrantization' of Muslims turned out to be an effective strategy, leaders now had to convince society that there was no fundamental contradiction between being Muslim and being a European citizen. Many young leaders considered 'migrantization' a weak bid, as it emphasized the role of Muslims as victims and outsiders. As to religion many spokespersons adopted a strategy of pillarization. As individual citizens migrants should integrate into society, but as Muslims they should have the right to set up their own institutions just as Catholics and Protestants do. This shift paralleled the emerging discussion about the place of Islam in European nation-states and the gradual 'racialization' of Islam (Silverstein, 2005).

In short, the developments of the last two decades have distorted the religious life of Muslims in Europe and unsettled power relations. Taking a closer look at the changes, we can observe two (seemingly contradictory) developments. On the one hand, the Islamic landscape in Europe has increasingly operated according to local dynamics and become less dependent on agents in the countries of origin to determine their agendas. On the other, a relatively wealthy, well-educated, and mobile middle class has emerged among Muslims in Europe. Due to the rapid spread of the modern mass media, transnational networks have increased, producing a multiplicity of forms and modes through which Muslims sustain relations across borders. Islamic organizations in Europe have to resort to other means than the 'old' emotional, familial, and financial bonds that once linked migrant communities with their country and region of origin. Other Islamic movements are also changing their strategies, and new players have emerged. Today we find a wide array of different organizational patterns and networks operating simultaneously among Muslims.

While the countries of origin used to be the dominant guiding factor in determining the development of organized Islam among migrants in Europe, the changing situation has seriously undermined this dominance. The contemporary landscape of European Islam must be approached as a complex multi-polar and multi-directional field, in which the modern mass media and socio-economic developments are crucial co-shaping factors. 
When we look at the present-day Islamic landscape in Europe, the picture is complex. Organizations have changed or reformulated their policies and activities. The number of mosques and religious associations that are not organized along ethnic lines has increased sharply. A considerable number of young people no longer go to ordinary ethnicity-based mosques or have abandoned Islam altogether, while others opt for more radical variants of Islam or explore new modes and expressions of religiosity and piety. This has had a tremendous impact on the established ways of conveying religious knowledge. Traditional sources of religious authority have come under pressure; there is an enormous increase of semi-religious activities and practices that do not fit the picture of 'mainstream' religion.

\section{$4 \quad$ Islamic authority: Future prospects}

As I stated above, the fragmentation of religious authority and knowledge production should not be seen as a shorthand for the process of individualization, a 'copy-paste' or 'do-it-yourself' Islam under the influence of an ongoing secularization process (Cesari, 2004). Young Muslims also seek guidance and develop new notions of belonging. However, the circumstances and conditions in which this takes place are fundamentally different from those in a migration context. Consequently, the sources for the making and re-making of religious authority have also changed. Today the sources of Islamic authority are more diverse and unstable than ever before; modernization, the changing characteristics of migration, globalization, and the emergence of the modern mass media have unsettled traditional religious authority. The multiplicity of public voices has affected the making of Islamic authority in European countries. The authoritative frames and institutional settings that emerged in the early years of migration are still functioning, but their legitimacy is questioned by a growing number of Muslims born and raised in Europe. A wide variety of issues of faith that used to be undisputed are now brought into question. Religious authority has to be reconfirmed and reproduced continuously, and in contemporary media-saturated societies it increasingly needs to respond to the forms of auratic and charismatic power found in the mass media. In most studies that deal explicitly with doctrinal issues, Islamic leaders and organizational arrangements - in short, established institutional settings - are the principal focus. I contend that the role of ordinary Muslims in the making of religious authority and leadership is a crucial, but neglected venue of inquiry. 
This is of course not a uniquely Islamic phenomenon. The increasing diversification and multiplication of religious audiences, the growing competition for followers, and the emergence of religious marketplaces have changed how religious practitioners perceive religious authority. This should not be understood in the narrow sense of a market system of demand and supply, where people make choices based on rational calculations of profit. Instead it should be understood more loosely, in the sense of a field of competition for audiences and followers who can be attracted by a strong public presence and seducing and convincing rhetoric, performance, and imagery. The older 'legitimized' and established categories of authority erode, and the capacity to disseminate specific understandings of religious practices and beliefs become increasingly based upon rhetoric, performances, and visual events (image bites). Miranda Klaver (2011) showed how 'pastorpreneurs' in the Pentecostal church have developed a mode of authority in which they combine entrepreneurial business skills with an orthodox Christian message, fostering a neo-Pentecostal style of spirituality. In this case, the new media create, inform, and facilitate a particular mode of leadership built upon the 'media-savviness' of the local preacher.

The growth of the modern mass media has produced new forms of religious leadership and has fundamentally changed the modes through which religious messages are communicated and disseminated. ${ }^{3}$ Modern mass media has become a serious challenge to traditional forms of Islamic authority, mainly because it has allowed a tremendous increase in the number of voices in the public sphere (Schulz, 2006; see also Warner, 2002, p. 50). Traditional forms of religious learning are complemented and increasingly challenged by 'rival and alternative articulations of belief and practice' (Eickelman and Anderson, 2003). New technologies of communication circumvent traditional centres of learning and address new publics - mainly young Muslims in urban centres. They engage with parts of the public sphere that are considered secularized. The complexities of the modern urban life in which the majority of young Muslims live require specific competences. Robert Orsi argues that:

[they] arise out of the complex desires, needs, and fears of many different people who have come to cities by choice or compulsion (or both), and who find themselves intersecting with unexpected others (and with

3 As Meyer and Moors argue: '[new forms of mediation not only create] new styles of selfrepresentation, but also pinpoint new forms of religious experience that cast believers as spectators, spectacles as miracles, and God's blessing as prosperity' (2006, p. 9). 
unexpected experiences of their own subjectivities) on a complex field and in a protean physical landscape that insists on itself with particular intensity. (2005, p. 45)

They are both preachers and simultaneously opinion leaders - public figures that act upon certain situations and events. Sometimes they emerge from within the ranks of organizations, and in the course of becoming publicly known, they tend to detach from their original organizational bedrock and become free-floating public figures. They deliver speeches, appear in the media to comment on events, and in some cases become the centre of new devotional practices and beliefs. Sometimes these figures are genuine celebrities with fans rather than adherents. Their persuasive qualities emanate from a particular style of address and presentation (Meyer, 2006).

Performative styles, aesthetics, sensorial experiences and contextual factors are as important as discursive content to grasp the prominence of religious leadership (Schulz, 2006, p. 212). Leadership shifts from mere representation of a group to a form where the religious message and the representative's presence merge in particular and interdependent ways. The Islamic leader becomes part of the religious experience (Gräf and Skovgaard-Petersen, 2009; see also De Witte, 2008). New forms of religious mediation also constitute new audiences (Hirschkind, 2012, p. 5). These audiences consist of relatively unstable overlapping constituencies that have no institutional ties to leaders; similarly, there is no sharp distinction between opinion leaders, entrepreneurs, brokers, priests, stakeholders, celebrities, and politicians. Where these roles used to be separated, they are increasingly merging. They preach, but also deliver speeches, appear on television, take part in debates, operate websites, and make use of social media (see Boender and De Ruiter, Part I). There is no sharp distinction between Muslim and non-Muslim, religious and non-religious, and political and non-political spheres. It is precisely their elusiveness, in combination with the fact they do not correspond to the image of the traditional imam, that makes them suspect in the eyes of many politicians. For this reason, much of the research on Islamic leadership treats them as a potential danger (Niblett, 2006).

In the light of these developments, the question is how and in what direction the Islamic landscape of Europe will develop. The fragmentation process has prompted some observers to call for a European centre of religious authority to counter the ever-increasing, un-coerced and deregulated playing field in which these new preachers operate (see Galguera, Part II). Others have reflected on the development of fiqh for Muslims in minority 
situations (Al-Alwani, 2004; see also Auda, Part I), or the installation of sharia courts to deal with questions of Islamic law and morality of ordinary Muslims. What would be the main constituents of a 'European imamate'?

More generally, the question of why fragmentation is considered problematic arises. Governments no doubt fear a loss of control, as do established centres of religious authority, but why do countries need interlocutors who will speak on behalf of as many Muslims as possible? And why do the spokespersons of established Islamic institutions express worry about the loss of control over a growing proportion of the Muslim population? It is clear that there is a somewhat odd common interest between governments and religious elites in a 'domesticated Islam'. Elsewhere I have discussed this term to understand how and why European governments attempt to domesticate religious practices and institutions (Sunier, 2014; see also Bowen, 2004; Humphrey, 2009; Sunier, 2009). John Bowen uses this term to come to grips with the 'structural problem of articulating a global religious field onto a self-consciously bounded French nation-state'. He shows how the strategies through which the French state tries to create 'domesticated forms of Islam' imply a set of dilemmas regarding the control of transnational religious communities (Bowen, 2004, pp. 43-44). These dilemmas revolve around three basic issues: the behaviour of Muslims, control of the republic, and adaptation of Islamic norms to France.

This is not unique to Islam. The issue of loyalty has been raised in the case of other transnational religions as well (see Baker, 1997; Casanova, 1994; Sunier, 2004). However, while 'domestication' or the gradual rooting of a once-imported religion has usually been described as an organic process that takes years, in the case of Islam it has become a state project with a considerable sense of urgency. Loyalty has to be enforced rather than developed organically. The same occurs with respect to religious authority. Instead of facilitating the recasting of the religious landscape, European governments increasingly interfere in religious issues, thereby violating their own principle of the separation of religion and state.

\section{References}

Abadan-Unat, Nermin. 2011. Turks in Europe: From Guestworker to Transnational Citizen. New York: Berghahn Books.

Akgönül, Samim. 2005. Religions de Turquie, religion des Turcs. Paris: L'Harmattan. Al-Alwani, Taha. 2004. 'Toward a Fiqh for Minorities'. In Muslim Place in an American Public Square, edited by Zahid Bukhari, Sulayman Nyang, Mumtaz Ahmad, and John Esposito, 3-37. Walnut Creek: Alta Mira Press. 
Asad, Talal. 1983. 'The Construction of Religion as an Anthropological Category'. In Genealogies of Religion, edited by Talal Asad, 27-54. Baltimore: John Hopkins University Press.

Baker, Don. 1997. 'World Religions and National States: Competing Claims in East Asia'. In Transnational Religion \& Fading States, edited by Susanne Hoeber Rudolph and James Piscatori, 144-172. Boulder: Westview Press.

Beekers, Daan. 2015. 'Precarious Piety: Pursuits of Faith among young Muslims and Christians in the Netherlands'. PhD thesis, VU University Amsterdam.

Bowen, John. 2004. 'Does French Islam have Borders? Dilemmas of Domestication in a Global Religious Field'. American Anthropologist, 106(1): 43-55.

Bracke, Sarah. 2008. 'Conjugating the Modern-Religious, Conceptualizing Femal Religious Agency: Contours of a "Post-secular" Conjuncture'. Theory, Culture and Society, 25(6): 51-68.

Caeiro, Alexandre. 2010. 'The Power of European Fatwas: The Minority Fiqh Project and the Making of an Islamic Counterpublic'. International Journal of Middle East Studies, 42: 435-449.

Canatan, Kadir. 2001. Turkse Islam: Perspectieven op organisatievorming en leiderschap in Nederland. Rotterdam: Erasmus Universiteit.

Casanova, Jose. 1994. Public Religions in the Modern World. Chicago: University of Chicago Press.

Cesari, Jocelyne. 2004. When Islam and Democracy Meet: Muslims in Europe and in the United States. New York: Palgrave.

Chaves, Mark. 2003. 'Religious authority in the modern world'. Society, 40(3): 38-41.

Davie, Grace. 2006. 'Religion in Europe in the $21^{\text {st }}$ Century: The Factors to Take into Account'. European Journal of Sociology, 47(2): 271-296.

De Certeau, Michel. 1984. The Practice of Everyday Life. Berkeley: University of California Press.

De Koning, Martijn. 2008. Zoeken naar een 'zuivere' islam: Geloofsbeleving en identiteitsvorming van jonge Marokkaans-Nederlandse moslims. Amsterdam: Bert Bakker.

De Witte, Marleen. 2008. 'Spirit Media: Charismatics, Traditionalists, and Mediation Practices in Ghana'. PhD thesis, VU Amsterdam.

Duyvendak, Jan Willem, Evelien Tonkens, and Menno Hurenkamp. 2010. 'Culturalization of Citizenship in the Netherlands'. In Managing Ethnic Diversity after 9/11: Integration, Security, and Civil Liberties in Transatlantic Perspective, edited by Ariane Chebel d'Appolonia and Simon Reich, 233-252. New Brunswick: Rutgers University Press.

Eickelman, Dale and Jon Anderson. 2003. New Media and the Muslim World: The Emerging Public Sphere. Bloomington/Indianapolis: Indiana University Press. Gräf, Bettina and Jakob Skovgaard-Petersen, eds. 20og. Global Mufti: The Phenomenon of Yüsufal-Qaraḍ̄ài. London: Hurst \& Co. 
Hirschkind, Charles. 2012. 'Experiments in Devotion Online: The YouTube Khutba'. International Journal of Middle East Studies, 44: 5-21.

Humphrey, Michael. 2009. 'Securitisation and Domestication of Diaspora Muslims and Islam: Turkish immigrants in Germany and Australia'. International Journal on Multicultural Societies, 11(2): 136-154.

Husinger, George. 1961. 'Truth as Self-Involving: Barth and Lindbeck on the Cognitive and Performative Aspects of Truth in Theological Discourse', Journal of the American Academy of Religion, $\mathrm{LXI}(\mathbf{1}): 41^{-} 56$.

Klaver, Miranda. 2011. This is my Desire: A Semiotic Approach of Conversion in an Evangelical Seeker Church and a Pentecostal Church in the Netherlands. Amsterdam: Pallas Publication/Amsterdam University Press.

Kühle, Lene. 2012. 'Mosques and Organizations'. In Islam in Denmark: The Challenge of Diversity, edited by Jørgen Nielsen, 81-95. Boulder: Lexington Books.

Lambek, Michael. 1990. 'Certain Knowledge, Contestable Authority: Power and Practice on the Islamic Periphery'. American Ethnologist, 17(1): 23-40.

Landman, Nico. 1992. Van mat tot minaret: De institutionalisering van de islam in Nederland. Amsterdam: VU-Uitgeverij.

Laurence, Jonathan. 2012. The Emancipation of Europe's Muslims: The State's Role in Minority Integration. Princeton: Princeton University Press.

Mahmood, Saba. 2005. Politics of Piety: The Islamic Revival and the Feminist Subject. Princeton: Princeton University Press.

Mandaville, Peter. 2007. 'Globalization and the Politics of Religious Knowledge'. Theory, Culture and Society, 24(2): 101-105.

Maréchal, Brigitte and Farid El Asri. 2012. Islam belge au pluriel. Louvain-la-Neuve: Presses Universitaires de Louvain.

Masud, Muhammad Khalid, Armando Salvatore, and Martin Van Bruinessen, eds. 2009. Islam and Modernity: Key Issues and Debates. Edinburgh: Edinburgh Press.

Maussen, Marcel. 20o6. Ruimte voor de Islam? Stedelijk beleid, voorzieningen en organisaties. Amsterdam: Het Spinhuis.

Meyer, Birgit. 2006. 'Religious Sensations: Why Media, Aesthetics and Power Matter in the Study of Contemporary Religion'. Inaugural Lecture, VU Amsterdam.

Meyer, Birgit and Annelies Moors. eds. 2006. Religion, Media, and the Public Sphere. Bloomington: Indiana University Press.

Mügge, Liza. 2010. Beyond Dutch Borders: Transnational Politics among Colonial Migrants, Guest Workers and the Second Generation. Amsterdam: Amsterdam University Press.

Niblett, Robin. 2006. Islamic Extremism in Europe. Washington: Center for Strategic and International Studies (CSIS).

Nielsen, Jørgen. 1992. Muslims in Western Europe. Edinburgh: Edinburgh University Press. 
Orsi, Robert. 2005. Between Heaven and Earth: The Religious Worlds People Make and the Scholars Who Study Them. Princeton: Princeton University Press.

Rath, Jan, Rinus Penninx, Kees Groenendijk, and Astrid Meyer. 2001. Western Europe and its Islam. Leiden: Brill.

Salvatore, Armando. 2006. 'Power and Authority within European Secularity: From Enlightenment Critique of Religion to the Contemporary Presence of Islam'. Muslim World, 96: 543-561.

Salvatore, Armando. 2007. 'Authority in Question: Secularity, Republicanism and "Communitarianism" in the Emerging Euro-Islamic Public Sphere'. Theory, Culture and Society, 24(2): 135-160.

Schielke, Samuli and Liza Debevec, eds. 2012. Ordinary Lives and Grand Schemes: An Anthropology of Everyday Religion. Oxford: Berghahn Books.

Schulz, Dorothea. 20o6. 'Promises of (Im)Mediate Salvation: Islam, Broadcast Media, and the Remaking of Religious Experience in Mali'. American Ethnologist, 33(2): 210-229.

Shadid, Wasif and Sjoerd van Koningsveld. 2008. Islam in Nederland en België. Leuven: Peeters.

Silverstein, Paul. 2005. 'Immigrant Racialization and the New Savage Slot: Race, Migration and Immigration in the New Europe'. Annual Review of Anthropology, 34: $363-84$.

Sunier, Thijl. 1996. Islam in beweging: Turkse jongeren en islamitische organisaties. Amsterdam: Het Spinhuis.

Sunier, Thijl. 2004. 'Naar een nieuwe schoolstrijd?' BMGN, 119(4): 552-576.

Sunier, Thijl. 2009. 'Beyond the Domestication of Islam in Europe'. Inaugural Lecture, VU Amsterdam.

Sunier, Thijl. 2014. 'Domesticating Islam: Exploring Academic Knowledge Production on Islam and Muslims in European Societies'. Ethnic and Racial Studies, 37(6): 1138-1155.

Sunier, Thijl and Nico Landman. 2015. Transnational Turkish Islam: Shifting Geographies of Religious Activism and Community Building in Turkey and Europe. Houndsmill: Palgrave Macmillan.

Taylor, Charles. 2002. Varieties of Religion Today: William James Revisited. London: Harvard University Press.

Van Bruinessen, Martin. 2003. 'Making and Unmaking Muslim Religious Authority in Western Europe'. Paper presented at the Fourth Mediterranean Social and Political Research Meeting, Robert Schuman Centre for Advanced Studies, European University Institute, Florence, 19-23 March.

Volpi, Frédéric and Bryan Turner. 2007. 'Making Islamic Authority Matter'. Theory, Culture and Society, 24(2): 1-19.

Warner, Michael. 2002. 'Publics and Counter Publics'. Public Culture, 14(1): 49-90. 
Woodhead, Linda. 2013. 'Tactical and Strategic Religion'. In Everyday Lived Islam in

Europe, edited by Nathal M. Dessing, Nadia Jeltoft, Jørgen S. Nielsen, and Linda Woodhead, 9-23. Farnham: Ashgate.

Yükleyen, Ahmet. 2012. Localizing Islam in Europe: Turkish Islamic Communities in Germany and the Netherlands. Syracuse: Syracuse University Press.

Zigon, Jarrett. 2007. Morality: An Anthropological Perspective. Oxford: Berg Publishers.

\section{About the author}

Thijl Sunier is a Full Professor of Cultural Anthropology and holds the chair of 'Islam in European Societies' (VU Amsterdam). He is currently conducting a research project on Islamic authority and leadership in Europe. He is the Chairman of the board of the Netherlands Inter-University School for Islamic Studies (NISIS) and Executive Editor of the Journal of Muslims in Europe (JOME/Brill). One recent publication (with Nico Landman) is Transnational Turkish Islam. Shifting Geographies of religious Activism and Community Building in Turkey and Europe. (Palgrave Macmillan, 2015). 


\title{
4 Islams in Europe
}

\author{
Satellites or a Different Universe?
}

Jonathan Laurence

Hashas, Mohammed, Jan Jaap de Ruiter, and Niels Valdemar Vinding (eds), Imams in Western Europe: Developments, Transformations, and Institutional Challenges. Amsterdam: Amsterdam University Press, 2018 DOI: 10.5117/9789462983830/CHO4

\begin{abstract}
This chapter examines the process of adapting organized Islam to the institutional needs of the modern state. The adaptation processes that Islam is currently undergoing in Europe are compared to similar developments in the history of the Catholic Church.
\end{abstract}

Keywords: Islam in diaspora, Seminaries, church-state relationship, Catholic Church, United States

\section{1}

\section{Introduction}

The process of adapting organized Islam to the institutional needs of the modern state in Europe is happening less than a century after the agreements between the Catholic Church and the European states, and two centuries after that of Judaism. However, Islam cannot really be considered late if we take into account the great number of Muslim-majority countries that endured colonial continuity after the withdrawal of the Ottoman Empire, with the arrival of the French, British, and Italian Empires. Only through national independence has Islam begun to find a role in state institutions, a process that has become clearer through the pressure for democratization. This chapter compares the adaptation processes that organized Islam is currently undergoing in Europe with similar developments in the Catholic Church in the nineteenth-century United States. 
The democratization of Islamic nation-states is happening at the same time as the migration that has given birth to an overseas diaspora. We are thus witnessing the natural reaction of the older centres of Islamic religious authority to the appearance of new demographic groups. For example, there is growing investment by the capital cities of origin countries in the construction of monumental mosques in Europe for the use of their diaspora (Fuess, 2007). There is a range of training programmes for imams that are adapted to the language and culture of the European destination countries. And we can see the beginnings of hierarchical structures of ulama that are adapted to everyday life in Europe, of which the European Council of Moroccan Ulema is a prime example. In the past, these efforts were mostly uncoordinated and eclectic - and they still do not always manage to meet the actual demand for infrastructure and religious authority to respond to daily life. As of yet, none play the role of the ministry of waqf or traditional habous ('religious endowments') in Muslim-majority countries. From a historical point of view, it is natural for such an institutional gap to close slowly. Islamic schools are still rare on the European continent: the Netherlands counts a small number, while Great Britain has significantly more. Mosques built for the purpose of training make up only a small proportion of the Muslim places of worship in Europe.

One may wonder why the representative bodies of Islam such as the CFCM (Conseil français du culte musulman; French Council of the Muslim Faith) or the Deutsche Islam Konferenz (German Islam Conference) have not succeeded in managing everything after ten years of work (Kortmann and Rosenow-Williams, 2013). This delay is quite normal, considering the transformation of Islam into a minority religion on Western soil. It is unrealistic to imagine that such a transition could happen over a short period of time. This situation is stimulating an institutional response from the 'religious' capitals of various countries of Sunni Muslim origin, particularly those in the Maghreb (North Africa) and Turkey. Ultimately, the persistence of imported imams has had the greatest impact. The vast majority of imams in Germany were trained in Ankara, while most formally educated prayer leaders in France, Italy, and Spain have attended religious schools in Morocco, Algeria, Tunisia, or the Gulf. This is the case for the imams who arrive in Europe with visas for four or five years, as well as the hundreds of prayer leaders and reciters of the Quran who are sent to Europe to preach during the month of Ramadan. However, the home states have failed to provide sufficient religious personnel to cover all of the places of 
worship, hospitals, and prisons that serve the diaspora in Europe. How are we to consider this state of affairs? Is the pursuit of 'externalization' and the use of national Islamic bureaucracies in foreign countries just a quick fix? Are European societies missing the opportunity to take up the task of acclimatization?

There are ample tangible signs that more durable institutional solutions have begun to take shape among the Islamic diasporas in Europe. Despite the appearance of disarray, there are several institutional developments that mark the permanence and true beginning of various European national Islams. I hypothesize that this represents the passage 'towards European Islams' - a French Islam, a German Islam, a British Islam, etc. At the same time, it is important to emphasize that the idea of creating a 'European' Islam cut off from its origins in Muslim countries does not make sense; it would be rather like insisting on dropping the reference to Rome in 'Roman Catholicism'.

I would like to examine the logic governing the recent developments in this area to determine where these efforts place the institutional history of Sunni Islam since the end of the Ottoman Empire. We are witnessing a phase of 'professionalization' in Islamic religious training that is part of a broader institutional response to both the 'exogenous shocks' experienced by 'religious centres', including, for example, Algiers, Ankara, Rabat, Tunis, and, more recently, the challenge of a diaspora that is beyond the reach of the law and administration of the host countries (Bauböck and Faist, 2010). What we see is the attempt to maintain religious influence over a group that has grown dramatically during a very short period of time. Unlike the countries of origin, where there is one imam for every one or two mosques, until now it has not been possible to meet the demand for imams in Western European societies (Qattab, 2009). While what is happening in the diaspora represents only a small portion of the tip of the iceberg of changes in Islamic religious authority, mass immigration - sometimes equalling as much as 1o per cent of the country of origin's population - is the same fundamental challenge that led another world religion (Roman Catholicism) to take religious training more seriously in the nineteenth century.

The analogy that can and must be made between the institutional development of Islam and that of other religions that have recently experienced a diaspora - such as Catholicism in the nineteenth century - lies in what is 
now being set up to organize religious affairs relating to the Muslim faith. Indeed, it was the unplanned and involuntary establishment of Catholics as a religious minority outside of their religious metropoles that eventually allowed local Catholic bureaucracies to thrive (United States Conference of Catholic Bishops, 1992). We are witnessing the same process today in the development of Islamic religious governance in European host countries. The religious institutions of both Catholics and Sunni Muslims have reacted to this 'accident' of history - that is, the diasporas - that developed in the Americas in the nineteenth century for Catholics and in Europe in the twentieth century for Muslims. The comparison of these two religions requires a change in perspective and a revision of the common description of Islamic religious governance as 'non-hierarchical' or 'non-clerical'. The main institutional stakeholders here are precisely the hierarchical ministries of Islamic affairs in the countries of origin and the formal councils (ulama) that oversee the large and growing demand for guidance in prayer and religious education. At every major turning point of modern European history, religions have been the first to struggle to maintain their influence and their centralized control over diasporas. Religious capitals - the Vatican for Catholicism and Rabat, Alger, and Ankara for Islam - have never been passive actors in this process.

The migrations of Roman Catholics to North America resulted in the formation of an unexpected minority that created what could be called an 'Emigrant Empire'. The residence of Catholics in non-Catholic majority countries provoked an adaptive institutional response from the Catholic Church (Bauböck and Faist, 2010). Even when the legal authority of a religious capital becomes null and void, its spiritual influence can still cross national borders in the form of theological power. Two main tasks were and are imposed on the Catholic Church: awareness of its new role to support the religious practice of its minorities abroad; and, as a consequence, the right to defend the same people against proselytism. At first, most American Catholics led their lives outside of the reach of a consecrated chapel - infrastructural density was thin: there were 1500 Catholics per church (United States Conference of Catholic Bishops, 1992). This number is just below the average of 1700 Muslims per mosque in twenty-first century Europe (Cameron, 2015).

While hardly an exact equivalent, the experiences of Catholicism in the United States and Islam in Europe are similar in order and nature. Because of inadequate infrastructure, diasporas are exposed to certain risks; from the perspective of the 'religious capital' they are extremely susceptible to external influences, for example. There was also the risk that as successive 
generations of Catholics attended public schools, they might fall under the spell of Protestant missionaries from hundreds of sects - proselytizing Methodists or Mormons, or even secularist Republicans. There were tensions within the diaspora because of the variety of customs, languages, and traditions practiced by groups from different origin countries, as well as the varying prejudices each part of the community was exposed to. Since the nineteenth century, reports issued by envoys of the Pope were quick to arrive in Rome stating that many Catholic immigrants in the United States were losing their faith, and that Rome would need to intervene to counteract the problem. This challenging scene is not entirely different from that of the contemporary Muslim diaspora in Europe.

This great and unexpected 'Emigrant Empire' was first ignored, and then shortly thereafter considered a risk. The national Catholic Churches competed with each other, and priests had to be imported from the countries of origin. The New World became a site of imperial rivalry for the souls of both the indigenous peoples and the settlers. The British and Dutch competed with each other for colonial dominance, overshadowing the Spanish, French, and Portuguese. The United States was effectively written off by the Roman Catholic Church after the Seven Years' War, which ended in 1761 with France's surrender of most of North America to England.

However, the new Catholic population that arrived in the mostly Protestant United States through labour immigration a century later again attracted the eyes of Rome. This was the beginning of the internationalization of ecclesiastical authorities outside of Europe, with the spread of dioceses, training seminars, theological faculties at universities, and the sending of bishops and cardinals all over the world to serve the Catholic minorities (in addition to services intended for overseas colonies). In just 30 years, between 1820 and 1850 , the number of Catholic churches in the United States increased from 124 to 1124 , and from $185^{\circ}$ to 1860 it again doubled to $255^{\circ}$ (Cassidy, 1924). The construction of churches and the arrival of a sufficient number of priests happened fast enough, but the foundation of schools and on-site seminars took time. In 1821 an isolated, solitary seminar in Baltimore started to train priests, but this one programme was not enough for the onslaught of millions of Catholic immigrants who arrived at the continental territory of the United States throughout the nineteenth century (Goebel, 1937). The same delay occurred for secondary education. To address the shortage of clergy, there had been proposals to train priests in Leuven, Belgium, as a short-term solution; an American college was opened there in 1859. However, the number of churches evidently increased faster than priests could arrive or be trained. The linguistic plurality of immigrant communities (German, 
Irish, Italian, and Polish) complicated the situation further. A generation after the massive influx of Catholics, there were still only a handful of formal seminars to train the priests meant to serve a Catholic population of close to six million. As a result, many priests were not 'professionals', and were often uneducated in the rites.

This situation provoked a centralized response from Rome. In 1853, the Church sent a nuncio to visit the major cities in the United States with a Catholic minority and undertake a first inspection of the locally created organizational culture. This is comparable to the visits of the President of the Turkish Diyanet, the Moroccan Minister of Habous, or the Secretary General of the Muslim World League to their allied organizations in Europe. The nuncio discovered that 'Many immigrants had lost faith [...] more than those who had joined other churches.' Following this report, in 1854 the Pope proposed the creation of an 'American College' in Rome. He also established French, Irish, Polish, and Latin American colleges. The original Collegio Romano and Collegio Germanico date from the sixteenth century (Cassidy, 1924); the idea was to invite American students to Rome to learn how to become 'proper' Catholic priests - a form of signalling that they needed to follow institutional standards if they really wanted to regulate the religious life of the immigrant populations. As a response to the new 'emigrant' Church, the Pope personally supervised the creation of a record number of dioceses and archdioceses to cater to Catholics overseas: 130, or 15 per cent of the existing dioceses in the world at the time.

\section{The Muslim diaspora in Western Europe}

For the Sunni Islam diaspora a century later, it is obviously Western Europe that plays the role of the United States in comparison to the various Islamic 'religious capitals'. When the religious capitals' political power was taken away by the fact that they are foreign citizens, spiritual leadership became their only transnational currency. Once there is a sufficient mass of believers residing in a foreign jurisdiction, there are few options other than resorting to 'soft power' (Ozdora-Aksak, 2014). The creation of a foreign diaspora raises some difficulties (quantity and quality of services), challenges (defending against rivals and extremists), and opportunities (power struggles or evangelization). How can we understand the efforts implemented by states of origin to fill the void of religious services for their citizens and their citizens' descendants abroad? 
The first and most urgent question always concerns the quantity and quality of the religious infrastructure, i.e., the places of worship and the clergy. With the passing of time, however, the missionary goal turns into one of socialization: continuing religious traditions through subsequent generations. This socialization is happening in the twenty-first century; for example, the number of Islamic educational establishments in France increased from 9 in 2010 to 34 in 2014 (Barou, 2014). The number of prayer spaces also increased from 1300 in 2001 to 2500 today. There is still a real shortage of imams. There are two kinds of educational institutions needed: one for the clergy and teachers, and one for the children and students of the community.

The countries of origin have sometimes sought to literally appropriate the existing prayer spaces and mosques of their diasporas. From the early $1980 \mathrm{os}$ to the 2000s there have been supporting operations from Turkey through the CCMTF (Comité de coordination des musulmans turcs de France; the Coordinating Committee of Turkish Muslims in France) and the FNMF (Fédération nationale des musulmans de France; National Federation of Muslims in France), as well as through related associations from Morocco (Senay, 2013). These same networks have made the construction of new mosque-cathedrals (i.e., big mosques, rather than small prayer-rooms) possible: there is now one in Cologne and one in Strasbourg, both symbols of the new, lasting presence of Islam in the institutional and architectural landscape of these European cities (Allievi, 2009).

Finally, it is vital to draw the reader's attention to institutional developments that parallel the development of the Roman Catholic Church in the United States. We see the same pattern of institutionalization through both the 'collegio' model - training targeted at the diaspora, but taking place in the country of origin - and the diocesan seminary model, which is located in the host country (Catholic Church, 1958). With relocation, the trusteeship of the Congregation Propaganda Fide was lifted, which brought the Catholics in the United States under the centralized Church hierarchy and Canon Law - both in the early twentieth century. For Islam, the equivalent of the 'collegio' was opened in the early twenty-first century; for example, since 2006 more than $35^{\circ}$ foreign students, almost all Europeans, have been registered at a religious training course in Istanbul. Similarly, in Rabat the King Mohammed VI International Imam Training Centre opened its doors to the first class of 50 students from France in 2015 (Brown, 2015; see also Hashas, Part I). In terms of religious 'hierarchy', the anchoring of the European Council of Moroccan Ulema in Brussels is a key sign of institutional adaptation to the permanence and specificity of the European diaspora as a 
religious minority and the recognition of new religious realities for believers, without creating a new jurisprudential section. In the end, 'the territory' of the modern Muslim state also incorporates the diaspora of millions of European Union citizens with origins in that country.

This is, of course, far from the level of institutional internationalization demonstrated by the cardinals who serve in the various governmental bodies of the Vatican. For the moment, European Islam only has what could be considered the equivalent of apostolic delegates - for example, the ambassadors of countries representing official Islams. However, Mohamed Moussaoui and Dalil Boubakeur are among the first 'bishops' of Moroccan and Algerian Islam, respectively, in France today. The religious centres of authority need to nurture, manage, and then maintain their relationships with the faithful after a temporary loss of power. In short, this is the story of transnational religion: the religious capital must recognize political 'defeat' and accept the transfer of administrative and legal control over the faithful who become citizens of a third country. While doing so, the religious capital seeks to preserve its natural role in the spiritual supervision of its diaspora believer-citizens. In the end, the religious centre accepts the weakening of its temporary political relationships in exchange for spiritual fatherhood.

In the history of Catholicism, the Vatican has accepted this exchange after 6o years of crossing the desert, during which the 'Roman Question' remained an open wound. Before that happened, however, the new European national authorities put the Catholic hierarchy under the yoke of national governments, insisting on the right to approve the appointment of priests and bishops sent by Rome. One can think of the Civil Constitution of the Clergy in France, but also of the anti-clerical laws of the late nineteenth century, which saw the takeover of Catholic hierarchies by national governments in Germany, Spain, and Italy. It had not been long since the wars of the Investiture Controversy - and it is impossible to deny the similarities with current European Islam. Only with the Vatican's establishment as a sovereign state in 1929 did Europe's nation-states manage to close the Roman Question - more than a century after the concordats. Internal autonomy is restored to a religious community that can organize itself as it wishes under local legal frameworks. Can we assume that the relationship between the major Muslim capitals - such as Rabat, Algiers, or Ankara - and their diasporas will in the future look like the Rome of today, each with its own natural and organic sphere of influence?

It is important to realize that Catholic and Muslim diasporas were considered temporary. Rome has come to accept the permanence of its minority - and has therefore gotten down to sanctioning the spread of schools and 
seminars. Similarly, Turkey, Algeria, and the Morrocan Ministry of Endowments and Islamic Affairs did not consider their migrants in Western Europe a permanent minority until recently (Hosseini, 2013). This is a process that requires the operation of localization so that it absorbs the diversity of the periphery. In the United States, it took 50 years before the number of churches and schools met the demographic requirements (in the late nineteenth century). It took one hundred years before there were enough schools and Catholic teachers (between the two World Wars) (Cassidy, 1924). Decades passed before American Catholics got a cardinal. Even more patience was required for obtaining their fair share in the College of Cardinals - and it still took a few more decades, until the mid-twentieth century, for the majority of Catholic priests in the United States to be US graduates.

Paradoxically, asking foreign religious capitals to 'drop' control in this context must take the form of the creation of bureaucracies designed to precisely fit the targeted diaspora, which can actually leave much room for localization. What we see now is the spiritualization of international religious networks that no longer have jurisdiction beyond their own borders, and whose new currency is therefore only spiritual. In a way, this is the resolution based on the 'success' of relations between the state and the church. The church-state relationship is loaded, and necessarily creates a tense atmosphere. To function, neither party should think of itself as completely victorious or 'defeated'. Rather, it demands mutual tolerance, after the recognition of legal and political competence in a separate manner. This is what seems to be happening now with Islam in Europe, albeit slowly. Internationalization and negotiation as a minority can provide support for this historic change.

\section{References}

Allievi, Stefano. 2009. Conflicts over Mosques in Europe: Policy Issues and Trends. London: Alliance Publishing Trust.

Barou, Jacques. 2014. 'Integration of Immigrants in France: A Historical Perspective'. Identities, 21(6): 642-657.

Bauböck, Rainer and Thomas Faist. 2010. Diaspora and Transnationalism: Concepts, Theories and Methods. Amsterdam: Amsterdam University Press.

Brown, Jonathan. 2015. 'Is Islam Easy to Understand or Not? Salafis, the Democratization of Interpretation and the Need for Ulema'. Journal of Islamic Studies, 26(2): 117-144.

Cameron, Jeffrey. 2015. 'Integration of Muslims into Western Liberal Countries'. The Review of Faith and International Affairs, 13(1): 83-87. 
Cassidy, Francis Patrick. 1924. Catholic College Foundations and Development in the United States (1677-1850). Washington, D.C.: Catholic University Press.

Catholic Church. 1958. L'ordinamento dei seminari da S. Pio X a Pio XII. Vatican City: Tipografia Poliglotta Vaticana.

Fuess, Albrecht. 2007. 'Islamic Religious Education in Western Europe: Models of German Integration and the German Approach'. Journal of Muslim Minority Affairs, 27(2): 215-239.

Goebel, Edmund J. 1937. A study of Catholic Secondary Education During the Colonial Period Up To the First Plenary Council of Baltimore, 1852. New York: Benziger.

Hosseini, S.A. Hamed. 2013 "Political Identity" of Muslim Youth in Western Diaspora: Towards an Integrative Research Agenda'. Journal of Muslim Minority Affairs, 33(4): 464-476.

Kortmann, Mathhias and Kerstin Rosenow-Williams, eds. 2013. Islamic Organizations in Europe and the USA: A Multidisciplinary Perspective. New York: Palgrave Macmillan.

Ozdora-Aksak, Emel and Juan-Carlos Molleda. 2014. 'Immigrant Integration Through Public Relations and Public Diplomacy in the Capital of the European Union'. Turkish Studies, 15(2): 220-241.

Qattab, Tarik. 2009. 'Islam en France: Le Maroc et l'Algérie à couteaux tirés'. Le Soir Échos, 18 February.

Senay, Banu. 2013. Beyond Turkey's Borders: Long-Distance Kemalism, State Politics and the Turkish Diaspora. London: I.B. Tauris.

United States Conference of Catholic Bishops. 1992. The American Catholic Heritage: Reflections on the Growth and Influence of the Catholic Church in the United States. Rome: Pontifical North American College.

\section{About the author}

Jonathan Laurence is a Professor of Political Science at Boston College and Nonresident Senior Fellow in Foreign Policy at the Brookings Institution. He is the author of The Emancipation of Europe's Muslims (Princeton, 2012). 


\title{
5 The European imam
}

\author{
A nationalized religious authority
}

\section{Mohammed Hashas}

Hashas, Mohammed, Jan Jaap de Ruiter, and Niels Valdemar Vinding (eds), Imams in Western Europe: Developments, Transformations, and Institutional Challenges. Amsterdam: Amsterdam University Press, 2018 DOI: $10.5117 / 9789462983830 /$ CHO5

\begin{abstract}
This chapter argues that the position of the European imam is being nationalized and consequently rendered more dependent on both religious scholarship and political authority, and that the transmission of an ethicist message has become its major mission. First, this chapter briefly overviews the crisis of modern Islamic religious authority, situating the place of the imamate in Islamic scholarship to demonstrate that it is not an independent scholarly position but rather an administrator of the religious affairs of believers at the local level. Second, the chapter presents the model of the Moroccan imamate as a way of understanding the role that is expected of imams by modern political and religious authorities. Third, reference is made to the situation of the French imamate as an example of the situation of imams in Western Europe. The reflective closure of the chapter raises points about how the question of ethics is becoming central in the sermons and teachings of a growing number of imams, and how important it may be as a field for further research.
\end{abstract}

Keywords: Islam in Morocco, Moroccan imams, French imams, King Mohammed VI International Imam Training Center 
In the Sunni tradition, the study of the imams and imamate is a very recent phenomenon for two main reasons. ${ }^{1}$ First, simply paging through the tables of content of Islamic scholarly classics cannot direct you to chapters or clauses dedicated to the position of the imam and/or his roles. This is because neither the Quran nor the Sunna uses or emphasizes the term 'imam' as we know it today (i.e., 'the leader of prayers and the mosque'). However, the term or its derivatives do appear in both. Second, this study originates in Western liberal societies whose state institutions have been unable to understand their Muslim minorities, or simply citizens of Muslim belief, since World War II. This confusion is partially a result of the fact that the Islamic religious authorities have not been able to agree on a modern reading of the tradition that would allow easier integration into modern state institutions and pluralist contexts where Muslims are a minority. Consequently, the imamate has emerged as a space in which authority - religious, political, or both - is negotiated. It has become a sign that shows the crises of governing authorities, and thus the space where they are reclaimed differently.

This chapter argues that the position of the European imam is being nationalized and consequently rendered more dependent on both religious scholarship and political authority, where his functions take place for the transmission of an ethicist message. Three major features distinguish this new position of the European imamate: (1) it is dependent on religious scholarship, and does not stand as an independent authority; (2) it is under the sovereignty and interests of the political regime within whose institutions and territories it functions; and (3) its major authority lies in direct contact with the community of believers, to whom it transmits an ethicist religious discourse. I illustrate this argument in three major steps. First, after a preliminary note on defining the imamate, this chapter provides a brief overview of the crisis of modern Islamic religious authority and its impact in Europe; it situates the place of the imamate in Islamic scholarship to

1 What has developed as a fiqh al-aqalliyāt ('fiqh of minorities') does not focalize the role of imams but the role of mosques, muftis, and scholars of Islam. This means that imams as an independent category or authority are considered only channels of scholarship, not its main thinkers or leaders. For example, the publications of the European Council for Fatwa and Research (ECFR), founded in Dublin in 1997, do not devote clear space to the category of the imam and his functions. This chapter does not delve into the literature of the minority fiqh or of the ECFR. Rather, it examines the place of imams within broad Islamic scholarship and their newly focalized functions. For more on the state of the art of training imams in Europe, see Aslan and Windisch (2012); Drees and Van Koningsveld (2008); Ferreiro (2011); Husson (2007). 
demonstrate that it (the imamate) is not an independent scholarly organization, but more of an administrative structure for the religious affairs of the community of believers at the local level. Second, the chapter presents the Moroccan imamate model to illustrate the role that modern political and religious authorities expect imams to fill. Finally, I refer to the situation of the French imamate according to recent anthropological-sociological studies.

\section{The imam in Islamic religious authority: An overview}

The word 'imam' literally means 'the one who leads', and in the Sunni Islamic tradition it indicates the male leader of the five daily prayers. Though rarely used in the Sunni tradition, the term 'imamate' means the function of carrying out such a task. In Shia Islam the 'imamate' takes on a totally different meaning: infallible leadership of the community or the umma. The 'imam' is then the infallible leader of such a community. Thus the Shia definition of 'imam' and 'imamate' are close to the Sunni meaning of 'caliph' and 'caliphate', although the latter is basically a political position empowered with theological roles, while the Shia version is a theological position empowered with political roles. Al-imāma al-kubrā ('greater imamate') is another name for the 'the caliphate', while al-imāma as-șughrā ('lesser imamate') means 'leadership of prayers'. In this chapter, I use the term 'imamate' to mean the organizational duties of imams in the Sunni tradition.

The Quran makes at least five references to the term 'imam' and 'imamate' in the sense of a leader of prayers, or leader of the people, or leader of the people of the Book. ${ }^{2}$ The prophetic hadiths also use 'imam' to mean a leader in prayers, although in one example it is used for the leader of the army. ${ }^{3}$

2 See Quran 2:124, 15:79, 17:71, 25:74, and 36:12.

3 Examples of hadiths include: idhā 'amma aḥadukom al-nāsa fal yukhaffif, fa inna fīhim al-ṣaghīr wa-l-kabīr wa al-ḍa'īf wa al-marị̣, fa idhā șallā waḥda-hu fal yuṣalli kayfa shā' [When any one of you leads the people in prayer, he should be brief for among them are the young and the aged, the weak and the sick. But when one of you prays by himself, he may (prolong) as he likes]. Sahih Moslem 467 a, The Book of Prayers, 5 , Hadith 208; in kānū thalathatan fal ya'ummahum ahaduhum, wa ahaqquhum bil imāmati 'aqra'u-hum [If they, believers, are three, one of them leads them in prayers, and the most suitable for the imamate is the one who has the Quran by heart most], Sahih Moslem, The Book of Who Merits the Imamate, 54, Hadith 1561; wa 'innamā l'imāmu junnatun, yuqātalu min warā'ihi wa yuttaqā bihi [The imam is like a shield whose orders should be obeyed when they (the Muslims) fight, and where they should seek protection. If he enjoins fear of Allah and behaves justly, then he will be rewarded, but if he enjoins otherwise, then it will be a burden (of sin) on him], Sunan annasa'i, The Book of al-Bay a, Book 35, Hadith 71, also available at: http://qaalarasulallah.com. 
From the prophetic Sunna, some hadiths that use the word 'imam' or its roots or derivatives can be listed. Sunni medieval scholars rarely dedicated whole chapters to the functions of imams, which were instead covered as part of the 'books' or 'clauses' dedicated to rituals or prayers. In the Sahihs of Bukhari and Moslim, the two hadith collections that are considered the most authoritative written texts after the Quran, the word 'imamate' is used in the subtitles of 'books' or 'clauses'. ${ }^{4}$

The question of Islamic authority and representation has been a topic of debate for nearly two centuries, since the start of the modern encounter between the two commonly used and abused entities 'Islam' and the 'West'. On the one hand, the Orientalist view contends that Islam does not recognize the distinction between God and Caesar (i.e., between religion and state power), which renders it an outsider to the modern West that builds on the Christian tradition. The Islamic world, according to this view, is inherently incompatible with the separation of the powers of church and state required by the modern world. 5 On the other hand stand the defenders of Islamic diversity and its potential to adapt to the modern secular age. ${ }^{6}$ Islamic religious authority has commonly been considered autonomous, or at least quasi-autonomous even when tamed, from the political powers. That was the general case in the medieval Islamic times of caliphates and empires. The encounter with the concept of the modern nation-state during the European colonial period, and the postcolonial attempts of intellectual-political elites to establish Arab-Islamic nation-states have combined the two traditions and caused, apparently, a deep theological-philosophical confusion of concepts. ${ }^{7}$

4 For example, in Saḥiḥ Bokhari, there is a clause entitled abwāb șalāt al jamā'a wal 'imāma [Clauses on Collective Prayer and the Imamate], and a sub-clause entitled bāb imāmat al'abd wa-l-mawlā [Clause on the Imamate of the Slave and the Freed]. In Sahih Muslem, one finds kitāb al masājid wa mawādì al-șalāt [Clause on Mosques and Prayer Spaces], and beneath it a sub-title, among other entries, bāb man ahaqqu bi-l-'imāma [Clause on Who Deserves the Imamate Most]; here the imamate is used as a noun to mean the act of leading prayers. As to the imamate in its meaning of political leadership, or what is also known as the 'great imamate' or 'caliphate', it is referred to as imāra, as found in a subsequent Clause in Sahih Moslem, entitled kitāb al-'imāra [Book on Imara]. Following the same tradition, later scholars entitled some of their chapters or clauses using the word 'imamate'. The Hanbali scholar Ibn Qudama (1147-1223), for example sub-titles his kitāb al-șalät [Clause on Prayers] with bāb al-imāma wa șalāt al-jamā'a [Clause on the Imamate and Collective Prayers]. (Ibn Qudamah, al-Mughni [The Enricher] (10 vols.) (Beirut: Dār ihỵā’ atturāth al 'arabiyy, 1985).

5 Among the contemporary 'Western' scholars that support this line of thought there is Bernard Lewis, Samuel Huntignton, Francis Fukuyama, Joseph Schacht, Ernest Gellner, Martin Kramer, and Patricia Crone.

6 John Esposito and John Voll, to name but two, represent this perspective.

7 Scholarship on this includes An'naim (2008); El Fadl (2005); Hallaq (2005, 2009); Moosa (2009, pp. 158-181); Zaman (2002, 2012). 
The established Islamic view that religious scholarship (led by the ulama, be they jurists, muftis, or theologians) supports the just ruler of a just society has not been respected during all of Islamic history. Islamic empires and dynasties largely allowed the adoption of various madhhabs ('legal schools') even within a narrow territory or in the same big city, let alone in big territories. The waqf (pl. awqāf, 'endowments') enjoyed by the religious establishment and scholarship resulted in substantial independence and quasi-immunity from political interventions and dictates, especially regarding issues that were not political (Hallaq, 2013; Winter, 2009).

However, the modern nation-state seeks the centralization of authority, which means unifying the legal tradition(s) into statutory laws. Since its encounter with 'Euro-modernity' through the Napoleonic attempt to conquer Egypt (1798-1801) and the later successful attempts at colonialism, the Islamic world has entered a phase of hybridization, in which it tries to form modern states that still preserve the basic Islamic requirements. The so-called incomplete Arab-Islamic 'Renaissance' and the failures of Arab-nationalisms in the heartlands of Islam have contributed to the fragmentation of Islamic religious authority through its cooptation or domestication by the 'undemocratic' state. For example, since the era of Egypt's former President Gamal Abdel Nasser, Al-Azhar in Cairo has become a state institution, whose clerics are now salaried civil servants of the state. Likewise, the Grand Muftis of each modern Arab-Islamic state have become state-salaried, and nearly each state has created its own Council of Religious Scholars, often presided over by the monarch or president of the state. Each state has also adopted a single madhhab ('legal tradition'), and turned it into a pillar of the culture of the state (Hallaq, 2013; Lo and Haron, 2015; Maussen, Bader, and Moors 2012; Nasr, 2015). The postcolonial states in Islamic societies either refer to sharia as the source of their legislation, as in Egypt, or refer to Islam as the religion of the state - thereby appearing to give more space to legal interpretations and avoiding the statement that sharia is the source of legislation - as in Morocco.

The pre-colonial and postcolonial conditions of the imams have not raised serious challenges to society and state institutions through their profession, particularly because they are not listed as an authority in Islamic classical religious scholarship. While the imams of big mosques in big cities are usually appointed by the local state authorities, mosques of lower status and size are often led by imams who are either appointed by the local inhabitants who care about religious matters in their area, or are self-appointed in the sense that, since they have learnt (at least some of) the Quran by heart, they gradually win the status of a țālib ('seeker 
of knowledge in the Islamic sciences') or faqih ('learned in the Islamic sciences') within their community. The self-appointed imam starts by leading prayers and maybe giving sermons on Fridays, and voluntarily durūs ('teaching/preaching lessons') on particular days, or gains respect during the month of Ramadan when the whole Quran is recited in the tarāwīh ('night prayers') each night after the evening prayers. Traditionally, such a religious position does not entitle the imam to payment, as it is first and foremost a service based on piety. Custom, however, requires that the community support the imam financially, either directly by handing out little amounts of money frequently and also on the occasion of marriages, funerals, circumcisions of baby boys, and other religious get-togethers, or indirectly by offering the imam a space on the outskirts of the mosque, which he can use for his own business and needs. If the mosque and its nearby endowments are big enough, the imam may also be given a house as a part of his 'job'.

Both before and during the colonial period, learning (parts of) the Quran was part of the education most males received from their local mosques. Some would continue their religious education in nearby cities or bigger cities in the country, memorizing the whole Quran and learning the other sciences that complement its understanding, such as language, tafsir , and hadith. Those who received some higher education but did not complete it and receive ijäzas ('licenses') of scholarship from the senior ulama, which would allow them to enter the club of scholars, could easily become imams in big mosques.

During the colonial era, the modern school was introduced. It was not welcomed by the masses, though graduates could find jobs in the administration of the colonial state or with the ally native authorities that continued to hold minimal power under colonial rule. In the early colonial period, the modern school was not appreciated for two main reasons: first, it was a school created by colonists, the boycotting of whom was a political statement; second, modern schools did not teach Arabic or Islam, or taught them only minimally, while the masses cared about the religious education of their children. Even when the modern school became part of the new postcolonial state institution, the tradition of national schools kept going: before going to school in the morning, for instance, kids were obliged to pass by the local school (called al-kuttāb or al-massìd in Morocco) to learn some of the Quran before going to the modern school. Now modern schools teach Arabic and Islam, including the Quran, so there is less need for extra religious education - but this need is very present among Muslims in the West, who seem to be reviving the process of parallel schooling (i.e. 'religious/Islamic 
schools' in addition to 'secular' ones) because 'secular schools' do not teach, or only teach a little, about their religion. ${ }^{8}$

After the Second World War, Europe recruited guest workers/labourers mostly from the former colonies in the Islamic world. These immigrantlabourers travelled to the new secular and liberal space of Europe with the socio-political and religious background referred to above. In terms of the organization of religious institutions and administration of community affairs, the immigrants often found themselves functioning in modern new territories using traditional practices.

Practicing Muslims or Muslims that identify as such, whether practicing or not - the number of which has increased, especially with the second generation and the so-called resurgence of Islam beginning in the late $1960 \mathrm{~s}$ and 1970s - would either choose a respected believer to become their leader in prayers or, later, sought to import an imam from their own village or city in their country of origin. Because religious education in the wider Islamic world was still in the making during the postcolonial era, these imported imams either had a conservative education and were therefore not open to modern state institutions or liberal multicultural society, or they were not trained as imams at all, but were laymen who had learnt the Quran, or part of it, by heart at madrasas rather than modern schools or universities. The latter untrained type of imams could only lead prayers as an extra responsibility given by the community or taken up willingly as a divine call. The irregular functioning of imams in Western Europe would bring challenges and changes to their traditional role in Muslim-majority societies.

State interference in the religious affairs of the immigrant communities was also present. The sending postcolonial states of South Asia and the broad Middle East and North Africa established their own versions of 'Embassy Islam' to ascertain the religious identity ties between the diaspora abroad and the homeland, and to secure economic benefits through remittances. 'Embassy Islam' also attempted to combat transnational Islam, or 'Political Islam', which engendered the legitimacy of the political authority of these countries back home (Laurence, 2012; see also Laurence, Part I).

At the time, European states were not interested in the religious question. The immigrants were guest workers that had to go back after the expiration of their work contracts. For this reason, the European state found it more convenient to generally 'outsource' the care of the religious needs of the immigrants to the governments of the sending countries and

8 More on the Moroccan kuttāb, or madrasa, in Eickelman (2010, pp. 131-148). For an insider's look into the madrasa in modern times, see Moosa (2015). 
petrodollar-rich Gulf states (Laurence, 2006). Employing companies would often provide prayer rooms for the workers to avoid their demands for better work conditions and higher salaries, and workers would then appoint their own imam to lead prayers and do the needed rituals. Friday sermons were often prepared by Islamist groups, when the imam of the sending government and the hosting state was absent or was not provided (Kepel, 1987).

Especially after the terrorist events of 11 September 2001, European states adopted laws to tighten the surveillance of radical movements and preachers whose discourses could endanger public security or the public good, and some values of liberty and equality. In the process of 'taming imams', France, for example, deported twelve imams in 2004, some because they did not condemn polygamy or the practice of husbands beating their wives. After the 7 July London bombings in 2005, Britain listed some 50 imams for deportation because of statements that endangered public security. Since this was against the European Union treaty forbidding the deportation of suspected criminals to countries where domestic security and intelligence services employ torture, the British government signed contracts with some Middle East governments pledging that the detainees would be humanely treated upon repatriation (Haddad and Balz, 2010). In 2007, a report requested by the European Commission (DG-Justice, Freedom and Security) and prepared by experts at King's College reported that 'radical imams' were no longer the magnates of radicalism, and underlined the emergence of new Islamist recruiting militant groups that especially operate through Internet recruitment. The new media of the Internet, has 'opened up new spaces of religious contestation where traditional sources of authority could be challenged by the wider public' (Mandaville, 1999). This is even so when this religious authority is challenged by religionists in a diaspora position, as is the case with (especially young) Muslims in the 'West', particularly in Europe where Islam and its traditions are being re-interpreted and imbued with new meanings (Mandaville, 2001). While a good number of sociological, anthropological, and theoretical works read such challenges to classical Islamic authority from progressive perspectives, giving them meanings that defend the idea of Europeanization of Islam and that Islam is inlandish [i.e. at home in Europe] (Allievi, 2003), some tragic events inside and around Europe indicate a new regressive appropriation of religious authority. In other words, if traditional religious authority can be given different meanings, one can be radically violent. This is manifest in the formation of the bloodthirsty Islamic State in June 2014, to which a good number of foreign fighters have joined from all over the world, including Europe. Out of some 11,00o foreign fighters, statistics note 1,500 European Muslims, including women, adolescents, born Muslims, and converts (Byman and Shapiro, 2014). 
Violent incidents like the 24 May 2014 killing of four people in the Jewish Museum in Brussels by Mehdi Nemmouche, a French citizen who had spent a year fighting in Syria, and the 7 January 2015 massacre of Charlie Hebdo journalists in Paris by the brothers Kouachi, who belong to the Al-Qaeda network in Yemen, exemplify the possible orientations the new meanings of religion can take in the age of 'digital Islam'. To face this challenge, globally recognized religious scholars have come together to condemn violence in the name of religion, Islam here; some 125 Muslim scholars have come together to condemn the birth of the 'Islamic State' as not only non-Islamic, but also anti-Islamic. ${ }^{9}$ Muslim religious leaders at the international, national and local levels have spoken out against such atrocities (Kuruvilla and Blumberg, 2015). Imams themselves have also come out to 'reclaim the Internet' from violent jihadists (Wyatt, 2015). Female leaders have come out to challenge not only violent jihadists, but also the moderately conservative religious authorities that do not allow women to lead prayers (El Fadl, 2015; McLaughlin, 2005, 2012; Taylor, 2015). Another challenge emerges from gay imams, who try to provide what they describe as the spiritual needs of lesbian, gay, bisexual, and transgender Muslims that the broad community of believers fails to meet (Jama, 2015; Khan and Waheed, 2013).

3

\section{The Moroccan imam: Submitted, depoliticized, and} ethicist

Amidst the predicament of who speaks for Islam, models seem a requisite. Morocco, a centuries old monarchy that enjoys religious legitimacy, appears to be confident of its model of 'moderate Islam', in which it has started to invest heavily in the last decade through, for example, the recently founded King Mohammed VI International Imam Training Center. ${ }^{10}$ Countries like Mali, Tunisia, and France have requested that Morocco provides training for their imams, and Belgium has also shown an interest (Alaoui, 2015). ${ }^{11}$

9 'Open Letter to al-Baghdadi and to the Fighters and Followers of the Self-Declared "Islamic State”', issued 19 September 2014. http://www.lettertobaghdadi.com/.

10 'King Mohammed VI Inaugurates International Imam Training Center in Rabat in Push to Promote Moderate Islam'. Morocco World News, 28 March 2015. http:/www.marketwired.com/ press-release/king-mohammed-vi-inaugurates-international-imam-training-center-rabat-pushpromote-moderate-2004480.htm.

11 Also see 'Belgium, Interested in Morocco's Imam Training Experience- Minister'. Morocco World News, 3 March 2015. http://www.moroccoworldnews.com/2015/03/152934/ belgium-interested-moroccos-imam-training-experience-minister/. 
The Moroccan model is institutionalizing the religious training of imams to avoid the potential that it could become a tool in the hands of political movements that may radicalize or show political dissent, a model that appeals to European institutions. Since 2010, the European Council of Moroccan Ulema (CEOM), based in Brussels, has used this model. Among other aims, the council organizes scholarly seminars on religious issues and offers training and guidance for imams throughout Western Europe (CEOM, n.d.). This model also guides the Mohamed VI Foundation of African Ulema, founded on 13 July 2015 to maintain Morocco's historical ties with (especially sub-Saharan) African Islam. ${ }^{12}$

Among the state institutions and Islamic councils that have voiced concerns about the structure of Islamic authority, the Moroccan Ministry of Endowments and Islamic Affairs, led by Dr. Ahmed Toufiq since 2002, has clearly underlined the vital religious and political role of imams. This declaration was made during Toufiq's speech to the fifth conference of World Religious Leaders in Astana, Kazakhstan, in June 2015. His speech, which merits careful consideration here, can be divided into two major arguments, the first indicates the place of imams in society and their role therein, and the second describes a model for training imams to meet socio-cultural, religious, and political needs.

Toufiq opened the speech by saying that while religious institutions, leaders of religious sects and movements, and religious scholars may be the first that come to mind when it comes to religious authority, the imams that are present in every city, village, and district, and that are thus the closest to the people, have the greatest opportunity to make an impact on the community. While other religious leaders make decisions at the top level, where contact with the people is at a minimum, imams' tasks bring them close to the society: leading the prayers five times a day; offering durūs (courses on religious teachings); giving Friday sermons; and being the community's religious reference during marriage arrangements and consultations, weddings, marriage reconciliations, funerals, circumcision festivities, and the like. Toufiq then underlines the role of imams in encouraging peace at various levels, both local and global:

Henceforth, it is obvious that the imam should be taken into consideration if religious leaders at the top level want to invest religious teachings and their energizing powers and incentives for the sake of serving peace, the 
spreading of virtuous values and ethics among people, and the rectification of many a disequilibrium that the world suffers from. (Toufiq, 2015) ${ }^{13}$

With the imam primarily entrusted with spreading such an ethical perspective, Toufiq moves on to his second major point: how to train imams to uphold such messages and consequently clarify their role in society and within religious and political authority. This training model has been tested in Morocco, and is being implemented in 50,00o mosques throughout the country, according to Toufiq. He outlines his training model in eleven points, summarized as follows (Toufiq, 2015):

1 Modernize the organization of ulama ('religious scholars') to allow the 'a $\bar{l}$ im ('scholar') to be faithful to the nation's historical choices of creed, madhhab, and customs.

2 Organize the fatwas on public affairs within state scientific institutions, and consider any fatwa that comes from outside these channels a mere personal opinion, which is respected but does not guide the collective religious conscience of believers - itself based on a political choice for the preservation of the public good and the avoidance of fitna ('rebellion') and dogma.

3 Connect and harmonize what the ulama and the imams say about the references that make the identity of the nation.

4 Consider the state's laws legitimate for public good, as long as they do not contradict a clear $h u k m ~ q a t^{c} \bar{\imath}$ ('clear religious jurisprudential inscription').

5 Circulate a guidebook among imams to remind them of the prophetic manners of communication and proselytization, to avoid that imams attribute their statements to fake names or to personalities outside the tradition.

6 Provide extra training to young imams who are graduates from universities with distinction and learners of the Quran, and appoint them to tutor other imams in various mosques.

7 Integrate social sciences into the training programmes for young imams.

8 Provide equal training for murshidàt ('women religious guides'), who provide guidance to women believers.

9 Organize continuous training programmes for already-working imams.

10 The ulama and imams should take the responsibility of not only training and preaching, but also practicing lived ethics that are based on ease and hope, to be close to the common human condition. 
11 Consider religion a good for all and avoid bringing political disputes into religious affairs. This means politically neutralizing mosques and upholding the values of mercy, justice, and universal compassion in religious discourse.

Three major points from Toufiq's speech summarize the Moroccan project of training and forming imams according to the Sunni Maliki legal madhhab and Ash'ari theology, imbued with a Sufi orientation.

First, imams remain a dependent religious authority. They follow religious scholarship, led by the ulama, and cannot compose a new or independent body of authority, however important their role becomes. This is the classic definition of the place of the imam within religious hierarchy and scholarship. Imams enjoy liberty in their sermons; views that might go against the established stream are considered personal views that are not binding to the community - views for which the imam may be held accountable by the state and its religious authority.

Second, imams, as part of religious leadership, are banned from political activities. Imam training follows the overall religious interpretation of the country's ulama for the public good, as ensured by the bay ${ }^{c} a$ ('pact') that bonds the monarchy, ulama, and society at large; in other words, the religious authority and the imams that follow it have no (direct) political role to play. While religion is an important part of the political legitimacy of the state and monarchy, there is now a clear depoliticization of religious actors, backed by a royal decree issued in July 2014 that banned religious leaders from participating in any form of political activity. ${ }^{14}$

Third, the major role of imams is to bring ethical sharia into the daily life of the believers. Since imams are neither a leading religious authority nor political agents, they are focused on applying the dominant view of Islam as conceived by the ulama and endorsed and influenced by the political powers. Imams are preachers of ethics, justice, and compassion, as Toufiq described, and transmitters of moderate Islam. Such transmission may not be led by the imams - since they are themselves led by the ulama and political authorities - but they play a big role in its accomplishment. Because they are the "closest" to the believers, imams

14 'Morocco Prevents Religious Leaders from Participating in Politics', Al Arabiya News, 3 July 2014. http://english.alarabiya.net/en/News/middle-east/2014/o7/o3/Morocco-preventsreligious-leaders-from-participating-in-politics.html. It should however be noted that while the State forbids religious leaders and imams from politicizing their religious positions, it alone enjoys such a right, for example through Friday sermons that it controls and through public TV religious festivities. 
are supposed to know how to relay the proper interpretation of religious messages according to believers' levels of understanding. A lot of the 'ethicization', 'localization', or 'nationalization' of sharia takes place at this level. To examine some aspects of the roles of imams in a minority context, within a secular-liberal society, the next section considers the example of France.

\section{The French imam: Dependent, controlled, and conciliatory}

Two major sociological-anthropological works were published in 2013, each a result of six years of fieldwork: Romain Sèze's Etre imam en France and Solenne Jouanneau's Les Imams en France (Jouanneau, 2013; Sèze, 2013; see Jouanneau, Part I, and Sèze, Part II). Their findings describe the changing status of the imam, and depict the transformation of his religious position, or newly growing religious authority. Three major themes of this book can be summarized as follows:

1 Imams' lower levels of education and socio-economic status contribute to making them dependent on the ulama's scholarship. Eight out of the 30 imams that Sèze interviews make the category of what he refers to as an 'imam-labourer', with very low levels of education or none at all (Sèze, 2013, p. 39). This kind of imam is requested by his community of workers to lead prayers because he is pious, knows some of the Quran by heart, or provides some answers to the social needs of the community. The 'imam-labourer' in Sèze's work is close to Jouanneau's typology of the 'indigenous-invisible imam', though their typologies differ because Sèze focalizes imams while Jouanneau focalizes the imamate and its chronological development in France (Jouanneau, 2013, p. 25). Eighteen out of 30 imams interviewed by Sèze had a background in religious education, which they studied in their country of origin in the Islamic world. These imams did not travel to Europe with the intention of becoming an imam, but found themselves making a living out of it because they had no other choices. They are often more confident, charismatic, and knowledgeable than 'imam-labourers', and thus gain more respect in their communities; with time, they may find their way to being imams in bigger mosques, in big cities. This type of imam is close to what Jouanneau terms an 'imam of the district' (2013, p. 69). Finally, only one out of the 30 interviewed imams had received a diploma from training as an imam in France (Sèze, 2013, p. 75). 
Imams are not state-funded and do not receive salaries from the state. Because they depend on their countries of origin and community associations for a living, imams are often in a bad economic condition; a lot of them do not enjoy health coverage. This impacts their social standing: no one wants to be trained as an imam only to find themselves jobless or badly paid (Sèze, 2013, p. 88) - including the students enrolled in the imam-training programme the state has recently tried to offer in cooperation with universities like the one in Strasbourg. This also explains the lack of imam-chaplains in the military, prisons, and hospitals (Sèze, 2013, p. 122). The dire economic situation of imams is especially noticeable among those of Moroccan origins because they usually did not enter France intending to become an imam, but end up doing it anyway because of the circumstances they find themselves in. This is very different from their Turkish and Algerian counterparts, who are often legal and living in better conditions because of the state's (France) conventions on importing imams from Turkey and Algeria (Jouanneau, 2013, pp. 296, 310, 315; Sèze, 2013, p. 47). Overall, imams' lower general education, or non-religious profound education, and socio-economic condition contribute to making them dependent on ulama scholars - a position that imams have held historically.

Politics and state construction of the 'good imam'. Jouanneau's work with about 30 imams and mosques in the East and South of France reaches two main conclusions. First, through her access to numerous state archives, statements, and municipal police documents, she found out that French authorities have tried to intervene in the internal affairs of the Muslim community. For instance, the French state has tried to play a role in the selection of imams that would be sent to its territories, following the conventions signed with the Turkish and Algerian authorities. Imams chosen in this way are what Jouanneau refers to as the 'consular imam', or what documents from the French authorities refer to as the 'good imam' (Jouanneau, 2013, p. 307). The French authorities also intervened in the signing of conventions with two state universities to train imams (on non-religious/theological issues, since the 1905 law does not allow that) - an initiative that has had few results, because the training programmes were either boycotted or not trusted by the Muslim community and Muslim representative bodies; some of these programmes were soon closed, allegedly because of a shortage of finances (Jouanneau, 2013, pp. 296, 310, 315). The French authorities, then, do not enjoy having an established religious scholarship, or ulama, but do depend on Arab-Islamic authorities for the importation of 'good 
imams' who understand the apolitical position required of them in a secular-liberal society.

3 Imams' role as an identity marker for the community of believers in a multicultural-liberal society. Based on the fieldwork by Sèze and Jouanneau, it seems that imams have three separate but related roles in Muslim communities in France. Institutionally, the imam co-administers the community of believers and is a symbol of its identity; socially, he interacts with and is close to the community; and theologically, he is an eclectic-ethicist. First, institutionally, the imam does not lead the community alone; instead, he co-administers it with the rector or director of the mosque, or with the head of the Islamic cultural association that is in charge of the prayer hall. Since most imams come from Muslim-majority countries, and some from small communities enjoy modest educational levels and/or speak little to none of the language of the majority society, they are often unable to stand as the spokesperson of the community - with the French authorities for legal issues, with other religious denominations for religious dialogue and civil society activities, or with the media that seeks religious authorities for feedback on certain issues concerning Muslims and the rest of society. An 'indigenous-invisible imam', in Jouanneau's words, or 'imam-labourer' in Sèze's, is unable to play the role of the communicator for the community, often because of his educational level. Instead, it is the rector of the mosque or the director of the association who is often highly educated and carries out the tasks of external communications.

More importantly, the imam becomes the cultural symbol of the community. He leads prayers, gives Friday sermons, the two ${ }^{c} \bar{l} d$ ('feast') sermons, and presides over funerals. He plays the role of a matchmaker, in the sense that he knows the community and helps the believers find partners for marriage; he intervenes in solving family conflicts or cases of divorce. The imam also acquires new roles that are related to identity, possibly more than roles that are related to the core creed of Islam. One example is marriage ceremonies. A number of families hold part of the wedding ceremony in the mosque, in the presence of the imam, who reads the fätiha Quranic verse and blesses the marriage after it has gone through civil legal authorization and authentication. Traditionally, Islamic marriages are civil and do not require the presence of an imam, but only the presence of a legal authority/notary (Sèze, 2013, pp. 115-119). Socially, the educated imam interacts constantly with the community of believers. After having spent time observing an imam in Assalam (anonymous) Mosque, Jouanneau notes that there is interaction in his 
work; he does not dictate opinions on certain issues the community raises. For example, when asked about the permissibility of adopting children or listening to music in Islam, the imam gives the mainstream and classical Islamic view, and cites the permissibility expressed by other Islamic classical scholars, but his interlocutors make their own choices in the end, and sometimes make choices a priori. One of the women still defends the idea of adoption, and another listens to music anyway - though the latter tries to explain her choice by saying that she actually watches the Star Academy show featuring talented Arab young singers, which is visual; since music is only secondary in this TV show, according to her, it is permissible. In other words, she emphasizes watching instead of listening as a way of allowing herself to watch the musical programme Star Academy (Jouanneau, 2013, p. 454).

A second example of an interaction between an imam and his community was when an imam refused to put a dividing line in the mosque to separate women and men, but the community elders and the administrators of the mosque erected the divider anyway (Jouanneau, 2013, p. 471). ${ }^{15} \mathrm{~A}$ final example concerns a woman, a teacher, who, after being on parental leave for some years, was considering returning to her job after the French ban of the veil. She planned to consult the imam of the mosque, but stated in advance that she may not consider what he says, if he were to say that a majority of scholars consider the veil mandatory for women - an answer she seemed ready to oppose a priori (Jouanneau, 2013, p. 430).

Theologically, for various reasons, the imam finds himself eclectic and ethicist. The imam is in a secular-liberal society, and his discourse has to adjust to both the law of the country and the level of religiosity of the believers he talks to. Only three out of the 30 imams interviewed by Sèze had a license to pronounce fatwas; of these, two were issued and recognized by Turkish authorities, and the other was a Shiite imam who had a scholarly reputation in Lebanon, and had received a PhD from Sorbonne University. This Shiite imam was able to issue fatwas and divorce certificates recognized by Lebanese authorities due to his religious scholarship and reputation (Sèze, 2013, p. 141). These imammuftis, as well as other imams like the public figures Tareq Oubrou and Hassan Iquioussen, speak of the necessity of an eclectic approach that is rooted in tradition but comes from different legal theories - theories that, if followed completely, might not accommodate the wide range

15 Sèze (2013, p. 114) could not access the women's side, but says they organize their activities under the tutelage of men. 
of individual cases and questions that imams receive from believers (Sèze, 2013, pp. 188-189, 217).

The use of eclecticism indicates that one (legal) school of thought does not have harmonious or adequate answers for the issues faced by believers of various races, genders, ages, and geopolitical belongings. To stay rooted in the tradition while adapting to the new secular-liberal context, the imam needs to emphasize the aspects of the tradition that he considers more basic at the expense of others that the context renders obsolete or not applicable, and thus not essential. This is why when asked about homosexuality, for example, most of the interviewed imams stressed the idea that it is religiously unacceptable, but still emphasized the importance of human respect and the rule of law (Sèze, 2013, pp. 192-193). Sharia law is therefore ethicized (Sèze, 2013, pp. 164, 183, 212), in the sense that it is considered an ethical responsibility targeting the individual and his or her internal communication with God, family care and protection, and the environment or outside world with which the believer has to be engaged ethically and responsibly in defence of social justice (Sèze, 2013, pp. 168-171). Values like respect, forgiveness, and dedication at work are emphasized as fundamentally Islamic (Sèze, 2013, pp. 48, 170). However, this is not the case with all imams. Some ambiguities remain for those who do not straightforwardly preach gender equality, or who speak derogatively about homosexuality and abortion (Sèze, 2013, p. 164). Broadly, the tone that appears to dominate the studied sermons ( 25 out of 30 ) is conciliatory, in the sense that it invokes eschatological arguments and the world of judgment and punishment (al-tarhib), while also invoking the importance of the here-and-now through ethical engagement (al-targhïb) (Sèze, 2013, p. 168).

\section{$5 \quad$ Reflective closure}

This chapter shows some of the challenges that Islamic religious authority is experiencing in modern times, with a focus on the figure of the imam in European secular-liberal societies. I argue that the imam is a dependent figure that adheres to the Islamic religious authority of a particular (political) trend and/or madhhab, and to the political institutions governing where he functions. The Moroccan model of the imamate is presented by the political-religious institution of the country as a way to illustrate the roles expected of the imam, especially in times of socio-political instability and tension, and the restraints his position entails. I also examine these roles 
and constraints through some recent socio-anthropological work on the French imamate. One of the main aspects of an imam's agency, within the religious-political powers that have influence over him, is the transmission of an ethicist message that preserves what he considers to be the core of the tradition and avoids going against the overall context in which he works, though cases of antagonism and incompatibility continue to be expressed by some imams on issues like female leadership and equality.

This argument suggests three main points that require further research. First, the imamate is not an independent or organized religious authority that can change the discourse on Islam in Europe, and on European Islam, unless it is nurtured and influenced by religious-political powers. This in no way belittles its fundamental role in the transmission of messages to the community of believers with which it is in direct contact, or to the community of non-believers when some imams participate in inter-religious dialogue initiatives or in the media as representatives of their community and religion. Because the imamate is not an independent religious authority, the authorities that influence it should be examined - especially in Europe, where the state authorities seem to be more organized and powerful than the Islamic religious authorities. That is, the neutrality of the modern secular state should be examined to see how far it is influencing the internal dynamics of religion and religious actors. At the same time, the religious authority that the imam clings to or that influences his thought and work has to be examined as well, to understand its sources, be they intellectual or financial. This can help scholars understand the dynamics of religion in modern contexts, including state institutions, bilateral agreements between European and Arab-Islamic countries, and transnational movements.

Second, the message of ethics also needs more examination. Ethics appears to have become an important discourse among theologians, philosophers, and engaged scholars trained in traditional seminaries and modern universities. The fact that the European imam, as a possible new agent in religious authority, seems to be adopting this ethicist discourse may gradually herald a paradigm shift in the 'episteme' of European Islam (Hashas, 2014, pp. 14-49). Put otherwise, is this ethicist message an approach that is rooted in the tradition itself while being re-appropriated, or it is a new development required by text and context? Who influences this new direction: the religious authorities in Europe, the ones 'back home' outside Europe, state interference, or all of these factors? Are imams transforming Islamic theology and law in a bottom-up approach, or are they mere transmitters of its modern internal dynamics? And what is the place of female leader-imams? 
Third, the role of imams and their ethicist messages intertwine with the issues of integration (especially of Muslim youth) and the construction of new meanings of being European. Religion in this sense becomes a way to fuse various identities together for a better feeling of citizenship. But can the imam in his mosque and community do that alone? What about the school and curricula, the media, and the mainstream European externalization of Islam? Has the imam failed to transmit his ethicist message to the European foreign fighters in Syria and Iraq? Or, as a dependent authority, does he find himself unable to do much? These issues remain to be studied, and can shed light on the profound and at times invisible roles a minor religious authority can or cannot play, and through which that authority either increases or decreases. Imams act within a local and national geography in which other factors and agents intervene.

\section{References}

Alaoui, Abdelmalek. 2015. 'Why Morocco Wants to Become a Major Islamic Training Hub'. Forbes, 31 March. http://www.forbes.com/sites/abdelmalekalaoui/2015/03/31/ why-morocco-wants-to-become-a-major-islamic-training-hub/.

Allievi, Stefano. 2003. 'The International Dimension'. In Muslims in the Enlarged Europe: Religion and Society, edited by Brigitte Maréchal, Stefano Allievi, Felice Dassetto, and Jørgen Nielsen, 449-488. Leiden/Boston: Brill.

An'naim, Abdullahi. 2008. Islam and the Secular State: Negotiating the Future of Sharia. Cambridge/London: Harvard University Press.

Aslan, Ednan and Zsófia Windisch, eds. 2012. The Training of Imams and Teachers for Islamic Education in Europe. Frankfurt am Main: Peter Lang.

Byman, Saniel and Jeremy Shapiro. 2014. 'Be a Little Afraid: The Threat of Terrorism from Western Foreign Fighters in Syria and Iraq'. Foreign Policy at Brookings, Policy Chapter, 34(November). https://www.brookings.edu/research/be-afraid-be-a-littleafraid-the-threat-of-terrorism-from-western-foreign-fighters-in-syria-and-iraq/.

CEOM (Conseil Européen des Ouléma Marocains). Introduction. N.d. Accessed 25/01/2017. http://www.ceomeurope.eu/ar/council/articles-8.

Drees, Willem and Pieter Sjoerd van Koningsveld. 2008. The Study of Religion and the Training of Muslim Clergy in Europe: Academic and Religious Freedom in the ${ }_{21}{ }^{\text {st }}$ Century. Leiden: Leiden University Press.

Eickelman, Dale F. 2010. 'Madrasas in Morocco: Their Vanishing Public Role'. In Schooling Islam: The Culture and Politics of Modern Muslim Education, edited by Robert W. Hefner and Muhammad Qasim Zaman, 131-148. Princeton: Princeton University Press. 
El Fadl, Khaled. 2005. The Great Theft: Wrestling the State from Extremists. New York: HarperCollins Publishers.

El Fadl, Khaled. 2015. 'On Women Leading Prayer'. 2o September. http://www. scholarofthehouse.org/onwolepr.html.

Ferreiro, Juan. 2011. Islam and State in the EU: Church-State Relationships, Reality of Islam, Imams Training Centres. Frankfurt am Main: Peter Lang.

Haddad, Yazbeck Yvonne and Michael J. Balz. 2010. 'Taming the Imams: European Governments and Islamic Preachers Since 9/11'. Islam and Christian-Muslim Relations, 19(2): 215-235.

Hallaq, Wael. 2005. The Origins and Evolution of Islamic Law. New York: Cambridge University Press.

Hallaq, Wael. 2009. Sharia: Theory, Practice, Transformations. New York: Cambridge University Press.

Hallaq, Wael. 2013. The Impossible State: Islam, Politics, and Modernity's Moral Predicament. New York: Columbia University Press.

Hashas, Mohammed. 2014. 'Is European Islam Experiencing an Ontological Revolution for an Epistemological Awakening?' American Journal of Social Sciences, 31(4): 14-49.

Husson, Jean-Francois. 2007. Training Imams in Europe: The Current Status. Brussels: King Baudouin Foundation.

Ibn Qudamah, Abdellah Ben Ahmed. 1985. al-Mughni [The Enricher], 10 volumes. Beirut: Dār ihyā̄' atturāth al 'arabiyy.

Jama, Afdhere. 2015. 'Five Imams Who Are Openly Gay'. LGBT Muslims, 20 January. Jouanneau, Solenne. 2013. Les Imams en France: Une autorité religieuse sous contrôle. Marseille: Agone.

Kepel, Gilles. 1987. Les banlieus de l'Islam: Naissance d'une religion en France. Paris: Seuil.

Khan, Azmat and Amina Waheed. 2013. 'Meet America's First Openly Gay Imam'. America Tonight Flagship Blog, Al Jazeera, 20 December. http://america.aljazeera. com/watch/shows/america-tonight/america-tonight-blog/2013/12/20/meetamerica-s-firstopenlygayimam.html.

Kuruvilla, Carol and Antonia Blumberg. 2015. 'Muslims Around the World Condemn Charlie Hebdo Attack'. Huffington Post, 7 January. http://www.huffingtonpost. com/2015/01/o7/muslims-respond-charlie-hebdo_n_6429710.html.

Laurence, Jonathan. 2006. 'Managing Transnational Islam: Muslims and the State in Western Europe'. In Immigration and the Transformation of Europe, edited by Craig Parsons and Timothy Smeeding, 251-173. Cambridge: Cambridge University Press.

Laurence, Jonathan. 2012. The Emancipation of Europe's Muslims: The State's Role in Minority Integration. Princeton: Princeton University Press. 
Lo, Mbaye and Muhammed Haron, eds. 2015. Muslim Institutions of Higher Education in Postcolonial Africa. London/New York: Palgrave Macmillan.

Mandaville, Peter. 1999. 'Digital Islam: Changing the Boundaries of Religious Knowledge?' ISIM Newsletter 2 (March). https://openaccess.leidenuniv.nl/ bitstream/handle/1887/17137/ISIM_2_Digital_Islam-Changing_the_Boundaries_of_Religious_Knowledge.pdf?sequence=1.

Mandaville, Peter. 2001. 'Reimagining Islam in Diaspora: The Politics of Mediated Community'. Gazette, 63(2-3): 169-186.

Maussen, Marcel, Veit Bader, and Annelies Moors, eds. 2012. Colonial and PostColonial Governance of Islam. Amsterdam: Amsterdam University Press.

McLaughlin, Kathleen. 2005. 'Woman Leads US Muslims to Prayer'. BBC News, 18 March. http://news.bbc.co.uk/2/hi/americas/4361931.stm.

McLaughlin, Kathleen. 2012. 'A Mosque of Their Own'. ChinaFile, 18 September. http://www.chinafile.com/mosque-their-own.

Moosa, Ebrahim. 2009. 'Colonialism and Islamic Law'. In Islam and Modernity: Key Issues and Debates, edited by Muhammad Masud, Armando Salvatore, and Martin van Bruinessen, 158-181. Edinburgh: Edinburgh University Press.

Moosa, Ebrahim. 2015. What is a Madrasa? North Carolina: North Carolina University Press.

Nasr, Vali. 2015. 'European Colonialism and the Emergence of Modern Muslim States'. In The Oxford History of Islam, edited by John Esposito. Oxford: Oxford University Press.

Sèze, Romain. 2013. Être imam en France: Transformation du 'clergé' musulman en contexte minoritaire. Paris: CERF.

Taylor, Jerome. 2015. 'First Woman to Lead Friday Prayers in UK'. Independent, 10 June. http://www.independent.co.uk/news/uk/home-news/first-woman-tolead-friday-prayers-in-uk-1996228.html.

Toufiq, Ahmed. 2015. 'addawr addīnī wa-ssiyyāssī li 'a-'i-mmat al-masāğid' (Religious and Political Roles of Mosque-Imams). Speech at the Fifth Forum of Leaders of Universal and Traditional Religions, 10-11 June, Astana, Kazakhistan. http:// www.habous.gov.ma

Winter, Michael. 2009. "Ulama Between the State and the Society in Pre-Modern Sunni Islam'. In Guardians of Faith in Modern Times: 'Ulama in the Middle East, edited by Meir Hatina, 21-45. Leiden: Brill.

Wyatt, Caroline. 2015. 'Imams Try to "Reclaim the Internet" with Haqiqah Magazine'. BBC News, 27 March. http://www.bbc.com/news/uk-32078681.

Zaman, Muhammad Qasim. 2002. The Ulama in Contemporary Islam: Custodians of Change. Princeton: Princeton University Press.

Zaman, Muhammad Qasim. 2012. Modern Islamic Thought in a Radical Age: Religious Authority and Internal Criticism. Cambridge/New York: Cambridge University Press. 


\section{About the author}

Mohammed Hashas is a Postdoctoral Research Fellow at LUISS Guido Carli University of Rome. In 2017 he was a Visiting Research Fellow at the Oxford Center for Islamic Studies and a Guest Scholar at the Leibniz-ZMO Zentrum Moderner Orient in Berlin. Besides the publication of various journal articles, Hashas has co-edited Islam, State and Modernity: Mohamed Abed AlJabri and the Future of the Arab World (Palgrave, 2018), and is authoring The Idea of European Islam (Routledge, 2018). 


\title{
6 Imam training in Europe
}

\author{
Changes and challenges
}

Farid el Asri

Hashas, Mohammed, Jan Jaap de Ruiter, and Niels Valdemar Vinding (eds), Imams in Western Europe: Developments, Transformations, and Institutional Challenges. Amsterdam: Amsterdam University Press, 2018 DOI: 10.5117/9789462983830/Сно6

\begin{abstract}
This chapter examines the various religious trends in European Islam by identifying examples of leadership and highlighting areas where trends interact to construct a training agenda for imams. It highlights the schematized training spaces that intellectually nourish the individual beliefs of particular citizens of Muslim faith, who are considered sources of future Muslim discursive practices. These discursive practices, in turn, can be considered tools for future religious leaders who seek to reconstruct the dominant Islamic discourse in Europe. Several major intertwining elements are studied in this chapter: mosques, imams, space and identity dynamics, actors of Islam and the construction of leadership, the formation of authority in European Islam, and the training of imams in Europe.
\end{abstract}

Keywords: Muslim citizenship, fiqh of contextualities, fiqh of priorities, religious authority, fragmentation of authority

What do imams preach in their sermons? How can we fight religious radicalization? How can we develop an environmentally friendly Islam of modernity that is in line with existing constitutions? How can we deal with Muslim countries without running the risk of political interference into the fabric of their faithful subjects? How can we achieve an aggiornamento of Islam for and by Muslims? (Arkoun, 2012). Each of these questions is likely to provoke different policies and inspire observers, institutional Muslims, and the stakeholders who are directly involved in the training of imams, to 
weigh the political and sociological paradigms suggested for understanding European Islams and to plan the construction of a single Islamic agenda congruent with Western democracy (Abou El Fadl, 2004; Dassetto, 1996).

Viewed in all of its complexity, the Gordian knot of the debate about Islam in Europe remains an issue of philosophical, theological, and epistemological order. Training religious leaders in Europe is almost analogous to directly touching the construction of a semiotics of faith, which involves considering the selection of methodologies, the choice of scientific disciplines, and the filtering of theological currents. In other words, the project consists of a certain degree of interference into the religious mechanisms that (re)define the European representations of Islam's overall future function. It goes without saying that the persistent need of an urgent functional effect in the present implies that the various actors involved in the project of training imams are not always aware of the scope of their interference into the future. This blind spot merits serious reflection and indicates the need to implement a programme of religious training that can build a structural platform, religious reform, and the formation of what might be called an 'Islam of tomorrow' - a kind of training model corroborated by consequent analyses that commits to profiling a functional corporatism of imams recognized by such training (Filali-Ansary, 2003).

The bulk of the reflections that feed on existing experiences to foster types of religious studies in Europe has led to a complex stream of readings of mainstream policies, guidelines, methods, contents, and training pedagogies, including training professionals in functional religious matters. In this chapter I propose to develop an examination of the alternative religious trends in European Islam (Leveau, 1998; Roy, 1999), identifying examples of leadership and highlighting areas where these trends could interact to construct a training agenda for imams (Mahmood, 2006). In other words, I try to highlight the currently active, schematized training spaces that intellectually nourish the individual beliefs of particular citizens of the Muslim faith, and take them as sources of future Muslim discursive practices - as tools to shape further future religious leaders. I also explain how media tropes have been squarely remodelled, shifting attention from random religious practices within the local community to the rhetorical voices of religious leaders or counsellors (Oubrou, 1998). The focus of training entails not only a return to religious sources, but also an attempt to (re)construct a dominant Islamic discourse in Europe. The role of religious leaders is therefore not limited to a simple response to their own community's affairs. Rather, they are required to act as credible interfaces between a quickly 
changing society and congruent religious affiliations in action. Individuals with this type of profile do exist; nonetheless, the drafting of projects that are structurally designed for this purpose intensifies the necessity of redesigning an effervescent context around Islam per se and leaving open the prospect of a particular European Islam in the making.

2

\section{A mosque's spotlights}

Delving into the reality of the cultural unconscious of European Islam, we cannot help coming to terms with a variety of religious experiences - itself a challenge to highlight an engineering management of training projects. Diversity involves national, cultural, religious, and linguistic aspects. On the one hand, the framework of ethnicity is very important and does impact the religious habitus within mosque premises. Discrepancies between European Muslim groups continue to play a role at the level of religious institutions within different cults, which is clearly manifest on large ethno-religious maps, prescribing trendy and diverse religious discourses. This diversity demands a wide typology of imams or religious leaders, including the leading figures from European Muslim associations. On the other hand, even the second and third generations of European Muslims have not produced many transnational Muslims who bridge different points of views, tendencies, and agendas. The debate over a common language and identity politics is also pending. Although language can bring together generations of converts and justify a coherent training programme, the inherent divergences are still powerful. Even if emerging actors of the religious fabric may seem to be effective at mediating the different sub-groups, a standard encounter remains a forlorn exception.

So far, the reality of Islam in the European cultural landscape is the outcome of a three-step transformation. We have gone from Muslims as a temporary presence, resulting in the discovery of other peripheral transits, to the expectation of acculturation and political calls for social integration. The religious component of this socialization into European society was initially dominated by specific ethnic markers, but it has ultimately gone on to establish other identity markers, ${ }^{1}$ entailing a degree of awareness of

1 The first significant expressions were thus focused on exclusively ritual aspects, nested in imported cultural forms. Building up Islam in a new and largely non-Muslim context was, at the time of the arrival of Muslims in Europe, complicated by attachments to the particularities of immigrants' language, ethnic, or national origin and non-European cultures. 
the existing Other ${ }^{2}$ and hence legitimizing the final cohabitation between various religious dimensions and interpretations.

Viewed in this light, the outstanding visibility of Islam is further expressed through the explicit re-joining of nascent religious dimensions. Ultimately, rooting an Islamic epistemology in Europe requires the culmination of a long trajectory of social and political insertions. The latest trend discloses a complicit maturation of the inaugural presence and a more confirmed status of a novel self in Europe. We have thus tended to move from the study of a silenced Muslim presence to that of the manifest, voiced outburst of a religious movement, collectively and gradually organized around mosques, which seeks to develop a theological-canonical approach that will reflect a new Muslim semiosis in the European context. The slow process of growing a ritualized, normative, intellectual, and institutional presence has been constructed according to circumstantial conditions, reinforced by trialand-error experimentation and a checks-and-balance positioning in the European context.

Changes in who represents Muslims in Europe on a given axis (e.g. foreign labour, immigration, social integration, citizenship, and the like) have fostered the (re)consideration of new centres of interest for the collective unconscious of an Islamic cross-border cause. Initial training platforms coincide, on the one hand, with the process tracing the roots of Muslim presence in the European context, thus breaking with the migration trajectory that would normally lead to the next step of citizenship, and, on the other hand, with the emergence of a Muslim youth that is in search of broader Islamic references. This swift change of perspective differs from religious transmission within the family and home, converging with intergenerational congruity and local community narratives (i.e., lectures, sermons, schooling, mentoring, and the like). Mosques, for example, were originally proclaimed to be functional spaces where identities pool in the search for religious observance, spiritual peace, reassurance, counselling, orientation, and a quest for self-assertion and self-preservation. This reading takes us back to the 196os and 1970s, when we witnessed a statutorily unregulated population that was confronted, in an unprecedented way, with non-Muslim European communities and societies. At that time, the urgent need arose to adopt new strategies or principles and invoke new benchmarks to gradually

2 The visible presence of Muslims in Europe has actually been reinforced since the beginning of the 1960 s through the migratory cycle of foreign labour, which helped in the reconstruction of post-war Europe. A young population from North African countries, the Balkans, Pakistan, and Turkey was the main population of Muslim origin in a number of European countries. 
re-appropriate the European cultural mindset. To contend with this new process of integration, Muslims in Europe gathered vocational imams from villages and the countryside of their home countries, who were stuck in traditional roles and needed time to evolve. These imams were hampered by deeply inconsistent societal expectations, and in their isolation sought to play the role of guardians of the temple. Therefore, they could only take on the role of moral safeguards and proponents of the traditions upheld by the subconscious of generations of expatriates, feeding on their spiritual angst and perpetuating therapeutic kinds of religious healing and cultural rituals.

These 'ritual coaches' were originally young, single imams whose civic role started with monitoring the Muslim workers who were economic migrants, eventually becoming counsellors for migrant Muslim families. Mosques then became a space for family planning and, in the process, adopted a discourse that was highly identity-focused. There were structural instabilities in these new functions and integral dynamics of the professions of imams, as clearly highlighted in Profession imam by the French imam Tareq Oubrou (2009; see also Baylocq in Part II).

The contested status of imams by the mosque structures, discrepancies between ethnic-community and moral duties, and the instability of the imams' contractual commitments are all parts of imams' functioning and malfunctioning. This precarious reality of spiritual leaders or coaches calls for the development of a system of rotation, in which imams could move from one mosque to another as requested by the representatives of a board of mosques where momentary modalities would be negotiated by a committee of imams. Religious trends, sermon content, preaching styles, relational affinities, involvement with the mosque's contributors, and wages were the main motivations behind the development of such a rotational system and the increased mobility of imams. Confined to their assigned mosque appointments, imams were likely to become more visible in their cities. Many Muslim advocates of district imams supported the requirement for imams to have strong cultural capital so as to be able to deal with the required level of internal and external duties.

Returning to the issue of transferring knowledge to the youth, considered the Achilles heel of serene religious transmission, I argue that religious schooling has to be first discussed in respect to the linguistic, ethnic, religious, and cultural indicators of the host country. Then comes the task of searching for a cultural environment that can ensure the vitality of religious practices during successive immigration stages. New dynamics will eventually be developed by upcoming generations that will make religion a local form of self-assertion, both in the visibility of worship, ceremonies, 
rituals, and practices and in the production of Islamic teachings that are reconsidered from within European cultural praxis.

The pioneering spaces of training, the intense mobility and low cost of Islamic sciences, and the ample investments and involvements of applicants for training programmes have resulted in structuring the admission requirements for religious education/knowledge in Europe. The highly skilled scholarship taught in these programmes, meant to empower the Islamic sciences, have been reinforced by organizational programmes, the management of educational, financial, and real estate institutions, teaching practicums, the mobility of teaching staff, and the selection criteria, moral pre-requisites, and expectations of the students themselves (El Asri, 2011a).

An analytical deconstruction of the content of the training practicums, assigned from the agreed curricula, should take time into account. Indeed, a short chronology of religious training in Europe indicates that each programme falls into distinct pathways that are dictated by current needs and trends (El Asri, 2006). The environment and development of training conditions strongly determine the nature and type of teaching experiences. We can, for example, set aside the proposals for Arabic curricula, which are traditionally open to the public, and instead favour proposals that promote functional training, which tends to match the expectations of potential students. It is now possible to detect an emerging market requesting customized Islamic vocational training in Europe. To support this tangible need for qualified professionals in religious training, the existing experimental programmes of Islamic schooling in Europe should be updated and maintained in response to the changing profiles of potential candidates (El Asri, 2015a).

\section{3 Imams' timeline}

Taking into account the migration trajectory foregrounds a number of changes in religious discourse and project reports with respect to the historicity of Islamic discourse and its symbolic manifestations. This retrospective reading allows us to understand which contents of Islam will work towards the implementation of Islamic education programmes in Europe and assessments of candidates for the chairs of Quranic schools and mosques. The early situations of Muslims in Europe indicate that their status, added to the remoteness of their country of origin, awakened in them an interest in religion and Arabic as a way to recapture a distorted and/or lost identity (El Asri, 2011b). This has increasingly reduced their 
expectations from broad religious scholarship to mere utilitarian worship, family protectionism, and the dream of a reconstruction of a fading sense of national belonging to the country of origin. The double exposure to different cultures evokes an identity split resulting in a two-fold quest: to reconstruct the bits left there (in the country of origin) and reunite them with the others built here (in Europe). The pioneering Muslim generation thus projected a Europeanized Islam as an extension of the original Islam practiced back home, which they fear has experienced a certain shortness of breath in the conservation of traditional practices, especially during generational transitions.

The second stage concerns the socialization of Muslims in their endeavour to fulfil the citizenship requirements of their host countries (Maréchal and El Asri, 2012). The 'masters' of Islam are then ascribed the role of spokespersons who offer a renewable representation of an imagined Islam. The expected image is that of a sensible, pure Islam, rooted in national languages and perceived as a devout and intelligent creed that can defend Muslim subjects (to counter the controversial perception of Islam that has been distorted through biased media reports). This demand for representation explains the success of the ongoing conferences and the logic of identity assertion. Knowledge of elite authorship thus translates a close understanding of social realities, including the reorientation or rectification of popular culture. The dissemination of knowledge is thus filtered through a discursive dialogic of moral and pedagogical interfaces.

The existing analyses of successful 'merchants of knowledge' who market services or products based on Islamic scholarship to European Muslim masses show that demand is gradually shrinking due to a growing pragmatism of cultural practices and socio-religious issues that cross into the everyday worries and anxieties of Muslims (El Asri, 2012). We can concur that the expectation a synthesis between 'how to be a Muslim' per se and 'how to be a European Muslim' remains a temporal rather than spatial semiosis of intent. These moments of desire for a strong identity and nostalgic therapy continue to dominate the transcultural landscape, despite the growing unconditional knowledge acquisitions within specific lifestyles and realities. Spaces of reflection and production of theologies, disconnected from social anchors, are still perceived as a luxury. Therefore, a number of sites of theological reflection are being sacrificed on the altar of eschatological preaching and ordinary community services like marriage, divorce, and disputes over property ownership. The current bestsellers in 'Islamic libraries' deal mostly with these issues. The social value of Islamic knowledge can therefore only contribute to its pragmatic appeal. 
The question worth asking at this stage is how to deterritorialize these new mind-sets via ascending critical perspectives. In other words, can we afford a fundamental epistemological deconstruction of Islamic knowledge through the critical construction of a hybrid Muslim identity?

\section{$4 \quad$ Space and identity dynamics}

If we consider the question of training youth in Islam, we cannot help but discard the issue of European space and the evolution of its definition through a complicit religious discourse and Muslim representations (Sellam, 1998; Turki, 1998). The peculiarity of the Muslim presence in Europe requires a particular legal expertise and provides the key to a dialogical understanding that can create a viable standpoint for Muslims. The stakeholders involved in the development of Islamic training should take different perspectives into account, as well as the legal-canonical context. Again, different religious paradigms have integrated to form an untested 'archaeology of faith.' From an Islamic point of view, a schematized Europe would allow the application of jurisprudential accounts and the legitimization of fatwas prescribed by a legal view of European reality. A classification of areas of knowledge, each prescribed according to specific contexts, should be developed in their contemporaneity and integrated into the historicity of European scholarship. We talk about a fiqh al-wāqi' ('fiqh of contextualities'), fiqh al-awlāwiyyāt ('fiqh of priorities'), and fiqh al-aqaliyyāt ('fiqh of minorities') - all independent of the dominant sharia matrix - to propose deductive, practical, and applied legal provisions in contexts in which Muslims are considered to be minorities (Al-Alwani, 2007). The concept of 'minority' can be further criticized as a factor in psychosocial ghettoization, provided that these urban extensions, which serve as a way to understand a multi-layered context, function mostly as healing management tools. Religious annotations are used to draw on legal exceptions in the past to develop viable fatwas for European Muslims. The context and newly introduced facts, such as the headscarf ban, bank credit, and marriage with non-Muslims, put the flexibility of Islamic law to the test just as much as the resources deconstructing traditional hindrances do. ${ }^{3}$

3 As early as 1970, Zaki Badawi, one of the leading figures of British Islam, initiated debate on the practical management of the experiences of Islam, focusing particularly on the issue of inheritance and women's testimony. Imam Tareq Oubrou describes a denser relationship between the theological sources and the secular context of France, outlining a theory of the contraction of sharia into secularization through the concept of 'sharia of minorities' (Oubrou, 1998). 
Besides the dominance of highly codified Islamic knowledge, in practice interpretative literature focusing on metonymic readings or allegorical meanings has emerged. The questioning of the compartmentalization of disciplinary boundaries is becoming more common and invokes a multidisciplinary approach. At the same time, deconstructionist and epistemological questioning tends to favour empirical readings of the Muslim world. The critical works of Mohamed Arkoun (d. 2010) and Nasr Abu Zayd (d. 2010) fall within this trend. Thus, the question of the overflow of the legal framework, which ensures the viability of the institutions and practices of Islam, proclaims the exit of the permissible and the forbidden and opens up debate on the concept of mașālih ('advantages') - equivalent to the logic of a common homogeneity or grammar of the 'forms of thought', as defined by Kenneth Burke (1969) - which overlooks the closed readings of the fuqahä'('Muslim jurists') and conventional imams. The crisis of Islamic discursivity in Europe testifies to the palpable tension between mainstream narratives and the expectations of the new Muslim readership. While no call for the reinvention of the core Islamic legacies has yet been made, a post-identity approach could make new theological prospects possible in this new context. The particularity of European Muslim mainstream theology allows for irregularities in religious scholarship. How can we perceive of Islamic training in such a context? Should we consider dialogized training in the legal concept of minority, for example? Or, on the contrary, should we privilege approaches that encourage historical-critical readings?

In any social group, and more specifically in any religious system, leadership is crucial for guiding the development of the community in question (El Asri, 2009). Religious leadership performs various functions: improving social cohesion, promoting resources, managing social relations with the divinity, producing knowledge, and transmitting religion to the next generation.

As it is organized in Europe, Islam seems to be associated with appointing leaders first, then other intermediary actors and groups, and finally through considering new influences. The fact that Muslim leaders, trained in Muslim countries that are at the forefront of pure Islam, come on stage through sociocultural praxis also presupposes the appearance of new figures, new leaders - a fact that introduces into Europe the concerns of Muslim countries, including their own vision of the present state of things and claims that European society is not considered particularly functional or appropriate to their needs. 
Similarly, we have lately begun to note the return of members of the second generation of immigrants after studying the Islamic sciences in Muslim countries, all of whom are aware that their studies cannot be continued in Europe. This return with an Islamic background that cannot easily be adapted for the new socio-cultural environment in which they find themselves is even more important because extremist Salafi groups could easily influence it. In other words, European Islam continues to be affected by the dynamics of a global Islam, in this case the global tributaries of Islams (Cesari, 2014). Nevertheless, European Islam is not only imported, but also imprinted by actors born in European territory (Dassetto, 1996).

The internal organization of European Islam is never finalized; leaders are few, and the board of scholars is constantly being reconstituted. Populations are not yet ready to take full possession of their rights in the European public space of their host countries, and a large number of Muslim citizens remain hampered by daily difficulties and incessant feelings of insecurity. The political drive to develop a training practicum of imams, chaplains in prisons, and creed consorts spells out the priorities of the government, which does not guarantee a healthy construction of self-projection in the near future (El Asri, 2015b).

Steps towards grasping the paradigms of Islamic practice are schematized by the social recession and other urgent matters. Though the process of precipitation might sometimes offer interesting creative outcomes, the result is generally much more complex. European, and especially French, Islam, for example, gains momentum from a politically correct narrative; if the issue of Islam is submitted to the heat of unfriendly news lobbies, it is likewise too often tampered with based on election agendas.

\section{Muslim leadership in construction}

Compared to other religions like Roman Catholicism, European Islam does not have a rigid structure with a monopoly on legitimate power. In Muslim societies there are clear-cut authorities that derive their legitimacy from acquired religious scholarship (the ulama), or whose legitimacy is delegated to them by a public authority (Muslim jurists, even if some of them are also regarded as scholars). These include the murshids ('guides') or Sufi masters, who are legitimized by their spirituality. These leaders exert their power $d e$ facto and cannot claim to be part of a monopoly with respect to a hierarchy or more legitimate religious authority. 
The development of a school syllabus with an educational agenda, coupled with empowering mass communication systems such as satellite transmissions and social media, have significantly changed how leadership is developed in Muslim countries. New leaders appear on the boards of traditional structures of Islamic universities and in other public arenas of the brotherhood networks. In their transfer to the European context, a large number of these religious leaders have become popular public figures, such as Larbi Kechat in Paris, Tahar Toujgani in Antwerp, and Adnan Ibrahim in Vienna. Each of these leaders was trained in Islamic sciences and only afterwards introduced to European cultural models. They may be known as the isolated leaders of immigrants, or might be recognized by Islamic organizations. Other leaders are members of international Islamic agencies within their home countries, whose agenda they represent and implement in Europe; the work of the Turkish Directorate of Religious Affairs (Diyanet) in Europe is a major example of this. In most cases, these leaders exercise a certain degree of bureaucratic authority, bolstering their efficiency through their relationship with the structure that has mandated their role, and are sometimes supported by European state agencies (like the Muslim World League and the Turkish Diyanet, the Directorate of Religious Affairs). Some leaders are part of the political fraternities of students who complete graduate studies in Europe, but upon returning home resort to Islamic activities (whether as their main activity or a separate professional project). While some are self-taught, others have received hasty and intensive Islamic training. All claim to be, often more or less, experts in disciplines like medicine, economics, sociology, agriculture, and information technology, to name but a few.

Another type of leader, like Tareq Oubrou in Bordeaux, consists of individuals who have been able to cross into European territory through mixed marriages since the 1980s. Immigration through marriage and family reunion has become a common strategy to access Europe. Some of these leaders acquired their socialization in religious studies in their country of origin in the 1980s; after marriage, the newlyweds transferred their knowledge and religious expertise into their European lifestyle. While certain leaders have even been born, bred, and immersed in European culture, immigrants have had their own leaders since the moment Islam arrived in post-World War II Europe. It was the older generation of immigrants (often retirees, sometimes victims of work accidents and social security recipients) who received more Quranic training from an early age and undertook organizational tasks in Europe, including the role of imam in the prime prayer rooms. Starting in the mid-199os, the younger generation from immigrant families, but who 
were educated or even born in a European country, began to play a more important role on the European Islamic scene. Some examples of leaders from this second generation are Yacob Mahi, Rachid Haddach, and Mustafa Kastit in Brussels. These new leaders were so successful that a generational conflict seems to have divided the 'founding fathers' and other pioneer immigrants who still exercised authority from the younger generation, whose leaders wished to invest in a future European Islam.

Thanks to study grants and research partnerships, some of these young Muslims were able to finance their studies and training in Muslim countries, where courses are offered in traditional Islamic universities (Zeytouna in Tunis, Al-Azhar in Cairo, Al-Qarawiyyine in Fez), as well as in Turkish universities, in Saudi universities, and in the madrasas of Pakistan. Some were also able to undertake internships with Muslim NGOs and state institutions. After their studies, some of these young Muslims returned to Europe and began to play an active role in European Islam.

Another category of leaders consists of European converts to Islam like Franck Amin Hensch in Verviers or Dawud van Beveren in Brussels. Apart from the well-known public figures in politics, cinema, sports, and music, a large number of common men and women, often young, are attracted by Islamic teachings and choose conversion. Of course, these new converts to Islam do not all aspire to be leaders. For many of them, the conversion is desirable for mystical or spiritual reasons involving no public action whatsoever. Others still adhere to a spirit of intellectual, organizational, and political leadership that lead them, in their dual positioning, to undertake great responsibilities in the European settlement of Muslim populations, particularly with respect to leading the scholarship on how to bridge Islamic creed and embrace public activism.

The current political predicaments that have brought the crisis of Islam to a global scale raise the sensitive issue of authority. The new presence of Islam in Europe addresses this issue as a small, original case, but it can indicate the reflexive tracks that can be applied to a larger scale. We consider this reflection on the authority and training agenda in Europe to be a potentially malleable experience, rather than an isolated concern confined by its sociological and geographic specificity. The legitimacy of Muslim intellectual authority in Europe is assessed above all based on scholarly training. This legitimacy varies according to the scholar's degree of connection to the 
Muslim reality and the depth of their scriptural lineage. The conventional transmission of knowledge from master to disciple and credentials from traditional universities retain strong symbolic capital in the assignment of authority. Places of seniority and the direct transfer of Islamic sciences to others by the Islamic scholars remain the symbols of authenticity from which a genealogy of authority has developed.

The relocation of young Muslim Berliners or Londoners to places of knowledge in Islamic lands is therefore explained by the lack of local supply, but also by an inappropriate natural breeding-ground for what will make up authority. A case in point is a bachelor's degree in theology from the university in the collective mind-set of Muslims. The relentless reasoning that continues to forge Muslim representation is that authority must be sought outside of Europe. This is true despite major political turmoil across the Arab world, which has given birth to a good number of so-called natural, in the sense of non-organized, religious authorities through the ijāza ('license') system offered by a known scholar or sheikh to new graduates. Many of them are newly perceived as seraglio authorities in perpetual loss of credibility and legitimacy. The interweaving of Islam and politics has tinged the credentials of muftis in Egypt, sheikhs in Syria, scholars from the Gulf countries, and popular media preachers, tainting their reputation through their audience's mistrust (El Asri, 2012).

In addition to the religious training curriculum necessary in European Islam, religious authority draws on community experiences. The authority of theologians or Muslim intellectuals in Europe is a social construction prompted by mediators and faith managers. It is the outcome of individuals' interpretations and readings, ranging from the modes and production of concrete holy texts to their pragmatic earthly use. The leaders produce ideas in communion with the community's customized needs as well as for public consumption more broadly. They interact with reality and may gradually gain recognition from the public. Since the 1990s, the construction of the status of Muslim scholars and intellectuals has changed. These are now intellectuals who weigh political, economic, and religious affiliations at the crossroads of valuable formal training. The training programmes led by public institutions or formed by Muslim organizations are channels that fuel the emergence of welltrained religious figures and intellectuals from Muslim backgrounds. The teaching of Islamic and social sciences initiated in 2015 by the Exécutif des Musulmans de Belgique (Council of Muslims in Belgium) and the Faculty of Theology of the Catholic University of Leuven is one example of work in this direction. 
In examining the sociological reality of Muslim leaders in Europe one soon realizes that the process of fragmentation and proliferation of religious authority is inherited from Islam's various contexts (Gaborieau and Zeghal, 2004). A theological contest has been launched between 'traditional Islam' and 'modern Islam', extending most particularly to the divide between the intellectual and traditional ulama. However, there is the possibility of challenging the authority of each of these groups based on the legitimacy of their training, thus ensuring the continued internal criticism of scriptural sources and Islamic teachings.

The Muslim religious landscape shows significant fragmentation of religious authority, resulting in a segmentation of public audiences. The process of individualization of Muslims arises in this cacophonous situation (Roy, 1999). The entry of Islam into secularized European cultural space, which is specifically tailored towards the importance of individual choices, reveals poignant differences of religious orientation. This individualization is caused by the gradual breakdown of ethno-religious referents to imagined sources. One of the major intellectual challenges is to rethink the multiplicity of forms of membership, their relative autonomy, and the profound unity of the Muslim community. The umma-egocentres operate in the religious field through the trial of identities, where new dictates of the self are (re) constructed. This growing individualization that leads to an Islamic text in the first person causes the impact of authority to erode; leaders become mediators between the difficulty of accessing sources (including language barriers) and the choice of individual orientations. New converts draw on a variety of religious offerings, including a blurred typology of Islamic leaders. They have a plethora of choices between the conservatives, school mentors, secularists, liberals, radicals, 'new thinkers', literalists, and so on.

This trend still demonstrates a shared intellectual reality between the in-house authors, who produce an extension of the hermeneutics of religious texts, and the advocates of an unconditional hermeneutics dictated by interpretative purity. This approach to theological literature and the required hermeneutical efforts have yielded stringent problems within Islam in Europe. It is worth asking, then, whether it is better to develop a training practicum that grants participants a single choice, or one that allows them to adopt different approaches.

In light of this question, we should note that there is a category of theologians who advocate a hybrid curriculum, inspired as much from theology as from the social sciences (El Asri, 2015a). They propose new ways of understanding religious texts beyond the conventional interpretative pamphlets. These voices stand out as proponents of exceptional profiles, 
which are increasingly solicited by Muslim trainees, and whose teaching portfolios attract certain training projects related to applied theology. This issue of profiles and guidelines emphasizes the ultimate end of the training beyond oratorical advances of the urgent fight against radicalization.

Muslim audiences are looking for a relatively easy way to meet their needs provided by leaders with multidisciplinary profiles. This analysis is based on our follow-up of the continuous training offered at the Catholic University of Leuven from 2007 to 2017 in a course entitled 'Social and religious sciences: Islam in the modern world'. Some 500 students that have gone through this training believe that the allocation of religious authority must now reflect a mastery of the complexities of related issues. We are far from the imprints of the first trends installed in Europe, which have been in rupture or which were subjected to a repositioning against Islamist ideologies of the $1960 \mathrm{~s}$, and closer to an overflow of the historicized and contextualized interpretation of texts for religious purposes. The progressive decline of judicial and normative approaches to Islamic authority implies the necessity of moving away from religious formalism. More objectivist approaches and multidisciplinary methods of reading Islam are gaining ground in the implementation of an Islamic discursivity, despite the surge in literalist readings that is clearly visible in some Muslim groups and associations.

\section{Towards a scrutiny of Islamic training projects in Europe}

Support for the spiritual and rational credentials of religious scholarship has, to different degrees, affected local communities in Europe. Drafted for and adapted to changing circumstances, and gradually legitimized through progressive academic and institutional programmes, religious training packages show a curve of nascent trends, as well as projections of a new Islam. Apart from sermons and religious preaching at mosques, there are three basic configurations of religious training: (1) within private circles in Europe; (2) expatriation to a Muslim context; and (3) in-between, i.e. anywhere where training is (or was) done in Europe, including cases where certification was acquired through an internship-based immersion in a religious authority (El Asri, 2006).

Private circles are informal, sometimes spontaneous, and often of a nuclear nature. Seminar circles called halaqāt, which are similar to types of Sufi gatherings, are one example. They provide an outline of structured lessons, with a specific needs-analysis of daily expectations. These halaqāt cover a variety of subject areas, including mysticism, religious norms, and 
patterns and ethical standards. Eventually, it is from these structured religious commitments that the dynamics of future training sessions are adapted.

Starting from the second generation of immigrants to Europe and with the gradual conversions to Islam, new departures and imam-training programmes developed in Muslim countries to provide further studies. The potential return to Europe after a few months or years of training in either academic or traditional teachings has created a new profile for the leading figures of local Islam. Saudi Arabia, Yemen, Jordan, Syria, Egypt, and Morocco are the target countries for Muslim youth in search of such knowledge. The general guidelines, readings, and quality of the training are variable and depend on the orientation of the religious organization that provides the training and its stream of thought.

Finally, the tradition of $i j a \overline{z a}$ (literally, 'authorization/permission to preach') is a middle path that has been appropriated for pedagogical and ideological purposes. It consists of a set of skills and tools used to assess a teacher's ability to control learners' acquisition of religious material. In an Islamic context, a religious authority or individual with disciplinary jurisdiction in the Islamic sciences performs this comprehensive competency assessment. It seeks to evaluate the transmission of knowledge from master to disciple, reminiscent of the teachings of the prophet in early Islam. Ijazza can extend from reading from the Quran to a minute critique of classical reference books, a discipline, or a whole school. Upon graduation, the right to convey the referenced knowledge for which the $i j a z z a$ is delivered is conferred onto the graduate. This title and the accompanying teaching certification have traditionally been highly valued and authoritative. Its holders are given maximum respect in some countries (by virtue of the rigor attributed to their receipt of the title), though they may also be subject to doubt in others. ${ }^{4}$ The status of the $i j a z a$ is unlikely to be compromised, but it is still not safe from scrutiny and criticism. This process is contested more so in Europe, where religious authorities offer either all or part of the traditional certifications in religious curricula (Roussillon, 2005). More traditional training institutions are also being set up, such as the Islamic University of Rotterdam. Their activism is indicative of the quietist presence of Islam, which is dominated by the language of the country of origin.

The structural transformation of Islamic training environments coincides with the projection of Islamic life into the European context, over more

4 Muslim countries, particularly in the Middle East, are sometimes known for how easy it is to receive $i j a \bar{z} a$ there, which brings the credibility of the title into question. 
than a decade at least. Austrian jurists, for instance, have allowed the establishment of a school to train religious counsellors. However, for 25 years we have mostly seen attempts to transplant models, mainly Arabic- or Turkish-speaking ones, into Europe. These models mostly attract students from Muslim countries (El Asri, 2006).

The linguistic transition to European languages has been imposed by the scarcity of individuals with the ability to cope with both the requirements of the original language and the need to adapt to new demands of the Muslim community. Over the last fifteen years, we have witnessed a growing demand for training from French-speaking, English-speaking, and Spanish-speaking candidates, among others. There are now more than 100 hundred training projects dotted across European countries (El Asri, 2006). Initiatives include more than one hundred enrolled, leading to better and diverse training pathways.

Over at least the last five years, serious initiatives have been taken up in various European contexts to train imams within the context in which they have to function. Still, European Muslims have suffered from a severe lack of new training experiences. Those that are already on track, for example, at the junction of the research of official recognition on the part of the political, academic, national institutions or universities in Muslim countries, as well as public authorities' contributions, are all eager to build up a certain Islamic narrative. Thus, in addition to market demands, public recognition, academic conventions, and institutional partnerships, the result will be an efficient training practicum that meets the expectations of the public sector.

\section{References}

Abou El Fadl, Khaled. 2004. Islam and the Challenge of Democracy. Princeton: Princeton University.

Al-Alwani, Taha Jabir. 2007. Introduction au statut des minorités: Vers un figh des minorités musulmanes en Occident. Paris: IIIT.

Arkoun, Mohamed. 2012. La construction humaine de l'islam. Paris: Albin Michel. Burke, Kenneth. 1969. Grammar of Motives. Berkley: University of California Press. Cesari, Jocelyne. 2014. The Oxford Handbook of European Islam. Oxford: Oxford University Press.

Dassetto, Felice. 1996. La construction de l'islam européen: Approche socioanthropologique. Paris: L'Harmattan.

El Asri, Farid. 2006. Offre de formation en sciences islamiques. Brussels: Fondation Roi Baudouin, CISMOC, UCL. 
El Asri, Farid. 2009. 'Les défis d'une pédagogie de l'accompagnement: Analyse d'un processus à la lumière des intellectuels musulmans'. In Intellectuel engage: Patrimoine islamique d'Europe, edited by Mohamed Mestiri, 151-162. Paris: IIIT.

El Asri, Farid. 2011a. 'Le contenu scientifique et pédagogique et la formation des cadres religieux musulmans'. In Islam en Europe:formation des cadres, éducation religieuse et enseignement du fait religieux, 233-249. Rabat: Marsam.

El Asri, Farid. 2011b. 'Finalité de l'enseignement de l'arabe à l'étranger: Dynamiques migratoires et offre publique et privée'. In Langues en immigration, mutations et nouveaux enjeux, edited by La Croisée des Chemins, 41-49. Casablanca/ Paris, Séguier.

El Asri, Farid. 2012. 'Les savoirs théologiques musulmans à l'épreuve de l'Europe'. Paper presented at the conference on 'Mutations des Religions et identités religieuses', Louvain-la-Neuve, September.

El Asri, Farid. 2015a. 'Les enjeux de la formation islamique en Europe francophone'. Religiosités musulmanes dans le monde francophone, 36(4): 79-105.

El Asri, Farid. 2015b. 'An Outline of the Construction of the Islamic Council for Prisons in Belgium'. In Contemporary Religious Diversity and Rehabilitation Issues in European Correctional Facilities, edited by Irene Becci and Olivier Roy, 47-59. Cham: Springer International Publishing.

Filali-Ansary, Abdou. 2003. Réformer l'islam? Une introduction aux débats contemporains. Paris: La Découverte.

Gaborieau, Marc and Malika Zeghal. 2004. 'Autorités religieuses en islam'. Archives de Sciences Sociales des Religions, 125: 5-21.

Leveau, Rémy, ed. 1998. Islam(s) en Europe: Approches d'un nouveau pluralisme culturel européen. Berlin: Centre Marc Bloch.

Mahmood, Saba. 20o6. 'Secularism, Hermeneutics and Empire: The Politics of Islamic Reformation'. Public Culture, 18(2): 323-347.

Maréchal, Brigitte and Farid El Asri, eds. 2012. L'islam belge au pluriel. Louvain: Presses Universitaires de Louvain.

Oubrou, Tareq. 1998. 'Introduction théorique à la charî'a de minorité'. Islam de France, 2: 33-47.

Oubrou, Tareq. 2009. Profession imam. Paris: Éditions Albin Michel.

Roussillon, Alain. 2005. La pensée islamique contemporaine, acteurs et enjeux. Paris: Téraèdre.

Roy, Olivier. 1999. Vers un islam européen. Paris: Éditions Esprit.

Sellam, Sadek. 1998. 'Peut-on être un bon musulman quand on est citoyen d'un état non musulman?' Islam de France, 1: 28-30.

Turki, Abdel-Majid. 1998. 'Pour ou contre la légalité du séjour des musulmans en territoire reconquis par les chrétiens: Justification doctrinale et réalité historique'. Islam de France, 1: 43-61. 


\section{About the author}

Farid el Asri, Anthropologist, is an Associate Professor of Political Science at the International University of Rabat, where he holds a chair in Cultures, Societies and Religion. He is also a Researcher at the Anthropology Laboratory at the Catholic University of Leuven (UCL), and a Guest Professor at Saint-Louis University in Brussels. He is the Scientific Director of the 'continuous training in religious and social sciences: Islam in the contemporary world' project at UCL, and the European Muslim Research on Islamic Development (emridNetwork) in Brussels. His recent works include Islam belge au pluriel (with Marichal Brigitte) (Louvain: UCL, 2012). 



\title{
$7 \quad$ Studying Islamic theology at European universities
}

\author{
Göran Larsson
}

Hashas, Mohammed, Jan Jaap de Ruiter, and Niels Valdemar Vinding (eds), Imams in Western Europe: Developments, Transformations, and Institutional Challenges. Amsterdam: Amsterdam University Press, 2018 DOI: $10.5117 / 9789462983830 / \mathrm{CHO} 7$

\begin{abstract}
The primary aim of this chapter is to describe the relationship between the last decade's discussions and debates about theology and religious studies and the start of courses in academic Islamic theology at European universities. After a brief outline of the most important positions in this debate, I turn to how Muslim theologians sometimes behave when they describe how the study of Islamic theology 'should' be performed. A second aim is to discuss, with the help of a survey sample from Sweden, whether and to what extent Muslims who seek a theological education at a European university are interested in courses on academic Islamic theology. A third and final aim is to discuss why European universities are interested in starting courses in a subject that is often promoted under the title of academic Islamic theology.
\end{abstract}

Keywords: Islam in Sweden, Islam in Germany, Islamic theology, secular universities

Some more-or-less organized studies of Islam and Muslim texts have been part of the academic curriculum of European universities since the Middle Ages (Martin, 1995). The earliest studies were primarily philological and polemical, often with an overarching purpose of demonstrating that Islam was a false religion. After the rise of the history of religions as a sub-discipline at the end of the nineteenth and the beginning of the twentieth centuries, Islamic studies continued primarily to be the study of history and ancient texts, a process in which Islam and Muslims were generally, if not always, 
seen as non-European. The Swedish Professor of History of Religions at Uppsala, Geo Widengren (1907-1996), serves as an example here, as he is quoted as having claimed that: 'Yes, when it comes to the study of Islam I have never done anything on this side of the 12th century' (quoted in Hjärpe, 2012, p. 270, my translation). I suggest that this quotation tells us much about the early study of Islam in Western Europe, namely that it was rooted in the idea that Islam was only a relevant object of study in relation to the Christian theological traditions, and that consequently scholars should focus on texts and not on living Muslims. Today the situation has changed, as it is evident that large numbers of Europe's very heterogeneous population have Muslim cultural backgrounds. These structural changes have challenged the study of religions in many ways. For example, more academic studies have focused on sociological and contemporary issues of so-called lived religions. One could say that the tables have been turned, and that there is currently less focus on history and philological questions. Apart from the risk of losing important philological and historical aspects of religious studies, one new advantage is the rich diversity in terms of faith, worldviews, ethnicities, and languages of university students today. However, it is evident that the study of Islam and Muslims has not taken the theoretical and methodological implications of these changes sufficiently into account. According to Aaron Hughes (2007), the field could, in fact, be described as immature when it comes to theoretical and methodological issues; there is, then, a great need to develop the study of Islam and Muslims in a scientific and critical manner.

Leaving Hughes' critique aside, the primary aim of this chapter is to describe the relationship between the last decade's discussions and debates about theology and religious studies and the start of courses in academic Islamic theology at European universities. After a brief outline of the most important positions in this debate, I turn to how Muslim theologians (sometimes) behave when describing how the study of Islamic theology should be conducted. My intention is to highlight the possible differences between how Muslim theologians envisage Islamic theology and how an academic Islamic theology might be taught at European universities, most of which are secular by nature. A second aim is to discuss, with the help of a sample survey in Sweden, whether and to what extent Muslims who seek a theological education at European universities are interested in programmes that offer academic Islamic theology. A third and final aim is to discuss why European universities are interested in starting courses in a subject that is often promoted under the title 'academic Islamic theology'. Sometimes these initiatives are presented as parts or rather as modules in imam training 
programmes, but in other cases they are 'only' labelled as courses in Islamic theology. Given the focus of Part I, it is important to underline that the difference between so-called Islamic training programmes and courses in Islamic theology is unclear, and that the two terms are often used as synonyms. The focus in this chapter is on courses in Islamic theology, but these courses can often be parts of larger programmes, some of which could have the ambition to educate Islamic theologians or imams.

First, it is clear that all academic subjects must be situated in a theoretical, methodological, and conceptual understanding that addresses the problem of what to include and what to exclude, and how the 'subject matter' should be delimited and studied. Although I am well aware that the scope and definition of what to include and what to exclude in the general rules of science is debatable and has changed over time, I wish to primarily focus on the importance of coming to conclusions that are based on intersubjectively testable observations and studies that are based on hypothetical-inductive methods. It is therefore important to decide whether the study of Islam and Muslims should form part of the general programmes covering the history of religions. Is this field an area study in a geographical sense? Does it have its own theories and methods, or does it follow the general rules of academia?

Second, it has also become more important to consider the real or imagined boundary between the academic study of religions and theology, especially since a growing number of universities in Europe have started imam-training programmes (Larsson, 2009) and to set up courses in academic Islamic theology and philosophy, such as the one at the University of Uppsala, Sweden. Should the theological study of Islam follow a different set of rules, live up to other expectations, or should this topic be part of the curriculum at universities that are often secular by nature?

Without going into these sometimes heated debates in great detail, the issue at stake seems closely related to questions about the nature and scope of the study of religions and whether theology should be considered a scientific discipline. On the one hand, there are those who strongly argue that universities should be driven by critical and scientific agendas that follow the basic requirements promoted by most scholars of the natural sciences. This understanding is, for example, advocated by many scholars who adhere to the programme that often is known as the cognitive study 
of religions (Pyysiäinen, 2014). Accordingly, the university scholar should only be a critic and not a caretaker that works like an apologist (Lincoln, 1996; McCutcheon, 2001). In the words of the Canadian professor of religious studies Donald Wiebe:

the academic study of religions must be undertaken for academic - that is, purely intellectual/scientific reasons and not as instrumental in the achievement of religious, cultural, political or other ends. This means, quite simply, that the academic/scientific study of religion must aim only at understanding religion where 'understanding' is mediated through an intersubjectively testable set of statements about religious phenomena and religious traditions. As with any other scientific enterprise, therefore, the academic study of religion aims at public knowledge of public facts. (1988, p. 407)

Still, we also find scholars and thinkers who are more open to the idea that the study of religions could be innovative, constructive, and contribute to the development of so-called theological thinking (Ford, 2009, p. 34). In Jeppe Sinding Jensen's understanding, this approach is often characterized by a common explicit or implicit agreement that religions 'have a "common essence" and refer to something metaphysically real (e.g. "God") that is considered the origin and cause of religion' (2014, pp. 21-22). While the first position, i.e. the scientific study of religions, leaves little to no room for theology, the other position is more open and positive towards theology and other forms of constructive sociological and historical enquiry, such as post-colonial studies (Joy, 2001), gender studies, or the critique of ideologies.

Between the two positions I have described above according to a somewhat Weberian ideal-type model, it is also possible to find a large number of scholars occupying what we might call the middle ground. Scholars like Craig Martin (2012) and Russell McCutcheon (2001) have problems with propositions that are based on religious claims, i.e., with some kind of reference to a transcendent reality, but not with theories that are based on, for example, social constructivism, post-colonialism, or gender studies. These scholars emphasize the importance of considering language, semiotics, hermeneutics, and power constellations when studying religions to a much greater degree than, for example, Wiebe. Because of their understanding of science, they are also more inclined to express doubts about explanations that primarily equate the study of religions with the natural sciences. Hence, it is essential to stress that there is no consensus among scholars. Instead, there are a number of different and often conflicting understandings of the 
definitions of both theology and religious studies (Jensen, 2014). David Ford envisages a combination of religious studies and theological studies, with the two approaches coexisting in the university (2009), but for a thinker and Thomist like Gavin D'Costa, theology should be theology. In his own words, 'If theology is not theological, it should abandon its name' (D'Costa, 2009, p. 53). Leaving aside these interesting differences over how to teach religious studies and theology, it is still necessary to ask what these questions have to do with the study of Islam at European universities today.

Before I turn to this question, however, I should make my own position clear. According to my own understanding and scientific outlook, religious studies consist primarily of the study of humans and what individuals do with something they call religion, both in history and today. Consequently, it is beyond the scope of science to decide whether God exists or not, and the matter of interpretation has nothing to do with God or any other superhuman agencies. Rather, it is a matter of conflicts over authority and legitimacy. Interpretations about what God thinks, approves, or dislikes, or what 'religion says' is nothing more or less than information about how humans interpret and make use of something they call religion to gain power or influence in society. My attitude to religious studies is therefore reductionist and in line with the approach commonly known as the critical academic study of religions, an approach upheld and supported by thinkers such as Russell T. McCutcheon, Craig Martin, and Donald Wiebe, three academics to whom I refer and quote extensively in this text. That said, it should be clear that I have problems with speculations that make reference to something transcendent, for example: 'this is the will of God', or this is in line with 'proper' Christianity, or something similar, but this scientific outlook does not automatically rule out the ability to make normative or ethical statements. In my understanding, the university should be free from confessional statements, but it should not be free from normative statements concerning values like democracy, equality, or justice.

One way to describe how the majority of Muslims have approached Islamic theology is to turn to an educational text compiled for Muslim students who want to learn about Islamic dogmas and creeds. Still, when using the word 'creed' in an Islamic context, it is important to bear in mind that the 'notion of creed comes from the Christian thought world' and that it is difficult to find an exact parallel in Islamic traditions when it comes to 
form and function (Speight, 1995, p. 139). Within Christian traditions, creeds are often the outcome of Church synods and discussions of conflicting opinions about how to understand and apply Christian theology. In Islamic traditions - which are the focus of this chapter - there are in most cases no similar way to lay down a creed. One Islamic parallel that is very similar to a Christian creed is the shahada, the declaration of faith ('I witness that there is no God but God and that Muhammad is the messenger of God'), the utterance that generally constitutes the minimal qualification for an individual to be counted as a Muslim. Yet another parallel to Christian creeds are the debates about 'aqì $d a$, generally translated as 'creed', 'doctrine', 'dogma', or 'article of faith'; a formula written with the aim of 'defining the position of an individual, school or sect on some disputed point' (Watt, 2013, p. 332). While there does not seem to be much conflict over the content of the shahada, there are evidently more disputes concerning the issue of 'aqìda. Drawing a boundary around the Islamic faith is complicated because there are few if any organizational structures among Muslims that resemble the organizations found among Christian churches. As a consequence, there are few instances or people that can claim the authority to stipulate a definition that would automatically become valid for or applied to all Muslims around the world. ${ }^{1}$ Thus, when discussing creeds it would, of course, be possible to choose many different texts, but one illustrative example that is often recommended by Sunni Muslim theologians is from the ninth-century theologian Abu Ja'far al-Tahawi al-Hanafi's very popular text, Aqidah al-Tahawiyya (On the life of al-Tahawi, see Calder, 2012/2014). ${ }^{2}$

The Aqidah al-Tahawiyya is a short text that lists what Muslims 'should' believe in and what they 'should' refrain from, in al-Tahawi's understanding. Explicitly or implicitly, the text contains references to a number of so-called

1 One example is the rise of the Ottoman Empire and the Turks, who tried to impose Hanafi law on their subjects by installing a chief theologian with authority over how Islam 'should' be applied and understood by Muslims. This position was held by the Shaykh al-Islam (Hallaq, 2009, pp. 55-56, 80-82). Today the situation is different, and several states in the Middle East and the Gulf region have so-called state imams and muftis, who try to lay down how Islam should be interpreted, applied, and understood in a specific country. One illustrative example of this development is found in Skovgaard-Petersen's study of Egypt and the rule and function of the Al-Azhar Institute and the dār al-iftā' (Skovgaard-Petersen, 1997). See also Waardenburg (200o) for more examples.

2 The text Aqida al-Tahawiyya is easy to find online in both translation and in Arabic (with or without commentaries). One such collection of different editions and translations can be found at: http://attahawi.com/2009/03/21/english-aqidah-tahawiyyah-translations-and-commentaries/, consulted on 10 November 2014. An academic translation of the text is also found in Watt, 2007, pp. $48-56,33^{2-}-33^{6}$. 
Muslim sectarian opinions, or, to use a more scientific language, positions that are different from or in conflict with al-Tahawi's views. These groups are the $\mathrm{Mu}^{\mathrm{c}}$ tazila, Jahmiyya, Qadriyya, Jabriyya, Shia, Khawarij, and those aiming at the mystical interpretation of Islam, i.e., interpretations that are generally subsumed under the heading of Sufism. Because of the limitations of this chapter I do not have enough space to go into any theological or historical details about any of these sets of ideas (for general references see, for example, Encyclopaedia of Islam, 2nd edition). However, the most important point is that readers of al-Tahawi's creed should be sceptical or even openly critical of the approaches, interpretations, and ways that are associated with these ideas. The text confirms over and over again that a Muslim should believe in Allah, his messengers, the books, the angels, divine destiny, the end of time, and judgement day. To give one example from al-Tahawi's compendium:

The Quran is the word of Allah. It came from Him as speech without it being possible to say how. He sent it down on His Messenger as revelation. The believers accept it, as absolute truth. They are certain that it is, in truth, the word of Allah. It is not created, as is the speech of human beings, and anyone who hears it and claims that it is human speech has become an unbeliever. (Al-Tahawi, n.d., p. 7)

Based on this brief summary and quotation from the Aqidah al-Tahawiyya, as well as other observations (Boender, 2013), most Muslim students who are interested in theology seem to be concerned about learning about God and how to become a good Muslim. For example, Jacques Waardenburg makes the following observation regarding books on other religions used in Muslim countries: 'As far as I could ascertain, most of these books directly (in often blunt terms) or indirectly make it clear to the reader that Islam is the only true religion, and the true alternative to the other religions that are described' (2000, p. 97). Boender also confirms that many young students who want to work in Islamic organizations or mosques are more interested in acquiring a confessional training rather than a secular understanding of Religious or Islamic Studies. She concludes: 'the attractiveness of foreign imams and Islam education is relatively large - Muslim students, born and raised in the Netherlands, go to the University of Medina or to Al-Azhar if they want to study Islam' (Boender, 2013, p. 244). The desire to learn about God and how to become a good Muslim is very different from how scholars of religious studies in the West approach religious texts and traditions (Jensen, 2014, p. 22). In stark contrast to McCutcheon's research credo, the whole purpose of this kind of study is that the student should become a 
caretaker, not a critic. Faith should be upheld, maintained, and defended against heresy and all forms of corruption. However, before I leave this discussion it is important to stress that this understanding of the rule and function of theology and theological education as an apologetic enterprise is not unique to those Muslims who want to act as, for example, religious leaders in mosques or Islamic institutions. Similar ways of understanding the purpose of religious education can be found among most, if not all, religious traditions, no matter their time and place. Consequently, many religious leaders have been sceptical and suspicious of the academic theology that is found in many European universities. An illustrative example can be found in the words of Lars Lewi Pethrus (1884-1974), the organizer of the Pentecostal movement in Sweden. With regard to theological education, for which he uses the term 'seminaries for preachers', he says regretfully:

Christianity is a revelation that can only be received through revelation (Matthew 16:15-17). It is because of this [perception] that one loses track when one tries to move the salvation of Jesus Christ to the area of science. The innermost in Christianity cannot be grasped by any science in the world, for Christianity is foremost and in its innermost essence divine life. Hence it is obvious that no intellectual learning can bring any deeper knowledge to the question of salvation. (Pethrus, 1929, p. 24, my translation)

He continues by stressing that every congregation should know that no institution of intellectual learning is capable of giving a preacher the 'true' qualities that are required to understand God's secrets. It is only through salvation and the fruits of the Holy Ghost that a preacher has the potential to attain a 'sound' knowledge of the Bible and of God (Pethrus, 1929, p. 32). Without giving further examples, this should be enough to indicate that Christian theologians can also express concerns and even doubts about the value of so-called academic theology, and that there are different understandings of what one might mean by Christian theology.

\section{$4 \quad$ Muslims at European universities}

Having established a basic outline of the differences between the secular study of religions and Islamic theology, we must now ask why Muslims study Islam at European universities at all. This question can undoubtedly be answered in many different ways, and each student should primarily be looked on as an individual and not as a part of some religious collective. 
We must not assume that, for example, all Christians or Muslims have the same expectations, wants, or needs just because they belong to the same religious tradition or family. In addition, this question is of an empirical nature, and to the best of my knowledge we lack studies examining why students actually choose to study the 'subject matter' we call religion, or for that matter theology or Islamic studies at universities. Leaving this significant lacuna aside, I still believe it is possible to identify some general and plausible trends, explanations, and ideal-type positions. One reason could be that students from a Muslim cultural background are interested in learning more about their own traditions (Waardenburg, 2000, p. 94). This is especially true if the students have been born and raised in the West. For students who fit this description, a critical study is generally not a problem: most of those who belong to this category have, for example, absorbed the importance of a critical approach to science and knowledge from European and for that matter Western school systems (Vertovec and Rogers, 1998). Some of these students could also be more interested in a critical approach than in studying and learning about religion in ways that are based on the so-called theological ways of thinking that could be described as a 'caretaker position' (McCutcheon, 2001). Some of them could also have been raised and taught according to specific norms and values, i.e., how to understand and apply Islam in a 'proper' way, in their homes, mosques, or other Islamic institutions. These might consequently want to learn other ways of studying their own traditions, and turn to European universities as a result. Others could be interested in finding new ways of developing their modes of thinking about Islam and Muslim traditions, perhaps wanting to develop a new kind of Islamic theology with the aid of, for example, philosophy, critical theory, gender studies, post-colonial theories, or academic theology (Waardenburg, 200o, p. 94). This approach could easily be compared with the 'subject matter' that many theologians label 'academic theology'. In the words of Ford, academic theology is defined and characterized in the following way:

It seeks wisdom in relation to questions, such as those of meaning, truth, beauty and practice, which are raised by, about and between the religions and are pursued through engagement with a range of academic disciplines. (2010, p. 94, italics in original text)

For Ford, academic theology is different from 'ordinary' theology because of its 'relation to the various disciplines of the academy' (2010, p. 94). However, the ways in which this type of theology is different from 'theology in general' (Ford, 2010, p. 93) are not that clear. 
Moving from the question of how to define academic theology and differentiate it from the academic study of religions to the opinions of Muslim leaders who have actually been asked about Islamic theological programmes at European universities, the picture becomes more complicated. Before I provide some data from Sweden, it is important to stress that most imam training programmes that were started (and in some cases ended; see Boender and De Ruiter, Part I) in Europe (for example, in the Netherlands or Germany; Boender, 2013; Larsson, 2009, 2014a) have neglected to take into account the possible differences between the theological study of Islam and how Islam is studied at a secular university. From Boender's study of imam training programmes in the Netherlands, it is also clear that many mosques and other Muslim organizations are sceptical of how European universities study and teach Islam. One interviewee gave voice to this feeling by saying:

Some see our programme as in function of the Dutch government; we are sometimes accused of being here 'to confuse the young' and 'to assimilate them.' Until now, mosque boards have often kept a distance. (quotation taken from Boender, 2013, p. 243)

As indicated by this quotation, it is clear that the expectations and demands of confessional viewpoints and secular or scientific ways of studying religions could be very different, and that there might be clashes between the two.

The differences in expectations outlined above were clearly seen in Sweden in 2009, when the Ministry of Education asked Muslim leaders about the possibility of setting up a Swedish imam training programme that would include courses in Islamic theology and the history of religions as well as courses about Swedish society and its history. To acquire some background information on Muslims' opinions and needs, the Ministry of Education launched a government enquiry, and a questionnaire consisting of thirteen questions was sent to 181 mosques and Islamic institutions in Sweden. In total, 121 questionnaires were answered and returned (Staten och imamerna, 2009, pp. 38-39; the questions are found on pp. 117-120). The questions from the 2009 survey were repeated in 2014, when 73 responses were collected (Larsson, 2014b, p. 121). There are several reasons why the number of returned responses was lower in the 2014 survey. First, the Muslim religious leaders had already answered the same questions in 2009, and on the basis of 
Figure 1 Attitudes towards the proposal to start an educational programme for imams in Sweden

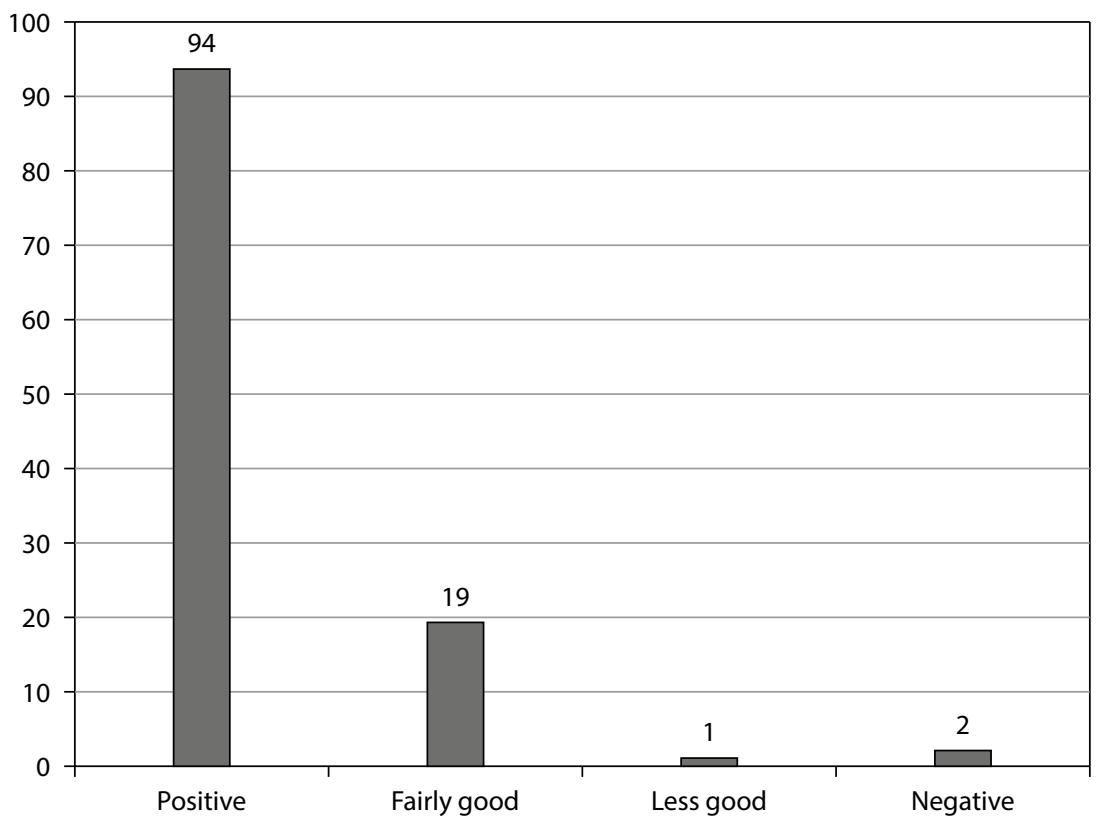

Source: Staten och imamerna, 2009, p. 46

that enquiry the government and the Ministry of Education decided not to start an imam-training programme in Sweden (Staten och imamerna, 2009). Second, the Swedish Commission for Government Support to Faith Communities had already launched a course for religious leaders working in Sweden in 2014. ${ }^{3}$ Held in the cities of Stockholm, Göteborg, and Helsingborg/ Malmö, this course could partly be seen as a response to some of the requests that imams had made in the 2009 survey. This course did not include any modules on Islamic theology, and the content focus was on Swedish society. Figures 1 and 2 present data on how the Muslim leaders responded to the prospect of setting up an imam-training programme in Sweden.

Figure 1 shows clearly that most of the imams who returned the questionnaire felt positive about the idea of starting a Swedish imam-training programme.

3 For more information on these courses, see: http://www.sst.a.se/sstsuppdrag/kompetensutv ecklingfortrossamfundsledare.4.4c4bo74714116bocfa29f6o.html, consulted on 17 November 2014. 
Figure 2 What kind of educational needs are imams asking for in Sweden?

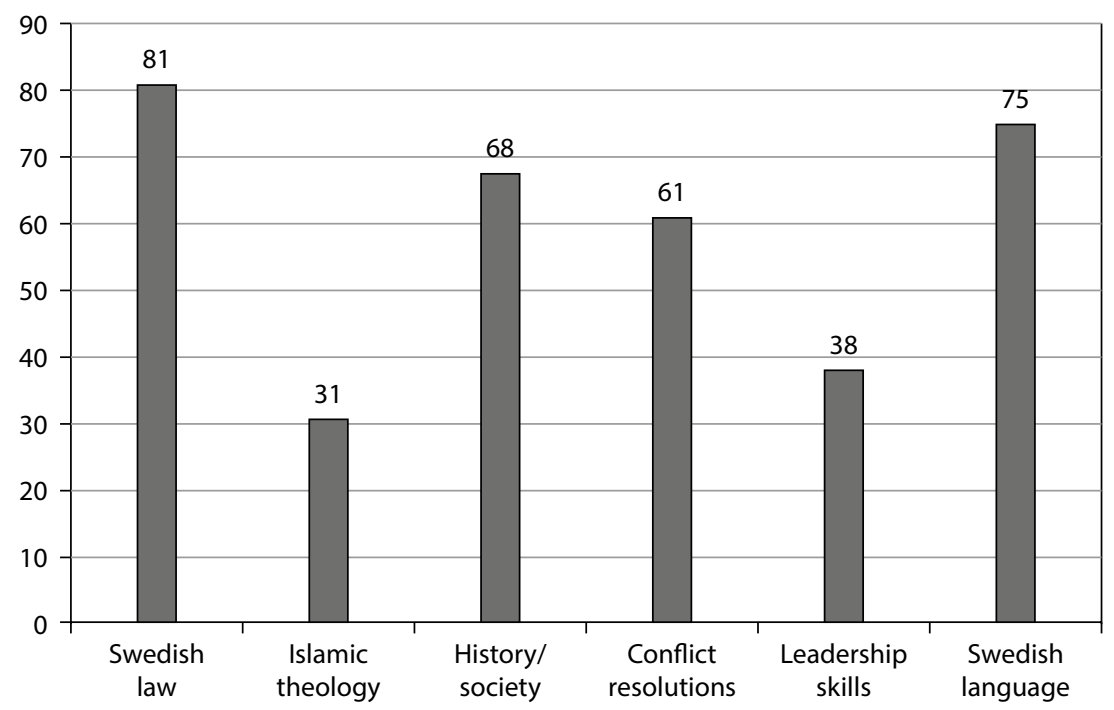

Source: Staten och imamerna, 2009, p. 47

Still, Figure 2 shows that most of those who answered the questionnaire were asking for training in so-called 'non-theological' subjects, such as the Swedish language, conflict resolution strategies, and Swedish law.

To properly understand Figure 2, it is important to know that each respondent could give several answers, and that most respondents who requested Islamic theology stressed that it should be taught by Muslims, not by non-Muslims at Swedish universities (Staten och imamerna, 2009, p. 47). However, it is clear from the survey results that the great majority wanted to acquire more knowledge of the Swedish language, how Swedish society works, rights and responsibilities in Sweden, and similar topics that are broadly related to living in Sweden.

These results could be interpreted as indicating that the respondents were not asking for a 'secular' or non-confessional education in Islamic subjects - i.e., these subjects should only be studied and taught by devout Muslims and not by non-Muslim academicians - or that they already had received a theological education from a Muslim institution. Would it have been possible to find different responses to these questions if the survey had been conducted among, for example, young Muslims who were born and raised in Sweden? This question is critically discussed by Jonatan Bäckelie (2011), who tends to answer it in the affirmative given the fact that most of 
the imams who were included in the 2009 survey had already had a long period of education in countries like Turkey, Bosnia, Saudi Arabia, or Egypt (Staten och imamerna, 2009, pp. 42-44).

Without going into great detail about the surveys, and no matter how we interpret the collected data, it is clear that the great majority of respondents were not interested in acquiring a degree in Islamic theology from universities that were secular by nature. It was also clear that internal differences among Muslim groups and competing madhhabs ('legal schools'), ethnic differences, and variations in language and political outlook were too great; it would be impossible to offer a single educational model that could cover every aspect of Islamic theology. To put it differently, most European universities do not have academics who are knowledgeable in every aspect of Islamic theology, such as kaläm, tafsìr, hadith, fiqh, and tașawwuf. And if different theological systems, such as the different opinions of the law schools, were mixed up in one educational programme, it would draw strong criticism from Muslim leaders and potential students who wanted to obtain a specific form of Islamic theological training according to one particular Muslim tradition or school. The survey of the Ministry of Education in 2009 made these tensions quite clear. It would be unlikely that imams who, for example, were trained according to the Turkish Diyanet model would be interested in a training programme moulded in accordance with the curriculum of the schools in Medina in Saudi Arabia, or of Al-Azhar University in Cairo, Egypt. Though we should refrain from drawing the conclusion that the opinions of Muslim leaders automatically correspond to or match the way 'ordinary' Muslims would like to learn about Islamic theology, I believe that the answers in the Swedish surveys give us an important indication of the possibility of a gap between what Muslims would like to learn about Islamic theology and how the subject is taught at European universities.

\section{Academic Islamic theology at European universities}

From both historical and contemporary examples, we can plausibly argue that most (but not all) Muslims who go to university to study Islam for theological reasons might have different expectations than students who want to study Islam with the aid of secular theories and methods. These differences in expectations should come as no surprise, and the tension between a theological study and a critical academic study has been highlighted in several publications over the years (Bird and Smith, 2009; McCutcheon, 2001; Wiebe, 1988). Most of the examples and positions in this debate have been 
derived from Christian and secular positions (Bird and Smith, 2009), but in this chapter I have tried to highlight these debates through the example of the study of Islam and Islamic theology. The problems I have discussed here are therefore not unique, and the positions in the debate primarily concern different opinions about science and the role and function of theology in the higher education system. I now leave these debates and turn to the crucial question: why do European universities want to start programmes in academic Islamic theology?

This question can, of course, be answered in many different ways, but it is still possible to outline some views and reasons. First, it is clear that most debates about, and attempts to start, imam training programmes in Europe have been closely related to the political debate about Islam and Muslims in Europe. Integration, security, and a need to gain control over Islamic theology have been important implicit and explicit reasons behind the setting up of many imam-training programmes in Europe (Birt, 2006; Sunier, 2009). This concern has, of course, increased in importance because of the rise of international terrorism in the name of Islam that has been carried out on European soil.

Second, the universities, especially within the field of humanities, are under great pressure to gain more money and new students, and to show that they have the potential to be useful and to contribute to society (cf. Nussbaum, 2010). From this point of view, imam training programmes and courses in academic Islamic theology can be perceived as a way to fulfil these needs.

Third, it is clear that some scholars who embrace the idea of an academic theology also want to make a positive contribution to how Islamic traditions could or 'should' be interpreted in a new, and maybe also more modern and egalitarian, way (cf. Martinson, 2004, 2009). For scholars who adhere to this position, theology should be constructive; the rule and function of the theologian is to arrive at a position from which it is possible to know 'how we should talk about God in a fruitful way today' (Martinson, Sigurdson, and Svenungsson, 2007, p. 15; my translation). In accordance with this understanding, the aim is to develop interpretations that are capable of contributing to debates and challenging established opinions on subjects such as gender issues, sexuality, justice, and interfaith relations. Today it is possible to find this kind of academic theology when it comes to Christian traditions, and for Mattias Martinson (2004, 2009) it is important to close the gap between Christian and Islamic theology. He argues that the division of labour that predominates at Swedish universities - i.e. that theologians are primarily if not only studying Christian traditions, that scholars of religion 
only study non-Christian religions, and that the former are more positive about 'theological thinking', while the latter are outspoken critics of theology at secular universities - puts many Muslims in a difficult position. ${ }^{4}$ If, he argues, 'Muslim students' decide to follow the path of a critical and secular study of religions, they will only meet an 'instinctive fear and disgust against the very idea of being involved in a more constructive interpretation of Islam' (Martinson, 2009, p. 82). But if they choose to do theology, they will only meet theologians who are interested in Christianity and who are 'more or less incompetent when it comes to the field of Islam' (Martinson, 2009, p. 82). This approach is stressed, for example, in a press release posted on the webpage of the University of Uppsala, in which Mikael Stenmark, the dean of the faculty of theology for the year 2012, explains how the university's courses in Islamic theology and philosophy are structured. He states:

Within the new programme [at Uppsala University] we will be able to offer studies about the specific content in Islam: the creeds, ethical guidelines, legal principles and religious texts that are included. By this procedure we take Islam as seriously as we take the Christian faith; that is, with a critical and constructive approach to the content. ${ }^{5}$ (my translation and italics)

This quotation illustrates how some Swedish theologians understand and envisage the content and objective of academic Islamic theology - an approach that can be easily compared with that of many Muslim feminists, like Amina Wadud (2006) and Asma Barlas (2002) to give just two examples. Similar ideas are also found in the texts of thinkers such as Tariq Ramadan (2010), Tareq Oubrou (Hashas 2014), and Omid Safi (2003), who promote so-called modern or progressive interpretations of Islam. For example, in the introductory chapter to the edited volume Progressive Muslims: OnJustice, Gender, and Pluralism, Safi claims to have been inspired by Bob Dylan and his song The Times They Are A-Changin' when he writes:

4 Martinson's mode of argumentation resonates with that of Wilfred Cantwell Smith's over the distinction between theology and religious studies (Smith, 1987, p. 12). But it should also be emphasized that Martinson's description of the distinction between the two could be called into question if we look at what topics historians of religions have actually studied. If we turn to Sweden, we can easily find scholars of religions who have studied Islam and Muslim traditions as well as Christian traditions (Marsh and Thurfjell, 2013; Westerlund, 2009). From this point of view, Martinson's distinction tells more about the interests of the theologians who work at Swedish universities.

5 The original quotation in Swedish is taken from: http://www.uu.se/press/pressmeddelanden/pressmeddelande-visning $/ ? \mathrm{id}=1825 \&$ area $=3,8 \&$ typ $=$ pm\&na=\&lang=sv, consulted on 22 August 2017. 
It is time to start 'a-changin'. It is time to acknowledge the complicated mess around us, and to aim for the implementation of the vision of justice and goodness-and-beauty that is rooted in the Quran. We start by admitting that it is not just our time that is worth saving, but also our very humanity, the most precious blessing we have been given by God. (2003, p. 2)

Tellingly, the writers who are included in Safi's edited volume are presented as 'thinkers and activists', and from the quotation above it is tempting to compare this enterprise with how many academic Christian theologians outline their scholarly projects. Like their Christian counterparts, who are inclined to start with an implicit understanding of what constitutes the essence of Christianity, it is clear that a so-called progressive Muslim interpretation has to start from and have its roots in what Safi calls 'the soil of Islam'. He writes further:

To state the obvious, a progressive Muslim agenda has to be both progressive and Islamic, in the sense of deriving its inspiration from the heart of the Islamic tradition. It cannot survive as a graft of Secular Humanism onto the tree of Islam, but must emerge from within that very entity. It can receive and surely has received inspiration from other spiritual and political movements, but it must ultimately grow in the soil of Islam. (Safi, 2003, pp. 7-8)

In the quotation above, it is not clear what Safi includes or excludes in relation to the rich diversity that exists in Muslim historiography, i.e., what Muslims write about so-called Islamic traditions, and it is also unclear what he means when he talks about 'the soil of Islam'. As a result, there is a great risk that the theologian, thinker, or activist is doing nothing more or less than projecting his or her own values onto Islamic traditions or 'the soil of Islam' (Martin, 2012, pp. 14-15 and Figure 1.1 on p. 12). Safi's expression 'the soil of Islam' also seems to be analogous to the phrase 'the essence of religion', which, according to Jensen, is one of the most persistent yet unclear concepts found in the history of the study of religions (Jensen, 2014, p. 40).

Yet another position involving Islamic theology at European universities - and this is my fourth and final point - is found among those scholars who argue that Muslims should be given equal opportunities and rights to set up programmes for their own religious education. If priests and Christians can learn about Christian theology at European universities, why shouldn't Muslims be given a similar right (Martinson, 2004, 2009, and partly also 
Mårtensson, 2010)? One could argue that this position is primarily based on a political vision that stresses how equal opportunities should be given to all religious groups.

\section{$7 \quad$ Conclusions}

From this discussion and the empirical data from the Swedish survey, it is clear that the issue of academic theology, whether Christian, Islamic, or something else, is closely related to the current debates about how to study religion at European universities. To put it more bluntly, does the so-called academic study of theology belong in the modern research university? While some will answer this question negatively, others will be more moderate and try to argue that both theology and religious studies should coexist, and that both belong in the university (Ford, 2009). No matter how we tackle this difficult but very important question, it is uncertain how many students from a Muslim confessional background are actually looking for an education in academic Islamic theology - at least from the Swedish sample I have referred to in this text. Why students in general or students from a Muslim cultural background in particular turn to the academic study of religions is something we actually know very little about (Sultán Sjökvist, 2009). Maybe some of them are interested in gaining insight into how religions can be studied from a secular academic point of view, or maybe they want to find something different that they may either reject or embrace from the confessional and normative approach to the study of religions. But should an academic institution really care about these questions, and what will happen if universities are primarily driven by a will to adjust and pick up on new trends without critical discussion? The primary aim of a university must be to seek better and more substantiated knowledge of how the world functions and why individuals believe and act the way they do. Hence, it is necessary to establish scientific models that are open to criticism and that can be tested intersubjectively by other scholars using a scientific approach that leaves no room for transcendent speculations. What God wants or thinks about the world is beyond scientific knowledge, and consequently to talk about God in a meaningful way produces nothing but speculation. Although some of these issues and discussions might be provocative, it is clear that both the questions and our answers must be related to how we view the study of religions and how the 'subject matter' that we call religion relates to the thing we call science. 


\section{References}

Al-Tahawi. N.d. Aqidah al-Tahawiyya. Translated by Iqbal Ahmad Azami. http:// www.masud.co.uk/ISLAM/misc/tahawi.htm.

Barlas, Asma. 2002. 'Believing Women' in Islam: Unreading Patriarchal Interpretations of the Qur'an. Austin: University of Texas Press.

Bäckelie, Jonatan. 2011. 'Religion and Politics - A Valid Divide? Confessionality in Politics and Higher Education'. Essay, Göteborgs Universitet. http://hdl.handle. net/2077/25887.

Bird, Darlene and Simon Smith, eds. 2009. Theology and Religious Studies in Higher Education: Global Perspectives. London: Continuum.

Birt, Jonathan. 2006. 'Good Imam, Bad Imam: Civic Religion and National Integration in Britain Post 9/11'. The Muslim World, 96(4): 687-705.

Boender, Welmoet. 2013. 'Embedding Islam in the "Moral Covenants" of European States: The Case of a State-Funded Imam Training in the Netherlands'.Journal of Muslims in Europe, 2(2): 227-247.

Calder, Norman. 2014. 'Al-Tahawi'. In Encyclopaedia of Islam, Second ed., online version. Leiden: Brill.

D'Costa, Gavin. 2009. 'Theology and Religious Studies OR Theology Versus Religious Studies?' In Theology and Religious Studies in Higher Education: Global Perspectives, edited by Darlene Bird and Simon Smith, 44-54. London: Continuum.

Ford, David. 2009. 'Theology and Religious Studies for a Multifaith and Secular Society'. In Theology and Religious Studies in Higher Education: Global Perspectives, edited by Darlene Bird and Simon Smith, 31-43. London: Continuum.

Ford, David. 2010. 'Theology'. In The Routledge Companion to The Study of Religion, edited by J. Hinnells, 93-110. London/New York: Routledge.

Hallaq, Wael. 2009. An Introduction to Islamic Law. Cambridge: Cambridge University Press.

Hashas, Mohammed. 2014. 'Tareq Oubrou's Geotheology: Shari'ah of the Minority and the Secularization of Islamic Theology in the European Context'.Journal of Muslim Minority Affairs, 34(4): 365-385.

Hjärpe, Jan. 2012. 'Perspektiv på islamologin: Essentialism eller religionsantropologi?' In Islamologi: Studiet av en religion, edited by Jonas Otterbeck and Leif Stenberg, 265-279. Stockholm: Carlssons.

http://attahawi.com/2009/o3/21/english-aqidah-tahawiyyah-translations-andcommentaries/.

Hughes, Aaron. 2007. Situating Islam: The Past and Future of an Academic Discipline. London: Equinox.

Jensen, Jeppe Sinding. 2014. What is Religion? London/New York: Routledge. 
Joy, Morny. 2001. 'Postcolonial Reflections: Challenges for Religious Studies'. Method \& Theory in the Study of Religion, 13: 177-195.

Larsson, Göran. 2009. 'Imamutbildningar: En europeisk utblick'. In Staten och imamerna: Religion, integration, autonomi, 125-161. Stockholm: Fritzes.

Larsson, Göran. 2014a. 'The State and the Imams: Summary of a Government Report on Training Programmes for Imams in Sweden'. Tidskrift for Islamforskning, 8(1): 302-313. http://islamforskning.dk/files/journal/2014/FIFO-2014-1-del11.pdf.

Larsson, Göran. 2014b. Islam och muslimer i Sverige: En kunskapsöversikt. Stockholm: SST.

Lincoln, Bruce. 1996. 'Theses on Method'. Method \& Theory in the Study of Religion, 8: $225-227$.

Marsh, Adrian and David Thurfjell, eds. 2013. Romani Pentecostalism: Gypsies and Charismatic Christianity. Frankfurt am Main: Peter Lang Publishing Group.

Martin, Craig. 2012. A Critical Introduction to the Study of Religion. Sheffield: Equinox. Martin, Richard. 1995. 'Islamic Studies: History of the Field'. In The Oxford Encyclopaedia of the Modern Islamic World, edited by John Esposito, 325-332. Oxford: Oxford University Press.

Martinson, Mattias. 2004. 'Nio teser om kritisk religionsvetenskap i dagens Sverige'. Svensk Teologisk Kvartalskrift, 80: 146-159.

Martinson, Mattias. 2009. 'The Irony of Religious Studies: A Pro-Theological Argument from the Swedish Experience'. In Theology and Religious Studies in Higher Education: Global Perspectives, edited by Darlene Bird and Simon Smith, 74-86. London: Continuum.

Martinson, Mattias, Ola Sigurdson, and Jayne Svenungsson. 2007. 'Inledning'. In Systematisk teologi: En introduktion, edited by Mattias Martinson, Ola Sigurdson, and Jayne Svenungsson, 9-19. Stockholm: Verbum.

Mårtensson, Ulrika. 2010. 'Review: The State and the Imams: Religion, Integration, Autonomy Swedish Public State Investigation'. DAVO, 32: 109-111.

McCutcheon, Russell. 2001. Critics not Caretakers: Redescribing the Public Study of Religion. Albany: State University of New York Press.

Nussbaum, Martha. 2010. Not for Profit: Why Democracy Needs the Humanities. Oxford: Princeton University Press.

Pethrus, Lewi. 1929. Predikanten och hans utbildning. Stockholm: Förlaget Filadelfia. Pyysiäinen, Ilkka. 2014. 'The Cognitive Science of Religion'. In Evolution, Religion and Cognitive Science: Critical and Constructive Essays, edited by Fraser Watts and Leon Turner, 21-37. Oxford: Oxford University Press.

Ramadan, Tariq. 2010. What I Believe. Oxford: Oxford University Press.

Saf, Omid. 2003. Progressive Muslims: On Justice, Gender, and Pluralism. Oxford: Oneworld Publications. 
Skovgaard-Petersen, Jacob. 1997. Defining Islam for the Egyptian State: Muftis and Fatwas of the Dar al-Ifta. Leiden: Brill.

Smith, Wilfred Cantwell. 1987. 'Theology and the Academic Study of Religion'. Iliff Review, 44(3): 9-18.

Speight, Marston. 1995. 'Creeds: An Overview'. In The Encyclopaedia of Religion, edited by Mircea Eliade, 138-140. New York/London: MacMillan Publishing Company.

Staten och imamerna: Religion, integration, autonomi (SOU 2009:52) (Stockholm: Fritzes, 2009).

Sultán Sjökvist, Madeleine. 2009. 'Studentröster om religionsvetenskaplig utbildning'. In Kritiska tänkanden i religionsvetenskapen, edited by Ulf Jonsson, Mattias Martinson, and Lina Sjöberg, 19-50. Nora: Nya Doxa.

Sunier, Thijl. 2009. Beyond the Domestication of Islam in Europe. Amsterdam: Vrije Universiteit.

Vertovec, Steven and Alisdair Rogers. 1998. Introduction to Muslim European Youth: Reproducing Ethnicity, Religion, Culture, edited by Steven Vertovec and Alisdair Rogers, 1-24. Aldershot: Ashgate.

Waardenburg, Jacques. 2000. 'Observations on the Scholarly Study of Religions as Pursued in Some Muslim Countries'. Method \& Theory in the Study of Religion, 12(1): 91-109.

Wadud, Amina. 2006. Inside the Gender Jihad: Women's Reform in Islam. Oxford: Oneworld.

Watt, Montgomery. 2007. Islamic Creeds: A Selection. Edinburgh: Edinburgh University Press.

Watt, Montgomery. 2013. 'Akīida'. In Encyclopaedia of Islam, edited by Peri Bearman, Thierry Bianquis, Clifford Bosworth, Emeri van Donzel, and Wolfhart Heinrichs. Brill Online.

Westerlund, David, ed. 2009. Global Pentecostalism: Encounters with Other Religious Traditions. London: I.B. Tauris.

Wiebe, Donald. 1988. "'Why the Academic Study of Religion?" Motive and Method in the Study of Religion'. Religious Studies, 24(94): 403-413.

Competence development for community leaders. Retried from www.sst.a.se/ sstsuppdrag/kompetensutvecklingfortrossamfundsledare.4.4c4bo74714116b ocfa29f6o.html (accessed 2017-12-21) 


\section{About the author}

Göran Larsson is a Full Professor in Religious Studies and Deputy Dean for the Faculty of Arts at the University of Gothenburg. While his research is focused primarily on the study of Islam and Muslims in Europe, he has also written about Islamic theology, Quranic studies, and issues related to religion and the media. He has published a large number of books and articles in publications like Journal of Muslims in Europe, Islam and Christian-Muslim Relations, Journal of Religion, Method, and Theory for the Study of Religions. 



\title{
8 The reinvented role of imams in French society
}

\author{
Solenne Jouanneau
}

Hashas, Mohammed, Jan Jaap de Ruiter, and Niels Valdemar Vinding (eds), Imams in Western Europe: Developments, Transformations, and Institutional Challenges. Amsterdam: Amsterdam University Press, 2018 DOI: 10.5117/9789462983830/CHo8

\begin{abstract}
Based on the findings of a research project that combined ethnographic and socio-historic approaches, this chapter investigates how imams in France progressively established themselves as one of the main embodiments of Islamic authority under the dual impetus of Muslim communities and state authorities, particularly at the local level. Retracing the sociohistorical stages of the reinvention of their role(s), it shows both how French imams have emerged as a distinctive type of 'organic intellectuals of migration' in their places of worship, and how they became the objects of public policies in lä̈que ('secular') French society.
\end{abstract}

Keywords: (history of) Imams in France, laïcité, immigration, state policy

This chapter is based on the findings of a doctoral study I conducted in France (Jouanneau, 2009a), ${ }^{1}$ in which I investigated how imams have progressively established themselves as one of the main embodiments of Islamic authority under the dual impetus of Muslim communities and state authorities - particularly at the local level. Imams, who lead the main rites of the daily prayers and the Friday congregational prayers in French mosques, interact with a wide range of actors: the faithful, leaders of Muslim associations, consulates of their countries of origin, local politicians, and agents of the central French authorities.

1 The translation of this chapter into English was made possible by the Excellence Initiative of the University of Strasbourg, and funded by the French government's Future Investments programme. Mr. Jean-Yves Bart skilfully executed the translation. 
In my doctoral research, I explored why imams play a much more central role in France than they do in countries where Islam is both the state and majority religion (Frégosi, 2004, p. 137). This required retracing the socio-historical stages of their changing role(s) to identify the processes that have allowed imams to emerge as a distinct type of 'organic intellectuals of migration' in French places of worship. It also sheds light on the influence of civil servants in redefining the imamate in France. Indeed, civil servants have gradually made imams the objects of public policies, as they saw them as an 'immigrant clergy' that could have some authority over immigrants and their descendants.

I used a range of methods combining ethnographic and socio-historic approaches to conduct this research over a six-year period. In the early years, I carried out fieldwork in several Muslim prayer rooms in Eastern and Southern France to collect accounts of the life stories and practices of around 30 imams. I also spent several months making daily observations in a neighbourhood prayer hall. In the following stage of my research, I looked for traces of imams' historical presence in various archives, particularly those of the Ministry of Internal Affairs. Additionally, I interviewed about fifteen senior civil servants who had been assigned to work on Islam in France at some point in their careers.

This chapter briefly presents the main findings of this research. In the first part I retrace the main steps in the institutionalization of the social role of imams in France, as Muslim immigrant workers and their families settled into French society. The focus is on the conditions that made genuine community leadership possible for imams in France. I also describe the most important features of imams' role in contemporary France. The second part shows that from the 1990s onwards imams also became the targets of public policies aimed at influencing Islam's identity in France as oppositional political Islam gained momentum in major countries of Muslim emigration.

\section{From imams in the trenches to neighbourhood imams}

The first French imams left very few traces and are seldom mentioned in the archives of the French administration. Historians and sociologists of immigration generally did not consider them until the late 1990s. Yet, based on archival material, interviews, and second-hand sources, a short socio-history of their settlement in France can be retraced. These sources allow us to identify the various stages of the formation of the imamate in France, which are to a great extent connected to the phases of Muslim migration to France and of the structuring of French Muslim faith. 
2.1 The colonial legacy and the invisibility of the indigenous imam

In the twentieth century, the earliest records that indicate the presence of imams in mainland France date to the beginning of the First World War, when French military commanders decided to 'send imams among the Muslim troops stationed in France in January 1915' (Le Pautremat, 2003, pp. 153-154), and to build mosques in military depots (Laurens, 2004, p. 42). When the war ended some of these imams - soon to be joined by others - continued to meet the needs of immigrant workers coming from the French colonies, whose numbers were rapidly growing. For instance, there is evidence of the existence of a wooden mosque in Toulouse, built on the initiative of a French employer 'wishing to create a good environment in his business' in the 1930s (Clément, 1990, p. 98). In Paris, the chronicles of the Renault car factory recount the death of the Moroccan imam tasked with meeting the religious needs of the company's Muslim colonial workforce in the same period (Garache, 1984). However, employers' practices aimed at ensuring the loyalty of colonial workers are not the only explanation for the presence of these imams. In certain cases, the imams also seem to have been directly mandated by the migrants' community of origin to accompany those who were given the responsibility of migrating to mainland France from rural communities (Sayad, 2004).

Unfortunately, very little is known about these early imams in metropolitan France and the practical conditions they faced in exercising their religious duties. These imams, who were both migrants and colonized, left few traces. The few documents that mention them are from the press or archives of administrative, military, and productive institutions (like factories), or of those monitoring immigrant workers (like the Sonacotra foyers). ${ }^{2}$ These archives let us look at these migrant clerics only through the words of the non-Muslims who wrote about them (Spivak, 1988). There is another reason for the scarcity of sources. In the 'era of empires' (Hobsbawn, 2009), the Muslim religion was seen as a factor of control in most French colonies (Luizard, 2006), particularly in Algeria where attainment of the role of imam was tightly controlled by the prefectural authorities (Achi, 2004). However, French authorities seem to have had little interest in the religious practices of the natives of the colonies after they migrated to the mainland. This was partly because the authorities thought that this immigration would

2 The term foyer refers to social housing units built mostly in the 1950 s for the specific purpose of accommodating migrant workers. The social Housing Sonacotra was initially established for Algerian migrant workers. 
be temporary (Tripier and Rea, 2003, p. 41), but it also reflected the reality of the migrants' religious practices to some extent: most specialists of Islam in France agree that, until the tail end of the 1950s, there were few religious demands from Muslim immigrants. The majority tended to consider their experience as migrants as 'a space of freedom in which, for a certain time, Islamic precepts did not apply' (Cesari, 1994a, p. 36).

\subsection{The makeshift Islam of the factories and foyers of migrant workers in the $1970 \mathrm{~s}$}

Under the influence of three distinct but highly congruent phenomena, the exposure of Islam and the number of imams both started to gradually increase in 1970s' France. First, the continual extension of the stays of migrants from the former French colonies tended to favour their mobilization to organize Muslim worship during the migration period. Second, starting with the decision to end immigration in 1974, a state discourse developed around the need to 'facilitate [among migrants] the preservation of religious tradition[s]', so as to allow 'foreigners who wish to pursue temporary immigration' to 'preserve their ties to their culture of origin' (Dijoud, 1974). Third, at roughly the same time, as strikes in factories and foyers became increasingly frequent, some officials in charge of immigrant workers' affairs were inclined to use imams as 'antidotes to leftism' (Kepel, 2004, p. 299). The imams of the 1970s, who were largely self-taught volunteers, can be split into two distinct groups: the 'isolated imams' and the 'affiliated imams'.

Isolated imams were first and foremost workers or foyer residents who were appointed to fulfil the role of imam, partially in response to requests from the migrants and partially to humour the paternalistic goodwill of employers and foyer managers. They were generally appointed following a consultation among the 'inner circle' of attendants of the newly-created prayer halls, i.e., those involved in their day-to-day running (such as cleaning, decorating, and making repairs). It is worth noting that the evaluation of these imams' religious competence was always connected to the social, familial, professional, and symbolic prestige they enjoyed among their peer group. Among different candidates with an equivalent amount of religious capital, the one chosen would generally be the man with the best reputation - a reputation based on age, seniority within the group of migrants, and social position within the factory or foyer. These imams who did not belong to any organized group were often in vulnerable positions and dependent on the institutions that employed or housed them. Taking a stance that contradicted the interests of their employers or landlords would potentially 
be detrimental to their situation as migrants: they risked being fired or expelled from their foyer. It could also impede the effective functioning of the prayer hall, which might be closed down, or cause prayer time arrangements to be discontinued. Additionally, they had little legitimacy to serve as imams due to their lack of religious knowledge. Thus, caught between the hammer of potential dismissal and the anvil of losing religious legitimacy in the eyes of the faithful, these 'worker imams' were often assigned a strictly ritual incarnation of the role of imam. Lacking conviction in their Islamic knowledge and wishing to avoid the risk of writing their own sermons, they contented themselves with the Friday 'reading of a pre-prepared sermon, obtained in advance by some Islamic association or taken from a collection' (Kepel, 2004, p. 299). These 'imams of fortune' experienced an insecurity reflecting that of the Muslim immigrants to whom they preached in factories or foyers; it is doubtful whether under such conditions they were able to exert any real religious authority over believers.

In contrast to these 'isolated imams', the 'affiliated imams' became imams due to their involvement in the Islamic associations that were active in the early days of the structuring of Muslim worship in France. These included the Association des étudiants islamiques en France (AEIF, founded in 1963), which represented a reform movement of Islam in France; Foi et pratique (founded in 1972), the French branch of the Tablighi Jamaat pietistic movement; and the Mouvement islamique des mourides en Europe (MIME, founded in 1977), founded by West African students who had come to France to complete their studies. In many cases, these affiliated imams were not workers, but students or self-employed professionals. To Muslim immigrant workers, they embodied a model of self-accomplishment. Furthermore, because of their involvement in Islamic movements they generally acquired complementary religious training in addition to their religious education in the family and at school. Although they were self-taught in the handling of 'Islamic salvation goods', their religious discourse displayed a consistency and systematization not usually found in those of the worker imams who acted autonomously. Third, the movements of which they were members had a history of reflecting on what 'being a Muslim' means in a country where Islam is not the majority religion. Thus, beyond fulfilling a purely ritual function, they were also generally predisposed to accompanying migrant workers in the process of rethinking their religious beliefs, which until their arrival in France had been deeply rooted in village customs (Thomas and Znaniecki, 1996). By using the language of Islam to explain how to live in France within Muslim communities, they gave the faithful a sense of belonging in a community of destiny experiencing the same 
living conditions. Therefore, they were able to play the role of 'organic intellectuals' in their communities better than the 'isolated imams' were. By prescribing certain self-representations and behaviours for 'Muslims' living on French soil, they gave them an existence as a social group (Gramsci, 1978, p. 309). Finally, given the frequently conservative leanings of the Islamic associations of which they were members, they were also more often able to get in the good graces of the factory bosses and foyer managers than the worker imams were.

\subsection{The emergence of neighbourhood imams in the $1980 \mathrm{~s}$ and $1990 \mathrm{~s}$}

A number of processes involved in the rooting of immigrants in French society - longer stays, more frequent family reunifications, increasingly restrictive immigration policies - also played a part in reshaping the institutional framework of imams' practices in France. ${ }^{3}$ This was especially the case after 1981, as the right of association was expanded to include foreigners (Wihtol de Wenden and Leveau, 2001). Between the late 1970s and mid-1980s, places of Islamic worship opened at a faster rate, and factories and foyers ceased to be the main locations of these prayer halls. As of 1981-2, the majority of imams in France practised in working-class neighbourhoods that had large proportions of Muslim immigrants. This trend continued into the 1990s. By 2004, only 18 per cent of the Muslim prayer halls registered with the French Council of Muslim Worship (CFCM) were still located in foyers for migrant workers (Godard and Taussig, 2009, p. 116).

New prayer halls opened outside of factories and foyers were granted institutional representation in the form of officially registered associations (Kepel, 1987, pp. 229-234). These new prayer halls facilitated the embedding of Muslim worship in the municipal space. They also enabled the development of relationships with local politicians (as they were progressively included in local associative life). To the Muslims that frequented them, these prayer halls were a source of collective pride: they were no longer symbols of the generosity of some factory or foyer manager, but objective evidence of the group's existence and of its capacity for collective mobilization (Bourdieu, 1980).

In addition to giving imams more local recognition and exposure, these associations also transformed the practical conditions of their religious leadership. Indeed, with the creation of these Islamic associations came a gradual separation of the roles of 'imam' and 'president of the association'.

3 The Ministerial Circular issued by Schumann on 29 July 1968, the Ministerial Circular issued by Marcellin-Fontanet on 24 January 1972, and the Council of Ministers Circular of 3 July 1974. 
This prompted discussions within mosques about the imam's role in France. The imam's legitimate authority progressively came to be defined as that of a cleric, who was in charge of handling the goods of Islamic salvation. The president of the association was chiefly a notable member of the community commissioned to represent the group's administrative, symbolic, and political interests.

Another development that transformed imams' practices in the $1980 \mathrm{~s}$ and 1990 s was the bureaucratization of the Islamic associations managing prayer halls for the purpose of rationalizing their functioning and increasing their financial resources. In many mosques, this professionalization process inspired the idea that it was necessary to pay imams. In 2004, according to a Ministry of Internal Affairs survey, only 45 per cent of imams practicing on French soil were regularly paid. ${ }^{4}$ Yet, since the early 1990 s, paying the imams had become an ideal for most Islamic associations, much as they dreamed of one day owning their own mosque. While costly, placing imams in an employer-employee relationship had the immediate advantage of allowing association leaders to have control, if not a monopoly, over the appointment of the imam and the definition of his scope of action. Also, this mercantile relationship placed imams under the direct authority of board members, whereas previously different forms of authority were able to coexist without a clear hierarchy.

With the introduction of this mercantile relationship and the continuously increasing number of Islamic prayer halls in France, the backgrounds of French imams became more and more varied. When imams were still unpaid, those aspiring to be imams in neighbourhood mosques had similar backgrounds to those practicing in factories and foyers during the previous decade. These individuals were self-taught in the handling of Islamic salvation goods. Whether they were affiliated with national or international Islamic movements or not, for them being a voluntary imam was never a reason to emigrate or a professional activity: they always did it alongside paid employment in another sector or in addition to pursuing secular studies.

Conversely, the paid imam positions that began to develop in the 1980 s attracted several categories of individuals who saw religion as a potential profession. First, there were students with a degree in Islamic studies and/ or experiences of activism in (political or trade union) organizations with ties to oppositional political Islam. Having arrived in France with the goal of completing advanced graduate studies, they had high amounts of educational

4 These figures come from the statistics reported by the technical adviser in charge of the 'Islam file' at the Bureau central des cultes between 2000 and 2010 (interview, July 2005). 
capital and were well versed in Islamic culture. These new positions were in some cases the means for them to pay for their studies in France. For those with ties to organizations such as the Union des organisations islamiques de France (UOIF) - itself close to the Muslim Brotherhood movement -, the positions were direct extensions of their political engagement in favour of political Islam, as well as an opportunity to disseminate their political and religious ideology to others.

The second category of paid imams that appeared in the 1980 s comprised individuals who came to France at their own expense, often illegally. Out of the paid imams who applied for a residence permit as 'ministers of religion' between 1990 and 1997, only 29.5 per cent had entered French territory with the 9o-dayvisa required to subsequently be granted 'visitor' status for one year (Jouanneau, 2009 b). They hoped to be recognized for their religious competences by word of mouth and paid by Islamic associations. These competences could come in the form of an Islamic degree, or of experience as imam or muezzin in their home country. They had generally come to France for financial reasons, and chose to be imams out of a sense of 'pragmatism'. As conditions of residence became gradually more strict between 1980 and the end of the 1990s, the perspective of a salary (however low) and of a residence permit (however temporary) was an enticing prospect for individuals with no hope of obtaining a regular work permit, but with the ability to monetize a religious capital that was still rare on French soil. These early migrants aspiring to the title of imam were often considered excellent candidates by the presidents of associations who were able to pay imams a regular salary for two reasons. First, they often possessed enough religious experience and competence to make them credible in the eyes of the faithful. Second, they were generally doubly dependent on the association in which they practised: they relied on it for both their salary and the certificate required to obtain a residence permit.

Finally, from the 1990 s on, civil servant imams sent to France by some Muslim countries of emigration - such as Algeria, Turkey, and, to a lesser extent, Morocco - made up a third category of paid imams. Islamic associations were often formed on the basis of shared national origins and languages. Those in charge of such associations often managed to secure funding to have 'professional' imams come to France through the consular representatives of their country of origin. As these imams' salaries were paid by their home countries, they came at little cost to the associations; as their status as imam was officially recognized by the consulates, they were generally perceived as highly legitimate by immigrant workers (Akgonul, 2005, p. 123). However, compared to the other categories fewer civil servant imams spoke French and were familiar with French society, and they sometimes 
struggled to fulfil the religious needs of Muslims born or socialized in France - whether converts or the children of migrants.

\subsection{How imams became local community leaders}

During the First World War, France already had imams who were able to perform the main Muslim group rites. Yet, until the late 1970s their authority was largely reduced by the weight of the institutions in which they officiated: the army, the factories, and the foyers. In contrast, the structuring of Muslim worship that began in the 1980s transformed the material conditions of imams' practice in ways that directly contributed to increasing their influence over the faithful. It gave them a more central role in the process of the social construction of a Muslim community with a newly established, local anchoring.

They might often have been just as cramped and worn down as the older ones, but the prayer halls that opened in working-class neighbourhoods were a source of collective and individual pride for those frequenting them. They were no longer the symbol of the generosity of a factory or foyer boss, but objective evidence of the group's existence and capacity of collective mobilization. By offering a new visibility to Muslim worship and more space for the faithful to gather, these prayer halls favoured a form of appropriation of communal space and by extension the '(re)constitution of community life on the scale of a residential unit' (Cesari, 1994b, pp. 112-113). By actively participating in the creation of this religion-inflected community life, the imams themselves progressively found the opportunity to experiment with a certain form of leadership over their faithful.

As keepers - and in a more prosaic sense 'janitors' - of the mosques where they officiated, neighbourhood imams first found themselves occupying a crucial place in the creation of community networks of mutual assistance. In the process they contributed to transforming their prayer groups into genuine 'communities of shared purpose'. In addition to their community-building role, the imams of the 1980 s and 1990s also helped define the specificity of the Muslim community within French society at the neighbourhood level. Indeed, while the presidents of Islamic associations worked towards the recognition of the existence of a 'Muslim community' with specific needs among 'non-Muslims', particularly municipal authorities, imams offered their flock 'procedures for dichotomization between us (Muslims) and them (non-Muslims)' (Streiff-Fenart, 1996, p. 39). They did this by focusing on the supposed bans and recommendations of Islam. These procedures had considerable symbolic power, especially because they drew on religious terminology that conferred a degree of sanctity. 
Finally, as it became clear that families of Muslim workers had durably settled in France, neighbourhood imams - clerics 'mandated to assure the production, reproduction, conservation and diffusion of religious goods' (Bourdieu, 1971, p. 305) - promoted an increasingly practical and detailed discourse about the everyday behaviour required from a 'good Muslim' in France. As they agreed to reply to the faithful's questions on the 'right way' to live an Islamic life in France, most imams found themselves in a position to propose to their religious communities what one might call 'Islamically desirable forms of acculturation' to French society, in a more or less conscious and intellectualized manner depending on the cases (Jouanneau, 2013).

3

Imams as a public problem: The paradoxes of laïcité

As I noted above, in the postcolonial period of the 1970s the French authorities started addressing Islam and Muslim worship. Initially managed by the little-known Secrétariat d'Etat aux travailleurs immigrés (State Secretariat for Immigrant Workers), this gradually became a more significant policy area during the 1980 s as the government tackled the necessary 'integration of immigrants' more broadly (Escafré-Dublet, 2008, p. 337). In the case of Islam, this translated into a discourse on the need to 'upgrade Muslim worship' to bring it up to the standards of other religions with a longer history on French soil (Commission Culture et Immigration, 1979).

However, as long as the government approached the question of Islam only in terms of how to remedy its material and symbolic 'indigence', like the lack of cultural centres, absence of representation in chaplaincies, and absence of religious broadcasts on public channels, the imamate received little exposure. The situation began to change radically in the early 1990s, when 'Islam and Muslim worship' became marked as a 'sensitive issue' by French government agencies because officials at the Ministry of Internal Affairs were increasingly concerned that the civil conflict in Algeria and the rise of oppositional political Islam in North Africa could have a fallout in France (Frégosi, 2008, p. 256; Jouanneau, 2013, pp. 245-250).

\subsection{Development of the surveillance of imams' sermons}

French authorities thus began to be concerned by the development of oppositional political Islam in the late 1980s. The Ministry of Foreign Affairs was worried about the potentially harmful consequences of the rise to power of 'Islamists' for France's diplomatic relations with its former colonies. For 
their part, officials from the Ministry of Internal Affairs grew concerned about the influence such movements might have over immigrants of North African origin and their children. As a result, the French authorities started adopting a security-centred approach to the question of Islam and Muslim worship (Frégosi, 2008, p. 256), which is abundantly documented in the Ministry of Internal Affairs archives from the 1990s and 2000s that I was able to consult. ${ }^{5}$

Starting in Pierre Joxe's second term as Minister of Internal Affairs (19881991), these archives mentioned a 'fundamentalist threat' to France. In response to this 'threat', the minister's advisor wrote that the government should, on the one hand, encourage a 'moderate, tolerant Islam, wellintegrated into French society' and, on the other, fight 'the unregulated development of mosques whose imams preach fundamentalism, intolerance and violence' ${ }^{6}$

This preoccupation became more visible during the term of Charles Pasqua (1993-1995), who was the first to order the surveillance of sites of Muslim worship. This surveillance was ramped up during Jean-Louis Debré's term (1995-1998), after the wave of attacks in 1995 orchestrated by the Algerian Groupe islamique armée (GIA; Armed Islamic Group) that culminated in the bombing of a train in Paris. Due to the involvement in these attacks of Khaled Kelkal, an Algerian-born youth who grew up in the banlieues of Lyon and who was radicalized in prison, the Ministry of Internal Affairs' agents became increasingly suspicious of immigrant clerics in France.

As the surveillance of imams' sermons widened, the Ministry of Internal Affairs entrusted intelligence agents with the tasks of identifying any attempt by imams to import the political conflicts in North Africa and the Middle East into France, and reporting cases of support for certain forms of religious radicalism among disenfranchised youth. ${ }^{7}$ In other words, in the 1990s, as the new focus on public security and efforts to monitor the fallout of faraway geopolitical conflicts combined with older discourses on the 'integration' of foreigners, imams became an object of governmental attention more than ever.

5 This refers to the archives of the cabinets of the Ministers of Internal Affairs Pierre Joxe, Jean-Louis Debré, and Jean-Pierre Chevènement. Charles Pasqua, Philippe Marchand, and Paul Quilès refused to grant access to their archives.

6 Contemporary Archives Center (CAC), v. 19920417, art. 2, 'Questions de fond soulevées par la disparition du recteur de la Mosquée de Paris', May 1989. Administrative memorandum of 'Islam' technical Adviser to the Minister of Internal Affairs Pierre Joxe.

7 CAC, v. 19970347, art. 4, l. 1. For example, the administrative memorandums written by the Central administration of the Renseignements généraux, Les échos des prêches et de la communauté musulmane, on 19 August 1996 and on 2 September 1996. 
3.2 A double-edged government discourse: Imams as problems and as solutions

Until the late 1980s, French authorities generally accepted the fact that Muslim worship was essentially structured at the local level through the creation of a multitude of Islamic associations largely independent of each other. In the subsequent decade, the fear of Islamism spreading to French soil brought Ministers of Internal Affairs to turn the organization of Muslim worship in France into a 'public problem' requiring state intervention. This concern for rationalizing the structure of France's 'second religion' was publicly justified by left- and right-wing politicians alike on the grounds of the necessary emergence of an Islam à la française, a phrase that amalgamated two distinct projects. The first, openly acknowledged, consisted of ensuring religious equality in the country by improving the conditions of Muslim worship in France, and thus meeting the legal definition of laïcité ('secularity') set forth in the 9 December 1905 law on the separation of church and state. The second, which was less covered and more overt as it did not strictly fall within the legal bounds of laïcité, was to introduce government monitoring of a religion that worried the authorities in several respects.

Examination of the archives of the Ministry of Internal Affairs confirms that attempts to push the creation of a central representative body for Muslim worship almost always came with the institutionalization of a public state discourse on imams. This happened on numerous occasions, from the creation of the Conseil de réflexion sur l'islam en France (CoRIF, Council for Reflection on Islam in France, 1990-1993) under the impetus of Pierre Joxe, to the assisted birth of the Conseil français $d u$ culte musulman (CFCM, French Council for the Muslim Faith, since 2003) by Nicolas Sarkozy, the Conseil consultatif des musulmans de France (CCMF, Consultative Council of French Muslims in 1995) by Charles Pasqua, and the Istishara association (Consultation, in 1999) initiated by Jean-Pierre Chevènement.

For Ministry higher-ups, these ambivalent developments gradually came to embody either the problems allegedly posed by the Muslim religion in France - such as the dependence on foreign countries, the threat of fundamentalism, and the dispersion of religious authority due to the lack of institutional structures - or opportunities for the diffusion of a more liberal Islam' that was 'modern' and 'adapted' to French society. In their briefs, Ministry technical advisors presented 'foreign imams' at best as having an 'outdated theological training' and, at worst, as having 'marked Islamist 
tendencies' (Debré, 1997, p. 102-103). ${ }^{8}$ At any rate, they were 'incapable of speaking French' and of 'understanding the problems of young French people living in the banlieues'. As a response to this, the belief progressively emerged that the 'creation of imams should be undertaken'9 to promote a model of 'French imam' or, failing that, of a Francophone imam trained in France.

In other words, from the 199os onward imams increasingly came to play a crucial role in the symbolic apparatus through which French government agents defined and planned to address the alleged issues pertaining to the Muslim religion in France. In the official discourse, 'the foreign imam' became one of the root causes for the supposed 'inadequacy of Islam' to meet the 'values of the French Republic'. In contrast, the 'French imam' 'integrated', 'well trained', and 'moderate' - was held as the possible 'solution' to this 'inadequacy'.

This belief did not only become widespread among officials working in the Ministries of Internal and Foreign Affairs and the presidential advisors. The Ministers of Internal Affairs and their representatives - ministerial advisers, heads of the Bureau central des cultes, and police officers - publicized it in the media; in the second half of the 1990s, it became a staple of French mainstream media discourse.

However, before further describing the forms of government intervention into the structuring of the imamate in France it is worth noting that in this policy area the authorities had to act indirectly due to the objective constraints of the legal and constitutional framework of laïcité. The following section provides more clarity on this subject.

\subsection{The particulars of state action toward imams in the context of laïcité}

The so-called law on the 'Separation of Churches and State', adopted on 9 December 1905, heralded a turning point in the French authorities' management of religions. Since then, the French Republic has ostensibly been a laïc ('secular') regime, refusing all forms of religious identity or affiliation. It neither recognizes, nor subsidizes, nor provides salaries for any religion (Article 2), but ensures freedom of conscience and the free

8 CAC, v. 19970347, art. 4, l. 1, ref: no. 38 / AN MO - CHM, 'Lislam et la poussée islamiste en France', 1997. Administrative memorandum written by the technical adviser to the Ministry of Foreign Affairs to the attention of the cabinet of the Minister of Internal Affairs Jean-Louis Debré. 9 CAC, v. 19970347, art. 4, 1. 1, 9 July 1997. Administrative memorandum written by the technical adviser for religious affairs of the Minister of Internal Affairs Jean-Louis Debré.

10 Idem. 
exercise of religion in the entire country (Article 1). Laïcité, as it is defined in the 44 articles of the 1905 law, breaks the ties that formerly bound the State and religious institutions together under the Concordat regime (Chantin, 2010). While the State's religious neutrality might have been asserted, this did not mean that its representatives would necessarily or systematically ignore the existence of the religious sphere, or even give up on regulating it entirely. Indeed, laïcité is not only the legal translation of the socio-historical process through which government agents have progressively managed to impose the principle of a distinction between order in religious activities and order in political activities (Lalouette, 2005); it is also - and perhaps more importantly - the idea that the latter prevails over the former, considering the fact that struggles over the control and legitimization of these spaces of differentiated activities cannot be separated from struggles over their hierarchy (Lagroye, 2003, pp. 361-362). From this perspective, laïcité is not only aimed at ensuring the freedom of religion and the state's religious neutrality, but is also a possible tool for politically de-legitimizing the religious contestations of the 'national order' that political representatives and civil servants are supposed to guarantee (Bourdieu, 1971; Noiriel, 1991). Yet it is also a means of regulating religions that translates into legal and/or administrative norms. These norms define the nature of the relationships that state agents are legally authorized to have with the actors of institutions that are defined or that define themselves as 'religious'. They also establish the practical scope of the intervention of administrations into the religious sphere for the purpose of managing or regulating such activities within the social space (Boyer, 2005, p. 2). Since 1911, there has been a bureau within the Ministry of Internal Affairs that is in charge of the compliance of religious organizations with public rules. The members of that bureau, the Bureau central des cultes, can force religious institutions to conform to the general organizational rules stipulated in the 1905 law. It is also worth recalling that the 1905 law lays the groundwork for the surveillance of places of worship and their ministers by public authorities. Under Article 34, 'Any ministers of religion who, in those places where religion is exercised, has publicly [...] insulted or defamed a citizen charged with public service, will face a fine of $€ 3,75^{\circ}$ and a one-year prison sentence, or one of these two penalties'; under Article 35,

If a speech given or a piece of writing posted or publicly distributed in places where religion is exercised contains a direct incitement to resist the implementation of laws or legal acts of the public authorities, or if it tends to cause an uprising or to arm one group of citizens against others, the 
minister of the religion who has made himself culpable will be punished by a prison sentence of three months to two years, without prejudice in a case where the incitement is followed by a riot, revolt or civil war.

Yet, since the implementation of the 1905 law the French Republic is no longer authorized to interfere in the selection and appointment of 'ministers of religion': this domain has been legally defined as the sole responsibility of religious communities. This means that French government officials have no legal right (in theory) to express an opinion on whether a given individual is fit to play that role. To maintain the appearance of compliance with the legal framework set by laïcité, civil servants and political representatives largely have to act through back channels, in policy areas where the legal and political basis of state intervention cannot be legally questioned.

The second characteristic of the public policies targeting imams is the involvement of multiple institutions. Because of the principle of laïcité, there is no administrative department in France that deals officially and practically with all aspects of Muslim worship. Depending on the case at hand, imams may be managed by the Direction de la surveillance $d u$ territoire (DST, Directorate of Territorial Surveillance), or Direction centrale des renseignements généraux (DCRG, Central Directorate of General Intelligence), or by their local branches when surveillance is required; the Bureau central des cultes on questions linked to the training and status of imams in particular; the Direction des libertés publiques et des affaires juridiques (DLPAJ, Directorate of Public Liberties and Legal Affairs) and the prefectures' departments for non-nationals on questions about the regularization or expulsion of foreign imams; or the Conseiller pour les affaires religieuses (CAR, Counsellor for Religious Affairs) and Direction de l'Afrique du Nord et du Moyen-Orient (Directorate for North Africa and the Middle East) for the diplomatic component of negotiation with countries of Muslim emigration. Of course, the number of institutions that are involved has consequences for how each issue is handled. Each of these administrations not only has its own imperatives, but also has a distinct 'administrative culture' that endows its agents with a distinct ethos that does not necessarily coincide with those of other agencies (Jouanneau, 2009b).

Finally, aware of the fact that they were playing with the legal limits of laïcité, the successive Ministers of Internal Affairs have generally tried to remain discreet about the internal attempts by some of their advisers and top officials to restructure Islamic worship in France. This constraint manifests in the often-unofficial status of technical advisors working on the question of Islam in France within the Ministry's offices. These advisors, 
whose ranks do not include graduates of the Ecole nationale d'administration (ENA, National School of Administration), are often civil servants recruited informally on the basis of their pre-existing ties with the Ministers to 'coordinate' a public policy with a limited scope of action (Jouanneau, 2013, pp. 266-270).

\subsection{Three forms of the state monitoring of imams}

The legal rules of laïcité preclude Ministers of Internal Affairs from directly reforming the recruitment of imams to officiate in France. However, in the 1990s, they developed at least three measures aimed at indirectly altering the profiles of Muslim 'ministers of religion', with varying outcomes.

Based on the premise that 'from a Muslim point of view, France is a mission country, i.e. a country that receives foreign missionaries', ${ }^{11}$ the first policy option for monitoring French imams consisted of approaching the selection of imams as a specific component of diplomatic relations with the countries of so-called 'Muslim emigration'. The intention was to introduce a 'bureaucratic rationalization' of the monitoring of foreign imams through enrolling the consular networks of their countries of origin. If imams were going to be foreign nationals anyway, they were at least going to try to promote those whose status as an imam was officially guaranteed by the governments in their countries of origin (Jouanneau, 2014). This measure rested on the assumption that the selected candidates would preach an Islam that is in conformity with the interests of the governments in place in those states and - the flipside of the same coin - that would not promote Islamism in France. Furthermore, supporting consular procedures for monitoring the emigration of imams allowed Ministry officials to rely on trusted diplomatic partners who were capable of keeping the concerned imams in check, or even of revoking their residence permits in case of problems. Not only do 'consular imams' depend on the diplomatic authorities of their countries of origin for their pay and status, but during their stay in France they also find themselves embedded in hierarchical structures which, both in everyday life and in the case of problems, makes them potential mouthpieces and channels for French government officials.

A second measure dating to November 1990 consisted of introducing a confidential procedure for monitoring the visa applications of Muslim

11 CAC, v. 19970347, art. 4, l. 1, 10 January 1996. 'Situation actuelle de l'islam de France'. Administrative memorandum written by the technical adviser for religious affairs of Minister of Internal Affairs Jean-Louis Debré. 
'ministers of religion'. ${ }^{12}$ Indeed, as the overwhelming majority of Muslim clerics are not French nationals, ${ }^{13}$ the Ministry of Internal Affairs systematically used the right of residence as a roundabout way of recruiting 'good candidates' and turning down 'bad' ones (Jouanneau, 2009b). This method was directly in line with a long-attested French tradition of 'à la carte treatment of foreigners' through the frequent use of ad hoc circulars (Spire, 2005, p. 13). This measure, which only affected professional imams - volunteer imams generally do not apply for visas in their capacity as ministers of religion, instead using their main occupation - had only a marginal impact on the profiles of imams in France, but it was symbolically useful for the Ministry of Internal Affairs. Whether the imams who applied for residence were expelled or granted more or less short-term residence permits, each of the stages in the administrative investigation served as a reminder of 'what any foreigner who fails to comply with the rules of good conduct exposes himself to'. Here these rules were the obligation 'of being respectful of the existing order [and of] its system of values' (Sayad, 1999, p. 9). The policy also contributed to facilitating the bureaucratic identification of foreign imams, chiefly by centralizing 'the body of information at the disposal of the different administrations' on the same imam and therefore 'recording, and eventually (should the need arise) punishing all deviant behaviour, or behaviour suspected to be deviant' (Spire, 2005, p. 58).

The third measure devised by officials of the Ministry of Internal Affairs received more coverage. It consisted of unofficially encouraging and supervising projects intended to ensure the training of imams à la française, in a bid to influence the profile of imams officiating in French mosques in the long or short term. The intention of this measure was to set up training programmes in which individuals would learn how to conduct the profession of imam, and in the process create places where Islamic religious rationality was adjusted to French State rationality by defining the 'good practices' and 'legitimate beliefs' of future imams to better reflect the 'values' of French society. For government agents, promoting and steering the creation of training institutions for the role or 'profession' of imam also stemmed from a desire to establish a more formal definition of the pre-requisites for becoming an imam. To make an educational institution the main means of

12 CAC 200030069, art. 28. Confidential telegram issued by the Sub-Directorate for Aliens and Cross-border Travel (SDECT), dated 21 November 1990.

13 In 2005, B. Godard (special adviser to the Central Bureau for Religious Worship) stated that 'less than 20 per cent of the imams in France had French nationality' and that 'they were less than a handful a decade ago'. 
obtaining the status of imam was also to progressively reduce the credit of other forms of legitimization that might have been employed by individuals striving to become the imam in a given mosque (Jouanneau, 2013, pp. 333357). However, most of the training projects launched or supported by the Ministry of Internal Affairs struggled to take off, and subsequently to function effectively. In addition to financial difficulties, these programmes also had problems recruiting students because of the current state of the structuring of Muslim worship in France; training appeared to be an expensive investment for such a poorly paid 'occupation' (Frégosi, 1998).

\section{Conclusion}

In their efforts to introduce formal standards and certificates for imams, the monitoring policies devised by the Ministry of Internal Affairs (often with the help of the Ministry of Foreign Affairs) all encountered the issue of the legitimacy of the imams they attempted to select or endorse. As both the archives and my ethnographic research indicate, these measures failed to address the conditions of the emergence of a religious authority which in practice rests not so much on official titles and degrees as on the elective affinities that develop between an imam and those who over time became 'his' faithful. Indeed, in the absence of a single ecclesiastical institution or a bureaucratization of the imamate (resembling the system in place in certain countries of origin), in France an imam's 'audience' remains the main yardstick to gauge the religious legitimacy of a Muslim cleric (Jouanneau, 2012). Try as it might, the government will never be able to fully 'rationalize' the ability of the imams it selects to meet the expectations of a wide array of faithful. No title, no foreign state can ensure the success of this co-optation, which' forms vary depending on the place of worship, and which is necessary for an imam to 'establish' himself or 'emerge' within a mosque. This is undoubtedly a thorn in the side of the French government actors who contend that imams have the power to facilitate or hinder the 'cultural integration' of French Muslims and seek to indirectly control their profiles. But in fact, this limitation of state power is in keeping with the legal spirit of laïcité. 


\section{References}

Achi, Raberh. 2004. 'La séparation des Eglises et de l'Etat à l'épreuve de la situation colonial: Les usages de la dérogation administrative dans l'administration du culte musulman en Algérie (1905-1959)'. Politix, 17(66): 81-116.

Akgonul, Samim. 2005. Religions de Turquie, religion de Turcs: Nouveaux acteurs de l'Europe élargie. Paris: L'Harmattan.

Bourdieu, Pierre. 1971. 'Genèse et structure du champ religieux'. Revue Français de Sociologie, XII(3): 295-334.

Bourdieu, Pierre. 1980. 'Le mort saisit le vif: Les relations entre l'histoire réifiée et l'histoire incorporée'. Actes de la Recherche en Sciences Sociale, 32(1): 3-14.

Boyer, Alain. 2005. 'Comment l'Etat laïque connaît-t-il les religions?' Archives en Sciences Sociales des Religions, 129: 37-49.

Cesari, Jocelyne. 1994a. Etre musulman en France, associations, militants et mosquées. Paris: Karthala-Irenam.

Cesari, Jocelyne. 1994b. 'De l'immigré au minoritaire: Les Maghrébins de France', Revue Européenne des Migrations Internationales, X(1): 112-123.

Chantin, Jean-Pierre. 2010. Le régime concordataire français: La collaboration des Églises et de l'État (1802-1905). Paris: Beauchesne.

Clément, Jean-François. 1990. 'Historicité de l'islam en France'. In L'islam en France, edited by Bruno Etienne, 89-98. Paris: Ed. du CNRS.

Commission Culture et Immigration. 1979. Réflexions et propositions sur les besoins éducatifs, sociaux et culturels des travailleurs émigrés et de leurs familles. Paris: ICEI.

Debré, Jean-Louis. 1997. En mon for intérieur. Paris: JC Lattès.

Dijoud, Paul. 1974. Communication sur la condition des travailleurs immigrés et la politique de L'immigration, Communication au Conseil des Ministres du 10 octobre 1974, Secrétariat aux travailleurs immigrés auprès du Ministère du Travail.

Escafré-Dublet, Angeline. 2008. 'Etat, culture, immigration: La dimension culturelle des politiques françaises d'immigration, 1958-1991'. PhD thesis, Institut d'études politiques,

Frégosi, Franck, ed. 1998. La formation des cadres religieux musulmans en France: Approches socio-juridiques. Paris: L'Harmattan,

Frégosi, Franck. 2004. 'L'imam, le conférencier et le jurisconsulte: Retour sur trois figures contemporaines du champ religieux islamique en France'. Archives des Sciences Sociales des Religions, 125: 131-146.

Frégosi, Franck. 2008. Penser l'islam dans la laïcité. Paris: Fayard.

Garache, Jean-Bernard. 1984. 'Accident: 6 février 1933 explosion de l'atelier 17'. Bulletin de la Section d'histoire des usines Renault, 28(juin): 151-157. 
Godard, Bernard and Sylvie Taussig. 2009. Les musulmans en France. Paris: Hachette. Gramsci, Antonio. 1978. Cahiers de prison, vol. 3. Paris: Gallimard.

Hobsbawn, Eric. 2009. Age of Empire. London: Abacus.

Jouanneau, Solenne. 2009a. 'Les imams en France: Réinvention et tentatives d'appropriations d'un magistère religieux en contexte migratoire', $\mathrm{PhD}$ thesis, l'Université Paris Diderot-Paris 7.

Jouanneau, Solenne. 20ogb. 'Régulariser ou non un imam étranger en France: Droit au séjour et définition du "bon imam” en pays laïque'. Politix, 86: 147-166. Jouanneau, Solenne. 2012. 'L'imam, clerc sans clergé ni Eglise: Les répertoires d'une autorité dissimulée dans les cadres de l'interaction'. Genèses, 88: 6-24.

Jouanneau, Solenne. 2013. Les imams en France: Sociologie d'une autorité religieuse sous contrôle. Marseille: Editions Agone.

Jouanneau, Solenne. 2014. 'L'invention des “Imams ELCO”: La tentation de l'externalisation diplomatique dans la gestion par l'État du dossier des imams en France'. In Trajectoires de neutralité, ed. by Valérie Amiraux and David Koussens, 103-118. Montréal: Les Presses l'Universitaires de Montréal.

Kepel, Giles. 1987. Les banlieues de l'Islam: Naissance d'une religion en France. Paris: Éditions du Seuil.

Kepel, Giles. 2004. Jihad: The Trail of Political Islam. New York: IB Tauris.

Lagroye, Jacques. 2003. 'Les processus de politisation', In La politisation, edited by Jacques Lagroye, 359-372. Paris: Belin.

Lalouette, Jacqueline. 2005. La séparation des Églises et de l'État: Genèse et développement d'une idée (1789-1905). Paris: Seuil.

Laurens, Henri. 2004. Orientales II: La IIIème république et la France. Paris: CNRS Éditions.

Le Pautremat, Pascal. 2003. La politique musulmane de la France au $20^{\text {ème }}$ siècle: De l'Hexagone aux terres d'Islam - Espoirs, réussites, échecs. Paris: Maisonneuve et Larosse.

Luizard, Pierre-Jean, ed. 2006. Le choc colonial et l'islam: Les politiques religieuses des puissances coloniales en terres d'islam. Paris: La Découverte.

Noiriel, Gérard. 1991. La tyrannie du national. Paris: Calmann-Lévy.

Sayad, Abdelmalek. 1999. 'Immigration et pensée d'État'. Actes de la Recherche en Sciences Sociales, 129: 5-14.

Sayad, Abdelmalek. 2004. The Suffering of the Immigrant. Cambridge: Malden Mass. Spire, Alexis. 2005. Etrangers à la carte: L'administration de l'immigration en France (1945-1975). Paris: Grasset.

Spivak, Gayatri Chakravorty. 1988. 'Can the Subaltern Speak?' In Marxism and the Interpretation of Culture, edited by Cary Nelson and Lawrence Grossberg, 271-313. Urbana: University of Illinois Press. 
Streiff-Fenart, Jocelyne. 1996. 'Frontière ethnique'. Vocabulaire Historique et Critique des Relations inter Ethniques, handbook IV: 37-40.

Thomas, William and Florian Znaniecki. 1996. The Polish Peasant in Europe and America. Chicago: University of Illinois Press.

Tripier, Maryse and Andréa Rea. 2003. Sociologie de l'immigration. Paris: La Découverte.

Wihtol de Wenden, Catherine and Rémi Leveau. 2001. La Beurgeoisie: Les trois âges de la vie associative issue de l'immigration. Paris: CNRS Éditions.

\section{About the author}

Solenne Jouanneau is a sociologist and political scientist. She is an Assistant Professor at Science Po Strasbourg and member of the Research Unit SAGE (UMR 7363). In 2013, she published Les imams en France. Une autorité sous controle (Agone Editions). 



\title{
9 The imam as an organic public intellectual
}

\author{
The case of Yassin Elforkani in the Netherlands
}

Welmoet Boender and Jan Jaap de Ruiter

Hashas, Mohammed, Jan Jaap de Ruiter, and Niels Valdemar Vinding (eds), Imams in Western Europe: Developments, Transformations, and Institutional Challenges. Amsterdam: Amsterdam University Press, 2018 DOI: $10.5117 / 9789462983830 / \mathrm{CHog}$

\begin{abstract}
This chapter describes the case of a Dutch imam, Yassin Elforkani (b. 1982), who is struggling to negotiate his position as an authoritative mediating religious leader in Dutch civil society. It follows Elforkani's steps of becoming an influential public figure and gaining a certain level of prestige as a religious authority in a secular context, while also meeting strong resistance from different audiences, both Islamic and non-Islamic. The chapter also discusses the broader question of the role and influence of imams as 'public intellectuals'.
\end{abstract}

Keywords: Islam in the Netherlands, public intellectuals, populism, Salafism, institutionalization of Islam

\section{1 Introduction}

On 17 June 2015, the Dutch national newspaper Trouw reported the following: 'Face of moderate Islam in the Netherlands quits.' Due to serious security threats to him and his family, Yassin Elforkani, by then known by his chosen title of 'imam of the young', announced his resignation as the spokesman and board member of the largest national representative body of Muslims 
in the Netherlands, the Contactorgaan Moslims en Overheid (Contact Organ of Muslims and Government, CMO). ${ }^{2}$

Since around 2004, Elforkani had been very active in the Dutch public sphere after making a name for himself as an imam in several mosques in Amsterdam and other Dutch cities. Highly accessible to the media, especially in his position as spokesman of the $\mathrm{CMO}$, he has played a public role in the debate on Islam and Muslims in an increasingly tense national and international context.

Whereas most imams opt for an inward-oriented approach focused on leading the mosque community (Boender, 2007, 2014) with less exposure to the public, Elforkani is among the small group of imams that play an explicitly public role and actively contribute to the public debate. In this sense, Elforkani answers the call for a stronger civic engagement of imams in the public sphere not only in the Netherlands, but elsewhere in Western Europe as well. National authorities in Western-European societies often regard imams as communication channels between the governments and Muslim communities. Their role has recently been under close scrutiny for both integration and security concerns.

Since 2006, the Dutch state has provided a subsidy for imam-training and Islam programmes at two Dutch universities and one University of Applied Sciences (Boender, 2013; Ghaly, 2008). In 2013, however, the boards of both Inholland and Leiden University announced the closure of their programmes due to low success rates as measured by the number of graduates. The boards considered the programmes too expensive. This was in contradiction to both the national plan and the government's expectations. Particularly since the attacks of 11 September 2001 and the murder of the Dutch filmmaker Theo van Gogh by the Moroccan-born Mohammed Bouyeri in November 2004, there has been a strong anxiety about so-called 'hate-imams', a specific type of travelling preacher who rejects the non-Muslim environment and encourages his followers to separate themselves from mainstream society (Cesari, 2004), and who sometimes are refused entrance visas for European countries. Similar to other Western European countries, the Dutch state has been balancing between policies of emancipation and of restriction.

2 CMO represents 380 of the 450 mosques in the Netherlands, most Moroccan, Turkish, Surinamese, or Bosnian (Boender, 2014; FORUM, 2010, p. 7). Elforkani was a board member of CMO from 2012 to the summer of 2015. The CMO, however, is in a difficult position. Its authority and position is not obvious in relation to its constituencies (see Boender, 2014). The Dutch Muslim population is diverse. Many Muslims are not even aware of the existence of the CMO. The CMO is, then, barely supported by its 'own constituencies' (Vellenga and Wiegers, 2011). At the same time, it is an indispensable institution in the realization of legal rights, including the right to spiritual care in prisons and the army. 
In this chapter, we aim to show how Elforkani has operated within the constraints of a polemic public debate on Islam in the Netherlands, moving strategically between Muslim communities, the Dutch government, and the general public. Using the philosophical concept of the 'public intellectual' based on the definition proposed by Odile Heynders (2016; see below), we discuss whether this imam is being accepted in his public performance. The concept of the 'public intellectual' brings in an analytical perspective that allows us to discuss the contested expectations of his civic engagement as a religious leader.

Several other imams have been prominent in the public debate in the Netherlands. For instance, Abdulwahid van Bommel, a convert, was among the very first spokespeople of the Muslim community in the Netherlands, during the first phases of their integration and institutionalization. Mohammed Cheppih was able to reach second generation Muslims by explaining the Islamic sources in Dutch, unlike most mosques' imams at the time (Boender, 2012). The 'new kid on the block' is Azzedine Karrat, a young imam of the Essalam mosque in Rotterdam. He received his religious education in the Netherlands and - just like Elforkani - is regularly present on television, radio, and social media. Another publicly outspoken imam is Abdul-Jabbar van de Ven, a convert who has propagated a Salafi form of Islam. He made a name for himself through his public debate with Hans Jansen (1942-2015), a renowned Arabist and member of the European Parliament from Geert Wilders's populist Party for Freedom - a debate that was later published in book form (Jansen and Van de Ven, 2008). In this chapter, however, we confine our discussion to the case of Elforkani, as he is a prominent example of an imam balancing between different audiences and expressing his own voice.

The chapter is divided as follows. Section 2 presents some considerations about the definition of a 'public intellectual', including arguments both for and against the inclusion of religious leaders in the category. Section 3 sets out the key currents in the Dutch public debate on Islam to which Elforkani contributes. In Section 4, we present Elforkani's professional background and core message. Section 5 provides some key responses of recognition and rejection of Elforkani's message, as expressed through (social) media. Section 6 presents our conclusion.

Can a religious person, in this case a Muslim, contribute as an independent thinker to a public debate? Or does religious doctrinal bias permeate every level of his/her thinking, preventing him/her from adding a critical 
contribution to public debate in the secular public sphere? In the literature, three main positions can be distinguished.

Professor of literature Heynders describes the role of a public intellectual as follows: 'The public intellectual intervenes in the public debate and proclaims a controversial and committed stance from a sideline position. $\mathrm{S} /$ he has critical knowledge and ideas, stimulates discussion and offers alternative scenarios in regard to topics of political, social and ethical nature, thus addressing non-specialist audiences on matters of general concern' (Heynders, 2016, p. 3). Public intellectuals are expected to provide a rational contribution to the formation of the public sphere. Table 1 presents Heynders' view on what she calls 'component frames' that indicate 'which themes and strategies are dominant in regard to certain cases of public intellectual performance' (Heynders, 2016, p. 21).

\section{Table 1 Heuristic four-level scheme for researching public intellectuals}

\begin{tabular}{ll}
\hline Public intellectual (PI) & \\
\hline Cultural Authority & $\begin{array}{l}\text { The PI has ideas, cultural authority and credentials, and } \\
\text { the talent to give a broad, condensable, popularizing, } \\
\text { and new perspective on issues of general concern } \\
\text { The PI operates in a specific (trans-) national, societal, } \\
\text { and economic context, which provides a narrative frame } \\
\text { that is used as well as criticized }\end{array}$ \\
$\begin{array}{l}\text { The PI introduces an issue, using the appropriate media } \\
\text { Production and Reception }\end{array}$ & $\begin{array}{l}\text { and a particular rhetoric (style of arguing and framing) } \\
\text { The PI implements aesthetic features in texts and } \\
\text { performances, and consciously creates a persona in the } \\
\text { Theatricality }\end{array}$ \\
& media with an effect on audiences \\
\hline
\end{tabular}

We apply this 'four-level' scheme to the question of whether Yassin Elforkani can be regarded as a public intellectual. In treating the question of independent thinking, Heynders goes back to Gramsci (1971), who distinguished between 'traditional' and 'organic' intellectuals - the former independent of a social class and the latter organizing particular social classes or groups. Heynders quotes Edward Said, who followed Gramsci in arguing that '[e] veryone working in any media field associated with the production or the distribution of knowledge is [...] an organic intellectual in giving voice to certain ideas and groups' (Said, 1996, p. 4, in Heynders, 2016, p. 8). Heynders argues that it is inevitable that public intellectuals will develop political preferences, which at a certain point they can no longer hide. She mentions the playwright, dissident, and later president of Czecho-Slovakia Václav 
Havel as an example, and also notes that Mario Vargas Llosa, writer and candidate for the presidency in Peru in 1990 was an exemplary organic intellectual (Heynders, 2016, p. 8). From Heynders' arguments, it could be concluded that it does not really matter whether a public intellectual uses religiously based arguments.

Jan Peter Hartung (2013) takes a different position. He considers the term 'Muslim public intellectual' a contradictio in terminis ('contradiction in terms'). In his view, the concept is used without proper justification. He argues that 'this tag appears to be ascribed to those Muslims who, by emphasizing rationality over slavishly adhering to a textual tradition, support the general compatibility of Western and Islamic social and political values' (Hartung, 2013, p. 35). Criticizing Weber (1972) and Schluchter (1991) for including religious thinkers or even 'clerics' as intellectuals, Hartung presents two arguments to support his position. First, he argues that the label of religious intellectual 'is very much the production of dogmas [... It] leads ultimately to conflict with a philosophical concept of "intellectual" (p. 37). According to him, religious dogmas oppose philosophical conceptions by their very nature, as dogmas are inherently considered immutable or fatalist. Hartung's second argument is that modern Arab societies themselves distinguish between the roles of religious thinkers and public intellectuals, referring to the first as ulama who represent a religious authority, and the second as mufakkirūn which can be translated as 'intellectuals' and stresses their secular nature. Hartung thus refuses to see religious leaders as independent thinkers.

Jürgen Habermas takes an 'in-between position'. Habermas stipulated that a pluralist society is an extremely complex ensemble of groups, each striving for their own interests, and as such living in an ongoing situation of conflict. The public sphere is die Öffentlichkeit ('public space') in which competing sets of norms and values have to be discussed to decide how the Öffentlichkeit should look like (Habermas, 1962). Later, Habermas (2006) argued that in post-secular liberal societies it is relevant to accept religious thinkers as partners in this public discussion. Since it is not self-evident for secular societies and/or politics to accept the public contributions of a (new) cohort of religious leaders as rational contributions to the formation of the public sphere, this should be done through a vocabulary that is shared by different agents. This can only be possible in secular terms, Habermas states (2006). Evidently, this argument only concerns contributions in the public sphere, since most activities of religious groups take place in the nonpublic sphere of the congregation. Their actions become public when they involve interactions outside of this sphere. Based on these three different 
positions, we discuss Elforkani's performance in the public debate on Islam and Muslims in the Netherlands with the aim of determining whether he could be regarded a 'public intellectual', and if so, of what nature.

\section{Actors in the public debate on Islam}

Islamophobia increasingly has affected Dutch public debate about the integration of Muslims (Sheehi, 2011; Taras, 2012; Van der Valk, 2012). Populist neo-nationalist parties such as Geert Wilders's Party for Freedom have considerably grown in size and influence (De Ruiter, 2012a, 2012b). At the same time, Salafism has grown in popularity among young Muslims who feel discriminated and increasingly segregated from society (De Koning, Becker, Roex, and Aarns, 2014). While radical Islamist groups create fear through violent international attacks, populist movements come up with unrealistic solutions (De Ruiter, 2016). In this section, we present a short overview of the different currents of these debates, illustrated with examples of different publicists, to show the narrative frames in which Elforkani operates. These range from anti-Islam ideologists to individuals who are very open towards Islam, and Islamic religious voices that can basically be divided into streams of openness to Dutch society or isolation. We start with presenting some main statistics on the Muslim presence in the Netherlands.

\subsection{Islam in the Netherlands}

The Dutch Muslim community is ethnically, culturally, and religiously diverse and politically divided. According to the Dutch Central Office of Statistics (Maliepaard and Gijsberts, 2012), 825,000 people in the Netherlands are Muslim, which is around 5 per cent of the total population of nearly 17 million. 296,000 of them have a Moroccan background and 285,00o have a Turkish one, together making up 67 per cent of the total number of Muslims (Berger, 2012-2013; Maliepaard and Gijsberts, 2012). Other major groups of Muslims in the country have backgrounds from Suriname (34,00o people), Afghanistan (31,000), Iraq (27,000), and Somalia $(20,000)$. There are around 13,00o Dutch converts. Around 95 per cent of the Muslims in the Netherlands have a non-Western background (Berger, 2012-2013; FORUM, 2012). There are also several different Shiite communities, including Turkish Alevites, Iraqis, and Iranians, that together make up a population of around 100,000 to 150,000 people. Within Sunni circles, the number of Salafi Muslims has 
been growing in the past decade, and now numbers approximately 25,000 (De Koning, Becker, Roex, and Aarns, 2014; De Koning, Wagemakers, and Becker, 2014).

\subsection{The ideology of the Party for Freedom}

Since its birth in 2006, the Party for Freedom lead by Geert Wilders has been relatively successful in general, regional, local, and European elections. Although it has suffered some electoral setbacks and internal scissions, it is a powerful political force in the country. ${ }^{3}$ The party's core issue is the 'battle against Islam' (De Ruiter, 2012a, 2012b). In public statements, Wilders, assisted by his 'party ideologue' Martin Bosma (2010), has repeatedly claimed that he has 'nothing against Muslims but everything against Islam'. In 2010-2011, Wilders faced trial for his public statement of 'How do we imagine a country without Islam?' - for which he was eventually acquitted (De Ruiter, 2012a, 2012b). At an election meeting on the occasion of the Municipal Elections in March 2014, he asked his supporters if they wanted 'less Moroccans' in the country; in answer the crowd cheered 'less, less, less', to which Wilders responded, 'Then we are going to organize that.' Thousands of complaints were filed against him for these statements, and he again faced trial. Eventually Wilders was found guilty of the charge of inciting discrimination, but he was not punished. To remove this guilty verdict, Wilders filed an appeal and as of the publication of this book the outcome of that appeal is not yet known. Wilders is not alone in this fight against Islam; a small group of opinion makers also espouses this political ideology, such as the publicist Joost Niemöller (2012; 2017).

\subsection{Other voices}

There is hardly any opinion leader in the Netherlands that has not expressed a specific opinion on Islam, Muslims, and their integration into Dutch society. There is one group that accepts Muslims as they are, and another that demands that they adapt to Dutch-Western values. On the one end of the scale is Afshin Ellian, a professor of law at Leiden University and political refugee from Khomeini's Iran, who does not cease to inform the public of

3 Between November 2010 and April 2012, Wilders's party supported the minority government of Liberal Party leader Mark Rutte together with the Christian Democratic Party. He dropped his support for this coalition, as he declared he was no longer able to support the budget cuts proposed by the cabinet. 
the crimes committed in the name of Islam. But he does not deny Muslims their existence in the country. The other end of the scale is symbolized by the suggestion of Labour politician and ex-mayor of Amsterdam Job Cohen, who asked people to 'drink tea' with Muslim leaders to 'keep things together' (Sohorto, 2010). Cohen was accused of engaging in dialogue with Muslims whose anti-democratic and misogynist attitudes were well known.

The Socialist Minister of Social Affairs from 2012-2017, Lodewijk Asscher, was also concerned about the debate on Islam in the country. He regularly organized meetings with the representatives of the Muslim communities in the country to discuss their role in the further integration of Muslims. In speeches, press conferences, and newspaper articles, Asscher expressed an assimilationist vision by encouraging Muslims and migrants to subscribe to Western values of democracy, the freedom of speech, and women's and gay rights. ${ }^{4}$ In the spring of 2014, Salafi imams and leaders were invited to the Ministry for a meeting, during which they expressed their dissatisfaction with the government's views on Islamic issues. In fall 2015, the Labour Party MP Ahmed Marcouch, himself of Moroccan origin, suggested in Parliament that the Salafi movement should be forbidden. ${ }^{5}$ This proposal was met with strong criticism, not only from the Salafis, but also from other political parties that stated that the Labour Party was no longer far from Wilders's view that all of Islam should be forbidden. Since then, a fierce debate has continued about the position of Salafis in particular in the country.

\section{$3.4 \quad$ Islamic voices}

Muslim voices are not homogeneous. In addition to jihadists and Salafis, there are also the mainstream so-called moderates, the culturally Muslim, and the former Muslims who have since declared themselves atheists.

The number of jihadi Muslims in the country is low (cf. De Koning, Becker, Roex, and Aarns, 2014), and they are under the surveillance of the secret services and police. Obviously, most of their activities take place in secret, but they still appear occasionally to proclaim their support for the Islamic State or Al-Qaeda and their aversion to democracy (Zeegers, 2016).

There are still relatively few Salafi Muslims in the country; in 2007, the Dutch intelligence services mentioned a number between 20,000-30,000

4 http://www.euro-islam.info/2015/02/20/dutch-vice-prime-minister-lodewijk-ascher-muslimsbelong-in-the-netherlands/.

5 http://www.trouw.nl/tr/nl/4728/Islam/article/detail/4270410/2016/o3/25/MarcouchNederland-naief-over-salafisme.dhtml. 
(AIVD-NCTV, 2015). The Institute for Migration and Ethnic Studies of the University of Amsterdam estimated that 8 per cent of the Muslims in the Netherlands could be regarded as 'orthodox and sensitive for Salafism' (Roex, Van Stiphout, and Tillie, 2010). Salafi ideology acknowledges that Muslims can live in a non-Muslim country while also obeying a complex set of rules based on the sharia. There are basically two streams within Salafism. One is explicitly non-political; they strive to keep a distance from mainstream society (De Koning, Becker, Roex, and Aarns, 2014). Young people are told not to mix with Dutch society and to only focus on Islam. The other allegedly has a political agenda. It rejects democracy, but strives to develop through the democratic system to gain more political support for the Salafi lifestyle. ${ }^{6}$ However, the researcher and expert in jihadi-Salafism Shiraz Maher has recently argued that this two-fold classification is not without problems. Maher (2016) suggests using a more individual approach to understand Salafis, which captures the relationship between how the actors view their connection to power and the manner in which they wish to engage with or change it.

There are plenty of so-called moderate voices in the Muslim communities of the Netherlands. They share the opinion that Islam and democracy, and Islamic values and Western values, are compatible. They attempt to understand the meaning of the Islamic sources in the context of their original time and place. One example is Enis Odaci, an Alevi Muslim who manages a website called Humanislam. ${ }^{7}$ He seeks a rapprochement between the Islamic and Western value systems. Others underline the importance of both value systems while embedding their thinking in an orthodox Sunni interpretation of Islam. An example is Stella van de Wetering, a staff member of the Amsterdam Centre of Islamic Theology of the Amsterdam Free University. Mehmet Cerit, the editor-in-chief of the former Turkish-Dutch journal Zaman Vandaag (the off-spring of the Turkish newspaper Today's Zaman, which was forcibly closed by the Turkish government in March 2016) is a fervent supporter of the combination of Western and Islamic values. ${ }^{8}$

Finally, there is a group of voices that considers themselves Muslim by culture and to whom Islam is an identity marker, such as the novelist Abdelkader Benali. Others declare that they have broken with Islam, and are continuing their lives as atheists or agnostics. One example is Hafid Bouazza, the author of highly symbolic novels.

6 Recently, the validity of this distribution into two streams of Salafism has been questioned, especially by one of the authors of this chapter, De Ruiter.

7 http://www.humanislam.com/.

8 http://www.zamanvandaag.nl/. 


\section{4 Elforkani: background and message}

Yassin Elforkani calls himself an 'imam of the young'; he has been frequently in the spotlight in the debate on Islam, particularly since the murder of Dutch filmmaker Theo van Gogh by Mohammed Bouyeri in November 2004. Elforkani is married and the father of two children. He runs a business firm with several partners. Born in a small town near Amsterdam to firstgeneration Moroccan migrants ${ }^{9}$ from a rural area of Morocco, Elforkani was raised in an orthodox family where Islam played an important role. His father and grandfather were imams. From a young age, Elforkani was interested in the sources of Islam, the Quran, and Sunna of the Prophet, and in studying Islamic theological works. He spent part of his childhood in Morocco, where he learned the Quran by heart, and studied in several Islamic institutions both in and outside of Europe, such as Al-Azhar University in Cairo. ${ }^{10}$ Elforkani allegedly has a conservative Islamic past during which he condoned or even stimulated the visit of conservative preachers from abroad, some of whom were close to Salafism. He has also been accused of having financial ties with oligarchs from Kuwait in order to fund mosques in The Netherlands. ${ }^{11}$ Elforkani has strongly contested these allegations. ${ }^{12}$

In 2010, he became the spokesman of the Contact Organ of Muslims and Government (CMO). He has expressed his drive as wanting to encourage young Muslims to integrate into and function in Dutch society while at the same time maintaining their Muslim identity. He combines the roles of a religious leader, youth social worker, and socio-political debater. This threefold role is visible through his aesthetic performance: he wears a jellaba ('robe') while preaching - providing him with the aura of a traditional imam -, the jeans and t-shirt of a social worker, and the black tie of a debater. During a relatively short period of time, he has developed into an important Muslim participant in the public debate on Islam in the Netherlands. In the summer of 2015, however, he withdrew from his position as spokesperson of

9 It was in the 1960 s and 1970 s that the Dutch government and companies recruited labourers from Turkey and Morocco, who were later followed by their spouses and children. Although the mind-set of the Dutch governments at the time was that they would later return to their home countries, the opposite happened. Today we are witnessing a second and third generation of immigrants (cf. De Ruiter, 2016).

10 https://www.facebook.com/yassin.elforkani/about.

11 http://www.carelbrendel.nl/2015/o6/26/yassin-elforkani-vertelt-het-fabeltje-van-de-aapen-de-krokodil/.

12 http://www.republiekallochtonie.nl/europe-trust-nederland-geen-justitieel-onderzoeknaar-el-forkani-en-van-der-blom. 
the CMO, a decision reinforced by ongoing security threats to him and his family. After the second Paris attacks in November 2015, he stepped back onto front stage, appearing in several media channels and on Twitter and Facebook, and has been active since then. In March 2016, he issued a public warning to society that pointed at the ongoing unrest and radicalization in certain Muslim circles in Amsterdam, and predicted possible terrorist attacks. Muslim spokesmen heavily criticized him for this, accusing him of sowing unnecessary fear. ${ }^{13}$

Elforkani's public performances occur in the highly complicated social and political context described above. In a society where Muslims as a group have difficulty being heard, Elforkani has acted as one of the main representatives of both the Moroccan and wider Muslim community in the Netherlands. Using a variety of platforms, he responds to diverse topics, such as radicalization of the youth, violent jihad, the (sexual) equality of men and women, liberal democracy, and political representation. In answering these calls, Elforkani has tried to provide several 'counter-points' against the essentialist and one-sided views on Islam and Muslims propounded by populist political parties. We have identified at least five 'counter-points' that Elforkani espouses.

First, he calls for the active participation of young Muslims in society. Elforkani expresses his view that Islam fits well within democratic societies. He urges young people to do their best to build a future for themselves in the country, go to school, and take up responsible jobs. He states that Islam encourages young people to integrate and help build the country in which they live. He calls upon young Muslims 'to come out of their comfort zone to reach out to the other', as he stated in a speech and interview in February 2016. ${ }^{14} \mathrm{He}$ conveys the importance of openly confessing belief in the Muslim faith in society, and participates in the ongoing public debate about the (in)compatibility of Islam and democracy, of which the equal treatment of women and homosexuals are core issues. Although he does not seem to take the initiative in expressing his opinion of the rights of these two groups, when confronted he states that everyone in the society has the right to live as he or she wants. While this is not the same as condoning these alternative lifestyles, it is Elforkani's conviction that Islam and Muslims can only find their appropriate place in Dutch democracy on the basis

13 http://www.rtlnieuws.nl/nieuws/binnenland/waarschuwing-jeugdiman-elforkanigevaarlijke-angstzaaierij.

14 http://ekklesia-amsterdam.nl/upload/multimedia/toespraak+interviewYassinElforkani-2. pdf. 
of mutual acceptance. In this way, Elforkani tries to bring an essentially internal Muslim religious debate into the public space, which fits well in his vision that Muslims should not separate themselves from the rest of society. He also wants to show the non-Muslim part of society that these and similar debates do take place within Muslim communities, and that in his opinion it is important to hold these debates to find the place of Islam and Muslims within society.

Second, Elforkani fiercely expresses his disapproval of young Muslims travelling to Syria to join jihadi groups. In his view, these young people have not correctly understood the sources of Islam; in his sermons, he provides a contextual interpretation of the sacred texts. He also adds that the conflicts in Syria and the Middle East in general are not young Dutch Muslims' conflicts. While condemning the possible support of the community for jihadists, he calls the community to provide a religious answer. He claims that it is not Islam but the interpretations of the sources that should be critically discussed, as these would lead to concepts as the Caliphate, Islamic State (IS), jihad in Syria and Iraq (interview February 2016). '[The r] uthless reality is that the perpetrators of the attacks in Paris on 13 November 2015, have legitimized their acts theologically. We cannot sustain that all this has nothing to do with Islam,' he said in the national newspaper de Volkskrant (Groen, 2015). 'You have to come from another planet to not want to speak out as a Muslim [...] you as Muslim can no longer look away. ${ }^{15}$

Third, one of his major concerns stems from his realization that radical Muslims discredit 'mainstream' Muslims, which severely harms their position as equal citizens of the Netherlands. At the same time, he opposes the idea that Muslims should regard themselves as victims of discrimination or discriminatory attitudes, 'wallowing in feelings of victimization'. He urges the Muslim community to vehemently resist the Islamic State's interpretations of the Quran, 'particularly in small circles, when you, parents, discuss with your children about faith, or during your conversations amongst yourselves in coffee- and teahouses'. Muslims should back off from their role as victims, and should not just keep whining that they are always singled out for wholesale condemnation (de Volkskrant, 14 November 2015).

His recommendation that Muslim communities put their own houses in order - concerning pedagogical weaknesses of the Moroccan community, for example - means that he brings internal community affairs and social

15 http://www.nltimes.nl/2015/11/16/amsterdam-imam-we-cannot-say-this-has-nothing-todo-with-religion/. 
weaknesses into public discussions. He not only utters this critique towards his own community, but also directs it towards politicians, both right wing and left wing.

Fourth, his focus is on influencing policies relating to the prevention of radicalization. In a television documentary of the Muslim Broadcast Organization in November 2013, he expresses his concern as follows (our translation): $:^{16}$

We have a problem now, which politicians have as yet not even noticed [i.e. radicalization], let alone having thought of solutions for it. There are a number of smaller municipalities [in this case Zoetermeer] that face problems that politicians have no idea about. And if you do not know then you just cannot talk at all about it. [...] they think they know, they talk about a phenomenon they have no sense of at all. So I would say: 'politicians, go once again to the community, and see what exactly is going on. ${ }^{17}$

Understanding these and other integration problems as a shared concern of the diverse Muslim communities and society at large is his fifth 'counterpoint'. It formed an important part of his message in his political role as spokesman and board member of the CMO, in which he attempted to play the role of a liaison between the government and the Moroccan, Turkish, Surinamese, Bosnian, and other Muslim communities.

By attempting to provide a counter-narrative, Yassin Elforkani has clearly tried to act as an intermediary between various groups. He wants to play a bridging role that connects the social realities of the young and elder generations. He also tries to connect the worlds of the Muslim communities and the local municipalities. Finally, he attempts to defend the interests of Muslim communities at the national level. In these mediating roles, he manifests in both the internal socio-religious sphere of Muslim communities and in the public, secular context.

Elforkani has gained support from Muslims and non-Muslims alike, who praise him for playing this intermediary role. However, he has also faced considerable criticism from many different sides, from anti-Islam circles to 
Salafi groups. Whereas voices such as the ones expressed by the populist website GeenStijl, which is close to the Party for Freedom, consider Elforkani a 'wolf in sheep's clothing' and accuse him of 'double-speak', ${ }^{18}$ jihadi-radicals, low in number but strong in voice, are most likely the ones who have issued threats to stop him from talking in public. As he himself stated, 'Syria radicals threaten [me] more than they threaten Wilders,' in the Dutch newspaper Trouw on 18 December 2013. ${ }^{19}$

Mainstream groups of Muslims also do not spare him from critique, often through social media and in internal debates. On the one hand, there are young Muslims who in principle look at him in a favourable way, but are constantly confronted with prejudices and (hidden and open forms of) discrimination on the labour market (Siebers, 2010; Siebers and Dennissen, 2012). These negative experiences make them turn against Elforkani's discourse and lead to blaming him for supporting something that in their eyes is 'just not realistic': why support Western values if that same West does not give you a fair chance? Some Salafis, in turn, accuse Elforkani of cooperating with the secular and therefore kâfir ('unbeliever') government. These circles have doubts about his formation and appointment as imam, holding the fact that he did not follow the right path to reaching this status against him. Furthermore, he is sometimes distrusted by a 'moderate' or mainstream Dutch public that is inclined to support him in his efforts, but still has continuous doubts about his integrity, and especially accuses him of being supported financially by the state of Kuwait in its attempt to spread a conservative form of Islam. This 'conservative heritage' of being a Muslim Brother is always attached to him.

It is not always easy to distinguish between the Elforkani who is a 'youth imam', the 'imam of the Amsterdam Blue Mosque', 'spokesperson of the CMO', and 'interlocutor' of the former Minister of Social Affairs, Lodewijk Asscher - making Elforkani difficult to label. These different roles might be confusing for various audiences. As a journalist phrased it, 'He wears so many hats that it raises doubt' (van Walsum, 2015). Elforkani is a religious leader, a social worker, and a socio-political debater at the same time, and is involved in both the private and public spheres. The fact that he is so versatile makes it more interesting to examine whether he can be labelled a public intellectual.

18 http://www.geenstijl.nl/mt/archieven/2014/o8/pappen_en_nathouden_pappen_en_nathouden_pappen_en_nathouden_pappen_en_nathouden_pappen_en_nathouden_.html. 19 http://www.trouw.nl/tr/nl/4728/Islam/article/detail/3564297/2013/12/18/Imam-Syrieradicalen-bedreigen-vaker-ons-dan-Wilders.dhtml. 
Elforkani presents himself in public debates as a supporter of the complete integration of Muslims into Dutch society. He believes that Muslim and Western values can meet and that young Muslims should do their best to build Dutch society at large. His positions as imam of the youth, social worker, and spokesman and board member of the CMO have given him the opportunity to express his views in an increasingly polarized public debate.

Actively bringing in a counter-narrative, this Muslim religious leader has become a pronounced public figure in the debate about the status of Islam - and religion in general - in society. He has actively tried to influence public opinion and decision makers' stances towards the highly debated topics of integration and radicalization. As such, he answers the definition of Heynders of a 'public intellectual': he intervenes in public debates and proclaims a controversial and committed stance. Elforkani moves in the public space; his presence is difficult to ignore; he addresses non-specialist audiences through numerous interviews in the press, radio and television, and on the Internet. He presents critical knowledge and ideas concerning the subjects he tackles, i.e., Islam and Muslims in Western societies, daring to go beyond the lines of what many Muslims in particular consider to be permitted, and thereby showing what Heynders calls 'cultural authority'.

Obviously, one of Hartung's major objections to the idea of religious public intellectuals is that they would be stuck in their dogmatic convictions and therefore be unable to put things in different or progressive perspectives. However, we have seen that one of Elforkani's characteristics is that his contribution to the public debate is contested in religious circles. At the same time, he does not confine himself to (purely) religious or theological matters, but also captures an externally focused public stage. Elforkani inserts controversial ideas into the public debate on Islam and Muslims. His arguments, basically an amalgam of Islamic and Western values, provoke fierce reactions from both conservative Islamic circles, such as the Salafi ones, and the populist circles who by definition hardly trust Muslims anyway; he also provokes young Muslims who no longer have no faith in equal chances in society, as well as the part of the mainstream Dutch public that is infected by the virus of mistrust and suspicion of Muslims. He neither disposes of a strong support in his own community nor in society at large. This is part of Heynders' concept of the 'public intellectual'. At the same time, Heynders notices that public intellectuals almost inevitably show their 'political feathers' while giving voice to certain groups - in this case, religious groups. 
Be they secular or religious, public intellectuals' most important characteristic was 'proclaiming a controversial and committed stance', thus offering 'alternative scenarios' (Heynders, 2016, p. 3). They present meta-narratives, maintaining debates based on arguments. Religious arguments, then, can make sense to a post-secular public debate. Applying Habermas's view that public intellectuals necessarily use secular arguments in any societal debate, one could postulate that the debate on Islam and Muslims in the Netherlands is not led only by religious arguments. Elforkani seeks Quran-based arguments, but he does so to improve the integration of Muslims into society. In fact, he contributes to a reconciliation between secular society and the religious, cultural, and social tenets of Muslim communities. In conclusion, we could classify Yassin Elforkani as an organic public intellectual, as he represents an important Muslim voice, even if some audiences are unwilling to accept his words - or maybe for exactly that reason.

\section{References}

AIVD-NCTV. 2015. Salafisme in Nederland: Diversiteit en dynamiek. Den Haag: AIVD \& NCTV.

Berger, Maurits. 2012-2013. 'Islam in the Netherlands: Entering the twenty-first century'. Canadian Journal of Netherlandic Studies/Revue canadienne d'Études néerlandaises, 33(2) and 34(1): 1-16.

Boender, Welmoet. 2007. Imam in Nederland: Opvattingen over zijn religieuze rol in de samenleving. Amsterdam: Uitgeverij Bert Bakker.

Boender, Welmoet. 2012. 'Mohammed Cheppih: Publieke intellectueel en publieke gelovige'. MANAzine, 5: 40-47.

Boender, Welmoet. 2013. 'Embedding Islam in the 'moral covenants' of European states: The case of a state-funded imam training in the Netherlands'. Journal of Muslims in Europe, 2: 227-247.

Boender, Welmoet. 2014. 'Polderen in de participatiesamenleving: De kantelende positie van het Contactorgaan Moslims en Overheid'. In Achter de zuilen: Op zoek naar religie in naoorlogs Nederland, edited by Peter van Dam, James Kennedy, and Friso Wielenga, 255-277. Amsterdam: Amsterdam University Press.

Bosma, Martin. 2010. De schijn-élite van de valse munters: Drees, extreem rechts, de sixties, nuttige idioten, Groep Wilders en ik. Amsterdam: Uitgeverij Bert Bakker.

Cesari, Jocelyne. 2004. L'islam à l'épreuve de l'Occident. Paris: La Découverte.

De Koning, Martijn, Carmen Becker, Ineke Roex, and Pim Aarns. 2014. Eilanden in een zee van ongeloof: Het verzet van activistische Da'wa netwerken in België, 
Nederland en Duitsland. Radboud Universiteit Nijmegen/Universiteit van Amsterdam: IMES Report Series.

De Koning, Martijn, Joas Wagemakers, and Carmen Becker. 2014. Salafisme: Utopische waarden in een weerbarstige praktijk. Almere: Uitgeverij Parthenon. De Ruiter, Jan Jaap. 2012a. De ideologie van de PVV: Het kwade goed en het goede kwaad. Amsterdam: Rozenberg Publishers.

De Ruiter, Jan Jaap. 2012b. The Speck in Your Brother's Eye: The Alleged War of Islam Against the West. Amsterdam: Rozenberg Publishers.

De Ruiter, Jan Jaap. 2016. 'Muslims in the Netherlands: A Threatening Community or a Community under Threat?' In New Horizons of Muslim Diaspora in North America and Europe, edited by Moha Ennaji, 229-242. London: Palgrave Macmillan.

FORUM (Instituut voor Multiculturele Vraagstukken). 2010. De positie van moslims in Nederland. Utrecht: FORUM.

FORUM (Instituut voor Multiculturele Vraagstukken). 2012. Muslims in the Netherlands. Utrecht: FORUM.

Ghaly, Mohammed. 2008. 'The Academic Training of Imams: Recent Discussions and Initiatives in the Netherlands'. In The Study of Religion and the Training of Muslim Clergy in Europe: Academic and Religious Freedom in the $27^{\text {st }}$ Century, edited by Willem B. Drees and Pieter Sjoerd van Koningsveld, 369-402. Leiden: Leiden University Press.

Gramsci, Antonio. 1971. Selection from the Prison Notebooks, edited and translated by Quinten Hoare and Geoffrey Novel Smith. New York: International Publishers.

Groen, Janny. 2015. 'We kunnen niet blijven zeggen dit heeft niets met de islam te maken' In De Volkskrant, November 14. http://www.volkskrant.nl/ buitenland/-we-kunnen-niet-blijven-zeggen-dit-heeft-niets-met-de-islam-temaken a4186542/.

Habermas, Jürgen. 1989[1962]. The Structural Transformation of the Public Sphere: An Inquiry into a Category of Bourgeois Society. Translated by Thomas Burger. Cambridge: Polity.

Habermas, Jürgen. 20o6. 'Religion in the public sphere'. European Journal of Philosophy, 14(1): 1-25.

Hartung, Jan-Peter. 2013. 'What Makes a "Muslim Intellectual"?: On the Pros and Cons of a Category'. Middle East - Topics \& Arguments, 1: 35-45.

Heynders, Odile. 2016. Writers as Public Intellectuals: Literature, Celebrity, Democracy. London: Palgrave Macmillan.

Jansen, Hans and Abdul-Jabbar van de Ven. 2008. Bombrieven. Amsterdam: Uitgeverij van Praag.

Maher, Shiraz. 2016. Salafi-Jihadism: The History of an Idea. London: Hurst \& Company. 
Maliepaard, Mieke and Mérove Gijsberts. 2012. Moslim in Nederland. Den Haag: CBS.

Niemöller, Joost. 2012. Het immigratietaboe: 10 wetenschappers over de feiten. Amsterdam: Uitgeverij van Praag.

Niemöller, Joost. 2017. Kwaad. Nederlanders over immigranten. Amsterdam: Uitgeverij van Praag.

Roex, Ineke, Sjef van Stiphout, and Jean Tillie. 2010. Salafisme in Nederland:Aard, omvang en dreiging. Amsterdam: Instituut voor Migratie- en Etnische Studies, Universiteit van Amsterdam in cooperation with Centraal Bureau voor de Statistiek.

Said, Edward W. 1996. Representations of the Intellectual: The 1993 Reith Lectures. New York: Vantage Books.

Schluchter, Wolfgang. 1991. Religion und Lebensführung: Studien zu Max Webers Religions- und Herrschaftssoziologie. Frankfurt am Main: Suhrkamp.

Sheehi, Stephen. 2011. Islamophobia: The Ideological Campaign Against Muslims. Atlanta: Clarity Press.

Siebers, Hans. 2010. 'The Impact of Migrant-Hostile Discourse in Media and Politics on Racioethnic Closure in Career Development in the Netherlands'. International Sociology, 25(4): 475-500.

Siebers, Hans and Marjolein Dennissen. 2012. "Traces of hate": How the dominant migrant-hostile discourse in Dutch media and politics influences inter-ethnic relations between employees in Dutch work settings'. Tilburg University: Tilburg Papers in Culture Studies, 31.

Sohorto, Russell. 2010. 'The Integrationist'. The New York Times Magazine, 28 May. http://www.nytimes.com/2010/05/30/magazine/3oMayor-t.html?_r=o.

Taras, Raymond. 2012. Xenophobia and Islamophobia in Europe. Edinburgh: Edinburgh University Press.

Van der Valk, Ineke. 2012. Islamofobie en discriminatie. Amsterdam: Amsterdam University Press.

Vellenga, Sipco and Gerard Wiegers. 2011. Religie, binding en polarisatie: De reacties van de leiding van levensbeschouwelijke organisaties op islamkritische uitingen. Amsterdam: UvA, Faculteit der Geesteswetenschappen.

Walsum, Sander van. 2015. 'Yassin Elforkani kan het ook nooit goed doen'. De Volkskrant, May 31. https://www.volkskrant.nl/binnenland/yassin-elforkanikan-het-nooit-goed-doen a4044847/.

Weber, Max. 1972. Wirtschaft und Gesellschaft: Grundriß derverstehenden Soziologie. Tübingen: Mohr.

Zeegers, Maarten. 2016. Ik was een van hen: Drie jaar undercover onder moslims. Amsterdam: Podium. 


\section{About the authors}

Welmoet Boender (Ph.D. in Religious Studies at Leiden University) specializes in the role of imams, imam training, and the development of Islamic theology in Western Europe. She is a Lecturer in Islamic Studies at Leiden University and a staff member of the Leiden Islam Academy. She is an affiliated member of the Erlanger Zentrum für Islam und Recht (Germany). Key publication: 'Embedding Islam in the "Moral Covenants" of European States: The Case of a State-Funded Imam Training in the Netherlands', Journal of Muslims in Europe, 2 (2013), pp. 227-247.

Jan Jaap de Ruiter is an Assistant Professor at Tilburg University and trained as an Arabist. He is active in the public debate in the Netherlands on Islam and Muslims, and is the author of numerous opinion articles and columns in all of the major Dutch newspapers. Columns of his appeared on the website of Al Jazeera and the Huffington Post. His The speck in your brother's eye: Islam's perceived war against the West (Amsterdam: Rozenberg Publishers, 2012) analyses the ideology of the Dutch Party for Freedom in relation to Islam. 



\title{
10 i-Imams studying female Islamic authority online
}

\author{
Claudia Carvalho
}

Hashas, Mohammed, Jan Jaap de Ruiter, and Niels Valdemar Vinding (eds), Imams in Western Europe: Developments, Transformations, and Institutional Challenges. Amsterdam: Amsterdam University Press, 2018 DOI: $10.5117 / 9789462983830 / \mathrm{CH} 10$

\begin{abstract}
Using Facebook as a case study, this chapter details how self-proclaimed jihadist women construct and disseminate an online discourse to engage their audience with jihadist ideology. The empirical data provide a glimpse into the mechanisms that enable female Islamic authority online, while the theoretical framework describes the elements of jihadist propaganda used to grant legitimacy to those who assume the roles of, in this case, female i-Imams. The study shows that female online authority promotes the transformation of women into warriors.
\end{abstract}

Keywords: i-Imam, i-Khutba, female virtual leadership, jihad, Islamic State

1 Introduction

Since the advent of the Internet, and with it Islamic websites, in the late 199os, Islamic religious authority has acquired a new layer of complexity: cyber religious authority. Online spaces that are used by i-Imams to inform, lecture, and decide about Islamic subjects are very popular, particularly among Muslim youth. The online minbar ('pulpit') has become a virtual platform for the i-Imams: a (usually) hardly controlled space where communications formatted as fatwas are often issued without any legal validation or guarantee of the professional or educational training of the issuers. The question of legitimacy and authenticity is even more pertinent because the Internet is an open, free, and global communication tool. Moreover, i-Khutbas ('Internet sermons') are attractively presented in simple English via Facebook, YouTube, or Google Plus and offer an interactive way to debate all aspects of Islamic living from rituals to sacred sources. 
More recently, these sites also serve the goal of the radicalization and online recruitment of young women to engage in jihadist war scenarios, including in Syria and Iraq. In this chapter, i-Imams, understood from a female perspective and as a virtual Islamic authority, and i-Khutba, understood as the various shapes virtual Islamic discourse may take, are central to a state-of-the-art study of the imamate in Western Europe (Carvalho, 2014). The present chapter approaches the online construction of female authority through the analysis of the online performance of young Spanish-speaking Muslim women, specifically using Facebook as a social networking case study.

On Facebook, the female informants export similar rules of engagement to their online groups as those that prevail in their daily lives. The case study presented here concerns Spanish-speaking Muslim women of Moroccan origin, as well as convert Muslim women of Spanish origin, between the ages of eighteen and 40, counting in total 50 individuals, all of whom live in Catalonia. The women from both groups use similar building blocks of discourse and narratives, based upon 'a true part of Muslim tradition' (Mernissi, 1991, pp. vii-viii), in a self-constructed online participation that is not focused on gender opposition since they do not strive for a 'direct struggle against men' (Sadiqi, 2003, p. 35). Their online participation is part of an individual struggle to be mujāhidāt ('female participants in jihad'), and even muqātilāt ('women who fight with arms') - for the Quran does, they claim, call for qitāl ('conventional fighting') (Cooke, 2002, p. 232). In this online space, authority is constructed through the pursuit of religious knowledge and religious education, with the highest regard awarded to the women who are proficient in both Classical Arabic and Spanish. This model of authority founded on language competence was already noted by the Moroccan anthropologist Fatima Sadiqi, who acknowledged the social importance of code-switching among Moroccan women (2003, p. 39). The situation is similar on Facebook, where women who understand and write in Classical Arabic are seen as having a better understanding of the Quran, and therefore being more competent in interpreting the sacred sources.

Women who want to further their online role as i-Imams usually use a simple digital tool to achieve this goal: they make their Facebook profile public. Open access to their page implies that they are willing to give voice to their veil and claim their place among the religious authorities. The fact that the woman who wants to assume a distinctive online social status maintains a public Facebook page opens a bridge between the public sphere (polis), women (gender), and ritualization (religion). Public spaces and ritual practices in Islam are predominantly male. Hence, women are 
developing new cognitive schemes to format contexts and contents that will confer meaning and authority to ritualization processes. In fact, these new cognitive schemes lead women to both religious knowledge and new learned performances that, in the case of jihadism, introduce them to violent behaviour patterns.

This model of Islamic online authority has two sides. On the one hand, it is a 'bridge-building discourse' framed by the faculty of $i j t i h \bar{a} d$, defined as reasoning and interpretation; on the other hand, it is a bridge-building network process framed by the ideology of jihadism (Ahmed, 2011, p. 7). For this reason, it is relevant to attempt to build an empirical study of the female ritualization of religious violence and female religious agency together with the notion of local cultures to unveil the identities, roles, and activities of self-proclaimed online female jihadists.

This chapter first explores online female religious authority, and then discusses how the study's informants employ their online Islamic authority to direct their audience to migrate to Syria and become part of the offline jihadist fight. Our attention then turns to the online space, or the Web 2.0, to understand how its specific features help in promoting jihadist discourse among young cyber users. All of this is discussed in the context of a case study that aims to demonstrate how Spanish-speaking Muslim women use Facebook to develop jihadist narratives and, through them, convince other women to transfer their jihadist performances from the online world to the offline world, or more concretely to the so-called caliphate of the Islamic State in Syria and Iraq.

2 Methodological considerations

The present study addresses the Facebook social media network as the specific field of research, focussing on Facebook accounts and/or pages from Spanish-speaking, Sunni Muslim women residing in Spain, specifically in Catalonia. All of them were aware of my research activities and agreed to share the contents of their pages for the purpose of my study. Follow-ups were done in the shape of interviews (via private messages and Skype) to get to know the informants and their circumstances better, assess their actual religious knowledge, and clarify the goals of their performances online. In their study on the evolution of jihadism in Catalonia, Fernando Reinares and Carola García-Calvo (2015) wrote that between 2004 and 2012, 'four out of every ten individuals sentenced for jihadist terrorist activities in Spain during the period were located in Catalonia.' This high number of jihadist 
individuals highlights the importance of the Catalan region to the study of jihadism in Europe. This number should also be interpreted in relation to the high presence of Salafi imams in the area: '50 Salafi worship places, half of all those currently in existence in Spain' (Reinares and García-Calvo, 2015).

The dominant language of the informants is Spanish. They have some understanding of transliterated Arabic, although its syntax is frequently incorrect, and only a limited number have fluency in Classical Arabic - an important skill, since one's proficiency in Classic Arabic determines the individual's capacity to achieve a position of authority. The language level reflects one's hermeneutic competence in interpreting the sacred sources and indicates the possession of greater religious knowledge. ${ }^{1}$

In the offline context, language is also a crucial factor for understanding the role of imams in Spain, and more specifically in Catalonia since the autonomous region's official language is Catalan. The lack of training of the local imams can be detected directly through their communication tools, as not all of them are fluent in Spanish, let alone in Catalan. Originally from Morocco, many of the imams do not speak or understand Spanish and perform their sermons in Classical Arabic, hence creating a gap between themselves and the younger Muslim generations who prefer using Spanish. Another crucial factor is the role and the space of women in Spanish mosques. In 2014, when I conducted my fieldwork in the region, it was evident that the mosques were spaces reserved for male believers. Women are mostly only in mosques on Fridays and/or for Classical Arabic classes, which usually take place on weekday mornings. The perception of the 'invisibility' of women at the mosque was reflected in small details, such as the surprised and delighted reactions from children that were in clear contrast to the men's noticeably hostile attitude towards my presence in the mosques' courtyards.

During the period of data collection, none of the women declared that she had or was about to travel to the Islamic State controlled territory or that she was located in the region. Moreover, during the period of data collection, no information was shared that indicated that any of the informants had in fact travelled to the region. Still, because they expressed their desire to travel and to join the Islamic State, they are regarded as potential jihadist migrants. That was for example the case of S.C. (El Pais, 7 July 2015), a mother and converted Muslim who was in charge of the recruitment of young girls to the jihadist cause.

Even though there is no information on whether any of the informants in my study did in fact migrate to Syria, there are examples of Spanish-speaking

1 I translated all the quotes of the informants, in Spanish, Arabic, or other languages, in the study and in this chapter into English. Original quotes are listed in my dissertation. 
women who were not part of the study attempting to travel to territories controlled by Islamic State. One example is S.Y., a Moroccan-born Muslim, married and the mother of a three-year-old child. She worked as an online recruiter for the Islamic State and was captured in December 2014 in Turkey (Audiencia Nacional, 2015). At the time of her arrest she was waiting to enter Syria together with her child. For the specific purposes of this chapter, and considering that Spain is the location of the case study, I use the definition of a jihadist according to the law Ley Orgánica $2 / 2015:{ }^{2}$ it concerns individuals that are involved in "The act of accessing in a usual manner a website that has contents directed to promote recruitment to a terrorist organization or group, or to collaborate with it, or to pursue their goals. The facts will be understood as committed in Spain when the access to those contents is done from Spanish territory'.

The study also considers open source jihadist publications and comments, photos, and videos on Facebook that are posted online in a consistent and frequent manner. For this analysis, the publications that generate long threads of conversations, reactions, or a significant amount of 'likes' were given preference. Data collection was conducted between February 2013 and December 2014 through monitoring, selecting, collecting, and examining data posted on Facebook to get a representative view of the cyber jihad feminine sphere. Although this monitoring was aimed at Spanish-speaking Muslim women, I have also used information about and data from female Facebook users who expressed themselves in other languages. Even though the Spanish-speaking informants are in general not fluent in other languages, they frequently resort to the Facebook option of 'see translation', and in some cases ask other users to help with the translation. All informants use a kunya, or nom de guerre, to hide their true name. To protect the sources, I have opted here to designate them by using the Arabic word umm, meaning 'mother', and adding a different letter to indicate each informant. In the end, the study aims to formulate answers to the following questions:

- What are the key concepts explored by women who aspire to a role of religious authority?

- What are the elements and the events, be they of a religious, political, social, or cultural nature, that lead to framing and developing the online relationship between the female i-Imams and their female audience?

- How does an i-Imam give shape to her online authority?

2 The text of this law is available from the website of the Agencia Estatal Boletin Oficial del Estado, https://www.boe.es/boe/dias/2015/03/31/pdfs/BOE-A-2015-3440.pdf'Ley Orgánica 2/2015, de 30 de Marzo,' BOE, 77 (2015), pp. 27177-27185. 
To attempt to answer these questions it is imperative to analyse both the textual and visual components of their narratives, identify the key concepts of the female jihadist narrative, relate their discourse to the construction of agency in an online environment, determine whether these reflect the objective of acquiring authority, and finally relate this process of acquiring female authority to the female jihadist recruitment networks.

Gary Bunt's Virtually Islamic: Computer-Mediated Communication and Cyber-Islamic Environments (2002), Islam in the Digital Age: E-Jihad, Online Fatwas and Cyber Islamic Environments (2003), and iMuslims: Rewiring the House of Islam (2009) were the first scientific approaches to the online presence of Islam. Bunt introduced concepts such as 'e-Jihad' and 'cyber Islamic environments'. Since then, there has been much development in the field of Digital Media Studies in general and digital Islam in particular. As a matter of fact, Digital Media Studies evolved to integrate studies of the 'Internet of Things' with issues connected to the 'mobile' world (Carvalho, 2015). Therefore, the 'i' in 'i-Imam' depicts the 'i' in interface communications that include both Internet and mobile services. Similarly, I apply the notion of 'i-Khutba' to the digital Islamic sermons that occur with frequency, that vary in length, and that the sisterhood community considers an authentic religious service. In the term 'i-Imam', I include the collection of women who have been invested with a role of religious authority through their Facebook connections and who guide their online performance through a jihadist narrative.

\section{i-Imam: Female virtual leadership}

In the Sunni Muslim tradition, an imam is defined as the leader who constitutes the community, and without him God's ordinances cannot be implemented' (Crone and Hinds, 2003, p. 33). At the beginning of Islam, religious authority was in the hands of the prophet's companions, the individuals who had been in direct contact with him and thus could narrate his life's deeds. The companions transmitted narratives about the prophet's conduct to the people close to them, who in turn continued the chain of transmission to the next generations (Crone and Hinds, 2003, p. 2). For this reason, those who had learned from the sources closest to the companions could claim to have stronger religious authority. The same principle is respected and applied today by Salafis, a religious Islamic line of conservative thought that aims at imitating the deeds of the prophet Muhammad and of al-salaf al-ṣālị̣ ('the righteous predecessors', including the prophet's companions). 
This is also the vision shared by the Spanish-speaking Muslim women in this study, who use Facebook, have mastered Islamic studies and Classical Arabic, observe the pious Salafi doctrine, and are entitled to lead the online minbar and to teach their sisters the ways of salvation. Teaching, disseminating, and defending Islam are the main actions of da'wa, a mandatory task for all Muslims. According to Wiktorowicz (2006, p. 212), part of Salafism is the task of the promotion of 'a vast educational network' that branches into jihadism and religious violence.

The cyber environment is ideal for the endorsement of violent messages and rituals because it offers a less visible identity, fewer controls on authority and legitimacy, and a more feasible, faster way of disseminating jihadist discourse to a growing virtual audience (Lawrence and Cooke, 2005, p. 23). However, other women publicly contest the women's performance of religious authority, either about the correctness of their knowledge of Islam or about their language skills in Classical Arabic. In some of these public discussions men also interfere to set the tone of the arguments, recommending good manners, suggesting that they (i.e. the women) read other scholars' works, or even praise the guidance of the woman who is leading the group's conversation.

Leadership has always been a sensitive subject in the history of Islam, from the death of the prophet Muhammad. Like other forms, virtual Islamic leadership suffers from a lack of unifying religious guidance. Virtual leadership is, in the words of Philipp Holtmann: 'a steady process of trend-setting and steering communication to influence the behaviour of individuals in order to achieve a goal. This process, [which] involves the target-oriented use of forces and resources, is rendered by a computer and independent of time and space. It is based on mutual information' (2012, p. 72). Muslim women have transformed the problem of virtual Islamic leadership to their benefit by claiming a role of their own in the cybersphere. Islamic female agency is apparently evolving online, and the products of that evolution are being transferred into the offline world. One of those evolving products is ijtihād: allowing individuals to self-investigate the sacred sources. This is an important faculty that in the offline world is much more of a male domain. Cyber environments facilitate the exercise of $\ddot{j} t i h \bar{a} d$ by women because they do not exert gender segregation. For that reason the cyber gates of $\ddot{j}$ tihād are accessible to Muslim women who wish to employ this theological tool. At the same time, the use of it grants the possibility for Muslim women to affirm their agency online.

Another religious argument that these women use to construct online leadership is supporting their authority on legal dispositions of Saudi scholars. This is a paradoxical situation because Saudi scholars have a 
strict religious perspective on gender matters and contest any female religious authority. It is also a clear statement that proves that these women in particular, and sympathizers of Islamic State in general, have a basic level of religious knowledge and their interpretation method is reduced to 'cherry-picking extracts from the Quran' (Duderija, 2015, p. 8).

These arguments, together with the jihadist actions in Syria, Iraq, and Europe, shape virtual female Islamic leadership and work as motivational factors for the recruitment of female jihadists - justifying the importance of the scope of the present analysis. The next section treats how these women frame their religious views in the online space and how they adapt the jihadist narrative for a youth audience.

\section{The 'Call of Duty'}

Although the privatization and individualization of religious knowledge (Cesari, 2003, p. 138) are a dialectical component of living and experiencing the religious self (Campbell, 2012, p. 9), the reality is that the online individualization of religious knowledge is succeeded by the online networking and connection to other individuals that have similar profiles, group affiliations, language, likes, and preferences. For example, the popular computer game Call of Duty serves as an encoding use of language to reach Muslim youth and encourage them to become jihadists. In the opinion of Akil Awan, Andrew Hoskins, and Ben O'Loughlin (2011, p. 54), the utilization of references to youth culture is critical to attracting English-speaking 'diasporic Muslim audiences'. The Internet is the preferred means of communication between young women, who use it to socially interact, develop networks, and access information (Lövheim, 2008). What is more, the online presence of Muslim youth reflects the expression of what Jon W. Anderson labels the "missing middle" between the Islam of intellectual subject to textual analysis (of thought) and Islam of the masses more likely to be examined in terms of social forces' (2001). Facebook content created around the jihadist narrative is designed to be easily accessible to all types of audience.

The networks formed online by young Muslim women can be seen as 'neo-communities' (Allievi and Nielsen, 2003, p. 21), as they are the result of participation in a high-tech-oriented society by a European Muslim minority that is more attached to the virtual space than to a specific urban environment. The Internet as a social, religious, and transnational space has challenged the pertinence, and even the authority, of the offline 
imam (Sisler, 2007). The transfer of authority and legitimacy from the context of urban space into that of the Web 2.o has induced alterations in the notions of authority and legitimacy (Bunt, 2013). These changes are also felt in jihadist discourse and practice. The online reformulation of authority, legitimacy, and authenticity imposes great challenges on the offline imamate in Western Europe. Or, as one of my informants said: 'To identify the genuine imam against the false one, the quality of his being endowed with the knowledge of everything, is clearly marked out in the Holy Quran, Sura Yasin, 36:12, which text reads as follows: "We shall surely raise the dead to life and We record what they did and the traces of their deeds that they have left behind."' This sura has a two-fold meaning: first, the virtue of having a solid knowledge of the sacred Islamic sources; and second, the virtue of practicing the good deeds transmitted by that learning experience.

The next section treats how authenticity ('genuine Imam') and authority ('quality of knowledge') are employed to promote a sense of belonging to the Islamic sisterhood.

\section{Digital Umm, mother, and virtual sisterhood}

Da'wa (religious narrative) is the preferred way to spread the Islamic word, and dedication to it is one of the main female tasks online. As Umm G. says in a written Messenger conversation:

I use the Internet all the time to search and to share information about da'wa or to watch what is going on in Syria and Palestine. I also use it to connect myself with the other sisters. We help each other to become better Muslim women. We all seek a deeper understanding of Islam and of how to engage in jihad and it is more comfortable to do it among 'sisters'.

The dissemination of jihadism online is at full speed among women as a permanent reminder of the individual duty to pursue jihād fì sabīlilläh ('jihad in the path of God'). By using keywords such as ghurabä' ('strangers') or kuffār ('infidels'), they reinforce a clear separation between 'true Muslims' and the rest, whether they be 'weak' Muslims, the followers of other Islamic sects, or non-believers. By participating, a sister is immediately integrated into the process of virtual sisterhood, or becoming a digital Umm. The 'Umm sisterhood' is a connection to 
all the 'mothers' of jihadism who aim at achieving Paradise together. 'Imagine entering the gates of Jannah [paradise], hand in hand with those that you love. Yes, keep that in mind and continue to struggling [sic]' writes Umm M., after posting an image of a Muslim couple walking hand in hand.

The communications of the digital Umm are linked to the performance of religious rituals, the promotion of adab ('good manners'), and the exteriorization of affection and solidarity. Anna Piela (2012, p. 119) indicates that 'spiritual and emotional connection' are two key features for defining sisterhood. Even though the sisters are present online as a group, they also keep being individuals who have their own perceptions and experiences when it comes to letting these online narratives and practices structure their religious knowledge. The process called 'Individual Rituality' (Heidbrink, 2007, p. 177) is crucial for comprehending these religious manifestations online, and even more crucial for understanding the dynamic between offline-online-offline transfers of ritual activities (as will be seen below).

Another source of identification in the online sisterhood is the dress code. The sisters encourage each other to dress in allegedly Islamic clothing such as the hijab, the niqa $\bar{b}$, or even the burqa. Indeed, to them a vital element of proper feminine religious behaviour is the use of garments such as the niqāb and the burqa as the exterior symbol of pious Islamic practice. The sisters employ this in their profile picture on Facebook or as a part of the messages they convey via imagery. The imagery refers to transformations, and reflects the stages of ever-deeper radicalization of the 'sister'. For example, they might begin by choosing cute Islamic cartoons or female Disney characters dressed in Islamic clothes as their profile picture before they move on to displaying women who are brandishing weapons. The central message of the photos or cartoons is the beauty of modesty: 'Sisters don't let your last day on earth be the first day you wore the hijab,' said Umm F. to her female audience while reinforcing this principle of behaviour with a set of photos of women wearing the hijab. The apocalypse narrative, the idea that the world is coming to an end and that therefore the Last Judgement is imminent, is an integral part of the 'Salafi-Jihadi' discourse. Through the act of posting videos, images, photos, or text online, these women form a new community, a virtual sisterhood, and this includes a new shape of online agency in the domain of jihadism.

In their analysis of the work of the scholar Tariq Ramadan, Mohammad Hashas and Jan Jaap De Ruiter (2014, p. 159) point to the relationship 
between 'secularism and the issue of women in Islam' to explain that cultural practices should be distinguished from Islamic practices. In the offline realm, the Islamic community has always set limits on the presence and performance of women in jihad-related conflicts, framing these limits as in accordance with the principles of Islamic jurisprudence and cultural discourses. In addition, women who have digital agency and a digital authority framed by a jihadist narrative, pay for their religious activism with real-life costs to their personal safety and security. The vulnerabilities and risks they experience online are transferred into the offline world. The i-Virtue of the jihadist discourse deletes the innocence of the offline veil. Indeed, due to their typical Muslim attire they are directly identified and subject to public and official scrutiny, for instance by facing thorough airport security checks. Gaining ascendancy in the virtual world as well as relevance in the real world has important social, religious, and cultural implications that first and foremost affect European Muslim women.

The following section discusses how female authority is performed online and how that performance turns into an effective jihadist recruitment tool.

\section{$6 \quad$ Repeat after me, ukhti, my sister: on performing female authority}

'Giving birth', and 'being a mother' are expressions that help define jihad from a feminine perspective, in the opinion of my informants. A recurrent theme on many jihadist websites is inciting women to promote the love of martyrdom in their children. Moreover, mothers are also encouraged to accept their girl's martyrdom. For example, informant Umm Z. wrote: 'Mother do not be sad, Allah is with you! Prepare for my Janazah [burial]!! I am coming to meet you as a Shaheeda [female martyr]. Do not plan my wedding! As I chose my martyrdom day as my wedding day.'

The performance of each female i-Imam follows a very personal style. According to Umm T., her most important task while using her own online minbar, Facebook, was persuading other women to convert to Islam: 'The woman also can use the adequate opportunities to educate, guide and invite others [to the faith].' For some women, it is choosing and posting Quranic citations and/or parts of the hadiths. For others, it is spreading imagery and videos related to war scenes, jihadist fights, 
or just the visual symbols of jihadism (black banners, black horses, and swords, among others). Imagery plays a decisive role in the framing and legitimization of the jihadist narrative. Images convey messages without the need of translation, and often with a far more emotional impact than text. Arabic calligraphy and Islamic motifs are a constant presence in their online performance and narrative. The examples of Arabic calligraphy I collected during my research are usually in black and white, through the reproduction of small excerpts of the Quran. The Islamic motifs come from architectural details in symbolic mosques that have an important value in collective Muslim history. They represent ideological and political power, a strong past that is a reminder of the umma's glorious moments and achievements (Fighel, 2007, p. 35). According to Jonathan Fighel, these visual elements are an important instrument of the indirect process of radicalization online:

The Islamic motifs, in a sophisticated manipulation, are embedded within propaganda; they can be easily recognized as legitimate Islamic historical symbols and factors that support a radicalized interpretation of Islam. The new radical motifs can easily gain legitimacy, as they appear to be authentic when they are used in proximity to widely accepted mainstream Islamic symbols and cultural references. (2007, p. 36)

One interesting common denominator in the imagery of the sisters, shared through posting the same items over and over again, is that they are accompanied and justified by comments related to religious texts. Citations from the Quran are usually posted without historical or spatial context and without regard for their sequentiality, i.e., without referring to the preceding or following verses. These disconnected citations are part of the strategy of framing Islamic knowledge in such a way that violent conceptions of jihad become acceptable (Awan, Hoskins, and O'Loughlin, 2011, p. 27). Umm C., for example, wrote her name surrounded by bullets and two modified rifles, and posted the photo on her Facebook wall. Awan, Hoskins, and O'Loughlin (2011, p. 28) argue that here we are in the presence of the 'classical theory of cognitive dissonance which suggests that individuals seek out information confirming beliefs or behaviours while actively avoiding contrary information, in order to mitigate uncomfortable psychological tension.'

The same happens with the citations of hadiths, narratives of the prophet Muhammad's words and deeds, which should obey the authoritative criteria of analysis determined by the muhaddithūn ('scholars with great 
expertise in hadith') to evaluate the authenticity and the reliability of the hadiths. Umm B., who gradually acquired an online authority among the Facebook sisters, narrates for them the story of the best Muslim women in da'wa:

Umm Sulaim (one of the Prophet's companions) would teach her son Anas Ibn Malik about Islam, this she was doing knowing that her husband refuted Islam. [...] Her son Anas became a servant of the Prophet (pbuh). [...] If we speak in general terms we find women who had a very strong role in their sacrifice and service in the cause of Allah. Sumayyah was the first Muslim person to die for Islam. Khadija, the Prophet's first wife who was very rich, spent all her money supporting the da'wa.

This post is from 2013 and has been extensively shared and commented upon by the sisters. My informants firmly believe in the jihadist narrative, in the jihadist hero, and in the duty of doing da'wa for their spouses: 'The work of the women in the field of da'wa is to give strength to the work of our men, and to expand it to areas where the efficiency of women is higher than the efficiency of men.'

Likewise, nașāith ('advices') on how to promote their husbands' ultimate sacrifice and to help others who are willing to become a shahid ('martyr') are kindly spread throughout the feminine jihadist cyber sphere. Women give advice as a part of the da'wa process (Becker, 2013), to transmit Islamic knowledge to the online sisters. The contents of the advice vary from regular daily life subjects (clothing, food, children, relationships) to the translation and interpretation of the Islamic textual sources. Translation is a vital step in the process of correctly transmitting any religious knowledge, as many of the women are not fluent in Arabic. By translating and transliterating their comments, these women also broaden their audiences in number and diversify them in terms of both general education and physical provenience. In the sisters who are capable of translating from Classical Arabic, the women recognize a direct religious and linguistic authority. This authority is further bestowed on them when they bring into play jihadist linguistic terminology, which is perceived as proof of their absolute adherence to the jihadist narrative and above all their command of the subject. Table 1 summarizes words belonging to the jihadist vocabulary, the themes to which these words refer, and examples taken from the women's posts on Facebook. The author has translated the examples from Spanish to English. 
Table 1 Jihadist linguistic terminology

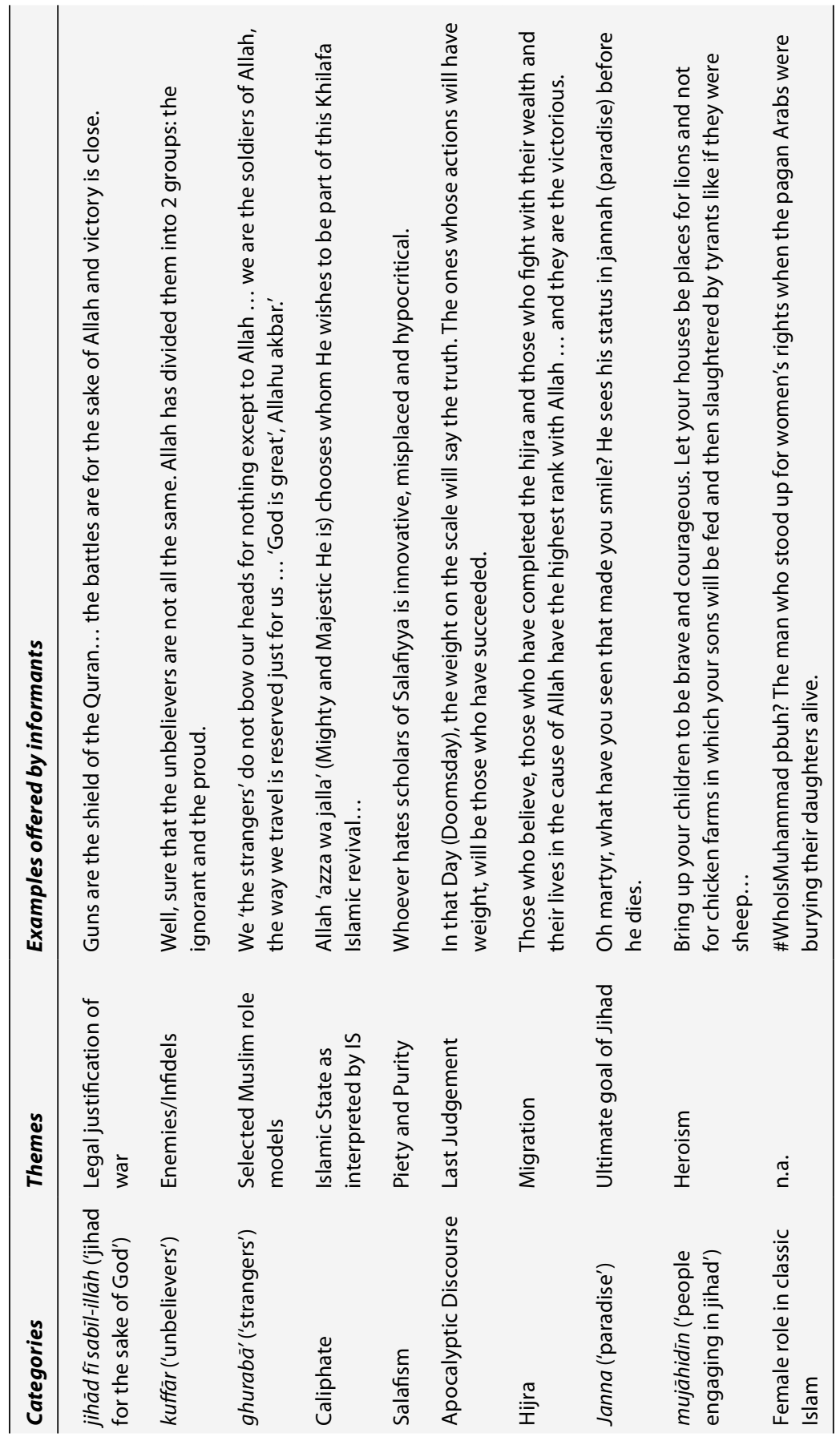


The above table contains examples of jihadist narrative elements that stimulated long and pertinent threads of discussion among the informants. This illustrates the role of the leading female informants, who in the eyes of the audience have better Islamic arguments and answers. As such, the audience members trust their more educated sisters to teach them, smoothing the path to their assimilation into and understanding of the ritualization of jihad in the religious Islamic framework. Their acts and performances online respect the need for a temporal and spatial structure. For example, the online space is sacralized by the niyya ('right intention') that the performer should keep at all times and in all spaces if they are rightly and truly committed to act with respect and purity. The sisters constantly issue reminders of the relevance of their religious mission online, and of their need to be even more of a role model online than they are offline, since they define social media platforms as sacralized spaces. Similarly, in terms of respecting a temporal structure, the sisters follow a precise timetable. For example, every Friday before the regular sermon they remind the rest of the online community of the need to pray special suras.

Still, the authority established online by these women has a limited reach, as female i-Authority appears valid only in the virtual world. In the offline world, female authority is graded down. Women may have a determinant role in the task of mobilization and recruitment online, but the arrangements for travelling to and settling in Syria are confided in a network of men, as notified through a public male Facebook profile: 'A salamou aleykum, the brothers that want to do the hijra send me a message, and for those who are sisters, my wife will take charge of you'. An additional fact that differentiates female authority and indicates that it is mostly only part of the virtual world is, for example, the question of using guns and women's physical and direct participation in the frontline of the war. Upon their arrival in Syria, women have commented on their personal Facebook pages that they receive small calibre guns, while the modified assault rifles are reserved only for men. Clearly, physical jihadist combat is, in the majority of cases, thought to be a male task.

\section{7}

'Umm' got married: Female authority and the jihadist recruitment

The perfect woman, the one that can be considered a female i-Imam, is, these days, the one who performs the hijra, supports her husband by cooking, raising jihad-loving children (Von Knop, 2007, p. 410), and posting all of 
her jihadist i-Khutbas daily on Facebook. Their endeavour is to perform rituals in a pure way, transmit the right knowledge, be authentic when selecting the sources, and be modest in behaviour. 'Good homes are built on the pious wife. Therefore, it is obligatory for a Muslim to choose a pious wife' posted Umm H., quoting the fatwa 'Advice to Muslim Women' of the Saudi preacher Shaykh al-Fawzan (b. 1933). Al-Fawzan publishes his work on websites like https://salaf-us-saalih.com and www.fatwa-online.com, and the women focused in this case study prefer his religious guidance.

Women depart for the caliphate of Islamic State in search of a jihadist authority position in the fight for Allah, and of a role of power in concord with their newfound online voice. After arrival, they again connect to the online world so that they can share their narratives of life in Syria. The other sisters are willing to listen, learn, and ask questions about the living conditions in Syria, and they urge those who are already there to fill them in on all sorts of details - from the mundane to the theological justifications of jihad. Historically, the idea of combining hijra ('emigration') with da'wa ('proselytism') and jihad is a tradition stemming from the prophetic times (Peresin and Cervone, 2015, p. 495).

The lives of the 'sisters' in Syria are described as happy and pious, just like in the time of the prophet Muhammad, as they constantly reassure the sisters online. Umm X. - 'Got married' is the most frequent Facebook status of the sisters, and they try to illustrate how pleasant their lives are in the 'Sham' (Syria) by posting photos that confirm this state of alleged happiness.

Conclusion

Female i-Imams that support the jihadist narrative in general and the ideology of the Islamic State in particular encounter an effective online space in which they can perform their religious authority and convince other women to enter jihadist recruitment networks. In that sense, the jihadist narrative has the elements and motivational factors to encourage individual participation in the jihadist fight. Islamic online female authority is anchored in online Islamic female agency, i.e., the practice of taking independent action online and the goal of being recognized as a leading religious individual, as a female i-Imam.

However, this online female authority is contested. As one Moroccan female religious scholar living in Catalonia (I have chosen not to reveal her name or location out of safety considerations) explained to me in an interview, these individuals speak for themselves and should not be trusted by their audience. In her opinion, 'wise imams' should have the exclusive 
right to issue fatwas about what is authentic jihad, and should condemn all forms of violence. Spanish mosques are controlled by the security and police forces, so the imams issue politically correct khutbas and coordinate statements that openly condemn jihadist discourses and activities. However, as mentioned before, this kind of khutba deals with the youth audience that is 'at risk', in terms of its language and contents. These khutbas are not in tune with daily face-to-face communication, and more needs to be done in terms of socio-economic and political measures to prevent the grievances that ultimately degenerate into engagement with extremist Islamic narratives. It is exactly this void that is being filled by jihadist sermons.

The vulnerabilities and risks associated with female online agency do not represent for these women an obstacle, but a concrete sign of their increasing power, authority, and value within the digital Islamic community. They feel they are on the right path to Allah, fì sabil-illäh ('on the path of God'), whether in the virtual world and/or on territory controlled by Islamic State. They are no longer innocent, passive religious subjects; now they are the ones endowed with religious authority, transmitting their message through an online minbar, or platform of communication. Through their online performance, the young Spanish-speaking Muslim women shape a form of religious authority that is framed by the jihadist narrative and results in effective jihadist recruitment.

\section{References}

Ahmed, Fauzia Erfan. 2011. 'Empire, Subalternity, and Ijtihād: Two Muslim Women's Leadership Models in the Post-9/11 US'. The Muslim World, 101(3): 494-510.

Allievi, Stefano and Jørgen Nielsen. 2003. Muslim Networks and Transnational Communities in and across Europe. Leiden: Brill.

Anderson, Jon W. 20o1. 'Muslim Networks, Muslim Selves in Cyberspace: Islam in the Post-Modern Public Sphere'. NMIT working paper. http://www.mafhoum.com/ press3/102S22.htm.

Audiencia Nacional, Administracion de Justicia. 2015. 'Diligencias previas no.: 117/2.014: P.S. Samira Yerou'. http://www.larazon.es/documents/10165/o/ video_content_2766175_20150310150714.pdf.

Awan, Akil, Andrew Hoskins, and Ben O'Loughlin. 2011. Radicalisation and Media: Connectivity and Terrorism in the New Media. London: Routledge.

Becker, Carmen. 2013. 'Learning to be Authentic: Religious Practices of German and Dutch Muslims Following the Salafiyya in Forums and Chat Rooms'. PhD thesis, Radboud University Nijmegen. 
Bunt, Gary. 2002. Virtually Islamic: Computer-Mediated Communication and CyberIslamic Environments. Chicago: University of Chicago Press.

Bunt, Gary. 2003. Islam in the Digital Age: E-Jihad, Online Fatwas and Cyber Islamic Environments. London: Pluto Books / New York: Macmillan. Turkish edition: 2007. Dijital Çajda Islam: E-Cihad, Online Fetvalarve Siber Islami Çevreler, translated by Nil Erdogan. Istanbul: Babil Yayınları.

Bunt, Gary. 2009. iMuslims: Rewiring the House of Islam. Cambridge: Cambridge University Press.

Bunt, Gary. 2013. 'Islam, Social Networking and the Cloud'. In Modern Islam: A Textbook, edited by Jeffrey Thomas Kenney and Ebrahim Moosa, 177-209. London: Routledge.

Campbell, Heidi. 2012. 'Understanding the Relationship between Religion Online and Offline in a Networked Society'.Journal of the American Academy of Religion, 8o(1): 64-93.

Carvalho, Claudia. 2014. 'Okhti? Online: Spanish Muslim Women Engaging Online Jihad? A Facebook case study'. Online Heidelberg Journal of Religions on the Internet, 6: 24-41.

Carvalho, Claudia. 2015. 'The Importance of Web 2.o for Jihad 3.0: Female Jihadists Coming to Grips with Religious Violence on Facebook'. In The Study of Culture Through the Lens of Ritual, edited by Paul Post and Logan Sparks, 3-18. Groningen: Instituut voor Christelijk Erfgoed/Instituut voor Liturgische en Rituele Studies.

Cesari, Jocelyne. 2003. 'Muslim Minorities in Europe: The Silent Revolution'. In Modernizing Islam: Religion in the Public Sphere in the Middle East and Europe, edited by John Esposito and François Burgat, 251-269. New Brunswick, N.J.: Rutgers University Press.

Cooke, Miriam. 2002. 'Islamic Feminism Before and After September $11^{\text {th }}$. Duke Journal of Gender Law \& Policy, 9: 227-235.

Crone, Patricia and Martin Hinds. 2003. God's Caliph: Religious Authority in the First Centuries of Islam. Cambridge: Cambridge University Press.

Duderija, Adis. 2015. 'The "Islamic State" (IS) as Proponent of Neo-Ahl Hadith Manhāj on Gender Related Issues'. Hawwa - Journal of Women of the Middle East and the Islamic World, 13(2): 198-240.

Fighel, Jonathan. 2007. 'Radical Islamic Internet Propaganda: Concepts, Idioms and Visual Motifs'. In Hypermedia Seduction for Terrorist Recruiting, edited by Boaz Ganor, Katherine Von Knop, and Carlos Duarte, 34-38. Amsterdam: IOS Press. Hashas, Mohammed and Jan Jaap de Ruiter. 2014. 'Young Muslims in the Netherlands: Understanding Tariq Ramadan'. In Europe as a Multiple Modernity: Multiplicity of Religious Identities and Belongings, edited by Martina Topić and Srdjan Sremac, 149-193. Newcastle: Cambridge Scholars Publishing. 
Heidbrink, Simone. 2007. 'Exploring the Religious Frameworks of the Digital Realm: Offline-Online-Offline Transfers of Ritual Performance'. Masaryk University Journal of Law and Technology, 1(2): 177-184.

Holtmann, Philipp. 2012. 'Virtual Leadership: How Jihadists Guide Each Other in Cyberspace'. In New Approaches to the Analysis of Jihadism: Online and Offline, edited by Rüdiger Lohlker, 63-124. Vienna: Vienna University Press at V\&R Unipress.

Lawrence, Bruce and Miriam Cooke. 2005. Muslim Networks: From Hajj to Hip Hop. Chapel Hill: University of North Carolina Press.

Lövheim, Mia. 2008. 'Rethinking Cyberreligion? Teens, Religion and the Internet in Sweden'. Nordicom Review, 29(2): 203-215.

Mernissi, Fatima. 1991. The Veil and the Male Elite: A Feminist Interpretation of Women's Rights in Islam. Oxford: Basil Blackwell.

Peresin, Anita and Alberto Cervone. 2015. 'The Western Muhajirat of ISIS'. Studies in Conflict and Terrorism, 38(7): 495-509.

Piela, Anna. 2012. Muslim Women Online: Faith and Identity in Virtual Space. London: Routledge.

Reinares, Fernando and Carola García-Calvo. 2015. 'Catalonia and the Evolution of Jihadist Terrorism in Spain'. Expert comment 33/2015, real instituto elcano. http://www.realinstitutoelcano.org/wps/portal/rielcano_en/contenido?WCM_ GLOBAL_CONTEXT=/elcano/elcano_in/zonas_in/international+terrorism/ commentary-reinares-garciacalvo-catalonia-and-the-evolution-of-jihadistterrorism-in-spain.

Sadiqi, Fatima. 2003. 'Women and Linguistic Space in Morocco', Women and Language, XXVI(1): 35-43.

Santana, Txema. 2015. 'Detenida una mujer en Lanzarote por reclutar niñas para el Estado Islámico'. El Pais, 7 July. http://politica.elpais.com/politica/2015/07/o7/ actualidad/1436250386_182748.html.

Sisler, Vit. 2007. 'The Internet and the Construction of Islamic Knowledge in Europe'. Masaryk University Journal of Law and Technology, 1(2): 205-217.

Von Knop, Katharina. 2007. 'The Female Jihad: Al Qaeda's Women'. Studies in Conflict \& Terrorism, 30(5): 397-414.

Wiktorowicz, Quintan. 2006. 'Anatomy of the Salafi Movement'. Studies in Conflict and Terrorism, 29(3): 207-239. 
About the author

Claudia Carvalho is a PhD Student at Tilburg University, School of Humanities, analysing the theme of Female Online Jihadism. In 2003 she completed her Master Degree in International Relations with a thesis about the IsraeliArabic conflict that was later published as a book. She then attended the Course on National Defence promoted by the Portuguese Defence Ministry in 2005. Key publication: 'The Importance of Web 2.0 for Jihad 3.0: Female Jihadists Coming to Grips with Religious Violence on Facebook', Heidelberg Journal of Religions on the Internet, 11 (2016). 


\title{
11 Islamic female religious authority between agency and governmentality
}

\author{
From the Moroccan model to 'multicultural' Europe
}

Sara Borrillo

Hashas, Mohammed, Jan Jaap de Ruiter, and Niels Valdemar Vinding (eds), Imams in Western Europe: Developments, Transformations, and Institutional Challenges. Amsterdam: Amsterdam University Press, 2018 DOI: $10.5117 / 9789462983830 / \mathrm{CH} 11$

\begin{abstract}
This chapter analyses the 2004 reform of the Moroccan Ministry of Endowments and Islamic Affairs, which established official women preachers and experts in Islamic Law. Based on ethnographic fieldwork, I discuss whether these female religious authorities mark a real evolution in the traditional male monopoly of Islamic spaces and discourses. The study also explores some of the challenges that the adoption of a similar model would imply for Europe. With reference to the recent debates about multiculturalism, gender equality, and Islam, I finish with a reflection on the contemporary challenges of the eventual promotion of official Muslim women preachers and scholars in Europe and the changes they might bring to Islam, religious authority, and the gender equality debate.
\end{abstract}

Keywords: Islamic female religious authority, agency, dispositive of power, governmentality, multiculturalism

In this chapter, I analyse the gender-based reform of the Ministry of Endowments and Islamic Affairs of Morocco which, in 2004, institutionalized women's participation in the official Islamic bureaucracy and knowledgeproduction structures. This reform established murshidät (sing. murshida), women preachers who have the task of teaching the 'right' Islam in mosques, as well as encouraging 'âlimāt (sing. 'âlima), female scholars in Islamic Law, 
to participate in the construction of a national Islamic discourse. The fact that a woman is allowed to speak about Islam officially and in the public space of the mosque and other Islamic institutions, which are traditionally monopolized by male voices, has been perceived as a significant step towards the application of gender mainstreaming in public - including religious - institutions, and as a form of 'Islamic State feminism' (Eddouada and Pepicelli, 2010). Islamic feminism aims at a deep egalitarian access to religious discourse and institutions based on the right to have the authority needed to interpret sacred texts, from a 'gender jihad' perspective (Wadud, 2006). From this perspective, religious authority can contribute to questioning the Islamic patriarchal tradition and to affirming gender equality in society (Mir-Hosseini, 1999). In this chapter, I aim to demonstrate that the Moroccan reform analysed here does not aim at establishing respect for legal gender equality in public and private spaces, however inclusive it may be of women religious authorities: it merely renders it in continuity with the patriarchal conception of the gendered division of labour in the country. Therefore, the reform of the Moroccan Ministry of Endowments and Islamic Affairs (2007a, $2007 \mathrm{~b}, 2007 \mathrm{C}, 2011)$ appears to be one of the results of a bi-dimensional political strategy, interested first in disciplining the national Islamic discourse - a project that is contested by some Islamist movements, such as Al Adl wal Ihsane (the 'Justice and Spirituality Movement') -, and second in showing that Morocco is respecting the universal gender equality narrative recognized by international conventions on human rights. During ethnographic fieldwork, I consulted the voices of women preachers and scholars of Islam to compare their personal views on women's rights and liberties in the public and private spheres with those expressed in their functional discourse. In particular, I aimed to problematize whether or not this 2004 reform produces a female religious authority that marks a real evolution of the traditional discourses on gender relations, which have been based on the male monopoly of Islamic spaces and discourses. I have come to consider women preachers and scholars as agents of both central state power and changes in religious authority. I also explored some of the challenges that the adoption of a model similar to the Moroccan one would imply for Europe. Even though the presence of Muslim women in pious movements is increasing in Europe, their claim to religious authority seems to still be contested. With reference to the recent debates about multiculturalism, gender equality, and Islam (Abu Lughod, 2010; Bracke and Fadil, 2012; Jouili and Amir-Moazami, 2006), I finish by reflecting on the contemporary challenges of the eventual promotion of official Muslim women preachers and scholars in the European context and the changes they might bring to religious authority and the gender equality debate. 


\section{2 The dispositives of Islamic power in Morocco}

The 2004 reform was meant to restructure the 'Islamic field', and was advanced by the Ministry of Endowments and Islamic Affairs of the Kingdom of Morocco. It institutionalized the murshidāt ('female religious guides'), who were charged with irshäd, the function of guiding and orienting the believers. They have the task of teaching other women 'right' Islam in the public space of the mosque. Moreover, murshidāt work in other domains of the welfare state, such as hospitals, schools, and prisons. At the same time, the reform encouraged the presence of àlimàt, women scholars and experts in Islamic Law, in the national network of ulama councils, official Islamic training schools, and other institutions of Islamic power. The difference between 'âlimàt and murshidāt resides in the fact that 'álimāt have an official religious authority to elaborate the interpretation of sacred Islamic sources based on ijtihād ('individual reasoning'), while murshidāt spread the official religious discourse. In addition, murshidàt's work is controlled hierarchically through periodic meetings with local ulama councils and delegations from the Ministry of Endowments and Islamic Affairs. This reform is relevant, because the presence of women in the traditionally male-dominated official and public Islamic space and discourse seems to be a symbolic change that could influence the patriarchal organization of society, which is also legitimized by the gender divide in religious authority (Mernissi, 1987).

In Morocco, as in all Muslim-majority countries, it is possible to identify a close relationship between Islam, central power, and the patriarchal social order. First, the construction of Islamic legal and ritual knowledge is very important for the legitimation of the central power: Morocco is a monarchy, in which Islam's central role emerges from the king's double title of 'Head of State' and 'Commander of the Believers' (in Arabic, amīr al-mu'minin). Rather than following the common description of the Moroccan political system as a theocracy, I argue that it makes more sense to speak of a nomocracy, following the definition of Muhammad Talbi (1996, pp. 109-112). This term (which comes from the Greek words nomos ('law') and kratos ('power')) indicates a mixed regime, in which an elected parliament exercises legislative power under the patronage of a figure - the king, in this case - who guarantees the conformity of state laws with a higher law, in this case inspired by Islam. This conformity is present in the Moroccan Constitution, including the most recent version of the text (1 July 2011) that was approved after the uprising sparked by the 2oth February Movement in 2011. It is possible to observe the accordance of this last version of the 
constitution with the historical symbolic pillars of the nation based on the Islamic legitimacy of the central power, territorial continuity and integrity, and the monarchy - well explained by the national formula 'God, Homeland, King'.

These constants are strictly linked to the foundations of the state's official Islamic discourse, which are the Quran and Sunna, the dogma of the king's role of 'Commander of the Believers', the theological doctrine of Asharism, the Maliki madhhab ('juridical school'), and Sufism. At a social level, the family represents the institution that maintains the social patriarchal order which, after the achievement of independence in 1956, was codified in the Personal Status Code (1957), later reformed and renamed as the Family Code $(1993,2004)$ thanks to the lobbying activity of the feminist movement. This code is inspired by Islam, as well as by the political power that is nourished by the structures that produce, organize, and spread official Islamic discourse: therefore, Islamic power in Morocco is a guarantee of both central and patriarchal power (Charrad, 2001).

A review of Moroccan religious and political studies (Belal, 2012; Darif, 2010; Laroui, 1977; Zeghal, 2005) shows that in postcolonial Morocco official Islamic power functions through some structures that, from a Foucauldian perspective, we can consider dispositives (Agamben, 2006; Foucault, 1976). According to this notion, central power acts through 'dispositives of control' that are useful for the production and consolidation of the national 'regime of truth', namely the discursive narratives that influence and discipline the worldview, behaviours, and relations between citizens. Specifically, a 'dispositive of control' is defined as a set of technologies and mechanisms of the production of truth, namely rules, rituals, and institutions that are simultaneously imposed by an external power and internalized by the citizens through systems of beliefs and feelings (Foucault, 1976, pp. 72-76). In this sense, the 'dispositive' can be interpreted as the main instrument of a repressive power that, through its own governmentality - the art and processes of governing - controls and disciplines the sets of values and attitudes of the faithful and citizens. Thanks to these Foucauldian concepts, it seems possible to interpret as dispositives the following seven structures of Moroccan Islamic power:

1 The Ministry of Endowments and Islamic Affairs (2007a, 2007b, 2007c, 2011). It manages the system of awqāf (sing. waqf, 'endowments') and mosques, and supervises all official religious activities in the country through its mandūbiyyāt ('local delegations'). It provides competitive examinations and training courses for imams and murshidāt. The 
ministry also provides for some institutions of the 'Islamic legitimization system' (Darif, 2010): for example, it organizes local and national awards for Quran readings and publishes journals like Da'wat al-haqq (Spreading the truth) (Fernandez, 2012).

2 The Superior Council (al-majlis al-ilmīal-a'āa) and the local councils of ulama. The Superior Council of ulama is the high council that has the power to issue legal opinions, fatwas, on the conformity of national life and policies with national Islam. It is composed of the most prestigious ulama in the country, while the regional councils of ulama work at a local level.

3 The al-rābița al-muḥammadiyya li-l-ulamā's an association of ulama that is considered independent from the central power, but whose general secretary is appointed by the king. According to the secretary Ahmed Abbadi, whom I interviewed, 'this institution has the role of adapting Islam to modernity' (Rabat, 4 May 2012).

4 The dār al-hadìth al-hassaniyya. Established in Rabat, this is the main institution in Morocco for Islamic training of the official ulama.

5 The al-durūs al-hassaniyya. Every year at the Royal Palace in Rabat, the Ministry of Endowments and Islamic Affairs organizes a set of daily conferences and meetings on Islam. These conferences, first initiated by King Hassan II, take place during Ramadan in the presence of the king, and Moroccan and foreign ulama. During the conferences, distinguished scholars are invited to speak on issues related to Islam and political and social life.

6 Islamic TV and radio. In 2004, the religious channel Al-Sādisa ('The sixth') was founded as the sixth national television channel in honour of King Muhammad VI. There is also the radio station Muhammad VI du Saint Coran, which broadcasts Islamic contents.

7 University courses in Islamic Studies. Departments of Islamic Studies are part of the Faculties of Humanities, in addition to courses in Islamic studies and Islamic thought offered by other departments.

Women are now part of these different structures through which the official Islamic discourse is produced and articulated. In the next section, I analyse their different roles and the discourses that - depending on the level of religious authority - are both opening space for the participation of women in the national Islamic discourse and reinforcing that same national discourse. 


\section{Mapping women's Islamic professions in Morocco}

During four years of fieldwork (2008-2012), I analysed the participation of women in the seven dispositives of official Islamic power described in the last section. My research particularly focused on Rabat, the capital of the kingdom and the core of national Islam, where the central offices of the Ministry of Endowments and Islamic Affairs that organizes the training course for murshidāt and imams are located. In total, I interviewed more than twenty murshidāt in Rabat, Meknes, Fes, Tanger, Tetouan, and Tata. I also interviewed fifteen 'âlimāt, including members of the superior and local ulama councils. I also interviewed two imams, three male scholars and academics in Islamic Studies, and nine officials of the Ministry of Endowments and Islamic Affairs. This led me to draw a cartography of women's participation in official Islamic professions, in which I analysed the work experience and discourse of women preachers and scholars in the seven dispositives of Islamic power described above:

1 At the Ministry of Endowments and Islamic Affairs, women are preachers in mosques and other educational centres. According to Aziz Darwiche, the ministry's General Director of the Division for Mosques from 2005 to 2012, 1,021 imams and 359 murshidāt have been trained: women therefore make up 26 per cent of the total number of those trained (interview, Rabat, 23 April 2012). Women are employees as well as officials. No woman, however, is in the highest levels of the administration, as emerges from a United Nations study (UN-Women and Ministère de la Fonction Publique, de la Modernisation et de l'Administration, 2012).

2 In the network of ulama councils, women exercise the role of employees and, more importantly, 'âlimāt, thanks to a quota system that provides for the presence of at least one woman in every council. Three women are currently (i.e. in 2017) in the Superior Council.

3 In the al-rābița al-muḥammadiyya li-l-ulamä', women are researchers, 'àlimāt, and employees.

4 In the dār al-hadith al-hassaniyya, women are students; there is one female professor of sharia.

5 In the al-durūs al-hassaniyya, women are allowed to participate in personal conferences since of 2003 , but only one woman has ever delivered a speech during the period of the monthly conference.

6 In religious TV and radio programmes, there are female tele-preachers and speakers.

7 In university courses in Islamic Studies, women are both students and professors of fiqh, sharia, and Islamic thought. 
In Table 1, I summarize the in-depth interviews that I conducted with 55 actors in the Islamic field in Morocco.

Table 1 List of in-depth interview participants

\begin{tabular}{|c|c|c|c|}
\hline Institution & Total interviews: 55 & Female: 35 & Male: 20 \\
\hline Ministry of Endowments & 9 officials & 1 & 8 \\
\hline and Islamic Affairs & 17 preachers & 15 & 2 \\
\hline Ulama councils & 6 scholars & 6 & \\
\hline al-rābița al-muhammadiyya & 2 officials & - & 2 \\
\hline li-I-'ulamā' & 5 scholars/researchers & 5 & \\
\hline \multirow[t]{3}{*}{ dār al-ḥadīth al-ḥassaniyya } & 3 professors & 1 & 2 \\
\hline & 3 officials & - & 3 \\
\hline & 7 students & 4 & 3 \\
\hline al-durūs al-ḥassaniyya & 2 scholars & 2 & - \\
\hline Religious TV and Radio & $\begin{array}{l}\text { some interviewed female } \\
\text { preachers work here }\end{array}$ & - & - \\
\hline University Islamic courses & 1 professor & 1 & - \\
\hline
\end{tabular}

The interviews were conducted in three different sections corresponding to the individuals' socio-economic origins, personal motivation to be part of Islamic dispositives, and individual opinions about women's rights in Islam and in Moroccan families and society. In particular, I checked if the individual agreed with the gender equality or with the gender complementarity principle. The principle of takāmul ('complementarity') provides for rights and duties related to the sexual and biological characteristics of women and men, respecting the primary male role of breadwinner and the primary female role of family care and reproduction. This last section was articulated through three dimensions related to the following points:

1 Marriage. Questions such as the following: Do women have the right or duty to share responsibilities with their husband, or do they have to accept his decisions? Do women have a role in decision-making processes inside the family? Do women have the right to divorce? Do they agree to the principle of polygyny?

2 Economics. Questions such as the following: Do women have the right to work without male permission? Do you think that the unequal system of inheritance is right? 
3 Body and sexuality. Questions were asked about issues like abortion, the obligation to respect the $i d d a,{ }^{1}$ the relationship between female virginity and family honour, and the phenomenon of violence against women.

Finally, I related the analysis of the views emerging from these perspectives with general questions about the self-representation of the informants as feminists, as Moroccan citizens, and as Muslims. In particular, I asked religious actors whether and in what sense giving women religious authority could change the patriarchal organization of society.

\section{$4 \quad$ Women's religious authority between piety and agency}

In the scenario described above, I analysed the discourses of women preachers and scholars, paying attention to variations in their approaches depending on their different authority levels. These correspond to their different roles, which for murshidāt consist of irshād ('guidance in understanding and simplifying Islam'), and for 'âlimāt consist of the production of 'ilm, Islamic knowledge based on the capacity to interpret sacred texts through ijtihād ('juridical reasoning'). I conducted my analysis from a gender history perspective, highlighting the historical gender divide in the religious field and in religious authority that reflects the gendered divide of the public-private continuum of the social and political spheres (Butler, 2006; Harding, 2012; Mernissi, 1975; Scott, 1988). In Genèse et structure du champ religieux Pierre Bourdieu underlines the interests of those who produce and spread religious discourses that are useful to maintaining the social order, contributing to the legitimation of the power of dominant groups and to the domestication of the dominated' (1971, p. 299). Inspired by Marx and Weber, he defines the 'religious field' (le champ religieux, in French) as a market of religious goods, in which symbolic values and ritual practices are produced, sold, and demanded according to the need of producers to symbolically dominate others. This hegemony is established thanks to a profit derived from a surplus of religious authority capital (Bourdieu, 1971). In this system of power relations in Muslim majority societies, we observe a historical 'gender division of religious labour' that Fatima Mernissi explains through a kind of 'elite's theory'. According to this perspective, the professionalized

1 This is the sexual abstinence period of three menstrual cycles that women must follow after divorce or the death of the husband. The reason for this social practice is to demonstrate that the woman is not pregnant by her earlier husband so that there is no confusion in the patrilineal line. 
male elite of ulama and imams works with the central power to marginalize women from the construction of religious knowledge and legal scholarship (Mernissi, 1987). In the Maghreb, Bruno Etienne observed that the 'sacred' field has been historically associated with written discourses produced by men, while female religious roles have been limited to an informal space, with the consequent exclusion of women from official religious authority (Etienne, 1990). Indeed, in the Moroccan tradition female religious works have been mainly oral and based on memorization of the Quran and Sunna, but at the same time they have also been crucial for the survival of what we can call 'national Islam'. In fact, some Moroccan historical sources testify to the historical continuity of women's participation in the construction of Islamic knowledge as mufassirāt ('female exegetes'), qāri'āt ('female experts in the Quran'), muhaddithāt ('female experts in the transmission of the sunna'), and female experts in tajwid ('Quranic psalmody'), sìra nabawiyya ('prophet biography'), and as teachers of Islam in private houses (Al-Matimāh, 1978; Lakhmari, 2012; Zahrawi, 2008) - like in the entire Islamic world (Nadwi, 2007). Nonetheless, some Moroccan scholars also observe a historical 'invisibilization' of women from the main Islamic functions and related religious authority (Chickhaoui, 1999).

From this perspective, in the introduction of Speaking for Islam: Religious Authorities in Muslim Societies, Gudrun Kramer and Sabine Schmitdkte answer the question 'Who speaks for Islam?' by affirming the male monopoly of religious knowledge and authority (2006, pp. 1-14). According to them, religious authority is the

capacity to influence others' conduct without the use of coercive power, or the ability - chance, power, or right - to define orthodoxy and orthopraxy; to identify, marginalize, punish or exclude deviance, heresy and apostasy. In the monotheistic religions founded on revealed scriptures, religious authority further involves the ability - chance, power, or right - to define the canon of authoritative texts and the legitimate methods of interpretation. (Kramer and Schmitdkte, 2006, pp. 1-2)

At the same time, religious authority can also contribute to bringing Islamic patriarchal traditions into discussion (Abou El Fadl, 2001). In this framework, Islamic feminists and reformist scholars like Nimat Barazangi, Asma Barlas, Riffat Hassan, Asma Lamrabet, Ziba Mir-Husseini, Amina Wadud, and many others aim for egalitarian access to religious discourses and institutions and the necessary authority to interpret sacred texts from a gender equality perspective (Barazangi, 2006; Lamrabet, 2012; Mir-Hosseini, 1999; Wadud, 
1999, 2006; Webb, 2000). The supporters of an Islamic feminist approach emphasize the compatibility between the claims of gender equality in international discourse on human rights and Islam, which is conceived as a moral and spiritual system of values promoting social justice, solidarity, and non-discrimination against women (Badran, 2002; Mir-Hosseini, 1999).

Based on these considerations, I evaluate the potential and limits of the reform of the Moroccan Ministry of Endowments and Islamic Affairs, which appears to aim at modifying the basis of traditional religious authority to create a more equal gender perspective. What content do Moroccan women preachers and scholars profess? Is this content oriented towards gender equality? Can we speak about a new women's religious authority, and in what sense? I attempt to answer these questions in the next section.

The gender-based reform of the Moroccan Ministry of Endowments and Islamic Affairs

Royal decrees 1-03-103 of 4 December 2003 and 1-03-300 of 22 April 2004 started the reorganization of the Islamic bureaucracy in Morocco. The first decree reorganized the fields of intervention of the Ministry of Endowments and Islamic Affairs, while the second strengthened central control over the councils of ulama by redefining their functions. After the implementation of the New Family Code in 2004, the Moroccan Islamic sector was also restructured through a gender-based reform that included women in the activity of spreading and producing the content of official national Islamic messages.

A new training programme for preachers has produced 50 women murshidāt and 150 imams every year since 2005. To be admitted to the programme, candidates are required to hold a bachelor's degree and be no older than 45 years. They take exams that assess their knowledge of the Islamic sciences and their capacity to memorize the Quran. Because men can become imams, they are required to memorize the whole sacred text, while women are only required to memorize half. The programme consists of a one-year training in religious and social disciplines, such as the Islamic sciences, Arabic, sociology, economics, law, and history, as well as the arts of preaching and public speaking. This course allows graduates to serve as religious guides across the country. After the training, murshidāt receive a monthly salary of nearly 5,000 Dirhams (nearly €450) for their work in mosques, which consists of teaching the basics of a modern, non-violent, and moderate Islam in conformity with the pillars of national Islam, which 
are articulated in the manual Dalïl al-imām wa-l-khațīb wa-l-wāiz (Guide for the Imam, the Preacher, and the Spiritual Guide; Ministry of Endowments and Islamic Affairs, 2007a). The classes taught by murshidāt in mosques are structured to address specific disciplines: fiqh al-usra ('family law'), ethics, and relations within the family and with neighbours. Classes often include explaining and reciting the Quran and exegesis; using Moroccan colloquial Arabic, the dominant language of communication in Morocco, is useful for better conveying their message. There are also counselling sessions where women discuss their social and psychological problems. The work of murshidāt is organized through commissions in partnership with other ministries: women preachers work in prisons, hospitals, schools, orphanages, and nursing homes.

Even though the first women had access to the Islamic University of Al-Qarawiyyin in Fes in 1956, in an interview Hanan Haddad, the national Coordinator of the network of the Units for Women, Family and Children of the ulama councils of Morocco, told me that the 'âlimāt (female Islamic scholars) accounted for around 13 per cent of the total ulama (Rabat, 6 July 2012). Haddad has introduced a journal for women scholars, guides, and preachers called Majallat al-ālimātwa-l-wā'izāt wa-l-murshidāt (Review of Female Experts in Islamic Law, Spiritual Guides and Preachers), published by the Superior Council of Ulama since 2011. In this journal, the 'âlimät write comments and opinions on different issues related to women's conditions in society and the Islamic field, such as women's access to religious professions and authority throughout history and in contemporary society, or specific questions related to women's rights in Islam. The review has proven to be a first step in the passage from 'invisibilization' to public recognition of women's role in the field of official Islam. However, it is noteworthy that although Haddad had been working on this project since 2004, the first issue of the review was published only seven years later, in 2011 (interview, Rabat, 6 July 2012). In the first issue of the review there is a report on the first national meeting of 'âlimāt, murshidāt, and $w \bar{a} ' i z \bar{a} t$ ('female experts in Islamic law, preachers and spiritual guides'), which was organized in Tetouan in 2009. On this occasion, the king encouraged women to actively take part in the official Islamic space and discourse to contribute to the struggle against social exclusion and violence, to guide people and awaken their religiosity. The king's message testifies to the clear intention of the central authorities to support women's participation in the Islamic field.

Nonetheless, beyond this rhetoric, the gender-based reform of the Ministry appears to be a result of a bi-dimensional political strategy that was established with a double political purpose. At a national level, this reform 
was aimed at disciplining the internal Islamic discourse in the country and was contested by some Islamist movements that are very critical of the monarchy. One example is Al Adl wal Ihsane, the Justice and Spirituality Movement; Nadia Yassine, the well-known daughter of the movement's founder, created a programme of religious training for women that was later forced to stop functioning due to state repression and resistance within the movement (conversations with author, Rabat, 2012). At an international level, the government's reform may be meant to show that Morocco is respecting the gender mainstreaming proposed by the universalizing narratives of international conventions.

Although this reform could effectively be perceived as a significant gain in the application of gender mainstreaming in public secular and religious institutions, my interviews demonstrate that the discourse of female religious actors complies with the traditional principle of gender complementarity - rather than gender equality - and male dominance in decision making in both the family setting and the state. Based on this observation, the question is whether it is possible to consider women preachers and scholars as not only agents of the central power but also agents of change, and in what ways their female religious authority could help to improve women's rights. Even though Moroccan women preachers and scholars cannot become imams, they could be considered, and do consider themselves, examples of a new female religious authority that is based on their religious agency.

This religious authority can be identified through three traits: piety, social recognition, and civic engagement. First, a central element in preachers' religious authority is the spiritual sentiment of piety, conceptualized by Saba Mahmood in terms of the cultivation of religious virtues embedded in a specific Islamic tradition (Jouili and Amir-Moazami, 2006, p. 619; Mahmood, 2005, p. 148). Rausch indicates that piety could manifest through all fields of participation in public life, in which these women represent a model of Muslim citizens conforming to Islamic morals (Rausch, 2011). An interesting aspect of preachers' and 'âlimāt's agency is their capacity to negotiate the recognition of their authority, adapting the contents of their discourses to different audiences through what Mahmood calls the 'pedagogy of persuasion' (Mahmood, 2005, pp. 79-117). The second trait of the religious authority of murshidāt and 'allimāt is the social recognition and admiration directed towards them, which I observed when following some of them in their daily work in mosques and at the university of Rabat, as well as during a sermon in an association in Meknes, and in a school and a prison in Salé during Ramadan. Indeed, I found that the students, 
families, and neighbours of women preachers and scholars communicate a deep respect and reverence for them. The third trait of civic engagement emerged in their self-representation: murshidāt and 'ālimāt are visibly enthusiastic about their work, which is perceived by them as key factor in the progress of the whole society. In the interviews I conducted, religious guides and scholars proved very conscious of their subjective and collective role 'firstly as Muslims, then as women and as Moroccan citizens' (interview with a woman preacher, Rabat, 2012).

These aspects of the agency of female religious authorities show that these women are able to redefine the relationships between the public and private spheres of Islamic authority by inhabiting and performing in religious spaces, such as mosques and councils of ulama, as men do amidst other males. Thus, they could be considered 'docile agents' - the protagonists of a process of change that concerns the whole society - because the recognition of women's religious authority could also underline women's empowerment (Mahmood, 2001), hence further facilitating the acquisition of women's rights. This is a valid argument, even though they spread values and social visions that are generally in conformity with the hegemonic patriarchal discourse.

\section{Institutionalizing Islam in Europe: What space is there for female religious authority?}

In the European context, especially in Germany, France, Italy, the United Kingdom, Spain, and the Netherlands, the presence of Muslims is increasing due to immigration flows and religious conversion (Allievi and Nielsen, 2003; Nielsen, 1992; Pew Research Center, 2010). The cultivation of pious sensibilities by Muslim women within liberal-secular European societies, in particular, emphasizes the central role of Islam in public life and in defining women's identity and trajectories (Aune, 2011).

In general, western liberal discourse is presented as opposed to any religious consciousness or spiritual dimension. Secular modern values and Islam are therefore often imagined as incompatible. The secularity of the public sphere and women's equality with men are considered to be chief among European values, while the 'religionization' of the public sphere and intrinsic discrimination against women are considered chief among Islamic values. Secular liberalism in particular, too easily juxtaposes Islam with gender-egalitarian regimes (Abu-Lughod, 1998; Ahmed, 1992), opposing modern assumptions (regarding personal autonomy, freedom, selfrealization, and equality) against their traditional counterparts (submission, 
lack of freedom, and so forth) (Jouili, 2011). This attitude has contributed to a 'moral panic' towards the growing presence of Muslims in Western Europe and towards Islam more in general (Reilly, 2011). In the post 9/11 'war on terror' context, and from the 'clash of civilizations' perspective, the growing visibility of Muslims in Europe has often been analysed through the lens of an essentialist assumption that Islam is regressive and intrinsically opposed to human rights and women's rights 'frame' (Abu Lughod, 2010).

European debates on multiculturalism are profoundly infused with questions of gender and Islam, while public discourses aimed towards Muslim women highlight women's empowerment as an achievement of secular modernity and something that Islam supposedly lacks (Jouili, 2011). This is exemplified in the frequency with which topics like the 'headscarf' are broached in relation to multiculturalism (Bracke, 2011). The European practice of distinguishing between multicultural, as a description of situations, and intercultural, as a description of a process (Nielsen, 1992, p. 152), could be critically conceived (Bracke and Fadil, 2012). According to Bracke and Fadil, multiculturalism 'could be understood as a dispositive that creates distinctive fields of problematization [...], identifies a particular set of actors ("the immigrants" or "Muslims") and is accompanied by an institutional apparatus that seeks to transform the non-integrated "other", in order to include it into the social body' (Bracke and Fadil, 2012, p. 42).

In the recent debates about multiculturalism, the rhetoric of Muslim women's emancipation continues to be inspired by the colonial narrative of 'white men saving brown women from brown men' (Spivak, 1988), under the influence of an orientalist theoretical framework that conceives Muslim women as a homogeneous group of eternal victims that have to be accompanied to emancipation (Mohanty, 1988), with the exception maybe of educated covered Muslim women (Bracke, 2011). This kind of attitude also emerges in nation-states' attempts to institutionalize Islam in Europe. Despite European Muslims' relatively low levels of formal membership in any religious organization, including mosques, the ties between European Muslims and religious networks and movements is perceived as controversial, or as an obstacle to integration and intercultural processes (Nielsen, 1992; Pew Research Center, 2010). Muslim movements and networks often exert significant influence by setting the agendas and shaping debates within Muslim communities in Western Europe. Whether or not they reflect the views of most Muslims in the community, they are often instrumental in determining what 'Muslim issues' are addressed by the media, in government circles, and in the broader public debate about Islam in Europe. They are also instrumental in the construction 
of an 'Islamic other' in the West, and specifically in Europe. Over the last few decades, states and civil societies in Western Europe have focused on the 'integration' of Islam through its institutionalization in the European context (Amir-Moazami, 2011; Karlsson Minganti, 2012; also see Sunier and Laurence, Part I). For example, through the Deutsche Islam Konferenz (German Islam Conference), initiated in 2006, Germany has undertaken some initiatives with the objective of entering a structured conversation with Muslim communities and finding spokespersons who can serve as partners for the political authorities (Amir-Moazami, 2011). The process of an emerging 'institutionalization' of Islam has been analysed in its micro political articulation and in regards to its primary goal of institutionalizing the communications between local state actors and Muslims to improve the conditions in which Muslims practice their religion as well as regulate their conduct (Amir-Moazami, 2011). Using Foucault's category of governmentality, the German initiative becomes a tool of a broader hegemonic civilizing liberal project, not an instrument of a realistic dialogical encounter that is necessary for real intercultural processes (Amir-Moazami, 2011).

The articulation of the relationship between gender and Islam has been (and still is) a main aspect of the attempt to regulate Muslim subjects' and communities' presence in the European context (Amir-Moazami, Jacobsen, and Malik, 2011; Amir-Moazami and Salvatore, 2003; Jouili, 2011). This especially emerges in the way in which gender and Islam have played out in initiatives like the German one, where, according to Amir-Moazami, a hegemonic civilizational discourse has taken up concrete forms of political action with the goal of 'smoothly but authoritatively transform[ing] Muslims into liberal democratic subjects' (Amir-Moazami, 2011, p. 20). In the Netherlands, as Bracke explains, over the last few decades Muslim women's emancipation narrative has been used as part of a wider 'arsenal of tools to control Islam', linked to the surveillance of mosques and Islamic associations (Bracke, 2011, p. 35). Other sociological studies emphasize the subjectivity of women and of female religious authorities in Islamic groups in France, Germany (Jouili, 2015), Flanders (Jacobsen, 2011), the Netherlands (Bracke, 2008), Norway (Vanderwaeren, 2011), and Sweden (Karlsson Minganti, 2012). In countries like France and Germany, prayers rooms, religious instruction, and other services exclusively for female believers started to appear in the first decade of the twenty-first century in some mosques and Muslim organizations (Jouili and Amir-Moazami, 2006). Muslim women participate in the Islamic life of their community; organize religious activities; deliver sermons and lectures in mosque associations, study circles, informal groups, 
or other grassroots associations; and participate in da'wa activities within the Islamic revival movement in Europe (Jouili, 2011; Karlsson Minganti, 2012; Vogt, 2010).

These 'religiously committed women' (Jouili, 2011) face multiple obstacles as a result of patriarchal dynamics both inside and outside their community, in concert with racist and islamophobic prejudices. Concerning religious authority, they face a twofold pressure: from inside their community, they face obstacles to their active participation in Islamic discourses and practices because their claim to religious authority is often contested by their brothers in faith (Jouili, 2015; Karlsson Minganti, 2012; Vogt, 2010). From outside, pious Muslim women, especially young, highly educated pious Muslim women, face the imperative of emancipation following the secular European model. In this sense, Bracke explains that they could be considered a 'disturbing presence in relation to the hegemonic "saving Muslim women" script as they interrupt the linear time of emancipation upon which the dominant script relies', i.e., a linear time of emancipation distributes emancipation unequally and in a binary way between an emancipated 'us' and a non-emancipated 'them' (Bracke, 2011). Some sociological studies call into question this secularization thesis based on the narrative of a single modernity, whereas religion is expected to be a private aspect of individuals' lives (Reilly, 2011). They testify that discourses about women, gender, and Islam imply multiple reflections about religion, culture and state. This has given urgency to debates on the contradictions between discourses on women's rights and Muslim religious practices, spirituality, and forms of religious life in Europe, but also to possibilities of reconciliation between them (Amir-Moazami, Jacobsen, and Malik, 2011). Research on female religious authorities in France and Germany shows that the acquisition and dissemination of Islamic knowledge are not elements of women's subjection to authority; on the contrary, they could themselves be elements of the acquisition of religious authority (Jouili and Amir-Moazami, 2006). Some women interviewed by Jouili and Amir-Moazami (2006) claim that the acquisition of religious knowledge reinforces their faith and makes them resist secularist 'temptations'.

\section{$7 \quad$ Islam and gender equality as objects of governmentality in a multicultural context}

In this discussion of official Moroccan women preachers and scholars, I have interpreted them as having agency and the ability to perform their 
identity first as Muslims, then as women and as citizens. Their acquisition of Islamic knowledge is directly connected to their acquisition of a religious authority that, depending on the role they play as a preacher or scholar, challenges and reconfigures the hegemonic male-monopolized Islamic discourse. I observed that the work of the official Moroccan women Islamic scholars and preachers has a high impact on their community life, because it goes beyond the walls of the mosque and thus takes on a wider social scope. As Miriam Al-Haitami argues, women religious guides and scholars in Morocco construct a third space between the public and private (Al-Haitami, 2012). Here public and private spaces are conceived from a praxiological perspective that considers the definition of public and private as a contingent categorization, depending on the interaction between people, contexts, and situations (Dupret and Ferrié, 2005). The mosque, in fact, is effectively reconfigured: its public role could change and it could become an intimate and private and even collective space, as Amina Wadud suggested (interview, London, 11 September 2012). In this way, the space of the mosque could change from a symbol of the crystallization of a past where men monopolized Islam to a performative space of change and the reform of 'tradition' in a process of internal negotiation (Bano and Kalmbach, 2011; Holmes Katz, 2014). I also observed that Moroccan women religious authorities' discourse about gender relations is inspired by gender complementarity, not gender equality, and that they support a gender-based division of labour and a gender-based system of duties and obligations. In their vision, motherhood represents a fundamental value for women, in which an Islam-based educational model is preferred because of its capacity to serve the community. The high sense of responsibility that these women attribute to the role of a mother comes close to 'political motherhood' (Jouli and Amir-Moazami, 2006, p. 622), because motherhood and its manifestation in domesticity have a public impact on the whole community. Teaching the 'right' Islam to children through education and family care activities makes the private/domestic sphere capable of significant societal impact. Therefore, being a pious subject who is conscious of her Islamic knowledge reflects the ability of a female religious authority to go beyond the private/public binary, and could also have an impact on the redefinition of the patriarchal social order, which dictates the strict separation of the two social dimensions.

The post-colonial approach results in a more relevant framework for analysing the spectrum of female agencies in Morocco. Some studies of Islamic female experiences and discourses return respect to the voices that promote an ideal female model by appropriating Islamic symbols in 
the public sphere (Gole, 1996) or through Islamic pedagogy in the space of the mosque (Mahmood, 2005). In analysing female participation in Moroccan religious institutions, I consider women preachers and female Islamic experts as both agents of central power and agents per se, far from any perspective that considers only liberal secular feminists as the unidirectional perspective for the evolution of society. I consider all of the women religious authorities I encountered in Morocco to be agents of change. The result of the study is, then, a complex interaction of convergences and divergences of discourses, systems of values, experiences, and agencies that leads to considering women's bodies and subjectivities as 'contested spaces' in the debate about equality of citizenship - a focal element of any transition to democracy or, much more important, of any possibility of real respect for women's rights in Morocco.

Comparing the Moroccan case with the European context, we observe that both Islam and gender equality still appear to be objects of state governmentality, governmental techniques in a top-down political dynamic. In Europe, there are some national attempts at the institutionalization of Islam through a liberal discourse of gender equality; in Morocco, it seems that dispositives of Islamic power are useful to manage, control, and re-signify gender equality. In the European context, the interaction between the claim of women's equality and the claim of religion is a contested issue that some scholars have problematized by exploring the attempt of some states to create an institutional apparatus that seeks to discipline Muslim communities while instrumentalizing values of gender equality and promoting Muslim women's participation in a 'post-secular' public life (Amir-Moazami, 2011; Bracke and Fadil, 2012; Habermas, 2008). The European context could be defined as 'post-secular' because secularism is not a sine qua non condition for modernity, which could be - and practically is - more characterized by spirituality, pious identities, and piety movements. A more vital presence of female religious subjectivities could re-signify patriarchal dynamics within their community of faith, and at the same time the meaning of women's emancipation in Europe. The ways this process could interact with different European social contexts and institutions, or, in other words, how female religious leadership can contribute to the European inter- or multicultural process and the amelioration of women's lower status within their citizenship and faith communities, remain an open question that is worth researching further.

At the institutional level it could be very difficult to imagine a singular European model of 'state-sponsored Muslim women religious authorities' as implemented in Morocco. The national institutions of the different 
states play a role in how politics manages internal minorities. In this sense, the German case explored by Amir-Moazami presents some potential normative and normalizing implications of national initiatives for dialogue with Muslim minorities (Amir-Moazami, 2011). For example, there could be obstacles to the effective capacity of Muslim representatives chosen by the state to represent the whole community of faith, and the powerrelated implications of the acquisition of this possible role are not easy to manage. It could be possible to imagine the creation of a board of Muslim women spokespersons that would point European policies towards a more intercultural society, struggling against both stereotypes and islamophobia and the instrumental and patriarchal use of Islam within their community of believers. Encouraging a European process of dialogue between female religious authorities, women active in piety movements, Muslim and secular feminists, and activists in Islamist movements could provide different perspectives of women's rights and eventually arrive at a confrontation about women's common emancipatory priorities. Rather than constituting monoliths, Islam and gender equality values are continuously re-signified by individual and collective performances and agencies beyond the boundaries of public and private spaces, beyond the juxtaposition that perceives Islam as traditional and gender equality and liberal Western values as modern. In this regard, it is worth recalling that a segment of Muslim women socialized in Europe also redefine liberal values by articulating their piety and being fascinated by liberal discourses on dignity and self-realization (Jouili, 2011; Salih, 2010). In both Europe and Morocco, female religious authorities appear to be pious subjects and active citizens. Even though they may appear to not yet have produced a legitimized or very visible religious knowledge, their activity has an impact beyond the boundaries of Islamic costumes, religious discourses, or the socio-political division of spaces. Through the acquisition of religious knowledge, they appear as agents of a redefinition of the Islamic tradition while confronting their own pious subjectivities with the imperative of secular gender equality. At the same time, they are the protagonists of their own empowerment through a trajectory that is mainly religious: an empowerment that, in the long run, could match Islamic feminism's aims to promote gender equality also thanks to an equal access to the knowledge needed for the interpretation of sacred texts. Because of their dynamic capacity to bridge Islamic communities and women's empowerment, the very potential of Muslim women's authority should be far more recognized and discussed in contemporary Europe. 


\section{References}

Abou El Fadl, Khaled. 2001. Speaking in God's Name: Islamic Law, Authority and Women. Oxford: One World.

Abu-Lughod, Lila. 1998. Remaking Women: Feminism and Modernity in the Middle East. Princeton: Princeton University Press.

Abu-Lughod, Lila. 2010. 'Anthropology in the Territory of Rights, Islamic, Human, and Otherwise...', Proceedings of the British Academy, 167/ 2009 Lectures: 225-262.

Agamben, Giorgio. 2006. Che cos'è un dispositivo? Rome: Nottetempo.

Ahmed, Leila. 1992. Women and Gender in Islam: Historical Roots for a Modern Debate. New Haven, CT: Yale University Press.

Al-Haitami, Miriam. 2012. 'Restructuring Female Religious Authority: StateSponsored Women Religious Guides (Murshidāt) and Scholars ('ālimāt) in contemporary Morocco'. Mediterranean Studies, 2o(2): 227-240.

Al-Matimāh, Muṣțafā. 1978. 'Abdassalām, Al-mar'a al-mag்ribiyya wa al-tașawwuf [Moroccan woman and Sufism]. Casablanca: Dār al Kitāb.

Allievi, Stefano and Jørgen Nielsen, eds. 2003. Muslim Networks and Transnational Communities in and across Europe. Leiden: Brill.

Amir-Moazami, Schirin. 2011. 'Dialogue as a Governmental Technique: Managing Gendered Islam in Germany'. Feminist Review, 98: 9-27.

Amir-Moazani, Schirin, Christine Jacobsen, and Maleiha Malik. 2011. 'Islam and Gender: Subjectivities, Politics and Piety'. Feminist Review, 98: 1-8.

Amir-Moazami, Schirin and Armando Salvatore. 2003. 'Gender, Generation, and the Reform of Tradition: From Muslim Majority Society to Western Europe'. In Muslim Networks and Transnational Communities in and across Europe, edited by Stefano Allievi and Jørgen Nielsen, 52-77. Leiden: Brill.

Aune, Kristine. 2011. 'Much Less Religious, a Little More Spiritual: The Religious and Spiritual Views of Third-Wave Feminists in the UK'. Feminist Review, 97: 32-55. Badran, Margot. 2002. 'Islamic Feminism: What's in a Name?' Al-Ahram Weekly Online, 569(17-23 January). http://weekly.ahram.org.eg/.

Bano, Masooda and Hilary Kalmbach, eds. 2011. Women, Leadership, and Mosques: Changes in Contemporary Islamic Authority. Leiden: Brill.

Barazangi, Nimat Hafez. 2006. Woman's Identity and the Qur'an: A New Reading. Gainesville: University Press of Florida.

Belal, Youssef. 2012. Le cheikh et le calife: Sociologie religieuse de l'Islam politique au Maroc. Casablanca: Tarik éditions.

Bourdieu, Pierre. 1971. 'Genèse et structure du champ religieux'. Revue Française de Sociologie, $12(3)$ : 295-334. 
Bracke, Sarah. 2008. 'Conjugating the Modern/Religious, Conceptualizing Female Religious Agency: Contours of a "Post-Secular" Conjuncture'. Theory, Culture and Society, 25(6): 51-67.

Bracke, Sarah. 2011. 'Subjects of Debate: Secular and Sexual Exceptionalism, and Muslim Women in the Netherlands'. Feminist Review, 98: 28-46.

Bracke, Sarah and Nadia Fadil. 2012. 'Is the Headscarf Oppressive or Emancipatory? Field Notes from the Multicultural Debate'. Religion and Gender, 2(1): 36-56.

Butler, Judith. 2006. The Gender Trouble: Feminism and the Subversion of Identity. New York: Routledge.

Charrad, Mounira. 2001. States and Women's Rights: The Making of Postcolonial Tunisia, Algeria and Morocco. Berkeley: University of California Press.

Chickhaoui, Naima. 1999. 'La sainteté féminine face à l'occultation des femmes: Quel sens?' In Histoire des femmes au Maghreb: Réponses à l'exclusion, edited by Muhammad Monkachi, 19-37. Rabat: Université de Kenitra - Fondation Konrad Adenauer.

Darif, Muhammed. 2010. Monarchie marocaine et acteurs religieux. Casablanca: Afrique Orient.

Dupret, Baudouin and Jan Noel Ferrié. 2005. 'Constructing the Private/Public Distinction in Muslim Majority Societies: A Praxiological Approach'. In Religion, Social Practice, and Contested Hegemonies: Reconstructing the Public Sphere in Muslim Majority Societies, edited by Armando Salvatore and Mark Levine, 135-154. New York: Palgrave Macmillan.

Eddouada, Suad and Renata Pepicelli. 2010. 'Maroc: Vers un "féminisme islamique d'Etat"'. Critique Internationale, 46: 87-102.

Etienne, Bruno. 1990. 'La division sexuel du travail religieux: Le cas islamique actuel'. In Femmes du Maghreb au présent: La dot, le travail, l'identité, edited by Monique Gadante and Michéle Kasriel, 245-263. Parigi: CNRS.

Fernandez, Lidia. 2012. 'La formación islámica tradicional (al-ta'lìm al-aṣlī) vista a través de la revista Da'wat al-haqq', In Historia, identidad y alteridad: Temas y perspectivas de la historia, edited by José Celada, Paula Martinez, Iván Miranda, and Maria Garcia, 849-869. Salamanca: Universidad de Salamanca.

Foucault, Michel. 1976. La volonté de savoir: Histoire de la sexualité I. Paris: Gallimard. Gole, Nilufer. 1996. The Forbidden Modern. Ann Arbor: University of Michigan Press. Habermas, Jürgen. 2008. 'Notes on a Post-Secular Society'. In Politics and Society, pp. 17-29. http://www.staff.amu.edu.pl/ ewa/Habermas,\%2oNotes\%20on\%20 Post-Secular\%2oSociety.pdf.

Harding, Sandra. 2012. 'Postcolonialism and Science: Gender Issues', In Gendered Ways of Knowing in Science, edited by Stefanie Knauss, Theresa Wobbe, and Giovanna Covi, 133-154. Trento: Fondazione Bruno Kessler. 
Holmes Katz, Marion. 2014. Women in the Mosque: A History of Legal Thought and Social Practice. New York: Columbia University Press.

Jacobsen, Christine. 2011. 'Troublesome Threesome: Feminism, Anthropology, and Muslim's Women Piety'. Feminist Review, 98: 65-82.

Jouili, Jeanette. 2011. 'Beyond Emancipation: Subjectivities and Ethics among Women in Europe's Islamic Revival Communities'. Feminist Review, 98: 47-64. Jouili, Jeanette. 2015. Pious Practice and Secular Constraints: Women in the Islamic Revival in Europe. Stanford: Stanford University Press.

Jouili, Jeanette and Schirin Amir-Moazami. 2006. 'Knowledge, Empowerment and Religious Authority Among Pious Muslim Women in France and Germany'. The Muslim World, 96(4): 617-642.

Karlsson Minganti, Pia. 2012. 'Challenging from Within: Youth Associations and Female Leadership in Swedish Mosques'. In Women, Leadership, and Mosques: Changes in Contemporary Islamic Authority, edited by Masooda Bano and Hilary Kalmbach, 371-392. Leiden: Brill.

Kramer, Gudrun and Sabine Schmitdkte, eds. 2006. Speaking for Islam: Religious Authorities in Muslim Societies. Leiden: Brill.

Lakhmari, Sami. 2012. 'Lérudition au féminin'. Zamane - L'histoire du Maroc, 22-23: 47-49.

Lamrabet, Asma. 2012. Femmes et hommes dans le Coran: Quelle égalité? Paris: Al-Bouraq.

Laroui, Abdallah. 1977. Les origines sociales et culturelles du nationalisme marocain (1830-1912). Paris: Maspero.

Mahmood, Saba. 2001. 'Feminist Theory, Embodiment, and the Docile Agent: Some Reflections on the Egyptian Islamic Revival'. Cultural Anthropology, 16(2): 202-236.

Mahmood, Saba. 2005. Politics of Piety: The Islamic Revival and the Feminist Subject. Princeton: Princeton University Press.

Mernissi, Fatima. 1975. Beyond the Veil: Male-Female Dynamics in Modern Muslim Society. Bloomington/Indianapolis: Indiana University Press.

Mernissi, Fatima. 1987. Le harem politique: Le Prophète et les femmes. Paris: Albin Michel

Ministry of Endowments and Islamic Affairs of Morocco. 2007a. Dalïl al-imām wa-l-hațīb wa-l-wā $i z$. Rabat: Ministry of Endowments and Islamic Affairs.

Ministry of Endowments and Islamic Affairs of Morocco. 2007b. Dalīl wizārat alawqāf wa al-šūūn al-islāmī. Rabat: Ministry of Endowments and Islamic Affairs.

Ministry of Endowments and Islamic Affairs of Morocco. 2007c. Aḥwāl bi-l-masāğid al-mamlaka al-maġribiyya. Mudìriyya al-masāğid [Status of Mosques of the King of Morocco - Direction of Mosques]. Rabat: Ministry of Endowments and Islamic Affairs. 
Ministry of Endowments and Islamic Affairs of Morocco. 2011. Guide du ministère des Habous et des Affaires islamiques. Rabat: Ministry of Endowments and Islamic Affairs.

Mir-Hosseini, Ziba. 1999. Islam and Gender: The Religious Debate in the Contemporary Iran. New York: Princeton University Press.

Mohanty, Chandra Talpade. 1988. 'Under Western Eyes: Feminist Scholarship and Colonial Discourses'. Feminist Review, 30: 61-88.

Nadwi, Mohammad Akram. 2007. Al-Muhaddithat: The Women Scholars in Islam. London/Oxford: Interface Publications.

Nielsen, Jørgen. 1992. Muslims in Western Europe. Edinburgh: Edinburgh University Press.

Pew Research Center, The Pew Forum on Religion \& Public Life. 2010. 'Muslim Networks and Movements in Europe'. Report. http://www.pewforum.org/ files/2010/og/Muslim-networks-full-report.pdf.

Rausch, Margaret. 2011. 'Women Mosque Preachers and Spiritual Guides: Publicizing and Negotiating Women's Religious Authority in Morocco'. In Women, Leadership, and Mosques: Changes in Contemporary Islamic Authority, edited by Masooda Bano and Hilary Kalmbach, 59-84. Leiden: Brill.

Reilly, Niamh. 2011. 'Rethinking the Interplay of Feminism and Secularism in a Neo-Secular Age'. Feminist Review, Religion and Spirituality, 97: 5-31.

Salih, Ruba. 2010. 'Muslim Women, Fragmented Secularism and the Construction of Interconnected "Publics" in Italy'.Jura Gentium. http://www.juragentium. org/topics/islam/mw/en/italy.htm.

Scott, Joan Wallach. 1988. Gender and the Politics of History. New York: Columbia University Press.

Spivak, Gayatri. 1988. 'Can the Subaltern Speak?' In Marxism and the Interpretation of Culture, edited by Cary Nelson and Lawrence Grossberg, 271-313. Basingstone: MacMillan Education.

Superior Council of ulamā, ed. 2011. 'Ațā'-Majallat al-'âlimāt wa-l-wā'izāt wa-lmurshidāt yamdiruha al-majlis al-'ilmī al-'ālā' (Journal of Women Scholars, Guides and Preachers), 1 (October).

Talbi, Muhammad. 1996. Plaidoyer pour un Islam modern. Tunisi: Ceres.

United Nations-Women, and Ministère de la Fonction Publique, de la Modernisation et de l'Administration. 2012. La place des femmes fonctionnaires aux postes de responsabilité dans l'administration publique. Rabat: United Nations-Women.

Vanderwaeren, Els. 2011. 'Muslimah's Impact on and Acquisition of Islamic Religious Authority in Flanders'. In Women, Leadership, and Mosques: Changes in Contemporary Islamic Authority, edited by Masooda Bano and Hilary Kalmbach, 301-322. Leiden: Brill. 
Vogt, Kari. 2010. 'Religious Practice and Worldview of Muslim Women in Western

Europe'. In Women and Islam, edited by Zayn Kassam, 291-303. Santa Barbara: Praeger.

Wadud, Amina. 1999. Qur'an and Woman: Rereading the Sacred Text from a Woman's Perspective. New York: Oxford University Press.

Wadud, Amina. 2006. Inside the Gender Jihad: Women's Reform in Islam. Oxford: Oneworld.

Webb, Gisela, ed. 2000. Windows of Faith: Muslim Women Scholar-Activist in North America. New York: Syracuse University Press.

Zahrawi, Zahra Nagya. 2008. Mu'jam shahīrāt al-Maghrib [Dictionary of Famous Women of Morocco], 7. Marrakech: 'Ulamā' Council Edition.

Zeghal, Malika. 2005. Les islamistes marocains: Le défi à la Monarchie. Casablanca: Le Fennec.

\section{About the author}

Sara Borrillo is a Post-Doctoral Researcher in the History of Islamic Countries at the University of Naples L'Orientale. She is an Adjunct Professor of Islamic Countries at the University of Macerata and an Associated Researcher at the Centre Jacques Berque - CNRS in Rabat (Morocco). Her research interests are gender politics and Islam, secular and Islamic feminisms, new female religious authorities, and social transformations in the MENA region. She is a United Nations Development Program (UNDP) Expert for Gender Equality and Women's Empowerment in Public Administration (GEPA). Key publication: 'Islamic Feminism in Morocco: the discourse and the experience of Asma Lamrabet' in: Moroccan Feminisms. New Perspectives, ed. by M. Ennaji, F. Sadiqi, and K. Vintge, (Trenton: Africa World Press and Red Sea Press, 2016). 
Part II 



\title{
12 Towards a typology of imams of the West
}

\author{
Niels Valdemar Vinding
}

Hashas, Mohammed, Jan Jaap de Ruiter, and Niels Valdemar Vinding (eds), Imams in Western Europe: Developments, Transformations, and Institutional Challenges. Amsterdam: Amsterdam University Press, 2018 DOI: $10.5117 / 9789462983830 / \mathrm{CH12}$

\begin{abstract}
To understand the relevant and significant differences between imams of the West, this chapter suggests a typology of imams according to variations of institutional authority - that is, the significant dimensions of institutionally embedded authority available in the West - and what has been called epistemic authority, which emphasizes the primacy of knowledge-based authority in Islam. Focussing specifically on Islamic authority and providing relevant examples of imams that embody authority, the typology expresses the cross tabulation between the diverse institutional frameworks in the West and Islamic knowledge personified. This relationship between institutional authority and epistemic authority, its explanatory power and the actual imams, who exemplify them, is a telling indicator of the directions and future challenges of Islam in Europe.
\end{abstract}

Keywords: Imams in the United Kingdom, Germany, and Austria, typology of imams, chaplaincy, institutional and epistemic authority

1 Introduction

This chapter draws on the preliminary interviews from the research project titled 'Imams of the West' (2014-2017) and is an attempt at structuring and ordering the diverse types of imams in the West. The objective of the overall research project is to explore how imams are understood in the divide between Islamic authority and Muslim leadership in the West. Based on qualitative interviews of about 50 imams in Europe and North America ('the West'), the study falls at the intersection between Islamic studies and 
sociology of religion. It investigates how the Islamic religious institution of the imam changes in the challenging encounter with a global, multicultural, and post-migration 'Western' world.

The argument in this chapter is that one meaningful and appropriate way of organizing the diverse types of imams in the West - as well as, perhaps, in the rest of the world - is according to the relevant kinds of authority at play amongst them in the religious-organizational field (Rosenow-Williams, 2012; Vinding, 2013). Exploring authority with its associations of power, control, or legitimate rule is an especially acute concern for any study of imams that seeks to understand how and to what degree diverse types of imams have authority through delegation, and to what extent they are authorities because of certain qualities or capacities that they have as individuals. Therefore, this chapter organizes imams according to (a) variations in their institutional authority, that is, the significant dimensions of institutionally embedded authority available to them in the West, and (b) what has been called epistemic authority, which emphasizes the primacy of knowledge-based authority in Islam (Hallaq, 2001, 2009; Wilson, 1983, p. 13). Theoretically, and at this point in reporting of the project, the typology of imams is presented through these two parameters of authority. In the final reporting on the results of the 'Imams of the West' research project, this typological framework of authority will be discussed against the third dimension of the actual issues of Muslim leadership that are needed and demonstrated in Muslim communities in the West. The question of leadership is acute in many Muslim communities and, taking the typology presented in this chapter as a point of origin, will be the object of study in the upcoming book, Imams of the West.

This chapter opens with a preliminary discussion of what typologies do, what analytical contributions they can make to the ordering of empirical material in qualitative studies, and how to construct typologies. Rather than the simple categorization that just puts imams in pre-labelled boxes, this chapter builds a typology as a theoretical instrument that is both conceptualizing and classificatory, while also resonating with the empirical material drawn from the interviews so that it, in turn, describes the reality of imams' experiences. Therefore, in constructing the typology, this chapter makes explicit the theoretical implications of the empirical findings that merited a typology in the first place.

Then the chapter explores some of the most significant instances of state-of-the-art typologies of imams in the literature, including examples of chaplaincy in the United Kingdom, and typologies of imams in Turkish 
networks in Germany and at mosques in Austria. Each of these supplies highly relevant perspectives for creating a more complete typology of imams in the West.

Applying institutional and epistemic authority to the empirical material provided in the interviews, the chapter unfolds the typology and further discusses the chart, its dimensions, and its implications. The imams interviewed for the project are not everyday, average imams chosen to be proportionally representative of the many thousands of imams in the West; rather, they are key informants that reflect and critically engage in debate, and exercise in their religion not just one but many kinds of authority in an array of relations. As such, the interviews explore the depth and breadth of the field of imams, and the choice of each interviewee must be understood within the specific contexts, circumstances, and conditions that qualify the material.

Knowing this, it is important to stress that the typology created here remains ideal-typical, and that each of the imams discussed fits only to the extent that they exemplify the characteristics of the type. The contribution of the chapter remains a frame for thinking about and reflecting on imams in the West and the central aspects of being an imam. Before concluding, therefore, a number of caveats and problems with the typology are discussed and evaluated, and the chapter closes by highlighting some steps taken towards a meaningful and appropriate ordering of imams in the West.

2 Types, typology, and constructing typologies

Types and their internal relationships are constructs applied in qualitative studies, which are used to comprehend, understand, and explain complex social realities (Kluge, 200o). They offer a description of the similarities and differences in whatever is studied. As such, typologies are theories, that is, reflections on an empirical world, and not just simple categorizations or classifications of something we know to exist (Doty and Glick, 1994, p. 230). Simply put, typologies are organized systems of types that are analytically useful in the formation of theories, because they clarify concepts and create groupings based on empirical data (Collier, LaPorte, and Seawright, 2012).

At first glance, typologies look like simple categorizations and have a certain appeal as reasonable reductions of complexity. As with all categorization and ordering of empirical material, typologies come with a risk 
of generative structuration (Bourdieu, 1985, p. 13; Giddens, 1984, p. 25). The danger is that, in the theorization and building of the categories, the scholar forces a foreign structure onto the data, in turn misrepresenting it by labelling it. Unless very carefully constructed, the typology will produce its subject matter as the types themselves are theorized, thereby pushing description to become prescription. The typology might very well end up glossing over much of the grey zone and ambiguous cases between the predefined boxes and theorized types - in effect, missing the whole point. In addition, the step from simple categorization to essentialization is very short, and very dangerous in the light of the essentializations that have done so much damage to a nuanced understanding of Islam (Jung, 2011; McKelvey, 1982; Said, 1979).

D. Harold Doty and William H. Glick argue that seeing typologies as mere categorizations misunderstands what typologies are and thus fails 'to take full advantage of the unique form of theory building represented by the typology approach' (1994, p. 231). Classification implies a scheme of mutual exclusion and apparently exhaustive sets (Doty and Glick, 1994, p. 232) on the basis of a predefined rule or maxim that decides which is which. By contrast, typologies do not provide clear rules for classification that assume that the constructed classes are mutually exclusive, exhaustive, or discretionary. Rather, typologies have the analytical and theoretical benefit of identifying 'multiple ideal types, each of which represents a unique combination of the [...] attributes that are believed to determine the relevant outcome(s)' (Doty and Glick, 1994, p. 232). Typologies reflect the variance in one or more specified dependent variables and thereby organize identified types into a scheme of the governing rationales or dimensions at play (Doty and Glick, 1994, p. 232).

The core constructs of typologies are ideal types, but there are many other kinds of types, such as real types, prototypes, extreme types, and so on. However, the ideal types constructed in the typology are exactly that - ideals - and therefore of a theoretical nature; the types are abstract, hypothetical concepts (Weber, 1978). Ideal types are theoretical products of typology building that point to the descriptive elements that are common features of most cases of the type. This is in contrast to the empirical examples, which invariably deviate in one aspect or the other from ideal-types (Doty and Glick, 1994, p. 233). These in turn are the 'normal-types' of the empirical material, that is, the object of a study reflecting the real world, which remains different from the ideal-types that seeks an explanation or understanding of the real world in conceptual terms (Etzkorn, 1973, p. 137). 
In specific terms, the process of constructing typologies is delicate work and must be done with academic rigor and consistency, lest it becomes a gross approximation or haphazard misrepresentation of the material. According to qualitative methodologist Susann Kluge $(1999,2000)$, the virtue of the typology as a four-step process of systematization is that the divisions it proposes come from the defining or meaningful properties and attributes that describe the specific empirical data. These are the dimensions of the typology that order the material and make the types distinguishable by virtue of their similarities and differences.

In the construction of a typology the types should be as internally homogenous as possible, in addition to the internal similarity of the variable dimension. At the same time, the differences between the diverse types must be equally well defined in the external heterogeneity at the level of the typology, clearly demonstrating the variations in the empirical material (Kluge, 1999, 2000). This is what gives the dimensions their regularity. Simply put, the different boxes in the typology must reflect both distinct features and meaningful differences on a spectrum of variance, with an increasing degree of complexity in unfolding a multidimensional typology that combines the interplay of two kinds of variables in what will become a chart (see Table 1 below).

After that, a reduction of complexity might be needed. The crosstabulation of two dimensions leads to the combination of attributes into a number of types and spaces that are theoretical by nature, but which must be empirically verified. The ideal types must correspond to normal types. If no empirical case falls into a certain 'box', then it is not meaningful to include that type in the typology. Finally, the constructed types should be defined through reference to both their combined attributes and the empirical world that they propose to describe (Kluge, 2000).

‘Typologizing' attempts so far in Europe

While imams in Europe remain a neglected and understudied topic of qualitative social and humanities research, the last decade or so has seen some solid pioneering steps in not just studying imams, but also in ordering and categorizing them into more or less coherent typologies. Some of these typologies are somewhat undeveloped, while others demonstrate careful, systematic attempts at establishing analytical types that cast light on the complex social realities of imams. While there may be more such typological undertakings in Europe, this section presents three of the most substantial examples so far. 


\subsection{Understanding Muslim chaplaincy in the United Kingdom}

Sophie Gilliat-Ray, Muhammad Mansur Ali, and Stephen Pattison have studied Muslim chaplaincy in the United Kingdom in their work Understanding Muslim Chaplaincy (2013), which is concerned with 'Muslim chaplains employed in British institutions [...] working full-time. Part-time and voluntary roles can be found in prisons, hospitals, educational institutions, HM courts, shopping centres and airports, while others have formal association with police forces and leisure attractions' (Gilliat-Ray, Ali, and Pattison, 2013, p. 1). This is highly relevant for the development of a typology of imams, because it constitutes a recent development of a significant category of institutional authority amongst imams of the West.

Although Gilliat-Ray, Ali, and Pattison do not develop their profile of the chaplains as a typology, they do draw a very comprehensive portrait of the characteristics of who Muslim chaplains are, what they think, and what they do. Perhaps the most central contribution in their book is the understanding of the relationship between the religious authority, qualifications, and training of the imams and the expectations, developments, and needs of the wide sector of institutions and organizations that employ imams as chaplains. The conversation or relationship between imams and public institutions is very much developing, producing 'a new Muslim professional religious role' (Gilliat-Ray, Ali, and Pattison, 2013, p. 7). The relatively new involvement of Muslims in pastoral care raises significant questions with regard to the educational background, religious training, and 'authorization of chaplains' (Gilliat-Ray, Ali, and Pattison, 2013, p. 43). Summarizing their study, it seems that imams' production of Islamic knowledge and successful acquisition of a reputation as a legitimate religious authority are paramount for the success of this new Muslim professional role. Simultaneously, the study shows the ability of public institutions and employers of Muslim chaplains to establish an overdue 'pattern of institutionalized Islamic pastoral care' while still maintaining their multi-faith and public secular norms (Gilliat-Ray, Ali, and Pattison, 2013, p. 43).

To stress personal, professional, and theological differences, Gilliat-Ray, Ali, and Pattison differentiate between the chaplains' various sources of education and training. Among their sample of chaplains, $5^{8}$ per cent were recognized religious professionals who had trained in 'a formal programme of confessional Islamic Studies, and had acquired the title or recognised position of 'alim or 'alima' (Gilliat-Ray, Ali, and Pattison, 2013, p. 46). Such formal training seems increasingly to be a requirement and part of a growing 'professionalization', perhaps corresponding to a growing recognition of 
this kind of Islamic religious authority by employers. Equally, the study concerned itself with the secular educational qualifications of the chaplains, which it - and many of the informants - distinguishes from traditional training. The study finds that 46 per cent had received a mainstream higher education degree, thus demonstrating that 'the vast majority of chaplains either have a traditional religious qualification, or a more advanced mainstream educational qualification' (Gilliat-Ray, Ali, and Pattison, 2013, p. 47). There is very little overlap between these two kinds of qualifications. The remaining category of chaplains who perform the role with no training but the relevant experience is also there, but they are very few. Many of the chaplains in the study add relevant experience to their qualifications, and many have been teachers or educators of sorts - in public institutions, the private sector, or within Muslim communities or in mosques. There is clearly a movement of professionals and chaplains from mosques to public and private sector institutions, and vice versa.

Becoming a chaplain in these institutions is increasingly formalized and standardized, with competitive salaries, compensations, employee rights, job descriptions, and transparency in the employment. This includes a rigorous selection and recruitment process with the increased use of aptitude testing and an emphasis on pastoral care skills (Gilliat-Ray, Ali, and Pattison, 2013, p. 50, 53). While most clearly seen in the HM Prison Service, where security is a significant issue, this is part of the recruitment process in other sectors as well. Chaplaincy employment caters to a specific segment and accentuates the difference between institutional employment and mosque-based, 'traditional' imam positions. The increasing expectations of institutional employers pose challenges to otherwise well-qualified religious scholars, the ulama whose 'training will have largely involved the acquisition of religious knowledge and etiquette' (Gilliat-Ray, Ali, and Pattison, 2013, p. 51). On the other hand, those who seek and get employment in institutions also express an increasing dissatisfaction with the terms and conditions of mosque-based jobs in Britain; work as a chaplain contrasts significantly with mosque positions, where the patronage of the committee and community relations are vital.

Looking at the changing expectations of Muslim professionals in more general terms, it seems clear that the opportunities and conditions of employment will be a significant factor in defining Muslim professionals in the future, essentially changing how religious authority and knowledge is produced and legitimized. The different demands of institutional employers bring into question the necessity of being a qualified ${ }^{c} \bar{a}$ lim in order to work as a chaplain, marking a shift away from the epistemic virtues 
of traditional training to a growing focus on the needs of the institution. However, notwithstanding the requirements of the job and the authority the chaplains wield on behalf of institutions, Gilliat-Ray, Ali, and Pattison found that amongst their interviewees authoritative religious knowledge was essential for establishing legitimacy in their work as chaplains. A good chaplain with worth and confidence is one whose authority is also based on substantial religious knowledge.

While Gilliat-Ray, Ali, and Pattison never develop their work as a typology as such - nor they are concerned with the kind of theoretical reflection pursued here -, their portrait of Muslim chaplaincy corresponds nicely to the first row-category of what I call institutional imams and chaplains in the typology presented here (see Table 1 below), highlighting a high degree of institutionalization and a close relationship with the institutional employer.

\subsection{Ceylan's fourfold typology of imams in Germany}

As a pioneer in research on imams in Germany, Rauf Ceylan constructed a typology of imams based on years of fieldwork with Turkish networks and umbrella organizations in Germany in his book Die Prediger des Islam (The Preachers of Islam; 2010). Ceylan classifies imams as theological authorities and important social and political agents (Ceylan, 2010, p. 17). He sketches the diversity of the functions and extensive use of imams in Germany, as preachers, educators, pastors, and life and marriage counsellors. Drawing on such initial observations, and on the basis of his qualitative interviews, Ceylan constructs four types of imams that are very much centred on Germany, but certainly relevant to the rest of Europe.

Ceylan's first group of imams, 'traditionally conservative imams,' are often associated with bilateral networks or umbrella organizations, and connected to their dogmatic and liturgical traditions. Conservative imams are challenged by the diversity of their social tasks and responsibilities in accommodating believers who live in a completely different world culturally, linguistically, and socially (Ceylan, 2010, p. 51). Ceylan estimates that these imams make up about three-quarters of German imams.

The second group of imams is 'traditionally defensive imams,' who are a minority amongst German imams. They represent an unresolved, anti-intellectual Islam in which traditional nationalism, occultism, and end-of-day worldviews are central to the defence of true Islam against moral decay. This is expressed as an incoherent opposition to a 'Germanification' of Islam and Muslims. Based on his select, non-representative interviews, Ceylan pejoratively labels these imams 'medicine men and exorcists' (Ceylan, 2010, p. 79). 
The third category of imams, 'intellectual-offensive' imams, accounts for 15 per cent of German imams, whom he describes as progressive, offensive, and rationally critical (Ceylan, 2010, p. 110). These intellectual preachers have demonstrated how imams can promote integration in a non-Muslim majority society and reinterpret Islam in the context of its diaspora existence. With both the Quran and the constitution in hand, Ceylan sees these as the imams that can fight growing extremism.

The fourth category is the 'neo-Salafi imams,' who seek to reconstruct a mental framework of an original Islam of the first, pious Muslim generations. This is a product of much later modern interpretations and customs and promotes a fundamentalist, extremist, and revolutionary Islam. This category is distinguished from the second group by its willingness to use violence and its uncompromising view of the West. Ceylan stresses that they have acquired their theological knowledge auto-didactically and that they maintain contact with violent jihadi groups, who ultimately seek to leave Germany to immigrate to a 'proper Islamic State.'

Ceylon's typology is more a portrait of the imams that he knows from his own context and experience than a systematically constructed typology that follows the rigid demands of typology construction. In the typology developed in this chapter (see Table 1, below), the imams at umbrella organizations and networks in Germany studied by Ceylan correspond in principle to what I call 'ambassador or network imams' in the second row: imams who are employed by national, bilateral, or larger international networks of mosques, associations, or ministerial departments. There is, however, a substantial overlap into other types in the typology, mostly due to the lack of a clear methodological selection by Rauf Ceylan.

\subsection{Typology of Austrian imams}

As part of the Wiener Beiträge zur Islamforschung (the Vienna Contributions to Islam research), Ednan Aslan, Evrim Ersan-Akkılıç, and Jonas Kolb (2015) explore Imame und Integration (Imams and Integration) in Austria. The object of this very thorough study is to explore what contribution the imams from mosque communities could make to integration in a plural society, so that Islam might no longer be seen as foreign, but rather as part of the social reality of Austria.

In all, 43 mosques were chosen with a solid ethno-religious and geographical spread, and imams were interviewed following a methodologically solid and well-designed semi-structured guide. Aslan, Ersan-Akkılıç, and Kolb carefully follow Kluge (1999) in grouping their cases according to the 
principles of internal homogeneity and external heterogeneity (Aslan, Ersan-Akkılıç, and Kolb, 2015, p. 89). Following Kluge's analytical framework, Aslan, Ersan-Akkılıç, and Kolb first mapped biographical backgrounds, structural conditions, the work of the imams, theological questions, and positions on integration and strategies in integration policy. From that, the researchers grouped concrete cases together and analysed the extent to which these could be ordered, and what kind of variations and regularities there were amongst the imams. Then the differences and commonalities were explored, leading to an appropriate reduction into the relevant categories and characteristics that made sense to the objectives of the study, which was concerned with the question of integration.

From these preliminary exercises a coherent, fourfold typology was distilled. Their typology of imams in Austria comprises (1) imams with iṣlaḥ-missions (reform-missions); (2) imams as bridge builders; (3) imams as guardians of religious identities and traditions; and (4) imams with limited manoeuvrability. In their study, Aslan, Ersan-Akkılıç, and Kolb illustrate the substance of these types by investigating just a few named imams as concrete cases of the types.

The first type is imams with ișlah-missions, who seek to reform their mosques and communities by bringing about new, critical interpretations of the Islamic sources in light of the new contexts and conditions of Muslim life. In general, these imams consider the communities in Austria to be religiously ignorant and misled. They consider it their duty to guide Muslims on the right path and to bring them back to a true Islam (Aslan, Ersan-Akkılıç, and Kolb, 2015, p. 94).

The second type is imams who work as bridge builders in their mosques. These imams promote both integration into the Austrian context and connections with the countries of origin, building bridges between the two. Bridge-builder imams are attentive to the questions and problems of integration that are often accompanied by conflicts in the everyday life of Muslims in a migration context. A great number of activities take place with their mosques that are open to the wider Muslim public, which includes education, consultation, and social work for women, children, and newcomers to the Muslim community. Such activities of bridge-builder imams enable the members of the community to integrate themselves into the wider Austrian society (Aslan, Ersan-Akkılıç, and Kolb, 2015, p. 152).

The third type is the imam as a guardian of religious identity and tradition. Significant to this kind of imam is that they consider mosques and their facilities the heart of a protected Islamic identity. Within a protective framework, these imams defend their ethnic, cultural, and religious identities and the traditions 
connected thereto. Religion does not take priority, but remains part of a heritage to be preserved. Patriotic or national identities are found in this context, and these imams play the role of transmitting a traditional understanding of religion to the next generation (Aslan, Ersan-Akkılıç, and Kolb, 2015, p. 213).

The final type in this typology is imams with limited manoeuvrability. The key characteristics of these imams are that the integration of the members of their communities has very little to do with their functions as imams. For these imams, none of the relevant dimensions of integration - on cognitive, identifiable, social-interactive, or structural levels - are addressed in the mosque community (Aslan, Ersan-Akkılıç, and Kolb, 2015, pp. 270-271). The core assignments of these imams are the conduct of the communal prayers, the khutba, and the teaching of the Quran. Activities related to issues of integration are not part of their area of responsibility.

In light of the study's concerns, this typology very much reflects the specific societal problem of integration. As such, it speaks mainly, if not only, to aspects of the integration work of imams associated with mosques. In the typology developed in this chapter (see Table 1 below), the imams from mosque communities as studied by Aslan, Ersan-Akkılıç, and Kolb correspond in principle to what in the third row is called imams with local mosques, associations, or organizations, separately or organized into smaller networks. There is, however, an overlap with other subtypes in the typology.

\section{Theorizing institutional and epistemic authority}

The typology presented in this chapter is multidimensional and captures the meaningful interplay between institutional authority, on the one hand, and epistemic authority, on the other. These are the two overall rationales that distinguish and differentiate imams in the West in a meaningful way.

Inspiration is drawn from Bruce Lincoln's work Authority: Construction and Corrosion (1994), which understands authority as a capacity to perform (p. 2) with a desired effect in a 'frame' or on a 'stage' dependent on time and place (p. 5). Lincoln elegantly presents an understanding of authority as both performance and effect, that combines the understanding of being 'in authority,' as a wielder of a delegated authority, and of being 'an authority,' as a wielder of an internalized authority (pp. 3-4). Simply put, the effect that is authority is the product of the relationship between position and qualifications. This in turn demonstrates one of Lincoln's key points, namely that the discursive nature of authority rests between its performance or application and its effect or perception (p. 10). 
This works very well as a prerequisite for the following typology of imams, which uses the dimensions of institutional authority and epistemic authority as the appropriate and significant variable identifiers of imams in the West. Most imams wield both kinds of authority, but in very different ways and to greatly varying degrees. This typology develops the complex confluence between these two kinds of authority. Although discussions of authority very much lead to questions of actual leadership, such a perspective is beyond the present chapter; it will, however, be the topic of future reporting on 'Imams of the West.'

\subsection{Institutional authority}

By 'institutional authority' is understood the institutional power of the employer, organization, or network that engages the imam and therefore delegates unto and authorizes the imam in his conduct and business as an imam. This kind of institutional authority is qualified in degrees of institutionalization, ranging from deep institutional embeddedness within a state or national framework such as in hospitals, prisons, armed forces, and universities, at one end, to having no relation with any governing or organizing structures, at the other - accentuating the individual, informal, non-institutionalized, and commonplace practices of imams that have 'no relation with any governing or organizing structures.'

Institutionalization is characterized by convention and congruence with existing social patterns and stability in the 'taken-for-grantedness' of certain social facts or aspects of social life (Berger and Luckmann, 1966). Applied to the context of imams, institutionalization speaks to the relative strength of the employing organization or institution to frame the work and function of imams relative to the wider surrounding society. Institutional authority is delegated authority that is socially approved and accepted as legitimate by the wider society, drawing explicitly on the ethos, conditions, and purpose of the employer institution. Patrick Wilson makes clear that 'the point of a formal organisation is to give authority to offices that do not depend exclusively on the characteristics of the individuals occupying their offices' (Wilson, 1983, p. 81). As such, the authority of imams in institutions stems from the fact that society as a whole accepts that those very institutions have a legitimate right to such authority, including when it is delegated to the imams.

\subsection{Epistemic authority}

In contrast to institutional authority, 'epistemic authority' is the kind of training (formal or informal), accumulation of knowledge, or recognition 
of merit that demonstrate that the qualities of an individual are sufficient for him to conduct the business of an imam, regardless of what kind of employment or function as imam or chaplain he might have. By 'epistemic' I mean 'pertaining to or related to knowledge or knowing,' particularly in relation to acquiring, producing, or disseminating Islamic knowledge. Authority and knowledge are profoundly linked in Islam, to the extent that in his The Prophet's Pulpit Patrick D. Gaffney notes that 'the one notion that probably summarizes the predominant ideal associated with Islamic authority would be the concept of 'ilm, or knowledge' (1994, p. 34). Concerning the concept of knowledge in Islam, Franz Rosenthal writes:

There is no branch of Muslim intellectual life, of Muslim religious and political life, and of the daily life of the average Muslim that remained untouched by the all-pervasive attitude toward 'knowledge' as something of supreme value for Muslim being. Tlm (knowledge) is Islam, even if the theologians have been hesitant to accept the technical correctness of this equation. (1970, p. 2)

Obviously, there are multiple and concurrent kinds of knowledge in Islam with numerous definitions that draw on the divine and secondary sources of knowledge in Islam, on the didactics and epistemology of the different schools of Islamic thought and mystic circles of learning, and even on the modernist, traditionalist, fundamentalist, and secularist views of each of these. Equally, there are many strategies for obtaining, producing, and applying Islamic knowledge as teaching, counselling, interpreting, and preaching, but - akin to Bruce Lincoln - Gaffney stresses the efficacy of knowledge itself as a distinct sort of authority:

For knowledge to be socially effective, it must be converted into authority and for authority to be established it must be projected as knowledge. Thus a preacher's influence in a local context depends fundamentally on the concepts of knowing that are found there and on how these qualities are understood to be portrayed. (Gaffney, 1994, p. 35)

It is fair to hold that 'ilm as Islamic knowledge is one of the most important sources of Islamic authority for the imam. In qualifying the credentials, merits, and capacity to perform as an imam, training becomes central to appropriating this Islamic knowledge, which is specified as Islamic epistemic authority. 
Wael B. Hallaq is concerned with understanding the genealogical origins of Islamic law, including the question of why and how the different doctrinal schools of law, the madhhabs, came into being in the first place (Hallaq, 2001, 2009). His explanation is that the law and legal authority were constructed through ijtiha $\bar{d}$ - that is, as knowledge production - and not contingent on political, social, or religious circumstances, Legal authority in Islam is therefore epistemic authority. He even goes so far as to say that 'epistemic authority is the defining feature of Islamic law $[. .$.$] masterly knowledge of the law was the$ sole criterion in deciding where legal authority resided' (Hallaq, 2009, p. 35).

In contrast to institutional authority, epistemic authority is a personal authority that is not delegated by some external power. It is of course very likely to be dependent on the merits of a number of external factors and institutions, but it shows itself as a kind of capacity. Simply put, epistemic authority expresses the degree to which imams have expert knowledge and how aptly it is applied in their work.

5

\section{Applying institutional and epistemic authority to the typology}

This typology is based on interviews with almost $5^{0}$ imams as part of the qualitative sociological study 'Imams of the West.' The interviewees were drawn from a long list developed since 2014 that includes over 300 imams in Europe and North America, each of whom has contexts and insights that are relevant to the objective of the study. From this list, the imams actually interviewed were those who had previously reflected publicly and systematically on what it means to be an imam, so that the interview for this study would be able to go into much greater detail and invite the interviewee to a deeper reflection on being an imam and the challenges that come with a global, multicultural, and post-migration 'Western' world. As mentioned, sociological questions of leadership amongst Muslims remains a continuous third perspective, but at present the typology is only concerned with the cross-tabulation of authority.

Institutional and epistemic authority are the dimensions depicted in the rows and columns of the typological chart in Table 1 below. As such, these depict degrees of institutionalization and categories of qualified knowledge. Each dimension of variables has then an interval that locates the positions of the chart, giving way to both poles as well as intermediate types. At the poles of each is the highest and lowest degree of institutionalization or kind of training from formal to informal, with the possibility - in theory - of the extreme of 
no institutionalization and no training. These are not in any way meant as absolutes for either institutional or epistemic authority: newer, more extreme positions may develop or the chart may be in need of further elaboration or nuance. For each, an example is given from the empirical interview data to illustrate the characteristics and approximations to the ideal-types.

Table 1 Typology of 'Imams of the West'

\begin{tabular}{|c|c|c|c|}
\hline \multirow{2}{*}{$\begin{array}{l}\text { Epistemic } \\
\text { Authority/ } \\
\text { Institutional } \\
\text { Authority }\end{array}$} & \multicolumn{2}{|c|}{ Formal training or education } & \multirow{2}{*}{$\begin{array}{l}\text { Informal or } \\
\text { no training or } \\
\text { education }\end{array}$} \\
\hline & $\begin{array}{l}\text { Western, secular } \\
\text { education }\end{array}$ & $\begin{array}{l}\text { Traditional } \\
\text { training }\end{array}$ & \\
\hline $\begin{array}{l}\text { Institutional imams } \\
\text { and chaplains, } \\
\text { employed in } \\
\text { hospitals, prisons, } \\
\text { universities, armed } \\
\text { forces, etc. }\end{array}$ & $\begin{array}{l}\text { Institutionally } \\
\text { aligned imams } \\
\text { Monawar Hussain, } \\
\text { United Kingdom }\end{array}$ & $\begin{array}{l}\text { Legitimized } \\
\text { institutional imams } \\
\text { Asim Hafiz, United } \\
\text { Kingdom }\end{array}$ & $\begin{array}{l}\text { Self-taught } \\
\text { chaplain imams } \\
\text { Tanvir Ahmed, United } \\
\text { Kingdom }\end{array}$ \\
\hline $\begin{array}{l}\text { Ambassador or } \\
\text { Network imams, } \\
\text { employed by } \\
\text { bilateral or larger } \\
\text { international } \\
\text { networks }\end{array}$ & $\begin{array}{l}\text { Western-trained } \\
\text { ambassador imams } \\
\text { Ramil Balyaev, Tatars, } \\
\text { Finland }\end{array}$ & $\begin{array}{l}\text { Traditionally } \\
\text { trained ambassador } \\
\text { imams } \\
\text { Senad Kusur, Austria }\end{array}$ & $\begin{array}{l}\text { Self-taught } \\
\text { network imam } \\
\text { Ani Zonneveld, United } \\
\text { States }\end{array}$ \\
\hline $\begin{array}{l}\text { Imams with } \\
\text { local mosques, } \\
\text { associations or } \\
\text { organizations, } \\
\text { either separate } \\
\text { or organized into } \\
\text { smaller networks }\end{array}$ & $\begin{array}{l}\text { Western-trained } \\
\text { local mosque imam } \\
\text { Brahim Laytous, } \\
\text { Belgium }\end{array}$ & $\begin{array}{l}\text { Traditionally } \\
\text { trained local } \\
\text { mosque imam } \\
\text { Muhammad Muslim } \\
\text { Eneborg, Sweden }\end{array}$ & $\begin{array}{l}\text { Self-taught mosque } \\
\text { imam } \\
\text { Tareq Oubrou, France }\end{array}$ \\
\hline $\begin{array}{l}\text { Independent } \\
\text { imams, either } \\
\text { loosely or not at all } \\
\text { associated with any } \\
\text { kind of institutional } \\
\text { authority }\end{array}$ & $\begin{array}{l}\text { Western-trained } \\
\text { independent imam } \\
\text { Halima Krausen, } \\
\text { Germany }\end{array}$ & $\begin{array}{l}\text { Traditionally } \\
\text { trained } \\
\text { independent imam } \\
\text { Salahuddin Barakat, } \\
\text { Sweden }\end{array}$ & $\begin{array}{l}\text { Self-taught } \\
\text { independent imam } \\
\text { Abdul Wahid Petersen, } \\
\text { Denmark }\end{array}$ \\
\hline
\end{tabular}

From the spread of the chart, it becomes clear that, from the top left corner to the bottom right, we see a shift from highly institutionalized and welltrained imams with close proximity to formal structures to imams who are distanced from such structures because they are independent or have informal qualifications, or both. 
From the dimension of institutional authority, the imams whose authority is most contingent on their employment are the chaplains and Muslim professionals employed in hospitals, prisons, universities, armed forces, and elsewhere. While they bring different educational backgrounds and different sources of epistemic authority into their work to varying degrees, they are nonetheless legitimate in their position of authority because what they do is publically accepted, including that they align themselves with the ethos, conditions, and purpose of their employer institutions. As mentioned above, Gilliat-Ray, Ali, and Pattison (2013) explore this much further in Understanding Muslim Chaplaincy. One example of such an imam or chaplain is Monawar Hussain from the UK, who is Muslim chaplain and advisor with Oxford University Hospitals and the NHS Foundation Trust as well as a Muslim tutor at Eton College ${ }^{1}$. He has vast organizational experience in both business and local affairs. Equally, his epistemic merits and authority are derived from the University of Oxford, where he received a Bachelor of Theology with a focus on Islam and the West. On paper, he is an example of an institutionally aligned imam, although the interview revealed that he was also closely connected to Zaki Badawi, who was the principal of the Muslim College in London, suggesting an additional albeit less formal source of legitimacy (interview with Monawar Hussain, 16 December 2015). Another example is Asim Hafiz, who is a chaplain at the Ministry of Defence of the United Kingdom; he was trained at the Darul Uloom al-Arabiya al-Islamiya seminary in North Manchester, but supplemented his traditional training with a Master's in Islamic Studies (interview with Asim Hafiz, ${ }_{15}$ December 2015). One of the few self-trained institutional imams is Tanvir Ahmed, an engineer who was a chaplain with the HM Prison Service, with which he has been working since the early 1990s, first as a volunteer and then as an employee. Until recently, he was the chair of the Muslim Chaplains Association, and has supplemented his career with further qualifications in Islamic Studies (Ahmed, 2012). These imams have influence in the system and structures they work in, but are also challenged by the fact that they must follow the institutional line in a number of cases that might conflict with more traditional Islamic interpretations. Asim Hafiz, for example, is charged with the difficult task of explaining how and why it is legitimate for Muslim soldiers and servicemen and -women to join the British efforts in Afghanistan and Iraq.

1 All interviewees were given ample information about the purpose of the research, confidential treatment of private information, the intended use of the results, and the consequences of participation in the research project. They consented to participation freely, knowingly, and without coercion. Also, it was agreed that the interviewees would confirm any explicit quotes or citations. 
It is a short step from the first category to the second, ambassador or network imams, as they too are in a sense affiliated or employed, except through bilateral relations between the established religious authority of a country of origin (e.g. Turkey, Morocco, Bosnia-Herzegovina) and the country of residence. These are visiting, semi-permanent, or permanent residents who have an obligation to lead both the prayer and the community in a pastoral sense, in agreement with the national office and the international agency that sends these expatriate imams. The Diyanet of Turkey provides an excellent example of these ambassador-imams and the soft power they resume in the international relations of Turkey (Ceylan, 2010; Gözaydın, 2010). However, the Diyanet imams are far from the only examples. The 'Imams of the West' research project includes several Bosnian imams who follow a similar postOttoman organization of pastoral service to international communities around the world. There is also one example of also a Tatar imam, Ramil Balyaev, from the Tatar Community in Helsinki in Finland, who was trained in Moscow (see Martikainen and Latvio, in Part II on Tatars in Finland). In 2006, he was sent to Helsinki by his chief-mufti as an official delegate (interview with Ramil Balyaev, 18 August 2016). Similarly, Senad Kusur in Austria is an imam with the Verband der Bosniakischen Islamischen Vereine in Österreich. He trained as an Islamic theologian in Sarajevo, with a significant emphasis on traditional training - an important part of the educational structure of Bosnian imams (interview with Senad Kusur, 8 April 2016). I also count Ani Zonneveld, a female imam of Malaysian-American origins from Los Angeles amongst these imams. She is the president and founder of Muslims for Progressive Values (MPV), a faith-based, grass-roots human rights organization that embodies and advocates for the values of social justice and equality for all as they find them in the Quran, for the twenty-first century. ${ }^{2}$ The foundation has affiliates in Canada, Europe, Chile, Australia, and Malaysia. Zonneveld studied economics and political science in college, but she is also a professional Grammy Award-winning singer and songwriter and works as an imam in the local community around the MPV (interview with Ani Zonneveld, 7 July 2016).

In the third row are the imams at local mosques and associations. These are locally organized and part of a local Muslim community in the West, which is usually defined by one distinguishing set of features: ethnic, national, or 'Western' for converts or native speaking communities. An example here is Brahim Laytous, who is imam and the director of a local Mosque in Ghent in Belgium. He is a PhD student at the University of Antwerp and

2 Muslims for Progressive Values, 'Who are we ?' http://www.mpvusa.org/who-we-are/ (accessed 1 December 2017) 
is writing about radicalization. He very much bridges the local mosque community with the local political and media environment, nimbly keeping conservative elements in the mosque in check by opening the mosque to the public (interview with Brahim Laytous, 12 November 2015). Another example is the Swedish convert Muhammed Muslim Eneborg, who is an imam at the smaller Masjid Aysha in Stockholm. He converted in 1980, is trained at Islamic colleges in England, learned Arabic, Urdu, and Islamic Sciences, and is qualified as an ${ }^{c} \bar{a} l i m$. He is also a Sufi. Eneborg holds progressive opinions; he advocates for Islamic training for Muslim women and argues that the unionization of imams will improve their integration into the structures of society (interview with Muhammad Muslim Eneborg, 23 October 2015).

The example of a self-taught mosque imam is a highly interesting case. Tareq Oubrou is an autodidact imam of Moroccan origin at the mosque in Bourdeux, France; he has proven himself to be brilliant Muslim thinker and intellectual. He is trained in biology and medicine, and describes himself as a product of secularization. He feels lucky that he did not inherit any theological biases as part of a specific religious education and that with his Western thinking he can critically interrogate and revise his Islamic religion (interview with Tareq Oubrou, 22 April 2015). The product of this rethinking and his intellectual work has had a significant impact (see Baylocq, Part II, and Hashas, Part I).

In the fourth row are the independent imams, who are either loosely or not at all associated with any kind of institutional authority and are therefore autonomous in their work as imams. These are hard cases that are difficult to pin down, and imams with this kind of loose institutional authority represent a residual category to some extent. An example of a Western trained, independent imam is the German imama Halima Krausen from Hamburg. She is an early convert from a Christian upbringing and studied Arabic and Islamic Studies through extensive travels. She graduated in Islamic Studies, Islamic Law and Theology, and is considered a Muslim scholar with the title sheikha. In 1983, she was one of the founders of the Inter-Religious Dialogue Center at the Department of Theology at Hamburg University, where she was later employed as a research associate, working on interreligious dialogue and Quran exegesis. She also works as the imama of the Congregation of German-Speaking Muslims, and has been called 'Europe's Leading Muslim Woman Scholar' by the Radical Middle Way and An-Nisa Society (Spielhaus, 2012, p. 443). In this typology, Krausen is a hard fit and her profile is ambiguous: a clear indicator of the limits of theoretical typologizing when looking at the empirical realities. She draws institutional authority from a number of contexts but remains employed as an academic, and is equally authoritative through both her Western academic merit and Islamic religious knowledge and studies (interview with Halima Krausen, 8 April 2016). 
An example of a traditionally trained, independent imam is sheikh Salahuddin Barakat, a Swedish imam of Lebanese origin who grew up in Malmø in southern Sweden. He has travelled in Turkey, Lebanon, Pakistan, Mauretania, and Yemen, and his formal merits are from Dar al-Mustafa and Ribat in the Hadramaut Governorate in Yemen. Barakat lists a number of important teachers; he has his $i j \bar{a} z a$ and is therefore authorized by a higher authority to transmit Islamic knowledge. Barakat actively teaches in a number of different mosques, associations, and high schools in both Sweden and Denmark, and he works for a number of councils and religious projects. In 2013, he founded Islamakademin, a rapidly growing Islamic school with a vision of becoming the foremost traditional Islamic school in Sweden. Again, Barakat is associated with a number of institutions and organizations, but he is not delegated an office or ministry from them; rather, it is his Islamic epistemic authority that these institutions seek.

The self-taught, independent imam in this typology is exemplified by Abdul Wahid Petersen, who functions as an imam in Nørrebro, a popular Muslim area of Copenhagen. He runs a bookshop, is the general secretary of Danish Muslim Aid, and is very much a provocateur and free intellectual (Vinding and Christoffersen, 2012). He was born into a non-religious, DanishFinnish, working class, socialist family in the countryside of north-eastern Jutland and was baptized and confirmed in the Church of Denmark, but chose to become a Muslim at the age of 28 in 1982. While he has no formal education, Petersen is associated with a number of mosque associations, including the Danish Islamic Centre, ${ }^{3}$ which caters to converts and a Danishspeaking congregation. Here he calls himself an imam by popular election and considers himself a 'Hillbilly' Muslim convert. He insists that 'islam is not different. And therefore for me, being a Dane and being a Muslim is just expressing Islam in a Danish way of living. ${ }^{4}$

\section{$6 \quad$ Caveats and problems with the typology}

After exploring some of the specifics of the typological chart of imams in the West, it becomes clear that there are certain limits to the explanatory power of this kind of typology. It concerns itself with the authority of imams

3 Dansk Islamisk Center, http://dicenter.dk/, (accessed 1 December 2017)

4 Akbar Ahmed, 2017, 'This Self-Described 'Hillbilly' Muslim Convert Is A Refreshing Link Between Islam And His Danish Culture,' Huffington Post, http://www.huffingtonpost.com/entry/ muslim-convert-denmark-islam_us_5935ba7oe4bocfcda916c756\# (accessed 1 December 2017) 
and is an appropriate analytical tool for discussing the interplay of Islamic epistemic authority within a religious-organizational setting in the West. The typology does not, however, look at the functions and tasks of imams, which would be an entirely suitable basis to differentiate imams, especially with a view to leadership. Do they work pastorally? Do they teach? How is the imam recognized as a legitimate authority by Muslim congregations? Additional relevant perspectives to be included are the age, ethnicity, and gender of the imams in question. As this research project is a qualitative study, the interviewees all reflect their own specific stories and contexts, which call for much deeper discussions about the history, geography, current events, and political and media trends that inform the circumstances of imams in the West.

The question of conversion has not come into play in this chapter, although it very much seems to be a factor in the distribution across the different types. Nor have I included information about how imams see their work in terms of activism, production of knowledge, or other forms of active leadership. Neither do theological positions feed into the typology. A relevant and productive alternative typology of imams could discuss whether they are they are modernist, traditionalist, fundamentalist, and so on. Such distinctions have much wider applications, and are not just limited to imams, but also to the Muslim communities in the West of which imams might be seen as indicative.

Fundamentally problematic to the dimensions of the typology is that the imams plotted in them are very likely to change or migrate across the types across time. An imam may accept another position or resign from his work to become more independent. Also, he is likely to pursue further education, perhaps a $i j \bar{a} z a$ or a master's degree or Ph.D. at a Western University. Equally, an imam may be employed part time with a local mosque and part time as a chaplain, which makes it impossible to fit him into a single category. These perspectives and problems - and many more - will be discussed in the much more detailed and comprehensive monograph that will be the result of the research project.

\section{7}

\section{Conclusions}

This typology is work in progress and an invitation for further discussion on how, and according to which parameters, to systematize the study of diverse types of imams in the West. The applicability of a typology like this one depends on its ability to make meaningful distinctions in the often-blurry 
field of imams. The typology presented here is an attempt at a meaningful and appropriate ordering of imams in the West, based on the significant dimensions of institutionally embedded authority available in the West and what has been called epistemic authority, which emphasizes the primacy of knowledge-based authority in Islam.

In deciding to focus on these two expressions of religious authority, and arguing for their centrality to the legitimacy of imams in their work, this typology expresses a cross tabulation between diverse institutional frameworks in the West and Islamic knowledge personified. This relationship, its compatibility, and the concrete imams who exemplify the types, are telling indicators of the directions of Islam in Europe.

Analytically, this typology opens highly relevant distinctions for navigating the study of imams of the West. With an understanding of the institutional context of imams as well as the kind of epistemic authority they bring with them, it becomes apparent how much distance there is between institutionally aligned imams with secular training and well-paying jobs in the context of the modern Western state and self-taught, independent imams, who find another basis for the leadership they seek to present to the Muslim communities.

Many people and organizations have a vested interest in Islam in the West, and therefore also in imams and Muslim leadership. There are diverse expectations for imams in different institutional settings in the West, which lead to a significant competition of various kinds of authority. Looking at the changing expectations of the Muslim professionals in more general terms, it seems clear that the opportunities and conditions of employment will be a significant factor in defining Muslim professionals in the future, essentially changing how religious authority and knowledge is produced and legitimized. The different demands of institutional employers bring into question the necessity of being a qualified ${ }^{c} \bar{a} l i m(a)$ to work as a chaplain, marking a shift away from the epistemic virtues of traditional training to a growing focus on the needs of the institution. Equally, the chaplains themselves highlight the importance of their religious knowledge, and many seek to not only demonstrate this in their work, but also to convince their institutional employer of the strong convergence between the two kinds of authority.

This typology is relevant not just for analysing who authorizes imams and what kind of authorities they are, but also for the wider discussion of legitimate authority in Islam in the West. Institutional authority as contextcontingent delegation and epistemic authority as the qualified capacity to speak or perform is not just about the authority of imams in their leadership challenges, but also about the very future of Islam in the West. Simply said, 
if authority derives from authorship, then the key questions become to whom, by whom, and how is the authorship of Islam in the West delegated, and what kinds of freedom, responsibility, and limitations come with such delegation? What kind of leadership will arise based on these issues of authority? Resolving these central questions of legitimate authority will be essential for any kind of future leadership of Islam in the West.

\section{References}

Ahmed, Akbar. 2017. 'This Self-Described 'Hillbilly' Muslim Convert Is A Refreshing Link Between Islam And His Danish Culture.' Huffington Post, http://www.huffingtonpost.com/entry/muslim-convert-denmark-islam _ us_5935ba7oe4bocfcda916c756\#

Ahmed, Tanvir. 2012. 'Introduction of Chair'. Unpublished manuscript.

Aslan, Ednan, Evrim Ersan-Akkılıç, and Jonas Kolb. 2015. Imame und Integration, Wiesbaden: Springer.

Berger, Peter L. and Thomas Luckmann. 1966. The Social Construction of Reality: A Treatise in the Sociology of Knowledge. New York: Anchor Books.

Bourdieu, Pierre. 1985. 'The Genesis of the Concepts of Habitus and Field'. Sociocriticism, 2(2): 11-24.

Ceylan, Rauf. 2010. Die Prediger des Islam. Imame - Wer sie sind und was sie wirklich wollen. Freiburg: Herder.

Collier, David, Jody LaPorte, and Jason Seawright. 2012. 'Putting Typologies to Work: Concept Formation, Measurement, and Analytic Rigor'. Political Research Quarterly, 65(1): 217-232.

Doty, D. Harold and William H. Glick. 1994. 'Typologies as a Unique Form of Theory Building: Toward Improved Understanding and Modeling'. The Academy of Management Review, 19(2): 230-251.

Etzkorn, Peter K. 1973. 'Ferdinand Tönnies as a Formal Sociologist'. In Ferdinand Tönnies: A new Evaluation, edited by Werner Jacob Cahnman, 125-139. Leiden: Brill Archive.

Gaffney, Patrick D. 1994. The Prophet's Pulpit: Islamic Preaching in Contemporary Egypt. Oakland: University of California Press.

Giddens, Anthony. 1984. The Constitution of Society: Outline of the Theory of Structuration. Cambridge: Polity Press.

Gilliat-Ray, Sophie, Muhammad Mansur Ali, and Stephen Pattison. 2013. Understanding Muslim Chaplaincy. Abingdon-on-Thames: Routledge. 
Gözaydın, İştar. 2010. 'Religion as Soft Power in the International Relations of Turkey'. Political Studies Association. http://paperroom.ipsa.org/papers/ paper_26422.pdf

Hallaq, Wael B. 2001. Authority, Continuity and Change in Islamic Law. Cambridge: Cambridge University Press.

Hallaq, Wael B. 2009. An Introduction to Islamic Law. Cambridge: Cambridge University Press.

Jung, Dietrich. 2011. Orientalists, Islamists and the Global Public Sphere. London: Equinox Publishing Ltd.

Kluge, Susann. 1999. Empirisch begründete Typenbildung. Zur Konstruktion von Typen und Typologien in der qualitativen Sozialforschung, Opladen. Wiesbaden: Springer.

Kluge, Susann. 2000. 'Empirically Grounded Construction of Types and Typologies in Qualitative Social Research'. Forum: Qualitative Sozialforschung / Forum: Qualitative Social Research, 1(1).

Lincoln, Bruce. 1994. Authority: Construction and Corrosion. Chicago: University of Chicago Press.

McKelvey, Bill. 1982. Organizational Systematics: Taxonomy, Evolution, Classification. Oakland: University of California Press.

Muslims for Progressive Values. 'Who are we?' http://www.mpvusa.org/who-we-are/ Rosenow-Williams, Kerstin. 2012. Organizing Muslims and Integrating Islam in Germany: New Developments in the $2{ }^{\text {st }}$ Century. Leiden: Brill.

Rosenthal, Franz. 1970. Knowledge Triumphant: The Concept of Knowledge in Medieval Islam, vol. 2. Leiden: Brill.

Said, Edward W. 1979. Orientalism. New York: Vintage.

Spielhaus, Riem. 2012. 'Making Islam Relevant: Female Authority and Representation of Islam in Germany'. In Women, Islam and Mosques: Changes in Contemporary Islamic Authority, edited by Hillary Kalmbach and Masooda Bano, 437-455. Leiden: Brill.

Vinding, Niels Valdemar. 2013. 'Muslim Positions in the Religio-Organisational Fields of Denmark, Germany and England'. Ph.D. thesis, Copenhagen University. Vinding, Niels Valdemar and Lisbet Christoffersen. 2012. Danish Regulation of Religion, State of Affairs and Qualitative Reflections. Copenhagen: Copenhagen University, Faculty of Theology.

Weber, Max. 1978. Economy and Society: An Outline of Interpretive Sociology. California: University of California Press.

Wilson, Patrick. 1983. Second-Hand Knowledge: An Inquiry into Cognitive Authority. Santa Barbara: Praeger. 
About the author

Niels Valdemar Vinding is an Assistant Professor at the Department of Cross-Cultural and Regional Studies at the University of Copenhagen, with a specific focus on Islam in Europe and European Muslim institutions. His current research, 'Imams of the West', is funded from 2014 to 2017 by the Carlsberg Research Foundation. His Ph.D. (2013) was on Muslim Positions in the Religio-Organisational Fields of Denmark, Germany and England. 


\title{
13 For a 'visible' Islam
}

\author{
The emergence of protest speech in French mosques
}

\author{
Romain Sèze
}

Hashas, Mohammed, Jan Jaap de Ruiter, and Niels Valdemar Vinding (eds), Imams in Western Europe: Developments, Transformations, and Institutional Challenges. Amsterdam: Amsterdam University Press, 2018 DOI: $10.5117 / 9789462983830 / \mathrm{CH} 13$

\begin{abstract}
Many imams attempt to promote the visibility of Islam in the public space, both in France and in other European countries, and this issue has become the subject of heated debates. Imams participate in the search for recognition based on their ability to embody an 'acceptable Islam': one that is supposedly acceptable for all actors in the public debate. To reverse the discourse that describes Islam as a religion that is foreign and maybe even incompatible with the principles of western democracies, imams in France aspire to the acculturation of Muslim identity or identities, while at the same time stimulating the Muslim faithful to integrate into French society.
\end{abstract}

Keywords: Islam in France, religious authority, militancy, secularization, Muslim identity

\section{1 The expression of Muslim identity in the public space}

In many respects, the practice of Muslim worship in public spaces causes concerns for European democracies, but as well for imams because the state and the surrounding society expect them to facilitate the 'integration' of Islam into national realities. France is no exception to this phenomenon. Imams adjust their roles in response to these pressures; indeed, far from perpetuating North African or Middle Eastern norms, as debates on imam training often continue to assume, their ways of showing their Muslim identity in the public sphere reflect their involvement in the emergence of what is sometimes called (in the case of France) a 'French Islam'. More specifically, the changing stances of imams are involved in the negotiation of the place of Islam in a secular society. 
The place of Islam in France is not always obvious, despite the fact that Muslims have been present in French territory for several decades. On the contrary, the visibility of religions, and of Islam in particular, is now more than ever a cause of dissension in the country. The veil, for example, has probably never been so widely worn as it is now; at the same time, it has never generated so many prohibitive laws and controversies. Never have 'great mosques' been so numerous or given rise to so many protests and desecrating acts. Prayers in the streets of Paris, Nice, and Marseilles have suddenly become an unprecedented political problem. Debates arise from these conflicts, even within mosques themselves. For example, in 2014 the Rencontre annuelle des musulmans du Sud (Annual Meeting of Muslims living in the South of France) hosted a conference entitled 'Islam and Muslims - what visibility?' Tareq Oubrou, the imam and director of the Mosque of Bordeaux who has become famous for his work on Islam in France, has declared himself in favour of a 'discreet Muslim visibility' (Oubrou, 2013; see also Baylocq, Part II, and Hashas, Part I). Naturally, the views of different imams also differ. There are Salafi prayer rooms where preachers dictate increased religious ostentation, and there are some imams who regularly advocate the abandonment of identity markers that provoke negative reactions in public spaces. Oubrou (2013) claims that the hijab is not an Islamic obligation; Hassen Chalghoumi, the imam of the Mosque of Drancy, is publicly against the wearing of the niqā $b$ ('full-face veil'). ${ }^{1}$ The purpose of this chapter is not so much to provide an overview of these debates as to explain what is at stake in the discourses of French imams.

This chapter is based on research carried out between 2006 and 2012 in France. During that period, I conducted 6o semi-structured interviews with 30 imams considered to be 'moderates' and I undertook as well a series of observation sessions, paying attention to their various functions, including khuțba (pl. khuțab; 'sermons'), legal consultations, discussion groups, classes, interreligious meetings, and social gatherings. All of the interviewed imams were born abroad, mostly in Morocco, Algeria, and Turkey, but also in West Africa and a few other countries. They fall into two main sociological profiles. First there are the 'imam-workers', who account for approximately a third of the interviewed imams. These immigrants came to France in the 196os and chose the profession of imam because of the practical necessity of leading prayers, without being well trained. These imams generally practice in small prayer rooms. They originally followed the

1 http://www.leparisien.fr/societe/drancy-l-imam-qui-dit-non-a-la-burqa-22-01-2010-787034. php, consulted in August 2014. 
unofficial route of peer networks, finally finding opportunities in French mosques. The other two-thirds of the interviewed imams were immigrants who had received training in the Islamic sciences in their home countries. Some of them had also practiced as imams in their country of origin. They are hired and supervised by consular networks in France for periods of four years. These imams exercise responsibilities in large mosques where various religious, cultural, educational, and other services are offered.

After the end of these investigations, the results of which have been published (Sèze 2012, 2013, 2014a), I continued to meet with some of the imams, and in some cases with their successors, and have cultivated opportunities for informal exchange with other imams. It appears that over the past decade, imams have made efforts to communicate their speeches in the public space by diverse means, set up websites for mosques, and use social networks like Facebook, hosting sites like YouTube, and other media.

The present chapter is structured as follows. The first part shows how imams in France have gradually come to embody community leadership. Since the public expression of Muslim identity is currently a source of dispute and sometimes even of struggle, imams tend to position themselves as the leaders of an oppressed minority. It is in the light of this observation that the second part analyses the ways imams promote or manifest Muslim identity in the public space. Generally, during the interviews or in their sermons, interactions with the faithful, and public statements, imams promote discourses that lie between two poles: denouncing the injustice of laws that tend to evict religious expression from public spaces, on one end, while not hesitating to denigrate the 'excessive' visibility of some Muslims, on the other. What remains in the space between these two poles is likely a matter of 'ethical exemplarity', civic participation, and other exhortations inspired by the shahada ('testimony') and consistent with many initiatives undertaken by Muslim associations since the 1990s, such as interreligious meetings, social work, and humanitarian aid. Muslims are therefore called upon to appear as such in the public space through actions that will bring them recognition. In other words, the imams' speeches belong to a particular moment in the history of the Muslim presence in France, in that they question and try to negotiate the position of Muslims in a minority context.

2

\section{Becoming minority leaders}

During the institutionalization of Muslim worship in France, imams have gradually emerged as congregational leaders whose legitimacy depends 
largely on their ability to deliver speeches that make sense to all of the faithful. In doing so, they tend to behave like leaders of an oppressed minority. The importance of this position for the legitimacy of imams can be observed in the criticisms attracted by those who refuse to appear as such.

\subsection{Structuring French Muslim leadership}

Although Muslim worship in France dates back to the Middle Ages (Renard, 1999), Islam became a major social phenomenon with the migratory flows between $195^{\circ}$ and the 1973 oil crisis. The number of prayer rooms expanded significantly, especially in hostels for migrant workers such as those built by the Société nationale de construction de logements pour les travailleurs (Sonacotra; National Company for the Construction of Workers' Housing) in response to the strikes that regularly broke out in the 1970 . $^{2}$ In 1976 there were 90 prayer rooms in the country, and by 1980 this number had increased to 150 (Legrain, 1986). In the absence of substantial support from the countries of origin and from transnational Muslim associations, Muslim immigrants themselves had to lead the worship. This was the origin of the 'imam-worker' - a man appointed as a leader because of the practical necessity of directing collective prayers, rarely qualified in religious sciences but endowed with social qualities such as humility, charisma, respectability, and notability, all of which gave him a certain pre-eminence over his coreligionists.

In the late 1980 s and early 1990 os a new organizational model for worship was born. The economic crises caused (in part) by the 1973 oil shock led to a review of immigration policies. The massive flows of immigrants were stopped, and family entry was encouraged. ${ }^{3}$ France's Muslim population was growing in numbers and included women and children; the newcomers sometimes had new academic and professional profiles (Cesari, 1997) ${ }^{4}$. In this context, the visibility of Islam and its management by the authorities, the countries of origin, and transnational Islamic organizations were

2 Sonacotra is a semi-public company created in 1956 to address the issue of Algerian immigrant slums. It began with the construction of the first workers' hostel in 1959 (Argenteuil) and has built 450 dwellings to date.

3 The mass regularization of immigrants, easing access to the right of permanent residence (i.e., cancellation of the Bonnet Law), suppression of assistance for return, project for a foreigners' right to vote, and establishment of residence permits that are valid for ten years (Law $n^{\circ} 84-622,1984$ ). 4 Turkish migrants mostly came after North African migrants and often hold more favourable professional and economic positions. These policies also lead to the presence of students from North Africa who came to France to pursue higher education (Geisser, 200o). 
simultaneously redefined. Islam became emancipated from workers' hostels and moved into districts where Muslims were concentrated in large numbers (Kepel, 1991), and it became more autonomous. At this time the development of mosques was based on the initiatives of Muslims who formed associations, ${ }^{5}$ with the help of foreign institutions like the Muslim World League; these associations increasingly became the owners of their places of worship. This gave rise to 'mosques' that were recognized at both the legal and institutional levels.

There were 500 Muslim places of worship in France in 1985 and 2,368 in 2011, including 316 in the French overseas territories, according to the Ministry of Internal Affairs. ${ }^{6}$ It is difficult, however, to provide an exact number of imams because of the many forms their leadership can take. In some small prayer rooms, for example, it is not uncommon for two or three volunteers to share this responsibility, while larger mosques often have professional imams (and there are of course many cases that fall in between these two). The only reliable census concerns consular network imams, who numbered 300 in 2014. The Ministry of Internal Affairs uses a 'professional' definition of an imam, i.e., the one who usually gives sermons. Using this definition, a survey commissioned by the Direction centrale des renseignements généraux (Central Directorate of General Intelligence) managed to identify 1,026 imams and 1,685 Muslim places of worship in 2004. This is, of course, less than the actual figure, which is ultimately impossible to rigorously quantify.

In any event, 'new generation' imams gradually supplanted the figure of the 'imam-worker'. A 'new generation' imam is rarely trained in France, and is more often recruited through Turkish and North African consular networks, or through peer networks that feed on the pool of graduates in Islamic sciences that are disappointed by the saturated labour market in their home country (Roy, 2002). These imams are duly trained in the Islamic sciences and considered professionals who work full-time, and are even protected by an employment contract and paid by the mosque's association. More than their predecessors, the 'imam-workers', these professional imams were placed in the position of acting as a community leader. In the absence of theological and legal central authorities in a society where Islam is a

5 This was promoted by the 1981/09/10 Law, which includes associations created by foreigners under the law of associations of 1901. This was the end of the law of 1939, which stated that foreigners had to obtain permission from the Ministry of Internal Affairs if they wanted to form an association. 6 This census was based on participation in the elections of the Conseil Français du culte musulman (French Council of Muslim Worship). http:/questions.assemblee-nationale.fr/ q13/13-15308QE.htm. 
minority religion, they seem to be a point of reference - for the faithful, who urge them to define acceptable norms in a non-Muslim society; for the media, which broadcasts concerns about the 'Islamic threat'; for Islamic organizations, as shown in the 'Charter of Muslim Worship' (Boubakeur, 1995); ${ }^{7}$ and for the French State, which would like to have them as partners working towards the development of a civil religion that would be easy to integrate (Peter, 2006).

In the framework of efforts to classify the different kinds of religiosities that shape the diversity of Islam in France, imams have often been presented as the guardians of what is supposed to be immutable (i.e., Islamic laws and rituals), and therefore out of touch with the expectations of young Muslims who are trying out different ways to reconcile religious and civic identities (Venel, 2004) and who are longing to hear discourses that make sense of their own experiences (Babès, 1996, 1997). In her ethnographic survey of French mosques, Solenne Jouanneau (2013; see also her chapter in Part I) clearly shows that imams de facto have only the authority that the faithful give them, circumstantially, and no more. This being the case, the institutionalization of Muslim worship in France has progressively led to the emergence of community leaders who propose more interactive kinds of speeches to keep in touch with their audiences. In the following section, I demonstrate that imams hold views that reflect the common denominator of their audience, namely the experience of being a minority.

\subsection{Internalization of a minority consciousness}

The collective feeling of a minority consciousness in France is rooted in the 'making of the Muslim problem', which dates back to the 1980 os and is still relevant today (Hajjat and Mohammed, 2013). Debates regarding Islam and Muslims are occurring at such a hectic pace that they inevitably impact interviews with imams, to the point that my field notebook turned into a list of grievances. There are also new issues for controversy, which are often related to the visibility of Islam. The issue of the hijab has been recurring since 1989 due to a series of disputes in which head-teachers

7 The Charte du culte musulman (Charter of Muslim Worship) is a document written with the advice of university scholars, comprising 37 articles on the organization of Islam in France. This charter includes the willingness to 'clericalize' Muslim worship (such as the appointment of muftis at the regional level and the definition of imams' roles), based on the Algerian model. Although this initiative initially spanned the main Islamic federations of the day, in the end it sanctioned the hegemony of the Great Mosque of Paris. Therefore, other Islamic federations refused to sign the document. 
refused to allow veiled students into their schools. These disputes were finally 'settled' by the 2004 law that banned 'obvious [in French: ostensibles] religious symbols' (including the veil) at school. ${ }^{8}$ Still, the issue has remained highly controversial, as shown by the 'Baby Loup case' (a nursery where an employee was dismissed in 2008 because the director considered her wearing of the veil to be an infringement of the laws applying the principle of secularism). Then the niqāb ('full-face veil') was banned by a 2012 law on the 'concealment of the face' in public spaces. ${ }^{9}$ Although most imams call for laws to be respected, they sometimes state that such laws that ban the wearing of religious signs at school specifically target Islam (Sèze, 2013). They hold similar views in regard to the ban on 'concealment of the face' in public spaces (interview, Paris region, May 2014). This feeling is maintained by debates about the possibility of veiled mothers accompanying their children on school trips, by the imprecations of politicians against Islam, and also by the increase in attacks against veiled women (particularly in 2014). ${ }^{10}$

The same tension is expressed around mosques. While they initially blended inconspicuously into the urban landscape, 'Great mosques', i.e., mosques with explicit if not spectacular architecture, have been on the rise since the 2000s. ${ }^{11}$ This sudden visibility has engendered negative reactions, such as graffiti urging Muslims to leave France, insulting letters, and desecrations (Godard, 2015). During a conversation about the many desecrations of his mosque, a Moroccan-born imam denounced such acts and described society at large as increasingly 'racist' (interview, East of France, March 2014). The 'street prayer case' is another example. Although the situation is improving, the size of the mosques is insufficient in some districts, and

8 http://www.legifrance.gouv.fr/affichTexte.do?cidTexte=JORFTEXToooooo417977\&categorie Lien=id.

9 http://www.legifrance.gouv.fr/affichTexte.do?cidTexte=JORFTEXToooo22911670.

10 Collectif contre l'islamophobie en France, Annual report, 2014. http://www.islamophobie. net/sites/default/files/CCIF-RAPPORT-2014.pdf.

11 Since the 200os, the following cities (among others) have been the site of Great Mosque construction (including mosques in service, under construction, and at the planning stage): Alençon, Avallon, Amiens, Aubervilliers, Aulnay-sous-Bois, Avignon, Béthune, Blois, Boulogne-Billancourt, Bobigny, Bordeaux, Brive-la-Gaillarde, Bussy-Saint-Georges, Caen, Cannes-la-Bocca, Carcassonne, Carpentras, Carrières, Cergy, Charleville-Mézières, Choisy-le-Roi, Clamart, Decazeville, Déchy, Décines, Épinal, Évreux, Gennevilliers, Grande-Synthe, Grigny, Guéret, Hérouville-Saint-Clair, La Réole, La Roche-sur-Yon, Le Havre, Le Mans, Limoges, Lorient, Marseille, Massy, Metz, Mérignac, Mons-en-Barœul, Montigny-Lès-Cormeilles, Mulhouse, Nanterre, Nantes, Narbonne, Niort, Nogent-le-Rotrou, Orléans, Ostricourt, Paris, Poitiers, Reims, Robertsau, Roubaix, Saint-Louis, Saint-Quentin, Sarcelles, Saint-Denis, Saint-Etienne, Saint-Florentin, Sète, Sochaux, Stains, Strasbourg, Tours, Toulouse, Ulis, Valence, Vaulx-en-Velin, Vernouillet, Vigneux-sur-Seine, Villefranche-de-Rouergue, and Villeneuve d'Ascq. 
on busy days Muslims pray in the streets. These 'street prayers' have been taking place in Paris since the 1990s, but they suddenly became problematic in the winter of 2010, when both far-right leaders and 'identity groups' initiated a massive campaign in which they denounced what they felt to be the illegitimate desire to ostentatiously occupy public space for a religious reason. Following the declaration by Marine Le Pen, president of the French populist party Front National, that it is not Islam that is the problem, but its visibility', ${ }^{12}$ another imam (born in Turkey) did not see anything in her words that reflected the French principle of laïcité ('secularism'), but rather a 'hatred of Muslims' (interview, East of France, January 2014).

In imams' offices, therefore, protest flows easily; this feeling of injustice feeds the defining of a collective identity. Favourite stories related in imams' speeches include Egypt during the reign of Pharaoh (which was then polytheistic), events like the Expedition to Tabuk and the Battle of Badr, and the prophet Muhammad's life in Mecca, during which the early Muslims were persecuted. All of these references are presented as foundational experiences of a minority status that are useful for making sense of the present at the local level, with reference to islamophobic attacks; the national level, with reference to the imprecations of politicians who are hostile to Islam and laws against veils; and the international level, with reference to armed conflicts in the Arab world and Western imperialism (Sèze, 2013). When, in addition to debates over the visibility of Islam, the decisions of school leaders, mayors, judges, the National Assembly, and the Senate are added to the mix, Muslims' 'possibility of participating as equals with others in social interaction' (Fraser, 2011, p 54) is challenged. In this sense, French Muslims are not only a minority because they are quantitatively fewer; they also become a minority because of these structures of power (Asad, 2003) and because they internalize the resulting feelings of being dominated (Akgönül, 2007). Imams' sermons express this collective consciousness by defining Muslim identity in opposition to a 'them', with Islam becoming the 'religion of the oppressed"13 (Sèze, 2013).

Imams talk to a 'community of experiences' in the sense that 'beyond the simple relationship to an inherited identity, it is the experience of discrimination and social contempt that is the source of a shared sense of unworthiness' (Boubeker, 2011). Reference to Islam was not a component of the collective identities of immigrants on their arrival in France in the 1970s, which was

12 Interview published by Zaman France in April 2013. http://www.zamanfrance.fr/article/ marine-pen-n-est-pas-l-islam-qui-pose-probl-me-visibilit.

13 This expression comes from Farhad Khosrokhavar (1997). 
instead marked by the predominance of Arab nationalism. Following the failure of Arab nationalism in the 1980s, however, the countries of origin started to include references to Islam in the construction of their collective identities, in which Muslim immigrants in France, and today some of their children, have reinvested (Cesari, 1997). However, this religious identity is also sometimes formulated in terms of race (Asal, 2014), and is now the target of both the new European populism and widely disseminated attitudes. According to the Institut français d'opinion publique (French Institute for Public Opinion) survey in 2012, 43 per cent of the French people interviewed said the presence of Muslims was a threat to the identity of their country; 68 per cent stated that they were poorly or not integrated; 68 per cent said that if Muslims were not well integrated it was because they refused to integrate; 63 per cent associated Islam with the rejection of Western values, 57 per cent with fanaticism, 46 per cent with subjugation, and 38 per cent with violence; 60 per cent said that the influence and visibility of Islam were too great; 68 per cent would have been hostile to the existence of political parties or trade unions based on Islam; and 33 per cent would have been hostile to the election of a Muslim mayor in their municipality. ${ }^{14}$ Imams can hardly evade this reality. Their positions are also linked to the collective aspirations that, as leaders, they are required to channel and that involve their legitimization. 'In order to be authenticated [recognized as such], the authority must be received by those to whom it is addressed, and this "reception" involves the faithful body,' writes sociologist Danièle Hervieu-Léger (2003, p. 289). Manifesting as a minority religion is a way to unite a plural audience under one banner. In this context, imams are not only congregational leaders, but also minority leaders.

\section{3 'Corrupted imams from the West'}

The authority of an imam can always be subject to dispute, because being an imam is an adventitious function that is accessible to lay people'. This sometimes makes this kind of authority fragile. It is relatively common for imams to face neo-fundamentalist Muslims who challenge their authority, and who are in fact intent on contesting and appropriating it ${ }^{15}$ (Sèze, 2013). Faithful support is not always enough to oppose these destabilizing attempts, although cooperation with intelligence services (Sèze, 2014a) and the more

14 Ifop, 'L'image de l'islam en France', 2012. http://www.ifop.com/media/poll/2028-1-study_ file.pdf.

15 Imams' power, authority, role. 
professional and solid organization of mosques limit the risk that small militant groups will try to seize power (Godard, 2015). Yet it is these same imams who have the feeling of betraying an oppressed minority and who are sometimes the most severely challenged - to the point that they are presented by radical groups as 'corrupted imams from the West'. There are two imams in France who are particularly exposed to this rhetoric, albeit to different degrees: Tareq Oubrou and Hassen Chalghoumi.

Tareq Oubrou was born in 1959 in Morocco. He came to France to study medicine and biology, but quickly dedicated himself to the Muslim community by taking on the role of imam in several cities before settling at the Mosque of Bordeaux. The author of several books and known for holding 'liberal' public positions, he is France's only imam who has publicly challenged the obligation to wear the hijab (Oubrou and Lieven, 2012; see also Baylocq, Part II, and Hashas, Part I). He argues that the veil is related to a 'minor and ambiguous prescription', and that it is only advisable as part of an ethic of decency. The ethic, he argues, has now been lost because the veil is sometimes worn with presentations of the self that contradict this value (i.e., slinky, provocative clothes), or because it is worn as part of a search for 'oppositional identities' (Oubrou, 2013) by looking to break from society - neither of which conforms to the message originally conveyed by Islam. For this reason, Oubrou no longer considers the wearing of the veil to be obligatory. He even questions whether it might be a 'divine [and obligatory] requirement' today (Babès and Oubrou, 2002, p. 216). This position is part of his general call for a 'moderate' (Oubrou and Lieven, 2012) or 'discrete' (Oubrou, 2013) visibility of Muslims, in line with what he first termed a 'sharia minority' (which consists of adapting Islamic laws to a non-Muslim society: Oubrou, 1998, 2004; see Auda in Part I) and that he has continued as part of what he calls a 'theology of acculturation' (2013). Oubrou tries hard to provide a normative framework that will facilitate the easy integration of the practice of Islam into the French context - by 'erasing' norms that are, from a theological point of view, unnecessary sources of blockages. In this, however, he has exposed himself to criticism, a significant example of which comes from the anonymous author of an article posted on the website Oumma.com. ${ }^{16}$ This author first criticizes Oubrou's position on the veil for not being consistent with the title of his book An Angry Imam (Un imam en colère; with Lieven, 2012), in which Oubrou defines himself as a 'protester'. The critic further declares that Oubrou's view leads to the

16 'Tareq Oubrou, l'imam qui veut rendre le foulard et les barbes invisibles', November 2012. http://oumma.com/14717/tareq-oubrou-limam-veut-rendre-foulard-barbes-invisibl. 
'dehumanization of Muslims'. Another anonymous detractor accuses Oubrou of 'despising' Muslims and wanting to make them into 'ghosts'. ${ }^{17}$ It is not Oubrou's arguments themselves that are discussed by these critics, but rather the purpose of his reasoning, because being visible is not automatically reducible to a defensive identity reaction; it is also seeking to exist in the eyes of the other, sometimes even through reactions of rejection (Monnot and Piettre, 2014). Visibility is also an aspect of the social construction of the self, as a subject (Honneth, 2013).

The debate aroused by Oubrou's positions is nowhere near the vast and sometimes acrimonious disputes among Muslim associative networks concerning Hassen Chalghoumi. Born in 1972 in Tunis, Chalghoumi was trained in the Islamic sciences during several stays in different Muslim countries. Having arrived in France in 1996, he first preached at a workers' hostel, while cultivating a close relationship with the Tablighi Jamaat (a pietist and proselytizing movement). In 2008, he was placed at the head of the Mosque of Drancy by its mayor Jean-Claude Lagarde (rather than 'appointed' by his co-religionists); this, in addition to his position in favour of banning the $n i q \bar{a} b^{18}$ (sometimes perceived as discriminatory, particularly among people sensitive to the defence of 'Muslim causes') and his publicized proximity to state bodies and Jewish authorities like the Conseil représentatif des institutions juives de France (Representative Council of Jewish Institutions in France), and the Union libérale israëlite de France (Liberal Israelite Union of France), which awarded him the Copernic Prize for Dialogue, Peace, and Brotherhood in 2013, has significantly eroded his legitimacy, especially when populist and conspiratorial fantasies had the wind in their sails. The vast smear campaign initiated by the sheikh Yassine Collectif (a militant group for the defence of Muslims), which demonstrated in his mosque in 2010 and disseminated videos supposed to prove his duplicity, has highlighted and reinforced the unease generated by Chalghoumi's commitments. This led to his labelling as a 'state imam', stigmatized for his alleged lack of loyalty to the umma. In June 2012, the Collectif pour la dignité des musulmans (Collective for the Dignity of Muslims) wrote an open letter calling upon Chalghoumi to resign that was signed by Muslim militants and intellectuals. ${ }^{19} \mathrm{He}$ is often repudiated in discussions both inside and outside of the mosques, especially on social media. A simple Google search of his name shows the

17 http://doulfikar.com/enquetes/Oubrou.html.

18 http://www.leparisien.fr/societe/drancy-l-imam-qui-dit-non-a-la-burqa-22-o1-2010787034.php.

19 http://www.petitions24.net/chalghoumi_ca_suffit_appel_a_sa_demission. 
mass of invectives, insults, and hate he is confronted with. This also led to him - involuntarily, obviously - appearing in recruitment videos for jihad in Syria ${ }^{20}$ as one of the 'corrupted imams from the West', as well as his placement under police protection.

\section{$3 \quad$ Protest speeches in French mosques}

Imams' position is often the basis of protest speeches, which are driven by a search for recognition and formulated in socially acceptable categories. In sermons, the definition of religious identity is not reducible to dogmatic criteria, but is put into perspective through exhortations to 'exemplary ethics' that invite Muslims to appear in an environment where their identity is sometimes belittled. This goes hand-in-hand with frequent exhortations for their participation in social life, the aim of which is to concretely demonstrate this daily exemplarity by assuming the status of full partners in social interactions and thereby encouraging Muslims' full belonging to the national community. The following three subsections look at different aspects of these developments.

\section{1 'Exemplarity' as a logic of engagement}

Based on Muslims' 'minority consciousness', there are at least two possible horizons (Roy, 2014) of 'ideal types' that can be used to identify dynamic working commitments in the name of Islam in France, both of which can be found in the sometimes-contradictory speeches of imams. The first possibility is neo-fundamentalism, that is, withdrawal into an identity at odds with an environment perceived as pagan; some imams who are close to Salafism or radical Islam adopt this approach. The second possibility is not to break away from mainstream society, but instead try to build bridges. Most imams favour this second possibility, and criticize the zeal of some young converts who want to socially exalt their religious differences. These imams are challenged by the teenagers who choose to wear the veil because of an 'identity crisis' more than because of virtues (see also Lieven and Oubrou, 2012), or they condemn 'victimizers' views' for calling for Muslims to be held accountable if they want to see the world change (Sèze, 2013).

20 '19HH', edited by Omar Diaby and available on YouTube: https://www.youtube.com/watch? $\mathrm{v}=\mathrm{GtIDBT} k \mathrm{thbo} \& \mathrm{t}=15 \mathrm{~s}$ 
As it appears in sermons, Muslim identity is not limited to dogmatic criteria such as observing fundamental beliefs and obligatory practices. Instead, Muslims are also defined as worthy, just, good, fair, honest, tolerant, patient, and chaste beings. Religious identity is also made up of ethical references; as such, it supposedly becomes audible to the majority. This is what imams are aiming at in their appeals to Muslims to embody socially attractive behaviours. This purpose is sometimes explicit; indeed, in a sermon in September 2014, Tareq Oubrou said 'you have to be visible in the sense of generosity, kindness and dialogue.. ${ }^{21}$ One mosque director (born in 1958 in Morocco, with no training in the Islamic Sciences) urged the faithful 'to remain dignified in the face of polemics that disfigure Islam' by never ceasing to present themselves as 'models for society' (sermon, June 2011). A relatively young imam, born in Algeria, prefers to talk about an 'exemplarity' that involves acting every day in such a way that Muslim identity will be associated with socially valorized behaviours (sermon, June 2013), while one of his colleagues, a mosque director born in 1958 in Morocco, likes to promote the ideas and concepts described by Tariq Ramadan in his 'testimony' (2003) ${ }^{22}$ and of the Union des organisations islamiques de France (Union of Islamic Organisations of France). Leaders of the Ahmadi ${ }^{23}$ minority have issued a 'call for jihad' (often translated as 'holy war', but in this case implying struggle with the 'pen' and not the 'sword') with exactly the same concern of spreading the peaceful message of their 'community' and 'mak[ing] the Truth triumph' over the misrepresentation of the media (Sèze, 2015, p. 250-258). ${ }^{24}$

21 Sermon delivered in September 2014, and consulted on YouTube in August 2015. No longer available on the Internet, but the author has saved a copy.

22 According to a classification of the world produced by Muslim jurists, France is not part of the Muslim countries (Dar al-Islam), but is included either among territories with which Muslim countries are at peace (Dar al-'Ahd) or the territory of war (Dar al-Harb). Tariq Ramadan has challenged this division of the world. He states that Muslims are at home in France and suggests considering France as part of what he calls a 'space of testimony' (Dar al-Shahada). Muslims are asked to 'testify', i.e., to demonstrate to non-Muslims their values and the greatness of their faith, and thus to contribute to their society (Ramadan, 2003).

23 The Ahmadiyya is a reformist and missionary community founded in the late nineteenth century in Punjab by Mirza Ghulam Ahmad, who proclaimed himself Mahdi (guide) of Islam, and which has been banned from the umma (Muslim community). Ahmadis have been established in France since the 1980s.

24 'Lislam en quête de repères: le rôle de la jeunesse islamique Ahmadiyya': http://www. islam-ahmadiyya.org/conseils-aux-jeunes-ahmadiyya/95-islam-terrorisme-musulmans-occidentsintolerance.html (August 2010); http://www.islam-ahmadiyya.org/commuiques-ahmadiyya/394appel-au-jihad-lance-par-le-calife-de-la-communaute-islamique-ahmadiyya.html. 
This definition of Islamic identity is, first, a self-presentation to the extent that it is aimed at an audience. To define a Muslim visibility that is not disruptive (Göle, 2013), but rather in the register of 'exemplarity' in French society, also means encouraging a revision of the pejorative meta-discourses about Muslims and making them able 'to relate positively to [their] special qualities and [their] practical abilities' - in other words, to obtain social recognition (Honneth, 2006).

\subsection{Participation in social life in imams' speeches}

The exhortations to 'exemplarity' outlined above are manifested in the collective impetus for participation in social life that is conveyed by a growing number of Muslim leaders. The start of the school year, such as those in September 2007 and September 2008, presented an opportunity for sermons urging young people to achieve academic success and to become influential members of their societies (Sèze, 2013). Another sermon from an imam born in Morocco glorified the value of work and promoted participation in unions during a conversation group (personal observations, 2012). One of his colleagues, an 'imam-worker' born in Algeria, used a sermon about alms to encourage solidarity, such as food distribution to the homeless by local services (personal observations, 2012), while another imam, born in Morocco, encouraged women to achieve academic and professional success (using examples of 'sisters' becoming doctors and teachers), to 'get out' of their homes and take part in activities offered by the mosque, and not to withdraw from public life, including educational institutions.

Participation in social life also represents a collective commitment. During the French presidential elections of 2007, one mosque director exhorted the faithful to what he called 'positive citizenship' (sermon, 2007). In concrete terms, he meant 'contribut[ing] to the development and prosperity of their society' by establishing a presence in educational bodies, socio-cultural centres, 'civil society institutions and organizations that defend just causes and by participating in all elections'. ${ }^{25}$ Along the same lines, in a sermon before the departmental elections in March 2015 Farid Darouf (imam at the Mosque of Montpellier) urged the faithful to vote, saying to his coreligionists: '[y]ou must be present in the ballot box on Sunday. [...] You must be active citizens. [...] You must participate and give value to your citizenship. [...] You are great people! You are in France! You must express your citizenship 
with your ballot. ${ }^{26}$ Mohammed Khattabi, another imam at the Mosque of Montpellier, exclaimed in a sermon early in 2015:

How can French society trust in Muslims if Muslims are disconnected? We do not participate in anything! 'The election is haram! The army is haram!' [...] If we keep this spirit, we are condemned to suffer. [...] Either we are an integral part of this society [French society], its defence, its stability, its integrity, its prosperity, or we are nothing! And if we are nothing, one day we will get thrown out! [...] It is important for Muslims to be aware of this European reality in 2015. [...] And believe me, in twenty years' time, or fifty years' time, things will change, and Muslims will be recognized as a European community and not as people who have come to work, to make money and to go back home! All of that is now over! ${ }^{27}$

Not only imams, but also occasional preachers, $d \bar{a} \bar{\imath}$ (pl. $d u \bar{c} t$, 'itinerant speakers'), and mosque directors encourage the faithful to adopt such an attitude of engagement in society. Rachid Abou Houdeyfa, ${ }^{28}$ Mohamed Bajrafil, ${ }^{29}$ Dalil Boubakeur, Hassan Iquioussen, ${ }^{30}$ Ahmed Mikhtar, ${ }^{31}$ Tareq

26 Sermon delivered in March 2015, and consulted on YouTube in August 2015. The sermon is no longer available on the Internet, but the author has saved a copy.

27 https://www.youtube.com/watch?v=zexjARppF3c\&feature=share\&fb_ref=share.

28 Sermons at the Mosque of Brest: 'Doit-on voter?' (https://www.youtube.com/watch? $\mathrm{v}=\mathrm{qWiZVi3} \times \mathrm{b} 6 \mathrm{Y}$ ); 'Respecte les non-musulmans' (https://www.youtube.com/watch? $\left.\mathrm{v}=Z K G b w M X \_k C M\right) ;$ 'Réagir aux agressions islamophobes' (https://www.youtube.com/ watch? $\left.\mathrm{v}=\mathrm{KF} 7 \mathrm{~S}_{7} \mathrm{dWpxEY}\right)$..

29 A number of lectures and sermons are available on YouTube:

'L'Islam, citoyenneté et démocratie' (https://www.youtube.com/watch?v=LyvtTGdn2xo);

'Allez voter!' (https://www.youtube.com/watch?v=Tr55rEJfx 38 );

'Le musulman, citoyen avant tout' (https://www.youtube.com/watch?v=ffvVCbfpaMI);

'Le musulman, un acteur positif dans sa cité' (https://www.youtube.com/watch?v=15KnQOrgRNw) 30 'La France, tu l'aimes ou tu l'améliores' (https://www.youtube.com/watch?v=Rek-iOH${ }_{5} \mathrm{BXU}$ ); 'La participation citoyenne: un devoir' (https://www.youtube.com/watch?v=iR8s5Ethubs); 'Musulman et citoyen' (https://www.youtube.com/watch?v=pUCeIAQrlfk);

'Le rôle de la mosquée dans la société' (https://www.youtube.com/watch?v=nP3J_s2cwtc);

'La responsabilité individuelle, familiale et sociétale' (https://www.youtube.com/watch? $\left.\mathrm{v}=6 \mathrm{yvFc}_{7} \mathrm{~F}_{1} \mathrm{fJc}\right)$;

'La participation citoyenne à la lumière des textes' (https://www.youtube.com/watch? $\mathrm{v}=$ pTz4FMJIOVA);

to some extent 'S'engager pour l'islam, une nécessité' (https://www.youtube.com/watch? $\mathrm{v}=$ ef $39 \mathrm{qkZJydg})$.

31 Sermon at the Mosque of Villeneuve d'Ascq: 'Soyons acteurs pour l'intérêt general' (December 2013). https://www.youtube.com/watch?v=FNxgt6O1smk. 
Oubrou (2013), Dhaou Meskine (Bowen, 2010), Tariq Ramadan (2003, 2009) ${ }^{32}$ and others have incorporated participation in social and civic life into their speeches to varying degrees, even while they disagree on many other issues; being a responsible citizen, voting, fighting discrimination, acting in the public interest, and 'improving France' are among the common exhortations of Muslim leaders.

Such speeches have a normative character, the field of which exceeds the framework of worship in the strict meaning of the term. The aim of these performances cannot be reduced to a worship-related issue.

The possibility of actors managing to forge a self, a conception of themselves in an inter-subjective relationship, and entering into relationships of recognition with others depends on their ability to make themselves visible, to exist and to be seen and heard. The first condition of a relationship of recognition is the ability to exist in a world of speech and action, to 'count' to others and to contribute thereby to the collective practice. (Voirol, 2005, p. 117, my translation)

The aim of such speeches is to concretely demonstrate this daily exemplarity by participating in social life, and so to assume, as Muslims, the status of full partners in social interactions.

\subsection{The issues associated with involvement in city life}

The issue of participating in social life is not limited to certain imams' speeches; it is also sustained by initiatives on the part of many mosques. From the late 1980 s and early 1990s, the organizational processes of Muslim worship in France adjusted themselves to their minority condition. This is a process common to all Western countries that have experienced recent Muslim immigration - and that is why it has attracted the interest of observers in both Western Europe and North America (see Laurence, Part I). In France, mosques started offering services that are traditionally entrusted to different institutions in Muslim countries (Cesari, 2004), including prayers, religious celebrations, births, weddings, and funerals; legal advice; conflict mediation; lessons in Arabic and religious courses, often offered on the weekend, for children and teenagers, and sometimes also for adults; conferences for both young Muslims and more diverse audiences; fun activities such as cultural

32 See also: 'Il y a un vrai djihad de la citoyenneté active à mener.' http://www.lepoint.fr/societe/ tariq-ramadan-il-y-a-un-vrai-djihad-de-la-citoyennete-active-a-mener-27-09-2014-1867221_23.php. 
and sporting events, sometimes organized during school holidays; chaplaincy services; and women's groups which conduct activities for themselves. Far from being limited to places of worship, mosque associations are keen to respond to the diverse needs of local Muslim communities based on the model of immigrant associations. This dynamic has led to the view that Muslim communities are organizing themselves based on the pattern of Catholic parishes (see in particular Cesari, 2004, pp. 183-205; Étienne, 1989, p. 98; Frégosi, 2006, pp. 65-67; and Laurence, Part I).

Yet it must also be noted that this process is the result of many initiatives designed to encourage involvement in city life and the development of activities aimed at a non-Muslim environment. Mosques organize conferences where Muslim leaders, scholars, believers, and curious citizens can meet; festivities such as iftar meals for breaking the daily fast during Ramadan and the celebration of the Mawlid (anniversary of the prophet Muhammad's birth), to which local elected officials are invited; and events such as 'open days', which are both social gatherings and places of exchange. Since the 1990s, Muslim leaders have participated more frequently in religious meetings, the challenge of which is to show that they can also be engaged in the initiatives of living together (Lamine, 2005) and in parity with other religions. This parity was an explicit issue of debate in September and October 2014 (Sèze, 2014b) after protests against atrocities perpetrated by the Islamic State, as well as following the Charlie Hebdo attack in January 2015. Mosques also participate in humanitarian endeavours such as collective donations to southern countries in the wake of natural disasters. They have developed partnerships with non-governmental organizations such as Islamic Relief Worldwide, Muslim Hands France, and Ummah Charity, as well as taking part in food distribution during the winter. Some mosque directors have also created partnerships with the French Blood Establishment (Établissement français du sang) blood bank system. All such practices are a manifestation of the faith, and also show the solidarity and 'public utility' of Muslims. This is the value of their activities in partnership with socio-cultural associations, through which Muslim leaders want to lead young people, who are often considered an 'at-risk population', to both social and religious conformity, thus contributing to social peace (Bowen, 2010; Kepel, 2012).

These scattered initiatives on the part of Muslim leaders are not only the answer to prosaic and occasional needs. All of them are driven by the same concern, namely a desire for recognition. Nevertheless, it is clear that this quest brings few results. Imprecations against Muslim leaders remain common; indeed, while imams miss a certain 'openness', they allegedly do not sufficiently condemn the crimes perpetrated in the name of Islam, 
especially those of the Islamic State, and they make 'inappropriate' speeches in the French context. All of these efforts therefore seem to remain 'dead letters'. After the French sociologist Vincent Geisser denounced the role of the media in the making of a 'new islamophobia' (2003), the journalist Thomas Deltombe showed how the production of attitudes that involve Islam and Muslims still largely escapes them (2007). Hence the efforts of Muslim leaders to bring their actions to the attention of the media. Most mosques have a website and sometimes a Facebook page that attest to the republican values of the association. Mosque leaders are accustomed to speaking, mainly in the local media, whenever the opportunity arises - to condemn terrorism, for example. They communicate via social networks and community websites regarding the events planned by their mosques, and sometimes broadcast their sermons on YouTube. While Muslims are suspected of 'communitarianism' (in the French context, this means forming a solidarity group that is disloyal to the French Republic), Muslim leaders who urge their faithful to demonstrate ethical exemplarity and increase their participation in society intend to confirm that their 'values and abilities' correspond to those of France (Honneth, 2013). In so doing, they seek to legitimize their presence in the public space and more fundamentally to have their full belonging to the national community recognized. The publicizing of all of these initiatives is part of a 'struggle for visibility', defined as the

[s]pecific dimension of an action which, starting from an experience of invisibility or symbolic depreciation, deploys practical techniques and communication processes to manifest in a public scene and have political practices or guidelines recognized. (Voirol, 2005, p. 108; my translation)

This public presence thus becomes an additional resource in the quest for recognition.

\section{Conclusion: Imams as a 'medium for political communication'?}

While Muslim worship has been institutionalized and has become more autonomous in France, imams have gradually emerged as congregational leaders and, in this minority context, also the leaders of an oppressed community. There are, however, different ways of representing a minority. The few studies since the 199os that have examined sermons note that imams 
could be part of a political protest that echoed the Algerian civil war (19912002), protect Muslims against temptations in a non-Muslim environment, or fall back on casuistry (Babès, 1997; Ismaïl, Chaabaoui, N'Diaye, and Diop, 2002; Reeber, 1993, 2005; Ternisien, 2002). During that period, the horizons of their lives seemed to lie outside of France. There was no question of getting involved in it. But the time for 'withdrawal' has passed; even Salafis have now entered the processes of acculturation in France (Godard, 2015). A new search for recognition has emerged, and this paradigm shift means the stakes have changed. The 'objective conditions', the fact that material resources are distributed in order to guarantee individuals the independence and the ability to express themselves, are no longer a serious obstacle to 'participation parity'. The challenge is now to act on the 'inter-subjective conditions', i.e., the institutionalized patterns of interpretation and evaluation that widely deprecate the quality of Muslims and that do not ensure equality of opportunity in the pursuit of social esteem (Fraser, 2011). Nancy Fraser (2011) considers the denial of recognition to be an injustice that is rooted in social relations. She states that the mobilization of imams is needed not only to challenge hostile attitudes towards Muslims, but also to assert the legitimacy of their presence in the public space and therefore to negotiate their place in a minority context. This shift occurs with Muslims who understand that France is their 'national space' too, and who reject the implications of the 'minorization' discourse. The dynamism described in this chapter reflects the ability of imams - though mostly foreign and sometimes untrained - to support Muslims in the challenges they face in their struggle for recognition and integration in the French Republic (Schnapper, 2007).

\section{References}

Akgönül, Samim. 2007. 'La naissance du concept de minorité en Europe'. In Minorités religieuses dans l'espace européen: Approches sociologiques et juridiques, edited by Jean-Pierre Bastian and Francis Messner, 37-59. Paris: PUF.

Asad, Talal. 2003. Formations of the Secular: Christianity, Islam, Modernity. Stanford: Stanford University Press.

Asal, Houda. 2014. 'Islamophobie: La fabrique d'un nouveau concept: État des lieux de la recherche'. Sociologie, 5(1): 13-29.

Babès, Leïla. 1996. 'Le croire dans l'islam: De l'intellectualisation à la spiritualisation'. In Les nouvelles manières de croire: Judaïsme, christianisme, islam, nouvelles religiosités, edited by Leïla Babès, 121-137. Paris: Éditions de l'Atelier. 
Babès, Leïla. 1997. L'islam positif: La religion des jeunes musulmans de France. Paris: Éditions de l'Atelier.

Babès, Leïla and Tareq Oubrou. 2002.Loi d'Allah, loi des hommes: Liberté, égalité et femmes en Islam. Paris: Albin Michel.

Boubakeur, Dalil. 1995. Charte du culte musulman en France. Monaco: Éditions du Rocher.

Boubeker, Ahmed. 2011. 'L'homme capable à l'épreuve de l'invisibilité sociale'. Le Portique, 26. http://leportique.revues.org/2511.

Bowen, John. 2010. Can Islam be French? Princeton: Princeton University Press.

Cesari, Jocelyne. 1997. Etre musulman en France: Associations, militants et mosquées. Paris: Karthala-IREMAM.

Cesari, Jocelyne. 2004. L'islam à l'épreuve de l'Occident. Paris: La Découverte.

Deltombe, Thomas. 2007. L'islam imaginaire: La construction médiatique de l'islamophobie en France, 1975-2005. Paris: La Découverte.

Étienne, Bruno. 1989. La France et l'islam. Paris: Hachette.

Fraser, Nancy. 2011. Qu'est-ce que la justice sociale? Reconnaissance et redistribution. Edited and translated by Estelle Ferrarese. Paris: La Découverte.

Frégosi, Franck, ed. 2006. L'exercice du culte musulman en France: Lieux de prière et d'inhumation. Paris: La Documentation Française.

Geisser, Vincent, ed. 2000. Diplômés maghrébins d'ici et d'ailleurs: Trajectoires sociales et itinéraires migratoires. Paris: CNRS Éditions.

Geisser, Vincent. 2003. La nouvelle islamophobie. Paris: La Découverte.

Godard, Bernard. 2015. La question musulmane en France. Paris: Fayard.

Göle, Nilüfer. 2013. 'La visibilité disruptive de l'islam dans l'espace public européen: Enjeux politiques, questions théoriques'. Sens Public, 15/16: 165-184.

Hajjat, Abdellali and Marwan Mohammed. 2013. Islamophobie: Comment les élites françaises fabriquent le 'problème musulman'. Paris: La Découverte.

Hervieu-Léger, Danièle. 2003. Catholicisme, la fin d'un monde. Paris: Bayard.

Honneth, Axel. 2006. La société du mépris: Vers une nouvelle théorie critique. Edited and translated by Olivier Voirol, Pierre Rusch, and Alexandre Dupeyrix. Paris: La Découverte.

Honneth, Axel. 2013. La lutte pour la reconnaissance. Paris: Gallimard.

Ismaïl, Mohsen, Mohammed Chaabaoui, Salatou N'Diaye, and Mustapha Diop. 2002. 'Typologie des khuțba du vendredi: Étude sur les imams'. Report prepared for IHESI, ERISM, and the INALCO.

Jouanneau, Solenne. 2013. Les imams en France: Une autorité religieuse sous contrôle. Paris: Agone.

Kepel, Gilles. 1991. Les banlieues de l'islam: Naissance d'une religion en France. Paris: Seuil.

Kepel, Gilles. 2012. Quatre-vingt-treize. Paris: Gallimard. 
Khosrokhavar, Farhad. 1997. L'islam des jeunes. Paris: Flammarion.

Lamine, Anne-Sophie. 2005. 'Mise en scène de la "bonne entente" inter-religieuse et reconnaissance'. Archives des Sciences Sociales des Religions, 129: 83-96.

Legrain, Jean-François. 1986. 'Islam en France, Islam de France'. Esprit, 119: 1-30.

Monnot, Christophe and Alexandre Piettre. 2014. 'Being Recognizable in Order to Overcome the Crisis: The Struggle for Recognition and Visibility by Muslim Actors in France and Switzerland'. In Religion in Times of Crisis: Critiques and Change, edited by Gladys Ganiel, Heidemarie Winkel, and Christophe Monnot, 153-171. Leiden: Brill.

Oubrou, Tareq. 1998. 'Introduction théorique à la sharia de minorité'. Islam de France: Revue d'Information et de Culture Musulmane, 2: 26-41.

Oubrou, Tareq. 2004. 'La sharia de minorité: Réflexions pour une introduction légale de l'islam'. In Lectures contemporaines du droit islamique. Europe-Monde arabe, edited by Franck Frégosi, 207-230. Strasbourg: PUS.

Oubrou, Tareq. 2013. 'Pour une visibilité musulmane discrète: Évitons les interdictions supplémentaires'. Le Monde, 4 October, p. 21.

Oubrou, Tareq and Samuel Lieven. 2012. Un imam en colère. Paris: Bayard.

Peter, Frank. 2006. 'Une religion civile en quête d'autorités religieuses'. Confluences Méditerranée, 57: 69-81.

Ramadan, Tariq. 2003. Les musulmans d'Occident et l'avenir de l'islam. Paris: Sindbad. Ramadan, Tariq. 2009. Mon intime conviction. Paris: Presses du Châtelet.

Reeber, Michel. 1993. 'Islamic Preaching in France: Admonitory Addresses or a Political Platform?' Islamic and Christian-Muslim Relations, 4(2): 210-222.

Reeber, Michel. 2005. Petite sociologie de l'islam. Paris: Milan.

Renard, Michel. 1999. 'France, terre de mosquées?'. Hommes et Migrations (Islam d'en France), 1220(1): 30-41.

Roy, Olivier. 2002. L'islam mondialisé. Paris: Seuil.

Roy, Olivier. 2014. 'Sécularisme et fondamentalisme: Les deux faces d'un même phénomène?' In Charles Taylor, religion et sécularisation, edited by Sylvie Taussig, 191-212. Paris: Éditions du CNRS.

Schnapper, Dominique. 2007. Qu'est-ce que l'intégration? Paris: Gallimard.

Sèze, Romain. 2012. 'Prédication et autorité des imams en France'. Revue d'Éthique et de Théologie Morale, 270: 37-51.

Sèze, Romain. 2013. Etre imam en France: Transformations du 'clergé' musulman en contexte minoritaire. Paris: Le Cerf.

Sèze, Romain. 2014a. 'Les imams de France: Des agents de prévention des processus de radicalisation?' Les Cahiers de la Sécurité Intérieure: Revue de l'Institut National des Hautes Études de la Sécurité et de la Justice, 26: 73-81.

Sèze, Romain. 2014b. 'Condamnations des crimes perpétrés par l'État Islamique par les leaders musulmans de France: De l'unanimisme aux débats'. Observatoire 
Pharos: Pluralisme des cultures \& des religions. https://www.observatoirepharos. com/wp-content/uploads/2014/10/S\%C3\%88ZE-Romain_Mobilisations-etd\% $3 \%$ Agbats-EI_Phar.pdf.

Sèze, Romain. 2015. 'La Ahmadiyya en France: Une minorité musulmane en recherche de reconnaissance'. Archives de Sciences Sociales des Religions, 171 (juillet-septembre): 247-263.

Ternisien, Xavier. 2002. La France des mosquées. Paris: Albin Michel.

Venel, Nancy. 2004. Musulmans et citoyens. Paris: Presses Universitaires de France. Voirol, Olivier. 2005. 'Les luttes pour la visibilité: Esquisse d'une problématique'. Réseaux, 129-130: 89-121.

\section{About the author}

Romain Sèze, Ph.D. in Political Science from the School for Advanced Studies in Social Sciences (EHESS) is a Research Fellow at the National Institute of Advanced Security and Justice Studies (INHESJ) and a member of the Group Societies, Religions and Secularisms (GSRL-CNRS). His research focuses on contemporary Islam, jihadism, and countering radicalization. He is the author of Etre imam en France (Le Cerf, 2013). 


\title{
14 From conservative Islam to the 'Theology of acculturation'
}

\author{
The social and religious trajectory of a French imam
}

\author{
Cédric Baylocq
}

Hashas, Mohammed, Jan Jaap de Ruiter, and Niels Valdemar Vinding (eds), Imams in Western Europe: Developments, Transformations, and Institutional Challenges. Amsterdam: Amsterdam University Press, 2018 DOI: $10.5117 / 9789462983830 / \mathrm{CH14}$

\begin{abstract}
This chapter sheds light on a well-regarded French imam of Moroccan origins and his growing leadership in society, not only at the local but also at the national level. It locates Tareq Oubrou's unique trajectory and discourse within the field of contemporary Muslim leadership, and examines his key contributions to the institutionalization of Islam in France - if not his founding role in the birth of 'French Islam'. The chapter outlines Oubrou's progressive shift from a conservative understanding of Islam in his early twenties to playing a leading role in the theological 'acculturation' and 'secularization' of Islam in France, a process he considers necessary and even urgent in light of the growing tensions in French society.
\end{abstract}

Keywords: Islam in France, theology of acculturation, Tareq Oubrou, sharia of minorities, secularization

On 25 February 2015, one-and-a-half months after the 7 and 9 January 2015 terrorist attacks in Paris led by three French Muslim young adults, the French Minister of Internal Affairs, Bernard Cazeneuve, chose to visit the mosques of Bordeaux and Cenon in South-Western France to publicly announce the creation of a 'National Dialogue Commission with French Islam' (Instance nationale de dialogue avec l'islam de France). This commission gathered for the first time on 15 June 2015, and aims to supplement the work of the 
existing Conseil français du culte musulman (CFCM), a representative body of the main Islamic federations in France, created in 2003, by dialoguing more broadly with French Muslims in order to tackle pressing issues such as imam training, countering islamophobia and radicalism, searching for solutions to the lack of mosques in certain parts of the country, or facilitating the organization of religious feasts. This was a new turn for France. By making such an important announcement in those particular mosques, the French Minister of Internal Affairs might have been suggesting that the local clergy there are good examples of Republic-compliant imams.

A renowned imam leads the first mosque, which was visited by Minister Bernard Cazeneuve in Bordeaux. For almost a quarter century, Tareq Oubrou has been acting as El Huda Mosque's main imam and rector. Its representatives commonly refer to it as the 'Mosque of Bordeaux' to foster its local rooting and facilitate its symbolic appropriation by the non-Muslim neighbourhood. This mosque was established in 1982 in a former wood factory in Bordeaux. Born in 1959 in Taroudant, Morocco, Oubrou has been recognized as a local and national figure - if not role model - in the French imamate. Oubrou progressively shifted from holding a conservative, if not rejectionist, understanding of Islam in his early twenties to playing a leading role in the theological 'acculturation' and even assumed 'secularization' of Islam in France - a process he has deemed necessary and even urgent in light of growing tensions and conflicts. The second mosque visited by the Minister is located in Cenon, a popular neighbourhood facing the wealthy city of Bordeaux on the other side of the Garonne River where a significant number of North African migrants settled during the 1970s and 1980s. Like the El Huda Mosque, it is owned and run by the Fédération musulmane de la Gironde (FMG), the former Association des musulmans de la Gironde (AMG), which changed its name in 2010 as a result of a clash between the followers of Oubrou and his local opponents. The French-Mauritanian cleric Mahmoud Doua, Oubrou's closest disciple, is the imam in chief at this mosque.

In this chapter, I locate imam Tareq Oubrou's unique trajectory and discourses within the field of contemporary Muslim leadership in France and examine his key contributions to the institutionalization of Islam in France, if not his founding role in the birth of 'French Islam'.

\section{Biographical elements and pastoral trajectory}

His father, who was the director of an elementary school, and his mother, who taught French in the same school, brought up Tareq Oubrou in Taroudant. 
As a result, 'books have always been part of [his] environment' (interview with Oubrou, Bordeaux, March 2003). While Taroudant is known for training Maliki clerics, nothing in Oubrou's early life predestined his later embrace of a clerical vocation. His father was 'not deeply religious' (ibid.), and his mother wanted him to become a physician, certainly not an imam. In fact, they would even consider his current profession to be a social disgrace, as his migration to France was initially in the pursuit of higher education.

Oubrou left Morocco at the age of nineteen and settled in Bordeaux in the South of France, where he studied biology and medicine. It was in Bordeaux that Tareq Oubrou experienced what he called 'the encounter with God, a mystical experience' (interview, Bordeaux, March 2003), which would radically transform his life and change his trajectory. At that time (in the early 1980s), Islamic organizations were not yet well established or were about to emerge in France. Local Muslim communities mostly consisted of North- and West-African migrant workers, some French Muslims born in France, and students who mostly came from North Africa (such as Oubrou), Lebanon, and Syria. At that time, Muslims living in France lacked clerics who could lead the prayers and provide basic teachings about Islam. It is in this context that Oubrou began his journey in the imamate, moving from Bordeaux (1980-1982) to Pau (1983-1986), Nantes (1986-1987), and Limoges (1987-1992), and eventually returning to Bordeaux to take up a position as the resident imam at El Huda Mosque. Beginning as the imam in charge of leading the prayers, he became an imām al-atfäl ('imam for kids'), and then served as the imām khațīb ('sermon imam'). Eventually he became the main figure of the local Muslim community, and started to provide legal consultations (Baylocq, 2008), courses, and conferences on traditional disciplines such as the general approach to the Quran (rather than tafsir), elements of figh, and kaläm ('Islamic theology'), in addition to his continued role in preaching and leading prayers. Furthermore, he increased the realms of own expertise to encompass Islam and secularism, the sharia of minorities, and the theology of acculturation/secularization. Following Frégosi's typology (2004), Oubrou combined at least three functions that are usually divided among distinct clerics: imam, jurist, and lecturer.

Oubrou's work has received little attention in the academic community (Bowen, 2004; Caeiro, 2006; more broadly, Hashas, 2014; Sèze, 2013). While these studies shed much-needed light on his intellectual project, it is important to note that the practical and theological aspects of Oubrou's activity are inseparably intertwined, as we will see below.

From the beginning of the 2000s, Oubrou became involved in the broader local landscape: participating in interfaith dialogs, organizing conferences 
outside the mosque, engaging in debates with academics, and participating in institutional meetings, most notably with Alain Juppé, the mayor of Bordeaux since 1995 who later became a Minister. Since late 2009, Oubrou regularly gives interviews to newspapers and frequently participates in media programmes, particularly on the radio station France Culture and a weekly programme on Islam that is broadcast by the state-funded television channel France2. He has become increasingly regarded as the articulate, outspoken, and moderate Muslim interlocutor that non-Muslim audiences were looking for.

Apart from these public activities, most of his time remains dedicated to his function as the imam of the Bordeaux mosque. There, he has implemented bilingual sermons in French and Arabic and was the first in France to designate a room for Muslim women on the same floor as men (at the back of the ground floor, their space being differentiated by a small step of about 30 centimetres). Yet, his lay involvement beyond the strict borders of the Muslim community has brought scathing criticism from his local opponents. He has been particularly accused of being more oriented 'toward the outside' than towards the needs of his Muslim fellows, as well as being 'compromised' by his activities in the political field. These allegations and tensions eventually led to clashes with threats and rushes in 2010 inside the Association des musulmans de la Gironde (AMG) - an organization related to the Union des organisation islamiques de France (UOIF), which is usually considered an avatar of the Muslim Brotherhood. Jawad Rhaouti, a teacher of mathematics and former president of AMG, wanted to wrest control of this local institution from Oubrou and his followers, whom he accused of not doing enough for the community and for abusing the money collected as zakat. Oubrou and his coalition took the case to court and won the right to continue leading the organization.

But Oubrou's personal and social trajectory has not always been a success story. Until his return to Bordeaux ten years after beginning his clerical career there, he endured social hardship: 'I was a homeless imam without even realizing it', as it was at that time 'considered normal for an imam to work for free' and an honour to hold that position (Oubrou, 2009, p. 27). The poor socio-economic conditions of Muslim communities in France at the time should not be overlooked, a situation exacerbated by the fact that French law forbids the public funding of religions (the 1905 law on 'the separation between the Churches and the State'). Oubrou would regularly sleep in mosques or, at best, in a flat provided to him by one of his coreligionists. A number of French Muslim activists from the 1980 os and 1990s acknowledge the challenges he faced and the poor social conditions he experienced during 
this period. While some of these activists did not share his liberal opinions, they kept his past experiences in mind and did not reject him, unlike the new generation of the French Muslim Brotherhood and, more notably, the Salafis. Oubrou therefore gained his religious legitimacy through acting directly in the French Muslim field before he started thinking and making theological propositions.

Yet a symbolic element could also explain Oubrou's current place in the French Muslim field. David Henning Fluharty has established the conditions that lead to the advent of a charismatic religious leader: 'The charismatic leader finds the living conditions of certain people objectionable and seeks modification of their conditions' (1990, p. 63). Fluharty then draws on the figure of the Zaddik ('exemplary men of good acts' in the Hebraic tradition) as a paradigm for understanding what constitutes religious charisma:

In general terms, prior to becoming recognized by many people, the potential charismatic leader must become aware of the earthly conditions, the good and the bad, and commit himself to improve - for his people or tribe - those conditions he finds objectionable. (Fluharty, 1990, p. 63)

While Oubrou eventually came to be widely recognized at the stateinstitutional level for his reformist approach towards Islam in a secular context, his legitimacy as an engaged imam at the grass-roots level preceded this recognition. This partly explains why he allows himself to be provocative about sensitive issues within the Muslim community such as the veil or minarets. Accordingly, one of the reasons for Oubrou's founding of the Association des Imams de France (The Association of imams in France) in the 199os was to tackle the social issues faced by imams in France and to foster collective discussions on imam training. Yet, he deliberately kept this association quiet to avoid competition with the Chateau Chinon Institute for Human Sciences - an imam-training institute associated with the Union des organisations islamiques de France, believed to be the French branch of the Muslim Brotherhood - and with Dar al-Fatwa (Interview, November $14^{\text {th }}$ ) the religious theological body from the same organization - even though these two institutions had failed to address the issue of the socio-economic status of imams in France or to establish themselves as the uncontested religious authorities in the country.

Oubrou positions himself not only on theological matters but also at the crossroad of different areas of knowledge. For instance, in a conference organized in 2014 he characterized postmodernity as follows: the advent of 
'technics', 'emotions', and 'tensions'. ${ }^{1}$ Ongoing secularization has generated a religious backlash, and modern imams must according to him, carefully handle this process by issuing relevant religious fatwas that will not exacerbate social, religious, and intercultural tensions. In Oubrou's view, one cannot frame sermons and disseminate religious opinions in abstracto or by referring to the ninth- and tenth-century 'episteme' (that is, the classical founding period of the traditional Islamic schools of law), as he likes to phrase it in a Foucaldian fashion. One should rather use the term of what he calls 'proximal theology'. He therefore advocates the advent of Islamic scholars who are both ${ }^{c}$ älimūn bi-l- ${ }^{c}$ așr wa ${ }^{c} \bar{a} l i m u \bar{n}$ bi-l-sharì ${ }^{c} a$ (scholars of contemporary times and of Islamic law), by which he means that European imams of the twenty-first century should be knowledgeable in both the profane and religious sciences and should apply their profane knowledge to the interpretation of their religious traditions. While Mohammad Arkoun (1984) dreamed about a secular and deconstructionist approach - which would hardly be followed by a large section of observant Muslims - Oubrou wishes to accomplish this goal from the inside, that is from the inner circle of observant Muslims and through the use of traditional disciplines such as fiqh.

\section{Classical Ikhwanis discourse from the 1980s}

Oubrou did not always hold reformist and 'liberal' views, however. In an old video first released by a local member of the Muslim Brotherhood and circulated in 2007 by a far-right website through the Google Video online platform, we can see and hear Oubrou debiting the all-encompassing 'conspirationnist' and hegemonic themes consistent with classical radical Islamist thought of the 1970s-1980s. ${ }^{2}$ Examples of his comments in this video are the following: Mustafa Kemal Atatürk, who abolished the last Islamic Caliphate, is 'in reality a Jew disguised as a Muslim'; anti-Western statements and moral panic discourse about 'the decadency of moral values in Western

\footnotetext{
1 'L'Islam est-il sécularisable? Une approche à travers le concept de furūqyyia', 9 October 2014, 'The people, the State and Politics in the Mediterranean. Between Islam and Secularization?' colloquium organized by the Center Jacques Berque for the Study of Human and Social Sciences (CNRS USR 3136), the Institut Français in Morocco, and Mundiapolis University, under the supervision of the author.

2 Available at: https://www.dailymotion.com/video/xıygqq_hasan-al-banna-conference-enfranca_news (the other links are indicated at the bottom of this link). The video is presented as having been recorded at the beginning of the 1990s, but it is possible that it was recorded in the late 1980s, when Oubrou was about 27 years old.
} 
societies'; and assertions that the truth comes only from Islam and that what comes from the outside is 'misguiding'. He further states that 'the umma was in an illegal situation, I would even say in a sinful situation as the caliphate is an obligation'. He dwells upon an apology of the founding father of the Muslim Brotherhood, Hassan al-Banna, whom Oubrou used to consider a 'saint' and even to have abilities similar to those of the prophet Muhammad in shaping human behaviours. He then develops the usual Islamist holistic conception of Islam as regulating every aspect of life, which is a leitmotiv in Islamist organizations and political parties (see, notably, Pontificio Istituto di Studi Arabi e d'Islamistica, 1981-1982; and Tibi, 2014, pp. 259-260).

Oubrou quite visibly no longer holds these views. When questioned about this early period, he stated that this logiciel islamiste ('islamist hardware') had wasted his time, and that he now urges young French Muslims to refrain from similar wasted efforts.

\section{$4 \quad$ Oubrou's key theological concepts}

At the beginning of the new century when Oubrou first started to introduce reformist views on Islam into the public debate, he was initially reluctant to use the term 'adaptation', or even 'reformation', instead choosing to talk about 'revisiting' the tradition. However, he progressively took up those terms (adaptation and reformation) to define his work and, since 2010, has even bypassed them by forging a notion of the 'theology of acculturation' and stressing the need for a 'secularization of Islam' in the contemporary French and European contexts. Later, he even used the term 'endogenous' to refer to the much-needed separation between politics and/or traditional Arabic culture on one hand, and Islam as a faith and spirituality on the other hand (lecture, Casablanca, 2014). His book on this matter is still pending; he has spoken of its publication but it is not yet released. In addition to my own enquiry (Baylocq, 2008), the originality of Oubrou's theological and canonical reflections have been noted by several scholars (Bowen, 2004; Caeiro, 2006; Hashas, 2014). The following sections discuss some of the core theological principles through which he approaches Islamic sources.

\subsection{General hermeneutical approach towards the Quran}

To better understand Oubrou's approach towards traditional Islamic sources in contemporary contexts, it is crucial to stress his attempt to distinguish the content of revelation that is dedicated to the first receptors of the message 
- that is, the Arabs of the Arabian Peninsula in the seventh century - from the Quranic content that is dedicated to humanity as a whole. This distinction is fundamental: here lies the major divide between Oubrou and traditionalist trends such as classical Ikhwanis or Salafis, who decline to apply a hierarchical reading of the verses of the Quran. Oubrou aims at qualitatively distinguishing two levels of Quranic discourses from those delivered by God to humanity through its first Arab recipients. Accordingly, his return to foundational principles is a literalist one. In this regard, Oubrou is not thoroughly innovative, as classical traditionalists have already forged the notion of asbāb al-nuzūl ('the circumstances of revelation') to determine the specific historical and political circumstances under which each verse was revealed. But Oubrou has articulated a more extensive concept than asbāb alnuzül; instead, he speaks of 'the Quranic moment'. This particular 'moment' requires reflecting upon the whole anthropological, cultural, socio-economic, and political living conditions of the Arabs from the Arabian Peninsula at that time. Oubrou's key idea is that God not only delivered a universal message, but also took into consideration the cultural reality of the time of the revelation. This is a recurrent view that Oubrou often expresses during sermons, courses of Islamic theology, and public talks, notably through the sentence: "The fact that God took into account the context of the revelation does not mean he canonized it' (interview, Bordeaux, August 2007). Here lies a subtle indication of the 'divine intention', which Oubrou uses to offer a paradigm for organizing, classifying, and giving a hierarchical structure to the vast normative material provided by the Quran. Without this paradigm, Oubrou asserts, the divine words become unintelligible and lead a lot of young Muslims to misguided behaviours in the contemporary world.

To put it differently, to be understood and obeyed by the first recipients of his divine message, God had to take into account the anthropological background of Bedouin society (Oubrou, 2006b, pp. 66-70). ${ }^{3}$ Oubrou considers this a token of God's great wisdom, as it would ease the reception of his message. If the revelation intended to transform the seventh-century Arab pagan context and to challenge Judaism and Christianity (while accepting them as part of its own genesis), it did not aim at radically revolutionizing this context, in Oubrou's views. God would not have intended to implement a brutal rupture through his revelation and take the risk of his prophet being definitively misunderstood, as other prophets had been before him. In this

3 See our English translation of 'A brief historical overview of the birth of Islamic theology, its adaptation and formalization', translated from Oubrou, 2006b, and published as an annex of an interview with the imam at http://iqbal.hypotheses.org/842 (March 2013). 
regard, relying on Ibn Taymiyyah, Oubrou says that God and his prophet applied a universal paradigm of ease of religion for people, based on the verse: 'Allah intends for you ease and does not intend for you hardship' (Quran 2:185). In Oubrou's views, this indicates 'the divine pedagogy', a closely related concept that he often stresses. Muslim individuals are urged to be inspired by this gradual perspective in relation to their faith. God is the omniscient and omnipotent and could have imposed everything at once if he wanted to, and yet he did not. For Oubrou, this attitude is exemplified by the fact that God did not abolish slavery, even though he is 'the most merciful'. Abolishing slavery would have imperilled the whole economic system of the Arabs from the Peninsula at the time. But he did open up a possibility for enslaved people to be freed. Building on key principles of late Mu'tazili thought, Oubrou stresses that God allowed human beings to make use of their autonomy of judgment and reason. This also helps in accounting for what can appear to contemporary believers as an abuse (slavery) that is tolerated by the Quran. This hermeneutical paradigm, i.e., 'The fact that God took into account the context of the revelation does not mean he canonized it', predicated upon the contextualization of the sacred words of God (whether in their original context or in the contemporary context), constitutes a starting point for Oubrou's thought, rather than an all-encompassing and static theology. Consequently, Oubrou asserts that 'Islam must be disentangled (désenveloppé) from the Arab culture of the Quranic moment (la culture du moment coranique), ${ }^{4}$ which has been canonized together with the core tenets of revelation - that is, the revealed universal principles that are applicable to all times. This step aims at subtly differentiating the intangible parts of the divine message from the contextual and cultural circumstances of the Arab Peninsula in the seventh century. Ultimately, this désenveloppage ('disentanglement') process of Islam from its ancient cultural pellicle needs to go further: the core Islamic intangible values and principles should be réenveloppé ('re-entangled') into the local contemporary culture in which Muslims are living (in this case, France).

In short, it is necessary to return to the sources to discriminate what has been incorporated into the discursive vehicle of Islam, its traditional construction that is closely intertwined with specific historical circumstances, to better highlight the intangible and universal aspects of the divine message. Thus, this return to the sources does not intend at all following the literal

4 This idea was first articulated at the Congress of the former Association des Musulmans de la Gironde (AMG), 'Espace Marx', in Bordeaux, 5 March 2003, and then reiterated during several public occasions and further developed in an interview with the author in October 2006. 
behaviour of the prophet like Salafis do. This line of thought would eventually lead Oubrou to advocate an 'acculturation of Islam' into Europe in general and France in particular. Such an 'acculturation' implies that Islam would be peacefully integrated into new cultural contexts and thus more easily accepted, and would also be transmissible within new contexts as 'there is no transmission of religion without culture' (interview, Bordeaux, June 2009).

\section{2 'Sharia of minorities'}

Though 'sharia' has become a rather worrisome term, in Oubrou's thought it does not involve the all-encompassing meaning usually found in traditional Muslim jurists' definitions or in classical discourses of the Muslim Brotherhood. The Pakistani scholar Muhammad Khalid Masud, who is both traditionally and academically trained, framed the problem with classical hegemonic views of sharia in the following way:

Muslim jurists in the past were quite aware of the constant need to reconcile contradictions between social and legal norms. They continuously adjusted laws to bring them in line with the customs and norms of the people. The normative basis of the institutions and concepts such as family, property, rights, responsibility, criminality, civil obedience, social order, religiosity, international relations, war, peace, and citizenship have changed significantly over the last two centuries. The weakness of the traditional construction of the sharia in meeting social expectations stresses the need for a fresh quest for the normative basis. Consequently, Muslim views on the position of sharia in Muslim polity have become increasingly polarized between secularist and traditionalist viewpoints. (Masud, 2001, pp. 4-5)

In other words, Muslim thinkers should not replicate classical representations of sharia in a non-Muslim, secular country. Sharia cannot substitute for French secular positive law since, as Oubrou argues, 'The judgment of the judge is the only broadsword imposed upon people' (AMG Congress, Bordeaux, March 2003). Oubrou considers this situation as an opportunity and intellectual challenge, rather than a constraint. A key notion he has been keen on propounding is sharia de minorité ('sharia of minority'). In his own words, Oubrou aims

to draw the canonical basis for a canonico-legal Islam, that is to say conform to a sharia thought and elaborate it in the global French juridical and constitutional context. The goal is to realize a double conformity to sharia's canon and to the law of the Republic, showing there is neither 
antimony nor fracture between Islam and its secular context. This vision of sharia is dominated by an 'ethic of conciliation', oriented by the concern of Islam as a religion and spirituality totally integrated into the French reality. (Oubrou, 2006b, p. 420)

The term 'sharia of minority' refers to a revised version of Islamic normativity that is available for the use of a minority and operates at the individual level. A Muslim minority must refrain from challenging the current (secular) laws of the society it lives in.

Oubrou stresses that his thought is influenced by the reality of French Muslims and his day-to-day activity as an imam, rather than the reverse. This is what he refers to as a théologie proximale ('proximal theology') as mentioned earlier, a theology as close as possible to the people and their context. The outcomes of his canonical and theological reflections, themselves based on his observations and practices as an imam, are then worked back into his pastoral activity. For instance, he has created four types of legal responses (fatwas) to concrete problems and questions raised by French Muslims during his legal consultations: (1) 'the positive fatwa by articulation', the most simple type of fatwa, which is directly related to a formal, unambiguous, and available legal Islamic content and therefore generating an 'automatic enunciation', a quite direct answer; (2) the 'positive common fatwa', which appraises the general level of practice of the worshiper so that the fatwa will not destabilize his social life; (3) 'the positive situational or individualized fatwa', which is a biodegradable fatwa that should only be used in that one particular situation by the individual who requested it; and (4) 'the canonical mutism' or 'silence'. Response (4) is the most original: Oubrou theorizes the necessity for a mufti to sometimes keep silent to avoid disrupting the daily life of a fellow Muslim with non-adapted and unnecessary norms (see Oubrou, 2004, pp. 205-230, for this typology and Baylocq, 2008). Through this innovative attitude, he deliberately aims at tackling the 'normative cancer' (interview, Bordeaux, November 2006) that is often propagated within his community; this would eventually lead to the 'contraction of the domain of sharia' (to echo Abdolkarim Soroush's concept).

Applying Andrew March's model of 'Theocrats living under secular law', Oubrou's work would more or less fall under the 'Thicker Social Contract Model, or Overlapping Consensus' category, defined as 'a doctrine of affirming the substantive justness or legitimacy of a politico-legal system not based on one's own theocratic doctrine, but without abandoning, dissolving or moving beyond the terms of that theocratic doctrine' (March, 2011, p. 32) - although probably in a more secular-friendly fashion. 


\subsection{Toward a theology of acculturation/secularization}

The notion of a 'sharia of minority' has attracted the attention of a number of scholars (Bowen, 2004; Caeiro, 2006; Hashas, 2014), as it is the first serious European attempt to provide a solid theoretical foundation for the practices of and discourses on Islam in European secular contexts. Sheikh Fayçal Mawlawi, with whom Oubrou was acquainted in the mid-1980s (when the Lebanese scholar was the guide of the Union des organisations islamiques de France), was more circumspect in using the classical tool of the figh al-aqalliyya $\bar{a}$. Yet Mawlawi was the first to pave the way for an adaptation of Islamic normativity in line with the new European landscape at the theological and canonical levels; Oubrou also stresses the need to adapt discourses and practices.

In Oubrou's view, the culture and political philosophy of the majoritarian 'host' society must be taken into account by Muslim jurists and secondgeneration, French-born Muslims, who are likely to adopt and adapt a version of Islam forged in their parent's homelands or in Saudi Arabia (through the influence of cassette sermons; the Internet, particularly sermons on YouTube; Wahhabi books translated into French; Arab satellite television channels; and the like). In this regard, a footnote in his 2006b book arouses some interest. This quote is significant as it reveals Oubrou's subversive reading of Islamic history (here, of the Al-Andalus period) vis-à-vis Muslim apologists and even the majority of his community. By contrast, we can discern the kind of acculturation processes he advocates for Muslims living in Europe:

Islam did not invariably succeed in integrating into other cultures. Despite eight centuries in Spain, Muslims did not integrate themselves definitively. They stayed culturally selfish, anthropologically Arab-Berbers, linguistically Arabs, and ethnically community-based. The so-called model of Andalusian Islam, often depicted as a historical success, should not be considered as such. It is more to be considered a failure to be meditated upon. This presence, we admit, contributed to the progress of the West. It even indirectly contributed to the advent of the Enlightenment, thanks to its intellectual and scientific contribution, but at the same time it participated in energizing a hostile Christianity - which was not originally so - that expulsed it from Europe as a result. On the contrary, Islam succeeded in settling definitely in other civilizations and linguistic areas where it was acculturated and consequently still exists nowadays... Of course, Christian fanaticism played an important role in this rejection of Islam in Spain because, after the Reconquista, Christians were not as tolerant as the 
Muslims had been when they conquered Spain. But we did not mention this aspect in our critique because it is not directly related to our issue, dealing only with intrinsic factors of adaptation. (Oubrou, 2006b, p. 70, my italics)

As a consequence of this failure, Islam as a civilization collapsed while Islam as a religion survived. It has to borrow from the civilization or local culture in which Muslims are settled (in this case, Europe), if they wish to deep-root their religious belonging and make it accepted (rather than only 'tolerated'). Moreover, this process represents for Oubrou the only chance for Islam to be transmitted, disseminated, and reproduced.

Oubrou outlines one final step after the reconciliation of cultural and religious belongings: Muslims should seize the opportunity of living as a minority in a secular state to modify their episteme and adjust their approach to their religion. He remains aware of the fact that the current historical phases experienced by the Arab world (before the 2011 Arab Spring, at least) do not facilitate this project of reappraisal. Thus, the next and final phase of his theological project is to initiate a process of secularization that will ultimately end in merging the secular and the religious. Yet this process must be conducted within Islamic categories to be valid and fully accepted. Oubrou certainly anticipates that a 'savage secularization' would lead to a severe backlash. He is thus very careful in this project:

What I mean by 'intrinsic theological secularization' is a secularization that does not leave Islam. It remains fully intra-Islamic, in the sense of a relation of discernment and distinction between the sacred and the profane, the divine and the human, whose repertoires could join as well as depart from one another. It seems necessary in particular to distinguish the permanent matters from the temporary in the Quran and the Sunna. In this perspective, secularization is the result of interactions between different dimensions of Islam - notably between the theological and canonical, the metaphysical dogmatic and the practical sharia - in historical and anthropological conditions, which determine its shape and scope. Thus, it allows a perpetual renewal of Islam by a conscious, perspicuous, and humble interpenetration able to sort immutable divine principles from circumscribed thought. (Oubrou, 2006b, p. 102)

Here are the lineaments of an adaptation, a reformation of the traditional concept of sharia in the light of secularization, but still relying on the main Islamic ethical views and the maqāsid al-sharì ${ }^{c} a$ perspective, using fiqh rather than a completely secular approach such as those developed by modernist 
intellectuals like Malek Chebel, Abdenour Bidar, or Abdelmajid Charf. The notion of 'sharia of minority' appears to be the first step toward the notion of a 'theology of acculturation, which goes much further. The latter notion, as we have just seen above has the ambition to be the blueprint for a harmonious integration of Islam in the abode of secularism (i.e. France). It could thus be the occasion for a new case study once the present imam and theologian would have developed this notion in the future whether in publications, conferences, courses or sermons. In an anthropological perspective, the reception of this work among Muslim groups also promises to be an interesting point to work on ${ }^{5}$

\section{Conclusion: Pursuing liberal reform in a time of tensions and violence}

To understand Oubrou's positions on sensitive issues that have arisen in the French public debate, such as the veil or minarets, one must locate them in his broader theological project. Regarding the veil, he claims that a hierarchization of norms and practices is required in Islam. The veil, he first recalls, has not to be confused with al-ibādāt ('the ritual norms'), as it instead pertains to the domain of al-akhlāq ('the moral norms'). He is therefore highly critical of his coreligionists erecting this practice as a symbol, even as 'a flag of Islam' (interview, Bordeaux, May 2009). This position has caused him trouble with the French Muslim Brotherhood, up to the point that he was about to be expelled from the UOIF - particularly after an interview released in the newspaper Le Monde on 16 October 2009, in which he declared: 'If I were to be provocative, I would tell women: Put your veil in your pocket! Today I would rather say it is an implicit recommendation, which corresponds to an ethical modesty from the Quranic moment. Yet, women who do not wear a hijab do not commit a sin.' Less than a year after this statement, his disciple Mahmoud Doua, the imam of Cenon, organized a meeting at the Mosque of Bordeaux (14June 2010) for Oubrou to theologically address the problem of the hijab. He developed his views on the hijab during a three-hour conference, facing some fifty local Muslims, more than half of whom were women. The transcript of this lecture runs to eight pages.

5 He has not written extensively on that particular question since, but has developed the idea on different occasions: Oubrou Tareq, 'La sécularisation de l'Islam à travers la charia de minorité', Conference at the International Summer School of Anthropology $\left(5^{\text {th }}\right.$ edition), Irissary (French Basque Country), July 2010 (dir. Pierre Bidart and Abel Kouvouama), and 'L'Islam est-il sécularisable? Une approche à travers le concept de furuqiyya', October 2014, op.cit. 
As for minarets, the question is even easier to solve, as there is 'no canonical obligation (for a mosque) to display a minaret' (interview, March 2009). As a result, the new mosque project in Bordeaux, although bigger and more accessible through providing parking facilities, does not display a minaret. Coherent with his conception of acculturation and integration, he oriented the architect of the future mosque toward a locally embedded and modern style of architecture, stressing at the same time the fact that the building must be identifiable as a mosque from the outside, as the processes of integration and acceptance must be reciprocal, in his view.

This positioning on matters relating to the question of Islamic visibility which Oubrou wishes to be 'discrete' (Le Monde, October 2013) - in a secular public sphere must be read in relation to his ambition of progressively facilitating a peaceful and harmonious integration of Islam in France at a time characterized by conflicts (which Hashas examines as a 'Geotheology', 2014). In addition to this reformist project, he is committed to forming a theological and canonical perspective - in which one might also hypothesize that there is some influence from his Sufi orientation, an aspect that would require a separate inquiry.

In the aftermath of the Paris attacks in January 2015, the UOIF (with which he is affiliated) announced the creation of a Muslim Theological Council of France (Conseil théologique musulman de France, CTMF). It will be interesting to observe whether this structure will operate as a 'driving belt' of Oubrou's current line of thought, or if the conservative trend in UOIF will have the upper hand. The series of attacks in downtown Paris on Friday, 13 November 2015 illustrated the ever more urgent need for the propagation of a critical approach and liberal reforms among Muslim youth - a paradigm that would be likely to counter pervasive radical approaches and theologically accompany the current processes of secularization and acculturation overall.

\section{References}

Arkoun, Mohammed. 1984. Pour une critique de la raison islamique. Paris: Maisonneuve et Larose

Baylocq, Cédric. 2008. 'Questions de pratiquants et réponses d'imam en contexte français: Economie de la fatwa dans les consultations juridiques de Tareq Oubrou'. Revue des Mondes Musulmans et de la Méditerranée, 124: 281-308.

Bowen, John. 2004. 'Pluralism and Normativity in French Islamic Reasoning'. In Islam, Pluralism, and Democratization, edited by Robert Hefner, 326-338. Princeton: Princeton University Press. 
Caeiro, Alexandre. 2006. 'The Shifting Moral Universes of the Islamic Tradition of Ifta': A Diachronic Study of Four Adab al-Fatwa Manuals'. The Muslim World, 96: 661-687.

Fluharty, David Henning. 1990. 'Charisma as Attachment to the Divine: Some Hasidic Principles for Comparison of Social Movements of Gandhi, Nasser, Ben-Gurion, and King'. Ph.D. thesis, University Microfilms International, Ann Arbor, Michigan and University of New Hampshire.

Frégosi, Franck. 2004. 'Limam, le conférencier et le jurisconsulte: Retour sur trois figures contemporaines du champ religieux islamique en France'. Archives de Sciences Sociales des Religions, 125: 131-146.

Hashas, Mohammed. 2014. 'Tareq Oubrou's Geotheology: Shari'ah of the Minority and the Secularization of Islamic Theology in the European Context'.Journal of Muslim Minority Affairs, 34(4): 1-21.

March, Andrew. 2011. 'Theocrats Living under Secular Law: An Engagement with Islamic Legal Theory'. The Journal of Political Philosophy, 19(1): 28-51.

Masud, Muhammad Khalid. 2001. 'Muslim Jurists' Quest for the Normative Basis of Shari'a'. Inaugural Lecture, Leiden University.

Oubrou, Tareq. 2004. 'La sharî‘a de minorité: Réflexions pour une intégration légale de l'islam'. In Lectures contemporaines du droit islamique: Europe et monde arabe, edited by Franck Frégosi, 205-23o. Strasbourg: Presses Universitaires de Strasbourg.

Oubrou, Tareq. 2006a. 'Shari'a de minorité'. In Dictionnaire de Bordeaux, edited by Mario Graneri-Clavé. Toulouse: Loubatières.

Oubrou, Tareq. 2006b. L'unicité de Dieu:Des noms et des attributs divins. Saint-Denis: Bayane.

Oubrou, Tareq. 2009. Interview by Cédric Baylocq and Michaël Privot. Profession Imam (coll. Spiritualités). Paris: Albin Michel.

Pontificio Instituto di Studi Arabi e Islamici. 1981/1982. 'Courants actuels dans l'Islam: Les frères musulmans'. Etudes Arabes, $1 / 2$.

Sèze, Romain. 2013. Être imam en France: Transformation du clergé musulman en contexte minoritaire. Paris: Cerf.

Tibi, Bassam. 2014. Political Islam, World Politics and Europe: From Jihadist to Institutional Islamism. Oxon, New York: Routledge. 


\section{About the author}

Cédric Baylocq holds a Ph.D. in Anthropology from the University of Bordeaux. He is a research associate at the LAM, Sciences Po Bordeaux and the CISMOC, University of Louvain. He co-authored Profession imâm. Entretiens avec Tareq Oubrou (with Michaël Privot and Albin Michel, 2009, augmented ed. 2015) and has written a dozen articles on Islam in France and Morocco in peer-reviewed journals or edited volumes. He is currently in charge of a national fund dedicated to supporting social science research on Islam in France. 



\title{
15 Muslim chaplaincy as a model for imamship
}

From liminality to immanent spirituality

Mansur Ali

Hashas, Mohammed, Jan Jaap de Ruiter, and Niels Valdemar Vinding (eds), Imams in Western Europe: Developments, Transformations, and Institutional Challenges. Amsterdam: Amsterdam University Press, 2018 DOI: $10.5117 / 9789462983830 / \mathrm{CH} 15$

\begin{abstract}
What is the role of an imam? What is expected from an imam? How can an imam meet the expectations of the community? This chapter argues that the current state of imamship in the United Kingdom is in dire need of a model that could help imams understand and practice their role better. While there are many models available, this chapter considers the model provided by Muslim chaplaincy. It argues that current imam training is stuck in liminality; by employing an approach to spirituality (to be read as imamship) that is immanent (to be read as chaplaincy), as opposed to transcendent, imams will be better able to reconnect with their congregation.
\end{abstract}

Keywords: Islam in the United Kingdom, chaplaincy, chaplains, Darul Uloom, liminality

1 Introduction

You need to decide whether you are a mosque imam or a chaplain. If you believe you are a mosque imam, get the hell out of here! (field notes, 2011)

The above quotation is indicative of a possible confusion between the role of a mosque imam and the work of a Muslim chaplain. The context of the quotation happened to be a counselling session conducted by a senior Muslim hospital chaplain with a junior colleague who was facing formal disciplinary action (Ali and Gilliat-Ray, 2012, p. 90). Despite the apparent 
differences between the two roles, in this chapter I provide evidence that mosque imams can immensely benefit from Muslim chaplains and propose that Muslim chaplaincy is a good model for imams to follow. This chapter builds on the work of Asim Hafiz (2015) and provides support for his thesis, albeit using a different dataset and theory (that Muslim chaplaincy is a good model for imamship). The empirical evidence for the chapter comes from the dataset of a research project on Muslim chaplaincy conducted at Cardiff University between 2008 and 2011. The training of imams and the contributions of Muslim chaplains were theorized using variations of Victor Turner's 'liminality theory' $(1967,1991)$ and Sherman Jackson's theory of 'immanent spirituality' (2005). From the outset it is important to mention that when I use the word 'imam' in this chapter, I am referring to either those mosque imams in Britain who are from South Asia and have studied the Dars-i Nizami curriculum in a traditional seminary known as a Darul Uloom, or to their British colleagues who have studied in similar institutions in the West. Darul Ulooms, literally meaning a 'House of Sciences', are traditional Islamic seminaries found throughout the Indian subcontinent as well as in the diaspora where children are sent to train as imams and religious leaders (Geaves, 2008; Gilliat-Ray, 2006; Metcalf, 1982; Zaman, 2010). A chaplain can loosely be defined as a person who provides spiritual and pastoral care within an organization. Although chaplaincy traditionally evolved out of Christianity, the term 'chaplain' is now increasingly associated with other faith traditions (Gilliat-Ray, Ali, and Pattison, 2013).

With the 'securitization' of the Muslim community in European policy since the 199os (Birt and Lewis, 2010), much interest has been shown in the public role of imams and their training. In recognizing the important role imams play in the community, the British Home Office acknowledged that 'Imams are the religious leaders of the Muslim community', but they are 'in need of coordination and unity' (Home Office 2005, cited in Rahman, Syed Tohel, and Shaynul, 2006, p. 7). Despite this acknowledgement, imams and Muslim religious leaders were considered part of the problem and not the solution, and the plethora of reports and policy documents produced on them can almost certainly be said to be driven by security concerns (Birt, 2006) and a number of them are directly related to a counter-terrorism agenda (Dyke, 2009; Hussain, 2010; Hussain and Tuck, 2014). The concern with imams and their training is not confined to the United Kingdom, but has been the subject of much discussion in Europe (Husson, 2007).

The above notwithstanding, some policy makers have shifted their focus from viewing imams as a part of the problem to part of the solution. Birt 
(2006) argues that the government's ideal 'good imam', as opposed to a 'bad imam', was modelled on an Anglican template, so therefore a 'good imam' is understood in terms of what a 'good priest' should be. He argues that civic religion has defined the remit of the role envisaged for the 'good imam', which according to the government is: 'to embody civic virtues, interfaith tolerance, professional managerial and pastoral skills, possibly become involved in inner city regeneration, work as an agent of national integration (most importantly on behalf of his young unruly flock), and wage a jihad against extremism' (Birt, 2006, p. 687).

This has been aptly reiterated by the authors of a government report undertaken by the Department of Communities and Local Government entitled The training and development of Muslim faith leaders: Current practice and future possibilities (Scott-Baumann, Mukadam, Chowdhary, and Contractor, 2010). An assessment by Ataullah Siddiqui of Islamic Studies provided by higher education institutions in the United Kingdom and the possible accommodations that could be made for the training of imams in higher education (Siddiqui, 2007) led the then-Minister for Education, The Right Honourable Bill Rammell, to announce a grant of $£_{1} \mathrm{M}$ for the Higher Education Funding Council (HEFCE) to address gaps in Islamic Studies teaching and research (Lipsett, 2007).

Additionally, Muslim organizations have also been involved in conducting their own research on imams and mosques (Rahman, Syed Tohel, and Shaynul, 2006), as well as on imam welfare (FAIR, 2002). Most reports acknowledged that, while the imams' role is important to the health of the community, there needs to be major changes in how imams are trained and how they administer their responsibilities to their congregation. Despite this acknowledgement, there is some form of consensus that the onus to develop imams should organically grow out of community incentives and not from the pressures of government.

This chapter aims to contribute to this body of knowledge by proposing a model for imamship based on Muslim chaplaincy work. Tacit in this proposal is the assumption that current imamship practices are problematic (Hafiz, 2015), although these problems have less to do with government security concerns and more to do with being in tune with community concerns and possessing the skills to lead. Before I proceed, it is necessary to mention that the criticism of mosque institutions as not relevant to the concerns of the community is levelled at two groups of people: the mosque committee and the imams. Nearly all of the reports I have referenced note complaints about the lack of proper management and lack of professionalism of mosque committees (Donnelly, 2011). The Muslim Council of Britain report highlights a 
possible reason for this (Rahman, Syed Tohel, and Shaynul, 2006). It mentions that 50 per cent of mosque imams are under 40 years old, while 43 per cent of committee members are over 6o years old with very little knowledge of English (Rahman, Syed Tohel, and Shaynul, 2006, p. 10). This reinforces the prevalent view that mosques are still under the control of first-generation migrants (Geaves, 2008, p. 102). The above notwithstanding, my focus in this chapter is the imams, who are vested with a sense of authority through their specialist knowledge of the religion and have the potential to lead the community despite the shortcomings of the mosque committees.

\section{Current imam training and the responsibilities of imams}

A quantitative study of mosque imams in Britain (Geaves, 2008), shows that out of the 300-plus participants, 83.3 per cent were of South Asian origin and 8.1 per cent were British-born. Ron Geaves discovered that both the British-born and South Asian imams had gone through a system of study known as the Dars-i Nizami (Geaves, 2008) - amounting to 91.9 per cent of all of his respondents going through the same system. For this reason, I have chosen to confine my use of the title 'imam' in this chapter to South Asian-imported imams or their British counterparts who have gone through this system of education. I make no claims about imams who have had training outside or beyond this particular type of curriculum, as I have not consulted research regarding them.

The Dars-i Nizami syllabus was founded in 1695 by Mulla Nizamuddin (d. 1748) of the Farangi Mahall in India, ${ }^{1}$ and originally comprised a fine balance between the $m a^{c} q u \bar{l} l \bar{a} t$ ('rational sciences') and the manqūlāt ('revealed sciences') (Geaves, 2008; Robinson, 2001; Zaman, 2010). Muhammad Qasim Zaman remarks that the syllabus was originally flexible and meant to train scholars to work in the administration of the Mughal Emperors (1526-1857) as lawyers, judges, and religious professionals. However, as a reaction to British educational policy in British India the Dars-i Nizami became more or less standardized and started to function as a curriculum in the Darul Ulooms. The final, standardized version of the Dars-i Nizami curriculum has been adopted in the 25 or so Darul Ulooms in the United Kingdom.

1 The scholars of Farangi Mahall (English Palace) were a family of religious scholars in Lucknow, India, who were famous for their interest in the rational sciences. Their name is derived from a sequestered property belonging to a European merchant, which was gifted to them by the Mughal Emperor Aurengzeb in 1695. 
The purpose of these Darul Ulooms, and by extension the adopted Dars-i Nizami curriculum, is to 'strengthen one's own identity, to internalise excellent human qualities, and to realise one's potential' (Moosa, 2015, p. 4). The Darul Uloom is vital for two aspects of the student's life: 'First, it is central to the acquisition and circulation of knowledge, and second, it is vital to the personal spiritual growth or self-formation of the individual' (Moosa, 2015, p. 9). Muhammad Taqi Usmani believes that the virtues and skills learnt in the Darul Uloom make 'each individual serve not only their own countries and communities but [...] the whole of humanity' (Usmani, cited in Moosa, 2015, p. 4). In essence, the Darul Uloom is a bastion of religious learning that cultivates a deep religious internalization of knowledge that becomes embodied in the student. This embodied knowledge becomes the foundation for the new scholar to lead his community.

While I am not in a position to comment on the level of internalization of this learning, it is easier to gauge whether what is being taught and how it is taught is relevant and beneficial, and whether it fulfils the broader aims of these Darul Ulooms, i.e., to serve humanity. Much has been written about the ${ }^{c} i l m n a \bar{f} i^{c}$ ('utility of knowledge') in British India (Zaman, 2010). Where once the Dars-i Nizami functioned as a training programme for those who wanted to serve in the Mughal administration, with the rule of the East India Company being transferred to the British Empire after 1857, religious learning became a critical means of safeguarding Muslim identity and practice in British India (Zaman, 2010, p. 66). How is this being translated into the current British context, and how much do these concerns mirror Muslim conditions in contemporary Britain?

A number of researchers writing about British Darul Ulooms and the Dars-i Nizami (Geaves, 2008; Gilliat-Ray, 2006; Lewis, 2004), as well as Darul Uloom graduates (Mahmood, 2012), have identified the persistence of a yawning gap in the curriculum and pedagogy, which functions as a barrier for relating the teachings of the Darul Ulooms to the current concerns of the Muslim community. The relevance of certain topics taught in Darul Ulooms to the needs of the community is questionable. For example, what purpose does a detailed examination of what happens when a rat falls in a well serve for the modern Muslim community living in the West? One can argue that the fixation with this and other medieval issues creates a chasm between what the community wants from imams and what imams are able to offer.

So what does the community want from its imams? What are their responsibilities and duties? In 1989 an imam identified the role as carriers of 'vicarious memory' (Davie 2000, cited in Gilliat-Ray, 2010, p. 168) and 'bearers of cultures' (Schoenherr 1987, cited in Gilliat-Ray, 2010, p. 168), 
such as: leading the five prayers, teaching children, delivering the Friday sermon in Arabic with an accompanying lecture in Urdu, presiding over rites of passage such as calling the adhān, solemnizing marriages, preparing the dead for burial, preparing amulets, and in general offering advice

on the application of Islamic law and teaching (Birt and Lewis, 2010). Adding to this list, in the twenty-first century another imam discussed the heavy demands of his job, including dealing with drug abuse, youth problems, black magic, family breakdowns, mental health issues, bereavements, counselling, business disputes, and offering fatwas. The imam also mentioned that there are no appointed times for these activities and that the imam must be on call 24 hours a day, but for him it is most satisfying to see that he has made a positive change in people's lives (Syed and Ali, 2014).

\section{$3 \quad$ Models of imamship}

There are certainly a number of models that can be adopted to address the concerns raised by young British Muslims about leadership. Jonathan Birt (2005, p. 187) and Philip Lewis (2004, p. 179) have identified two strands of avant-garde imams who are adopting alternative models of leadership to meet the expectations of the younger generations. The first strand of ulama administers their religious work in a number of innovative ways that are different from normal mosque procedures. These include setting up in venues away from the mosque environment (Ali, 2013; Birt, 2005) and circulating Islamic knowledge through different forms of media and pamphleteering (Birt and Lewis, 2010). The second strand of ulama who are attempting to fulfil the new expectations of the young Muslim community are employed as Muslim chaplains or Muslim faith advisors in the chaplaincy departments of public institutions (Birt, 2005; Lewis 2004). I discuss the full details of the roles of Muslim chaplains below. What is common between these two strands of religious leaders is that they are moving away from the restrictive environment of the mosques to public spaces where they can fulfil the needs of the community without any hindrance. There is evidence to suggest that this has not always been a smooth transition; many of them have been criticized by the elders in the community (Birt, 2005, p. 190; Lewis, 2004, p. 178) or have even found their relationship with the community to be strained. Adam Dinham makes a generic observation that is reminiscent of Christian chaplain's experiences of often feeling that their work is undervalued or not recognized at all: 
Many faith-based projects, even where they started as initiatives directly arising from congregations, become dissociated, even divorced, from these roots as they grow and expand. Often by the time they have come to the attention of others outside of faiths they have travelled some considerable distance from the community of worshippers whose regular communion is a separate matter. (Dinham, 2009, p. 9)

Another, more targeted, model of addressing young Muslims' concerns has been suggested by Atif Imtiaz, the academic director at Cambridge Muslim College. In his typology of Muslims in Bradford, Imtiaz identifies three types of young Muslims: 'rude boys', 'coconuts', and 'extremists' (Imtiaz, 2011, pp. 84-90). 'Rude boys' are a hybrid mix of three cultures: South Asian, African-American hip-hop, and Northern Industrial England. Imtiaz believes that to help these youths a certain type of 'rude boy imam' is needed, who can talk the street language and understand their issues related to things like gang culture, drugs, and spiritual shallowness. The term 'coconut' is used pejoratively to describe a class of Muslims who are in danger of assimilation through social and economic progress. They have a different set of issues and concerns that only an imam who is trained in their field can tackle, such as the philosophical, scientific, and intellectual challenges to Islam (i.e., the notion of liberalism, human rights, and gender relations). These Muslims are the most prone to an assimilationist identity, and an imam who understands their worldview will be able to effectively steer them to the 'right' path in times of spiritual crisis. Imtiaz's third category of Muslims in Bradford is the 'extremist', described as such by those who are less practicing and who consider them to have developed an unbalanced approach towards religion. Imtiaz notes that those who are in this third category face a dual risk, which is also the greatest challenge for the British ulama: ghettoization and assimilation. Extremism is one outcome of this process and is caused by the total incomprehension of how to integrate into the wider society (Imtiaz, 2011, p. 88). For Imtiaz, this is equally about political and cultural engagement. He suggests that a class of ulama and religious leaders are needed who can develop a language and nomenclature that will allow Muslims to be able to express their religious sentiments while still feeling like they are part of the wider society. Imtiaz also mentions that the training provided by the Cambridge Muslim College addresses some of the issues and challenges mentioned above in some ways ${ }^{2}$ (see Ebbiary, Part II). 


\section{$4 \quad$ The Muslim chaplaincy model}

If Islam does not have an institutional role known as chaplaincy, how can it be used as a model for the role of the imam? While it is certainly true that Islam does not have a tradition of chaplaincy, it most certainly has a tradition of pastoral care (Gilliat-Ray et al., 2013; Winter, 2014). In addition, Muslim chaplains have been employed since the 1970s (Gilliat-Ray, 2008) long enough to warrant the designation of 'Muslim chaplain'; with their everyday involvement, the silhouettes of a slowly emerging distinctively Islamic practical theology can be observed (Abu-Ras and Laird, 2011; Ansari, 2009; Dudhwala, 2006; Gilliat-Ray, Ali, and Pattison, 2013; Hamza, 2007; Harris, 2009; Kowalski, 2009; Kowalski and Becker, 2015).

\subsection{The Muslim chaplaincy project}

As mentioned above, the data for this chapter came from a research project on Muslim chaplaincy conducted at Cardiff University from 2008 to 2011. Although the research on Muslim chaplaincy was not conducted with questions related to this chapter in mind, mining the archives of that research has provided rich material for writing it. The Muslim chaplaincy project ${ }^{3}$ was jointly funded by the Arts and Humanities Research Council and the Economic and Social Science Research Council as a part of their 'Religion and Society' programme. ${ }^{4}$ Over 28 months, the research team interviewed Muslim chaplains and stakeholders from different sectors in an attempt to establish the answers to four questions: who decides to become a chaplain; what is involved in chaplaincy work; how are Muslim chaplains able to negotiate institutional and state politics; and what impact are they having on their institutions, the Muslim community, and the wider British community?

To answer these questions, the research team interviewed 65 Muslim chaplains from a wide range of sectors and public institutions, including

3 Award reference: AH/Foo8937/1: 'Leadership and Capacity Building in the British Muslim Community: The Case of Muslim Chaplains' (2008-2011). The Principal Investigator was Professor Sophie Gilliat-Ray at Cardiff University; the Co-investigator was Professor Stephen Pattison at Birmingham University; and Dr. Mansur Ali was the full-time Research Assistant.

4 http://www.religionandsociety.org.uk/. The quotations in this chapter come from the Muslim chaplaincy project conducted between 2008 and 2011. The corpus and transcripts on which the quotations in this chapter are based are not available to anyone outside of the research team, since the data consists of sensitive and confidential material. This was agreed upon by the researchers and the two funding bodies mentioned above. The research findings, however, have been published in numerous publications, which are listed in the references of this chapter. 
prisons, higher education institutions, hospitals, airports, the military, courts, and community-based chaplains. Both male and female Muslim chaplains were interviewed, as well as part- and full-time chaplains from different Islamic schools of thought. In addition, the research team interviewed and observed some students who were training to be Muslim chaplains, especially through the Certificate Course offered by the Markfield Institute of Higher Education in Leicester.

Another group of interviewees included 'stakeholders', by which we mean those who have observed, or who have been directly involved in managing, the work of Muslim chaplains from a policy, training, or institutional perspective. The research team also spent short periods of time 'shadowing' Muslim chaplains at work, typically for two or three days at a time. This enabled them to have a more contextualized understanding of the Muslim chaplain's role, while offering Muslim chaplains themselves an opportunity to comment on their work. In a small number of prisons and higher education institutions, the team also conducted focus groups with the 'clients' of Muslim chaplaincy, and with key senior managers. Finally, one member of the research team travelled to the United States to interview Muslim chaplains there for comparative purposes. Below, I look at a segment of the data relating to the impact of Muslim chaplaincy on imams and mosques.

\subsection{Findings}

In what ways can Muslim chaplaincy be replicated as a model for mosquebased imams to adopt? The following vignette sheds some light on the effectiveness of Muslim chaplaincy for the mosque imam. I quote the narrative in its entirety as related to the research team in 2011 by a Muslim prison chaplain:

We have somebody who was released who was a chronic alcoholic but he was Asian. He was getting abused by the local community so I called the imam for a meeting from the local mosque, and I said to him, look, you know and I know that alcohol was drunk in the time of our prophet, where some of our prophets had a struggle issue to say 'don't'. But there was this way of, not abstinence straightaway, but you went through a process of detox. And I said to him this [is] what I'm requesting from you, is that you can only help this guy, because alcohol is only cushioning and bottling up his pain. Every time you lot slam the door in his face or you're beating him up in the community, you are making him feel that the cancer that is inside him, the issues, he can't talk to anybody about. 
And as a result, this imam, a young lad, recently qualified, said you're right. And he got in touch with Alcoholic Anonymous; he went on the soup kitchen duty. He saw poverty. He came out of his comfort zone. When this guy was released, he made an effort to go and see him. And even though the guy was drunk on one occasion, he just said to him, I'm going to come back another day. I just thought I would drop you off some food. And he said, you know, slowly from the crack of a door, he started opening up. And we found out that the guy had lost his family when he started drinking at the age of 17 . He was now 47. He had been on the slide and he had just messed up his life. And we found out where his family were, started talking to them and saying, you know, he's in a really bad state. His liver is not going to hang on for much longer if he keeps drinking like this.

And that's what I can do. Because I'm not attached to a mosque, I'm not attached to any denomination of Islam, I'm not attached to any group of Muslims or anything like that, I can instigate these conversations, knowing that I'm doing it for the best interest of that person who is leaving prison, or that family, or that individual, or that congregation that is supporting that. And they get an equal share of me.

A number of issues can be gleaned from the above interview extract. First of all, the narrative is revealing of how the mosque community and imams generally view people who have been incarcerated or who have (or have had) addiction-related problems. Second, it demonstrates the imam's lack of knowledge in such situations. Finally, it showcases the impact that a Muslim chaplain can have on the overall mentoring and development of an imam. Mining the data from the Muslim chaplaincy project, there is a ubiquitous feeling amongst most Muslim chaplains about mosque imams' lack of understanding of pastoral care. Furthermore, Muslim chaplains complained about the inability of imams to deal with complex situations brought to them by their congregation, which is mainly a result of their Darul Uloom training's focus on textual studies over pastoral issues.

Imams' lack of professionalism is another major criticism from Muslim chaplains. This is aptly captured in the quote at the beginning of this chapter, in which the senior Muslim chaplain reprimanded his junior colleague for acting in a conservative manner regarding gender interactions, which goes against both the ethos and the equality laws that regulate public institutions. One Muslim chaplain distinguishes the role of the chaplain from that of the imam by drawing attention to the way they converse with the people they minister to: 'Muslim chaplains speak with people, whereas 
imams speak to people' - thereby hinting that the hierarchy between the imam and the congregation might not always be healthy. Another Muslim chaplain describes how the imam ought to be as opposed to how they are by contrasting their understanding of the needs of the community in their country of origin with the needs of the community in modern Britain. By way of example, the chaplain picks the case of a parent who drops their child off late to the maktab ('evening supplementary school') because of a doctor's appointment. The chaplain argues that rather than disciplining the child for coming late, the imam should recognize the constraints on working parents, and instead thank the parents for bringing their child to the class at all.

A possible cause for imams' lack of professionalism, as identified by the Muslim chaplains interviewed for this research, is their lack of exposure to people and institutions beyond their own congregation and mosque. One hospital chaplain made the following observation in 2011: '[T]here is maybe a bit of an advantage that Muslim chaplains have, is that they are exposed, and they are more outgoing and see more than the imams in the mosque, so I think that's where maybe there needs to be a little change where the imams are exposed to people of different faiths.' In discussing a situation faced by both Muslim chaplains and imams in their line of work, another hospital chaplain ruminated over the markedly different responses elicited by each of them, which is revealing of the different types of people and institutions they have been exposed to:

I think I mentioned once about, for example, termination [of pregnancy], if I was asked a question about termination here, if the same people went to the mosque and asked the question about termination then they might get a different answer, because they're not exposed to the healthcare environment whereas I'm exposed to the healthcare environment and I can contextualize the question and give an answer according to the context, whereas they cannot contextualize that situation because they have been within the four walls; that's where the disadvantage is for an imam. (2010)

The interviewed Muslim chaplains listed what congregations expect of their imams, such as the ability to deal with (or at least some working knowledge of) the issues facing the community, including housing issues, domestic violence, youth problems, alcohol- and drug-related problems, and illicit sexual relationships, in addition to performing the purely religious elements of their role. The Muslim chaplains felt that imams are not adequately trained to tackle these issues, although, surprisingly none of them criticized the actual training that the imams went through in Darul Ulooms. A possible 
reason for this may be that Muslim chaplains do not view the training as irrelevant; they believe that it just needs a little bit tweaking. In fact, one Muslim hospital chaplain from London stated in 2011:

I was working in a hospital and I was also working as an imam in a mosque, and I had the same skills, the same knowledge but I had to move out of the mosque because I felt that the institution was restricting my skills and my capabilities. It wasn't allowing me the freedom to do what I felt was good for the community. So it's not the imam that is at fault, it was the institution that needed to change slightly from within.

Another possible reason for their lack of critique of the education system is that some chaplains may feel that their Darul Uloom education is supplemented with the training provided in chaplaincy sectors.

Nevertheless, Muslim chaplains do see themselves as the role models for mosque imams. Dinham's observation about chaplains' lack of recognition rings true in the case of Muslim chaplains, who appear frustrated since they are not understood or given a voice in the mosque despite the fact that they could contribute a lot by bridging the gap between the imams and their community. They suggest that allowing them to talk about their job in the mosque would function as an eye opener for the imams, who could subsequently raise the community awareness of important issues in their Friday sermons. One Muslim hospital chaplain responded to the question about Muslim chaplaincy's impact on the mosque as follows:

Well I think the main thing they can learn is [...] the chaplain in the hospital is there as a responsible person, he or she has a great responsibility and in fact we're here taking the responsibility from the community, doing the work of the Prophet șallā allāhu calayhi wa-sallam, visiting the sick, visiting the poorly, asking them how we can help them fulfil their needs, so I think that's very helpful and important that they understand that what we're doing is part of Islam and it's not for any other different reason, it's here. We're representing that community in the hospital and to the sick and the elderly.

One almost gets the feeling from this quotation that Muslim chaplains are trying hard to get recognition from the imams and the Muslim community. However, research has shown (Ali and Gilliat-Ray, 2012; Gilliat-Ray, Ali, and Pattison, 2013) that there is not yet the critical mass of Muslim chaplains needed to influence a major shift in practices, although anecdotal evidence (Birt and Lewis, 2010) of good practice does emerge from time to time. 

immanent spirituality

To bring some clarity to the discussion of imamship, and a plausible model for imams, I analyse the above discussion using two concepts: 'liminality' (Turner, 1967, 1991) and 'immanent spirituality' (Jackson, 2005). The first helps in understanding the current crisis of the imamship model, while the second assists in comprehending why chaplaincy is a good model for imamship. In this section, I discuss liminality and how it applies to the imams' situation; in the next section, I discuss immanent spirituality and its application.

The French anthropologist Arnold Van Gennep (1873-1957) gave the world the phrase 'rites of passage' (Turner, 1967). Van Gennep observed that in a rite of passage ritual, a beginner known as a neophyte goes through a three-fold process that involves separation, marginality, and aggregation. 'Separation' is when the neophyte leaves behind his or her previous life and enters a transitory phase, such as rituals involving boys progressing to adulthood. The 'marginal' situation where the 'not-boy-not-man' has to do certain things to prove himself (hunting, for example) is defined as 'liminality' by Victor Turner. According to Turner, liminality is an 'interstructural' situation where normal structures of society do not function and new forms of structures are erected. In a liminal situation the liminal persona is 'no longer classified and yet to be classified'; they are 'betwixt and between' (Turner, 1967, p. 48; 1991, p. 95). In this phase, there is a relationship of total submission to the master, as well as a complete equality among neophytes which Turner calls communitas (Turner, 1991). Turner writes, 'the authority of the elders is absolute, because it represents the absolute, the axiomatic values of society in which are expressed the "common good" and the common interest' (Turner, 1967, p.100).

Liminality does not necessarily need to be restricted to the individual. Bjørn Thomassen (2009) argues that it can be both temporal and spatial, involving individuals, larger groups, whole societies, or even entire civilizations. Turner acknowledges that although most liminal situations are temporary, it can also take a permanent form, which Erving Goffman calls 'the characteristics of total institutions' (Goffman, 2007). Turner writes: 'With the increasing specialization of society and culture, with progressive complexity in the social division of labour, what was in tribal society principally a set of transitional qualities "betwixt and between" defined states of culture and society has become itself an institutionalized state' (1991, p. 107). The idea of a permanent liminal state was further developed 
by the sociologist Arpad Szakolczai (2005), who identified three forms of permanent liminality that correspond to Van Gennep's three stages of rites of passage. Szakolczai notes that: 'Liminality becomes a permanent condition when any of the phases in this sequence becomes frozen, as if a film stopped at a particular frame. This can happen both with individuals undergoing an "initiation rite" and with groups who are participating in a collective ritual, "a social drama"” (2005, p. 212).

Szakolczai identifies the first kind of permanent liminality in the segregation phase as the monastic way of life, where the desire to transcend the mundane becomes permanent. The second phase of permanent liminality corresponds to Norbert Elias' 'court society'. Exploring the writings of Norbert Elias on 'court society', Szakolczai identifies it as in a permanent liminal condition, in the actual performance or 'staging' of the ritual. Szakolczai argues that when such a performance becomes permanent and individuals are stuck in their roles, the performing character of the ritual disappears. Individuals are required to identify with their role, which is no longer a play and becomes their life, permanently (Szakolczai, 2005, p. 213). Finally, the third possibility of permanent liminality, frozen in the final stage of the ritual where one is re-assimilated into society, is what Szakolczai calls 'Bolshevism' - a form of societal and cultural liminality that cannot proceed to a normal way of life. In this analysis of the roles of the imam, I focus on the first two kinds of permanent liminality.

Turner's liminality theory can be applied to mosque imams who have gone through the Darul Uloom Dars-i Nizami system. When students enter a Darul Uloom for the first time, they are required to leave their previous lifestyle at the gates of the institution. The students now have to embody a worldview and practice that is totally 'segregated' (both in terms of gender segregation and in Van Gennep's use of the term) and different from their pre-Darul Uloom days. This includes shedding their normal attire and adopting what they consider to be Islamic sartorial practices. Any kind of media devices such as smart phones or Internet access are forbidden unless under strict supervision. The only connectivity allowed is one that builds the student's connection to God and the Islamic tradition. The student has to follow a strict regime of habits including eating, studying, and resting, punctuated by the five daily prayers (Moosa, 2015). During the course of their stay in the institution, students are exposed to the works of classical Islamic 
scholars through pious hagiography and the framing of these narratives (Moosa, 2015), as well as through the unbroken human chain of transmission known as the isnād ('chain of authorities') system (Brown, 2009; Graham, 1993). The student, who is now different from the lay person but not yet a scholar, develops a communitas, friendship, and fellowship with other students that may last a lifetime in addition to cultivating a strong fidelity to the hierarchy and authority of the elders, similar to Turner's description of the neophyte.

Once a student completes the course successfully, he or she graduates as a scholar ready to lead the community with newfound authority. To celebrate this auspicious moment, some Darul Ulooms hold a graduation ceremony that begins with the reading of the final few hadiths of Sahih al-Bukhari, the most authentic book in Sunni Islam after the Qur'an (Brown, 2009), and concludes with the student's teachers placing a turban on the head of the graduate - an emblem of religious authority on the one hand and a symbolic gesture of the heavy burden the new scholar must shoulder, on the other.

One may argue that these phases are a normal part of the process for any student. While that may be true, the fact that imams are the objects of a deluge of criticism, both in reports and from their chaplain colleagues, is evidence that imams are stuck in the second phase of liminality, similar to Szakolczai's 'court society'. The ceremonial rituals of graduation help graduates identify with their role, but their actions in the mosque betray a permanent liminality in the staging phase. In this chapter, I have demonstrated that there are a number of ways for graduates to break out of this permanent liminality. One example is Muslim chaplaincy; graduates modelling themselves on Muslim chaplains are able to tweak their knowledge and skills to better align with the needs and concerns of the community. I believe Muslim chaplaincy is a good model because it adopts a working ethos that can be loosely defined as 'immanent spirituality'.

\section{'Immanent spirituality'}

'Immanent spirituality' is a term coined by the American Muslim intellectual Sherman Jackson (2005, p. 183) to address the 'spiritual health' of what he terms the 'Black American' Muslim community. Jackson argues that the mystical tradition in Islam, known as Sufism, advocates a type of spirituality that depends solely on transcending the physical body to become one with God. This form of spirituality emphasizes that human beings are insignificant in the grand scheme of things, and that total spiritual 
experience lies in $\operatorname{fan}_{\bar{a}}$ ' ('obliteration of the self) in the love of God, which eventually results in a mystical union with God that transcends the human body. In other words, the transcendental spirituality of mystical Sufism is predicated on the belief that experiential knowledge is superior to conceptual knowledge (Jackson, 2005).

Jackson finds the transcendental spirituality of the Sufis to be out of sync with and not suitable to the Black American Muslim experience. For him, the Black American is already someone who has been haunted by a nagging sense of nobodyness (Jackson, 2005, p. 184), and who has only recently come to terms with his selfhood and self-identity. A spirituality that demands the annihilation of this selfhood and transcending of this identity will not work well. In response, Jackson proposes an 'immanent spirituality', where the struggles of the Black American are seen as a spiritual exercise. For Jackson, this is a spirituality that celebrates the Black American identity and makes their struggle into a religious vocation. In other words, for Jackson, spirituality can reside in 'walking with', as opposed to 'transcending to', God (Jackson, 2005, p. 185).

Jackson's 'immanent spirituality' helps explain why chaplaincy is a good model for imams. The Muslim chaplaincy research revealed that a good Muslim chaplain is one with knowledge of and credibility in the local Muslim community in addition to possessing good communication - especially listening - skills. The Muslim chaplain manifests the qualities of respect, patience, tolerance, non-judgement, and confidentiality, features that are found in counsellors and chaplains of other traditions. The chaplain is also flexible and willing to work in a complex environment in which he or she needs to understand his or her institutional and social context. Demonstrating resilience and determination as well as diplomacy and flexibility in approaching their complex, diverse role and environment is also seen as a quality of a good Muslim chaplain. All of these acquired skills showcase that the chaplain is one who will be able to 'talk with', as opposed to 'talk to', the people. In contrast, rigorous scholastic training in authoritative books and absolute submission to the teacher develop a sense of hierarchy in the student where scriptural knowledge dominates and where the ulama reign as masters. This attitude is not helpful for dealing with people's concerns and problems, or for people who seek in their imams, not an authoritarian figure, but a pastoral shoulder with whom to share their burdens. In other words, imams' adoption of the chaplaincy model will enable them to realize that spirituality is immanent and lies in their everyday struggle of walking with their congregation, understanding their concerns, and at times sharing in the shedding of spiritual tears. 


\section{Conclusion}

In this chapter, I have argued that chaplaincy can function as a good model for imams. I argue that the current imams who are graduates from Darul Ulooms in South Asia and the United Kingdom are fixed in a liminality where their training involves regurgitating materials that are best suited to rural conditions. There are a number of methods and models available to pull these imams out of their liminality, and one example is brushing up their skills and knowledge by following the professional attitude of their colleagues in the chaplaincy sectors in the United Kingdom. The chaplaincy model, I argue, is one that can be called a model of 'immanent spirituality', where struggle is a part of the spiritual vocation of the chaplain and the chaplain 'talks with' the people as opposed to 'talking to' them. As one hospital chaplain says about his role:

With their own existing faith within God, it's about restoring that faith that they have and for a slight moment they are not lost, but there's a shadow, it's cloudy. It's like you're on the motorway and you think, am I on the right route or not? You're still travelling until your satnav says, take the next left in 200 yards or something and you think, yes, I am on the right route and I see that I am that satnav.

Compared to the number of imams, there is not yet the critical mass of Muslim chaplains necessary to make a significant dent in the current religious leadership exercised in the community, although anecdotes of good chaplaincy practice seeping into the community provide a glimmer of hope for the future (Ali and Gilliat-Ray, 2012; Birt and Lewis, 2010).

\section{References}

Abu-Ras, Wahiba and Lance Laird. 2011. 'How Muslim and Non-Muslim Chaplains serve Muslim Patients? Does the Interfaith Chaplaincy Model have Room for Muslims' experiences?' Journal of Religion and Health, 50: 46-61.

Ali, Mansur and Sophie Gilliat-Ray. 2012. 'Muslim Chaplains: Working at the Interface of "Public" and "Private"'. In Muslims in Britain: Making Social and Political Space, edited by Waqar Ahmad and Ziauddin Sardar, 84-10o London: Routledge.

Ali, Yunus. 2013. 'How and to What Extent can Modern Educational Practices be Employed to Help Make Traditional Islamic Education More Meaningful and 
Relevant for Young Muslims Living in Britain? A Case Study of The Amanah Centre'. Master's thesis, Cardiff University.

Ansari, Bilal. 2009. 'Seeing with Bifocals: The Evolution of a Muslim Chaplain'. Reflective Practice: Formation and Supervision in Ministry, 29: 170-177.

Birt, Jonathan. 2005. 'Locating the British Imam: The Deobandi Ulama between Contested Authority and Public Policy Post-9/11'. In European Muslims and the Secular State, edited by Jocelyne Cesari and Seán McLoughlin, 183-196. Aldershot: Ashgate.

Birt, Jonathan. 2006. 'Good Imam, Bad Imam: Civic Religion and National Integration in Britain Post-9/11'. The Muslim World, 96: 687-705.

Birt, Jonathan and Philip Lewis. 2010. 'The Pattern of Islamic Reform in Britain: The Deobandis between Intra-Muslim Sectarianism and Engagement with Wider Society'. In Producing Islamic Knowledge: Transmission and Dissemination in Western Europe, edited by Martin van Bruinessen and Stefano Allievi, 91-120. London: Routledge.

Brown, Johathan. 2009. Hadith: Muhammad's Legacy in the Medieval and Modern World. Oxford: Oneworld Publications.

Dinham, Adam. 2oog. Faiths, Public Policy and Civil Society. London: Palgrave Macmillan.

Donnelly, Brian. 2011. 'Sacked Imam Sues his Former Mosque for £65,00o'. Herald Scotland, 9 November. http://www.heraldscotland.com/news/13039795. Sacked_imam_sues_his_former_mosque_for_-_65_000/.

Dudhwala, Yunus. 2006. Building Bridges between Theology and Pastoral Care. Lisbon: European Network of Health Care Chaplains. http://www.enhcc. eu/o60518_theology_yunus.pdf.

Dyke, Anya. 2009. Mosques Made in Britain. London: Quilliam Foundation.

FAIR (Forum Against Islamophobia and Racism). 2002. 'Employment Status in Relation to Statutory Employment Rights'. Report prepared by FAIR, Muslim College, and Al-Khoei Foundation.

Geaves, Ron. 2008. 'Drawing on the Past to Transform the Present: Contemporary Challenges for Training and Preparing British Imams'. Journal of Muslim Minority Affairs, 28: 99-112.

Gilliat-Ray, Sophie. 2006. 'Educating the Ulama: Centres of Islamic Religious Training in Britain'. Islam and Christian-Muslim Relations, 17: 55-76.

Gilliat-Ray, Sophie. 2008. 'From "Visiting Minister" to "Muslim Chaplain": The Growth of Muslim Chaplaincy in Britain, 1970-2007'. In The Centrality of Religion in Social Life: Essays in Honour ofJames A. Beckford, edited by Eileen Barker, 145-157. Aldershot: Ashgate.

Gilliat-Ray, Sophie. 2010. Muslims in Britain: An Introduction. Cambridge: Cambridge University Press. 
Gilliat-Ray, Sophie, Mansur Ali, and Stephen Pattison. 2013. Understanding Muslim Chaplaincy. Surrey: Ashgate Publishing Limited.

Goffman, Erving. 2007. Asylums: Essays on the Social Situation of Mental Patients and other Inmates. London: Aldine Transaction.

Graham, William. 1993. 'Traditionalism in Islam: An Essay in Interpretation'. Journal of Interdisciplinary History, XXIII: 495-522.

Hafiz, Asim. 2015. 'Muslim Chaplaincy in the United Kingdom: The Chaplaincy Approach as a Way to a Modern Imamate'. Religion, State and Society, 43: 85-99. Hamza, Doha. 2007. 'On Models of Hospital Chaplaincies: Which One Works Best for the Muslim Community?' Journal of Muslim Mental Health, 2(1): 65-79.

Harris, Rabia. 2009. 'Supporting Your Muslim Students: A Guide for Clinical Pastoral Supervisors'. Reflective Practice: Formation and Supervision in Ministry, 29:154-69. Hussain, Dilwar. 2010. 'Development of Religious Instructions and Institutions: 'Imam Training' in Europe'. PPN Working Paper. Institute for Strategic Dialogue. Hussain, Dilwar and Henry Tuck. 2014. The Education and Training of Islamic Faith Leaders in Europe: A Comparative Evaluation of Approaches in France and Germany. London: Institute for Strategic Dialogue.

Husson, Jean-François. 2007. Training Imams in Europe: The Current Status. Brussels: King Baudouin Foundation.

Imtiaz, S.M. Atif. 2011. Wandering Lonely in a Crowd: Reflections on the Muslim Condition in the West. Markfield: Kube Publishing.

Jackson, Sherman. 2005. Islam and the Blackamerican: Looking Toward the Third Resurrection. New York: Oxford University Press.

Kowalski, Mumina. 2009. 'Names of God: Practical Theology for Muslim Chaplains in CPE'. Reflective Practice: Formation and Supervision in Ministry, 29: 178-186. Kowalski, Mumina and Wendy Becker. 2015. 'A Developing Profession: Muslim Chaplains in American Public Life'. Contemporary Islam, 9: 17-44.

Lewis, Philip. 2004. 'New Social Roles and Changing Patterns of Authority Amongst British Ulama'. Archives de Sciences Sociales des Religions, 125: 169-187.

Lipsett, Anthea. 2007. 'Islam Academics Wary of Conditional Funding'. The Guardian, 15 June. http://www.theguardian.com/education/2007/jun/15/ highereducation.uk.

Mahmood, Hamid. 2012. 'The Dars-e-Nizami and the Transnational Traditionalist Madaris in Britain'. Master's dissertation, Queen Mary, University of London. Metcalf, Barbara. 1982. Islamic Revival in British India: Deoband, 1860-19oo. Princeton, NJ: Princeton University Press.

Moosa, Ebrahim. 2015. What Is a Madrasa? Edinburgh: Edinburgh University Press. Rahman, Shafiur, Ahmed Syed Tohel, and Khan Shaynul. 2006. Voices From the Minaret: MCB Study of UK Imams and Mosques. London: The Muslim Council of Britain and $C_{3}$ ube Training and Consultancy. 
Robinson, Francis. 2001. The Ulama of Farangi Mahall and Islamic Culture in South Asia. London: Hurst \& Company.

Scott-Baumann, Alison, Mohamed Mukadam, Ashfaque Chowdhary, and Sariya Contractor. 2010. The Training and Development of Muslim Faith Leaders: Current Practice and Future Possibilities. London: Department for Communities and Local Government.

Siddiqui, Ataullah. 2007. 'Islam at Universities in England: Meeting the Needs and Investing in the Future' Report submitted to Bill Rammell MP, Minister of State for Lifelong Learning, Further and Higher Education.

Syed, Bilal and Mansur Ali. 2014. 'A Day in the Life of an Imam in Cardiff: Mufti Bilal in Conversation with Mansur Ali'. http://sites.cardiff.ac.uk/islamukcentre/ virtual-centre/public-lectures/2014-pubic-lectures/mufti-bilal-syed-andmaulana-dr-mansur-ali/.

Szakolczai, Arpad. 2005. Reflexive Historical Sociology. London: Routledge.

Thomassen, Bjørn. 2009. 'The Uses and Meaning of Liminality'. International Political Anthropology, 2(1): 5-28.

Turner, Victor. 1967. 'Betwixt and Between: The Liminal Period'. In The Forest of Symbols: Aspects of Ndembu Ritual, 93-111. Ithaca/ New York: Cornell University Press.

Turner, Victor. 1991. The Ritual Process: Structure and Anti-Structure. Ithaca/ New York: Cornell University Press.

Winter, Tim. 2014. 'Response to Ruth Armstrong'. Studies in Christian Ethics, 27(3): 310-313.

Zaman, Muhammad Qasim. 2010. The Ulama in Contemporary Islam: Custodians of Change. Princeton/Oxford: Princeton University Press.

\section{About the author}

Mansur Ali is a Lecturer in Arabic and Islamic Studies at Cardiff University in the United Kingdom. He is interested in practical theology and Islam and bioethics. He has co-authored a book with Sophie Gilliat-Ray and Stephen Pattison on Muslim chaplaincy entitled Understanding Muslim Chaplaincy (Routledge, 2013), and is currently working on a project on Islam and organ donation. 


\title{
16 Re-examining the decline narrative
}

\author{
Cambridge Muslim College and the changing face of imam \\ training in Britain
}

\section{Alyaa Ebbiary}

Hashas, Mohammed, Jan Jaap de Ruiter, and Niels Valdemar Vinding (eds), Imams in Western Europe: Developments, Transformations, and Institutional Challenges. Amsterdam: Amsterdam University Press, 2018 DOI: $10.5117 / 9789462983830 / \mathrm{CH} 6$

\begin{abstract}
The Cambridge Muslim College was established in 2011 with the purpose of giving a contextual 'update' to the heavily text-based training of British Muslim seminary graduates. It has been called a 'finishing school' that provides a higher education experience for graduates of the traditional Indian-style Darul Ulooms in the United Kingdom. The college offers a one-year programme for both men and women with a curriculum emphasizing citizenship, political and cultural awareness, interfaith understanding, community building, counselling, and other pastoral skills. This chapter discusses the Cambridge Muslim College programme and how it relates to earlier, more traditional imam-training programmes in the United Kingdom.
\end{abstract}

Keywords: Cambridge Muslim College, Darul Ulooms, imam training in the United Kingdom, Deobandi school

It is graduation day at the Cambridge Muslim College, ${ }^{1}$ marking the end of a year of intense intellectual growth and personal introspection for the cohort of students receiving diplomas in Contextual Islamic Studies. Like other graduation ceremonies held every year in Cambridge, this one is marked by grandeur and solemnity; unlike the other ceremonies held in 
this scholarly city for centuries, however, the graduating students mounting the stage to receive their certificates are all bearded Muslim men wearing topi and jubba and Muslim women wearing niqāb or jilbā $b^{2}$

'I have been pleasantly surprised over this year, in my engagement with the graduates' a research fellow of the college commented in his speech. 'The Darul Ulooms [religious seminaries] have taught their students $a d a b$ ['good etiquette'] and it's important not to throw the baby out with the bathwater. This institution is not here to correct or replace the Darul Uloom learning, it is here to augment and to take it further.'

To 'throw the baby out with the bathwater' suggests discarding what is valuable along with what is no longer useful. This is a theme that has preoccupied attempts at institutional and religious reform in the Muslim world over the last one-and-a-half centuries. But what exactly is considered to be the 'baby' and what constitutes superfluous 'bathwater' is subject to constant debate. In the context of Islamic higher education in Britain, the changing roles of imams and ulama have been central to this debate.

Since Muslims began settling in the United Kingdom in significant numbers, the training of religious leaders has been a hurried but necessary process. The first Islamic seminary was established in 1975 in Bury, near Manchester in northern England. According to one survey, there are currently 24 Islamic seminaries in the United Kingdom (Birt and Lewis, 2010). ${ }^{3}$ The survey authors reveal that

A sectarian analysis immediately reveals the domination of the Deobandi movement - sixteen Deobandi seminaries, five Barelwi, one Azhari, one Nadwi, one Shiite, and one Ikhwani (Muslim Brotherhood) - and the list as a whole largely reflects the predominance of Muslims in Britain with roots in South Asia, 74 per cent of the total in the Census of 2001. The seminaries reflecting traditions other than the main South Asian ones have smaller constituencies and therefore struggle to find broader acceptance. (Birt and Lewis, 2010, p. 92) ${ }^{4}$

2 The topi is the name common in South Asian languages for the short, round cap often worn by Muslim men.Jubba and jilbāb are Arabic names for the long loose gown commonly worn by men and women in the Arab and Muslim world. The niqā $b$ is the face veil.

3 However, they assert: 'This is a conservative estimate mostly compiled from seminaries that are formally registered as they provide statutory education up to sixteen years of age. However, there is no requirement of registration for those that only provide formal seminary studies for students older than 16' (Birt and Lewis, 2010, p. 93).

4 The proportion of South-Asian Muslims as a percentage of all British Muslims has gone down to 68 per cent in the 2011 census, but the older statistic better illustrates the influence of 
The Darul Ulooms in the United Kingdom represent a particular model of Indian Islamic higher education. ${ }^{5} 21$ of the United Kingdom's 26 Islamic higher education institutions follow this Indian seminary tradition. The institution of the Darul Uloom garners considerable controversy within the Muslim community in Britain. ${ }^{6}$ At worst, the tradition is described as an alien, outdated institution that has been transplanted into Britain with the arrival of post-colonial migration. It follows a syllabus calcified in Victorian India and is severely limited by conditions and assumptions that are both archaic and irrelevant to modern Britain. It is in desperate need of reform but is dragging its feet at the prospect of change. ${ }^{7}$

At best, the Darul Uloom tradition is seen as an intellectually empowering feature of the British Muslim educational scene. According to this view, British Darul Ulooms provide rigorous traditional training that has credibility not only in Islamic South Asia, but weight in other parts of the Muslim world. It democratizes religious knowledge, making it accessible to a generation of diaspora Muslims who might otherwise have lost touch with their textual religious heritage. It enriches the community with ${ }^{c} \bar{a} l i m s$ and ${ }^{c} \bar{a}$ limas ('male and female religious scholars') who are licensed to teach Islamic studies - that is, by studying at a Darul Uloom they receive a verifiable intellectual lineage. In an age of an international crisis of authority in the Sunni Muslim world, the Darul Uloom is a much-needed connection to the past. In this chapter I do not take either 'side' in the debate on the Darul Ulooms, instead aiming to show that the reality is far more complex than indicated by these two extremes. ${ }^{8}$

In Sophie Gilliat-Ray's study of this phenomenon, one of her interviewees suggests that Darul Uloom graduates are disenfranchised and need some kind of 'rehab' after their experience of studying. She writes: 'There are a number of initiatives outside of the Darul Uloom that are attempting to address that, but they're like sticking plaster' (Gilliat-Ray, 2006, p. 71). This begs the question, why does a 'traditional' education need to be remedied? Across Western Europe there have been a number of initiatives to train imams (see Martikainen and Latvio, Part II), which have attracted more attention since $9 / 11$ for 'reasons of both security and integration policy' (Van Bruinessen, 2010, p. 9). But beyond

the Indian subcontinent on Islamic institutional life in Britain.

5 Darul Uloom translates from Arabic as 'house of sciences'.

6 There is a strong academic argument that there is no such thing as a singular 'Muslim community' in Britain. Though I am wary of the dangers of essentialism in this case, I use the label 'Muslim community' in this chapter as it is used by my research participants.

7 See Birt and Lewis (2010), Geaves (2012), and Gilliat-Ray (2005, 2006).

8 See Robinson (2009). 
state concerns, there is an increasingly vocal discontent within the British Muslim community. Many Muslims are demanding better-trained imams who are more equipped to deal with the challenges posed by modern British society and to serve a quickly changing and overwhelmingly young community.

2

\section{The decline narrative}

Once upon a time, Islamic scholars were innovative pioneers in the fields of science, mathematics, and linguistics. Now they are arguing about beard lengths and the like. This is a crude caricature, but one that can be heard regularly in British mosques, at Muslim civil society meetings, and over dinner tables. The state - or lack - of a highly educated religious elite to match the polymaths of the so-called Muslim 'glory days' is a common lament of many a second-generation Western Muslims, and one that feeds into ideas of identity and communal self-esteem. Whatever happened to the ulama?

The ulama have historically taken up the role of Islam's 'guardians of literary memory' (Waines, 1995). However, a narrative of decline has dominated the history of Islam's religious elite. The narrative begins at the height of Islamic civilization and intellectual achievement, with the likes of Al-Ghazali and Ibn Sina. ${ }^{9}$ As Muslim empires flourished, so did intellectual and cultural production. As Muslim empires receded and European colonial encroachment increased, particularly from the eighteenth century onward, Muslim rulers became disempowered, as did the centres of religious learning.

During the colonial period, traditional systems of learning were devalued in favour of European-style schooling. This led to an inevitable change in the perceived hierarchy of vocations and valuable knowledge in the Muslim world..$^{10}$ Subjects that were once collectively taught in ostensibly religious institutions (such as history, medicine, mathematics, and geometry), went through a division into sacred and secular learning. The education and subjects offered in 'secular' institutions became more sought after and prized by socially mobile and able students. The establishment of secular education also created a space for a new breed of moral authority: the 'Islamic intellectual'.

9 There is no room here for a full appreciation of the complexity and development of medieval Muslim education and knowledge transmission; this has been adequately dealt with elsewhere (see Berkey, 1992; Makdisi, 1981).

10 There are a number of assumptions underlying this historic narrative that require deconstructing. Normative/lived Islam, traditional/modern, conservative/'progressive', etc. are not mutually exclusive categories, nor are they static, consistent terms. I reference them here as they appear in the literature and discourse surrounding these narratives of Islamic history. 
Meanwhile, the waqf or endowment system that ensured the financial independence of Muslim civil society and scholars was dissolved; the decreasing resources and poorer student intake of the institutions added to their fall in status. ${ }^{11}$ This, in turn, led to a change in the values and aspirations of Muslim elites. During the postcolonial independence period, newly independent nationalist secular governments continued the process of disempowering the religious class, which was often seen as a threat to state power. In many Muslim countries, the historic institutions of Islamic learning became nationalized and thus under the tutelage of temporal power.

The above is a brief synopsis of the key overarching themes surrounding the changing status of the ulama; it is beyond the scope of this chapter to discuss it in greater historic detail or regional variation. Suffice it to say that during the last century and a half there have been numerous threats to and competitors for the roles of Islamic religious leaders and scholars throughout the Muslim world. Is this narrative of decline simply about Muslims losing temporal power? To the contrary, there are many cultural and social forces that can explain this so-called decline. ${ }^{12}$

The apparent demise of Muslim worldly power and intellectual leadership has often been laid at the feet of the traditionally trained religious elites. A common trope among Muslim reformists over the last century has been the need to bypass the last thousand years of accumulated legal and literary canon and return to the key sources. Carol Kersten and Susanne Olsson (2013, p. 2) point out that two influential movements on opposite ends of the spectrum have contested established or 'traditional' authority: the Salafi movement and the university-educated Muslim intellectuals. One of the reasons for the decline of the ulama is the rise of new 'Muslim intellectuals' who directly challenged the ulama and their monopoly on Islamic interpretation - causing what some have termed a 'fragmentation of authority' (Kersten and Olssen, 2013, p. 11). The literature tends to pit 'Muslim intellectuals' with no formal religious training against the 'traditional ulama'. But the example of the Cambridge Muslim College, as I detail later, may help to disturb this neat dichotomy.

11 In some contexts this was even added to with occasions of 'eliticide', in which Islamic scholars were assassinated along with other educated elites as a result of colonialism, coups, or political upheaval (i.e., during the 1920 ' 'Kemalisation' in Turkey, 1880s British India, and the Bangladeshi War of Independence). It is worth noting that these historic incidents are not restricted to the Muslim world. There are similar patterns of discrediting the literate 'knowledge' elites within the Buddhist and Jewish traditions that are worthy of further study.

12 There is much scholarship on the dwindling credibility of traditional Islamic elites. See Eickelman and Piscatori (1996); for a focus on Syria, see Pierret (2013); and for a more global perspective, see Kersten and Olsson (2013). 
Much of the scholarship from both the East and the West on the role of the ulama has sidelined the former guardians of Islamic literary heritage. Khaled El-Rouayheb's (2015) recent work on the intellectual history of the Ottoman Empire and North Africa has done much to question the narrative of decline. ${ }^{13}$ He argues that three independent critiques of decline - the Ottomanist, the Arabist, and the Islamist - have together aggravated a harsh historic narrative that assumes the period after Islamic intellectual florescence and before colonial encroachment (i.e., the seventeenth and eighteenth centuries) to have been barren in terms of cultural and intellectual output. Many of the reformist and revivalist movements of the modern period see this age as 'marked by unthinking scholarly imitation (taqlidd), crude Sufi pantheism, and "syncretic" and idolatrous popular religious practices' (El-Rouayheb, 2015, p. 2). I would add that the ever-present elevation of the Muslim past as 'ideal' has further accentuated these damning assessments of the ulama, as well as the current moral health of the umma in the modern Muslim imaginary. ${ }^{14}$

One of the key historians of Islam's scholarly class, Muhammad Qasim Zaman, argues that generalizations about the adverse impact of modernity on the ulama's influence and authority are suspect (2002, p. 58). There can be little doubt that the ulama's authority has come under 'severe pressure and unprecedented challenges' in the age of mass education and new technologies, but the ulama also have a lot to gain. For example, Zaman explores how Muslim scholars in the Indian subcontinent, before and after independence, rose to the challenge of the print media by producing more works for both learned and lay audiences. But the critical question, for Zaman, is not whether the ulama's authority has increased or decreased, but how that authority is constructed, argued, displayed, and constantly defended.

I draw on El-Rouayheb and Zaman's analyses to argue that the decline narrative, although very real on a structural level, is more complex and fluid than a simple linear sequence of events. What counts as 'normative', 'traditional' Islam is not a static fixed entity, but rather a process. This can also be said for notions of religious authority. My research with the

13 I am grateful to Yakoob Ahmed, Ottoman historian at the School of Oriental and African Studies, University of London, for helpful discussions and critique of the 'decline narrative'.

14 Idealization of the past is a common trope that is not restricted to the Muslim historical imagination. What period 'the past' refers to depends very much on which Muslims are speaking. I use it here to refer to the 'golden age' so often held up to contrast with the present in contemporary Muslim discourse. However, the 'golden age' for other groups (such as Salafis) would be considerably earlier. 
Cambridge Muslim College and other examples shows how the discursive process of defining what constitutes 'normative Islam' is both continuing and incrementally eroding the historic divide between 'intellectuals' and the 'ulama'.

\section{$3 \quad$ The Indian experience}

The historic narrative of the rise of seminaries in South Asia is key to understanding the Muslim institutional (as well as civil society and mosque) landscape in the United Kingdom. These seminaries grew in a climate of encroaching colonialism, widespread perceived syncretism, and the decadence of indigenous rulers. As a result, many of their teachings speak to these concerns.

Because the Deobandi school (and its missionary offshoot the Tablighi Jamaat) dominates the scene of advanced Islamic religious training in the United Kingdom, it requires special attention here. The Islamic currents that originated in the Indian subcontinent are all based in the Hanafi madhhab ('school of thought'), one of the four major schools of legal thought in the Sunni Muslim world. The genealogy of Deobandism descends from the Hanafi School and its unique development in India under the Mughal Empire. In the literature on Islamic movements, it is often described as 'revivalist', 'reformist', or 'puritanical' (and by the less nuanced as 'fundamentalist'). It can rightly come under these broad categories, but in its original manifestation it was more a 'readjustment to political disempowerment' and a movement against syncretism.

The movement was concerned with the moral reform of the Muslim individual - a personalization of religion that is consistent with 'modernity'. The combination of mass education and a cosmology of self-reliance and defiance are fused together in the Deobandi worldview (Metcalf, 1996). Its origins and the historic circumstances of its development have a considerable influence on the way Islam is taught and learned in Britain. Partly due to their emphasis on right knowledge and strengthening normative Islam in India in the British context, the Deobandi are the sect that has most emphasized the importance of social reproduction through the formal apparatus of schooling. ${ }^{15}$

15 I use 'sect' here only for convenience. My research participants would often use the Christian term 'denomination', or sometimes maslak, which is more common to South Asian Islamic understandings of movements and sectarian differences. 
Deobandi seminaries were designed for mass education, borrowing selectively from Western educational models (Birt and Lewis, 2010, p. 92). Though 'traditional' in their educational aims, they were thoroughly modern in their methods, and they used the example of British educational institutions and missionary societies as sources of organizational inspiration (Gilliat-Ray, 2006, p. 56). The curriculum of most of the South Asian Darul Ulooms, both in India and in the United Kingdom, owes its origins to the work of the eighteenth century Farangi Mahall scholars who trace their lineage to Lucknow, India. The genius of this scholarly movement was its ability to draw from the rationalist tradition of scholarship associated with Persia (and characterized by an emphasis on logic and philosophy) and combine it with the traditional Islamic sciences of Quran, hadith, and fiqh. The resulting syllabus was known as Dars-i Nizami (see also Ali, Part II).

This syllabus was an ideal educational training ground for the production of legal professionals to serve in the public institutions of the Mughal Empire. However, with the collapse of the Mughals and the influence of colonialism, the nature of the Dars-i Nizami curriculum changed. The tradition of combining rational sciences with Islamic sciences, along with a growing emphasis on a contextual understanding of the Islamic texts was 'eroded in favour of a renewed emphasis on the Quran and hadith and the preservation of the core Islamic sciences in what they viewed as a hostile climate' (Birt and Lewis, 2010, p. 111). A curriculum and educational philosophy that had been interdisciplinary and interpretive, and that provided training in the skills of reasoning and understanding, gradually mutated into 'a curriculum which focused on the acquisition of information, and the ability to commit this information to memory' (Gilliat-Ray, 2006, pp. 64-65). It is not surprising to find that the curriculum of many Deobandi seminaries in Britain involves the study of commentaries; while it is still called 'Dars-i Nizami', what is actually studied is a shortened and adapted form of the curriculum (Gilliat-Ray, 2006, p. 65).

Different sectarian groupings and movements always exist within communities of a single national origin, and this is quite marked among Britain's South Asian Muslims. The core support for the Deobandi movement, whether for its ulama or lay preachers, comes from the Indian Muslim communities (Gujaratis, East African Asians, and some North Indians), who form only a fraction of the British Muslim community as a whole, less than 9 per cent - although it also has support from Bangladeshis and, to a much lesser extent, Pakistanis (Birt and Lewis, 2010, p. 109). Geographically, the centres of Deobandi influence in the United Kingdom are the post-industrial mill-towns of the North West, Bolton, Preston, and Blackburn; Leicester in the East Midlands; and West Yorkshire (Dewsbury and Batley in particular). Today these towns have 
become centres of learning and nodes for the dissemination of the Deobandi message nationally and even abroad; the ulama are at the centre of the Gujarati community and are able to determine the scope and direction of the further Islamization of these communities (Birt and Lewis, 2010, p. 111).

\section{$4 \quad$ The British context}

As mentioned earlier, the Indian Deobandi tradition has established more Islamic seminaries in Britain than any other sect. However, Jonathan Birt and Philip Lewis argue that the graduates produced by these seminaries far outnumber the imam positions available, and that most Darul Uloom graduates do not find employment in mosques or other sectors where they can apply their knowledge base (Birt and Lewis, 2010, p. 97). ${ }^{16}$ As one former Darul Uloom student told me, many of his peers ended up 'packing bananas or stacking shop shelves'. Gilliat-Ray $(2005,2006)$ points out that there are vast differences in the level, type, depth, and school of education offered by various Deobandi Darul Ulooms in the United Kingdom. The ones she surveyed have a curriculum and teaching staff that are bound very closely to their institutional and school origins in the Indian subcontinent, and in particular Gujarat. By contrast, the Muslim College in Ealing, West London (related to the Al-Azhar tradition) and Hawza Illmiya (a Shia institution) ${ }^{17}$, also in London, are both non-South Asian Islamic colleges, and both are seeking or have acquired validation from established secular universities - a process that involves an overhaul of curriculum and teaching methods. ${ }^{18}$ They attempt to combine theoretical and practical experience and show an appreciation of religious diversity and sources of knowledge outside of the Islamic tradition (Gilliat-Ray, 2006, p. 64).

What explains the differences between the 'South Asian' Darul Ulooms and the others? Is it related to a die-hard devotion to an outdated and anachronistic curriculum, or something deeper? According to Gilliat-Ray, the crucial difference is in their attitudes towards the need for training to have external validation from other Higher Education institutions and for

16 Ironically we have a similar situation in British academia, which has an over-emphasis on $\mathrm{Ph}$.D. funding opportunities and very few post-doctoral and other academic opportunities for early career researchers.

17 Shia institutions produce more academically competent individuals. For more on this see Van den Bos (2015).

18 For a thorough exploration of the process and politics of the university validation of UK Islamic higher education institutions, see Scott-Bauman and Cheruvallil-Contractor (2015). 
contextualization. Islamic colleges such as the Muslim College and Hawza Illmiya have thus 'met some of the challenges that South Asian dar ul-ulooms are now facing, though the extent to which this challenge is recognized differs' (Gilliat-Ray, 2006, p. 74).

Gilliat-Ray argues that Darul Ulooms in the United Kingdom are inadequate, anachronistic, and, in essence, backward. This portrait links to her key argument that times are changing too fast for the calcified Darul Ulooms:

The traditional role of the imam in Britain is in many cases expanding beyond mosques, to include more pastoral and youth work, chaplaincy, and involvement in local community projects. The curriculum of the dar ul-uloom is barely adapting to meet this changing role; the emphasis in the curriculum remains on inherited knowledge and textual study, and any modification of the curriculum would necessarily involve revision of a syllabus that has been actively preserved over generations. (Gilliat-Ray, 2006, p. 67)

Despite this strong critique, Gilliat-Ray was unable to gain fieldwork access to the Darul Ulooms she writes about. These remain shrouded in mystery for, and thus often forgotten by, many British Muslims - let alone the wider British public. This is, however, changing with recent media and government interest in Deobandi chaplains and how they are educated.

Gilliat-Ray did, however, conduct extensive interviews with community leaders and activists about their opinions about and relationships with these institutions - and her findings tell us a lot about how they are perceived within Muslim circles. She demonstrates that many in the wider Muslim community are (or should be) stakeholders in the project of building advanced religious training colleges, and how the Deobandi Darul Ulooms have not reached out to the majority Muslim community. Gilliat-Ray attempts an interesting democratization of critique by asking the Muslim civil society interviewees how they would like to see Darul Uloom training. Her survey shows that many Muslims want Darul Ulooms to connect more with the realities faced by the community and to include a practical placement in their training (Gilliat-Ray, 2006, p. 71). Many of the criticisms offered by those interviewed coincided with the linguistic and citizenship demands of the British government. ${ }^{19}$ However, these issues can sometimes be 'red herrings', because imams trained in the United Kingdom are not necessarily 'better' educated than those trained abroad. 
The studies by Gilliat-Ray and by Birt and Lewis both agree that the forms which the Darul Uloom model has taken in Britain are broadly out of touch with modern Britain and the current challenges facing the Muslim community. There is little research on the Darul Uloom tradition in Britain, but other analyses generally correspond with the above (see Bowen, 2014, and Geaves, 2012, both of whom are somewhat more critical). ${ }^{20}$

\section{$5 \quad$ Religious leaders' challenges}

From the production of imams, we now turn to the challenges these religious leaders face. The role and expectations of the imam have changed drastically through the process of immigration and mass settlement in Western Europe. For many, the once-humble position of prayer-leader has been plunged into the status of community representative and problem-solver by both congregations and state authorities. At Regents Park Mosque, one of London's largest and most famous mosques, an imam forum was held in 2015 to connect and share experiences among imams. ${ }^{21}$ A sense of heavy responsibility was in the air, tinged with the sound of desperation. Serving mosque imams from all over Greater London were present, from a kaleidoscope of backgrounds - Nigerian, Somali, Palestinian, Egyptian, Sierra Leonean, Moroccan, and the usual Pakistani and Bangladeshi - all, however, foreign-born and foreign-trained. Amongst the proceedings there were theological treatises and service delivery advice, and in between were questions and comments from attendee imams. Many complained about undemocratic mosque management committees, increasing demands for time and services with no extra support, as well as the constant piling-up of new legislation and calls for accountability. The message coming from the floor was a strong feeling of being under-resourced, under-paid, and over-burdened, as well as ill equipped and under-trained for the challenges laid at their feet.

As one prominent imam told me, most of his fellow imams are oblivious to the degree to which problems like drugs, teenage pregnancy, and domestic abuse are rampant in the Muslim community. Considering that the seminaries ban all use of social media within their grounds, it is not surprising there is a lack of awareness of these issues. At one lecture I attended, the speaker,

20 There is a dire need for more research on the topic of the UK's Darul Ulooms, particularly from the perspective of their enduring significance and influence.

21 This is based on participant observation at the event held on 15 March 2015. 
a prominent and learned British-born Islamic scholar, lamented about the number of young men who come to the mosque and yet also have girlfriends. He stated that he tries to encourage them to marry. 'He's really out of touch,' a young activist told me afterward. 'This imam doesn't realize that most of the audience here are probably also in non-marital relationships.'

\section{The Cambridge Muslim College}

In 2011, the Cambridge Muslim College (CMC) was established to deal with precisely these challenges by giving a contextual 'update' to the heavily textual training of British Muslim seminary graduates. It has been called a 'finishing school' that was established to provide a higher education experience for graduates of the traditional Indian-style Darul Ulooms in the United Kingdom. The college offers a one-year programme for both men and women with a curriculum emphasizing citizenship, political and cultural awareness, interfaith understanding, community building, counselling, and other pastoral skills.

Cambridge Muslim College recruits the crème de la crème of the United Kingdom's Darul Ulooms, those who should go on to become religious leaders and scholars, but who often find their legitimacy questioned by their peers on the 'streets' and by the more educated members of the Muslim community. ${ }^{22}$ Many Muslims regard these graduates as ill equipped by the archaic curriculum offered at the Darul Ulooms, which are famously insular and closed institutions. All of the enrolled students are ${ }^{c} \bar{a}$ lims and ${ }^{c}$ ālimas (male and female scholars) who have graduated from Darul Uloom seminaries and completed the Dars-i Nizami curriculum.

The Darul Uloom graduates have been trained mainly in the Deobandi or Barelwi traditions in institutions arguably more conservative, both culturally and religiously, than that offered by the CMC and its staff, who are part of Cambridge's relatively liberal and Sufi-inclined Muslim scene. The college is therefore in a position where it teaches mainly students from one particular denominational background, but does not necessarily share or promote that particular school of thought. This demonstrates an impressive degree of credibility and stakeholder relations with the 'feeder' seminaries - something that much of British Muslim civil society has been unable to achieve; in a highly fragmented and embattled Muslim community, this cannot be underestimated.

22 For more on contestations of authority in the UK Muslim community, see Ahmad and Evergetti (2010) and Jones et al. (2014). 
Cambridge itself has a small but burgeoning Muslim community with a relatively high educational and Islamic literacy level. They are linked through Sufi networks to other communities in the United Kingdom and internationally. The ethnic, regional, and class origins of the CMC students differ markedly from most of those in the wider Cambridge Muslim community, the majority of whom are connected in some way to the university, or to Cambridge's growing hospitals and science parks.

The culture of the college is decidedly English, and middle-class. The building itself is a converted vicarage, which has been islamicized with $w u d \bar{u}^{c}$ washrooms, a prayer room, and gender-specific common rooms. It is heavily influenced by the vision of its founder and dean Timothy Winter, Chair of Islamic Studies at the Faculty of Divinity in Cambridge University. Winter, also known as sheikh Abdal Hakim Murad, is, outside the ivory tower, a well-known and respected British Islamic scholar who appeals to a considerable audience in the British Muslim community and wider Anglophone Muslim world.

\section{$7 \quad$ Transforming Islamic education}

Cambridge Muslim College is modelled on the example of the Cambridge University colleges, but has no formal affiliation to the university. Students each have a tutor with one-to-one supervision sessions every week. The college employs a handful of staff and appoints two research fellows annually. This feature makes the college drastically different from its Darul Uloom forebears. The research fellows are usually postdoctoral or other early career researchers who have completed PhDs in Islamic Studies or related disciplines in universities in the United Kingdom, and who spend a year at the college working on their own research as well as providing occasional lecturing and supervisory duties. With these fellows the college positions itself as an aspiring higher education institution, with research output and the legitimacy to compete with universities in what constitutes 'Islamic Studies' in the academy.

Another key pedagogical difference is the emphasis on skills acquisition, as opposed to solely knowledge acquisition as taught by the Darul Ulooms. Students are expected to give presentations, have mock counselling sessions, and even produce creative work as part of their Art and Architecture module. A more holistic approach to educating the 'whole' student is also evident with the inclusion of Tai Chi and other martial arts as an obligatory part of the weekly timetable for all students. This is supplemented further with 
college trips to historic landmarks, museums, and even churches - a new experience for most of the seminary graduates.

The CMC is a small institution with a capacity of twenty students in the annual programme, although most years there are approximately ten men and five female students enrolled. The majority of these students are British nationals, but most years they also accept one to three students from overseas. For the majority of the students, their secondary education was boarding in a seminary for four to seven years. Unlike CMC, the seminaries were located outside an urban centre and allowed little to no contact with the wider community during their training. Almost all the enrolled students were from a South Asian ethnic background at the time of my fieldwork, and most of them came from suburbs or attended primary schools that were dominated by their own ethnic group. For many, it is likely that until their CMC experience they had very little educational or professional fraternization with people outside their own immediate communities.

One seminar I attended on medical ethics was particularly illustrative of the evolving pedagogical paradigm evident at the CMC. The visiting lecturer looked and sounded like a Darul Uloom graduate - he studied in Dewsbury and Karachi - and sported a white shalwar kameez, turban, and a long beard..$^{23}$ However, he also had several years of experience as a hospital chaplain and in offering counsel to Muslims and non-Muslims in difficult medical and ethical situations, setting him apart from the students.

A number of key ethical questions were discussed concerning organ donation, infertility treatments, and euthanasia. The teacher asked the students a series of hypothetical questions, positing a scenario and asking whether it would be acceptable to: (a) the sharia; (b) to their local mosque communities; and (c) to the wider British public. Example scenarios included: a Muslim woman being examined by a male medical practitioner, the routine use of contraception within marriage, taking a second wife, and leading a congregational prayer dressed in Western dress rather than 'traditional' or ethnic dress.

It became clear that most of the opposition lay in having new or unfamiliar interpretations and rulings accepted by the 'community'. The 'community' in many of the students' case meant their mosque congregations, the congregations who had supported them to study for so many years and which were invariably dominated by community 'elders'. Considering the fact that most British mosque committees are run by men over the age of 50 , for many

23 Dewsbury has the oldest and largest Islamic seminary in the UK and is Europe's key centre of Tablighi Jamaat preaching. 
of them this is the audience they would ultimately be accountable to. For many of these leaders-in-training, the 'community' may oppose a fatwa allowing contraception without 'valid reason' - even if it could be justified in Islamic jurisprudence.

'These are all aspects of 'urf [custom]' said the teacher, 'if norms change then so can the hukm [ruling]. Just because the șahāba [companions of the prophet] didn't practice something, doesn't mean we can't practice by default,' he continued. 'But Mufti Saab', one of the students asked, 'what if we have different norms in the same society due to immigration and multiculturalism?' The students buzzed with tentative legal solutions. The mufti continued:

Then we have to ask, what reasons make something permissible. Why do we need a reason to use contraception? Why are we so strict about it? Everybody is doing it. Otherwise you'd all have twenty siblings! Did the șahāba practice family planning? No very much, but they needed numbers for honour and protection. Just because they didn't do something, doesn't mean we can't do it today.

The teacher pushed them further: 'What if a woman wants to have an abortion just to keep her figure?' Discussion ensued, suggestions, giggles. 'Surely that is a cosmetic and superficial concern?' protested one of the students. 'But Maulana so-and-so has permitted it,' the teacher said, 'Are you stricter than our pious predecessors?' This was a rhetorical question not meant to be answered, and rightly so. No one is going to position themselves as superior, because part of the narrative of decline that exists internally within Muslim discourse is that the piety and spiritual insight of the umma is continually diminishing. A deep sense of humility is ingrained into the students of the Darul Uloom tradition, a humility so pervasive that it can sometimes make students hesitate to unsettle perceived norms. This fear of departing from what is acceptable is in part addressed pedagogically by having teachers from positions of authority in the Islamic tradition and/ or who are practicing Muslims themselves. The teacher in this case had achieved the rank of mufti, an Islamic scholar licensed to use independent reasoning to offer new legal opinions - the highest rank in Islamic scholarship. He upholds the sharia and applies it every day in his work. He speaks the technical language of Islamic jurisprudence and is not overtly pushing a 'liberal' agenda, which is often perceived by self-conscious upholders of the tradition as compromising their integrity and authenticity as Islamic scholars. This is tension no doubt common among many religious traditions today, but one that is particularly acute in this context. 
Hierarchy is important in the Deobandi and Barelwi traditions (the two most dominant Islamic interpretational traditions in British Muslim civil society). Being instructed in some of the most controversial modern issues by a scholar who is recognizably senior in the hierarchy is significant. First, it gives the students a familiar and authoritative framework through which to question and push boundaries; second, it provides adequate continuity with the hierarchical tradition they come from. It is even more interesting to see how the British context is taken into account and how students are encouraged to use their learning, while also being able to question and think beyond the arguably inflexible framework inherited from their home institutions.

We have here unfolding a unique approach to higher Islamic education, one that weaves together authentic Islamic learning that is considered credible by both the students and their communities with the expectations and know-how that characterizes modern British society. To better appreciate this approach, the next section takes a closer look at the differences between the CMC and the Darul Ulooms in Britain.

\section{Comparison to the Darul Ulooms}

The curriculum taught at the Cambridge Muslim College is vastly different from the students' prior education in the Darul Ulooms. In the seminary, the timetable starts after fajr ('dawn') prayer, and the morning and early afternoon are dominated by Islamic Sciences according to the Dars-i Nizami curriculum. In the mid-afternoon, usually after the ' $a s ̦ r$ ('mid-afternoon') prayer, National Curriculum lessons commence until the evening. ${ }^{24} \mathrm{CMC}$ students' prior learning was primarily a strict and disciplined regimen of lessons in the Islamic sciences, prayer, and other devotional practices in addition to homework time.

In comparison to the Darul Ulooms, 'worldly' knowledge is foregrounded though not necessarily prioritized at the CMC. At first glance, the timetable seems to show that explicitly religious learning is confined to the Quranic memorization class and Ihya Uloomuddin ('revival of religious sciences') session. From attending an average week of classes, however, I discovered that so permeating is the spiritual ethos of the institution that it is difficult

24 The National Curriculum is a common programme of study in schools that is designed to ensure a nationwide uniformity of content and standards in education in the United Kingdom. See: https://www.gov.uk/national-curriculum/overview. 
to go from a lesson on community leadership to the ethics of stem cell research and forget that we are in an Islamic institution. The college day fits around prayer times, and the teachers, whatever their own confessional backgrounds, make a point of acknowledging and working with the students' prior religious training. Lessons taught by non-Muslim lecturers take the form familiar to any college or university in the United Kingdom, though many of them try to anchor new material in something familiar to the students, or inquire whether similar concepts exist in the Islamic tradition. This is another aspect of the 'bridging' approach that characterizes the college. The division between worldly and religious knowledge is almost irrelevant in this context, where subjects like biology and astronomy are taught by practising Muslims and the teachers are comfortable using different genres of inquiry and analysis. Islamic education can be seen, through the example of CMC, to have come full-circle: from an approach that originally offered 'sacred' and 'secular' sciences together, then to their separation in the post-colonial era, and to their unification once again.

Another key difference between CMC and the Darul Ulooms is that all lessons, except the hifz ('memorization') class, are taught in a mixed-gender classroom. The significance of this arrangement in relation to the history of modern Islamic learning cannot be underestimated. Of the United Kingdom's 25 Darul Ulooms, four are female-only institutions. In the Darul Uloom setting, male students are not taught by female ${ }^{c} \bar{a}$ limas. However, female Darul Uloom students can be taught by male ${ }^{c} \bar{a}$ lims. To enable this they often wear niqābs in the male teacher's presence, or the teachers arrange an audio link to the classroom so that the students can hear the male ${ }^{c}$ älim but he does not have to be present in the classroom. At CMC, the male and female students sit on parallel sides of the classroom, and both male and female teachers teach them. Even outside of the Darul Uloom tradition, it is very common to find that British Muslim civil society, charitable, and other community events are often segregated, whether explicitly by organizers or voluntarily by attendees. However, it would be misleading to assume that this gender segregation is always male-imposed. Even casual conversations with Muslim women in mosques and Islamic events around Britain show that there is widespread support for it. There is evidently also strong support for educational gender segregation among the potential applicants to CMC, as I was told that some female students felt discouraged from applying because it was a mixed classroom setting.

My interviews with CMC students showed that they value and are grateful for the opportunity to expand their skills and knowledge base. However, when asked whether they would be able to recommend these courses to 
their alma maters, most believed that such constructive criticism would not be considered, though one student proposed going back and doing so after he moved up in the ranks of teaching staff. ${ }^{25}$ Change is uncommon and very slow at the Darul Ulooms, and would need to happen from the top-down rather than the bottom-up. Despite mounting evidence of alumni disgruntlement and wider community criticism, the Darul Uloom model remains very much intact and even flourishing, because they have credibility within the communities that support them. There is evidence to show that some Darul Ulooms have incorporated courses on professional skills, but whether this is due to the feedback from former graduates is unclear.

It is important at this point to note that the students who have graduated from Darul Ulooms and undertaken the Dars-i Nizami syllabus have been instructed as trainee ulama, and not so adequately as imams. These are both key roles in Islamic religious authority - and they can coincide in the same person - but they are not the same. The ulama are a class of religious intellectuals who, historically at least, could also have legal, academic, or even political-administrative functions. The imam is more of a community figure, whose basic function is leading the prayers in the mosque. With the growth of mosques as civil society institutions in their own right, particularly in minority Western contexts, the role of the imam has become more demanding.

While the Darul Uloom model emphasizes the acquisition of and proficiency in the Islamic sciences, at the CMC the professional acumen and wider-world knowledge of graduates is a key priority, as evident from the role it plays in their curriculum. However, a background in seminary education is a prerequisite for entry to CMC, because they are trying to offer a 'top-up' course of sorts. Students partake in lessons such as communication skills, community leadership, and counselling. During the course all students gain work experience as teachers or preachers in the local Muslim community of Cambridge, and more formally through a work experience module as a trainee chaplain with Cambridge's largest hospital. Students reported that the parts of the course that were based on direct contact with members of the public, such as chaplaincy and community placements, or that provided heavy pastoral skills training, such as counselling, were some of the most transformative in terms of personal growth and questioning their previously held assumptions.

Though there is an obvious emphasis on professional 'polishing', this is not to say that the diploma in Contextual Islamic Studies offered at CMC is a vocational course - quite the contrary. Over 60 per cent of the curriculum 
consists of academic subjects such as British political history, world history, science, social sciences, and English literature, which is designed to update their academic knowledge and expose them to other disciplinary traditions. These modules are all examined through essays and exams, as they would be in a British secondary school or university. 'We weren't taught to write essays at Darul Uloom, we didn't know how to order our thoughts and make an argument' one of the students told me, somewhat perplexed, when several impending deadlines were looming. One of the explicit purposes of this is to refine and practice their written academic English, which is highlighted as a weakness by most Darul Uloom graduates.

CMC has fostered a relationship with the famously insular Darul Ulooms, which generally rely on personal networks rather than institutional alliances, and has attempted to cultivate a sense of trust where other parts of the British Muslim community have failed. This creates necessary tensions, as the CMC has to maintain a delicate balance between honouring the past and innovating for the present. One example of this delicate balance is gender segregation. The students come from institutions where they have no contact with the opposite sex. While the lecture hall and canteen of the $\mathrm{CMC}$ are mixed, the prayer and common rooms are segregated. The CMC pushes limits, but not too far. While the CMC relies on the Darul Ulooms to provide students, its existence implies that the work of the Darul Ulooms is unfinished; they have to find a balance between traditions and moving forward - but not too fast. This potentially puts limitations on the kind of work the CMC can do, but - as befits such an institution - it is self-consciously evolutionary, rather than revolutionary, in its approach.

\section{Conclusion: The baby and the bathwater}

In the midst of such substantial pedagogical and curriculum developments, how is the Cambridge Muslim College managing to keep the 'baby' and dispense with the 'bathwater'? By emphasizing context while simultaneously upholding the traditional canon. The students' prior learning is celebrated, valued, and expanded upon; though there is pedagogical innovation, book learning is still central, and the inclusion of memorization classes in the curriculum is a nod to more 'traditional' Islamic learning methods. The broad legal and doctrinal premises of the normative Islamic worldview as expounded by the Darul Ulooms is shared by the College, as is an impetus to 'preserve' and 'protect' the tradition in the modern 
world. The College has undertaken extensive outreach efforts to connect with mosques and local communities around the country who send their children to, and support, the Darul Ulooms. As an institution, the CMC is a unique and innovative model that has nevertheless gained considerable respect and credibility from some of the most conservative sections of the Muslim community.

So what makes the Cambridge Muslim College different from its 'feeder' colleges? Both represent essentially two different educational approaches, but with broadly similar aims. Both aim to create a religious elite, but the emphasis of the CMC is on the training of leaders who have the knowledge and skills to serve the community in the time and space they are in now (hence the pioneering qualification received by the graduates, the diploma in Contextual Islamic Studies). The existence of the CMC is an acknowledgment that the knowledge base inherited from the 'old world' - the homelands of the first generation of migrants - is not enough. The establishment of institutions of higher learning (in this case the Darul Ulooms) is itself an acknowledgment that the migrant community has settled and no longer needs to send its religious trainees abroad. However, the establishment of a hybrid institution aimed at both 'raising the bar' and serving an increasingly younger, more educated, and professionalizing Muslim community is a further development in this direction. The relevance and implications of this difference can be numerous and consequential for both the Muslim minority experience in Britain and the wider Islamic narrative of religious expertise and leadership.

So are initiatives like the CMC stemming the narrative of decline that has so beleaguered Islamic religious leadership? It is too early to say. It is, however, possible to conclude that dramatic ruptures with the past do not seem to be favoured, but that there is enough support and willingness to give the traditionally trained ulama a chance to update and contextualize their knowledge and practice with an initiative like the CMC. A careful balance of affirming and upholding the old as well as valuing and promoting the new has shown the CMC to be a highly effective and quite unique bridging institution. Evidence suggests that the CMC is pragmatic about the changes it can bring about in one generation, but by pursuing such changes they will be more effective in the long run. If nothing else, it is clear from my research that the CMC has built up the confidence of this group of overlooked Muslim students and trainee religious leaders. In the process, it is also redressing the balance of the inverted education hierarchy - one that separates the sacred from the secular - and nurturing religious scholars' attempts to regain their rightful place in the Muslim imagination. 


\section{References}

Ahmad, Waqar I.U. and Venetia Evergetti. 2010. 'The Making and Representation of Muslim Identity in Britain: Conversations with British Muslim “Elites"'. Ethnic and Racial Studies, 33(10): 1697-1717.

Berkey, Jonathan P. 1992. The Transmission of Knowledge in Medieval Cairo: A Social History of Islamic Education. Princeton, NJ: Princeton University Press.

Birt, Jonathan and Philip Lewis. 2010. 'The Pattern of Islamic Reform in Britain: The Deobandis between Intra-Muslim Sectarianism and Engagement with Wider Society'. In Producing Islamic Knowledge: Transmission and Dissemination in Western Europe, edited by Martin van Bruinessen and Stefano Allievi, 91-120. London: Routledge.

Bowen, Innes. 2014. Medina in Birmingham, Najaf in Brent: Inside British Islam. London: Hurst \& Co.

Eickelman, Dale F. and James Piscatori. 1996. Muslim Politics. Oxford: Princeton University Press.

El-Rouayheb, Khaled. 2015. Islamic Intellectual History in the Seventeenth Century: Scholarly Currents in the Ottoman Empire and the Maghreb. Cambridge: Cambridge University Press.

Geaves, Ron. 2012. 'The Symbolic Construction of the Walls of Deoband'. Islam and Christian-Muslim Relations, 23(3): 315-328.

Gilliat-Ray, Sophie. 2005. 'Closed Worlds: (Not) Accessing Deobandi Dar ul-Uloom in Britain'. Fieldwork in Religion, 1(1): 7-33.

Gilliat-Ray, Sophie. 2006. 'Educating the 'Ulama: Centres of Islamic Religious Training in Britain'. Islam and Christian-Muslim Relations, 17(1): 55-76.

Jones, Stephen, Therese O'Toole, Daniel Nilsson DeHanas, Tariq Modood, and Nasar Meer. 2014. 'A 'System of Self-Appointed Leaders'? Examining Modes of Muslim Representation in Governance in Britain'. British Journal of Politics and International Relations, 17(2): 207-223.

Kersten, Carol and Susanne Olsson. 2013. 'Introduction: Alternative Islamic Discourses and Religious Authority'. In Alternative Islamic Discourses and Religious Authority, edited by Carol Kersten and Susanne, 1-15. Olsson London: Ashgate.

Makdisi, George. 1981. The Rise of Colleges: Institutions of Learning in Islam and The West. Edinburgh: Edinburgh University Press.

Metcalf, Barbara. 1996. 'Meandering Madrasas: Knowledge and Short-Term Itinerancy in the Tablighi Jama'at'. In The Transmission of Knowledge in South Asia: Essays on Education, Religion, History, and Politics, edited by Nigel Crook, 49-61. New Delhi: Oxford University Press.

Pierret, Thomas. 2013. Religion and State in Syria: The Sunni Ulama from Coup to Revolution. Cambridge: Cambridge University Press. 
Robinson, Francis. 2009. 'Crisis of Authority: Crisis of Islam?' Journal of the Royal Asiatic Society, 19(3): 339-354.

Scott-Bauman, Alison and Sariya Cheruvallil-Contractor. 2015. Islamic Education in Britain: New Pluralist Paradigms. London: Bloomsbury.

Van Bruinessen, Martin. 2010. 'Producing Islamic Knowledge in Western Europe: Discipline, Authority, and Personal Quest'. In Producing Islamic Knowledge: Transmission and Dissemination in Western Europe, edited by Martin van Bruinessen and Stefano Allievi, 1-27. London: Routledge.

Van den Bos, Matthijs. 2015. “Western Seminary”: On Transnational Shiite Higher Education in Britain'. Social Compass, 62(2): 238-254.

Waines, David. 1995. Introduction to Islam. Cambridge: Cambridge University Press. Zaman, Muhammad Qasim. 2002. The Ulama in Contemporary Islam: Custodians of Change. Princeton: Princeton University Press.

\section{About the author}

Alyaa Ebbiary is a finishing Ph.D. Fellow at the Department of Anthropology in the School of Oriental and African Studies. She is researching Islamic education and advanced religious training institutions within the British Muslim community, with particular attention to pedagogical practices and knowledge transmission. Her academic background is Anthropology and Middle Eastern Studies (BA, Manchester University) and Religious Studies (MA, Lancaster University). She has been a Research Assistant at the University of East London, Lancaster University, and the Lokahi Foundation. 


\title{
17 Imam training in the legal context of Islam in Spain
}

\author{
Juan Ferreiro Galguera
}

Hashas, Mohammed, Jan Jaap de Ruiter, and Niels Valdemar Vinding (eds), Imams in Western Europe: Developments, Transformations, and Institutional Challenges. Amsterdam: Amsterdam University Press, 2018 DOI: $10.5117 / 9789462983830 / \mathrm{CH1}$

\begin{abstract}
In this chapter, imam training in Spain is treated following three questions and lines of argumentation: How does the university system in Spain look like? What kind of religions are present in the country and how are imams getting trained? ${ }^{1}$
\end{abstract}

Keywords: Islam in Spain, Church State relations, Catholic Church, constitution, religious freedom

The Spanish university system consists of both public and private universities. There are 51 public universities, of which one (Universidad Nacional de Educación a Distancia, or UNED; the National University of Distance Learning) is an open university, and seventeen private universities. There are also two summer universities: Menendez Pelayo University and the International University in Andalucía. Of the seventeen private universities, one (the University Oberta de Catalonia) is an open university and seven belong to the Catholic Church. The Agreement of 3 January 1979 between the Spanish State and the Holy See concerning education and cultural affairs stipulates the following: 'State universities, with prior agreement from the

1 This chapter has been written as part of the research project 'The Arab Spring: integration of Fundamental Rights and Church-State relationship in the constituent processes of the new democracies', funded by the MINECO - Spanish Ministry of Economy and Finances (Ref.: DER 2012-33513). 
competent church authority, may establish centres of higher learning for the study of Catholic theology' (Article XII).

The Catholic Church thus has the right to establish faculties of theology within public universities, but has chosen not to do so. Instead, the church created faculties of theology within its own universities. There are three other groups - Jews, Protestants, and Muslims - that signed a Cooperation Agreement with the state in 1992. According to these Cooperation Agreements and the Organic Law 6/2001 of 21 December 2001, these groups are also allowed to establish university centres for theological studies, where their religious ministers can be trained and can receive a state-recognized certification after completion of the training. However, as of the moment of this book's publication, none of these groups have acted upon this opportunity. Protestants and Muslims have established their own theological centres, but without official recognition.

\section{2}

\section{Religions in Spain}

Article 16 of the Spanish Constitution recognizes the fundamental right of religious freedom for not only individuals, but also groups and communities. ${ }^{2}$ The only limits to manifestations of religious freedom, both for individuals and for groups, are those necessary for the maintenance of public order: 'Freedom of ideology, religion and worship of individuals and communities is guaranteed, with no other restriction on their expression than may be necessary to maintain public order as protected by law.' Law 7/1980 of 5 July 1980 (the Religious Freedom Act) implements the concept of public order as mentioned in the Constitution. This act enshrines two kinds of limits on religious freedom:

- Respect for the fundamental rights of others (like physical integrity, equality, and freedom of expression). All manifestations of religious freedom should respect, and thus not undermine, the fundamental rights of others.

- Public order, which is presented as a kind of triangular concept with the following sides: public health, public morality, and public security.

Thus, everybody can express his or her religion as long as he or she respects the area of this 'triangle'.

2 For information on the constitution, laws, decrees, and legal issues in Spain in several languages, see: http://www.mjusticia.gob.es/cs/Satellite/Portal/es/areas-tematicas/libertad-religiosa/ normativa-materia-libertad. 


\subsection{Register of religious entities}

In Spain there is a 'Register of Religious Entities' (referred to hereafter as RER, its abbreviated form in Spanish), as stipulated by Royal Decree 594/2015 of July

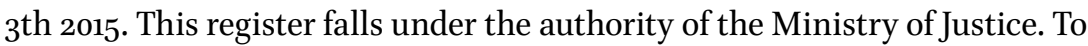
qualify for protection under the religious freedom laws, groups do not need to adopt any special legal form, but they do have the option to enrol in the Register. Registration is not compulsory, and registered denominations have only a limited number of legal advantages over non-registered ones. The main advantage is that after registration they are guaranteed legal representation as religious entities.

There are diverse requirements for enrolment in the Register of Religious Entities. The first step in the registration process is for the religious entity to submit a written request. This written application must be accompanied by a document containing data such as:

- Notice of the foundation or establishment of the organization in Spain.

- Entity name. The chosen name should be appropriate. This means that the entity's name cannot already be in use by another group, which could lead to misunderstandings. The religious entity should also present the address of its main location, or at least an address to receive notifications from the Ministry of Justice.

- Declaration of religious purposes. The expressed religious goals obviously must be considered in line with Spanish law. Therefore, they cannot go beyond the limits established in the Religious Freedom Act: respect for the fundamental rights of others and for public order.

- Representative bodies of the religious entity. The document should contain the procedures established according to the relevant internal norms, including the powers of the representative bodies and the requisites for a valid designation thereof.

According to the same Royal Decree (594/2015), there are, among others, these kinds of groups eligible to enrol in the Register:

- Churches, denominations, and religious communities

- Their respective federations.

- Religious congregations and their institutes.

- Religious associations that have been constituted as such under the ordinance of the churches they are linked to.

- Worship training centres.

However, there is a norm that allows only foundations associated with the Catholic Church to be enrolled in the Register of Religious Entities. As 
most of the religious foundations existing in the past were linked to the Catholic Church, Royal Decree $589 / 1984$ of 8 July was passed. To counter this problem, other royal decrees can be passed that would allow the enrolment of foundations related to other denominations in the Register of Religious Entities. However, until now there have been no new royal decrees allowing the registration of Jewish, Protestant, or Islamic foundations.

\subsection{Relations between political powers and denominations}

All relations between religious groups and public powers such as the central government, autonomous regions, or municipalities are expected to respect the tenets enshrined in Article 16 of the Constitution of Spain. It should be taken into account that the Religious Freedom Law (7/1980) does not only refer to those with religious creeds, but also to those who do not have them, i.e., to non-believers. Religious freedom is not only the right to believe, but also the right to not hold any religious creed. The law protects those two options in the same way, with the same strength. The second paragraph of Article 16, also referring to individuals, bans forced professions of personal beliefs: 'No one can be forced to declare his/her ideology, religion or beliefs.' This article specifies that neither the public powers nor any individual can force someone to make declarations about his or her beliefs. But it should also be taken into consideration that the consequences of keeping silent can sometimes be negative or harmful. For example, Spanish legislation permits individuals to get an identity card (DNI) with a passport photo in which they are wearing a headscarf, as long as the face is visible and the person in question can be easily identified. There have been some cases, however, of women presenting a photo of themselves wearing a headscarf to the police station when applying for an identity card and the police not only inquiring whether or not they are Muslim, but also requiring the presence of a document from the official representative of Spanish Muslims, i.e. the Islamic Commission of Spain, as testimony to the fact that they are, in fact, Muslim. If the woman refuses to answer or does not present the certificate, she will not get her identity card. In other words, she is being punished for her silence regarding her creeds - a practice that is clearly banned by the Spanish Constitution.

The third paragraph of Article 16 proclaims the following: 'No religion shall have a state character. The public authorities shall take into account the religious beliefs of Spanish society and shall consequently maintain appropriate cooperation relations with the Catholic Church and other confessions.' This paragraph deals with the constitutional model of the relationship between the state and religious denominations at three levels: municipalities, 
autonomous regions, and the central government. These relationships should be developed within the framework of two constitutional tenets: the principle of the non-confessional state, also called 'Secularism of the State', and the principle of cooperation between the state and religious groups.

\subsubsection{Principle of the non-confessional state}

During the dictatorship of General Franco (1939-1975), the fundamental laws proclaimed Catholicism to be the official religion of the state. After the death of the dictator, Spain went through a transition from a confessional to a nonconfessional state, which was ultimately established in the constitutional principles. The principle of the non-confessional state is based on two pillars: the separation between church and state, and the neutrality of the state vis-à-vis religious affairs. This tenet is contained in the first sentence of the Constitution's third paragraph: 'No religion shall have a state character.' The formula established in the draft constitution was even stricter: 'The state is to be non-confessional.' However, that expression was not retained in the final version, perhaps because it was too close to the formula that had been coined in Article 3 of the Constitution of 1932 (The Second Republic): "The State has no official religion' (Ferreiro Galguera, 2005, p. 62).

The formula adopted by the Constitution of 1978 to dictate the nonconfessional nature of the state could be considered 'shy' or modest for two reasons. First, because that paragraph was not included in the Preliminary Title. The Preliminary Title is the part of the Constitution where the State presents itself - in other words, where the State shows its ontological features, including its relationship with the sacred. Second, the expression 'No religion shall have a state character' is considered 'shy' or modest because it avoids focusing on the word 'state', which should be the subject of the sentence. Perhaps this 'modesty' is the result of the Constituent Assembly's attempt to find a middle ground between the Members of Parliament who wanted to maintain Catholicism as the religion of the state, as in the previous regime, and the ones who fought for a strict secularism and the removal of any mention of the Catholic Church from the text of the constitution. Taking into account that some principles are difficult to reconcile, it was decided to adapt the core of secularism to the needs of cooperation in the attempt to avoid traumatic changes and preserve the social peace. The memory of the unfortunate Spanish Second Republic, which ended in a civil war (1936-1939), seemed to enhance this.

In spite of its modesty, the constitutional expression 'No religion shall have a state character' perfectly reflects the secularism of the nonconfessional state. The basic idea encapsulated in this principle is that 
religious denominations and public powers (represented by the central government, autonomous regions, and municipalities) are independent and autonomous from each other. There is a consequence to this: the principle of non-interference in both directions. The state must not interfere in the realm of faith, and religious denominations must not meddle in the sphere of the state. In other words, the public powers cannot interfere in the internal realm of churches, which are entitled to organize themselves freely, and vice versa. As the Spanish Constitutional Court has reiterated in its decisions, the public powers must avoid any kind of confusion between state and religious functions. ${ }^{3}$ However, by virtue of the principle of cooperation, it is common for state powers to offer legal advice to denominations - but only if such legal advice is requested. On the other hand, no official posts may be reserved for religious ministers. However, they do have the same rights to participate in public affairs as any other citizen, for example by being a Member of Parliament or an official. Rabbis, priests, or imams may become civil servants if they pass the ordinary public examinations, which are inspired by and based on the constitutional principles of equality, merit, and capacity.

In some European countries, there are still remnants of a less clearcut relationship between church and state. In Denmark, for example, the laws that regulate the Lutheran Church are based on parliamentary acts. Moreover, the House of Lords in Great Britain still reserves seats for Anglican bishops. In Spain, seats are no longer reserved in Parliament for the high representatives of Catholic bishops (as was the case during Franco's regime), for doing so would go against the spirit of the separation between church and state and thus undermine the principle of the non-confessional state.

Neutrality is the other column on which the non-confessional principle rests. But what does neutrality mean? The Spanish Constitutional Court has described it as follows: "The state is not competent in religious affairs. ${ }^{4}$ Thus, (not) believing in a religious creed is only a choice (a right) for individuals and communities. As the Constitutional Court has established through its verdicts, individuals and groups are the real holders of the right to religious freedom, and consequently the only ones who can assess or evaluate whether religion is true - not the state. ${ }^{5}$

3 Among others, STC 24/1982 F.J.I. http://tc.vlex.es/vid/1-2-15034884.

4 STC 46/2001. http://mbarral.webs.ull.es/stc46-2001.html.

5 'The articulation of a Register [...] does not empower the State to undertake an activity of control to determine the legitimacy of religious beliefs [...] but only to verify, deriving to that end a mere act of stating and not rating, that the applicant group is not one of those entities excluded by Article 3.2 of the LOLR, and that the activities and behaviours developed for its 
For this reason, the term 'sect' - which has negative connotations - is not considered a legal term but rather a sociological one (Martí Sánchez, 2014, p. 13; Motilla, 1999, p. 112). The state cannot distinguish between the heterodoxy and orthodoxy of a specific religious group. So the state should accept that religious communities are groups if they consider themselves to be so. They can enrol in the Register of Religious Entities that falls under the Ministry of Justice once it is verified that they comply with the formal requisites imposed by the current legislation. Of course the state does control whether any group (religious or not) is acting within the limits of the law or is breeching a law or undermining public order or the human rights of others.

Officials must examine whether groups applying for inclusion in the RER fulfil the legal requirements described above. They are required to proclaim that they follow religious purposes, but the state cannot assess whether that statement is true. As long as it cannot be proven that the declared religious goals are illegal, officials belonging to the RER have to register them. The Scientology Church, for example, was registered in 2007 after having been rejected three times - after the National Court (Audiencia Nacional), which is lower in hierarchy than the Constitutional Court, ruled that it should be included in the RER. ${ }^{6}$ As Article 22.2 of the Spanish Constitution proclaims, associations (of any nature, including religious ones) pursuing goals or using means that can be considered criminal will be deemed illegal, and will therefore not only be prevented from registering, but may also be prosecuted. ${ }^{7}$ So, should the RER, in the absence of evidence, detect indications that suggest the applicant group is undertaking activities against the public order, it would be legitimate for the person in charge of the RER to suspend the application and send the dossier to the Public Prosecutor. Basic Law 1/2002, which regulates the Right to Association fixes this for associations (Articles 30.3 and 4; Pelayo Olmedo, 2007, p. 313).

practice do not threaten the rights of others in the exercise of their fundamental freedoms and rights, nor do they threaten the security, health and morality of the public, as elements that enshrine the public order protected by the law in a democratic society, which are referred to in Article 16.1 CE.' (STC 46/2001 FJ 8º). http://mbarral.webs.ull.es/stc46-20o1.html.

6 Sentencia Audiencia Nacional of 11 October 2007. http://audiencia-nacional.vlex.es/vid/ inscripcion-registro-entidades-religiosas-34438671.

7 As the Constitutional Court decrees (STC 46/2001): 'Only when the existence of a certain danger against the public security, health and morality, as they should be recognized in a democratic society, has been accredited before the court, it is pertinent to invoke public order as a boundary to the exercise of the right to religious freedom and freedom of worship' (FJ11). 
A lot of religious entities are registered in the RER: 13,101 of them belong to the Catholic Church, and 2,462 to non-Catholic religious groups. ${ }^{8}$ As already indicated, the Register is like a cupboard where the entities that consider themselves religions and comply with the legal requirements are registered. The main civil advantage that religious organizations obtain from being registered is the acquisition of a legal personality as religious entities, and thus the possibility of organizing themselves in an autonomous way. 9

Neutrality has certain consequences for the state. First, from an institutional point of view, public authorities are, as citizens, free to (not) follow any faith. Second, the state is neither confessional nor atheist; only citizens and groups can adopt these ideological positions. Lastly, the state should not maintain a radically secularist attitude towards its citizens. In this sense, it is important not to confuse the terms laico ('neutral') and laicista ('radically secularist'). For example, the state has a laicista attitude when it shows prejudices against religious groups in the state's administrative performance, laws, or courts. A laicista attitude would, for example, be at play when the state treats religious groups unequally, i.e., worse than it treats sports, cultural, or culinary associations. The principle of equality allows public authorities to establish differences between people or groups, but the differences should be proportional and reasonable. If these differences are not reasonable or are based on reasons related to birth, gender, race, or religion, they turn into discriminatory differences. Another example of a radically secularist attitude would be the confinement of religious manifestations to the private sphere, understood as the intimacy of the home, by forbidding religious manifestations in the public sphere, i.e., in the street. The state would in that case not be neutral because religious groups can obviously express themselves in the public sphere as long as they do it within the legal limits of the fundamental right of demonstration. Relegating religious expressions to the private realm would then be a kind of prejudice, because it denies the group the fundamental right of demonstration.

8 Recurso 352/2005.

9 Article 6 of Law 7/1980: 'Registered Churches, Faiths and religious communities shall be fully independent and may lay down their own organizational rules, internal and staff by laws. Such rules, as well as those governing the institutions they create to accomplish their purposes, may include clauses on the safeguard of their religion identity and own personality, as well as the due respect for their beliefs, without prejudice to the rights and freedoms recognized by the Constitution and in particular those of freedom, equality and non-discrimination.' 


\subsubsection{The principle of cooperation between State and denominations}

The second area of relations between church and state is cooperation. This principle is implicitly reflected in Article 9.2 of the Spanish Constitution, ${ }^{10}$ but it is enshrined in a more convincing way in the second sentence of Article 16.3. After the establishment of the non-confessional state - i.e., 'no religion will have a state character' - the Constitution gives two very clear orders to the public authorities:

- To take into account the religious beliefs of the Spanish population.

- To maintain relations of cooperation with the Catholic Church and other denominations.

The Constitution does not declare how cooperation with denominations should be developed. But from this double mandate, it is possible to extract the following consequences:

- Cooperation refers to religious faiths. It is referred to as the 'faith option'. Although the state can obviously cooperate with non-religious ideological groups as well, Article 16.2 specifically refers to the cooperation of the state with the Catholic Church.

- Relations of cooperation imply the existence of two different subjects, public authorities and religious groups, both of which are independent and autonomous. In other words, the principle of cooperation further strengthens the principle of separation.

- The order to cooperate implies a positive appreciation of religions on the part of the Constitution. The Constitution recognizes that denominations are at least potentially positive; otherwise, it would not have made it imperative to cooperate.

- In line with the principle of freedom, cooperation of the state with denominations should only take place at the request of the denomination; some denominations, by virtue of their autonomy, may not want to cooperate with the state.

The direct mention of the Catholic Church in this article of the Spanish Constitution has not been a peaceful issue. Some people considered it an implicit declaration that Spain was a confessional state. Those in the Constituent Assembly who had declared themselves against such an idea

10 Article 9.2 of the Constitution: 'It is the responsibility of the authorities to promote the conditions for the freedom and equality of individuals and the groups they conform to be real and effective; to remove the obstacles which impede and complicate their plenitude; and facilitate the participation of all citizens in the political, economic, cultural and social life.' 
argued that it was contradictory to the already-proclaimed principal of the non-confessional state. In the end, it was decided that the mention of the Catholic Church would remain. Some of the supporters argued that even though the mention was problematic from a legal point of view, from a political point of view it was reasonable because the intention at that moment was for the transition from a denominational state, i.e., the previous regime, to a non-denominational or secular state to be accomplished in a way that would not lead to future traumas.

In this sense, the attitude of Santiago Carrillo, the Communist Party's representative in the Constituent Assembly, can be considered wise. He supported the specific mention of the Catholic Church mainly, he declared, to avoid the possibility that those who had sided with Franco at the end of the Second Republic would support the reactionary forces that were opposed to democracy. ${ }^{11}$

In the end, the tenet of cooperation that was initially meant to temper secularism turned out to be a very effective tool in the integration of immigrants into Spanish society. Evidently, when the Constitution was approved in 1978 nobody foresaw the high numbers of immigrants that would come to Spain after 2000. The Constitution stipulates that the state must cooperate with denominations in terms of future action (i.e., 'the authorities will take into account ...'), but does not suggest any specific way to cooperate. The Parliament has 'answered' this open question on two different occasions.

Five days after the Constitution entered into force, on 3 January 1979, the Holy See signed four Cooperation Agreements with the Spanish State concerning legal affairs, educational and cultural affairs, economic affairs, and chaplaincy in the Armed Forces and the military service of clergymen and members of religious orders. Of course, these agreements were not prepared in five days; negotiations were held during the formation of the Constitution. Because the Holy See is a state, the Cooperation Agreements have the legal status of international treaties, so they enjoy a higher status than ordinary national agreements. They cannot therefore be abrogated or modified by an ordinary law.

The second step to implementing the constitutional mandate of cooperation was the enactment of the Religious Freedom Act of 1980, one year after the ratification of the Cooperation Agreements. According to Article 7.1 of the Religious Freedom Act, the state may establish Cooperation Agreements with registered religious entities that, given their scope or number 
of followers, obtain the classification of a notorio arraigo ('deeply rooted') denomination. Such Cooperation Agreements have to pass as laws in the Parliament. To sign a Cooperation Agreement with the state, a religious group must fulfil two requirements:

- To be registered in the RER located in the Ministry of Justice (Department of Relations with Denominations).

- To obtain the recognition of a notorio arraigo ('deeply rooted') denomination in Spain.

This 'deeply rooted condition' was a new legal concept, for the definition of which the Religious Freedom Act only offers two hints: the scope or extent and number of believers. This vagueness gave the Ministry of Justice the opportunity to develop the concept of 'deeply rooted' through the implementation of a regulatory norm, but in the end it failed to do so. The convenience of defining the objective requirements for a 'deeply rooted' denomination through an administrative norm was discussed in the Advisory Commission of Religious Freedom on 23 June 1982, but the outcomes of the discussion were rejected. Some believed that this should instead be done through a law of Parliament. Others thought that with the approval of such a regulation the government, specifically the Advice Commission of Religious Freedom provided by Article 7 of the Religious Freedom Act ${ }^{12}$ would lose the small amount of discretionary power it enjoyed. The Advisory Commission of Religious Freedom is a consultative body appointed by the Ministry of Justice, whose task and mission is to undertake studies, reports, and proposals for all issues applicable to the Religious Freedom Act, particularly the preparation of mandatory reports about future Agreements of Cooperation. ${ }^{13}$ The Advisory Commission proposed that, given the ambiguity of the term, it should be applied to each case separately - but it did offer some interpretive criteria for the legal terms 'context' and 'number of believers' (Fernandez Coronado, 1995, pp. 45-47). For example, the 'context' was not only used to refer to a number of followers sufficiently and significantly extended throughout the Spanish territory, but also to aspects such as the historical

12 This commission was created by royal decree 159/2001 on 26 October 2001: http://mbarral. webs.ull.es/calr.html.

13 Article 8.2: 'Created within the Ministry of Justice, this Advisory Commission of Religious Freedom is composed of pair numbers and with a stable character by representatives of the State's administration, churches, denominations, religious communities or federations, within which will certainly be those with a well-established following in Spain, and by people recognised as competent in the field whose advice is considered to be of interest and relevance to the material related to the present law.' Royal Decree 932/2013 currently implements this article. 
presence of the denomination in the country, the importance of its social, charitable, and cultural activities, the number of places of worship, and the number of religious ministers in proportion to its members.

Even though there was no specific legal prescription, the de facto government body that granted 'deeply rooted' denomination status turned out to be that same Advisory Commission for Religious Freedom. It therefore played an important role in the cooperation between the state and religious denominations. This ambiguity ended in 2015 when the Government issued the Royal Decree 593/2015 of July 3 th that regulates future declarations of deeply rooted character by the Ministry of Justice.

The Catholic Church did not need to obtain the classification of a 'deeply rooted' denomination because it was obvious, and was already specifically mentioned in Article 16 of the Constitution. In 1984, the Advisory Council of Religious Freedom granted the Jewish community and Protestant churches the classification of 'deeply rooted' denominations. Muslims received the classification of a 'deeply rooted' denomination in 1989. In 1992, three agreements came into effect that were signed by the Spanish State and the Jewish Community, the Protestant churches, and the Muslim Community of Spain, respectively. As set out in the Religious Freedom Act, these agreements were approved by Parliament as Laws 24, 25, and 26/1992 on 10 November 1992.

The negotiations preceding these agreements were held with the following entities, each representing their respective denomination: the Federation of Jewish Communities in Spain (Federación de Comunidades Judías de España, FCJE); the Federation of Evangelical Religious Entities of Spain (Federación de Entidades Religiosas Evangélicas de España, FEREDE); and the Islamic Commission of Spain (Comisión Islámica de España, CIE). When the agreement was signed, two other Muslim federations integrated into the CIE: the Union of Islamic Communities in Spain (Unión de Comunidades Islámicas de España, UCIDE) and the Spanish Federation of Religious Islamic Entities (Federación Española de Entidades Religiosas Islámicas, FEERI). The three organizations were compelled to unify into one commission to sign the agreement with the state. Otherwise, the agreement would not have been signed.

\subsection{Classification of religions in Spain from a legal perspective}

Four types of religions can be distinguished in Spanish law. First there are non-registered religious entities. Instead of registering, religious entities may choose to become an association under the Law of Association. ${ }^{14}$ To do 
so, they must submit an agreement between at least three individuals and a plan for internal regulation (in a public or private document) approving the organization of the association. If they choose to become an association, they can enrol either in the National Registry of Associations of the Ministry of Internal Affairs, if their sphere of activity refers to the whole country, or, if their sphere of activity is located in one of the seventeen autonomous regions of Spain. Intervention or approval by a public authority is not necessary for the group to be entitled to the fundamental right of religious freedom; the Constitution guarantees the right of religious freedom for all religious communities, whatever legal form they adopt, on the condition that they respect public order and the fundamental rights of others. Article 2 of the Religious Freedom Act refers to several manifestations of the religious freedom of individuals and communities, including the right of religious groups to hold worship celebrations, commemorate feast days, celebrate marriage rites, impart religious teachings, establish places of worship, appoint and train ministers, spread the group's creed, maintain relations with their own organizations and with other religious denominations, and provide religious assistance in public institutions such as the army, prisons, and hospitals.

Second are the religious entities enrolled in the Register of Religious Entities (RER). The most controversial aspect of the requirements for registration in the RER is the so-called 'declaration of religious purposes'. According to the Spanish Constitutional Court, the administration does not have the right or ability to assess religious purposes. Thus, registration can be refused only if the applying religious group does not meet the requirements, or if it can be legally proven (for example by a legal sentence) that the applicant group seeks to carry out illegal activities or goals.

Third type are the registered religious groups that also have the status of 'deeply or firmly rooted' denominations. Based on the already mentioned Royal Decree 593/2015 of July 3th, the Ministry of Justice can grant a 'deeply rooted' status to a registered religious group. These denominations will subsequently benefit from two main further legal advantages: the right to have a representative member in the Advisory Commission of Religious Freedom; and the possibility of reaching a Cooperation Agreement with the state. So far, four denominations - Mormons, Jehovah's Witnesses, Buddhists, and Christian Orthodox churches - have obtained a notorio arraigo ('deeply rooted') status, under the umbrella of the previous regulation, but have not yet signed a Cooperation Agreement with the state.

Fourth type are the religious groups that have been registered in the RER, received 'deeply rooted' status, and signed a Cooperation Agreement with 
the state. At this point, we can distinguish between the agreements signed by the Catholic Church and the three Cooperation Agreements signed by the official bodies of Jews, Protestants, and Muslims.

\section{$2.4 \quad$ Cooperation agreements}

The four Cooperation Agreements between the Holy See and the Spanish State have the legal status of international treaties, and so contain more privileges than those reached with Jews, Protestants, and Muslims in 1992. In the agreement concerning economic affairs, for example, the Spanish state promises to collaborate with the Catholic Church to obtain 'its adequate economic support'. This agreement foresees a system that has been implemented by further norms, and which is now formulated as the ability of all taxpayers to allocate a percentage of their income tax - currently 0.7 per cent - to the Catholic Church and/or to NGOs (including Catholic ones). Other important benefits of the agreements include religious education in public schools. The Agreement on Educational and Cultural Affairs foresees an educational system in which all public and private schools - the last ones called concertados - that receive funding from the state must offer classes on Catholicism although taking such courses is voluntary for the pupils. Other benefits refer to chaplaincy: according to the system established in the Cooperation Agreements and implemented by several norms, Catholic religious assistance in public establishments is regulated and paid by the state.

Once the respective federations representing Jews, Protestants, and Muslims received 'deeply rooted' status from the Advising Council for Religious Freedom, the three denominations negotiated three different but basically similar Cooperation Agreements that were immediately passed as laws in the Parliament (Laws 24, 25, and 26 on 10 November 1992). Some of the special rights enshrined in the three Cooperation Agreements are the following:

- Legal definition (juridical status) of places of worship and religious ministries.

- Civil effects of weddings celebrated according to the respective religious ceremonies.

- Spiritual guidance in public establishments.

- The right of parents to demand religious education for their children in public schools.

- Tax exemptions: more or less the same as those granted to the Catholic Church - except for the possibility of taxpayers to donate 0.7 per cent of their income taxes, which has so far only been prescribed for the Catholic Church. 
- Celebration of religious festivities and protecting respective cultural and historical heritages.

The benefits of the agreements only affect those religious communities that belong to the federations or commissions that signed the agreement with the state.

\section{$3 \quad$ Islam in Spain}

This section describes the diverse characteristics of the Muslim community in Spain. Islam was present in Spain from 711, when the Muslim leader Tariq Ibn Ziyad landed at Gibraltar, until 1502, when Muslims were told to choose between exile and conversion to Catholicism. At the beginning of the twentieth century Islam made a comeback in Spain through the process of migration.

Numbers. There are no official data about the number of Muslims in the country, as the Spanish census does not record the religion of the citizens. The figures offered here are merely estimates inferred from the immigration figures. Spain has a population of 47 million people, ${ }^{15}$ of which approximately 1.4 million are Muslim: 2.5 per cent of the population. 30 per cent of the Muslims are Spanish citizens and 70 per cent are immigrants from different national origins: largely Morocco $(717,992)$, but also Algeria, Pakistan, and Senegal. They mainly live in Catalonia, Andalusia, and Madrid. There are also about 5,000 converts.

Organizations. In 1989, Muslims associations organized under two big umbrella organizations: the Islamic Communities Union of Spain (UCIDE) and the Spanish Federation of Religious Islamic Entities (FEERI). In 1991, the Government forced these two associations to join the Islamic Commission of Spain (CIE) to sign the Cooperation Agreement (Law 16/1992 10 November 1992). In 2011 another fifteen Muslim religious federations were integrated into the Islamic Commission of Spain so that their members could enjoy the benefits of the Cooperation Agreement. In 2016 there were about 1,316 Muslim religious communities (associations) in the country, but only 900 of them were listed in the Register of Religious Entities of the Ministry of Justice.

Mosques. According to Article 2 of the Cooperation Agreement, mosques are buildings that are used exclusively and regularly for prayer, religious education and training, and spiritual guidance. Mosques are certified as such by the Muslim community in question, with the endorsement of the 
Islamic Commission of Spain. There are twelve mosques with minarets in Spain: two in Madrid, one in Valencia, three in Andalucía, four in Ceuta, and two in Melilla. According to the Observatorio del Pluralismo Religioso en España, there were 1,313 mosques or Islamic prayer halls in Spain as of January $2015 .{ }^{16}$ The registration of mosques in the Register of Religious Entities (RER) is voluntary. In July 2009, 176 mosques were registered: 113 from communities under CIE's umbrella and 57 from other communities that were not entitled to the benefits of the Cooperation Agreement.

Cemeteries. According to the Cooperation Agreements, Muslims have the right to their own cemeteries. They are also entitled to a reserved space for Muslim burials in municipal cemeteries. Currently there are five private Muslim cemeteries in Spain: in Cádiz (Islamic cemetery of Jerez), Málaga (Islamic cemetery Suhail in mezquita de Fuengirola), Madrid (cemetery of Griñón, built by General Franco after the Spanish Civil War of 1936-1939 as a reward for the Moroccan soldiers that fought on his side), and two in the autonomous cities of Ceuta (cemetery Sidi Embarek), and Melilla (Islamic cemetery of Melilla). There are spaces reserved for Muslim tombs in municipal cemeteries in Bilbao, Barcelona, Manresa, Tarrasa, Burgos, Zaragoza, Alicante, Valencia (2), Cádiz, Málaga (2), Sevilla, Córdoba, Granada (2), Palma de Mallorca, Las Palmas de Gran Canarias, and Logroño.

Imams. According to Article 3 of the Cooperation Agreement, Muslim religious leaders and imams who lead prayers, oversee religious education and training, and provide spiritual guidance must be in possession of a certificate stating that they can fulfil these duties. The Muslim community to which they belong must issue this certificate with the endorsement of the Islamic Commission of Spain. Imams are covered by the social security system with a status akin to that of employees. Their respective Muslim communities assume the rights and obligations of employers under the social security system, as stipulated in Article 5 of the Cooperation Agreement. Imams and Muslim religious leaders are entitled to the right to secrecy as stipulated in Article 3.2: under no circumstances may religious leaders and imams 'be forced to reveal information disclosed to them in the exercise of their duties as prayer leaders, preachers and spiritual counsellors, by virtue of the privilege of confidentiality conferred on them by law.' Royal Decree 176/2006 of 10 February 2006 sets out the terms and conditions for the inclusion in the social security system of religious leaders and imams from communities that are members of the Islamic Commission of Spain. As of December 2009, there were 109 imams that had been registered for Social Security. 
Prisoners and chaplaincy. Muslim inmates are entitled to receive spiritual guidance from imams or persons duly appointed by Muslim communities, subject to the authorization of the Islamic Community of Spain (Article 9). These spiritual authorities must be approved by the prison authorities and must meet certain requirements, such as not having a criminal record. While the 140 currently employed Catholic chaplains are paid by the state, the two Jewish chaplains and 250 Protestant chaplains do not receive any state salary because their respective Cooperation Agreements established that their respective churches and synagogues would cover the chaplaincy expenses. ${ }^{17}$ This is not the case for the Cooperation Agreement with Islam, where it is stipulated that the expenses of spiritual guidance would be covered in a way agreed upon by both the representatives of the CIE and the prison establishments (Article 9.3). While implementing this article, an agreement was reached on 12 July 2007 stating that Muslim chaplains can be paid by the Ministry of Internal Affairs provided they gather a group of ten or more prisoners. ${ }^{18}$ In 2016 there were seven imams offering religious counselling at prisons who were covered by this agreement. There were originally nine of them, but the Ministry of Internal Affairs suspended two for security reasons.

Education. In the Spanish educational system there are three types of schools: public schools, private schools without state funding, and concertados ('private schools with partial funding from the state'). So far, there is no private or concertado Islamic school within the Spanish educational system. However, Muslim pupils are entitled, upon request, to receive Islamic religious instruction in public schools, at the pre-school, primary, and secondary levels. Teachers of Islam in public schools are paid by the state as long as they have at least ten students.

For the school year 2013-2014, there were 45 Muslim teachers in primarylevel public schools in the following autonomous provinces: Andalucía (18), Aragon (3), Canary Islands (1), Basque Country (1), Ceuta (10), and Melilla (12). These five autonomous provinces are the only ones (out of seventeen) in which the payment of religious teachers in public schools has not yet been decentralized in compliance with the new norms of the educational system in Spain. Thus, the employer of these Islamic teachers is still the Ministry of Education of the central government.

17 Royal Decree 710/2006 of 9 June 2006 implements the right of inmates of prisons to receive spiritual guidance as established in the Cooperation Agreements with Jews, Protestants, and Muslims. Article 11 of this Royal Decree rules that the funding of this spiritual guidance shall follow the regulations established in the respective Cooperation Agreement.

18 Cooperation Agreement between the Spanish State and the Islamic Commission of Spain (CIE) in order to fund religious assistance in State prisons (12 July 2007). 


\section{4 Imam training centres in Spain}

This section briefly describes the situation of imam-training centres in Spain as they developed in the near past (4.1) and as they are now (4.2).

\subsection{The situation in the near past}

There used to be programmes of Islamic studies offered by two universities: the public National University of Distance Learning (UNED), and the private Camilo José Cela University. The latter organized a course on 'Islamic religion and culture'. Further, there were two courses offered by two Islamic organizations, the Islamic Council of Catalonia and the Islamic Federation of Murcia. None of these courses exist anymore, and none had official recognition.

The National University of Distance Learning (UNED) and the Pluralism and Living Together Foundation (a public foundation under the Ministry of Justice) organized a course called 'Islam and Democratic Principles' that was taught in the 2009-2010 term, after which it was suspended. It was not a course about theological studies or sharia, but about Islamic culture. The diplomas obtained by students of both university centres were not official, but were private documents recognized only by the two participating universities.

The Islamic Council of Catalonia ${ }^{19}$ ran an imam-training course starting in 2005. Some of the teachers were from Spain, such as the imam of Mataró (Barcelona), but there were also teachers from abroad, i.e., from Ibn Zohr University in Agadir, the University of al-Qarawiyyin in Fez, and Qatar University. The diplomas received did not have official recognition, and the course is no longer in process.

The Islamic Federation of Murcia is the second umbrella organization that provided imam-training courses. It did not originally belong to the CIE, but in 2015 it joined the Islamic Commission of Spain, so its community members are now entitled to all of the rights proclaimed in the Cooperation Agreement. Initially, the objective of the courses from the Murcia Federation was not only to provide theological training, but also to provide a basic education about Islam. The teachers who first participated in these courses came mainly from Belgium, France, Spain, Morocco, and Egypt. They offered the following subjects: the prophet's teachings, interpreting the Quran in the Western context, Spanish, computer science and Internet skills, and oratory.

19 It did not belong then to the Islamic Commission of Spain (CIE), but it is one of the fifteen federations that entered the Commission later. 


\subsection{Existing imam training centres}

In November 2013, the Spanish Federation of Religious Islamic Entities (FEERI, which is one of the umbrella organizations under the Islamic Commission of Spain) started a two-year course (i.e., running until December 2015). The classes were held mainly in weekends in the Assalam mosque in the city of Valencia. This two-year course is organized in cooperation with the Muslim Federation of the Valencia Community (FEMCOVA), the Spanish League of Imams, the European Institute of Islamic Sciences, and the Islamic University of Rotterdam. During the first year, a student can get a diploma in the following specialties: Quran and its Science, Islamic jurisprudence, Arabic Language and hadith, sira ('biography of the prophet'), and history. ${ }^{20}$ Successful students receive a diploma in Islamic Sciences that is recognized by the European Institute of Islamic Sciences and the Islamic University of Rotterdam - which so far do not have full official recognition in the university system of the Netherlands (Ferreiro Galguera, 2011, p. 298). This diploma allows them to attend another year of superior level studies. So far, the diplomas received by the students of these courses are not officially recognized by the Spanish State.

\section{$5 \quad$ Recommendations}

Islam is part of the history and culture of Spain. It is taught at public schools; there is Islamic chaplaincy in prisons and hospitals. And yet Spain still lacks deep and serious Islamic theological studies. As a result of my experience in the Ministry of Justice, where I was the deputy director of relations between the State and religious denominations, and at the request of the Commission of the European Union, I had the opportunity to research imams in the European Union. I wanted to formulate answers to questions such as how many imams there are in the European Union, where they come from, and where they had been trained, In my book Islam and State in the European Union, I tried to map the imam training centres in the European Union (Ferreiro Galguera, 2011). In that book, I pointed out that even when we finally have a clear idea about the real face of 'academic Islam' in our countries, we would still have two very important challenges ahead of us.

20 To obtain the diploma in hadith, sira, and history, the student has to attend and pass the following weekend courses: terminological science of hadith, content of hadith, sira, history of the Caliphate, and history of Al-Andalus. http://feeri.es/. 
The easiest and most feasible recommendation would be to draw up general guidelines related to aspects like advice for obtaining legal recognition of Islamic study programmes. A more ambitious objective would be to start a debate about the possibility of establishing a European Institute or University of Islamic Studies. This would be a university or institute similar to Al-Azhar University in Cairo, but in Europe. This initiative could possibly be developed within the framework of a cooperative project between European Islamic faith leaders and the institutions of the European Union. Such an institution would be of interest not only for imams, but also for any other European citizen looking for a solid Islamic theological training. Such a university might also work in close collaboration with other prestigious Islamic universities all over the world. The closer these collaborations, the better it would be for conveying knowledge and a sense of transparency about Islam. This could also be a platform for the convergence of all imam training centres and Islamic curricula in one common European context as an example of tolerance and intercultural dialogue.

If this project is to be established according to the principle of cooperation between political and religious authorities for the sake of promoting religious freedom, it would, naturally, require the agreement of both European public authorities and Muslim religious leaders. We should take into account that a project of this nature cannot be achieved if European Muslim representatives do not request it themselves. Everybody is aware of the difficulties involved in creating a representative Muslim voice in Europe; the network of leaders in European imam-training centres would be a useful tool for forming one. Once initiated by a representative Muslim academic authority, the project would also need the consensus of the pertinent political representatives in the European Union to participate in this endeavour for the promotion of religious freedom. I have in this chapter already identified some of the difficulties and challenges of the steps that follow. In any case, the next stage should be approached in a spirit of dialogue, cooperation, and unity. This is epitomized in the old but wise saying: 'If you want to walk fast, you walk alone. If you want to walk far, you walk together.'

\section{References}

Fernandez Coronado, Ana. 1995. Estado y confesiones religiosas: Un nuevo modelo de relación (los pactos con las confesiones: leyes 24, 25 y 26 de 1992). Madrid: Civitas. Ferreiro Galguera, Juan. 2005. Relaciones Iglesia-Estado en la II República Española.

Barcelona: Atelier. 
Ferreiro Galguera, Juan. 2011. Islam and State in the European Union: Church-State Relationships, Reality of Islam, Imams Training Centres. Frankfurt am Main: Peter Lang.

Martí Sánchez, José Maria. 2014. 'Sectas y protección de los menores en el Derecho'. Revista General de Derecho Canónico y Derecho Eclesiástico del Estado, 36-39. Motilla, Augustin. 1999. 'Las sectas en el ordenamiento español'. XVIIIJornadas de la Asociación Española de Canonistas. Sínodos españoles. Confesiones y sectas. Salamanca: Universidad Pontificia, Salamanca.

Pelayo Olmedo, José Daniel. 2007. Las comunidades ideológicas y religiosas, la personalidad jurídica y la actividad registral. Madrid: Ministerio de Justicia.

\section{About the author}

Juan Ferreiro Galguera is a Full Professor of Law at the University of Coruña. His expertise is in Human Rights and Church-State relations. Key publication: Islam and State in EU: Imams training centers (Peter Lang GmbH, 2011). 



\title{
18 The Italian legal system and imams
}

\author{
A difficult relationship
}

Francesco Alicino

Hashas, Mohammed, Jan Jaap de Ruiter, and Niels Valdemar Vinding (eds), Imams in Western Europe: Developments, Transformations, and Institutional Challenges. Amsterdam: Amsterdam University Press, 2018 DOI: $10.5117 / 9789462983830 / \mathrm{CH} 18$

\begin{abstract}
Nearly all imams in Italy are self-educated. In their everyday life they often have precarious jobs, and they perform their religious functions in their spare time. In their role as imam they play a very important role in local Muslim communities. This chapter analyses the status of imams in Italy, underlining how the social context and the legal framework that regulates church-state relations deal with non-Catholic issues in Italy.
\end{abstract}

Keywords: Islam in Italy, church-state relationship, Catholic Church, constitution

Religious ministers in Italy

Italy has a long and well-established tradition of church-state relations, which has been strongly influenced by the role played by the Catholic Church (Dalla Torre, 1995; Glenn, 2014; Netton, 2006). The most important results of this peculiar legal system are found in Articles 7 and 8 of the 1948 Italian Constitution. Article 7 is devoted to the relationship between the state and the Catholic Church, whose organization and structure are considered the prototype for religious denominations by the Italian government (Colaianni, 2012). The first section of Article 7 establishes the mutual independence and sovereignty of both the state and the church. The second section of Article 8 states a similar (albeit less strong) principle guaranteeing the free organization of denominations other than Catholicism. The second section of Article 7 affirms that the relationship between the state and the Catholic Church is 'regulated by the Lateran Pacts (1929)' and that any change to these pacts, if accepted by both parties, 'does not require the procedure of constitutional 
amendments'. In other words, in case of a bilateral agreement, a legislative - not a constitutional - act is sufficient to amend the pacts and regulate the connection between the state and the Catholic Church. The third section of Article 8 affirms that the relationship between religious minorities and the state is also regulated by legislation. This legislation must be based on specific agreements called intese (singular: intesa), which can be literally translated as 'agreements' between the state and religious denominations (Casuscelli, 2008). In other words, both the second section of Article 7 and the third section of Article 8 establish the 'bilateralism principle', which is a direct consequence of the religious autonomy established in the first and the second sections of the same articles (Bouchard, 2004; Varnier, 1995).

The 'bilateralism principle' requires the state to regulate questions regarding the specific needs and peculiar identity of a denomination through agreements with the concerned religious authorities. Once they have been signed by the Prime Minister and the representative of a religious organization, both Accords (which regulate the relationship between the state and Catholic Church) and intese (which regulate the relationship between the state and religions other than Catholicism) need to be ratified (Article 7, Section 2) or approved (Article 8, Section 3) by a legislative act of the Italian Parliament. This kind of act is an atypical form of legislation because, once approved, it can only be amended through a new agreement between the state and the concerned denominations: it is not possible for the parliament to make an amendment through unilateral legislation. In this way, the Catholic Church and some other denominations (i.e., those that have signed an intesa) have the guarantee that their legal status cannot be altered without their consent (Ferrari, 1993).

Now, with this system of bilateralism two main problems arise. First, it presupposes the existence of a relatively comprehensive religious institution that is capable of representing a denomination at a national level. This is a requirement that has proved problematic for some religions, including Islam (Decaro Bonella, 2013). The second problem is generated by the excessive amount of discretion given to the government to decide whether to accept or reject a denomination's proposal of entering into negotiations. ${ }^{1}$ Furthermore, these problems decrease by the principle stated in the first

1 In fact, so far as the relationship between the State and confessions is concerned, legislative Act no. 400 of 1988 attributes the general competence to the Council of Ministers. Legislative Decree no. 300 of 1999 gives some specific competences to the Ministry of Internal Affairs, such as those referring to the 'guarantee of the order and public safety' and the 'guarantee of civil rights, including those of religious confessions, of citizenship, immigration and asylum'. 
section of Article 8, under which 'all religious denominations are equally free before the law'. This principle implies that there cannot be a nonconstitutionally based distinction between not only the Catholic Church and other denominations, but also between minority religions that have signed an intesa with the state and those that have not yet done so (Tozzi, 2011).

As a matter of constitutional principles, the absence of an intesa cannot affect the right of a religious group or its members to worship freely; Articles 19 and, above all, 20 of the Italian Constitution clearly affirm that the religious character or religious aim of an association or institution cannot justify either special legal limitations or greater fiscal tax on their constitution, status, or any of their activities (Di Marzio, 1999; Finocchiaro, 2012; Fiorentino, 2006; Ricca, 2000). Yet the practical implementation of these constitutional principles has revealed many interconnected difficulties.

\section{$2 \quad$ The intese and the 1929 Act}

One of the difficulties regarding the practical implementation of the constitutional principles is the fact that agreements based on both Article 7 (Section 2) and Article 8 (Section 3) are used by the state to concede a set of rights or benefits. In this way, the principle of religious freedom becomes a matter of specific accords that are subject to the will of public actors such as the Italian Government - which, as mentioned above, has great discretion in the implementation of Section 3 of Article 8.

In the last 30 years the practical enactment of Section 3 has been characterized by the phenomenon of intese fotocopia ('photocopy agreements'): the substantial similarity of all twelve intese $e^{2}$ that have been signed by minority religions. As a result, the large majority of these agreements have established a de facto common legislation, when approved by the parliament, which is far from being considered general legislation (Carnelutti, 1951; Crisafulli, 1968). In other words, while this legislation is common to all of the religious denominations that have an agreement with the state, the provisions of the legislation cannot be applied to denominations that have not yet signed an intesa (Randazzo, 2008). This is why minority religions see the intesa more as an instrument of political legitimation than as a legal opportunity to express their specific needs and identity in the Italian legal system, which also explains why common legislation has given rise to a rush of requests for intese (Alicino, 2013a). 
The absence of any procedure regulating the negotiations between the state and religious denominations can turn the discretion of the government into obviously non-constitutional and unwanted forms of discrimination towards religious denominations that are excluded from the system of common legislation established through the photocopy agreements phenomenon. In fact, these denominations are regulated by the 1929 Act (no. 1159) on 'admitted religions', approved during the fascist regime, which legitimizes even greater discretionary power of the Minister of Internal Affairs. These denominations are excluded from the more favourable provisions of the legislation that is based on agreements between the state and some religions - a phenomenon that becomes even more evident in the fact that denominations possessing an agreement are no longer subject to the 1929 Act, the provisions of which are entirely replaced by the far more favourable rules in the legislation that approves an intesa.

We must keep in mind that the 1929 Act was designed to regulate traditional denominations other than Catholicism - a conceptualization of minority denominations based on the religious geography of the first half of the twentieth century. This geography has now changed completely (Laurence, 2006b) under the pressing processes of immigration and the elusive phenomenon of globalization (Ferrarese, 2012; Mazzola, 2010). This explains why the provisions of the 1929 Act do not always meet the needs of denominations whose presence in Italy is relatively recent (Allievi, 2000, 2002), including Islamic organizations and their specific religious ministers, usually called 'imams' (Laurence, 2006a).

\section{Religious ministers and State (secular) law}

It is important to keep in mind that, in regard to the civil status of religious ministers, there is a substantial difference between the provisions of the legislation from bilateral (church-state) agreements and the provisions established by the 1929 Act. The bilateral legislation implies an automatic recognition of religious ministers, to whom some important rights and civil benefits are granted simply because they exercise specific functions within a given denomination and in accordance with a corresponding religious law (Ferrari, 2008).

This is evident when considering the legislation ratifying the agreement between the state and the Catholic Church, i.e., the 1985 Act (no. 121), which ratified the 1984 Agreement of Villa Madama between the Holy See and the Italian Republic and almost entirely modified the 1929 Lateran Pacts. This agreement states: 'appointments to ecclesiastical offices are wholly made 
by ecclesiastical authorities.' This means that in the Italian legal system the Catholic authorities must only 'inform the competent civil authorities of the appointments of archbishops and diocesan bishops, of coadjutors, of abbots and prelates with territorial jurisdiction, including parish and other official appointments to ecclesiastical offices relevant to state administration' for the appointed individuals to be recognized as religious ministers.

This substantial difference in law is also affirmed through the bilateral legislation based on intese that has been signed and approved until now. This legislation affirms very similar provisions to those stated in the 1984 Accord between the state and the Catholic Church for Lutheran pastors, Evangelical ministers, Orthodox priests, Jewish clergies, and Buddhist masters - those who in the language of the intese are called ministri diculto, which can be translated as'ministers of religion' or 'religious ministers'.

This clearly demonstrates the fact that in both the 1984 Agreement (between the state and the Catholic Church) and the common legislation based on intese the principal reference for recognizing the civil status of a religious minister is the law of a denomination, rather than the state's law: in this matter, the state's law simply refers to the religious law. In practice, once a person has been defined and recognized as a minister by and within a religious community, he or she is considered a religious minister by the state as well. In brief, as far as the status of religious ministers is concerned, the rules that govern the internal activities of religious groups have almost automatic civil effects within the Italian legal system.

By contrast, under the 1929 Act a religious minister can have a civil status only after the public authority has formally recognized and appointed him or her. Moreover, the religious minister him- or herself must submit a specific request to the Italian Minister of Internal Affairs, who has to check whether the claimant meets the criteria established by Article 3 of the 1929 Act and by the relative Royal Decree of 1930 (no. 289). ${ }^{3}$ To be recognized as a religious minister by the state, the request must contain:

1 The religious act through which the minister was appointed by the religious authorities.

2 The documents showing that the designation was made in accordance with the religious rules of the denomination concerned.

3 The documents affirming that the religious minister is an Italian citizen, especially if he or she is planning to celebrate religious marriages with civil effects.

3 Regio Decreto 28 febbraio 1930, n. 289, Norme per l'attuazione della legge 24 giugno 1929, $n$. 1159, sui culti ammessi nello Stato e per il coordinamento di essa con le altre leggi dello Stato. 
In addition, the claimant must demonstrate the ability to speak Italian, and to be prepared to give all further and necessary information for a correct and complete 'legal enquiry'. Without government approbation, the state cannot recognize civil effects to acts, such as religious marriages, made by ministers of denominations governed by this law.

It is important to note that most of these criteria are especially formed on the basis of Catholic thinking: it is assumed that a hierarchical structure will be built around a 'church', in the Christian sense of the term. Because of the central role of a pastor or priest, it is assumed that those who perform religious rites will also represent the religion. Conceived as a general principle, this has become the principal reference for the definition of a religious minister for all religions, including denominations other than Catholicism. This is also evident by the fact that in this field the above mentioned 1984 Agreement of Villa Madama was followed by similar intese between the state and some other religions. ${ }^{4}$ The Waldesian Church was the first non-Catholic religion to sign an intesa in 1984. Since then, all of the other intese have shared an identical content, which explains the term 'photocopy agreements' (D'avack, 1989).

It was not without a reason that when the bilateral-common legislation procedure was extended in 2013 to some very 'new' religious organizations which have comparatively more differences from the Catholic Church - the provision regulating the civil status of religious ministers generated some very complex judicial disputes. A telling example is the agreement between the state and the Italian Buddhist Union (Unione Buddhista Italiana, UBI), whose provisions have produced intricate legal paradoxes through the 'strange' relationship between the common legislation based on intese and the 1929 Act on admitted religions.

On 9 June 2009, two dharma masters of the Temple of Shôbôzan Fudenji, a Buddhist organization that is member of the UBI, requested to be recognized by the state's authority so that they could celebrate religious marriage with civil effects. In accordance with the provisions of the 1929 Act and after a long administrative dispute, the Italian Minister of Internal Affairs appointed these dharmas as religious ministers in January 2013. Twenty

4 See in particular the six intese that were signed between 1984 and 1993 by: the Waldesian Protestant Church in 1984 (approved by Act 11 August 1984, no. 449); the Christian Churches of the Seventh-day Adventists in 1986 (approved by Act 22 November 1988, no. 516); the Assemblies of God, a Pentecostal Church, in 1986 (approved by Act 2 November 1988, no. 517); the Union of Jewish Communities in 1987 (approved by Act 8 March 1989, no. 101); the Christian EvangelicalBaptist Union in 1993 (approved by Act 2 April 1995, no. 116); and the Lutheran Church in 1993 (approved by Act 29 November 1995, no. 520). 
days later, however, an intesa between the State and the UBI association entered into force, completely replacing the jurisdiction of the 1929 Act with respect to all members of that association. ${ }^{5}$ This means that the dharma masters were no longer considered religious ministers under the 1929 Act, but they could acquire the status of a religious ministry through the norms of the 2013 agreement. From the dharmas' point of view, it did not seem to matter whether the 1929 Act was effective - which was not, in fact, the case. The 2013 intesa did not provide any rule regulating the civil effects of religious marriage, which, as said before, is the main, if not the only, reason the dharma masters wanted to be appointed by the state. Since the 2013 agreement entered into force, however, marriages celebrated by those masters no longer have a civil effect, unless the Temple of Shôbôzan Fudenji were to choose not to be part of the UBI association anymore and to re-submit itself and its members to the less favourable provisions of the 1929 Act.

This example clearly shows that, concerning the civil status of religious ministers, Italian legislation regulating the church-state relationship does not always meet the needs of 'new' (i.e. very different) denominations (Alicino, 2013b). This seems even more manifest in relation to the civil status of Muslim imams, as discussed in the next section.

Are imams religious ministers?

Under Italian law, the expression 'religious minister' is a nomen iuris that the state uses to define the civil status of the carriers of religious office' (Fiorita and Milani, 2010; Licastro, 2008; Parisi, 2014). At the same time, however, the law affirms that the recognition of a religious minister is a result of a connection between the state's legal system and the law of a religion (Grimm, 2013). In other words, the state attaches the civil status of a religious minister to those who, within a denomination, are already considered as such (Benigni, 2012; Cardia, 2010). Thus, as far as the civil notion of religious ministers is concerned, the connection between the state's law and the law of a given religion is based on two main features: ${ }^{6}$

5 See Act 31 December 2012, no. 245, which approved the intesa between the State and UBI signed on 4 April 2007.

6 See Comitato per l'Islam Italiano, Parere su Imam e formazione, 31 May 2011, at http://www1. interno.gov.it/mininterno/export/sites/default/it/sezioni/sala_stampa/notizie/Comitato_Islam_italiano/o054_2011_05_31_comitatoislam.html_746804720.html. 
1 The autonomy of a denomination in deciding who is able to play the specific role of a religious minister.

2 The right of the state to formally recognize the status of a religious minister, i.e., verifying whether a person appointed by the religious community effectively exercises activities that, within the community, distinguishes him or her from other 'normal' believers (Bettetini, 2000; Licastro, 2005; Mirabelli, 1975; Onida, 1990).

Taking these elements into account, in this section I consider the figure of the imam, analysing him in light of the state's law regulating the civil status of religious ministers.

Historically speaking, the figure of the imam dates back to the first period of Islam. He is in this context considered to be the guide of community prayers - not only the Friday prayer, but also other ones. He is, so to say, a person who, standing in front of other believers, recites some religious formulas and performs typical religious gestures such as bowing and prostrations (Madelung, 1986). The fact remains that imams are neither priests nor clergymen who, in Christian milieus, are purposely 'consecrated' for the role of religious ministers (Ciotola, 2007). Instead, Imams are generally selected at a local level (Saint-Blancat, 2008): members of a Muslim community choose someone who is considered knowledgeable and wise at that level, someone who understands the Quran and is able to recite it correctly and nicely (Branca, 2008).

We can therefore argue that generally an imam is a respected member of a given Muslim community or organization. In some communities, a Muslim believer may be recruited and hired to be an imam after undergoing special training. ${ }^{7}$ In other cases, imams are chosen from among the existing members of an Islamic group without any specific training programme. There is no universal governing body to supervise imams; everything is done at the community level.

The absence of such a body explains why in Italy, as well as in other European countries, imams are almost all self-educated as religious ministers. During the week they usually take care of duties other than religion. To see them working as imams, one must often go down into some underground parking or into apartments that have been converted into mosques, where minarets and other Islamic symbols are only present in pictures or paintings hanging on the wall (Casale, 2014; Rhazzali and Equizi, 2013).

7 See, for example, CO.RE.IS, Statuto degli Imam della Federazione dell'Islam Italiano, at http:// www.coreis.it/Testi/STATUTO\%2oDEGLI\%2oIMAM.PDF. 
In any case, imams fulfil a crucial role in Muslim communities, which all together make up more than one and a half million believers in Italy, the majority of whom are immigrants. We must further keep in mind that many mosques and their imams provide a range of welfare services that strongly affect the integration process of immigrants. Imams thus play an important social role (Bombardieri, 2010). All things considered, however, there is no doubt that imams' most important function is a religious one (Vincenzo, 2010). From the root meaning of the word 'imam', which is 'in front of', the imam comes to be the leader in prayer, and hence, by extension, the religious and political head of the whole Muslim community, whose task is to lead it in fulfilment of God's commandments. Their other functions, including the social and political ones, come from and are based on their religious authority (Pace, 2004). In fact, imams are recognized through their everyday leadership, whose legitimation derives directly from their religious role (Arnold, 1999; Sordel, 1986).

As far as Islamic organizations are concerned, the theological absence of a sacred ordination does not necessary imply the absence of persons who are capable of managing the sacred rules of Islam - persons who have the essential duty within Islam to ensure the correct observation of the transcendental law (Frégosi, 2003). This is more than enough for taking into consideration the status and role of imams, even from the state's point of view (Colaianni, 2003).

The real obstacle, then, is not the peculiar figure of the imam in comparison with the traditional - mostly Christian - notion of religious ministers. Quite the contrary, these obstacles are created by the fact that in Italy Muslim communities are usually not recognized as a religious creed: there is, then, no way to establish an effective connection between the state's legal system and the law of an Islamic community. This has two interconnected consequences: first, Muslim communities cannot fully affirm their autonomy as a religion; and second, the state cannot formally recognize the status of any imam simply because it cannot verify whether individuals appointed to this role by the religious community are effectively different from the other (normal) lay believers.

\section{5}

\section{The relationship between the state and Islamic organizations}

Any community with religious aims is able to operate within the Italian legal system without authorization or prior registration. The only limit is based on the protection of public order and common decency. Islamic organizations 
or their legal entities may choose among various types of legal organization. They, for example, may constitute themselves as a 'non-recognized association' in accordance with Article $36-38$ of the Italian Civil Code: this model implies independence in property matters and the possibility of receiving donations and the like. It is also used by political parties and trade union organizations, and it is the simplest model of association that does not provide for particular control from the state's authorities. According to Articles 14-35 of the Civil Code and the 2000 decree of the President of the Italian Republic (no. 361), entities can also choose the form of a 'recognized association', which provides legal personality through registration at a local prefecture. The civil capacity of Islamic organizations may also be obtained through Article 16 of the Disposizioni sulla legge in generale ('Provisions on law in general'), which, based on the principle of reciprocity, may grant foreign Muslim entities the same rights guaranteed to Italian legal bodies (Ferrari, 2011).

However, under all of these provisions there is almost no legal difference between an association with no religious purpose and an organization that is specifically based on religious aims. This is why attention is normally focused on the above-mentioned 1929 Act, which provides entities with the possibility of obtaining a legal capacity on the basis of their religious aims. Yet, even considering these provisions, there are still obstacles to the religious autonomy and legal recognition of Islamic organizations. For example, the 1929 Act may subject these groups to the control of the state, which is given a large amount of discretion; under this act, the state's authorities can annul the decisions made by the representatives of a religious entity, and may even replace them with state commissioners.

In addition, because of the lack of unitary representation at the national level and the strict interpretation of the Italian public order, Muslim groups are normally regulated by the general legislation concerning associations, in its double version of recognized and non-recognized associations. ${ }^{8}$ This means that Muslim groups are not only excluded from some important privileges - like those established through the intese and (albeit with problems) the 1929 Act -, but also from the possibility of being legally recognized because of their religious aims. In other words, Muslim organizations can only enjoy the legal benefits guaranteed to other, non-religious, private associations.

8 The only Islamic organization that is not an association and that, in accordance with the 1929 Act (no. 1159), has been recognized as a religious legal entity is the Italian Centre of Islamic Culture (Centro Islamico Culturale d'Italia). See the decree of the President of the Italian Republic, 21 December 1974. 
As in other European countries, there is no single national Muslim organization in Italy that represents all Muslims and Islamic institutions in the country (Donini, 2002; Guolo, 2000; Mancuso, 2012; Pacini, 2008). There are many local Islamic groups; others refer to either a transnational Islamist movement or an entity of a foreign state. There are a large number of immigrants in Italian Muslim organizations that, when wishing to operate in Italy, must respect the principles of the Italian Constitution. These principles must be taken into serious consideration to establish a proper connection between the state and the Islamic organizations that will solve questions, like those concerning imams. In this sense, the first step is to clarify whether these Islamic organizations can be defined as religious denominations in the legal sense. The problem of defining what a 'denomination' is has become significant in Italy with the spread of 'new' religious organizations, including Islamic ones, whose presence in the country is relatively recent. As there is a complete absence of statutory definitions, some say that the state is neither able nor competent to provide such a definition, so the state should rely on the self-assessment of the adherents of a group that wishes to be recognized as a religious denomination.

In other words, if the members of a community share the belief that they form a religious denomination, in general the state must accept their assessment. Still, some decisions of the Constitutional Court state that the term 'denomination' must have an objective and not a subjective basis. ${ }^{9}$ This is why some scholars have identified selected characteristics that a community must necessarily have to be considered a denomination. One of them is the 'belief' in a transcendental entity - not necessarily God - that is capable of answering fundamental questions about man's origin and destiny, providing a moral code, and creating an existential interdependence between the members and that transcendental reference. Most importantly, these groups must have a basic organizational structure (Ferrari, 1995).

Now, whichever of these paradigms are used it can be inferred that in Italy many - if not most - Islamic organizations can be defined as religious. This being the case, these organizations can (at least potentially) sign an agreement with the state in accordance with both the general principles of Italian Law and Article 8 of the 1948 Constitution. 


\section{$7 \quad$ Bilateral (church-state) legislation}

But what actually is the original aim of the bilateral legislation based on intese? To answer this question, it is important to keep in mind some of the Constitutional Court's decisions, which state that the bilateral instrument of intese is mainly conceived for two interrelated purposes. ${ }^{10}$

First, it is intended to facilitate and promote collaboration between the state and religious denominations, which is the precondition for granting the denominations public prominence within the state's legal system, as explicitly stated in the 1948 Constitution. This is a peculiar aspect of the constitutional order that, in fact, marks the difference between the limited Italian secularism model and the French principle of laïcité ('secularism') - a principle that is based on strict separation between the state and religions, and that therefore tends not only to relegate 'religious factors' to the private sphere (Laurence and Vaisse, 2007), but also to assimilate religious diversity into the founding principles of the French Republic (Robert, 2006; see also Jouanneau, Part I). ${ }^{11}$

The second purpose is that bilateral legislation based on Section 3 of Article 8 highlights the specific characteristics of a single denomination. This is because those characteristics risk being sidelined by the Parliament's unilateral legislation that, given its general-generic nature, is less capable of responding to the particular needs and peculiar identity of different religious groups. For these reasons, bilateral legislation may be a suitable instrument for solving the questions related to the presence of Islamic organizations in Italy. In particular, it could be an appropriate mechanism for regulating imams - perhaps also including their training, which, as some have claimed, seems to be one of the most important steps in the process of Muslims' integration (Ferarri, 2013).

It should be noted that the training of imams was neglected in Italy until a few years ago: while there had been some initiatives to educate imams from the Muslim side, public institutions preferred to avoid direct involvement. This situation came to an end in 2012, when a number of North Italian universities (namely, the Universities of Come, Alessandria, Milan, Padua, and the Catholic University of Milan) signed an agreement with the Minister of Internal Affairs in support of a course for the training of 'Muslim religious leader(s)' (see also Pallavicini, Part II). The Minister affirmed that

10 The Italian Constitutional Court, Decision no. 346 of 2002.

11 Robert (2006, p. 7). For a more general analysis, see: Balibar (2012, p. 66); Custos (2006, p. 398); Jeantet (2006, p. 29); Leveau and Kepel (1988); Rabah (1998); and Sayah (20o6, pp. 922-927). 
the state would actively participate in this training programme, thereby facilitating the possibility that imams and other Muslim leaders would obtain legal recognition and be appointed in accordance with the 1929 Act, which would also be particularly important for acknowledging the civil effects of Muslim marriages.

This training project was mainly based on the experience of other European countries. It does not provide a religious curriculum. Instead, it is intended to impart knowledge of the state's cultural and legal system, including family law, gender relations, and interreligious dialogue: themes that may help imams and other Muslim leaders better understand the specific connotation of Italy's principle of secularism, which, as mentioned earlier, is far from strict (Alicino, 2009). Training imams in Italy does not, then, imply religious teaching. Rather, it provides citizenship education, through which imams can learn about the place where they live and work and become more familiar with the culture, history, tradition, language, and values (including the constitutional principles) of the Italian State. At present, most imams in Italy come from Muslim-majority countries and know little about the country in which they conduct their activities as religious leaders. Given the role they play within the religious communities, training imams in Italy is also (if not mainly) considered a way of promoting the integration of Muslims into Italian society.

\section{The Italian State and Islamic organizations: A possible collaboration?}

The position of imams in Italy leads to the observation that the usual integration approach between Islamic groups and state's authorities should be revised and re-evaluated (Colaianni, 2009; Consorti, 2008; Macrí, 2007; Rivetti, 2007; Varnier, 2007). This is particularly true with regard to the question of training imams, which should not be solved by unilateral legislation that may generate forced assimilation and, perhaps, discrimination against Islamic organizations. Instead, these questions should be solved through active collaboration between the state and Muslim communities. The only available instrument for implementing this collaboration is stated in Section 3 of Article 8 of the Italian Constitution. According to this article, agreements may lead religious organizations to be active parts of the Italian legal system - which includes and presupposes the respect of constitutional principles. On the state's side, though, this bilateral system necessarily implies the responsibility of the public authorities to treat Islamic groups 
the same as other religious organizations, providing the same range of rights and benefits (Aluffi Beck-Peccoz, 2004).

Within the provisions of intese, the state and Islamic organizations can provide essential criteria, such as training programmes for imams as religious ministers recognized not only by their own organization, but also within the state's legal system. This would also give a new impulse to the constitutional instrument of intese, which can be finally used to support the peculiar characteristics of religious groups, rather than extending the phenomenon of photocopy agreements - a phenomenon that is not really consistent with the original scope of the bilateral system provided by Section 3 of Article 8 of the Italian Charter.

Some Muslim organizations have negotiated with the government to sign an intesa. This is the case for the Unione delle Comunità Islamiche d'Italia (Union of Islamic Communities and Organizations in Italy, U.CO.II), which, only two years after its establishment in 1990, publicly manifested that intention, prepared a draft agreement, and sent it to the government. Other Islamic organizations followed that same path, like the Associazione Musulmani Italiani (Association of Italian Muslims, AMI) from 1994 and the Comunità Religiosa Islamica Italiana (Italian Islamic Religious Community, CO.RE.IS, 1996; see Pallavicini, Part II; Acciai, 1995; Musselli, 1997; Tedeschi, 1996). It is noteworthy that from these drafts have come important efforts to adapt the status and position of imams and other Muslim authorities to the notion of the religious minister as established in all of the agreements between state and religions signed in Italy as of now (Cilardo, 2009).

All these efforts, however, have not been taken into consideration by the Italian public authorities, who have chosen instruments other than section 3 of Article 8 to regulate the state's relationship with Islamic communities. For example, in 2005 a Consulta per l'Islam italiano (Consultative Council of Italian Islam) was established by the Italian Minister of Internal Affairs (Ferarri, 2007). Since then, the council has been preparing documents to reaffirm the values of a secular state and religious freedom as well as encourage the creation of a federation of Islamic organizations.

In 2010 a Comitato per l'Islam Italiano (Committee for an Italian Islam) made up of nineteen members - representatives of Islamic organizations, scholars, professors, and journalists who are experts in Islam - was established by the Minister of Internal Affairs. This committee has been acting as a consultant, and the ministry has been listening to its views on some current questions. This approach has also been followed at the local level, where consultative forums with representatives of the local Muslim 
community and experts in law and religion have been established, for example in Milan (Alicino, 2011).

After a new government was established in November 2011, the Minister for Cooperation and Integration created a permanent conference on 'Religions, Culture, and Integration' in March 2012 with representatives of Muslim organizations and experts in Islam and in other religions. This conference was essentially conceived of as a space for meetings and seminars rather than as a consultative or decision-making body.

There was also a Memorandum of Understanding signed in 2015 between the Department of Penitentiary Administration (DAP) and the Union of Islamic Communities and Organizations in Italy (Unione delle Comunità e delle Organizzazioni Islamiche in Italia), which may be seen as an important effort towards a more reasonable approach towards the growing presence of Muslim inmates in the Italian prison system (Ministero della Giustizia 2015).

9

\section{Conclusion}

The Italian approach toward imams seems to be based on the fact that Islamic organizations are 'more other' (Allievi, 2009) than organizations that are allegedly more compatible with the traditional system of relations between church and state in Italy - a system established through the implementation of Articles 7-8 of the Constitution and the 1929 Act. This approach was originally conceived in reference to a specific religious geography that has now changed completely (Tozzi, 2009). It was tailored for a substantially mono-cultural society, and is therefore unfit to deal with today's religious reality in Italy. That is why this approach that seems attractive to some denominations can also be seen as a systematic disadvantage, if not a form of discrimination, by other creeds and their members (Fiorita, 2003). This is evident from the fact that, since the 1948 Constitution entered into force, there has been a sort of 'cold peace' between the state and 'new' denominations (in primis Islamic denominations) (La Croce, 2003).

The recognition of Islam in Italy still has a long way to go. In the meantime, Muslims will continue organizing themselves and numerous initiatives have been taken up to establish Islamic organizations, undertaking all kinds of activities (see Rhazzali and Pallavicini, Part II). Hopefully the church and state, i.e., the Muslim communities and the state, will find a satisfactory way to cooperate that will in the end lead to the formal recognition of Islam in the country, and, consequently, to its further institutionalization and reasonable forms of interaction and integration. 


\section{References}

Acciai, Riccardo. 1995. 'La bozza di intesa fra la Repubblica italiana e l'Unione delle comunità ed organizzazioni islamiche in Italia'. In Principio pattizio e realtà religiose minoritarie, edited by Vincenzo Parlato and Giovanni Battista Varnier. Torino: Giappichelli.

Alicino, Francesco. 2009. 'Liberté d'expression et religion en France: Les démarches de la laïcité à la française'. In La Constitution Française, edited by Marina Calamo Specchia, 29-61. Torino: Giappichelli.

Alicino, Francesco. 2011. Costituzionalismo e diritto europeo delle religioni. Padova: CEDAM.

Alicino, Francesco. 2013a. La legislazione sulla base di intese. I test delle religioni "altre" e degli ateismi. Bari: Cacucci.

Alicino, Francesco. 2013b. 'Lo strano caso dei ministri di culto buddhisti. Ovvero la legge sui culti ammessi vs la legge di approvazione delle intese'. Quaderni di diritto e politica ecclesiastica, 2: 409-429.

Allievi, Stefano. 2000. 'Immagini di un Islam plurale'. Humanitas, 55: 858-873.

Allievi, Stefano. 2002. Musulmani d'Occidente: Tendenze dell'islam europeo. Roma: Carocci.

Allievi, Stefano. 2009. 'Costruzione del nemico, bisogno di sicurezza e conflitto'. In I musulmani e la società italiana: Percezioni reciproche, conflitti culturali, trasformazioni sociali, edited by Stefano Allievi, 62-93. Milano: Franco Angeli.

Aluffi Beck-Peccoz, Roberta. 2004. 'The Legal Treatment of the Muslim Minority in Italy'. In The Legal Treatment of Islamic Minorities in Europe, edited by Roberta Aluffi Beck-Peccoz and Giovanna Zincone, 133-158. Leuven: Peeters.

Arnold, Thomas W. 1999. The Caliphate. Oxford: Oxford University Press.

Balibar, Etienne. 2012. Saeculum: Culture, religion, idéologie. Paris: Galilée.

Benigni, Rita. 2012. 'La qualifica di "ministro di culto" tra autoreferenzialità confessionale e discrezionalità amministrativa: Le intese del XXI secolo ed $\mathrm{i}$ recenti pareri del Consiglio di Stato, nn. 2748/2009 e 561/2012'. Revista General de Derecho Canónico y Derecho Eclesiástico del Estado, 30: 1-24.

Bettetini, Andrea. 2000. 'Alla ricerca del "ministro di culto": Presente e futuro di una qualifica nella società multireligiosa'. Quaderni di diritto e politica ecclesiastica, 1: 249-268.

Bombardieri, Maria. 2010. 'Why Italian Mosques are Inflaming the Social and Political Debate'. In Mosques in Europe: Why a Solution has Become a Problem, edited by Stefano Allievi, 269-299. London: Alliance Publishing Trust.

Bouchard, Giorgio. 2004. 'Concordato e Intese, ovvero un pluralismo imperfetto'. Quaderni di diritto e politica ecclesiastica, 1: 65-72. 
Branca, Paola. 2008. 'Quale Imam per quale Islam'. In Islam in Europa/Islam in Italia tra diritto e società, edited by Alessandro Ferrari, 219-231. Bologna: il Mulino.

Cardia, Carlo. 2010. Principi di diritto ecclesiastico: Tradizione europea legislazione italiana. Torino: Giappichelli.

Carnelutti, Francesco. 1951Teoria generale del diritto. Roma: Edizioni del Foro italiano.

Casale, Enrico. 2014. 'Islam italiano, cercasi imam'. Popoli, 17 February.

Casuscelli, Giuseppe. 2008. 'La rappresentanza e l'intesa'. In Islam in Europa/Islam in Italia tra diritto e società, edited by Alessandro Ferrari, 285-324. Bologna: il Mulino.

Cilardo, Agostino. 2009. 'Diritto islamico, diritto occidentale: Ambiguità semantica'. In Europa e Islam: Ridiscutere i fondamenti della disciplina delle libertà religiose, edited by Valerio Tozzi and Gianfranco Macrì, 85-95. Soveria Mannelli: Rubbettino.

Ciotola, Claudia. 2007. 'Note in tema di individuazione dei ministri di culto'. Diritto e Religioni, 1:142-195.

Colaianni, Nicola. 2003. 'Autorità religiose e ministri del sacro: Introduzione al tema'. Daimon, 3: 5-28.

Colaianni, Nicola. 2009. 'Islam ed ebraismo: Dall'integrazione all'interazione'. Quaderni di diritto e politica ecclesiastica, 1: 69-92.

Colaianni, Nicola. 2012. Diritto pubblico delle religioni: Eguaglianza e differenze nello Stato costituzionale. Bologna: il Mulino.

Consorti, Pierluigi. 2008. 'Pluralismo religioso: Reazione giuridica multiculturalista e proposta interculturale'. In Multireligiosità e reazione giuridica, edited by Antonio Fuccillo, 222-228. Torino: Giappichelli.

Crisafulli, Vezio. 1968. 'Voce Fonti del diritto (dir. cost.)'. Enciclopedia del diritto, XII, p. 948.

Custos, Dominique. 2006. 'Secularism in French Public Schools: Back to war? The French Statute of March 15, 2004'. American Journal of Comparative Law, 337:337-399.

D'avack, Pietro Agostino. 1989. 'Intese II) Diritto Ecclesiastico: Profili Generali'. Enciclopedia giuridica, XVII, p. 3 .

Dalla Torre, Giuseppe. 1995. Il fattore religioso nella Costituzione: Analisi e interpretazioni. Torino: Giappichelli.

Decaro Bonella, Carmela. 2013. 'Le questioni aperte: Contesti e metodo'. In Tradizioni religiose e tradizioni costituzionali: L'islam e l'Occidente, edited by Carmela Decaro Bonella, 17-56. Roma: Carocci.

Di Marzio, Paolo. 1999. L'art. 20 della Costituzione: Interpretazione analitica e sistematica. Torino: G. Giappichelli.

Donini, Pier Giovanni. 2002. Il mondo arabo-islamico: Chi sono e quanti sono $i$ musulmani nel mondo. Roma: Edizioni Lavoro.

Ferrarese, Maria Rosaria. 2012. Prima lezione sul diritto globale. Bari: Laterza. 
Ferrari, Alessandro. 2011. 'Libertà religiosa e nuove presenze confessionali (ortodossi e islamici): Tra cieca deregulation e super-specialità, ovvero del difficile spazio per la differenza religiosa'. www.statoechiese.it, July, pp. 1-28.

Ferrari, Silvio. 1993. 'Il Concordato salvato dagli infedeli'. In Studi per la sistemazione delle fonti in materia ecclesiastica, edited by Valerio Tozzi, 127-158. Salerno: Edisud. Ferrari, Silvio. 1995. 'La nozione giuridica di confessione religiosa (come sopravvivere senza conoscerla)'. In Principio pattizio e realtà religiose minoritarie, edited by Vittorio Parlato and Giovanni Battista Varnier, 19-47. Torino: Giappichelli.

Ferrari, Silvio. 2007. 'La consulta islamica'. In ISMU, Dodicesimo rapporto sulle migrazioni 2006, 249-263. Milano: FrancoAngeli.

Ferrari, Silvio. 2008. Introduzione al diritto comparato delle religioni: Ebraismo, islam e induismo. Bologna: il Mulino.

Ferrari, Silvio. 2013. 'The Training of Imams'. In Islam and Political-Cultural Europe, edited by W. Cole Durham, David Kirkham, and Tore Lindholm, 107-116. London: Ashgate.

Finocchiaro, Francesco. 2012. Diritto ecclesiastico. Updated by Andrea Bettetini and Gaetano Lo Castro. Bologna: Zanichelli.

Fiorentino, Sonia. 2006. 'Gli enti ecclesiastici e il divieto di discriminazione'. In Nozioni di diritto ecclesiastico, edited by Giuseppe Casuscelli, 57-62. Torino: Giappichelli.

Fiorita, Nicola. 2003. Remunerazione e previdenza dei ministri di culto. Milano: Giuffrè. Fiorita, Nicola and Daniela Milani. 2010. 'Il personale religioso (ministri di culto)'. In Proposta di riflessione per l'emanazione di una legge generale sulle libertà religiose, edited by Valerio Tozzi, Gianfranco Macrì, and Marco Parisi, 228. Torino: Giappichelli.

Frégosi, Franck. 2003. 'Islam, una religione senza clero? Una riflessione comparata'. Daimon, 3: 98-113.

Glenn, Patrick. 2014. Legal Traditions of the World. Oxford: Oxford University Press. Grimm, Dieter. 2013. 'Conflicts Between General Laws and Religious Norms'. In Constitutional Secularism in an Age of Religious Revival, edited by Susanna Mancini and Michel Rosenfeld, 3-13. Oxford: Oxford University Press.

Guolo, Renzo. 2000. 'La rappresentanza dell'Islam italiano e la questione delle intese'. In Musulmani in Italia: La condizione giuridica delle comunità islamiche, edited by Silvio Ferrari, 67-82. Bologna: il Mulino.

Jeantet, Thierry. 2006. 'Lécole et la laïcité'. Revue Politique et Parlementaire, 1038: 29-38.

La Croce, Luigi. 2003. 'I ministri di culto nel vigente sistema normative: Una prima ricognizione'. Quaderni di diritto e politica ecclesiastica, 2: 365-380.

Laurence, Jonathan. 2006a. 'Managing Transnational Islam: Muslims and the State in Western Europe'. In Immigration and the Transformation of Europe, edited by Craig A. Parsons and Timothy M. Smeeding, 252-273. Cambridge: Cambridge University Press. 
Laurence, Jonathan. 2006b. Knocking on Europe's Door: Islam in Italy. Washington, DC: Brookings Institution, Center on the United States and Europe.

Laurence, Jonathan and Justin Vaisse. 2007. Integrating Islam: Political and Religious Challenges in Contemporary France. Washington: Brookings Institution Press. Leveau, Rémy and Gilles Kepel, eds. 1988. Les musulmans dans la sociétéfrançaise. Paris: Presses de Sciences Po.

Licastro, Angelo. 2005. Iministri di culto nell'ordinamento giuridico italiano. Milano: Giuffrè.

Licastro, Angelo. 2008. 'Sui requisiti "morali” per l'approvazione della nomina dei ministri dei "culti ammessi" (osservazioni a TAR Sicilia - Catania, Sez. II, 28 settembre 2007, n. 1505)'. www.statoechiese.it, January, pp. 1-30.

Macrí, Gianfranco. 2007. 'Immigrazione e presenze islamiche in Italia: La Consulta per l'islam'. www.statoechiese.it, March.

Madelung, Wilferd. 1986. 'Imâma'. In The Enclycopaedia of Islam, III (H-IRAM), edited by Bernard Lewis, Victor Lewis Menage, Charles Pellat, and Joseph Schacht, 1163-1169. Leiden: Brill.

Mancuso, Anna Sveva. 2012. 'La presenza islamica in Italia: Forme di organizzazione, profili problematici e rapporti con le istituzioni'. www.statoechiese.it, 32, pp. 1-26.

Mazzola, Roberto. 2010. 'Laicità e spazi urbani: Il fenomeno religioso tra governo municipale e giustizia amministrativa'. www.statoechiese.it, March.

Ministero della Giustizia. 2015. Protocollo d'Intesa tra il Ministero della Giustizia, Dipartimento dell'Amministrazione Penitenziaria e l'Unione delle Comunità e delle Organizzazione Islamiche in Italia (UCOII). Ministero della Giustizia.

Mirabelli, Cesare. 1975. L'appartenenza confessionale. Padova: CEDAM.

Musselli, Luciano. 1997. 'A proposito di una recente proposta di bozza d'intesa con l'Islam'. Diritto ecclesiastico, I, pp. 295-296.

Netton, Ian Richard. 2006. Islam, Christianity and Tradition: A Comparative Exploration. Edinburgh: Edinburgh University Press.

Onida, Francesco. 1990. 'Voce Ministri di culto'. Enciclopedia giuridica, XX, p. 6.

Pace, Enzo. 2004. Sociologia dell'Islam. Roma: Carocci.

Pacini, Andrea. 2008. 'I musulmani in Italia: Una presenza plurale. Esperienze e prospettive di dialogo'. In Chiesa e Islam in Italia: Esperienze e prospettive di dialogo, edited by Andrea Pacini, 16-39. Milano: Edizioni Paoline.

Parisi, Marco. 2014. 'La figura dei ministri di culto acattolici delle confessioni "senza Intesa": Gli orientamenti del Consiglio di Stato tra consistenza numerica dei gruppi religiosi e discrezionalità della Pubblica Amministrazione'. Quaderni di diritto e politica ecclesiastica, 22(2): 373-386.

Rabah, Saddek. 1998. L'Islam dans le discours médiatique. Beyrouth: Les Éditions Al-Bouraq. 
Randazzo, Barbara. 2008. Diversi ed eguali: Le confessioni religiose davanti alla legge. Milano: Giuffrè.

Rhazzali, Khalid and Massimiliana Equizi. 2013. 'I musulmani e i loro luoghi di culto'. In Le religioni nell'Italia che cambia: Mappe e bussole, edited by Enzo Pace, 47-63. Roma: Carocci.

Ricca, Mario. 2000. 'Art. 20 della Costituzione ed enti religiosi: Anamnesi e prognosi di una norma "non inutile"'. Studi in onore di Francesco Finocchiaro, 1537-1571. Padova: CEDAM.

Rivetti, Giuseppe. 2007. 'Islam-Occidente: Nuove identità religiose'. In Religione, cultura e diritto tra globale e locale, edited by Paolo Picozza and Giuseppe Rivetti, 71-100. Milano: Giuffrè.

Robert, Jacques. 2006. 'Les fondements juridiques de la laïcité'. Revue Politique et Parlementaire, 1: 6-12.

Saint-Blancat, Chantal. 2008. 'Imām e responsabili musulmani in relazione con la società locale'. In Chiesa e Islam in Italia: Esperienze e prospettive di dialogo, edited by Andrea Pacini, 57-82. Milano: Edizioni Paoline.

Sayah, Jamil. 2006. 'La laïcité réaffirmée: La loi du 15 mars 2004'. Revue du droit public, 4: 922-927.

Sordel, Dominique. 1986. 'The Caliphate'. In The Enclycopaedia of Islam, III (H-IRAM), edited by Bernard Lewis, Victor Lewis Menage, Charles Pellat, and Joseph Schacht, 45-47. Leiden: Brill.

Tedeschi, Mario. 1996. 'Verso un'intesa tra la Repubblica italiana e la Comunità islamica in Italia?' Il diritto di famiglia e delle persone, 25(1): 1574-1582.

Tozzi, Valerio. 2009. 'Le moschee ed i ministri di culto'. In Studi in onore di Piero Pellegrino: Scritti di diritto canonico ed ecclesiastico, edited by Maria Luisa Tacelli and Vincenzo Turchi, II, 464-475. Napoli: ESI.

Tozzi, Valerio. 2011. 'Le confessioni religiose senza intesa non esistono'. In Aequitas sive Deus: Studi in onore di Rinaldo Bertolino, 1033-1049. Torino: Giappichelli.

Varnier, Giovanni Battista. 1995. 'La prospettiva pattizia'. In Principio pattizio e realtà religiose minoritarie, edited by Vincenzo Parlato and Giovanni Battista Varnier, 8-13. Torino: Giappichelli.

Varnier, Giovanni Battista. 2007. La ricerca di una legge generale sulla libertà religiosa tra silenzi e rinnovate vecchie proposte, Il Diritto ecclesiastico, I-II ().

Vincenzo, Ahmad Gianpiero. 2010. 'The History of Islam in Italy', In The Other Muslims: Moderate and Secular, edited by Zeyno Baran, 55-70. New York: Palgrave Macmillan. 


\section{About the author}

Francesco Alicino is an Associate Professor in Comparative Public Law, Faculty of Law, University of Lum 'Jean Monnet' (Casamassima, Bari, Italy). Key publication: I diritti umani nel mondo globale. Tradizioni religiose tradizioni costituzionali e 'mare nostrum' (Agonalis, 2016). 



\title{
19 In and around the mosque
}

\author{
Profile and territory of the Italian imam
}

Mohammed Khalid Rhazzali

Hashas, Mohammed, Jan Jaap de Ruiter, and Niels Valdemar Vinding (eds), Imams in Western Europe: Developments, Transformations, and Institutional Challenges. Amsterdam: Amsterdam University Press, 2018 DOI: $10.5117 / 9789462983830 / \mathrm{CH} 19$

\begin{abstract}
This chapter presents an assessment of the main trends directing the evolution of an understanding of imams in Europe, with a particular focus on the sociocultural profile of those who assume this role in Italy. The number of profiles of imams studied in this research project was one hundred from all over the country. The chapter also offers some updated figures based on the results of another research project, originally conducted between 2011 and 2013, on places of Muslim worship in the country. ${ }^{1}$
\end{abstract}

Keywords: European imams, Italian imamate, Imams and mosques in Italy, institutionalization of Islam

1 This contribution originates from the outcomes of two different research projects. The first is a qualitative and quantitative study entitled 'Socio-religious leadership of the imam in Italy: a European perspective' (La leadership socio-religiosa dell'Imam in Italia in prospettiva europea). The first of its kind in Italy and financed with internal funds by the University of Padua, the project aimed at analysing the transformations of Islamic religious authorities and community leadership figures in Italy, with particular attention given to imams. The research was conducted on a sample of 100 imams who were active throughout the Italian territory. The second project was carried out between 2011 and 2013 in the context of a PRIN-MIUR (National Interest Program of the Italian Ministry for Education, University and Scientific Research), which connected five Italian Universities (Padua, Bologna, Rome, Turin, and Palermo) to conduct a national study entitled 'Religious pluralism in Italy: mapping and interpreting the different socio-religious entities in Italian society' (Il pluralismo religioso in Italia: Per una mappatura e un' interpretazione delle diverse presenze socio-religiose nella societa' Italiana). The author was the coordinator of the interdisciplinary research unit (sociologists, psychologists, lawyers) for this second project that analysed the Muslim presence in Italy, and in particular the role of mosques and Islamic centres. 
Social science researchers have been using different approaches to elaborate a typological framework of Muslim leadership in Europe. Within this broader picture, they also have sought to identify the core features of an imam. Brigitte Maréchal (2003) has written a pivotal review of the research on Muslim leadership in Europe in which she identifies some fundamental issues: the autonomy, even within constraints, of the majority of mosques and their leaders; the recruitment and education levels of imams; the consequences of some countries' initiatives to organize worship opportunities for their compatriots; and finally the relationship between imams and European countries, which are sometimes keen to formalize their religious and community role, but are also afraid of the possibility of links between mosques and radical groups.

The studies by Wasif Shadid and Sjoerd van Koningsveld $(1999,2002)$ and Nico Landman (1992) describe imams' religious authority and role in the Dutch context, which Welmoet Boender and Meryem Kanmaz (2002) compare with that of Belgium. Some link the imams in each European country to a specific religious doctrine and ethnic background. Thus Philip Lewis (2004) considers imams in Great Britain in relation to the Deobandi tradition, while Sabine Kroissenbrunner (2002) analyses the role of Turkish imams in Vienna. Ural Manço (1997) touches upon Turkey's political outlook towards Europe, and Landman (1997) on the politics of the Turkish Directorate of Religious Affairs (Diyanet). Turkish imams have been an important part of the subject of many studies, such as the work of Kadir Canatan (2001) in the Netherlands and that of Gerdien Jonker (2002) in Germany. Then there are studies that focus on specific urban areas, like the one by Jordi Moreras (1999) describing imams in Barcelona, and by Felice Dassetto (2011), which touches on imams in the context of a comprehensive analysis of Muslim presence in Brussels. In 1998, Franck Frégosi edited a volum dedicated to the juridical profile of Islamic authorities from a historical and sociological perspective. Michel Reeber (2000, 2004) has focused on khuṭbas ('sermons') in France.

There is also research on the sociocultural profile of the imam as a social agent. The same Frégosi (2004) has sought to characterize the imam as a figure bridging the role of worship ministers and sociocultural mediators: on the one hand, the imam shows Muslims' participation in the public sphere, where citizenship is performed; on the other, he maintains the role of an ${ }^{c}$ alim, the lawyer-theologian, custodian, and recognized interpreter of the sharia. Jocelyne Cesari (2004) sketches a fourfold classification of 
imams: leaders that have been put in place by institutions of so-called Muslim countries; parish leaders, who manage activities within the mosque or within an Islamic centre or association in a defined area or neighbourhood; transnational preachers, who are nearly always connected to major Islamist currents or organizations such as the Tablighi Jamaat Movement, Wahhabites, or Sufi confraternities; and lastly, well-respected intellectuals that share their views on Islam, are legitimized by their cultural prominence, and are supported by a large audience of followers. In Cesari's perspective, an imam can assume more than one of these roles, even if his most prominent identification seems to be as a parish leader. Solenne Jouanneau is the author of the insightful monograph Les Imams en France (2013; also see her contribution in Part I), which proposes a variety of imam typologies from a historical perspective, from the invisible imam of the colonial period to the imamate as a real profession from the 199os onwards.

A framework for interpreting the Italian reality has been proposed by Chantal Saint-Blancat (2008), highlighting the plurality of strategies practiced by imams and community representatives, and drawing attention to the creative religious bricolage with which they try to mediate the need for inclusion and the intent to keep their ethical and religious viewpoint alive. I have studied contexts outside of the mosque that involve imams (Rhazzali, 2014, 2015b), and have noted an interesting interweaving, still in the making, between the theme of religious assistance (to patients of terminal illnesses in hospitals and to detainees in jail) and the practices of intercultural mediation that are supported by the public administration.

While it also highlights significant differences, this comparison between different countries indicates the need to identify, at least in its essential traits, a sociological profile of imams that would refer to the entire European Union context. One attempt at this is outlined in a study commissioned by the Policy Department of Structural and Cohesion Policies of the European Parliament in 2007 (Dassetto, Ferrari, and Maréchal, 2007).

Imams in Italy: Figures with changeable contours

Compared to other European countries, the phenomenon of migration in Italy has occurred over a relatively short period of time and has been marked by considerable internal differentiation due to the diverse cultural and national origins of the migrants. However, the history and current reality of imams in the Italian context are closely linked to the features that characterize the Islamic presence in Europe. 
Muslim communities, especially in the initial and middle phases of recent Italian history, have experienced an uneasiness in their interactions with Italian society, which approaches them with a mix of attitudes that oscillate from ideologically or religiously inspired solidarity, to the most aggressive mistrust, in the context of an extreme caution of public policies, which sometimes borders apathy. Islam is newly experiencing the phenomenon of being a minority, in which it must build a 'credibility structure' (Berger 1969) that will make its presence tolerable for both Muslims and those who interact with them, in a context characterized by marked sociocultural differentiation and rapid changes.

Thus, if an imam comes to fulfil the role of a guardian of the religious tradition, he de facto accepts the role of leader of an organization as well as the organization's link to the authorities. Above all, he takes on himself, often precariously and without juridical basis, at least some of the functions that were traditionally associated with an organized system of different roles such as ${ }^{c} \bar{a} l i m, ' a d \bar{u} l$, qadi, and mufti (scholar, notary, judge, and fatwa-giver) (Hallaq, 2004), as well as some new functions deriving from the need to create relationships with the local context - similar to the roles assumed by Christian religious authority figures in the context of the relationship between church and state (Allievi, 2010; Rhazzali, 2014, 2015a; Roy, 2008).

The history of the Italian imam mirrors the path that Italian Muslims have taken and are still treading to furnish themselves with the necessary cultural resources for interacting effectively with the sociocultural and political fabric of which they now claim to be a part, notwithstanding difficulties relating to the legal recognition of the Islamic 'cult'. Conducting a study on the figure of Italian imams requires their specific profiles to be differentiated from the more general background of the overall evolution of Islamic leadership forms. For this reason, the aim of this investigation was to reconstruct the interplay of factors that have most significantly contributed to imams' current, unique features.

\section{3}

\section{The first steps of the institutionalization of Islam in Italy}

In the 1970s and 1980s, the first wave of Muslim immigration into Italy - mainly constituting students of Middle Eastern origin - gave birth to the Unione degli Studenti Musulmani in Italia (Union of Muslim Students in Italy, USMI), an association that first proposed giving a stable structure to Islamic religious presence in the country. The political and cultural aspects of this group coexisted with a more strictly religious ethos that would manifest more fully 
in the following years with the birth of the Unione delle Comunità Islamiche d'Italia (Union of the Islamic Communities and Organisations in Italy, U.CO.I.I). This is the background of the formation of the first wave of religious agents.

At the very beginning of Italian Islam, the individuals steering the organization of mosques and working as religious guides were university students, professionals, doctors, and engineers originating mostly from Syria, Egypt, and Somalia, often with Italian citizenship. This group has continued to play a central role in the running of associations at the national level. In the wake of the rapid growth of immigration after 1990 - mostly from the Maghreb, and widely distributed throughout Italy -, the protagonists of the life of the mosques, especially at the national level, were often factory workers from industrial estates and businessmen connected to the so-called 'ethnic' economy. In those same years, Italy was experiencing a growth of local autonomy and a crisis of traditional ideologies and political parties. This might have limited the attractiveness of secular political and trade unionist associations, and in turn stimulated the initiative of religious players - particularly grassroots initiatives in which religion played a key cohesive role.

Amongst the promoters of religious bodies, among whom roles tend to continuously overlap and further diversify, some actors were 'elected' as religious guides of the community and assumed, somewhere between acclamation and self-proclamation, the title of imam. The decisive factor is often what can be termed 'religious entrepreneurial charisma', which is particularly evident in cases where a single or restricted group autonomously produced their own organization. In the Italian context, this element was no less important than the position of the imam as the guardian-preserver of 'Islamic social actions' (Dassetto, 2011). These imams, who sometimes stand out from and sometimes blend in with other community leaders, bring together different functions that are necessary to ensure an organized religious framework for their community and often also to respond to needs that are connected with religious themes in different ways, due to the not-so-simple relation between Islam and the problems of everyday life in Italian society.

\section{$4 \quad$ Imam profiles}

In the complex and changing scene of Islam in Italy, the individuation of the socio-cultural profile of the imam makes a definition indispensable. In this section, I present an obviously idealized typology based on the case studies analysed in the two research projects I have taken part in. 
First, there is the 'imam of the mosque'. As a place of worship, mosques require a figure that will, to some extent, identify with it and with the important activities that take place there, a guide for religious events, who therefore represents the continuity between the religious tradition and the organization that the community gives itself in a precise historical moment at a specific place. This essential element can mix with the most diverse roles. The imam can act as a teacher of Islamic doctrine and as an Arabic language tutor, but as soon as the mosque becomes a conspicuous size, as has happened in some metropolitan areas, these additional roles are allocated to others and the imam tends to be defined by his more 'pastoral' role. As a guide to prayer and as the khâțib ('person in charge of giving the Friday sermon'), the imam becomes the 'spokesman' of the mosque, so to speak - and through this he becomes the de facto representative of the human community that surrounds the mosque. This is an activity that the imam mostly carries out in a voluntary capacity: 85 per cent of the interviewed imams declared that they fulfil their role without receiving any payment, although in some cases they receive monthly reimbursements, sometimes as a proper wage and sometimes on an occasional basis - but most of the time unofficially. For the vast majority of cases, therefore, the position of the imam as a worker is precarious. Even in cases where the imam is paid, he does not benefit from a defined juridical framework that would give him a professional status.

The essential requirements for recruitment as an imam are the willingness to carry out voluntary work and the possession of theological knowledge, preferably acquired in the context of an academic course, together with the ability to communicate effectively and, in particular, to give public talks. Knowledge of Arabic is also a decisive factor, as the most important part of Islamic worship is conducted in that language. Knowledge of Italian is also considered important, but is not obligatory; a translator is frequently required for rendering at least the Friday sermon into Italian for those members who do not speak Arabic. Given the current demographic composition of Italian Muslims most sermons are in Arabic, though recently there have been cases of ethnically specialized mosques where the language used is Urdu, Bengali, or Albanian. A more complex aspect is represented by the (in)compatibility of the imam's 'theological-political' and sharia-legalistic views with those prevailing in the mosque and especially amongst its steering group. The imam does not always cover all the most relevant religious roles, either; sometimes he specializes in Friday sermons, relying on the presence of an imam-custodian that provides the other services during the week. Sometimes a 'travelling imam' can also substitute for the mosque's. 
This second type of imam (the 'travelling imam') is not permanently linked to a mosque and makes himself available to mosques only for Friday sermons or other specific occasions, thereby displaying some traits of being self-employed. He operates in a freelance fashion, sometimes with a background at a bigger or more famous mosque, and displays a level of competence that is deemed of such quality to justify a payment (at least to cover expenses). For 'travelling imams' references relating to a theological education are required, together with a reputation for social skills, elocution, and communicative abilities. As happens amongst self-employed individuals, there is competition between 'travelling imams'. For this reason, an important role is played by the imams' 'marketing' activities - especially a familiarity with computers and social media - and publication output, which is often characterized by a certain flexibility in dealing with the various doctrinal orientations of the contexts where he performs his services.

If his knowledge of Italian allows it, a 'travelling imam' can access a particularly rich 'market' by acting as an essential reference point for information agencies and making himself available as an experienced spokesperson for local and national institutions, which also provides him with access to media platforms such as television programmes. This media aspect is equally, if not more, important in transnational Islam, where the figure of the preacher (clearly analogous to that of the travelling imam) is taking on an ever-moreprominent role. To keep up with the competition, it becomes indispensable for the imams to possess rhetoric abilities and communication know-how, for example regarding to the formalities that regulate interreligious dialogue. These qualities become as important as doctrinal competence, and enable the imam to assume the cloak of a Muslim representative in competition with other leaders and imams who are more directly linked to mosques.

Third is 'the seasonal imam', who is particularly important for liturgical occasions such as Ramadan. In recent times, this type of imam is not infrequently seen entering the life of Italian mosques from abroad for short periods of time. In some cases they are sent by Muslim majority countries and in others they come through their own initiative or with the support of foundations or associations. Endowed with a high level of theological education acquired by following the models recommended by the country of origin, this kind of imam acts mostly in the context of ethno-national communities. This type of imam deserves independent study because of its many implications for the evolution of Italian Islam.

The fourth and last kind is the 'imam as religious assistant'. The need for a figure that represents religious symbolic power arises at certain moments, such as life stage transitions like births, weddings, and deaths. 
These are circumstances in which the imam is called to intervene. Imams may also be called upon in situations of heightened difficulty or great emotional involvement, such as in the case of losing a job or a house, or experiencing discomfort in family relations. In this case, part of the activity of the imam is defined through the interweaving of religious assistance and social and psychological help - similar to the role of priests in the life of Catholic parishes.

\section{5}

\section{Interactions between Islamic and state institutions}

The imam and those in charge of the mosque struggle to fulfil their commitments if places of worship are geographically spread out, if they require numerous visits, and if they include institutions such as jails and hospitals that require a specific knowledge of their 'logic' and their languages for appropriate intervention to take place. This type of interaction puts the representatives of Islamic religious authority in touch with secular state institutions. Often the institutions themselves ask for the intervention of an imam for tasks that are equivalent to those performed by a parson or chaplain. After receiving such a request, and if they have the capacity to fulfill it, mosques send an imam or a delegate of his - who is automatically considered an imam in the context of the interaction. Alternatively, the mosque could give way to independent professional 'travelling imams' or to intercultural mediators with sensitivity and some religious understanding. A space therefore opens for the imam to develop new expertise in providing religious/spiritual assistance within secular contexts, which has been experimented with for a long time in the European context, but is relatively new to the Muslim world, where it has only recently started to take shape through the murshid and mushida ('male and female guide'; see Borillo, Part I). In Italy, these religious assistants are voluntary (as far as we know); if they are paid, it is as intercultural mediators. ${ }^{2}$

It is especially through the figure of the intercultural mediator that female religious figures emerge for the first time. Women often end up carrying out the majority of the functions that are associated with the imam-religious assistant, often starting from a significant theological knowledge interwoven with university studies in the humanities, law, or

2 Systematic studies of this type of imam are hardly available. The author has conducted a study dedicated to Italian prisons (Rhazzali, 2014), but so far assistance in hospitals has produced only a qualitative research study limited to the theme of end-of-life care (Rhazzali, 2014). 
social sciences. In fact, women are predominant in the field of intercultural mediation, including Muslim women (Luatti, 2006, 2011; Rhazzali, 2015b). During our research, I had the opportunity to observe women carrying out - even though informally - a religious and welfare responsibility in jails that is extremely significant, covering tasks that otherwise would not be fulfilled through the resources of the mosques or the aid of voluntary services. These women performed the role of an imam, offering spiritual guidance to inmates, training the prison staff about specific issues that are sensitive to the Muslim community, and donating books on Islam to the prison library.

The four types of imam presented in Section 4 have one major point in common: the quality of the theological education of the imam and therefore his (or her) religious legitimacy. This is connected with an even more important issue that is by now an established theme within the debate surrounding European Islam: the elaboration of a doctrine that is able to interact with current reality in a genuine way. The tangible nature of this issue becomes more evident when one considers the challenges that imams and Islamic organizations find themselves dealing with, such as the political and ethical confusion of young Muslims and the new and in many ways revolutionary sphere of the Internet, which accelerates the processes of transformation by overturning traditional styles of religious communication.

Depending on the position from which one considers the current scenario, Italian Islam appears both precarious and rooted: integrated into the public space but to this day not recognized; simultaneously reconciled with Italy and an object of resentment. If the imams are bearing the weight of these contradictions, their 'mosques' carry all the signs of this as-yet-unsettled transition.

\section{Prayer places: Physical spaces and organizational aspects}

Offering an overall representation of the territorial distribution of Muslim places of worship in Italy together with an overview of the activities that are undertaken there and of the organizational forms they take is not an easy task because of the limited pool of data and bibliographical resources available for a sociological analysis.

When we first undertook our research, only two studies had been carried out, the first conducted by Stefano Allievi and Felice Dassetto in 1992 (1993), the second by Maria Bombardieri between 2008 and 2011 (2011). There was also the data on information policy for security published by the 
Dipartimento delle Informazioni per la Sicurezza (Department of Information Security, DIS, 2007), ${ }^{3}$ operating as part of the Presidency of the Council of Ministers, and the data published on the site of the Centro Studi sulle Nuove Religioni (Centre for Studies on new Religions, CESNUR), which relates to the monitoring of new religions in Italy. ${ }^{4}$

The notion of 'places of worship' in the Italian context entails the adoption of classification criteria that are difficult to define in the case of Islam. In Italy, both in media and everyday communication, the word 'mosque' is used to indicate a place where the social religious life of Muslims takes place. However, there are only a handful that can be strictly defined as mosques: one can mention with certainty the grand mosque in Rome, together with those of Milan (Segrate), Catania (currently inactive), Ravenna, and Colle Val d'Elsa. To this very limited catalogue can be added the many building attempts that were interrupted for various reasons before completion.

Indeed, the term 'mosque' is, in a strict sense, reserved for buildings that reproduce the architectural structure of a mosque, which, even though it displays forms that are very different depending on the time and place of construction, does maintain some common features, such as a courtyard for ablutions and a great prayer room that is able to host the faithful for the Friday prayer and the most important festivals in the Muslim calendar. A third element that has been the subject of heated controversy in some European countries, such as Switzerland, is the minaret, which Italian Muslims have never really claimed to be indispensable (Rhazzali, 2013). The mosque undoubtedly has a symbolic significance, evoking the public centrality of religious practices for Muslims and therefore of the cultural horizon to which the practices are connected. This in part explains the hostility of political parties, movements, and widespread forms of populism - which are generally diffident regarding the Islamic presence - towards the birth of full-fledged mosques.

Worship places in Italy can be more appropriately defined as mușallayāt (sing., mușallā): simple prayer rooms that in general re-use and adapt preexisting spaces for to the most essential needs of religious service. 5 They constitute the nearly always temporary attempt of Muslims to find spaces and times for group prayer in the immigration context, a difficult and

3 https:/www.sicurezzanazionale.gov.it/sisr.nsf/chi-siamo/organizzazione/dis.html.

4 Cf. http://www.cesnur.org.

5 In Muslim majority countries, this term currently indicates spaces in public structures such as airports, motorway service stations, universities, and hospitals that are set up as prayer facilities for religious people in transit and are based upon self-organization in the absence of an imam. 
sometimes painful quest that continuously faces political or bureaucratic resistance - which are strengthened by the generally lukewarm attitude towards the principle of religious liberty in Italy. This translates into a scenario of worship in garages, industrial warehouses, and better if situated on the edges of motorways, basements, or spaces that were originally designed for commercial activities. These spaces are constantly under threat of eviction, suspended leases, and disputed terms of use, even if they are sometimes made accessible through the local solidarity of individual secular or religious organizations as a result of the sensitivity towards interreligious dialogue that is fairly present in civil society. It must be remembered that, in the absence of an agreement with the state or any other legal recognition, Islam does not enjoy the legal status of an 'accepted form of worship'. This entails that the so-called 'mosques' cannot be formally recognized as worship places or gain access to the relevant benefits that are granted to religious premises by law (see also Alicino, Part II).

Therefore, except for the case of the mosque of Rome (which is based on an agreement that dates to a time before the unfolding of immigration in Italy and was signed between the Italian State and the diplomatic representatives of Muslim countries), all the other Islamic places for prayer or religious assembly legally present themselves as the headquarters of individual associations that are established with various social and cultural aims. The religious nature of the practices carried out there remains the private choice of the members; the local administration and State authorities can view this with respect and a willingness to collaborate, or, as has often happened, can favour the restrictive interpretation of laws and regulations to make the life of the mosque difficult if not impossible, with the ensuing swarm of legal controversies and the most diverse use of political rhetoric. Considering their size, their location in urban contexts, the national origin and linguistic features of those who frequent them, and the worship practices associated with them, aside from the few 'real' mosques previously mentioned, Italian mosques can be understood through the following typology:

Islamic cultural centres. In many cases, the group that leads the mosque describes itself as an 'Islamic cultural centre'. However, this definition technically only pertains to the limited number of cases where, aside from the space designated for prayer, there are also other rooms where other educational and cultural activities for a specific target audience can take place. These activities may include: a Quranic school; Arabic courses for the children of the congregation members or for Italians who want to know more about Islam; initiatives conceived for women or youths; and conferences and public meetings. The organizational level of the main 'mosques', which are 
mostly located in urban centres, allows more consistency and continuity in the elaboration and implementation of activities such as providing assistance in jails and hospitals or supporting families in returning the bodies of the deceased to their homeland for burial, although these services are also available in smaller mosques with less resources to a certain extent.

Nationality-based mosques. Until the recent past, people who attended mosques in Italy could hardly be traced back to a single ethno-national origin. The leading groups themselves were of mixed backgrounds. More recently, however, there is a tendency to organize along ethnic lines. Mainly located on the urban periphery and in small provincial towns, these mosques are progressively becoming the most common models. The difficulties of running so-called ecumenical mosques, together with the enduring legislative silence of the Italian State, has certainly not encouraged the institutionalization of an 'Italian Islam'.

Mosques of modest size. This is currently the most common type of mosque in Italy. They are sometimes unable to guarantee the traditional division of space between male and female worshippers, or to adequately host the Friday gatherings for the faithful to hear the khuțba. Located in buildings that are adapted with great zeal to the most essential needs of prayer, they represent a point of reference for local Muslims and often become the location of organized events ranging from economic activities aimed at the self-financing of the mosque through, for example, halal trade, to the setup of forms of micro-welfare aimed at benefitting the community.

Sufifraternities. Another case is the places that are run by Sufi fraternities. Sometimes characterized by ethnically homogeneous participation, these groups are often preferred by Italian converts, who arrive at Islam through intellectual and existential interest in Sufism. The relationship of the group with their physical setting is often tied to the most diverse circumstances and therefore tends not to stabilize, resulting in limited visibility of the Sufi 'mosques'.

\section{7}

Mapping Italian mosques

To produce an accurate mapping of Italian mosques, we have combined several data-gathering strategies, taking into consideration the extremely volatile nature and changeability of the situation under study. First, we reconstructed the relationship between the mosques and regional and national Islamic organizations, and asked for the direct involvement of the latter in the research project. Significant help was provided by the 
Unione delle Comunità Islamiche d'Italia (Union of Islamic Communities and Organizations in Italy, U.CO.II), the Confederazione Islamica Italiana (Islamic Confederation of Italy, CII) and the Comunità Religiosa Islamica Italiana (Italian Islamic Religious Community, CO.RE.IS), in combination with access to a catalogue of imams and community leaders created in during the action-research project 'New religious presences in Italy' (see also Pallavicini, Part II). ${ }^{6}$

The data thus gathered needed to be integrated with the outcomes of other investigations, such as verifying whether previously identified mosques were still active; searching local and national news and the Internet in order to identify mosques that had not previously been recorded; and contacting local administration offices and non-Muslim religious associations operating in areas where the information about the existence of places of worship was imprecise.

As of February 2013, the number of mosques in Italy was 655. This number is smaller than that provided by the Dipartimento delle Informazioni per la Sicurezza (Department of Information Security, DIS, 2007), which stated that there were 774 mosques, and that given in Bombardieri's research (2011), which counted 746 mosques. The differences can be ascribed to a partial discrepancy in the criteria adopted by individual researchers. In the case of the DIS report, the research aims were presumably guided by the needs of the intelligence services; the report does not contain a methodological note and does not indicate the criteria used in the investigation. In other words, it seems to have tried to capture the presence in Italy of any form of Muslim association in the most comprehensive way possible. Bombardieri's research (2011) a few years later seemed to confirm the final number provided by the DIS, from which it deviates only slightly. Bombardieri counted all Islamic entities mentioned in the media, thus including halls used for only brief periods, private apartments sporadically used as worship places, Sufi brotherhood spaces open only to members, and ethno-national associations for which religious activities were secondary. In this study, we deemed it necessary to conduct our research on the basis of a definition of 'mosques' that, even comprising the extreme variety of actual cases, would pinpoint some features of both a sociocultural and legal nature. We therefore chose to include only those places that were established with some formality, with some at least basic level of advertising, and which constituted their own legal entity.

6 The project was promoted by the Forum Internazionale Democrazia \& Religioni (FIDR) cofounded by the University of Padua - between 2010 and 2013, under the sponsorship of the Ministero degli Interni and the Ministero della Cooperazione. Cf. http://www.fidr.it/ progetto1_eng.asp. 
The geographic distribution of mosques in Italy mostly follows that of Muslim immigration, which in turn has been dictated by the territorial development of productive activities over the last few decades. For this reason, mosques are most numerous in Northern Italy.

We then conducted an analysis of mosque distribution by province, which demonstrates how the area mosques are more common in the big cities and their peripheries, such as Milan, Turin, and Bologna and their extended peripheries, as well as provinces such as Bergamo, Brescia, and Vicenza where the presence of manufacturing and commercial activities is particularly sizeable and widespread.

In the northern regions of the country, there have been manifestations of solidarity between the civil society and the Muslim communities. Still, the institutions and political world of these regions have not been very welcoming to a wider dialogue concerning the needs of Muslim communities. Attitudes inspired by mistrust - sometimes covert, sometimes explicit - have significantly inhibited attempts to advance mosque projects in Milan, Brescia, and Parma. Furthermore, there has been a opposition in the Veneto region against any attempt by Muslim communities to gain access to suitable places of worship. The Lombardy region even formulated a law in 2015 in which religions that are not qualified as 'accepted forms of worship' are given less ability to acquire their own space. Going down the peninsula the relative number of mosques diminishes, with the at least partial exception of Tuscany - where the mosque of Colle Val d'Elsa project, conceived in agreement with the local administration as both a mosque and an intercultural centre, has been completed - and of Rome, where in addition to the atypical grand mosque, there is also a varied landscape of Muslim religious organizations. Sicily is different than the rest of Southern Italy because the Islamic presence on the island derives from historically stratified relations with its neighbours on the other side of the Mediterranean (Branca and Scidà, 1990, pp. 43-44).

This description of the territorial distribution of mosques in Italy be decidedly incomplete without highlighting the importance of the relationship between most of local institutions, however small they may be, and the nationwide Islamic organizations. In the course of the last few decades these relations have started to assume an ever-more-important role in the elaboration of doctrinal orientations that guide the life of mosque communities, in the creation of a public forum discussing the meanings of Islam in the evolution of Italian sociocultural and political reality, and in maintaining a dialogue with State institutions. 
There appears to be two fundamental tendencies in the complex internal dynamic that characterizes the emergence of both imams and mosques in the Italian public space. On the one hand, there is an evident attempt to give life to an Italian Islam. Some groups of Muslims are making a concerted effort to integrate the prevailing part of their social and cultural experience that is now Italian, aiming to redefine their religious identity based on the specific location they now live and interact. The contribution of Italian converts to this effort cannot be neglected, especially due to their cultural activism (Allievi, 20o9; Rhazzali, 2013). On the other hand, there has also been a growth in a new form of valorization of ethno-national themes in recent years with the birth and growth of organizations of Muslims who share the same national origin, which are often economically and politically assisted by their respective 'home' countries.

Within these communities it has to be made clear that an intent to guarantee the continuity of relations with the country of origin does not necessarily contrast with the promotion of full participation in the life of the host country. Quite the opposite, in fact: amongst the most interesting aspects of this type of experience is the positive acceptance of what can be called a multiple identity. At the same time, one should not forget that the relationship with the country of origin is, in part, a substitute for the delays and reticence of the Italian State in regard to reaching a legal agreement with Muslim communities on the issue of religious practice.

The future will show whether Italy's political system and society are able to interpret the will of a rooted and complex Islamic reality to interact with the overall dynamics in which the country is evolving - a reality in which the Islam of the immigrants, of the so-called second and third generations, of the Italian converts, and of the imams all weave together to find both chances of participation and fundamental challenges within the shared Italian public sphere.

\section{References}

Allievi, Stefano, ed. 2009. I musulmani e la società italiana: Percezioni reciproche, conflitti culturali e trasformazioni sociali. Milano: FrancoAngeli.

Allievi, Stefano. 2010. La guerra delle moschee: L'Europa e la sfida del pluralismo religioso. Venezia: Marsilio. 
Allievi, Stefano and Felice Dassetto. 1993. Il ritorno dell'Islam: Imusulmani in Italia. Roma: Edizioni Lavoro.

Berger, L. Peter. 1969. The Social Reality of Religion. London: Faber and Faber.

Boender, Welmoet and Meryem Kanmaz. 2002. 'Imams in the Netherlands and Islam

Teachers in Flanders'. In Intercultural Relations and Religious Authorities: Muslims in the European Union, edited by Wasif Shadid and Sjoerd van Koningsveld, 169-180. Leuven: Peeters.

Bombardieri, Maria. 2011. Moschee d'Italia: Il diritto al luogo di culto. Il dibattito sociale e politico. Bologna: EMI.

Branca, Paolo and Giuseppe Scidà. 1990. Confronti transmediterranei: Nord-Sud. Milano: Jaca Book.

Canatan, Kadir. 2001. 'Turkse Islam: Perspectieven op organisatievorming en leiderschap in Nederland'. Ph.D. dissertation, University of Rotterdam.

Cesari, Jocelyne. 2004. L'islam à l'épreuve de l'Occident. Paris: La Découverte.

Dassetto, Felice. 2011. L'Iris et le Croissant: Bruxelles et l'islam au défı de la coinclusion. Louvain-la-Neuve: Presses Universitaires de Louvain.

Dassetto, Felice, Silvio Ferrari, and Brigitte Maréchal, eds. 2007. Islam in the European Union: What's at Stake in the Future? Brussels: European Parliament.

Dipartimento delle Informazioni per la Sicurezza (DIS, Department of Information Security). 2007.

https://www.sicurezzanazionale.gov.it/sisr.nsf/chi-siamo/organizzazione/dis.html.

Frégosi, Franck, ed. 1998. La formation des cadres religieux musulmans en France: Approches socio-juridiques. Paris: L'Harmattan.

Frégosi, Franck. 2004. 'L'imam, le conférencier et le jurisconsulte: Retour sur trois figures contemporaines du champ religieux islamique en France'. Archives de Sciences Sociales des Religions, 125: 131-146.

Hallaq, Wael B., ed. 2004. The Formation of Islamic Law. Aldershot: Ashgate.

Jonker, Gerdien. 2002. Eine Wellenlänge zu Gott: Der 'Verband der Islamischen Kulturzentren' in Europa. Bielefeld: Transcript Verlag.

Jouanneau, Solenne. 2013. Les Imams en France: Une autorité religieuse sous contrôle. Paris: Agone.

Kroissenbrunner, Sabine. 2002. 'Turkish Imams in Vienna'. In Intercultural Relations and Religious Authorities: Muslims in the European Union, edited by Wasif Shadid and Sjoerd van Koningsveld, 181-207. Leuven: Peeters.

Landman, Nico. 1992. Van mat tot minaret: De institutionalisering van de islam in Nederland. Amsterdam: VU Uitgeverij.

Landman, Nico. 1997. 'Sustaining Turkish-Islamic Loyalties: The Diyanet in Western Europe'. In Muslim Identity and the Balkan State, edited by Hugh Poulton and Suha Taji-Farouki, 214-231. New York: New York University Press. 
Lewis, Philip. 2004. 'New Social Roles and Changing Patterns of Authority amongst British “ulama”'. Archives de Sciences Sociales des Religions, 125: 169-188.

Luatti, Lorenzo. 2006. Atlante della mediazione linguistico culturale: Nuove mappe per la professione di mediatore. Milano: FrancoAngeli.

Luatti, Lorenzo. 2011. Mediatori, atleti dell'incontro: Luoghi, modi e nodi della mediazione interculturale. Gussago: Vannini.

Manço, Ural. 1997. 'Les organisations islamiques dans l'immigration turque en Europe et en Belgique'. In Facettes de l'islam belge, edited by Felice Dassetto, 143-158. Louvain-la-Neuve: Bruylant-Academia.

Maréchal, Brigitte. 2003. 'Institutionalisation of Islam and Representative Organisations for Dealing with European States'. In Muslims in the Enlarged Europe: Religion and Society, edited by Brigitte Maréchal, Stefano Allievi, Felice Dassetto, and Jørgen Nielsen, 151-182. Leiden: Brill.

Moreras, Jordi. 1999. Musulmanes en Barcelona. Barcelona: Cidob Edicions.

Reeber, Michel. 200o. 'Les khutbas de la diaspora: Enquête sur les tendances de la prédication islamique dans les mosquées en France et dans plusieurs pays d'Europe Occidentale'. In Paroles d'islam: Individus, société et discours dans l'islam européen contemporain, edited by Felice Dassetto, 185-203. Paris: Maisonneuve \& Larose.

Reeber, Michel. 2004. 'La prédication (khutba) dans les mosquées en France et en Europe: Enquête d'une nouvelle légitimité?' In Les transformations de l'autorité religieuse, edited by Martine Cohen, Jean Joncheray, and Pierre-Jean Luizard, 187-198. Paris: L'Harmattan.

Rhazzali, Khalid. 2013. 'I musulmani e i loro luoghi di culto'. In Le religioni nell'Italia che cambia: Mappe e bussole, edited by Enzo Pace, 47-72. Roma: Carocci.

Rhazzali, Khalid. 2014. 'The End of Life from an Intercultural Perspective: Mediators and Religious Assistants in the Health Service'. Italian Journal of Sociology of Education, 6(2): 224-255.

Rhazzali, Khalid. 2015a. Comunicazione interculturale e sfera pubblica:Diversità e mediazione nelle istituzioni. Roma: Carocci.

Rhazzali, Khalid. 2015b. 'Religious Care in the Reinvented European Imamate: Muslims and Their Guides in Italian Prisons'. In Religious Diversity in European Prisons: Challenges and Implications for Rehabilitation, edited by Irene Becci and Olivier Roy, 117-138. New York: Springer.

Roy, Olivier. 2008. La sainte ignorance: Le temps de la religion sans culture. Paris: Seuil.

Saint-Blancat, Chantal. 2008. 'Imam e responsabili musulmani in relazione con la società locale'. In Chiesa e Islam in Italia: Esperienze e prospettive di dialogo, edited by Andrea Pacini, 57-82. Milano: Edizioni Paoline.

Shadid, Wasif and Sjoerd van Koningsveld, eds. 1999. Beeldvorming over de imam in Nederland, in religie, cultuur en minderheden. Tilburg: Tilburg University Press. 
Shadid, Wasif and Sjoerd van Koningsveld, eds. 2002. Intercultural Relations and Religious Authorities: Muslims in the European Union. Leuven: Peeters.

\section{About the author}

Mohammed Khalid Rhazzali, Ph.D., is an Adjunct Professor of Sociology of Religion and Sociology of Politics at the University of Padua, where he co-directs the Masters programme in Studies on European Islam, and is the deputy director of the Interuniversity Center FIDR (International Forum for Religions and Democracy). He is the author of Intercultural Communication and the Public Sphere: Diversity and Mediation within Institutions (In Italian; Carocci, 2015). 


\title{
20 The training of imams in Italy
}

\author{
The case of CO.RE.IS
}

Yahya Pallavicini

Hashas, Mohammed, Jan Jaap de Ruiter, and Niels Valdemar Vinding (eds), Imams in Western Europe: Developments, Transformations, and Institutional Challenges. Amsterdam: Amsterdam University Press, 2018 DOI: $10.5117 / 9789462983830 / \mathrm{CH} 20$

\begin{abstract}
There are over one and a half million Muslims residing in Italy. This diverse Muslim community faces many challenges, including a lack of official recognition by the Italian government. The Islamic association Comunità Religiosa Islamica Italiana (Italian Islamic Religious Community, CO.RE. IS) has undertaken the task of establishing institutions addressing the importance of religious tolerance. Through building mosques, developing curricula, and providing training for imams in Italy, CO.RE.IS seeks to promote a united and moderate representation of Italian Islam. This chapter centres on the role of the CO.RE.IS in offering both imam-training courses and general courses on Islam since 1995 .
\end{abstract}

Keywords: Italian Islam, institution-building, Islam and democracy, mosques building

\section{$1 \quad$ Islam and the State in Italy}

Muslims in Italy are still waiting to receive the official government recognition that would give them the same status as the numerous other religions that have already signed agreements with the state. In the absence of an official body dedicated to these matters, the places of worship and ministers of the Islamic faith depend on initiatives undertaken by individuals or associations seeking to meet the religious needs of the about one and a half million Muslims in Italy. Flats, offices, cellars, and garages are often used as locations for the Friday prayers of Muslim communities, while volunteers - mainly immigrants from non-EU countries - and foreign imams sent by international Islamic organizations or the embassies of Muslim countries 
try to carry out the function of preacher and provide moral support to the community. The majority of Muslims in Italy are first-generation immigrants, mainly from Turkey, Albania, Morocco, and other parts of North Africa, but there are also growing numbers of Bangladeshi, Pakistani, and Senegalese Muslims who have had limited education or professional training, and who are often unfamiliar with the Italian legal system, culture, or language. For most of these immigrants, Islam is an expression of a natural sensibility and cultural heritage intertwined with memories of their youth in their home countries.

Given the growing presence of Muslims in the country, Italian state institutions have promoted some important initiatives in pursuit of a united and moderate representation of Italian Islam. In September 2004, for the first time in Italian history, the Italian President received a delegation of Italian Muslims at the Quirinale, his official residence in Rome. A year later, the then-Minister of Internal Affairs Giuseppe Pisanu, formed a group of sixteen Muslims to act as advisors for understanding Italian Islam. The President welcomed this delegation and permanently appointed them as the Advisory Board for Italian Islam (Consulta per l'Islam Italiano). Headed by the Minister of Internal Affairs and further empowered by Pisanu's successor Giuliano Amato, the Consulta is composed of the signatories of the 'Manifesto against terrorism and for life' (Manifesto contro il terrorismo e per la vita), which was published on 2 September 2004 in the newspaper Il Corriere della Sera. Representatives of Italian Islamic civil society and those responsible for the Muslim community used this manifesto to condemn the manipulation of religious identity and to express their full adherence to the principles of the Constitution and the values of Italian culture.

The Consulta per l'Islam Italiano unites Muslims who are Italian by birth with those who come from Albania, Algeria, Iraq, Jordan, Libya, Morocco, Pakistan, Senegal, Somalia, and Tunisia and who have either already obtained Italian nationality or are, to a large extent, integrated into the Italian society while still maintaining their original citizenship. These Muslim advisors connected to the Minister of Internal Affairs have successfully highlighted the differing perspectives on and interpretations of Islam within the context of the Italian public and political debate. However, this would not have been the case without the recent involvement of the members of the Consulta per l'Islam Italiano in various parliamentary commissions, for instance on the Constitutional Affairs Law on Religious Freedom and on Social Affairs and Family Conditions, and in the anticipatory discussions for the presentation of certain proposed laws concerning immigration, 
integration, citizenship, and equal opportunities. The importance and the social implications of religious pluralism and cultural diversity in Italy led Minister of Internal Affairs Giuliano Amato to establish La Carta deivalori della cittadinanza e dell'integrazione (The Charter of the Values of Citizenship and Integration $)^{1}$ with the active involvement of both the Consulta per l'Islam Italiano and stakeholders from other religious denominations and major ethnic associations present in Italy.

2

\section{CO.RE.IS}

Since 1995, CO.RE.IS ${ }^{2}$ has been promoting and organizing a programme of Islamic theological training for religious leaders, both men and women, and ministers of faith or imams. This programme is meant to enable these individuals to deepen their knowledge of traditional Quranic doctrines. Comparisons with the sacred scriptures of other traditions and study of the Italian legal system and the history of western thought are also regarded as essential elements for the training of Muslim religious leaders in contemporary civil society, and as a way to eliminate segregation and extremism.

In 1995, CO.RE.IS felt that the time had come to stop attending congregational prayers organized by the Islamic centres in a number of Italian cities. This dissociation had nothing to do with the Italian citizenship of the members of CO.RE.IS, for most are converts to Islam; this differs from other communities, which primarily consist of immigrants. It also did not concern a distinction between Westerners and those originating from outside Europe, between natives and immigrants, or between converts and those born into the religion. Rather, it was the distinction between everyday believers and political militants, between those sensitive to the nature of how they conceived the spirit of Islam and those who, in their sermons and conversations, used proselytising language and ideological propaganda. All too often, the sermons in the Islamic centres promoted Islamic extremism, theorized about alleged Christian imperialist plots, and emphasized the struggle against Zionism. Many Muslims, both those born into the religion and converts, felt very uncomfortable in these settings

1 Carta deivalori della cittadinanza e dell'integrazione, http://www1.interno.gov.it/mininterno/ export/sites/default/it/sezioni/sala_stampa/speciali/altri_speciali/carta_dei_valori; for the full text see: http://www.milano.istruzione.lombardia.it/edsalute/normativa/files/carta_valori_cittadinanza_integrazione.pdf.

2 http://www.coreis.it/13/. 
- places that were supposed to be prayer halls for the Friday community assembly, but that, in fact, had evidently been taken over by a number of extremists who were intending to build an international network. A number of Muslim immigrants were expelled from these Islamic social centres and, consequently, forced to restrict their religious practices to the private sphere to avoid being associated with the undesirable formation of a parallel society that they considered neither Islamic nor Arab, but simply set up as an alternative to the established democratic cultural and political system. This also resulted in Italian Muslims taking on the responsibility of training others, as they could not tolerate the unjustifiable exploitation of Islam and its values by extremist groups.

\section{$3 \quad$ CO.RE.IS's activities}

This section describes the activities that CO.RE.IS has developed.

\subsection{Building mosques}

When CO.RE.IS presented the details of the project for the Al-Wahid mosque in Milan to the municipal officials and politicians and those from the Lombardy region, it decided to concentrate on the essentials, avoiding issues such as minarets and simply requesting a place of worship in a building that CO.RE.IS already owned and that was in need of renovation. The aim was to promote urban, technical, judicial, cultural, and architectural coherence through a transparent agreement between the public administration and an accredited and trustworthy organization of Islam in Italy. The debate with some local officials and politicians led CO.RE.IS to look at the details in depth and to accept certain conditions that would have gone against this laudable collaboration, had both sides applied them in a bureaucratic or a close-minded manner. The Board for the Integration of the Municipality of Milan (Commissione per l'Integrazione del Comune di Milano) approved the project in December 2000, allowing CO.RE.IS to convert an industrial warehouse into a place of worship. Since then CO.RE.IS has undertaken similar efforts to raise the necessary funds to pursue new buildings and to start constructing the Al-Wahid and other mosques. The construction of a mosque in the heart of Milan as part of the urban environment and in full contact with the life of the city is of fundamental importance, not only as a confirmation of the call to a divine reality, but also as a symbol of Islam's interaction with the contemporary world. 


\subsection{Development of courses}

CO.RE.IS originally started to develop training courses with the intention of meeting the needs of Italian Muslims who wished to learn more about the doctrine and the practice of their faith. It was only later that these courses developed into their present forms - a course for imams, and a series of lessons for the training of Muslim religious experts and theologians. These two courses are different in character: while the training of imams focuses on basic knowledge of the Islamic religious sciences and the Italian legal system, the course for theologians combines programmes of comparative religious studies, the history of Islamic civilization, the history of Western philosophical thought, and intercultural education. There are also optional courses in Classical Arabic and Italian for foreigners.

The imam-training course provides the students with an expanded knowledge of the Quran, Classical Arabic, Italian, and the contemporary social context, to improve their ability to lead the prayers and prepare sermons. CO.RE.IS believes that imams who have successfully completed its courses will be recognized by Muslims in Italy as reliable and insightful, combining the wealth and depth of the Islamic doctrine with the harmonious testimony of the religion while seeking to respect Italian society in every way. The imams are taught to deliver sermons in Italian, in addition to the Arabiclanguage ritual prayers and Quranic and traditional formulae prescribed for the Friday prayers. The duties of an imam revolve in particular around the pillars of religion and the juridical rules that allow it to be practiced - in this case - in the contemporary Western world. This is a world where Muslim communities live as religious minorities in secularized societies. As religious minorities, Italian Muslims have particular identity heritages that they seek to protect from widespread prejudices and stereotypes. The imam must be able to guide the faithful to both spiritual devotion and a sense of responsibility towards the society in which they live, protect the community from the interference of foreign political forces and extremist influences, and ensure that the place of worship has the greatest possible transparency, reflecting the dignity that should characterize an Islamic religious space.

\section{$3 \cdot 3$}

The role of imams

CO.RE.IS often advises imams to avoid connections with centres that have an ideological, extremist, or sectarian background in order to preserve what it considers the true and authentic character of the Italian mosques where 
Muslim worshippers wish to meet. It is the intention of CO.RE.IS to present these places as models of widespread integration in the urban areas and as meeting places for Muslims that are free from internal political exploitation or the logic of marginalization. For this reason, imams must also be able to function as linguistic mediators - translating the tenets of the Islamic religion for the first generation of Muslim immigrants from various non-EU countries, while also being able to address these future European citizens in the language of the nation in which they live. It is important for young people to look up to the imam as not only a religious leader, but also a precious guide who can help them live their faith in a worthy and natural manner amidst fellow students or workers, and to learn to express this dignity in the context of their families.

While this does not necessarily mean that the imam must act as a social mediator, his spiritual and moral assistance can be decisive in bringing harmony to the relationship between faith, reason, culture, and human rights. The courses offered by CO.RE.IS are intended to eliminate the risk that the religion would be seen as incongruent with the contemporary Italian context. The imam cannot, by nature, represent a language, a culture, or a foreign nation, but he can be particularly effective as a faithful interpreter of not only the religious doctrine but also the way the doctrine is experienced by the believers he addresses in his religious role in the context of the language and culture of the country in which he lives.

In the eyes of CO.RE.IS, imported imams, or those appointed by international Islamic organizations from abroad or religious institutions of foreign governments, represent an obstacle to the active participation of the faithful and ministers in the country's activities. They are, in CO.RE.IS's view, conditioned by a vision that is not fully compatible with how Italian Islam should look. Therefore, it is CO.RE.IS's expectation that the new generation of Muslims born in Italy will not recognize these foreign imams as credible or useful guides for their lives in this country. To guarantee the effectiveness of this relationship, the CO.RE.IS courses do not follow a classic programme of study for either the language or doctrine as offered in many Muslim countries. Instead, the programmes start from the knowledge and experiences of each individual imam to allow him to expand his knowledge and assist the faithful in their spiritual orientation in their youth.

Themes such as life and death, study, work, love, and the family are particularly significant because they allow the imam to contextualize his doctrinal competence in a practical application. The CO.RE.IS courses for imams therefore focus on the following aspects: birth; the sacred value of human existence; the creation of the world and the responsibility of the 
representatives of God in this world; the equal dignity of men and women; the pillars of the religion; education and the search for knowledge; the transmission of knowledge; the principles of the Islamic faith; the stories of the prophet in the Quran; inter-religious dialogue; earning one's livelihood; family unity; civil and religious marriage; parents' duties towards their children; Islamic identity and active participation in the prosperity of society; political responsibility; and universal ethical values.

Additionally, the imam attends courses on health regulations in hospitals regarding childbirth, and the treatment of patients and the deceased, gains basic knowledge on the procedures for the registration of births, marriages, divorces, and deaths, and learns about the current legislation regarding training or work contracts in Italy. He is also trained in matters related to education in both state and private schools, and the rules concerning the specific needs of Muslim children regarding both teaching and the preparation of food.

When answering questions of the faithful, imams must not only aim to keep in line with the principles of the religion, but also think of a way to avoid conflict between the religious needs of the believers and full respect of the Italian legal system and cultural heritage. This is the only possible way for ministers of the Muslim faith to contribute in a significant manner to the constructive and active participation of Muslims in society: through facilitating their civil, intercultural, and professional roles and by maintaining and reviving the spiritual heritage of their religious identity. The imams are expected to be able to cooperate with state institutions of all levels and with Muslims in the process of integrating the Muslim community into the contemporary, religiously plural and culturally diverse Italian society. Thanks to the work of these imams, CO.RE.IS is confident that the new generations of Muslims in Italy will be able to both experience their religion in a serene manner and discover the meaning of citizenship in a democratic country.

The two-year course requires students to attend lessons for at least twenty hours a month, mainly on Fridays, to allow the future imams to continue other studies or work activities. There is also an additional pedagogical benefit to this way of working: the students can practice what they learn in the course while performing their everyday commitments. Another issue is the imam's uncertainty after completing the training course. The lack of an official organization with the task of managing or coordinating the Islamic places of worship in Italy means that there is no guarantee that the graduates will be appointed as an imam by any of the local Muslim communities. More importantly, very few communities are in a position to employ a full-time imam to provide for the needs of the faithful. 
In the past few years, the first group of Italian Muslims have successfully completed the imam-training course. They have since made themselves available to carry out their functions on a voluntary basis on various occasions in different parts of the country.

\subsection{Further initiatives}

The main obstacles to the continuity of the courses are a lack of financial and institutional support. CO.RE.IS is fully aware of this situation, and since 2005 has started collaborating with national universities and a network of national and international partners to empower these specialization courses. CO.RE.IS is not limiting itself to Muslims who wish to deepen their knowledge of the doctrine so as to carry out their functions of religious leadership in a capable and dignified manner; instead, the courses are available for every man or woman who is interested, for whatever reason, in a theological grounding and questions of social responsibility regarding the diverse aspects of contemporary Italian Islam. In addition to imams, there is a need for people with Islamic training inside the community, and who are also able to use their expertise outside the community to deal with governmental institutions, professional associations, social solidarity organizations, school administrations, cultural mediation, hospitals, social work, ethnic communities, and other religions.

The outcome of the first two-year training course held at the Al-Wahid Mosque in Milan has been gathered in the book Inside the Mosque (Pallavicini, 2007). Besides continuing the course at the Al-Wahid Mosque - which was later developed as the Mizan center project -, in the following years a Master's programme in Islamic and interreligious training was jointly proposed by CO.RE.IS, the Philosophy Department of the University of Genoa, and the Interreligious Studies Academy (ISA) in Milan. This programme requested financial support from the National Funds for the Integration of Immigrants. Later, the Institut des Hautes Etudes Islamiques (IHEI) based in Lyon successfully adopted the same training course in France.

To stimulate the further integration of Muslims in Italy, CO.RE.IS has introduced another two-year programme on interreligious theology and intercultural education. Besides maintaining the programme reserved for imams, lessons and seminars focusing on social sciences, politics, teaching methods, and liberal arts studies have been added. The following themes are dealt with in this programme: 
- The history of Islamic civilization; East and West; tradition and modernity; orthodoxy and extremism.

- The Quran and the prophetic traditions: the sources of Islamic doctrine and the interpretations of the law schools.

- North-South exchanges and Euro-Mediterranean cooperation; conflict prevention and the peace process in the Middle East; Islam and jihad, the Islamic caliphate and Arab nationalism.

- Sacred science and Western culture; state and private schools in Italy; religious education and the history of religions; globalization and ghettoization.

- Avicenna and Averroes, Al-Ghazali and Ibn Arabi: metaphysics, theology, intellectuality, philosophy, and reason; comparisons with the philosophy of Kant, Hegel, and Nietzsche; comparison with the Christian thought of Saints Bernard, Thomas Aquinas, and Augustine; comparison with the works of Plato, Meister Eckhart, and Dante Alighieri.

- Dialogue between believers and non-believers; the oneness of God and the Abrahamic brotherhood; the encounter with Judaism and Christianity.

- Freedom of expression and the language of religious symbols; ostentation and religious freedom in European societies; human rights and islamophobia.

- The Italian constitution; immigration law and the European Union's policy on integration; democracy, secularism, and pluralism; the Italian state and religious pluralism; the Concordat with the Catholic Church and the system of agreements; the Council for Italian Islam.

The aim of this programme, which is not restricted to Muslims, is to present a balanced synthesis between the Western cultural perspective and the Islamic one. The programme culminates in a master's degree and is aimed at future managers of Islamic cultural centres in Europe, social workers and intercultural mediators, headmasters/-mistresses and school teachers at all levels, religious teachers, those involved in interreligious dialogue, trade union groups and representatives of the private sector, professionals and entrepreneurs working abroad, employees of the public administration engaged in international missions, journalists, and people interested in learning more about Italian Islam and its development as interpreted by European Muslim intellectuals. 


\section{Conclusion}

A series of agreements for cooperation with state universities and Christian theological institutes are currently being examined with the aim of developing academic synergies. It is hoped that this will produce research projects and experiences of interest from scientific, intercultural, interreligious, and international points of view. The new European citizenship cannot disregard the contribution of the sacred dimension and, in particular, that of the three Abrahamic monotheistic religions: Judaism, Christianity, and Islam. A thorough knowledge of religious values and the composition of the various revelations can enrich the common cultural heritage, become a vital element for fighting phenomena such as antisemitism and islamophobia, and help in conflict prevention and resolution. ${ }^{3}$ Because Muslims are a religious minority in Italy, CO.RE.IS finds it important to react, in a constructive manner, to the tendency towards adopting a sense of victimization, vindication, or provocation that characterizes some Muslims. CO.RE.IS believes that every spiritual, intellectual, and social form of expression of all qualified believers and honest citizens is an added value and a specific responsibility, and that it is not dependent on the number of representatives or on the number of days one has actually lived in Europe. ${ }^{4}$

\section{References}

Al-Farabi. 2008. L'armonia delle opinioni dei due sapienti il divino Platone e Aristotele. Pisa: Edizioni Plus.

Al-Ghazali. 2009. Le livre de la Science. Paris: Albouraq.

Al-Jawziyya Ibn Qayyim. 2004. Medicine of the Prophet, translated by Penelope Johnstone. Cambridge: The Islamic Texts Society.

As-Suyuti, Jalalu'd-Din Abdur-Rahman. 1994. Medicine of the Prophet. London: Ta Ha Publishers.

3 For interreligious dialogue in Islam, see Demiri, 2011; Ford, 20o6; Ghazi bin Muhammad bin Talal, 2011; ISESCO, 2012; Morrow, 2013; Nagl-Docekal and Kaltenbacher, 2008; Schneier and Shams, 2013; Turrini and Nicelli, 2013; Volf, 2010; and Weisse, 2009.

4 Many efforts have been made to outline the Islamic viewpoint and needs through concrete topics such as the role of women, health and welfare, or education and science (see Al-Farabi, 2008; Al-Ghazali, 2009; Al-Jawziyya, 2004; As-Suyuti, 1994; Aslan, 2009; Guiderdoni, 2013; Naseef, 1999; Pallavicini, 2010a, 2010b; Ridwan, 2006). 
Aslan, Ednan. 2009. Islamic Education in Europe. Wien: Böhlau Verlag.

Demiri, Lejla. 2011. A Common Word: Text and Reflections. Cambridge: Muslim Academic Trust.

Ford, Davis. 2006. The Promise of Scriptural Reasoning. Oxford: Blackwell Publishing. Ghazi bin Muhammad bin Talal. 2011. Love in the Holy Quran. Chicago: KAZI Publications.

Guiderdoni, Abd-al-Haqq. 2013. Perspectives islamiques sur la science moderne. Rabat: ISESCO.

ISESCO. 2012. Initiative of the Custodian of the Two Holy Mosques for Dialogue among Followers of Religions and Cultures. Rabat: ISESCO.

Morrow, John Andrew. 2013. The Covenants of the Prophet Muhammad with the Christians of the World. New York: Angelico Press/Sophia Perennis.

Nagl-Docekal, Herta and Wolfgang Kaltenbacher. 2008. Viele Religionen - eine Vernunft? Ein Disput zu Hegel. Wien: Böhlau Verlag / Berlin: Akademie Verlag.

Naseef, Fatima Umar. 1999. Women in Islam. London: Institute of Muslim Minority Affairs.

Pallavicini, Yahya. 2007. Dentro la moschea. Milano: BUR.

Pallavicini, Yahya. 2010a. The Image of Islam and of Muslims in Educational and Cultural Policies in Italy, France, Germany, UK and Spain. Rabat: ISESCO Publications.

Pallavicini, Yahya. 2010b. Opportunities and Challenges in the Economic Field: Issues and Conditions of Central and Eastern European Muslims. Kingdom of Saudi Arabia: OIC Organisation of Islamic Cooperation, Warsaw Symposium.

Ridwan, Zaynab. 2006. Le statut de la femme entre tradition et modernité. Paris: Albouraq.

Schneier, Marc and Ali Shams. 2013. Sons of Abraham. Boston: Beacon Press.

Turrini, Abd al-Sabur and Paolo Nicelli. 2013. Pluralità nell'unità. Milano: Centro Ambrosiano.

Volf, Miroslav. 2010. A Common Word: Muslims and Christians on Loving God and Neighbor. Cambridge: Eerdmans.

Weisse, Wolfram. 2009. Theologie im Plural: Eine akademische Herausforderung. Münster: Waxmann.

\section{About the author}

Yahya Sergio Yahe Pallavicini is imam of the Al-Wahid Mosque in Milan, vice-president of CO.RE.IS. (Comunità Religiosa Islamica Italiana, Italian Islamic Religious Community), and a specialist on Italian Islam. In 2007, he published Dentro la moschea [Inside the Mosque] (Bur, 2007) and continues to contribute to scholarship and public policy on Islam in Europe. 



\title{
21 Efforts to establish an imam-training programme in Finland
}

\author{
Tuomas Martikainen and Riitta Latvio
}

Hashas, Mohammed, Jan Jaap de Ruiter, and Niels Valdemar Vinding (eds), Imams in Western Europe: Developments, Transformations, and Institutional Challenges. Amsterdam: Amsterdam University Press, 2018 DOI: $10.5117 / 9789462983830 / \mathrm{CH} 21$

\begin{abstract}
This chapter describes the process of creating an imam-training programme in Finland. Finnish Muslims and Finnish Muslim NGOs took the initiative to establish imam-training programmes after conducting a survey of imams' religious and societal training needs. It turned out that the majority of imams in Finland have some Islamic training, but it is still very basic. The imams indicated that they would welcome a Finnish training programme that would enhance their ability to work in local mosque organizations. After the survey, a limited training programme has already started, aiming mainly at enhancing imams' leadership and societal skills.
\end{abstract}

Keywords: Islam in Finland, imam training programmes, Tatars, Church State relations, NGO's

\section{1 Introduction}

Finland is unique among the Nordic countries in being the home of a small Tatar Muslim community since the 1870 ; Muslims have only settled in numbers in Denmark, Norway, and Sweden since the late 196os. The situation in Finland has, however, changed since the beginning of the 1990s, when immigration began to grow rapidly, new Muslim communities began to emerge, and pan-European debates and policy developments concerning Islam also came onto the scene. Whereas the historical Tatar Muslim community had generally not relied on external help but had organized its affairs internally, there is now an increasing number of external influences being exerted on the new Muslim communities (Martikainen, 2013b). 
Muslims in Finland are at a crossroads, with different agendas being put forward by a variety of actors. Besides the issue of transnational Islamic movements, particularly in Europe, there are other key developments such as state interventions into Muslim affairs and interreligious activities with other religious traditions. As has been argued elsewhere (Martikainen, 2013b, 2014), two significant features of many of the processes concerning Islam and Muslims in Finland are the new set of actors that have only recently become interested in Islam-related topics and the changing organizational environment in which this is taking place. There is little in this new environment that can be understood through the historical relations between church and state; instead, a new constellation of religious, civil society, and state organizations and networks has emerged. In the current academic literature similar developments have been noted in other Western countries with Muslim communities (e.g., Laurence, 2012).

The aim of this chapter is to present an outline of the ongoing efforts to establish imam-training programmes in Finland. The chapter starts with a brief history and overview of Muslims in Finland. Then it presents the background, methodology, and results of a study conducted on imams in Finland in 2012-2013. This is followed by a description of developments until the spring of 2017. The chapter ends with a discussion of the possibilities of an eventual imam-training programme in the Finnish context.

\section{$2 \quad$ Muslims in Finland}

The history of Finland shares much with its neighbouring countries of Sweden and Russia. Finland was an eastern province of Sweden from the thirteenth century to 1809, when it was annexed into the Russian Empire as a Grand Duchy. Finland remained part of Russia until 1917, when it declared independence in the aftermath of the October Revolution. Whereas there are only individual mentions of encounters with Muslims during the Swedish period, this changed during the Russian era. The Russian Empire was a multi-ethnic and multi-religious state, and its subjects were often dispersed across different regions through military, administrative, and commercial activities. The first Muslims to arrive in Finland in any great numbers came as part of the military. While historical records are incomplete, it is known that there were military imams serving soldiers from at least the 183 os onwards. It is also likely that they occasionally permitted Muslim civilians to participate in their religious activities (Halén and Martikainen, 2016). 
The first records of more permanently settled Muslim civilians date from the 1870s, when Tatar Muslims from the Nizhni Novgorod region southeast of Moscow started to seek commercial opportunities in the Grand Duchy. The community gradually grew and, though numbering only in the hundreds, spread to several Finnish localities during the latter part of the nineteenth century with the help of an evolving railway network. Initially military imams also served the Tatar community, but in time they started to take care of their own religious activities. The October Revolution and Finland's subsequent independence from Russia in 1917, combined with the increasingly closed borders between Finland and Russia's successor Soviet Union from the 1920 s onwards, led to the end of Tatar immigration to the country. After Finland liberalized its religious policies in its new constitution (1919) and passed the Act of Religious Freedom (1922) that made it possible for any religion to apply for state recognition, the Tatar Muslim community applied for recognition and received it in 1925. Over the first half of the twentieth century the Tatars created an effective infrastructure for the support of their own identity and the transmission of their culture, the Islamic faith, and the Tatar language. Their imams came from either within their own ranks or abroad, particularly from Turkey and Tatarstan. Since the 1970s, and especially after the collapse of the Soviet Union in 1991, the Finnish Tatars have sought to revive their relationship with their ancestral roots (Halén and Martikainen, 2016). The main characteristics and developments of the Tatars have been well documented and there is a rich body of literature on them in both the Tatar and Finnish languages (Bedretdin, 2011).

Until the 1980s, the Tatars were the only Muslim group in Finland that had mosques and mosque associations. Arabs living in Finland as professionals, students, and the spouses of Finnish women founded the first non-Tatar Islamic society in 1986. The situation started to change quickly after the beginning of the 1990s, with the increase of immigration to Finland. The reasons for this increased immigration were mainly external to Finland, and were related to changes on the world political scene and post-Cold War migration flows. The main migration flow has been that of UNHCR-quota refugees and asylum seekers, and associated family reunifications. To a lesser degree, international students, marriage migrants, and professionals have also played a role in the growth of Muslims in Finland, as have conversions. Tatars, who were the dominant Muslim group until the 1980 , are today a small minority of some 600 individuals compared to the estimated 60,000-65,000 Muslims living in the country in the early 2010s (Pauha and Martikainen, 2014). 
Thus the majority of Muslims in Finland are first-generation migrants, often with a refugee background, who arrived during the 1990s and 200os, and increasingly their Finland-born children, the second generation. The first non-Tatar mosque community - the Islamic Society of Finland (Suomen Islamilainen Yhdyskunta) - was founded in 1986; today there is a nationwide network of some sixty mosque associations, and many other Islamic associations that cater for the religious needs of the Finnish Muslim population. The most notable representative association, the Islamic Council of Finland (Suomen Islamilainen Neuvosto), was founded in 2006 as an umbrella organization to represent a collective Muslim voice (Pauha and Martikainen, 2014).

The Finnish Muslim population is diverse in its ethnic composition. The largest group is Somalis, who numbered 16,000 in 2013; Arabs (mainly from Iraq), Kurds, Turks, Kosovo Albanians, Iranians, and Bosnians all have constituencies in the thousands. As with immigrants in general, the majority of Finland's Muslim population lives in the Helsinki metropolitan area and in a few larger cities. The population has a youthful demographic structure and higher than average fertility, which in combination with continuing immigration implies that their share of the total Finnish population will gradually grow. People of Muslim background constituted a little more than 1 per cent of the Finnish population of 5.5 million in 2013 (Pauha and Martikainen, 2014).

Issues related to the growing presence of Muslims in Finland have emerged in the national political arena in the 2010 s to a greater degree, as there has been new political mobilization against the rise in immigration and the related increase in cultural and religious diversity. In the parliamentary elections of 2011, several candidates known for having anti-Islamic views, particularly candidates from the ranks of the Perussuomalaiset (the Finns Party, also known as the 'True Finns'), were elected to the Finnish parliament. After the parliamentary elections of 2015, the Finns Party is also included in the coalition government. In the Nordic context, Islam is still a relatively minor political issue, but due to some Finnish Muslims having joined the ranks of Islamic State in the conflict in Syria it is becoming increasingly controversial (Pauha, 2015).

\section{The imam-training survey}

The Finnish civil society organization Kulttuuri-ja uskontofoorumi FOKUS (Forum for Culture and Religion, FOKUS), ${ }^{1}$ conducted a study of imams

1 FOKUS is an ecumenical civil society organization that supports and promotes peaceful dialogue between religions and cultures by providing information and creating open forums for 
in Finland from June 2012 to March 2013 in cooperation with two Muslim umbrella organizations, Visioforum and the Finnish Muslim Union. The results of the study were published as a report Imaamit Suomessa:Imaamikoulutusselvitys 2013 (Imams in Finland: Imam Training Report 2013) in June 2013 (Latvio, Mustonen, and Rantakari, 2013). The aim of the report was to assess the educational background of imams working in Finland and their needs for further training. The study was based on a questionnaire and personal interviews conducted with the chairpersons of mosque associations and imams in these associations. To provide a background to the public debate, the report also included information about the role of imams and their education in some Muslim and European countries. The report was the first stage of a project aiming to improve imams' vocational skills and functioning in Finnish society. As the report has been published only in Finnish and is therefore not accessible to international readers, the key content of the report is summarized in this chapter.

\subsection{Background}

The immigration of Muslims is a significant aspect of the growing religious diversity in Finland over the past three decades. Together with the increasing politicization of certain religious questions that are often, but not only, related to Islam, has made the Finnish government, public authorities, and other significant actors more attentive to religious questions (Martikainen, $2013 \mathrm{~b}$ ). The challenges posed by migrant religious groups have been seen in Finland in the light of both pan-European debates on religion and immigration and national experiences. This has led to the gradually increasing recognition of the particular needs of migrant religious communities. One particular initiative worthy of mention is the Dialogue for Integration: the Engaging Religious Communities (DIRECT) project, which was run by the Helsinki Regional Office of the International Organization for Migration (IOM), an intergovernmental body, in 2010-2011. The DIRECT project mapped out research on the role of religion in migrant integration; it also conducted brief seminars for religious leaders, and legitimated a religion-specific focus on immigrant integration. It was one of the several networks that brought 
together different actors in the field, such as academics, civil servants, and the representatives of religious organizations in Finland (Martikainen, 2013a). According to the DIRECT project report, religion may play a positive role in the integration of immigrants. Religious communities and societies guide and help immigrants in matters such as employment, education, civil rights, language training, the schooling of children, and family life. Counselling and guidance that is available immediately on arrival in the new home country may promote a sense of belonging and the assumption of an active role as a citizen. The recommendations of the report include recognizing migrant religious communities as integration facilitators by providing them with political and institutional visibility and offering them better resources for information-sharing, referral, and capacity-building services (IOM, 2011).

In addition to such external pressures, in the interviews conducted for the report many Finnish Muslims also expressed their concern about securing well-trained imams and other religious personnel who are also familiar with the Finnish societal circumstances and legislation. Most of the imams are self-taught and work in challenging multilingual and multicultural communities. They are often recent immigrants themselves with only limited knowledge of Finnish society and culture. Finnish Muslims, just like the members of other religious communities, aspire to a wide variety of highquality religious services that would enable them to deal with challenges arising in their social context. There have also been appeals in the media for imam-training programmes from political and religious leaders, who argue that a good command of the Finnish language and a working knowledge of the regulations of the surrounding society - in addition to those of one's own religious tradition - are also necessary from the point of view of integration and good ethnic relations. Moreover, as the state-sponsored training of elementary and secondary schoolteachers of Islam was already initiated by the University of Helsinki in 2007 (see Sakaranaho and Martikainen, 2015), having a publicly recognized imam-training programme in Finland also seemed plausible and possible.

The survey itself was the result of two seminars held in Helsinki in 2011 and 2012 during the United Nations World Interfaith Harmony Week. ${ }^{2}$ These seminars discussed the situation of Muslim communities in Finland and the role and education of imams in both the European and Finnish contexts. The need for a comprehensive survey among Finnish mosque associations was acknowledged during the second seminar, since there was no 
systematic information available on the educational background of Finnish imams or on their needs for supplementary training. After consultations with different organizations it was decided that FOKUS would undertake the study in cooperation with the Finnish Muslim Union and Visioforum. The project received financial support from the Anna Lindh Foundation ${ }^{3}$ and was supervised by a steering group. ${ }^{4}$ Riitta Latvio from FOKUS was commissioned to conduct the empirical study and draft the report.

The starting point of the project was to look into the need for an imamtraining programme in Finland as well as its various aspects and possible implementation. The emphasis was on charting the present situation and the needs and wants of mosque associations, and on how these requirements might be fulfilled even in the short term. In this task the first step was to gather information about the role of the imam in these associations, their responsibilities with regard to co-believers and society in general, and the educational background of the people who act as imams in present-day Finland. Another aim was to raise public awareness of what being an imam means in general and in Finland in particular. Finally, the project strove to initiate a discussion about training Muslim faith workers in Finland to not only improve their competence in answering the needs of their faith community, but also develop their communication resources and skills for engaging in dialogue with the surrounding society.

\subsection{The survey}

The main research questions in the imam survey were: How are imams trained elsewhere in Europe and in Muslim-majority countries? What kind of training do the imams who are active in Finland have, and where did they obtain it? Do they require more training, for example more in-depth

3 This was the Common Project Action 'Do We Need Imam Training in Finland?' (2012-2013) of the Finnish Anna Lindh Network.

4 The steering group was chaired by Ambassador Ilari Rantakari (Chairman of FOKUS and Finland's UNAOC Focal Point), with representatives from the Finnish Muslim associations Abdessalam Jardi (the Finnish Muslim Union) and Pia Jardi (Visioforum and the Islamic Council in Finland); two imams (Tariq al Hidaya Imam Walid Hammoud and Imam Ramil Belyaev from the Finnish Islamic Congregation); two experts on education, Professor Tuula Sakaranaho (University of Helsinki) and Pekka Iivonen (the Finnish National Board of Education); and the executive director of FOKUS, Mrs. Satu Mustonen. This steering group was responsible for informing the Muslim community about the survey and providing contact information for the associations. It also commented on the research plan, questionnaire, and interview questions, the seminar preparations, and the draft of the report as well as the list of consulted authorities, organizations, and scholars. 
theological study of Islam or more knowledge about Finnish culture, language, and society? If so, how could imam training be feasibly arranged in Finland? The study was carried out among the associations that have either registered as religious Muslim associations in Finland or have a mosque or prayer house at their disposal, around 60 in all in 2012.

The first stage of the project involved the development of a questionnaire that was sent to both the chairs of the mosque associations and their imams. The chairs were asked to provide background information about the association, such as its year of foundation, the size of its membership, and how many imams it had; what kind of training the imams had had in the past; and whether the association wanted to become involved in developing imam training in Finland. In subsequent interviews with the chairs of the Muslim organizations, the current practices of recruiting and educating imams were further surveyed, including the chairs' views about the kind of education that would best cater to the needs of their communities. The purpose was to gather views on the present situation and future needs, particularly about arranging basic or supplementary imam-training programmes in Finland. The questionnaire for imams comprised questions about the responsibilities and role of imams in Finnish Muslim societies, the current levels of education - both religious and secular - of the imams, their experience as imams both in Finland and elsewhere, their language skills in Finnish, their labour market status, the needs of the associations, and the views of the imams themselves about what kind of training would best serve them and their associations. Thirteen chairpersons answered the questionnaire and fifteen chairs were interviewed, representing in all nineteen different mosque associations as some chairs participated both in the questionnaire and interview. Twenty-two imams answered the questionnaire, representing nineteen different mosque associations. Some questionnaires were not answered in full. Information was obtained from twenty (i.e., one-third) of the Finnish mosque associations.

\subsection{Results of the survey}

Of the mosque associations that participated in the survey, four had an educated and experienced imam from the time of the association's foundation, but most (at least ten out of nineteen) mosque associations have a history of using self-taught imams. Additionally, mosque associations indicated a practice of calling trained visiting imams from Muslim countries for teaching, consultation, and to conduct ceremonies, especially during Ramadan. Five of the mosque associations reported that it had not been 
as much a question of choosing an imam as of persuading those with the greatest proficiency in the Arabic language and thorough knowledge of Islam to fill the role. Later on, two of these five mosque associations had been able to choose an imam with some education from among the youngsters who had gone to study abroad in Islamic countries.

Seven of the interviewed chairpersons made clear that education and knowledge of the Islamic sciences alone are not sufficient criteria for being elected as an imam in their community: the individual's personality, views, and conduct also matter. They preferred imams with strong morals and devotion to Islam and with moderate values, rather than either extremely conservative or liberal ones.

With regard to the required level of knowledge of Islam, the chairs prioritized a good knowledge of the Quran and Islamic law. The chairs commonly held that where Islamic and Finnish law were in conflict, imams should teach the members of the faith to live according to the regulations of the Finnish legal system.

Of the imams that participated in the survey, five had worked as an imam elsewhere before coming to Finland. Some had attended courses given by visiting imams and scholars in the Finnish mosques (six out of nineteen), but did not have a coherent religious training. Twelve imams claimed that they had the requisite educational training to work as an imam, but of those two stated that they had acquired that training by participating in lectures in their own mosque. Three answered that they did not have proper training, but had attended some courses offered by their mosque and seminars in Finland or abroad, or had taken correspondence courses. Hence most of the imams (ten out of nineteen) either did not have a coherent theological training or were self-taught. One third had an academic education in one field or another, and some had acquired this education in Finland.

Ten of the imams had lived and worked as an imam in Finland for over ten years. The majority (fourteen) had another occupation to live on; four were full-time students. All but one imam worked unpaid and irregular hours for the mosque - some for only a couple of hours, but most (thirteen) for over twenty hours per week. Twenty of the imams thought they would be able to find some free time to attend a training programme, but because of other commitments would not be able to engage in full-time study.

Only two imams expressed doubts about a possible Finnish imam-training programme, of whom one suspected that qualified teachers could not be found; the rest liked the idea. The most popular topics for possible supplementary training programmes were academic Islamic studies and Finnish law (74 per cent), followed by courses in Finnish history and society, family 
consultation, and leadership training (68 per cent). They also prioritized studies in Finnish and communication skills (63 per cent), for instance to be able to deliver a khuța (Friday sermon) in Finnish or to better represent their community in public. Nearly all (nineteen) asked for the courses to be organized by a tertiary education provider. It was suggested that concerns about the legitimacy of the training in the eyes of future generations could be resolved by using imported scholars, especially if Muslims themselves chose them. Three imams felt that the tasks performed by an imam towards his brethren should not be remunerated, because being an imam is not seen as a job, but as an act of devotion, religious duty, and service to God. However, two others emphasized that it should be a position in which it was possible to earn a living for oneself and one's family, and which would thus be a full-time appointment.

Of the interviewed chairpersons, all but two expressed a moderate measure of acceptance of the idea of organizing imam-training programmes in Finland. All of the chairs thought that they could participate in the development of a Finnish supplementary training programmes. At the same time, the majority held that the so-called Islamic sciences should also be studied, or even entirely acquired, abroad.

In conclusion, the results of the study show that the surveyed mosque associations would prefer fully trained and qualified imams, and they welcome the idea of educational programmes for imams in Finland. A functioning religious community needs good spiritual leaders, teachers, and counsellors. If the Muslim community is to preserve and continue its practices, there needs to be a sufficient number of people trained in Islamic doctrine, law, and tradition who are able to transmit these to the Muslim community and the generations to come. The surveyed mosque associations attached particular importance to this last aspect of the education. Further, the survey displayed nearly as much demand for training in Finnish language, society, culture, and law as training in Islamic subjects.

\subsection{Models for imam-training programmes}

The study also looked into existing imam-training programmes in Europe and some Muslim-majority countries and gathered experiences by networking with European experts. ${ }^{5}$ Examples from Egypt, Iran, Morocco, and Turkey

5 Networking with European experts included participation in an international evaluation seminar of the Dutch imam-training programme at the Inholland University of Applied Sciences in Amsterdam, as well as direct contacts with universities that provide imam training and with 
were briefly described, noting for instance that there are few educational programmes in Muslim countries dedicated to educating imams only; instead, the most commonly recommended forms of education for imams are Islamic schools and universities, which offer a wide range of Islamic studies. Of the students who graduate with a degree in Islamic studies, only a few end up serving as imams; others take up positions teaching Islam in private or public schools, work within government departments of religious affairs, or advance to become scholars or muftis. A deep knowledge of Islam and classical Arabic is a requirement for Islamic studies at the university level in Muslim countries. In several Muslim countries there are both state-owned and independent mosques, and the functions and requirements for imams at each kind of mosque can vary greatly. The state may specify the selection criteria for imams in the state mosques, while independent mosques can define their own criteria when recruiting an imam. In Turkey and Morocco, the state has developed specific programmes for educating imams (see Borrillo and Hashas, Part I).

Five European countries were chosen as examples of different approaches to providing imam training: state-organized multi-faith training for religious leaders in Norway; state-organized non-theological supplementary training for imams in Sweden and Germany; state-organized vocational and theological imam training in the Netherlands; and private imam training in Islamic seminars with accreditation in universities in the United Kingdom.

Norway. Instead of religion-specific programmes, Norway has opted for a multi-faith training programme for immigrant religious leaders with the aim of offering a more thorough knowledge of Norwegian society and improving their ability to function within it. The training programme is called Being a Religious Leader in Norwegian Society, ${ }^{6}$ and it was designed and launched in 2007 by the Faculty of Theology of the University of Oslo. Representatives of various faith communities, the Islamic Council, the Buddhist Association, the Baptist Association, the Roman Catholic Church, and the Council for

scholars who have worked on the topic. We wish to thank Mark Chalîl Bodenstein, Ron Geaves, Karin Klausing, Göran Larsson, Oddbjørn Leirvik, Johan Meulemann, Rimke van der Veer, and Kari Vitikainen for helpful comments and for providing research and other material on European imam training. Requests for cooperation with education providers were sent to those countries who are represented by embassies in Finland, i.e., Egypt, Jordan, Morocco, Saudi Arabia, and Tunisia, to gather information about imam training in Islamic or Muslim-majority countries. The countries included in the report are those that responded to this request. In addition, the imam training systems of Turkey and Iran were reported through the help of a colleague, Mr. Kari Vitikainen.

6 http://www.tf.uio.no/studier/evu/kurs/relleder/english. 
Religious and Life Stance Communities were directly involved in the planning process, at the end of which each faith community was granted a quota and asked to nominate candidates for the first round of the programme.

The training programme takes one-and-a-half years to complete and consists of three modules: (1) Religion, Norwegian legislation, and international human rights; (2) Moral and religious counselling; and (3) Values, religious plurality, and interreligious dialogue. Among the participants, the largest groups were Muslim leaders, most of them imams, and Christian clergy from different denominations. The Norwegian Islamic Council recruits the Muslim participants. The feedback from students has been positive. The Norwegian model is appealing because it treats all of the minority religions equally and as such does not involve the stigmatization of any single religious group through assignment of the training. It also includes many of the subjects that were requested by the Finnish imams in the survey, although it does not provide the required training in the Islamic sciences.

Sweden. In 2008-2009, the Swedish government commissioned an enquiry on the question of a government-supported training programme for imams (Larsson, 2009). The enquiry concluded that the Swedish state should not support a specific training programme for imams. The chief impediment was that the Swedish state should be confessionally neutral, and therefore a specific training programme should not be required for any single religious group. Furthermore, it was argued that a training programme targeted at imams only might signal that Muslims present a problem for Swedish society and need training more than other religious groups. Other reasons for turning down imam-training programmes arose from the results of the survey: imams were not asking for a specific programme for religious training, but instead mainly for education about tackling social issues and to acquire language skills. There were also misgivings about imams being able to agree on any one imam training programme that would be capable of uniting all branches of Islam (Larsson, 2014).

Consequently the Swedish government has not provided any theological training programme for imams, ${ }^{7}$ although they may avail themselves of already-existing government language training for immigrants. Additionally, folk high schools (colleges) in Sjövik and Kista have provided some supplementary training for imams. ${ }^{8}$ The Ibn Rushd Educational Association ${ }^{9}$

7 This, however, is no longer the case, since Sweden launched a state-funded one-year programme in Islamic theology and leadership in Kista Folk High School in the autumn of 2016.

8 http://www.sjovik.eu/ and http://kistafolkhogskola.se.

9 http://www.ibnrushd.se. 
also offers courses on Islam in its curriculum. Recently, the Swedish Commission for Government Support for Faith Communities has started short multi-faith leadership courses focusing on social studies, the history of religious communities in Sweden, family law, and youth studies. ${ }^{10}$ According to Göran Larsson, most of the Muslim leaders were content with the decision and considered a Swedish imam training programme undesirable (Larsson, 2014). In a personal communication with the author of this chapter, Larsson recommended that, should Swedish (and Finnish) Muslims like to set up a private institution for the training of their leaders, the training of priests in the Swedish free churches might present a viable organizational model. Implementation of that option is still quite a distant prospect, considering the size and economic resources of the Finnish Muslim community (see Larsson, Part I).

Germany. In Germany, Islam - unlike Christianity and Judaism - has not yet achieved the status of 'a public law corporation', which would allow for numerous benefits including the teaching of its theology in state-funded universities. The confessional teaching of religion is, however, a legally guaranteed right in Germany and training programmes for teachers of Islam have been instituted in many universities since 2000 onwards. In 2010, the University of Osnabrück started a supplementary training programme for imams and spiritual advisers that included studies in German language, society, history, politics, and law, as well as community pedagogy, immigration sociology, and vocational skills for faith workers. ${ }^{11}$ In 2010 and 2011, the German Ministry of Education chose four new universities to host a department or institute for Islamic theology: Münster/Osnabrück, Tübingen, Frankfurt/Giessen, and Nürnberg/Erlangen. It is hoped that these new forms of training will fulfil the training needs of German Muslims. The new theological programmes have been very successful, but imam training has still not been professionalized.

The Netherlands. In the Netherlands, where there is quite a large (5 per cent) Muslim minority, the government initiated an imam-training programme with the aim to train imams who can speak both Arabic and Dutch and can take part in interreligious dialogue, working as a bridge between the Muslim community and Dutch society as a whole (Boender, 2013). The Inholland Imam/Islamic Spiritual Worker Training Programme commenced in 2006 and was developed as a joint initiative of three partners:

10 http://www.sst.a.se/sstsuppdrag/kompetensutvecklingfortrossamfundsledare.4.4c4bo74714116 bocfa2gf6o.html.

11 http://www.islamische-theologie.uni-osnabrueck.de/studium/lehrprogramme.html. 
Inholland University of Applied Sciences, several mosque umbrella organizations (the Milli Görus 'National Vision' Turkish diaspora organization, the Netherlands Islamic Federation (NIF), The Islamic Centre Foundation in The Netherlands (SICN), the Union of Moroccan Muslim Organizations in the Netherlands (UMMON), and the World Islamic Mission (WIM)), and, in the background, the Ministry of Education, Culture and Science. The study programme contained the Islamic religious sciences such as the study of the Quran, hadith, and fiqh, units relating to contemporary Western and, in particular, Dutch society, religion and modern society, monotheistic religions and interreligious dialogue, multicultural society and diversity, and training in various professional skills such as communication skills and pastoral counselling. Students could choose between three graduation specializations: imam, Islamic spiritual worker, or Islamic pedagogical worker (Meuleman, 2012).

This programme faced challenges related to questions of legitimacy, imam training in a secular context, and the diversity of Dutch society. The most serious question concerned how to combine traditional Islamic sciences with a Western academic educational concept. The programme's adopted background model of Christian theological training was eventually questioned by both students and teachers. Some of the students were also not accustomed to reading and producing academic texts; in consequence, students who had expected confessional studies became demotivated and dropped out of the programme. It was also felt that a period of 3-4 years was not sufficient for learning traditional Islamic sciences as well as other subjects. The graduates had difficulties finding work: having been taught allegedly by the 'orientalists', mosque associations would not readily accept them, while Dutch social praxis demanded multi-religious workers or general spiritual workers only (Boender, 2013).

The international evaluators of the programme felt that partnership with Muslim organizations was not sufficient, and that Inholland University of Applied Sciences should prioritize certain subjects, outsource Islamic studies to Muslim organizations, and introduce branded lectures by respected Muslim scholars as visiting lecturers. For the better employability of the students, major and minor degrees (e.g., major in law and minor in Islamic studies) were also suggested. The programme stopped taking in new students after 2013. The experiences of the Dutch programme make it clear that the training of imams in a European context should not be based on pre-existing Christian models.

United Kingdom. Muslim faith leadership training in the United Kingdom is provided by more than thirty private Darul Uloom (a form of traditional 
Islamic school in India; see Ali, Part II) seminars and institutes, which follow a curriculum of manqūlāt ('traditional Islamic religious sciences') and $m a^{c} q u \bar{l} \bar{a} t$ ('rational sciences'). The degree usually also includes study abroad. These seminars have been criticized for being conservative and hindered by strategies of isolation, not being able to cope with the requirements of modern secular British society, and being split along ethnic and theological divisions. The study of theological and spiritual issues should be combined with courses on Islamic pastoral care and counselling and courses for contextualizing Islam in contemporary society (Geaves, 2008). However, many of the seminars are now engaging in partnerships with the British higher education system, leading to the accreditation of their qualifications. ${ }^{12}$ An interesting development has been the creation of British Muslim chaplaincy roles in public sector institutions such as hospitals, prisons, universities, and the armed forces, and accordingly the creation of chaplaincy-training programmes (Gilliat-Ray and Ali, 2013; see Ali, Part II).

In comparison with the United Kingdom, the Finnish Muslim community is small and on its own does not have sufficient economic resources to set up private institutes for imam-training programmes. The Muslim population in the United Kingdom is large and long established, but it is split along several ethnic and theological divisions, such as the Deobandi and Berelvi Muslims (both of South Asian origin). This also relates to one of the concerns voiced by Finnish Muslim leaders: they would like to avoid the splitting of the Finnish Muslim community along ethnic lines as a result of the creation of separate training institutes for different ethnic groups sponsored by their countries of origin.

To conclude: European imam training programmes, whether organized by the private or public sector, by the Muslim community itself, or as part of the national system of education, all face challenges of credibility and legitimacy from either within the Muslim community or the authorities - or both -, as well as a lack of career opportunities for the students; all of these factors indicate a lack of sustainability. Countries with old or well-established Muslim minorities, such as the United Kingdom, usually have in-community training, but this training often reflects the views of a particular ethnic or political group or religious sect, and is not accepted by the wider Muslim community. Many Muslim scholars still choose to educate themselves in

12 Examples: The Markfield Institute of Higher Education, Leicestershire, http://www.mihe. org.uk/mihe/index.php; The Muslim College, London, http://www.muslimcollege.ac.uk/; The Islamic College, London, http://www.islamic-college.ac.uk/ (Larsson, 2009). 
Muslim-majority countries, and many Muslim organizations continue to recruit their imams from those countries.

\section{$4 \quad$ Ongoing preparations for imam-training programmes in Finland}

After completion of the survey, a follow-up project involving the same partners looked into the different options available for developing an imamtraining programme in Finland. A comprehensive training programme leading to a degree was discussed with the representatives of universities in Finland, but that would be a long-term project requiring years of study and planning. A viable short-term option is the planning of supplementary training for imams and other Islamic faith workers. The approach of this follow-up project has been to plan and prepare for two separate supplementary training programmes: first, a non-denominational training programme concerning the Finnish and European legislative, cultural, and social context in relation to Muslim faith and culture; and second, religious training in the Islamic sciences and spiritual guidance.

The non-denominational component of the supplementary training would comprise a basic knowledge of Finnish history, its social service systems, the role and functioning of the civil society sector, and the Finnish way of life. Study modules would also include tuition in the Finnish language and communication skills, as well as mediation skills, religious counseling, and leadership training. Finnish legislation and international agreements and instruments would constitute a module of its own.

In planning the religious element of the supplementary training there is a need for a dialogue within the Muslim community to learn the common wishes and needs of its members. It is also important to take into account the diversity of the Muslim community. With the help of international experts in the Islamic sciences, this module's contents could be customized according to the varying needs of the participants. Some modules could also be implemented outside of Finland. Special attention would be given to women, both as part of the Muslim community and as spiritual workers in Muslim societies (i.e., as murshidāt, see Borrillo, Part I). The aim of the training would be to enable them to work as guides and educators in their respective communities.

Between 2013 and 2015, work was also done to identify possible education providers and other cooperating partners, including partnerships with universities in Muslim and European countries. These negotiations led to a collaboration with the Helsinki Diaconia College and the moulding of 
the non-denominational part of the supplementary imam training into a pilot leadership-training programme for Muslim faith workers that is open to both men and women. Resourcing has been a critical issue and has to some extent delayed the planning and preparations for this training programme, but its implementation got underway when some funding for the non-denominational part of the training was secured from the Finnish Ministry of Education in autumn 2015.

The pilot programme was carried out in the Helsinki Diaconia College during 2016. The goals for the training were to learn about the basic values on which Finnish society, culture, and legislation rest, to strengthen students' knowledge of Finnish cultural practices, and to acquire skills in social, religious, and cultural dialogue and civil society involvement and thus support religious leadership in the Finnish milieu. The nine-month course comprised short periods of tuition (altogether fifteen days) with independent work through web modules, facilitated by tutoring. The contents of the training corresponded with the plan described above, except for the Finnish language classes. Studying through the Finnish language was a challenge to some of the students, but their participation was facilitated by enhanced tutoring and allowing the occasional use of English and Arabic in course assignments. Of the twenty participants enrolled in the course - imams, chairpersons, and active members of mosque societies - ten finished the course, including three women. ${ }^{13}$

The feedback from the students that finished the course was positive; they felt that they could utilize the information and skills gained from the course in their work in the Muslim associations. Of the course contents, information about the structure and service systems of the Finnish society, project planning and other organizational activities, management, and conflict resolution were particularly appreciated. The course also strengthened the networks of future Muslim leaders and their involvement in Finnish society - new skills were appropriated, for example through the development of meeting techniques; and two project ideas formed during the course were turned into concrete partnerships and project applications. State funding from the Ministry of Education and Culture allowed the implementation of the pilot leadership-training programme, but the continuation of the course is an open question. In the project report, Helsinki Diaconia College

13 The course participants were quite heterogeneous in terms of their academic, IT, and language skills. Some participants also faced problems in getting time off from their work or family to attend the training. In the feedback, the participants requested more precise information during the course recruitment process on the nature, contents, and requirements for the course. Testing of the applicants was also suggested, as some would have benefited from a pre-course to update their skills. 
recommends turning the course into a multi-faith leadership-training programme in the future. Negotiations carried out with Morocco between 2013 and 2015 regarding the religious part of the proposed supplementary training have not born fruit.

\section{Discussion}

The study and planning process concerning initiating a programme of imam training in Finland clearly illustrates how a number of religious and civil society organizations have jointly created a platform for empowering Finnish Muslims through leadership education. Whereas the already well-established religious traditions and their various denominations, including the Tatar Muslims, have had effective structures of their own for the education and training of their religious leaders for a long time, the new Muslim communities in Finland do not have any such infrastructure to rely on. As the Finnish State, which otherwise finances and regulates many educational facilities in Finland, has not so far taken an active stance towards providing educational opportunities for Islamic education, there is a demand for other actors to fill the void.

The initiative has instead been taken up by an active civil society organization, FOKUS, which has fostered cooperation with selected Muslim organizations and individuals. A key problem has been finding the resources and a suitable format for the training. While the process is evolving rather slowly, FOKUS has nevertheless been able to conduct the preparatory work that is necessary for the eventual establishment of such a programme. FOKUS possesses a good understanding of how to effectively progress ideas in the context of an administrative environment that requires funding applications, networking, and long-term planning. It also has good societal networks, and its key individuals have valuable connections with the public administration that make the gradual development of their plan possible.

Without the support of FOKUS, or another organization with similar willingness to help, it would be difficult to find the right channels along which to proceed. Whereas the interests of the two different parties - Muslim associations and FOKUS - diverge to some extent, they share the common conviction that an imam-training programme would be beneficial for the Muslim community and for Finnish society at large. It remains to be seen how this initiative will continue to unfold, as it has to some extent been eclipsed by the plans for a grand mosque in Helsinki, but it is certain that in 
the process new networks and alliances will be created that may eventually be used in other, as yet unforeseen contexts.

\section{References}

Bedretdin, Kadriye, ed. 2011. Tugan tel: Kirjoituksia Suomen tataareista. Helsinki: Suomen Itämainen Seura.

Boender, Welmoet. 2013. 'Embedding Islam in the "Moral Covenants" of European States: The Case of a State-Funded Imam Training in the Netherlands'.Journal of Muslims in Europe, 2: 227-247.

Geaves, Ron. 2008. 'Drawing on the Past to Transform the Present: Contemporary Challenges for Training and Preparing British Imams'. Journal of Muslim Minority Affairs, 28(1): 99-112.

Gilliat-Ray, Sophie and Mansur Ali. 2013. Understanding Muslim Chaplaincy. Farnham, Ashgate.

Halén, Harry and Tuomas Martikainen. 2016. 'Finland'. In Muslim Tatar Minorities in the Baltic Sea Region, edited by Ingvar Svanberg and David Westerlund, 86-104. Leiden: Brill.

IOM (International Organization for Migration). 2011. 'Dialogue for Integration: Engaging Religious Communities'. Discussion Paper. International Organization for Migration Regional Office for the Nordic and Baltic States and the European Neighbourhood Countries.

Larsson, Göran. 2009. Staten och imamerna: Religion, integration, autonomi. Stockholm: Statens offentliga utredningar.

Larsson, Göran. 2014. 'The State and the Imams: Summary of a Government Report on Training Programmes for Imams in Sweden'. Tidsskrift for Islamforskning, The Nordic Welfare State, 8(1): 302-313.

Latvio, Riitta, Satu Mustonen, and Ilari Rantakari, eds. 2013. Imaamit Suomessa: Imaamikoulutusselvitys 2013. Helsinki: Kulttuuri- ja uskontofoorumi FOKUS.

Laurence, Jonathan. 2012. The Emancipation of Europe's Muslims: The State's Role in Minority Integration. Princeton: Princeton University Press.

Martikainen, Tuomas. 2013a. 'Multilevel and Pluricentric Network Governance of Religion'. In Religion in the Neoliberal Age: Political Economy and Modes of Governance, edited by Tuomas Martikainen and François Gauthier, 129-142. Farnham: Ashgate.

Martikainen, Tuomas. 2013b. 'Uskonnon hallinta ja turvallistaminen valtiollisena toimintana'. In Islam, hallinta ja turvallisuus, edited by Tuomas Martikainen and Marja Tiilikainen, 253-277. Turku: Eetos. 
Martikainen, Tuomas. 2014. 'Muslim Immigrants, Public Religion and Developments Towards a Post-Secular Finnish Welfare State'. Tidsskrift for Islamforskning, 8: 78-105.

Meuleman, Johan. 2012. 'Educating for an Old Profession in a New Context: The Imam Training Programme of Inholland University, the Netherlands'. In The Training of Imams and Teachers for Islamic Education in Europe, edited by Ednan Asian and Zsófia Windisch, 223-239. Frankfurt am Main: Peter Lang.

Pauha, Teemu. 2015. 'Finland'. In Yearbook of Muslims in Europe: Volume 7, edited by Oliver Scharbrodt, Samim Akgönül, Ahmet Alibašić, Jørgen Nielsen, and Egdūnas Račius, 209-225. Leiden: Brill.

Pauha, Teemu and Tuomas Martikainen. 2014. 'Finland'. In Yearbook of Muslims in Europe: Volume 6, edited by Jørgen Nielsen, Samim Akgönül, Ahmet Alibašić, and Egdūnas Račius, 218-228. Leiden: Brill.

Sakaranaho, Tuula and Tuomas Martikainen. 2015. 'The Governance of Islam in Finland and Ireland'. Journal of Religion in Europe, 8: 7-30.

\section{About the authors}

Tuomas Martikainen, Ph.D., is the Director of the Migration Institute of Finland. His areas of expertise include migration, integration, and religious organizations in Finland. He is the author of Religion, Migration, Settlement: Reflections on Post-199o Immigration to Finland (Brill, 2013).

Riitta Latvio, M.A., is a Doctoral Candidate in the Study of Religions at the University of Helsinki. She is interested in interreligious encounters and the interface between medieval law and religion. She has conducted a study entitled 'Imaamit Suomessa: Imaamikoulutusselvitys 2013' (Imams in Finland: Imam training survey 2013). 


\section{Index}

abortion 95, 212, 329

Abu Hanifa (699-767) 43-44

acculturation $27,103,152,255,264,273,277$ passim

activism 24, 34, 67-68, 112, 116, 136, 149

aesthetics 63,66

aggiornamento 101

ahkam al-islam 41, 43; see also Islamic rules

Al-Ghazali (1058-1111) 318, 407-408

Al-Qaeda 87, 172, 203

al-Azhar University 32, 83, 112, 126-127, 133, 174, $323,35^{6}$

Albania 386, 400, 414

Algeria 70, 76-77, 92, 145, 150, 152-53, 225, 256, $258,260,267-268,273,351,400$

allegorical meaning 109

apologetic 27, 125, 128

aqida 126-127, 138

Arabic 20, 37, 84, 89, 106, 117, 126, 186, 188-189, 191, 196-197, 204, 207, 214-215, 248, 270, 280, $283,300,314,316-317,355,386,391,403,419$, $421,423,427$

asabiyya 46

assimilation 172, 199, 301, 371

Association of Italian Muslims 372

atheist 172-173, 344

audience $25,55,62-63,113-115,160,165,167-168$, $178-180,185,187,189,191-192,194,197$, 199-201, 216, 260, 283

authenticity 55, 113, 185, 193, 197

authority

bureaucratic - 111

cultural - 168, 179

delegated $-241-242$

divine -35

ecclesiastical $-73,363$

epistemic - 30, 231 passim

female -185 ff., 205 passim

independent -80

institutional $-25,231$ passim

intellectual -112

Islamic $-32,51$ ff., $70,82,86,88,115,143$, 185 ff., $237,243,382$

immigration -12

Jewish -265

legal - 72, 93, 244, 259

legitimate - 20, 149, 236, 251-252

local $-54,83$

normative -57

moral -318

municipal - 151

political - 12, 79-80, 85, 89-9o, 219

public - 110, 117, 156, 340, 344-345, 349, 356, $363,371-372,415$ religious - 11- $13,19,21,25-34,51,54-59,61-64$, 70-71, 76, 79-83, 86-88, 90-91, 93, 95-97, 101, 112-116, 147, 154, 160, 165, 169, 185-187, 189-192, 200, 205ff., 236, 255, 281, 309, $320,332,356,360,363,367,381-382$, 384,388

scholarly -21

state $-83,92-94,143,145,15^{2}, 154-155,325$, $364,368,371,391$

traditional -319

authorization $93,116,236,353,367$

autonomous $32,82,147,188,248,259,272$,

$340-342,344-345,349,35^{2-353,} 385$

autonomy $76,114,139,217,285,345,36$ o, $366-368,382,385$

Badawi, Zaki (1922-2006) 108, 246

bank 40, 108, 271

banlieu 98, 153, 155, 162, 274

Barelwi 316, 326, 330

Belgium 13, 73, 87, 113, 118, 245, 247, 354, 382

bilateral 24, 96, 238-239, 245, 247, 36o, 362-364, 370-372

bishop $72-73,76,78,342,363$

Bordeaux 111, 256, 261, 264, 277-28o, 284-287, 290-293

brokers 63

buddhist 319n, 349, 363-364, 374, 421

Bukhari, also as Bokhari 41, 45, 47, 82, 309

burqa 194, 256, 265

caliph 12, 20, 81, 202

caliphate $81-82,176,187,198,200,282-283,355$, $374,378,407$

Cambridge Muslim College 31, 301, 315, 319, 321, 326-327, 330, 333-334

capital

cultural -105

educational $-15^{0}$

religious $-70,72,74,76-77,146,150,212$

symbolic -113

Catalonia 28, 186-188, 200, 203, 337, 351, 354

Catholic 13-14, 26, 32, 6o, 69, 71-78, 110, 113, 115, 119, 271, 274, 337-353, 359-364, 370, 388, 407, 421

Catholic Church 26, 32, 69, 71-75, 78, 337-341, $344-346,348,350,359-364,407,421$

Catholic, non- $72,344,359,364$

Catholicism 71-72, 76, 110, 274, 341, 350-351, $359-360,362,364$

chaplain 21, 23, 31, 92, 110, 236-238, 243, 245-246, $25^{0-252,} 295^{f f ., ~ 324, ~ 328, ~ 332, ~ 346, ~ 350, ~ 353, ~}$ 388

chaplaincy 31, 231-232, 236-238, 246, 252, 271, $295 \mathrm{ff}, 324,332,346,355,425,429$ 
charisma $61,91,258,281,385$

civilization $218-219,288-289,307,318,403,407$, 415

cleric $55,72,76,83,145,149,15^{2-153}, 159-60,169$, $260,278-280$

cognitive $51,60,123,187,196,241$

collaboration $21,32,356,370-371,402,426$

communal networks $5^{8}$

community leadership 144, 257, 331-332, 381

communitarianism 272

Comunita Religiosa Islamica Italiana, also as

CO.RE.IS 32, 366, 372, 393, 399ff.

congregational prayer 143, 328, 401

Conseil Français du Culte Musulman (CFCM) $70,148,154,259,278$

constitution 40, 53, 76, 101, 151, 155, 208, 239,

286, 337-338, 340-349, 359-362, 369-374,

$400,407,413$

- of France 76

- of Italy $359,361,369-374,407$

- of Morocco 207

- of Spain 338, 340-349

Contact Organ of Muslims and Government

(CMO) 166, 174-175, 177-179

cosmology 321

counsel, also as counselling 23, 31, 102, 104-105,

$117,157,215,238,243,295,300,310,315$,

$326-328,332,35^{2-}-353,416,420,422,424-426$

courts $64,236,303,344$

creed $27,89,93,107,110,112,125-127,135,340$,

$342,349,367,373$

criminal $42,86,286,343,353$

crisis $79-80,109,258,266,301,307,317,336,385$

crisis of identity 266

culturalization 59,65

culture $24,35-37,59,65-67,70,74,83,97,103$, $107,111,118-119,140,146,150,152,157,161-162$, $173,182,187,192,202,220,225,227,249,252$, 275-276, 280, 283, 285-286, 288-289, 299,

$301,307,314,327,354-355,368,371,373-374$,

$397,400,404,407,409,413-414,416,418,420$,

424, 426-427

Arab -285

contemporary -285

European - 103, 111

Islamic $-150,354,368$

migrant -59

Muslim - 59, 173, 426

organizational - 74

curriculum 31, 113-114, 121, 123, 133, 296, 298-299,

$315,322-324,326,330,33^{2-}-333,371,423,425$; see also syllabus

dar al-Adl (ar.: Land of Justice) 39, 41, 43, 46-47 dar al-Harb (ar.: Land of War) 39, 43-44, 47, 267 dar al-Islam (ar.: Land of Islam) 25, 39-47, 267 Dars-i Nizami 31, 296, 298-299, 308, 322, 326,
Darul Uloom 31, 43-44, 246, 295-296, 298-299, 304-306, 308-309, 311, 315-317, 322-334, 424

da'wa (ar.: proselytizing) 28, 180, 191, 193, 197, 200; see also proselytism

debate $22,28,30,37,43,5^{2}, 5^{8}, 63,66,99,82$, 102-103, 108-109, 121-123, 126, 133-134, 137, $166-168,170,172,174-176,179-180,183,185$, 205-206, 218, 220, 222, 224-225, 227, 233, 255-256, 26o-262, 271, 283, 290, 316-317, 356, $374,389,400,402,411,415$

decline $115,284,315,317-321,323,325,327,329$, 331, 333-335

democracy $24,36,65,102,117,125,139,172-173$, $175,181,222,255,337,346,398-399,407$

Denmark 37, 66, 245, 249, 252-254, 342, 411

Deobandi 312, 315-316, 321-324, 326, 330, 335, 382,425

diaspora 26, 29, 52, 66, 69-78, 85-86, 99, 181, 239, $296,317,397,424$

dictator 341

discourse 11, 24-26, 29-30, 35, 37, 40, 59, 66, 80, 86, 90, 94, 96, 101-103, 105-106, 108, 146-147,

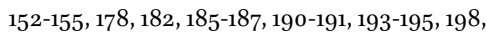
201, 205-210, 212-223, 227-228, 255-257, 260, $268,273,277-278,282,284,286,288,318$, 320, 329, 335

discrimination $171,176,178,214,217,262,270$, $344,362,371,373$

disenfranchised 153,317

diversity $65-66,77,82,103,118,122,136,238,260$, $323,370,397-398,401,414-415,424,426$

divorce 23, 33, 40, 93-94, 107, 211-212, 405

Diyanet (Turkish Directorate of Religious Affiars) 13-14, 52-53, 74, 111, 133, 247, 382, 396 doctrine $58,126,191,208,287,382,386,389,401$, $403-404,406-407,420$

double-speak 178

economic $25,59-60,85,91-92,105,113,168,201$, 211, 258, 280-281, 284-285, 301-302, 345-346, $35^{\circ}, 392,409,423,425$

economics 111, 211, 214, 247

education 14, 22-23, 27, 29-31, 34, 36, 72-73, 78, 84-85, 91-92, 97, 99, 106, 121-122, 127-128, 130-134, 136-139, 147, 167, 186, 197, 221, 227, 236-237, 240, 245, 248-250, 258, 279, 297-298, $303,306,311,313-318,320-323,326-328$, 330-332, 334-337, 350-354, 371, 381-382, 387, $389,397,400,403,405-409,415-428,430$

Egypt $59,83,113,116,126,133,252,262,325,354$, $385,420-421$

emancipation $66,78,98,166,218-220,222,226$, 429

entrepreneur 59, 63, 407

equality $29,58,86,95-96,125,154,175,205^{-206}$, 211, 213-214, 216-217, 220-223, 228, 247, 273, $304,307,338,342,344-345$ 
European Council of Moroccan Ulama (CEOM) 88,97

evangelical $66,348,363$

exegesis 215,248

expectation 14-15, 103, 105-107, 109, 115, 117, 123, 129-130, 133, 16o, 166-167, 236-237, 251, 26o, $286,295,300,324-325,330,404$

experimentation 104

Facebook 174-175, 185-187, 189-192, 194-197, 199-200, 202, 204, 257, 272

family reunion 58,111

fanaticism 263,288

fatwa 44, 65, 80, 89, 94, 108, 140, 185, 190, 200-202, 209, 281-282, 287, 291-292, 300, 329, 384 ; see also mufti

feminism 202, 206, 223-228

fertility 414

Finland 29, 32, 245, 247, 411-421, 423, 425-430

Finnish Muslim Union 415, 417

figh 39, 47-48, 64-65; see also Islamic law

First World War 28, 145, $15^{1}$

foreign labour 104

Forum for Culture and Religion 414

Foucauldian 55, 208

Foucault, Michel (1926-1984) 208, 219, 225

France 22, 24, 27-30, 36, 64, 70, 73, 75-78, 86-87, 91-93, 98-99, 108, 118, 143-155, 157-163, 217, 219-220, 226, 245, 248, 255-281, 285-286, 288, 290-293, 313, 354, 374, 377, 382-383, 396-397, 406, 409

freedom $22,25,30,36-37,39,42-45,47,53,5^{8}$, $86,97,146,155^{-15} 6,167,170-172,178,181,183$, 217-218, 252, 306, 337-340, 342-350, 356, 361, $372,400,407,413$ constitutional -53

- of religion 53,156

- of speech 172

- to practice $25,44-45$

religious - 22, 30, 36-37, 58, 97, 181, 337-340, $342-343,346-350,35^{6}, 361,372,400$, 407,413

Friday prayer $45,99,366,390,399,403$; see also khutba; sermon

Front National 262

gay rights 172

gender 29, 95, 124, 129, 134-135, 139-140, 186 , 191-192, 202, 205-207, 211-225, 227-228, 250, $301,304,308,327,331,333,344,371$

generations $25,27,73,75,103,105,177,188,190$, $239,300,324,395,405,420$

Germany 13-14, 22, 36-37, 66, 68, 70, 76, 121, 130, $183,217,219-220,224,226,231,233,238-239$, $245,253-254,313,382,409,421,423$

ghettoization 108, 301, 407

global 64-65, 88, 110, 112, 138-140, 185, 232, 244, $253,286,319$

globalization $19,34-35,51,54,61,66,362,407$ government $13-14,23-24,30,32,34,52-53$, $58-59,64,76,85-86,98,110,130-131,139,143$, 152-16o, 166-167, 171-174, 177-178, 216, 218, $297,314,319,324,340-342,347-348,351,353$, 359-362, 364, 372-373, 399, 404, 414-415, $421-423,429$

governmentality 205, 208, 219-220, 222

hadith $81-82,84,133,195-197,309,312,322,355$, 424

halal 392

Hassan al-Banna (19o6-1949) 282-283

headscarf 108, 218, 225, 340; see also veil

heritage $35,59,78,178,241,317,320,351,400$, $403,405,408$

hermeneutics 114, 118, 124

hierarchical 70, 72, 158, 284, 330, 364

hierarchy 19, 75-76, 90, 110, 149, 156, 305, 309-310, 318, 330, 334, 343

hijra (ar.: migration) 28, 198-200

Holy Ghost 128

Holy See 337, 346, 350, 362; see also Pope

hospital 23, 71, 92, 207, 215, 236, 242, 245-246, $295,303,305-306,311,313,327-328,332,349$, $355,383,388,390,392,405-406,425$

human rights 206, 214, 218, 247, 301, 343, 357, $404,407,422$

Ibn Sina (980-1037) 318

Ibn Taymiyyah (1263-1328) 41, 45-46, 48, 285

identity 30, 32-33, 77-78, 85, 89, 93, 97, 101, 103$109,114,144,155,173-174,187,191,202-203$, 217, 221-222, 224-225, 240-241, 255-257, 260, 262-268, 299, 301, 310, 318, 335, 340, 344, $360-361,370,395-396,400,403,405,413$

ideology $37,56,115,124,150,171,173,183,185,187$, $200,338,340,385$

iftar 271

i-imam 185-186, 189-19o, 195, 199-200

i-khutba 185-186, 190, 200

imam passim

ambassador -245

bad $-138,297,312$

civil servant -150

consular - 28, 92, 158

Francophone -155

French - 28, 79, 91, 105, 143-144, 149, 155, 158, 256,277

good - 28, 92, 138, 297, 312

hate -166

independent - 245, 248-249, 251

isolated - 146-148

Italian - 32, 381, 384

Moroccan $-79,87,145$

paid $-149-150$

seasonal -387

self-taught $-245,418$

super -36

surveillance of -s 152-153 
traditional $-63,174,315$

training of $-\mathrm{s} 35-37,88,97,101,159,181$, 296-297, 370, 376, 399, 401, 403, 405, 407, $409,424,430$; see also education vocational -105

youth -178

imama 248

imamate 19-20, 25-26, 30-31, 33-34, 64, 79-82, $91,95-96,144,152,155,160,186,193,278-279$, $313,381,383,397$

imamship 31, 295-297, 299-301, 303, 305, 307, $309,311,313$

immigrant 13-14, 22, 36, 52, 58, 66-67, 73-74, $77-78,85,103,110-112,116,144-148,150$, 152-153, 162, 174, 218, 256-258, 262-263, 271, $346,351,367,369,395,399-402,404,406$, 414-416, 421-422, 430

immigration policy 148,258

imperialism 262

information technology 111

innovation $23,54,56,124,198,284,287,300,318$, 333-334

institutionalization $12,26,28-32,52-54,75,144$, $154,165,167,219,222,238,242,244-245,257$, $260,277-278,373,381,384,392$

insurance 40

integration $14,22,24-25,27,33,48,57-58,65-66$, $77-78,80,97-98,103-105,134,138-140,15^{2-}$ 153, 16o, 166-167, 170-172, 177, 179-180, 218-219, 239-241, 248, 252, 255, 264, 273, 290-291, 297, $312,317,337,346,367,370-371,373,401-402$, $404,406-407,415-416,429-430$

intergenerational 104

interpretation $19,25-27,42,57,77,83,90-91,104$, $113,115,125,127,134-136,138,162,173,176,187$, 192, 196-197, 203, 207, 213, 223, 227, 239-240, $246,273,282,313,319,328,368,391,400,407$ interreligious dialogue 14, 32, 248, 371, 387, 391, 407-408, 422-424

interview $48,91,144,149,175-176,179,187,200$, 210-211, 215-217, 221, 231-233, 238, 244-248, 256-257, 260-262, 279-281, 284-287, 290-292, 303-304, 315, 324, 331-332, 415-418

Iran 12, 59, 170-171, 227, 414, 420-421

Iraq 97, 170, 176, 186-187, 192, 246, 400, 414

ISIS (Islamic State in Iraq and Syria) 203

Islam passim

crisis of $-112,336$

European - 22, 34, 36-37, 40, 6o, 71, 76, 96, $98,100-103,110,112-113,117,389,398$

Everyday $-5^{6}$

liberal -154

moderate $-87,90,165,214$

normative $-49,321$

political - 21, 85, 144, 149-150, 152, 162, 292

Islamic passim

- criminal law 41

- epistemology 104
- law 39-45, 47-49, 64, 98-99, 108, 138, 205, $207,215,224,244,248,253,260,264,282$, 300, 396, 419

- leadership 23, 43, 46, 63, 191-192, 384

- obligation $25^{6}$

- organization $31-32,59-60,78,111,127,258$, $260,279,354,362,367-373,389,392,394$, 399,404

- prayer 149, $35^{2}$

- Relief Worldwide 271

- rules 39,41

- salvation goods 147,149

- seminary $296,316,323,328$

- sources 40, 51, 167, 173, 193, 207, 240, 283; see also Islamic sources

- State $28,41,83,86-87,172,176,185,187-189$, 192, 198, 200-202, 206, 239, 271-272, 414

- studies 19, 30-31, 34, 37, 68, 77, 100, 121, 127, 129, 139, 149, 183, 191, 209-210, 231, 236, $246,248,297,314-315,317,327,332,334$, $354,356,419,421,424$

- threat 260

Islamism 154, 158, 292

Islamization 59,323

islamophobia $170,182,223,272,278,312$, 407-408

\section{jellaba 174}

Jesus Christ 128

jihad 140, 162, 175-176, 185-186, 189-19o, 193,

195-196, 198-204, 206, 228, 266-267, 297, 407 jihadists $28,87,172,176,187,192,202-204$

Judaism 14, 69, 284, 407-408, 423

justice $25,35,39,41-43,46-47,86,90,95,125$, 134-136, 139, 206, 214, 216, 247, 274-276, 339, $343,347-349,351,354-355$

Khomeini, Ruhollah (1902-1989) 12, 171

khutba 66, 185-186, 190, 200, 397; see also Friday prayer

Kosovo 414

kufr 43

Kuwait 174,178

labour $52,58,73,104,134,172,178,206,212,221$, $259,307,418$

labour immigration 52,73

laïcité 143 , 152 , 154-158, 160-161, 262, 370, 374, 376,378

land of Islam see dar al-Islam

land of justice see dar al-Adl

land of war see dar al-Harb

landscape $25,51-54,57-58,60-61,63-64,75,103$, $107,114,261,279,288,321,394$

Lateran 359,362

leftism 146 
legitimacy $24,28,30,34,54,56,61,85,87,90$, $110,112-114,125,147,160,185,191,193,196$, 208, 238, 246, 251, 257-258, 265, 273, 281, 287, $326-327,342,389,420,424-425$

liberal society 19, 29, 80, 91, 93-95, 169

liminality 295-296, 307-309, 311, 314

literacy 327

literature 21, 39-40, 56, 80, 109, 114, 168, 181, 232, $318-319,321,333,412-413$

madhhab 21, 27, 40, 43, 83, 89-90, 95, 133, 208, 244,321

madrasa $85,97,99,112,313,335$

majority $12,19,40,42,44-45,47,52-53,58,62$, 69-70, 72, 77, 85, 93-94, 125, 132-133, 144, 146-148, 159, 199, 207, 212, 224-225, 237, 239, $267,288,324,327-328,361,367,371,382$, $386-388,390,400,411,414,417,419-421,426$

Maliki 9o, 208, 279

marginalization 404

Markfield Institute of Higher Education (MIHE) 425

marriage 23, 33, 40, 84, 88, 93, 107-108, 111, 211, $238,300,328,349,363-365,371,405,413$

martyrdom 195

Mecca 44, 47, 52, 262

media $13,15,23,25,36,54,57,60-63,65-67,86$, 93, 96-97, 102, 107, 111, 113, 141, 155, 166-168, $175,178,182,187,190,199,201,218,248,250$, $257,260,263,265,267,272,280,300,308$, $320,324-325,387,390,393,416$

mass media $54,60-62$

Medina 127, 133, 335

memory 299, 318, 322, 341, 400

Messenger 126-127, 193

method 77, 102, 115, 123, 133, 139-141, 144, 159, 192, $213,311,322-323,333,406$

Methodist 73

military service 40,346

minbar $185,191,195,201$

missionary $73,75,158,267,321-322$

mobilization 146, 148, 151, 199, 273, 414

modernization 54,61

monarchy 40, 87, 90, 207-208, 216

monotheistic 213, 408, 424

Mormon 73, 349

Morocco 26, 29, 70, 75, 79, 83-84, 87-90, 97, 116, 150, 174, 188, 203, 205-211, 214-216, 221-228, 247, 256, 264, 267-268, 278-279, 282, 293, 351, $354,400,420-421,428$

mosque passim

British -s 318, 328

French -s 143, 159, 255, 257, 260, 266

Spanish -s 188, 201

muezzin 150

mufti $14,65,80,83,113,126,140,247,260,287$, 314, 329, 384, 421; see also fatwa
Muhammad 20-21, 47-48, 66, 97, 99, 126, 190-191, 196, 200, 207, 209, 225, 227, 236, 245, 248, 252, 262, 271, 283, 286, 292, 298-299, 312, 314, 320, 336, 408-409; see also Prophet

multi-religious state 412

multicultural $33,66,85,93,205,218,220,222$, $225,232,244,416,424$

murshid 110, 388

Muslim passim

Alevi -s 173

European -s 13, 24-25, 36-37, 48, 86, 103, 107-109, 117, 119, 192, 195, 218, 254, 312, $356,407,409$

- Brotherhood 150, 280-283, 286, 290, 316

- civil society 318-319, 324, 326, 330-331

- ruler $41,43,318$

- World League 74, 111, 259

non $-39-40,44,48,57,63,103-104,108,132$, $145,151,166,173,176-177,239,260,264$, $267,271,273,278,280,286,311,328,331$, 393

Tatar $-\mathrm{s} 411,413,428$

Turkish -s 52-53, 75

young -s 61-62, 65, 112-113, 132, 170, 174-176, 178-179, 192, 202, 260, 270, 284, 300-301, 312,389

mysticism 115

nationalism $83,238,263,407$

neo-fundamentalism 263,266

Netherlands 13, 22, 28-29, 31, 37, 52, 65-66, 68, 70, $127,130,138,165-167,170-176,180-183,202,217$, $219,225,355,382,396,421,423-424,429-430$ network $13,23,28,58,60,75,77,111,151,158,190$, 192, 200-201, 203, 218, 224, 227, 233, 238-239, $241,245,257,259,265,272,327,333,412,415$, 427-429

neutrality $26,37,96,156,341-342,344$

NGO 112, 350, 411

nomocracy 207

non-confessional state $341-342,345-346$

Norway 219, 411, 421

nuncio 74

October revolution 412-413

organization $13,19,21,23,30-32,5^{2-53}, 5^{8-61}, 63$, $66,74,78,81,85,89,110-111,113,116,126-127$, 130, 149-150, 154, 156, 177, 189, 207, 212, 218-219, 236, 238-239, 241-242, 245, 247, 249, 251, 258, 26o, 264, 268, 271, 278-281, 283, 296-297, 339, $344,348-349,351,354-355,359-360,362,364$, 366-373, 383-386, 389-395, 399, 402, 404-406, 411-412, 414-418, 424, 426, 428-430

orphanage 215

orthodox $62,173-174,213,343,349,363,407$

Ottoman Empire 69, 71, 126, 320, 335

Oubrou, Tareq (1959-) 30, 94, 102, 105, 108, 111, $118,135,138,245,248,256,264-267,270$, $274-275,277-293$ 
parliament $36,167,172,207,341-342,346-348$, $35^{\circ}, 360-361,370,383,396,414$

Party for Freedom, Netherlands 37, 167, 170-171, 178,183

pastoral $14,31,236-237,247,278,287,296-297$, $302,304,310,312-313,315,324,326,332,386$, 424-425

pastoral skills $31,297,315,326,332$

pastorpreneur 62

peace $44-46,88,104,265,267,271,286,341,373$, 407,415

philosophy 42, 48-49, 82, 102, 123, 129, 135, 167, $169,181,288,292,301,322,403,406-407$ educational -322 political - 288, 292

piety $61,65-66,84,198,212,216,222-224,226$, 329

pilgrimage $44-45,5^{2}$

pioneer 112,238

pioneers 318

pluralism 135, 139, 291, 354, 381, 401, 407

pluralist society 169

polemic 167,267

political economy of knowledge 56

political mobilization 414

Pope 73-74; see also Holy See

populism 15, 165, 167, 170, 175, 178-179, 262-263, 265,390

post-colonial 36, 42, 124, 129, 221, 317, 331

post-migration 232,244

power $20,26-27,54-57,60-61,65-67,72,74,76$, $82,84,88,90,96,110,124-125,15^{1-1} 5^{2}, 160$, 173, 196, 200-201, 205-210, 212-213, 216, 222, 231-232, 242, 244, 247, 249, 253, 262-264, 319, $339-340,342,347,362,387$

legitimate -110

religious -27

religious-political - 96

soft $-74,247,253$

structures of -262

pragmatism 107, $15^{\circ}$

prayer rooms $86,111,144,256,25^{8-259}, 39^{\circ}$

preaching $31,84,89,105,107,115,174,214,243$, $25^{2}, 275,279,328$

priest $11,13-14,24,26,34,63,73-74,76-77,136$, $297,342,363-364,366,388,423$

prison $23,71,92,110,118,153,156-157,162,166$, $181,207,215-216,236-237,242,245^{-246}$, 303-304, 349, 353, 355, 373, 388-389, 397, 425

private institution 23,423

professional 21, 26, 31, 74, 102, 106, 111, 146-147, 149-150, 159, 167, 185, 236-237, 246-247, 251, 258-259, 264, 268, 297-298, 311, 322, 328, 332, $385-386,388,400,405-407,413,424$

professionalism 26, 297, 304-305

professionalization $14,23,26,71,149,236$

propaganda $75,185,196,202,401$

Propaganda Fide 75

property $13,42,107,235,286,298,368$
Prophet 20-21, 44, 46, 116, 174, 190-191, 196-197, 200, 213, 243, 252, 262, 271, 283-286, 303, 306, 329, 354-355, 405, 408-409; see also Muhammad

proselytism 28, 72, 73, 89, 200, 265, 401; see also da'wa

Protestant Churches 348

Protestants 6o, 338, 350, 353

public institution $23,29,113,236-237,300,302$, $304,322,349,370$

public intellectual 28, 165, 167-170, 178-181

public policy 143-144, 157-158, 312, 384, 409

punishment 46, 95

puritanical 321

qadi 384

questionnaire 27, 130-132, 415, 417-418

Quran/Quranic 11, 20, 47-48, 70, 80-85, 89, 91, $116,127,136,174,176,186,192-193,196,198$, 208-209, 213-215, 239, 241, 247-248, 279, $283-285,289,322,354-355,366,403,405$, $407,409,419,424$

- discourses 284

- moment 284-285, 290

- schools 106

Rabat 26, 71-72, 75-76, 87, 118-119, 209-210, $215^{-217}, 225-228,409$

racialization 60,67

radicalism $86,153,278$

radicalization $33,101,115,175,177,179,186,194$, $196,248,276$

Ramadan 22, 36, 40, 45, 48, 52, 70, 84, 135, 139, 194, 202, 209, 216, 267, 270-271, 275, 387, 418

Ramadan, Tariq (1962-) 22, 135, 194, 202, 267, 270 recruitment $24,86,158,186,188-190,192,195$, 199-201, 237, 266, 382, 386, 427

reform $29,102,140,147,205^{-207}, 214-216,221$, $224,228,240,290-291,312,316-317,321,335$

reformist $213,267,281-283,291,319-321$

religion passim

history of - 121-123, 130, 407

tactical -56

world $-65,71$

religious passim

- knowledge $28,51,56-57,61,66,99,147$, 186-188, 192, 194, 197, 213, 220, 223, 237-238, 248, 251, 317, 331

- neutrality $15^{6}$

- obligation 43

- professional 21, 236, 298

- scholarship 55, 79-80, 83, 90, 92, 94, 107, 109-110, 115

- state 412

- symbols 261,407

republic $64,155,157,272-273,278,286,341,346$, $362,368,370$

Republican 73,272

revival $66,198,220,226,313,330,376$ 
revivalist 320-321

revolution $59,98,202,284,335,412-413$

rhetoric $25,62,168,215,218,264,387,391$

rites of passage $300,307-308$

Rome $26,32,37,71,73-74,76,78,100,224,381$, 390-391, 394, 400

ruler $41,43,83,318,321$

Russia 412-413

Salafi $28,48,77,110,165,167,170,172-174$, 178-182, 188, 190-191, 194, 198, 201, 203, 239, $256,266,273,281,284,286,319-320$

salvation $67,128,147,149,191$

school 12-13, 21, 24-25, 31, 40-41, 44-45, 68, 70, 73, $76-77,83-85,95,97,106,111,114,116-117,126$, $129,133,147,158,175,204,207-208,215-216$, 243-244, 249, 261-262, 268, 271, 276, 278, $282,290,303,305,315,320-321,323,326,328$, $330,333,336,350,353,355,375,391,405-407$, 421-422, 425

Second World War 19, 21-22, 80, 85, 111

secular 19-20, 24, 26-27, 29-30, 37, 40, 65, 82, 85, 91, 93-97, 108, 121-123, 127-128, 130, 132-138, $143,149,155,165,168-169,177-178,180$, 216-218, 220, 222-223, 225-228, 236-237, 245 , 251, 255, 273, 281-282, 286-289, 291-292, 312, $318-319,323,331,334,346,362,372,378,385$, $388,391,418,424-425,430$

secular law 287,292

secular society $27,138,169,180,225,255$

secular state $26,96-97,289,312,346,372,388$

secularism 19, 24, 32, 73, 114, 118, 195, 220, 222, $227,243,261-262,276,279,286,290,341,344$, $346,370-371,375-376,407$

secularization $22,61,108,138,220,248,255$, 277-279, 282-283, 288-289, 291-292

seminary $24,31,69,75,96,128,246,296,315-317$, 321-323, 325-326, 328, 330, 332, 336

sermon $23,79,84,86,88,90,93,95,101,104-105$, $115,147,15^{2-153}, 176,185,188,190,199,201$, 216, 219, 256-257, 259, 262, 266-269, 272, 279-280, 282, 284, 288, 290, 300, 306, 382, 386-387, 401, 403, 420; see also Friday prayer; khutba

sexuality 134,212

shahada 126, 257, 267

sharia 30, 40, 42, 49, 64, 83, 90-91, 95, 97-98, 108, 173, 210, 264, 275, 277, 279, 286-290, 292, 328-329, 354, 382, 386

sharia courts 64

Shia 12, 21, 41, 81, 127, 323

skills $14-15,31,62,116,132,191,237,297,299,306$, 309-311, 315, 322, 326-327, 331-332, 334, 354, $387,411,415,417-418,420,422-424,426-427$

Skype 187

slavery 285

social

$$
\begin{aligned}
& \text { - cohesion } 109 \\
& \text { - constructivism } 124
\end{aligned}
$$

- integration 103-104

- media $63,111,167,178,187,199,265,325$, 387

society passim

civil - 34, 93, 165, 219, 268, 318-319, 321, 324, $326,330-332,391,394,400-401,412,414$, 426-428

Modern -424

plural - 239

sociology 19, 65, 111, 182, 214, 232, 252-253, 314, $397-398,423$

sources $20,25,40,42,46,51,55,58,61,86,96$, 101-102, 108, 114, 144-145, 167, 173-174, 176, 185-186, 188-191, 193, 197, 200, 207, 213, 236, $240,243,246,264,283,285,319,322-323$, 407; see also Islamic sources

Soviet Union 40, 413

spirituality $31,33,55,62,110,206,216,220,222$, $227,283,287,295-296,307,309-311$

state passim

Stockholm 131, 138-140, 248, 429

Strasbourg 75, 92, 143, 163, 261, 275, 292

subjectivation 55

submission $55,217,307,310$

Süleymanli movement $5^{2-53}$

sunna 20, 80, 82, 174, 208, 213, 289

Sunni 12, 20-21, 41, 70-72, 74, 80-82, 90, 99, 126, $170,173,187,190,309,317,321,335$

Sunni tradition $80-81$

Sweden 29, 121-123, 128, 130-132, 135, 139, 203, $219,245,249,411-412,421-423,429$

syllabus 111, 298, 317, 322, 324, 332; see also curriculum

synod 126

Syria $87,97,113,116,176,178,186-189,192-193$, $199-200,279,319,335,385,414$

system 39-40, 42, 48-49, 62, 105, 109, 111, 113, 129, 133-134, 159-16o, 173, 207-212, 214, 221-222, 233, 246, 271, 285, 287, 298, 306, 308-309, $318-319,335,337,350,35^{2-353}, 355,359-363$, $365,367,369-373,375,377,379,384,395$, 400-403, 405, 407, 419, 421, 425-427 legal - 42, 287, 359, 361, 363, 365, 367, 369-

$373,375,377,379,400-401,403,405,419$ political $-40,207,395,402$

Tablighi Jamaat 147, 265, 321, 328, 383

tafsir 47

Tatarstan 413

Taylor, Charles (1931-) 20, 55, 275

technology 25, 62, 111, 203, 208, 320

terminology 151,197

terror 44,218

theological 14, 20, 27-28, 30, 51, 54-55, 66, 72-73, 81-82, 92, 102, 104, 107-109, 114, 121-125, 127-130, 132-133, 135, 139, 154, 174, 179, 191, 200, 208, 236, 238-240, 248, 250, 259, 264, $277-279,281,283,287-291,325,338,354-356$, $367,386-389,401,406,408,418-419,421-425$ 
theology $12,14,19,21,25,27,31,51,56,90,96,107$, 109, 113-115, 121-141, 173, 183, 246, 248, 253,

$264,277,279,281-285,287-293,302,312-314$, $338,406-407,421-423$

academic - 27, 128-130, 134, 137

Catholic -338

Christian $-126,128,136$

Islamic - 14, 27, 51, 96, 121-123, 125, 127-139,

$141,173,183,279,284,292,422-423$

practical - 302, 313-314

Protestant -14

tradition $13,25,35-36,44,73,75,80-84,86,89$, $94-96,105,116,122,124-129,133-136,140,146$, $159,169,186,190,200,206,213,216,221,223-$ 224, 238, 240, 281-283, 292, 296, 302, 308-310, 316-317, 319, 322-323, 325-326, 329-331, 333,

$359,371,376-377,382,384,386,401,407,409$, $412,416,420,428$

transnational 19, 21, 6o, 64-68, 74, 76, 85, 96, 98, $103,192,201,224,258,313,336,369,376,383$, 387,412

Turkey 40, 52-53, 67-68, 70, 75, 77-78, 92, 104, $133,150,174,189,247,249,253,256,262,319$, $382,400,413,420-421$

Twitter 175

type $32,59,85,91,102-103,106,111,115,124,129$, 143-144, 166, 192, 231-235, 238-241, 244-245, 250-251, 253, 266, 287, 298, 301, 305, 309, 323, $348-349,353,368,387-389,392,395$

typology of imams 29, 103, 231-233, 236, 238, $240,242,250,383$

ulama (also as ulema) $37,58,70,72,75,77$, 83-84, 88-92, 99, 110, 114, 169, 207, 209-211, 213-215, 217, 237, 300-301, 310, 312-314, 316, $318-323,332,334-336,397$

umbrella organization $53,238-239,351,354-355$, $414-415,424$
Union des Organisations Islamiques de France (UOIF) 150, 267, 280-281, 288, 290-291

Union of Islamic Communities and Organisations in Italy (UCOII) 377

United Kingdom 13, 29, 31, 42, 217, 231-232, 236, 245-246, 295-298, 311, 313-317, 321-324, $3^{26-327,330-331,421,424-425}$

United Nations 210, 227-228, 415-416

United States of America (USA) 21, 34, 65, 69, $72-75,77-78,303,377$

urban landscape 58,261

Vatican $72,76,78$

veil 94, 186, 195, 203, 226, 256, 261-262, 264, 266, 281, 290, 316; see also headscarf

victimization 176,408

Vienna 111, 203, 239, 382, 396

violence $87,153,187,191,201-202,204,212,215$, $239,263,290,305$

vocational training 106

Wadud, Amina (1952-) 135, 140, 206, 213, 221, 228 waqf $70,83,208,319$

war on terror 44,218

wine 40

worship 25-26, 28, 40-41, 44-45, 70-71, 75, 105, $107,143-144,146-148,151-154,156-157,159-160$, 188, 255, 257-26o, 270-272, 338-339, 343, 348-350, 361, 381-382, 386, 388-391, 393-394, 399, 402-403, 405

Zionism 401 